PEMBINAAN MODUL EQ UNTUK LATIHAN KECERDASAN EMOSI GURU-GURU DI MALAYSIA

SYAFRIMEN

TESIS YANG DIKEMUKAKAN UNTUK MEMPEROLEH IJAZAH DOKTOR FALSAFAH

FAKULTI PENDIDIKAN

UNIVERSITI KEBANGSAAN MALAYSIA

BANGI

2010 


\section{PENGAKUAN}

Saya akui karya ini adalah hasil kerja saya sendiri kecuali nukilan dan ringkasan yang tiap-tiap satunya telah saya jelaskan sumbernya.

12 Januari 2009

SYAFRIMEN

P31329 


\section{PENGHARGAAN}

Pertama sekali saya mengucapkan rasa syukur kehadirat Allah s.w.t kerana dengan rahmat dan hidayah-Nya saya telah dapat menyelesaikan tesis ini sesuai dengan kemampuan dan daya fikir yang dianugerahkan. Selawat beserta salam saya sampaikan kepada junjungan umat, Nabi Muhammad s.a.w contoh tauladan umat sehingga akhir zaman. Semoga tesis ini diberkati dan memberi manfaat untuk perkembangan ilmu pengetahuan hendaknya, amin ya rabbal alamin.

Ucapan terima kasih yang tidak terhingga saya ucapkan kepada penyelia saya Prof. Madya. Dr. Noriah Mohd. Ishak dan Prof. Datin. Dr. Siti Rahayah Ariffin, beliau bukan sekedar pembimbing akademik bagi saya, tetapi seperti seorang ibu yang telah mengajarkan pelbagai ilmu kehidupan untuk berdepan dengan pelbagai keadaan, sama ada sebagai seorang ahli akademik mahupun sebagai seorang insan yang bertanggungjawab sebagai khalifah Allah di muka bumi ini. Ucapan terima kasih saya kepada semua pensyarah yang telah memberikan ilmu, tunjuk ajar dan dorongan semangat serta sokongan sepanjang pengajian dijalankan. Seterusnya ucapan terima kasih kepada semua kakitangan fakulti pendidikan yang banyak membantu mempermudahkan semua urusan saya selama menuntut di fakulti ini. Budi baik dan semua bantuan yang diberikan selalu dikenang, dan Allah s.w.t sahaja yang akan membalasi segala kebaikan yang diberikan.

Penghargaan dan terima kasih setinggi-tingginya saya sampaikan kepada keluarga saya yang telah memberikan sokongan padu untuk menyelesaikan pengajian ini. Kejayaan dalam menyelesaikan pengajian ini bukanlah kejayaan saya peribadi, tetapi kejayaan untuk semuanya. Kepada ibunda Nurlela dan ayahnda Syafril (Allah Yarham) beserta kakak, abang dan seluruh adik-beradik saya, saya yakin berkat dorongan semangat dan do'a mereka akhirnya saya berjaya memperolehi pendidikan tertinggi dalam kehidupan ini. Buat isteri yang saya sayangi (Nova Erlina), dan ibu mertua yang telah melahirkan dan mendidik beliau, yang menjadi penyeri dalam hidup saya hari ini (Illana \& Yaumas beserta seluruh keluarga), doa dan sokongan yang diberikan tidak akan pernah saya lupakan sehingga ke akhir hayat.

Tidak lupa kepada buah hati yang saya sayangi "Mudhiyatul Huda dan Muhammad Afif Azka". Mudhiyah dan Afif dilahirkan semasa papa dan mama berjuang menyelesaikan pendidikan ini. Mudhiyatul Huda bererti "perempuan yang sentiasa menyinari orang lain ke jalan petunjuk", dan Muhammad Afif Azka bererti "lelaki terpuji, memiliki harga diri dan selalu menjaga kesucian (fitrah)". Nama ini sengaja dipilih dengan harapan semoga Mudhiyah dan Afif dapat berbuat sesuai dengan nama yang diberikan. Setiap waktu papa dan mama memanggil Mudhiyah dan Afif untuk mendo'akan semoga impian ini menjadi kenyataan. Sekiranya Mudhiyah dan Afif mengejar kecemerlangan, kejarlah kecemerlangan seperti yang papa dan mama maksudkan, iaitu seimbang antara kecemerlangan dunia dan kecemerlangan akhirat. Sebaik-baik manusia adalah manusia yang memberikan manfaat kepada orang lain. 


\begin{abstract}
ABSTRAK
Kajian ini bertujuan untuk membina modul EQ bagi membantu meningkatkan EQ dalam kalangan guru-guru. Kaedah gabungan (explanatory mixed methods designs) telah digunakan sebagai metod kajian. Kajian dijalankan melalui tiga fasa, fasa pertama menggunakan kajian tinjauan melibatkan 112 orang guru. Fasa ini bertujuan untuk menentukan kompetensi asas EQ yang perlu diberikan latihan. Fasa kedua menggunakan kajian kes iaitu menggunakan kaedah temu bual mendalam $(n=8)$, temu bual berkumpulan $(n=24)$ dan analisis dokumen $(n=12$ dokumen) sebagai kaedah pengumpulan data. Fasa ini bertujuan untuk menentukan kaedah dan modul yang sesuai untuk pembinaan kompetensi asas EQ yang telah dikenal pasti pada fasa pertama. Fasa ketiga pula pembinaan dan pegujian modul $(n=33)$. Modul dipecahkan kepada empat bahagian dan latihan dilaksanakan selama 4 hari. Data fasa pertama dan ketiga dikumpul mengunakan satu set instrumen EQ (IKEM/MEQI), dan dianalisis menggunakan statistik deskriptif berbantukan perisian SPSS Windows versi 15.0. Manakala data fasa kedua dianalisis secara tematik menggunakan perisian NVivo 2 dan NVivo 7. Dapatan kajian fasa pertama menunjukkan terdapat 11 kompetensi asas EQ yang perlu diberikan latihan (kesedaran emosi, penilaian kendiri yang tepat, keyakinan diri, niat, kawalan kendiri, kebolehpercayaan, dorongan pencapaian, memahami orang lain, mengembangkan potensi orang lain, mempengaruhi orang lain, dan pengurusan konflik). Fasa kedua pula menunjukkan terdapat kaedah tertentu untuk meningkatkan kompetensi asas EQ tersebut. Hasil pengujian modul menunjukkan wujudnya peningkatan pada 11 kompetensi asas EQ tersebut. Temubual yang dilakukan kepada peserta latihan menunjukkan bahawa latihan yang diberikan telah dapat: (i) meningkatkan rasa positif terhadap diri, (ii) meningkatkan kesedaran tentang perubahan yang dialami dalam diri, (iii) bertingkahlaku ke arah yang lebih positif, dan (iv) mendapat pemahaman yang lebih mendalam tentang isu berkaitan dengan emosi.
\end{abstract}




\title{
THE DEVELOPMENT OF EQ MODULE TO PROMOTE TEACHERS' EMOTIONAL INTELLIGENCE IN MALAYSIA
}

\begin{abstract}
The purpose of this study is to develop EQ module to help improve emotional intelligence among teachers. The study utilized explanatory mixed methods designs, and has three phases. The first phase employed a cross-sectional design $(n=112)$ and it examines the core-competencies of EQ among the teachers. The second phase utilized a case study design, and used in-depth interview $(n=8)$, focus-group interview $(n=24)$, as well as document analysis $(\mathrm{n}=12$ documents) as data collection techniques. These techniques were used to determine the appropriate methods can be used to develop the EQ module based on the core-competencies identified from the first phase of the study. Data for the first phase was collected using an EQ instrument (IKEM/MEQI), and was analyzed with descriptive statistic using the SPSS software version 15.0. Data from the second phase was analyzed with thematic approach using the NVivo 2 and NVivo 7 software. Findings from the first phase of the study shows that there are 11 EQ corecompetencies that needed intervention (emotioanal awareness, accurate selfassessment, self confidence, honesty, self- controll, trustworthiness, achievement drive, andertanding others, developing others, influence and conflict managemet) among the teachers. Concomitantly, findings from the second phase suggested that there are certain methods, corresponding to each core-competencies, that can be used to improve the level of EQ among the teachers. Results from both phases were used to develop an EQ module that was pilot tested on a group of teachers $(n=33)$. The module consisted of four sections and was conducted over a period of four days. Findings from the pilot study suggested an increase in EQ level among teachers who participated in the training workshop. The result of the study showed that there were improvements on those 11 EQ competencies. Interview conducted on the participants shows that the training was able to: (i) increase positive feelings towards self, (ii) increase awareness on changes experience by the self, (iii) behave more positively, and (iv) developed deeper understanding on issues related to emotion.
\end{abstract}


KANDUNGAN

Halaman

PENGAKUAN

PENGHARGAAN

ABSTRAK

ABSTRACT vi

KANDUNGAN vi

SENARAI JADUAL $\quad \mathrm{X}$

SENARAI ILUSTRASI - xi

SENARAI SINGKATAN xiii

\section{BAB I PENDAHULUAN}

$\begin{array}{llr}1.1 & \text { Pengenalan } & 1\end{array}$

1.2 Latar Belakang Kajian 8

$\begin{array}{lll}1.3 & \text { Pernyataan Masalah } & 12\end{array}$

$\begin{array}{lll}1.4 & \text { Tujuan Kajian } & 15\end{array}$

$\begin{array}{lll}\text { 1.4.1 Objektif kajian } & 15\end{array}$

$\begin{array}{lll}1.4 .2 & \text { Persoalan kajian } & 15\end{array}$

$\begin{array}{lll}1.5 & 16\end{array}$

$\begin{array}{lll}1.6 & \text { Batasan Kajian } & 17\end{array}$

$\begin{array}{ll}1.7 & \text { Kerangka Konsep kajian } \\ \end{array}$

1.8 Defenisi Istilah 32

$\begin{array}{lll}1.9 & \text { Rumusan } & 37\end{array}$

\section{BAB II KAJIAN KEPUSTAKAAN}

$\begin{array}{lll}2.1 & \text { Pengenalan } & 38\end{array}$

$\begin{array}{lll}2.2 & \text { Teori-teori Kecerdasan } & 38\end{array}$

2.2.1 Kecerdasan intelektual (IQ) 38 
2.2.2 Kecerdasan pelbagai (MI) Gardner $\quad 41$

2.2.3 Kecerdasan emosi (EQ) 42

2.2.4 Kecerdasan emosi Mayer, Caruso dan Salovey 45

2.2.5 Kecerdasan emosi Bar-On 46

2.2.6 Kecerdasan emosional Goleman $\quad 47$

2.2.7 EQ Goleman-Noriah et al. (2004) 50

$\begin{array}{lll}2.3 & \text { Kajian-kajian Berkaitan }\end{array}$

2.3.1 Kajian-kajian luar negara $\quad 72$

$\begin{array}{ll}\text { 2.3.2 Kajian-kajian dalam negara } & 77\end{array}$

$\begin{array}{lll}2.4 & \text { Latihan-latihan EQ Sedia Ada } & 79\end{array}$

$\begin{array}{lll}2.5 & \text { Rumusan } & 81\end{array}$

\section{BAB III METODOLOGI KAJIAN}

$\begin{array}{lll}3.1 & \text { Pengenalan } & 82\end{array}$

3.2 Reka Bentuk Kajian 82

3.3 Subjek Kajian 86

3.3.1 Subjek kajian fasa pertama $\quad 86$

$\begin{array}{ll}\text { 3.3.2 Subjek kajian fasa kedua } & 87\end{array}$

$\begin{array}{ll}\text { 3.3.3 Subjek kajian } & 90\end{array}$

$\begin{array}{lll}3.4 & \text { Instrumen Kajian } & 91\end{array}$

3.4.1 Instrumen fasa pertama $\quad 91$

$\begin{array}{ll}3.4 .2 \text { Instrumen fasa kedua } & 98\end{array}$

$\begin{array}{lll}3.5 & \text { Kajian Rintis } & 104\end{array}$

$\begin{array}{lll}\text { 3.6 Kesahan dan Kebolehpercayaan Instrumen } & 104\end{array}$

3.6.1 Kesahan instrumen IKEM/MEQI 105

$\begin{array}{ll}\text { 3.6.2 Kesahan protokol temubual } & 108\end{array}$

$\begin{array}{lll}3.7 & \text { Kebolehpercayaan Instrumen } & 109\end{array}$

3.7.1 Kebolehpercayaan instrumen IKEM/MEQI 109

3.7.2 Kebolehpercayaan soalan protokol 112

$\begin{array}{lll}3.8 & \text { Prosedur Pengumpulan Data } & 115\end{array}$

$\begin{array}{lll}3.9 & \text { Tatacara Penganalisisan Data } & 117\end{array}$ 


\section{BAB IV DAPATAN KAJIAN}

$\begin{array}{lll}4.1 & \text { Pengenalan } & 120\end{array}$

$\begin{array}{lll}4.2 & \text { Profil Responden Kajian } & 121\end{array}$

4.2.1 Profil responden analisis keperluan (Need Analysis) 121

4.2.2 Profil responden yang terlibat dalam latihan EQ 123

$\begin{array}{ll}\text { 4.2.3 Profil responden kajian kes } & 124\end{array}$

4.3 Kompetensi EQ Yang Perlu Diberikan Intervensi 126

4.4 Pandangan Pakar Dan Orang-Orang Berjaya Untuk Pembinaan 130 Kompetensi Asas EQ

$\begin{array}{lll}\text { 4.4.1 Pembinaan kesedaran emosi } & 131\end{array}$

4.4.2 Pembinaan penilaian kendiri yang tepat 138

4.4.3 Pembinaan keyakinan diri 145

4.4.4 Pembinaan niat 149

4.4.5 Pembinaan kawalan kendiri 153

4.4.6 Pembinaan kebolehpercayaan 158

$\begin{array}{lll}\text { 4.4.7 Pembinaan dorongan pencapaian } & 161\end{array}$

$\begin{array}{lll}4.4 .8 & \text { Pembinaan memahami orang lain } & 169\end{array}$

4.4.9 Mengembangkan potensi orang lain $\quad 172$

$\begin{array}{ll}\text { 4.4.10 Pembinaan cara mempengaruhi orang lain } & 177\end{array}$

$\begin{array}{ll}\text { 4.4.11 Pembinaan cara pengurusan konflik } & 181\end{array}$

4.5 Kaedah Yang Digunakan Dalam Latihan EQ 185

4.6 Model pembinaan Modul EQ 193

4.7 Kompetensi Guru-guru Sebelum Dan Selepas 195

Mengikuti Latihan Menggunakan Modul EQ

4.8 Pandangan Subjek Terhadap Training EQ Menggunakan 198

Modul Yang Dibina

$\begin{array}{lll}4.9 & \text { Rumusan } & 202\end{array}$

\section{BAB V RUMUSAN DAN IMPLIKASI KAJIAN}

$\begin{array}{lll}5.1 & \text { Pengenalan } & 203\end{array}$

5.2 Rumusan Hasil Kajian 203

5.3 Perbincangan Hasil Kajian 206 
5.3.1 Kompetensi EQ yang perlu diberikan intervensi dalam 207 kalangan guru-guru

5.3.2 Pandangan pakar dan orang-orang berjaya 214 dalam pembinaan kompetensi eq

5.3.3 Kaedah yang sesuai digunakan dalam latihan EQ 252

5.3.4 Profil Kompetensi EQ guru-guru sebelum dan 257 selepas latihan menggunakan modul eq yang dibina

5.3.5 Pandangan guru-guru tentang latihan EQ menggunakan modul latihan EQ yang dibina

5.4 Implikasi Amalan 262

$\begin{array}{lll}5.5 & 263\end{array}$

5.6 Sumbangan Kajian Kepada Ilmu 264

5.7 Sumbangan Kepada Masyarakat 264

5.8 Cadangan Untuk Kajian Lanjutan 264

$\begin{array}{lll}5.9 \text { Rumusan } & 265\end{array}$

$\begin{array}{ll}\text { RUJUKAN } & 266\end{array}$

\section{LAMPIRAN}

A Modul Latihan Kecerdasan Emosi 276

$\begin{array}{lll}\text { B } & \text { Protokol Temu Bual Pakar } & 398\end{array}$

C EQ Index Interpretation oleh Noriah (2007) 304

D Persetujuan Cohen Kappa temu bual individu dan berkumpulan 305 untuk mendapatkan komponen-komponen penting dalam pembinaan modul EQ 


\section{SENARAI JADUAL}

No. Jadual

Halaman

3.1 Kesahan konstruk instrumen IKEM/MEQI 107

3.2 Nilai Kebolehpercayaan Alpha Cronbach Instrumen 110

3.3 Nilai Kebolehpercayaan Alpha Cronbach instrumen 111 IKEM-MEQI pencapaian

$\begin{array}{ll}3.4 & \text { Nilai persetujuan Cohen Kappa }\end{array}$

$\begin{array}{ll}\text { 3.5 Tatacara analisis data mengikut persoalan kajian } & 119\end{array}$

$\begin{array}{lll}4.1 & \text { Profil responden kajian untuk analisis keperluan }\end{array}$

4.2 Profil responden yang terlibat di dalam latihan EQ 123

$\begin{array}{lll}4.3 & \text { Profil responden untuk kajian kes } & 125\end{array}$

4.4 Matrix Intersection kesedaran emosi 133

4.5 Kod yang digunakan untuk melaporkan hasil temu bual 133

4.6 Matrix intersection penilaian kendiri yang tepat $\quad 140$

4.7 Matrix intersection keyakinan diri 146

$\begin{array}{lll}4.8 & \text { Matrix intersection niat } & 151\end{array}$

4.9 Matrix intersection kawalan kendiri 154

$\begin{array}{lll}4.10 & \text { Matrix intersection kebolehpercayaan } & 169\end{array}$

$\begin{array}{lll}4.11 & \text { Matrix intersection dorongan pencapaian }\end{array}$

$\begin{array}{ll}4.12 & \text { Matrix intersection memahami orang lain }\end{array}$

4.13 Matrix intersection mengembangkan potensi orang lain $\quad 174$

4.14 Matrix intersection mempengaruhi orang lain 189

4.15 Matrix intersection menyelesaikan konflik 183

$\begin{array}{lll}4.16 & \text { Senarai dokumen yang dianalisis untuk mencari } & 186\end{array}$

$\begin{array}{lll}4.17 & \text { Aktiviti-aktiviti dalam latihan } & 194\end{array}$ 


\section{SENARAI ILUSTRASI}

No. Rajah

Halaman

$\begin{array}{lll}1.1 & \text { Kerangka konsep kajian } & 18\end{array}$

$2.1 \quad$ Model EQ Goleman (1999) 50

2.2 Model EQ Goleman-Noriah (2004) 71

3.1 Reka bentuk kajian $\quad 83$

$\begin{array}{lll}3.2 & \text { Prosedur menjalankan kajian } & 85\end{array}$

3.3 Tema kesedaran emosi, penilaian kendiri yang tepat dan 113

3.4 Tema niat, kawalan kendiri dan kebolehpercayaan 113

3.5 Tema dorongan pencapaian dan memahami orang lain 113

3.6 Tema mengembangkan potensi orang lain, mempengaruhi 113 orang lain dan pengurusan konflik

$\begin{array}{ll}4.1 & \text { Domain dan sub domaian EQ }\end{array}$

K.2 Kompetensi asas EQ yang perlu diberikan intervensi 129

4.3 Min yang diperolehi bagi setiap kompetensi asas EQ 129

$\begin{array}{lll}4.4 & \text { Pengalaman subjek dalam pembinaan kesedaran emosi }\end{array}$

$\begin{array}{llll}4.5 & \text { Pengalaman subjek dalam pembinaan penilaian kendiri } & 139\end{array}$ yang tepat

4.6 Pengalaman subjek dalam pembinaan keyakinan diri $\quad 146$

$\begin{array}{lll}4.7 & \text { Pandangan subjek dalam pembinaan niat } & 150\end{array}$

4.8 Pengalaman subjek dalam pembinaan kawalan kendiri 153

$\begin{array}{lll}4.9 & \text { Pengalaman subjek dalam pembinaan kebolehpercayaan } & 159\end{array}$

4.10 Pengalaman subjek dalam pembinaan dorongan pencapaian 162

$\begin{array}{lll}4.11 & \text { Pengalaman subjek dalam memahami orang lain }\end{array}$ 
4.12 Pengalaman subjek dalam mengembangkan potensi orang lain

4.13 Pengalaman subjek dalam mempengaruhi orang lain $\quad 178$

4.14 Pengalaman subjek dalam pembinaan pengurusan konflik 181

4.15 Kaedah yang sesuai digunakan dalam latihan EQ $\quad 187$

$\begin{array}{ll}4.16 & \text { Cara pelaksanaan latihan EQ }\end{array}$

4.17 Proses pembinaan modul EQ 193

4.18 Profil kompetensi EQ guru-guru sebelum diberikan latihan $\quad 196$

4.19 Profil kompetensi EQ guru-guru selepas diberikan latihan 197

4.20 Profil kompetensi EQ sebelum dan selepas latihan 197

4.21 Pandangan subjek terhadap latihan menggunakan modul 199 EQ yang dibina 


\section{SENARAI SINGKATAN}

$\begin{array}{ll}\text { FPN } & \text { Falsafah Pendidikan Negara } \\ \text { KPM } & \text { Kementerian Pendidikan Malaysia } \\ \text { UKM } & \text { Universiti Kebangsaan Malaysia } \\ \text { ESQ } & \text { Emotional Spiritual Quotient } \\ \text { KDPM } & \text { Kursus Diploma Pendidikan Malaysia } \\ \text { KPLI } & \text { Kursus Perguruan Lepasan Ijazah } \\ \text { KDP } & \text { Kursus Dalam Perkhidmatan } \\ \text { BPG } & \text { Bahagian Pendidikan Guru } \\ \text { MRSM } & \text { Maktab Rendah Sains MARA } \\ \text { IQ } & \text { Intelligence Quotient } \\ \text { MI } & \text { Multiple Intelligence } \\ \text { EQ } & \text { Emotional Quotient } \\ \text { WEIP-3 } & \text { Workgroup EI Profil Version3 } \\ \text { EIQ } & \text { Emotional Intelligence Questionnaire } \\ \text { EQI } & \text { Emotional Quotient Inventory } \\ \text { IKEM } & \text { Inventori Kepintaran Emosi Malaysia }\end{array}$




\section{BAB I}

\section{PENDAHULUAN}

\subsection{PENGENALAN}

Pendidikan merupakan satu proses yang berlaku sepanjang hayat yang mengarah kepada kemajuan diri seseorang. Ini memberikan implikasi bahawa pendidikan sentiasa berlaku pada bila-bila masa dan di mana sahaja, samada secara formal atau tidak formal (UNESCO; Sharifah 1987). Dwyer (2002) menyatakan setiap individu sememangnya mempunyai kebolehan untuk belajar sepanjang hayat mereka. Ini dilakukan untuk memperbaiki kehidupan dan menjadi sebahagian dari proses perkembangan diri.

Istilah pendidikan sepanjang hayat telah lama disentuh oleh Al-Quran seperti dinyatakan dalam surah al- ${ }^{\mathrm{c}}$ Alaq yang bermaksud;

Bacalah (Muhamad) dengan nama Tuhanmu yang telah menciptakan, telah menciptakan manusia daripada segumpal darah, bacalah dan Tuhanmu yang Maha pemurah, yang mengajarkan manusia menulis dengan pen, yang mengajarkan kepada manusia perkara-perkara yang tidak diketahuinya (Q.S Al'Alaq 1-5)',.

Seterusnya pendidikan sepanjang hayat juga telah dipopularkan oleh Rasulullah s.a.w seperti dinyatakan dalam sebuah hadis bermaksud;

Tuntutlah ilmu pengetahuan mulai dari ayunan sehingga ke akhir hayat (H.R. Bukhari). 
Di dalam riwayat lain rasulullah s.a.w juga menyatakan bermaksud;

Menuntut ilmu adalah wajib bagi muslim lelaki dan muslim perempuan (H.R. Bukhari)”.

Sentuhan al-Qur'an dan hadis di ini mengisyaratkan bahawa pembelajaran merupakan satu kemestian bagi setiap individu tanpa mengira jantina, umur atau latar belakang, dan pembelajaran tersebut tidak bermaksud ianya membawa kepada sesuatu pengijazahan atau pensijilan kepada sebarang bidang sahaja.

Konsep pendidikan sepanjang hayat ini juga selari dengan hasrat kerajaan yang mengambil berat tentang perkembangan pendidikan dalam kalangan remaja masa kini, dimana pembelajaran bagi sesetengah individu tamat selepas zaman persekolahan. Bagi individu yang berjaya, mereka akan meneruskan pembelajaran mereka ke tahap yang lebih tinggi. Bagi yang kurang berjaya, pembelajaran mereka akan berhenti sehingga sekolah menengah. Justeru, ruang yang lebih luas sepatutnya disediakan untuk individu yang kurang berjaya agar mereka dapat terus belajar dan menimba ilmu untuk kemajuan peribadi serta boleh berfungsi dengan berkesan dalam kehidupan seharian. Bagaimana pun, untuk menghasilkan remaja yang dapat menangani arus globalisasi dunia tanpa sempadan, mereka memerlukan bimbingan dari guru dan ibubapa yang memahami cabaran yang terhasil dari perubahan pantas masa kini.

Proses pembelajaran sepanjang hayat disentuh dalam Falsafah Pendidikan Negara (FPN) yang menyebut bahawa "Pendidikan di Malaysia adalah suatu usaha berterusan ke arah lebih memperkembangkan potensi individu secara menyeluruh dan bersepadu untuk melahirkan insan yang seimbang dan harmonis dari segi intelek, rohani, emosi dan jasmani berdasarkan kepercayaan dan kepatuhan kepada Tuhan. Usaha ini adalah bertujuan untuk melahirkan warganegara Malaysia yang berilmu pengetahuan, berketerampilan, berakhlak mulia, bertanggungjawab dan berkeupayaan mencapai kesejahteraan diri serta memberikan sumbangan terhadap keharmonian dan kemakmuran keluarga, masyarakat dan negara” (Kementerian Pendidikan Malaysia 1987). 
Falsafah Pendidikan Negara (FPN) mewadahkan satu cita-cita yang mulia; iaitu melahirkan insan yang seimbang, mempunyai pengetahuan (intelek) yang mantap, kerohanian (spritual) yang kokoh, emosi yang stabil serta memiliki jasmani yang sihat. Dari segi intelek FPN ingin melahirkan insan yang; (i) mempunyai kemahiran asas membaca, menulis dan mengira (3M), (ii) berkebolehan mendapatkan, meningkatkan dan menyebarkan ilmu, (iii) berfikiran kritis dan kreatif, dan (iv) boleh memanfatkan ilmu untuk diri sendiri dan orang lain. Dari segi rohani pula FPN ingin melahirkan insan yang sentiasa; (i) menyedari dan menginsafi adanya pencipta, (ii) menghargai dan mensyukuri pemberian pencipta, (iii) menyedari dan menginsyafi tanggungjawab, (iv) memupuk dan membina disiplin kendiri serta (v) membentuk akhlak mulia. Sedangkan dari segi emosi pula FPN berhasrat melahirkan insan yang mempunyai; (i) perasaan tenang dan tingkah laku yang terkawal, (ii) memiliki dan memupuk perasaan kasih sayang, (iii) memiliki semangat kekitaan dan perpaduan dan (iv) menghargai serta menilai keindahan dan keseniaan. Dari aspek jasmani pula FPN berhasrat untuk melahirkan insan yang sentiasa; (i) menjaga kesihatan, (ii) melakukan riadah, (iii) mengembangkan bakat dan kemahiran teknikal dan manipulatif, (iv) memanfaatkan tenaga fizikal untuk berdikari, (v) menggunakan tenaga fizikal bagi kepentingan masyarakat dan (vi) berusaha meningkatkan daya pengeluaran (Kementerian Pendidikan Malaysia 1987).

Untuk mewujudkan cita-cita mulia ini tentunya memerlukan sokongan dari pelbagai pihak termasuk kerajaan, ibubapa, guru mahupun persekitaran. Mereka mestilah memberikan sokongan yang padu untuk mencapai hasrat FPN tersebut. Ibubapa contohnya, boleh memberikan sokongan dengan memberikan perhatian yang padu terhadap pendidikan anak-anak mereka, sama ada di dalam mahupun di luar rumah. Persekitaran keluarga pula mestilah mampu menyokong cita-cita murni tersebut dengan cara memberikan sokongan sepenuhnya terhadap pelaksanaan FPN berkenaan.

Dalam pendidikan formal, peranan guru tidak dapat dipertikaikan, guru merupakan tonggak kepada kesuburan minda, kestabilan emosi, dan kesejahteraan fisiologikal pelajar-pelajar terutama apabila mereka berada dalam persekitaran pembelajaran di sekolah. Impak yang ditinggalkan oleh seseorang guru terhadap 
pelajarnya boleh mempengaruhi corak pembelajaran dan kerjaya pelajar tersebut di masa hadapan (Abu Bakar \& Ikhsan 2003). Justeru, guru merupakan teras kepada pelaksanaan proses pendidikan tersebut. Menurut mereka, terdapat tiga tanggungjawab asas guru dalam menjayakan pendidikan iaitu; (i) guru sebagai contoh ataupun role model, (ii) guru sebagai pembentuk akhlak yang baik, dan (iii) guru sebagai pakar bidang. Guru harus menjadi contoh bukan sahaja di dalam bilik darjah, malah juga di luar sekolah. Mereka juga perlu menjadi contoh kepada pelajar dan ahli masyarakat. Justeru, peranan mendidik mereka menjangkaui pendidikan formal yang diterapkan dalam sistem pendidikan sedia ada. Tanggung jawab guru sebagai pendidik, tidak selesai apabila tamat waktu bekerja, tetapi ianya berterusan selagi mereka berinteraksi dengan ahli masyarakat.

Profesion perguruan merupakan profesion yang sangat mulia. Bagaimanapun, keprofesionalan seseorang guru bergantung kepada sikap mereka terhadap profesion tersebut yang dicerminkan kepada pelajar. Sebagai pendidik, guru mestilah menjadi contoh yang baik, berkemahiran untuk melakukan rekfleksi kendiri (Parson \& Stephenshon 2005), berdisplin, rajin berusaha, menepati masa, berakhlak mulia, dan mempunyai emosi yang stabil. Keperibadian seperti ini dapat memberikan kesan positif kepada pembentukan sahsiah pelajar. Hal ini selari dengan perintah Allah s.w.t yang bermaksud;

Serulah olehmu kepada jalan Tuhanmu dengan bijaksana dan cara-cara yang baik (mau'izah hasanah) serta tegurlah mereka dengan dengan cara-cara yang sesuai (Q.S. An-Nahl: 125).

Tugas guru tidak hanya melahirkan pelajar yang cemerlang dalam akademik, tetapi juga bertanggungjawab membentuk akhlak dan sahsiah pelajar ke arah yang lebih baik. Guru mesti dinamis, sentiasa mencari dan menimba ilmu pengetahuan baru melalui pembelajaran dan pengalaman, serta mahu menerima perubahan yang sentiasa berlaku sesuai dengan perkembangan semasa. Tajul Ariffin dan Nor' Aini (2002) menyatakan guru yang baik sentiasa membina keunggulan sahsiah pelajar dengan mencorakkan suasana pengajaran dan pembelajaran yang berkesan. Mereka mempunyai keseimbangan dalam pengisian antara penghayatan agama dan moral dengan pelbagai ilmu bidang dan urusan kehidupannya. Mereka juga sentiasa 
meningkatkan kualiti diri menerusi latihan-latihan yang dapat meningkatkan keprofesionalan mereka. Guru perlu mewujudkan suasana pembelajaran yang selesa, menggalakkan pembinaan sahsiah murid secara menyeluruh, menyuburkan hubungan kemanusiaan yang sihat di sekolah, menyediakan pelajar untuk memahami realiti kehidupan, menguasai kemahiran hidup, keutamaan kepada penghayatan agama dan nilai moral serta mampu melaksanakan pendidikan yang berkualiti (Tajul Ariffin \& Nor' Aini 2002).

Hasrat kerajaan yang ingin menjadikan pendidikan di Malaysia bertaraf dunia merupakan cabaran kepada individu yang memilih profesion perguruan. Ini tentunya memerlukan kesediaan guru dari pelbagai aspek, sama ada dari segi ilmu pengetahuan, kaedah pengajaran mahupun dari aspek kesediaan emosi, kerana mereka akan berhadapan dengan pelbagai tekanan kerja bagi melahirkan pelajar yang cemerlang. Noriah et al. (2003) menyatakan quality teacher begets quality student. Ini bermaksud, pelajar yang cemerlang hanya boleh lahir dari guru yang berketrampilan. Justeru, untuk memenuhi keperluan membina kecemerlangan pelajar, guru-guru perlu mendahului usaha mempertingkatkan kualiti diri terlebih dahulu bagi mengendalikan pendidikan tersebut.

Bagaimanapun, akhir-akhir ini terdapat berita tentang sikap yang kurang bertanggungjawab oleh segelintir guru, yang boleh mencemarkan imej profesion perguruan. Guru bertindak menampar, menyepak dan memukul pelajar sehingga menimbulkan kesan fizikal, mental dan emosi yang negatif kepada pelajar (Berita Harian Ogos 2004; Berita Harian 15 Ogos 2004; Harian Metro 19 Mei 2005 \& Harian Metro 17 Jun 2005). Trenda salah laku guru-guru ini walaupun pada awalnya kelihatan seperti kes-kes terpencil, namun laporan mengenainya sering terpapar di muka akhbar sehingga ianya kelihatan seperti satu fenomena yang berlaku secara berterusan. Mengapa perkara ini berlaku? Adakah guru-guru mengalami tekanan emosi akibat bebanan tugas berlebihan? Tidakkah mereka didedahkan dengan cara-cara yang boleh menjaga kestabilan emosi mereka? Kajian Maslach (dlmTaniza 2002) mendapati bebanan kerja yang berlebihan menyebabkan guru mengalami keletihan emosi, dan kemungkinan keadaan sebegini menyumbang kepada ketidakstabilan emosi guru-guru tersebut yang seterusnya mencetuskan emosi yang negatif. 
Kajian Goleman, Boyatzis dan Mckee (2002) ke atas pekerja beberapa buah syarikat mendapati jika pekerja tersebut memiliki kekuatan pada domain "regulasi kendiri" ia mampu menyumbangkan keuntungan antara 78\% hingga 390\% dalam syarikat tempat mereka berkhidmat dalam setahun berbanding dengan individu lain yang tidak memiliki keterampilan tersebut. Demikian juga halnya dengan individu yang memiliki "kemahiran sosial". Pekerja tersebut mampu menyumbangkan keuntungan sebesar $110 \%$ setahun. Ini berbeza dengan pekerja yang hanya mempunyai kemampuan kognitif dan analisis yang tinggi. Mereka hanya mampu meningkatkan keuntungan syarikat sebanyak 50\% daripada keuntungan yang diperolehi sebelumya. Justeru, Goleman merumuskan bahawa kemampuan dan keterampilan kognitif (IQ) sememangnya membantu seseorang dalam menjalankan tugas. Namun, ini tidak mencukupi untuk memastikan mereka menjalankan tugas dengan jayanya. Goleman berpandangan bahawa kini wujud keperluan kepada kecerdasan EQ yang didapati lebih menyumbang kepada kejayaan seseorang berbanding dengan kemampuan dan keterampilan kognitif tersebut. Kajian yang sama telah dijalankan oleh Skovholt dan Rozario (dlm Syed 2005). Mereka mendapati guru-guru cemerlang iaitu, guru-guru yang mempunyai sifat empati dan kemahiran sosial yang tinggi, lebih disukai oleh ramai pelajar berbanding dengan guru-guru yang tidak mempunyai ciri-ciri tersebut. Ke dua-dua ciri itu merupakan domain penting dalam EQ. Justeru, guru-guru yang mesra pelajar mudah didampingi oleh pelajar dan ini memudahkan laluan pelajar untuk menerima proses pembelajaran.

Selari dengan pandangan di atas, Ary Ginanjar (2003) juga menyatakan kewujudan EQ sangat penting selain daripada IQ, sama ada dalam dunia usahawan mahupun pendidikan. Menurut beliau permasalahan yang sering dihadapi oleh individu bekerja sekarang adalah masalah komitmen kerja, integriti, motivasi, kreativiti dan mengekalkan semangat bekerja. Ary Ginanjar (2003) juga menyatakan, membina keterampilan teknikal adalah lebih mudah berbanding dengan keterampilan EQ. Justeru, beliau mengandaikan wujud kemungkinan hubungkait antara EQ dengan sifatsifat dalaman seseorang (kesedaran kendiri, regulasi kendiri, motivasi kendiri, empati, kemahiran sosial, kerohanian dan kematangan). 
Terdapat beberapa pandangan yang menyatakan bahawa EQ boleh dibina (Bagsaw 2000; Dulewicz \& Higghs 2004; Matthews, Roberts \& Zeidner 2003; Patricia \& Finian 2003). Bagaimanapun, sejauhmana EQ tersebut boleh dibina masih dipertikaikan (Cooper, 1997; Goleman, 1996, 1998; Higgh and Dulewicz, 1999 \& Martinez, 1997). Kajian Dulewicz dan Higgs (2004) menunjukkan bahawa terdapat beberapa kompetensi EQ yang boleh dikembangkan berbanding dengan sebahagian kompetensi EQ yang lain. Goleman (1999) pula menyatakan pembinaan kompetensi EQ berbeza dengan pembinaan IQ. Beliau mendapati IQ dan kemampuan kognitif individu relatif tidak berubah, berbeza dengan EQ yang boleh dipelajari dan ditingkatkan sepanjang hayat. Bagaimanapun, persoalannya adalah "Apakah bentuk latihan yang sesuai untuk meningkatkan EQ seseorang?". Menurut Ary Ginanjar (2003) kebanyakan latihan-latihan yang dilakukan hanya memberikan kesan sesaat, sehingga latihan-latihan tersebut kurang bersebati dengan perubahan sikap seseorang. Daripada pengalamannya, Ary Ginanjar (2003) membuat kesimpulan bahawa seseorang itu perlu melakukan latihan secara berterusan (continuosly improvement) yang boleh membentuk satu keperibadian yang mempunyai EQ yang tinggi.

Terdapat beberapa latihan EQ yang dilaksanakan oleh institusi di luar negara seperti; Institute for Health and human potential Pawliw, Bill Benjamin, Elizabeth Pawliw dan Blair Steinbach, six seconds the emotional intelligence network training Anabel Jensen dan Joshua Fredman, Emotional Spiritual Quotient Training oleh Ary Ginanjar, Emotional Intelligence Development Programmes oleh Andy Smith, dan Training Emotional Intelligence oleh Peter Sullivan. Setelah mempelajari beberapa latihan EQ yang dilaksanakan di luar negara tersebut, dan juga mengambil kira beberapa dapatan kajian tempatan, pengkaji berpandangan bahawa sedikit usaha diperlukan agar satu modul EQ yang sesuai digunakan kepada guru-guru dan bakal guru-guru tempatan dapat dibina. Pembinaan modul EQ dimaksudkan mestilah selari dengan Falsafah Pendidikan Negara sehingga dapat membantu guru-guru untuk mewujudkan cita-cita Falsafah Pendidikan Negara (FPN) yang telah dirancang semenjak 20 tahun yang lepas. Pembinaan modul tersebut juga diharapkan dapat membuka nuansa baru dalam kalangan guru-guru tentang pentingnya pengembangan aspek-aspek emosi dan bukan hanya melulu pada potensi akademik, seperti mana yang berlaku selama ini. 


\subsection{LATAR BELAKANG KAJIAN}

Kerajaan Malaysia telah meletakkan pendidikan pada kedudukan tertinggi dalam agenda pembangunan negara. Perkara ini dilakukan, kerana kerajaan berkeyakinan dengan menguasai ilmu pengetahuan akan membawa maruah negara ke peringkat global, sekaligus menjadikan negara Malaysia maju menjelang 2020. Hasan Said melaporkan pengurusan sistem pendidikan di Malaysia merupakan yang terbaik di dunia ketiga (Berita Harian 31 Mei 2005). Bagaimanapun beliau menyatakan masih terdapat pelbagai kelompangan yang perlu diperbaiki bagi mempertingkatkan kualiti pendidikan pada masa yang akan datang. Di antara kelompangan yang dimaksudkan ialah, memartabatkan profesion perguruan, meningkatkan mutu pendidikan prasekolah dan pendidikan khas, menyediakan kurikulum berteraskan pemikiran saintifik, sekaligus melahirkan pekerja yang mampu berdaya saing dan pada masa yang sama mengekalkan nilai moral yang tinggi. Untuk menjayakan semua perkara tersebut, beliau menyarankan supaya guru menjadi elemen utama dan sekaligus sebagai pelaksana berbagai revolusi dan reformasi pendidikan. Beliau juga menyatakan bahawa guru-guru tidak akan dapat mempercepatkan proses tersebut tanpa latihan dan sokongan yang mencukupi dari pelbagai pihak (Utusan Malaysia 31 Mei 2005).

Guru adalah ahli masyarakat yang mempunyai perhubungan sosial yang saling berkait rapat dengan pembentukan masyarakat madani dan kehadiran mereka memberikan impak kepada pembangunan ekonomi sesebuah negara. Mereka merupakan tenaga ikhtisas yang bertanggungjawab untuk mendidik pelajar yang merupakan aset masa hadapan (Mok Soon 1992). Selain bertugas sebagai pendidik dan pemudah cara dalam bilik darjah guru juga berperanan sebagai pengganti ibubapa pelajar. Justeru, tanggungjawab mendidik ini meliputi tugas-tugas sebagai penasihat, pembimbing, kaunselor, pengamal dan penyebar nilai budaya yang baik dan menjadi contoh sahsiah yang unggul dalam proses pembentukan sahsiah pelajar. Ini memberikan implikasi bahawa guru bukan sahaja bertindak sebagai penyampai ilmu tetapi juga pembentuk peribadi pelajar dengan menyemai sifat rajin dan tekun dalam kalangan mereka (Mahathir 2005). 
Untuk melaksanakan tanggungjawab sebagai pendidik dalam situasi yang semakin mencabar dan kompleks seperti sekarang ini, guru-guru perlu sentiasa mempersiap dan memperlengkapkan diri dengan pelbagai kemahiran dan kecekapan, seperti melakukan penambahbaikan terhadap kaedah pengajaran di dalam bilik darjah, menguasai teknologi pendidikan, membina suasana pengajaran dan pembelajaran yang harmonis dan membentuk hubungan guru-pelajar yang mesra. Kesemua ini memerlukan guru tersebut membina kecekapan dalam setiap aspek atau kompetensi EQ. Sekiranya aspek EQ ini diabaikan, tidak mustahil guru-guru tersebut menghadapi tekanan dan kecelaruan emosi dalam menghadapi karenah pelajar yang semakin mencabar.

Terdapat beberapa laporan akhbar dan media elektronik tempatan yang menggambarkan perlakuan kurang beretika dan tidak bertanggungjawab dalam kalangan segelintir guru-guru sekolah. Antara contoh tingkah laku agresif yang dipaparkan adalah seperti guru mendenda pelajar secara keterlaluan, mengetuk kepala pelajar dengan objek berat, mencedera, menampar dan menumbuk pelajar sehingga mengakibatkan pelajar terpaksa dirawat di hospital (Berita Harian Ogos 2004; Berita Harian 15 Ogos 2005; Harian Metero 19 Mei 2005; Noriah 2003; The Sun Ogos 1999, Disember 1999; Utusan Malaysia 24 Februari 2004). Selain daripada isu keagresifan guru ke atas pelajar, satu laporan yang memeranjatkan masyarakat baru-baru ini berkaitan dengan seorang guru di sebuah sekolah rendah yang ditahan oleh pihak polis kerana dipercayai menjadi pengedar dadah di kawasan tempat beliau berkhidmat (Harian Metro 17 Jun 2005). Fenomena seperti ini tidak hanya berlaku di Malaysia malah juga di negara-negara membangun yang lainya. Sebagai contoh, media elektronik Indonesia melaporkan bahawa seorang pesara guru telah merogol cucunya sendiri, dan pengetua sekolah berasrama telah merogol lima orang pelajar di sekolahnya (SCTV 7 Mei 2004).

Tingkah laku agresif segelintir guru seperti yang dipaparkan di atas tidak hanya memburukkan peribadi guru berkenaan, malah ianya boleh menjejaskan imej kerjaya dan keprofesionalan guru tersebut. Mengapakah perkara sebegini berlaku dalam profesion yang mulia ini? Adakah guru-guru tidak lagi menghayati Falsafah Pendidikan Negara (FPN) dan Falsafah Pendidikan Guru? Adakah kurikulum yang 
diberikan semasa menjalani latihan kurang mencukupi bagi mempersiapkan kualiti peribadi guru untuk berkhidmat sebagai pendidik di sekolah? Adakah pengetahuan tentang elemen-elemen yang berkaitan dengan kecekapan mengawal emosi belum cukup didedahkan kepada calon-calon guru semasa menjalani latihan perguruan, sedangkan kecekapan ini sangat penting dalam perkhidmatan yang melibatkan pembinaan modal insan cemerlang seperti pelajar-pelajar di sekolah.

Goleman dalam Noriah (2005) menyatakan bahawa;

...cognitive intelligence may provide some individuals entry into particulas (work) setting, (however) emotional intelligence could play a vital role in determining how successful they will be after entering the work setting .

Kenyataan Goleman ini boleh dikaitkan dengan profesion keguruan hari ini dimana guru-guru yang dilantik oleh Kementerian Pelajaran Malaysia adalah terdiri dari mereka yang memiliki kelulusan pendidikan dan latihan perguruan di peringkat diploma, sarjanamuda, sarjana dan doktor falsafah $(\mathrm{PhD})$. Ini menunjukkan bahawa guru-guru dalam perkhidmatan pendidikan hari ini tidak ketinggalan dari segi pengetahuan intelektual (IQ). Namun demikian ini tidak memastikan bahawa mereka dapat berfungsi dengan lancar sebagai guru sehingga boleh melahirkan insan-insan yang cemerlang. Kesan keagresifan yang ditunjukkan oleh sesetengah guru tersebut kini dipertikaikan kerana pada akhir-akhir ini terdapat banyak rungutan dari ibubapa dan masyarakat ke atas kebolehan guru menjadi pendidik yang berkesan.

Beberapa kajian luar dan dalam negara mendapati bahawa wujud kepentingan EQ di samping kemahiran intelektual (IQ) dalam kalangan pendidik (Ary Ginanjar 2003; Goleman 1995, 1999; Mohd Najib 2000; Noriah et al 2001; Noriah dan Siti Rahayah 2003; Noriah, Syed Najmuddin \& Syafrimen 2003; Noriah et al. 2004; Skovholt \& D'rozario 2000; Syafrimen 2004; Syed Najmuddin 2005; Wan Ashibah 2004; Zuria \& Noriah 2003). Oleh itu, telah sampai masanya bagi guru-guru untuk memahirkan diri dengan keterampilan tersebut. Pendedahan dan latihan berkaitan dengan EQ perlu diberikan pada peringkat latihan keguruan. Justeru, kajian ini cuba 
membina satu modul latihan EQ yang boleh digunakan dalam bengkel-bengkel (workshop) bagi membantu meningkatkan kecerdasan emosi guru-guru.

Kecerdasan dan sahsiah guru merupakan hasil latihan dan pengalaman yang dilalui oleh guru-guru tersebut semasa dalam pengajian, sehingga mereka dapat menguruskan pengajaran pembelajaran secara berkesan apabila bertugas di sekolah. Guru perlu mendapat latihan untuk memahami keadaan fizikal, dan psikologikal pelajar serta kaedah penyampaian yang lebih berkesan. Untuk mendapatkan kemahiran-kemahiran tersebut guru-guru perlu melanjutkan pelajaran ke peringkat yang lebih tinggi, menambah pengetahuan dan kemahiran selaras dengan profesion mereka, walaupun sudah memiliki sijil, diploma atau ijazah pendidikan (Mohammed Sani 2001). Untuk itu, penglibatan guru dalam program-program perkembangan profesionalisme perguruan adalah penting supaya dapat mengetahui perkembangan terkini dalam bidang pendidikan dan menyedari keperluan pendidikan masa kini. Mohammed Sani (2001) juga menyatakan bahawa kelulusan yang cemerlang dari universiti terkenal sekalipun tidak menjamin guru tersebut memiliki keterampilan sehingga dapat mempelbagaikan pengalaman dalam seting sebenar pendidikan. Pendidikan praperkhidmatan hanya membekalkan calon guru dengan kemahiran, pengetahuan, teknik dan sikap yang perlu ada untuk peringkat awal perkhidmatan sahaja. Justeru, guru-guru mesti sentiasa menimba pelbagai pengalaman untuk memastikan bahawa mereka boleh berjaya (Jessup dalam Mohammed Sani 2001).

Atan Long (1980) mengemukakan beberapa perkara asas yang perlu diperhatikan dalam penyediaan guru iaitu; pembinaan sikap yang baik dan mempunyai rasa penglibatan ikhtisas terhadap profesion perguruan. Guru perlu berdedikasi dan memberikan tumpuan penuh terhadap tugas mereka, sentiasa memikirkan cara-cara memperbaiki dan memajukan diri dalam kerjaya, serta merancang langkah-langkah dan tindakan yang perlu diambil, demi meningkatkan proses pembelajaran kendiri mereka. Perkara ini tidak dapat dilaksanakan secara sambilan. Atan Long (1980) juga menyatakan bahawa dalam menjalankan tugas mendidik, guru memerlukan ketekunan, kegigihan, inisiatif dan kecekalan, kerana sifat-sifat inilah yang akan membawa mereka ke arah mencapai kejayaan di dalam profesion tersebut. 
Atan Long (1980) juga menyatakan bahawa sebagai pendidik berkesan, guru perlu mempunyai sifat-sifat yang dapat menjaga imej profesion mereka seperti; (i) memiliki emosi dan mental yang stabil, (ii) mempunyai sikap yang jujur terhadap diri sendiri dan orang lain serta menghormati orang lain dengan penuh pengertian, (iii) mempunyai kecerdasan yang tinggi, kreatif, bertimbang rasa, berempati dan bijaksana dalam menyelesaikan masalah dan (iv) memiliki sifat sabar, ikhlas, tegas, selalu menepati masa serta sentiasa menjaga ikhtisas profesion perguruan. Guru seperti ini sentiasa menunjukkan keyakinan diri yang tinggi, cekal hati, mempunyai harga diri serta dapat menghargai diri orang lain. Justeru, latihan-latihan menggunakan modul EQ boleh memberikan satu pengalaman baru kepada guru-guru dalam usaha meningkatkan sahsiah yang mesti dimiliki oleh guru-guru tersebut.

\subsection{PERNYATAAN MASALAH}

Laporan yang dipaparkan oleh media menunjukkan peningkatan insiden ketidakstabilan emosi dalam kalangan guru-guru [Berita Harian (24 Ogos 2000, 21 November 2000, 7 Ogos 2003, 7 Mei 2004); New Straits Times 12 Ogos 2000 ; Utusan Malaysia (April 2001, 4 Januari 2002)); Syed 2005]. Walaupun bilangan guru yang menunjukkan insiden tersebut agak kecil dan terpencil berbanding dengan jumlah populasi guru, namun, ianya boleh memberikan impak yang negatif ke atas pelajar dan profesion perguruan.

Kajian-kajian oleh penyelidik sebelumnya mendapati bahawa ramai guru-guru hari ini terlibat dalam isu-isu yang berkaitan dengan tekanan kerja, kemurungan, tahap kepuasan kerja dan motivasi yang rendah serta kebimbangan kerja yang tinggi (Antoniou 2000; Noriah \& Aliza 2002; Taniza 2002). Fenomena tersebut boleh menyumbang kepada ketidak stabilan emosi guru-guru berkenaan. Menurut Antonius, Polychroni dan Walter (dlm Chua \& Adi 2002) tekanan kerja dalam kalangan guruguru tidak sahaja menyebabkan terjejasnya kesihatan fizikal dan mental, tetapi juga boleh mempengaruhi kualiti pengajaran guru tersebut. Justeru, peranan EQ sangat membantu guru-guru dalam menangani pelbagai tekanan yang dihadapi. Mengapakah keadaan ini boleh berlaku, sedangkan mereka telah dipersiapkan dalam latihan-latihan khas keguruan [seperti; kursus Diploma Pendidikan Malaysia (KDPM), Kursus 
Perguruan Lepasan Ijazah (KPLI), Kursus Dalam Perkhidmatan (KDP) seperti KSPK, kursus 14 minggu, kursus setahun dan sebagainya] menerusi kurikulum pendidikan yang disediakan oleh Bahagian Pendidikan Guru (BPG), Kementerian Pelajaran Malaysia? Persoalan seterusnya ialah "Adakah komponen EQ diterapkan dalam kurikulum pendidikan guru yang sedia ada? Jika ada, sejauhmanakah pelaksanaan dan keberkesanan kurikulum tersebut? Apakah bentuk modul yang digunakan untuk membantu meningkatkan EQ guru-guru berkenaan?

Falsafah Pendidikan Nergara (FPN) dengan jelas menyatakan bahawa pendidikan di Malaysia berhasrat untuk melahirkan insan yang seimbang dari segi jasmani, emosi, rohani dan intelek (JERI). Bagi merealisasikan cita-cita murni ini, guru merupakan agen dan pemangkin perubahan yang sangat penting, kerana sumbangan mereka adalah sangat besar dalam menentukan masa depan generasi akan datang. Hasrat ini dapat terlaksana apabila guru-guru mampu mendidik dengan berkesan. Martin dan Crossland (dlm Noriah 2002) menyatakan seorang guru mestilah menjadikan dirinya sebagai role model kepada pelajar dengan menunjukkan sikap dan tanggungjawabanya terhadap perkembangan sahsiah pelajar secara keseluruhan. Guru berkesan adalah mereka yang mempunyai IQ dan EQ yang seimbang (Awang Had 1998). Justeru, kurikulum latihan perguruan yang dilaksanakan sama ada di Institut Pendidikan Guru atau di universiti tempatan perlu mengambil kira kedua-dua elemen tersebut.

Menurut Noriah (2005) guru yang tidak mempunyai pengetahuan tentang emosi, sukar untuk mengarahkan emosi mereka dalam menghasilkan suatu pemikiran dan tindakan yang berkesan. Ketidaktahuan guru-guru ini boleh menjadi penghalang dalam membuat satu tindakan yang positif. Lazimnya mereka akan bergantung kepada perasaan dan dorongan emosi yang dominan. Sekiranya emosi yang dominan itu merupakan emosi yang negatif maka mereka akan mempunyai pemahaman yang cetek tentang perasaanya sendiri dan orang lain, serta tidak dapat mengarahkan emosi berkenaan sehingga tidak mampu bertindak secara positif. Individu yang kurang cerdas secara emosi, tidak berupaya memotivasikan diri sendiri atau orang lain. Mereka tidak mampu mengubah dan mengendalikan situasi yang buruk dengan cepat dan 
bersesuaian mengikut keadaan. Individu seperti ini biasanya sentiasa kurang selesa apabila menghadapi pelbagai keadaan yang kritikal.

Bahagian Kurikulum BPG, Kementerian Pelajaran Malaysia telahpun memasukan komponen EQ (kemahiran generik: kompetensi kecerdasan emosi) ke dalam kurikulum teras pendidikan bagi kursus persediaan calon guru-guru di peringkat ijazah yang berkuatkuasa mulai Julai 2004 (Kementerian Pelajaran Malaysia 2004). Bagi kursus perguruan lepasan ijazah (KPLI), komponen EQ hanya disisipkan dalam kursus psikologi pendidikan. Ini menunjukkan bahawa setakat ini belum terdapat satu modul latihan yang komprehensif piawai untuk membantu meningkatkan EQ guruguru. Selaras dengan matlamat kerajaan yang ingin menjadikan pendidikan di Malaysia bertaraf antarabangsa, maka kajian sebegini menjadi amat penting dijalankan supaya proses penambahbaikan kualiti perkhidmatan pendidikan guru dapat dipertingkatkan.

Kajian kecerdasan emosi (EQ) sudah banyak dijalankan di Barat, seperti kajian EQ yang dijalankan terhadap pekerja di Amerika Serikat, yang mendapati bahawa pendorong utama kejayaan dalam sesebuah syarikat adalah "kecerdasan emosi" (Ginanjar 2003; Goleman 1999). Bagaimanapun, diantara kajian-kajian yang dilakukan, sedikit sekali kajian dijalankan berkaitan dengan kecerdasan emosi dalam kalangan guru-guru, malah kajian tentang latihan untuk meningkatkan kecerdasan emosi amat kurang dilakukan. Justeru, kajian sebegini perlu dilakukan untuk melihat kesinambungan pelbagai dapatan kajian yang telah dihasilkan.

Di Malaysia, kajian tentang kecerdasan emosi telah banyak juga di jalankan, seperti kajian Mohd Najib (2000) yang memberi tumpuan terhadap kestabilan emosi guru-guru, kajian Noriah et al. (2003) ke atas pegawai kerajaan (polis, pegawai penjara, pegawai imegresen, jururawat dan guru-guru), kajian Wan Ashiba (2004) ke atas guru-guru sekolah berasrama dan tidak berasrama, kajian Syafrimen (2004) ke atas guru-guru sekolah menengah Zon Tengah Semenanjung Malaysia, dan kajian Syed Najmuddin (2005) ke atas guru-guru Maktab Rendah Sains MARA (MRSM). Kajian-kajian tersebut mendapati masih terdapat beberapa domain EQ yang perlu diberi perhatian dan latihan terhadap sampel dan subjek kajian terbabit. Kajian Noriah et al. (2003), kajian Syafrimen (2004) dan kajian Syed Najmuddin (2005) telah 
mendapati bahawa lima dari tujuh domain EQ yang wujud, masih berada pada peringkat yang relatif rendah. Sementara mengikut pandangan Goleman (1995, 1999), kelima-lima domain ini sangat berpengaruh dalam menentukan kestabilan emosi seseorang. Bagaimanapun kajian-kajian ini masih bersifat penerokaan tanpa mengambilkira pembolehubah latihan yang sesuai bagi membantu guru-guru ataupun sampel yang dikaji untuk meningkatkan EQ mereka. Justeru, satu kajian lanjutan yang memfokus kepada latihan untuk meningkatkan EQ tersebut perlu dijalankan, agar kesinambungan terhadap sesuatu hasil kajian tersebut dapat dilihat dalam sesebuah isuisu yang ingin dicari jalan penyelesaian.

\subsection{TUJUAN KAJIAN}

Kajian ini bertujuan untuk membina modul latihan EQ bagi membantu menyediakan garis panduan dalam latihan meningkatkan kecerdasan emosi guru-guru. Berdasarkan tujuan tersebut berikut adalah beberapa objektif kajian:

\subsubsection{Objektif Kajian}

i. Mengenal pasti kompetensi asas EQ yang perlu diberikan latihan dalam kalangan guru-guru?

ii. Mengenal pasti pandangan pakar dan orang-orang berjaya untuk pembinaan kompetensi EQ tersebut?

iii. Mengenal pasti kaedah yang sesuai untuk melatih kompetensi EQ tersebut?

iv. Mengenal pasti kompetensi EQ guru-guru sebelum dan selepas latihan menggunakan modul EQ yang dibina?

v. Mengenal pasti pandangan guru-guru tentang latihan EQ menggunakan modul latihan yang EQ dibina?

\subsubsection{Persoalan Kajian}

i. Apakah kompetensi asas EQ yang perlu diberikan latihan dalam kalangan guruguru? 
ii. Bagaimanakah pandangan pakar dan orang-orang berjaya untuk pembinaan kompetensi EQ tersebut?

iii. Apakah kaedah yang sesuai digunakan untuk melatih kompetensi EQ tersebut?

iv. Apakah profil kompetensi EQ guru-guru sebelum dan selepas latihan menggunakan modul EQ yang dibina?

v. Apakah pandangan guru-guru tentang latihan EQ menggunakan modul latihan yang EQ dibina?

\subsection{KEPENTINGAN KAJIAN}

BPG telah merangcang satu kursus persediaan berkaitan dengan kompetensi EQ yang dipanggil dengan kemahiran generik, berkuatkuasa mulai Julai 2004. Kursus tersebut dijadikan kursus teras bagi calon-calon guru yang mengambil ijazah perguruan di maktab-maktab perguruan Malaysia. Bagaimanapun didapati beberapa kelompangan pada kursus tersebut yang semestinya diberikan penekanan kepada mereka, seperti domain motivasi kendiri, kerohanian, kematangan dan beberapa kompetensi asas EQ seperti yang dikenal pasti di dalam kajian ini. Kajian-kajian yang dijalankan sebelum ini (Noriah et al. 2004; Syafrimen 2004; Syed Najmuddin 2005 \& Wan Ashibah 2004) mendapati kompetensi tersebut sangat penting dalam membina EQ seseorang. Justeru, pengkaji melihat satu keperluan untuk membangunkan sebuah modul yang dapat dijadikan sebagai panduan dan memberikan celik akal dan akhirnya membawa perubahan kepada peminaan EQ dalam kalangan guru-guru. Usaha sebegini dapat memberikan sumbangan bermakna kepada BPG dan penggubal kurikulum latihan perguruan, agar mengambil kira aspek-aspek penting seperti kompetensi asas EQ selain daripada IQ untuk melahirkan guru-guru yang berkesan, dalam merealisasikan hasrat Falsafah Pendidikan Negara.

Kecerdasan emosi sangat penting dalam proses P\&P. Di samping mempunyai kepakaran dalam sesuatu subjek, guru juga perlu mempunyai EQ yang tinggi. Guruguru akan mempunyai EQ yang tinggi, apabila mereka memiliki skor yang tinggi pada domain-domain EQ tersebut (kesedaran kendiri, regulasi kendiri, motovasi kendiri, empati, kemahiran sosial, kerohanian dan kematangan). Kajian Noriah et al. (2003), Syafrimen (2004) dan Syed Najmuddin (2005) mendapati pada umumnya guru-guru 
mempunyai skor yang tinggi pada domain kerohanian dan kematangan, namun mereka memperolehi skor yang agak rendah pada domain-domain yang lain khasnya pada kompetensi asas yang semestinya dimiliki oleh guru-guru berkenaan. Justeru, pembinaan modul latihan EQ menjadi penting untuk membantu memberikan celik akal kepada guru-guru, agar proses pembelajaran secara berterusan dapat berlaku, sehingga akhirnya menghantarkan guru-guru kepada tingkat kematangan EQ.

Kejayaan membangunkan modul EQ dalam kajian ini juga memberikan sumbangan bermakna kepada Kementerian Pelajaran Malaysia: seperti (i) dapat memberikan ruang intervensi berkaitan dengan kompetensi asas EQ yang mesti dimiliki oleh guru-guru, (ii) menyediakan platfom kepada guru-guru agar sentiasa memperbaiki diri untuk menjadi seorang guru yang berkesan melalui latihan-latihan EQ yang disediakan, dan akhirnya akan menambahkan keberkesanan pendidikan di sekolah. Dari segi teori pula, kajian ini dapat memperkuatkan lagi dapatan-dapatan kajian EQ yang diperolehi sebelum ini.

\subsection{BATASAN KAJIAN}

Terdapat beberapa batasan yang menghadkan dapatan kajian ini. Beberapa faktor yang membawa kepada batasan tersebut seperti dinyatakan di bawah ini:

i. Pada peringkat analisis keperluan kajian ini hanya melibatkan 112 orang guru yang sedang menuntut di peringkat Sarjana dan Doktor Falsafah di Fakulti Pendidikan Universiti Kebangsaan Malaysia. Pada fasa kedua pula melibatkan lapan orang pakar dan 24 orang orang-orang yang dianggap berjaya dalam bidang yang mereka ceburi, serta beberapa dokumen untuk keperluan analisis dokumen.

ii. Untuk tujuan pengujian modul, kajian ini baru berjaya melibatkan 33 orang guru yang dijadikan dalam satu kumpulan, kerana semasa pengujian modul tersebut melibat kos yang agak tinggi untuk pembiayaan makan, minum, tempat tinggal dan juga bahan-bahan keperluan latihan. Untuk mendapatkan komitmen penuh 
daripada guru-guru yang terlibat sebagai peserta latihan, pengkaji telah memenuhi semua perbelanjaan untuk keperluan latihan tersebut.

iii. Pengkaji baru berjaya menjalankan latihan selama empat hari kepada guru-guru dalam satu kumpulan seperti yang telah dikemukakan sebelum ini, seterusnya untuk melihat kesesuaian modul tersebut pengkaji baru berjaya mendapatkan pandangan guru-guru yang terlibat dalam latihan tersebut dalam bentuk maklum balas yang mereka berikan selepas latihan dijalankan. Pengkaji sememangnya memberikan ujian awal sebelum latihan dan juga selepas latihan menggunakan modul EQ dijalankan. Bagaimanapun pengkaji melihat kemungkinan akan lebih nampak keberkesanan modul ini apabila dilakukan dalam bentuk eksperimen sebenar dengan mewujudkan kumpulan kawalan, mengontrol segala pemboleh ubah luaran yang dapat mempengaruhi dapatan eksperimen. Sememangnya pengkaji mengharapkan akan ada kajian lanjutan selepas ini untuk menguji dan melihat keberkesanan modul ini menggunakan pendekatan sedekian.

\subsection{KERANGKA KONSEP KAJIAN}

Kerangka konsep kajian ini dibina berasaskan Falsafah Pendidikan Negara dan konsep EQ yang dicadangkan oleh Goleman-Noriah et al. (2004), seperti ditunjukan pada rajah 1.1 .

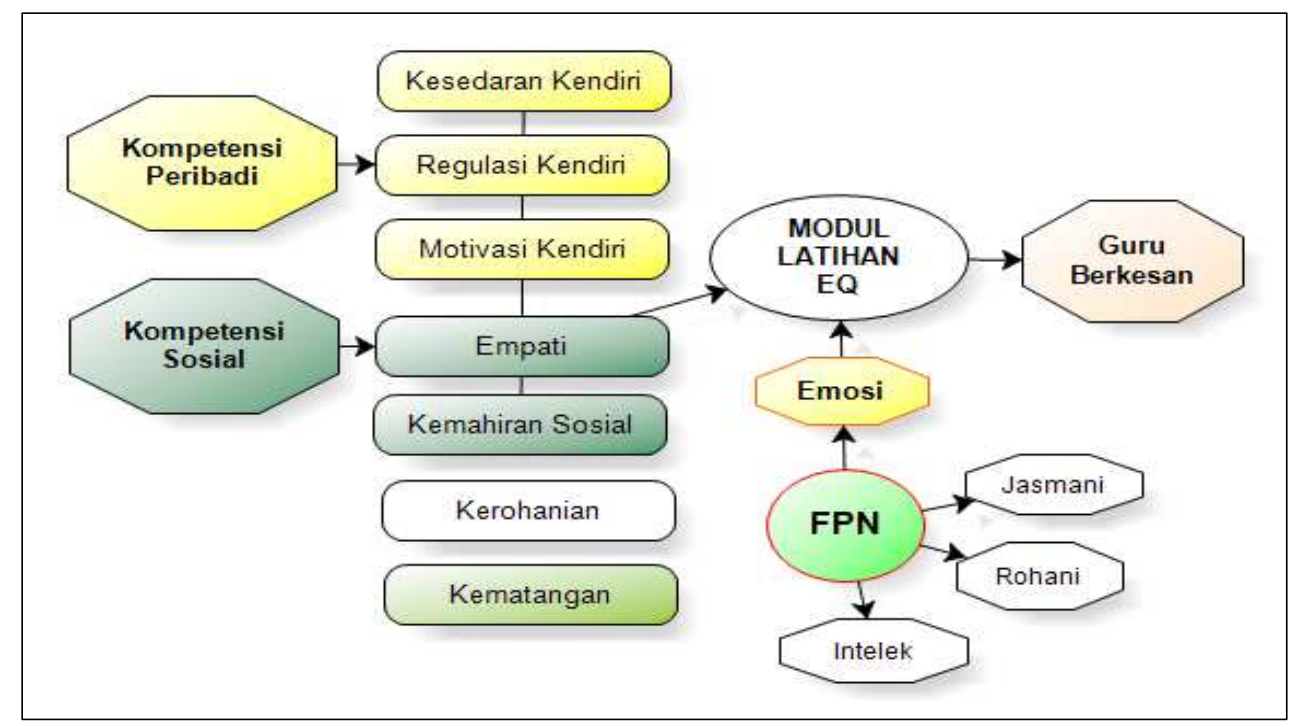

Rajah 1.1 Kerangka konsep kajian dibina berasaskan Falsafah Pendidikan Negara, konsep EQ Goleman-Noriah (2004) 
Falsafah Pendidikan Negara (FPN) merupakan acuan asas bagi membangunkan pendidikan dalam negara ini. FPN mempunyai cita-cita yang amat mulia iaitu berhasrat melahirkan insan yang seimbang dari segi Jasmani, Emosi, Rohani dan Intelek. Potensi Intelek yang dihasratkan oleh FPN adalah meliputi hikmah iaitu ilmu yang membawa kepada kebenaran, daya fikir yang beradab, kreatif dan inovatif, logik, dan analitis yang akan melahirkan ilmu yang bermanfaat dari segi teori dan praktis. Manakala potensi Rohani dan Emosi menyentuh aspek-aspek keyakinan kepada Tuhan, kepercayaan beragama, kematangan jiwa, penghayatan nilai-nilai murni dan norma masyarakat, berbudi pekerti mulia,berbakti dan berkorban. Potensi Jasmani pula menggarap aspek kecergasan fizikal dan kesihatan mental yang berfungsi untuk hidup berdikari dan patriotik terhadap masyarakat dan negara (Nor' Aini Dan \& Tajul Arifiin 2002).

Goleman dalam Noriah (2003) telah mengemukakan bahawa kecerdasan emosi dikaitkan dengan dua jenis kompetensi iaitu; kompetensi "peribadi" dan "kompetensi sosial". Kedua-dua kompetensi tersebut diwakili oleh lima domain EQ. Komptensi peribadi diwakili oleh tiga domain, iaitu; kesedaran kendiri (self-awareness), regulasi kendiri (self-regulation) dan motivasi kendiri (self-motivation),. Manakala komptensi sosial pula diwakili oleh dua domain, iaitu; empati (empathy) dan kemahiran sosial (social skills). Bagaimanapun, kajian yang dijalankan oleh Noriah et al (2003), mendapati wujudnya penambahan dua domain baru yang sangat berperanan dalam meningkatkan kecerdasan emosi seseorang. Dua domain tambahan tersebut adalah "kerohanian (spirituality)" dan "kematangan (maturity)".

\section{Kompetensi peribadi}

Kompetensi pribadi ini memberikan implikasi bagaimana seseorang menguruskan dirinya sendiri. Kompetensi ini mempunyai tiga domain iaitu kesedaran kendiri, regulasi kendiri dan motivasi kendiri.

Kesedaran kendiri ialah kebolehan seseorang mengetahui keadaan dalaman (perasaan), mengetahui apa yang sedang dirasakan pada satu masa tertentu, dan menggunakannya untuk memandu dalam mengambil sesuatu keputusan pada satu 
masa tertentu (Goleman,1999). Individu ini biasanya memiliki kayu ukur yang realistik atas kemampuan dan kepercayaan diri sendiri. Domain ini merupakan asas yang perlu ada sebelum wujudnya domain-domain yang lain dalam kecerdasan emosi. Domain ini mempunyai tiga subdomain iaitu:

\section{a. Kesedaran emosi (Emotional Awareness)}

Kesedaran diri ialah kemampuan untuk mengenal dan memilih-milih perasaan, memahami perasaan yang sedang dirasakan dan mengapa ianya diraskan serta mengetahui penyebab munculnya perasaan berkenaan. Kesedaran emosi merupakan keupayaan seseorang untuk mengenal pasti emosi yang wujud di dalam dirinya dan kesannya terhadap prestasi diri. Individu yang mempunyai kesedaran emosi yang tinggi biasanya dapat merasakan perasaan yang sedang bergejolak dalam dirinya (seperti; sedih, kecewa, marah dan sebagainya) serta boleh mengaitkannya dengan apa yang sedang dia difikirkan, dilakukan dan diungkapkan. Individu ini dapat mendengarkan bisikan hati dari dalam dirinya sendiri, mengenali bagaimana perasaannya dapat mempengaruhi hasil kerja yang sedang dijalankan. Individu ini juga dapat menyelaraskan diri dengan nilai-nilai yang diyakininya, dan sentiasa secara naluriah dapat menentukan tindakan yang terbaik. Individu tersebut juga sedar dan dapat mengandaikan kesan yang akan timbul akibat daripada luahan perasaannya terhadap dirinya sendiri dan orang lain.

b. Penilaian kendiri yang tepat (Accurate Self-Assessment)

Penilaian kendiri yang tepat merujuk pada keupayaan seseorang untuk mengetahui kekuatan dan kelemahan dirinya dalam melakukan sesuatu tugasan. Individu yang yang berkebolehan menilai dirinya dengan tepat sentiasa dapat menghargai kelebihan dan kekurangan orang lain. Sebaliknya, dalam memperbaiki kelemahan diri sendiri, individu ini akan lebih bersikap terbuka dalam menerima pandangan, dan kritikan daripada orang lain. Individu ini juga sentiasa bersikap terbuka dalam menerima maklumbalas dan cuba melihat idea atau pandangan baru yang dikemukakan dari perspektif yang baru. Individu berkenaan menganggap pandangan tersebut sebagai pembelajaran sepanjang hayat yang boleh diterima untuk lebih mengembangkan lagi potensi diri. Penilaian kendiri yang tepat juga 
akan menjadikan seseorang tahu, bila sepatutnya meminta bantuan dan dimana ia seharusnya memfokuskan diri untuk menumbuhkan kekuatan yang baru.

\section{c. Keyakinan Diri (Self Confidence)}

Keyakinan diri memberikan gambaran tentang keupayaan seseorang untuk menghargai diri sendiri dan dia percaya dengan kebolehan dirinya tersebut dalam melakukan sesuatu tugas. Individu sedemikian mempunyai keyakinan diri yang tinggi dan sentiasa berpegang kepada prinsip hidup yang dia yakini. Sebaliknya, mereka tidak mudah terpengaruh dengan gaya hidup orang lain. Individu ini tidak akan mengharapkan bantuan orang lain jika dia mampu melaksanakan sebarang tugas yang diamanahkan. Dia juga berani mengemukakan pendapat dan idea, walaupun pendapat dan idea tersebut kurang disenangi dan digemari orang lain. Individu ini sentiasa boleh membuat keputusan yang tepat walaupun terdapat tekanan dan pandangan yang mengelirukan daripada pihak lain.

Stein dan Book (2000) mengemukakan bahawa kesedaran kendiri merupakan asas tempat dibangunya semua domain kecerdasan emosi yang lain. Beliau mengatakan bahawa tidak mungkin individu akan berjaya meningkatkan domain EQ yang lain, seandainya individu tersebut tidak sedar dan mengenali dirinya sendiri. Individu yang mempunyai kesedaran kendiri yang tinggi akan mudah memperbaiki domain-domain kecerdasan emosi yang lainnya. Seseorang yang mempunyai naluri kesedaran kendiri yang kuat, dapat mengetahui saat mereka kurang bersemangat, mudah marah, sedih, ataupun terlalu gembira. Mereka juga menyedari bagaimana perasaan tersebut dapat mengubah perilaku mereka sehingga menyebabkan dirinya dijauhi oleh orang lain. Individu sebegini biasanya juga mengetahui punca-punca yang menjadi penyebab timbulnya perasaan berekenaan (Stein \& Book 2000). Dalam bahasa yang agak terkesan puitis, Stein (2000) juga mengukapkan bahawa;

...Tanpa kesedaran kendiri, walaupun kita bersungguh-sungguh untuk menyelasikan pelbagai permasalahan, pada akhirnya kita hanya akan berpusing-pusing dalam lingkaran permasalahan yang tiada hujung... 
Regulasi kendiri ialah kebolehan seseorang mengelola emosi sendiri sehingga memberikan impak yang positif dalam melaksanakan sesuatu tugasan. Individu ini selalu mengambil berat bisikan hatinya serta mampu menunda kenikmatan sesaat sebelum terwujudnya matlamat yang ingin dicapai (Goleman,1999). Individu ini juga mampu cepat pulih dari pelbagai tekanan emosi. Domain ini mengandungi lima subdomain iaitu:

\section{a. Kawalan kendiri (Self Control)}

Keupayaan mengawal naluri dan emosi-emosi yang destruktif. Seseorang itu dapat memantau perasaan dan menghalang tercetusnya emosi yang negatif daripada dikesan oleh orang lain. individu ini mempunyai cara tersendiri dalam mengelola emosi yang sedang terganggu. Dia sentiasa berusaha menyalurkan emosi berkenaan dengan cara-cara yang bermanfaat. Individu ini sentiasa tenang, berfikiran jernih dan tidak mudah goyah walupun dalam keadaan tertekan. Pengawalan kendiri ini diperlukan terutamanya dalam situasi seperti pertengkaran, perdebatan. Seseorang yang mempunyai kawalan kendiri yang bagus sentiasa dalam keadaan tenang dan dapat berfikir dengan jelas serta mampu memberikan tumpuan kepada isu yang sedang dibincangkan sebelum membuat sesuatu keputusan.

\section{b. Kebolehpercayaan (Trustworthiness)}

Kebolehpercayaan ialah kemampuan individu untuk mengekalkan kejujuran dan jati diri yang tinggi. Individu yang mempunyai kejujuran yang tinggi akan mudah didekati dan disenangi oleh individu-individu lain. Mereka akan sentiasa ikhlas dalam menjalin hubungan dengan orang lain, dalam melaksanakan tugasan serta memegang amanah yang diberikan. Ini dapat dilihat daripada ketulusan individu berkenaan dalam mengakui kesilapan sendiri serta keberaniannya menegur perbuatan orang lain yang kurang beretika. Individu ini juga berani membuat pendirian yang tegas berasaskan prinsip yang yang dipegang walaupun kurang disukai oleh orang lain. 


\section{c. Bertanggungjawab (Conscientiousness)}

Ialah seseorang yang mempunyai tanggungjawab diri yang tinggi ke atas pencapaian peribadi. Individu ini boleh menilai prestasi diri pada setiap masa dan sangat teliti dalam merencanakan sesuatu tugas, menyelesaikan tugas pada waktunya dan berdisiplin. Kebolehan ini penting dalam mengukur tahap persediaan diri seseorang dalam menjalankan sesuatu tugasan.

\section{d. Penyesuaian Diri (Adaptability)}

Ialah seseorang yang sangat luwes (flexible) dalam menangani dan menerima perubahan. Individu sedemikian mempunyai keterampilan dalam menangani pelbagai cabaran, terutama yang melibatkan perubahan yang drastik dan memerlukan respons dan tindakan yang selari dengan situasi yang anjal (fluid). Individu sentiasa boleh menyesuaikan diri dalam pelbagai situasi tanpa kehilang fokus, dia akan tetap nyaman dengan situas-situasi yang kurang menentu. Ciri keluwesan ini penting terutama bagi seseorang yang perlu membuat keputusan dalam situasi yang sentiasa berubah. Individu yang berkebolehan menyesuaikan diri dalam suasana kerja yang pelbagai akan menjadikan dirinya bertambah mahir dalam menyelesaikan sesuatu tugasan yang diberikan.

\section{e. Inovasi (Innovation)}

Ialah seseorang yang berkebolehan menerima idea-idea baru, pendekatan dan maklumat baru daripada sesiapa sahaja tanpa adanya perasaan negatif (negative thinking). Individu ini juga sentiasa mencari dan menjana idea-idea baru daripada pelbagai sumber. Individu ini mampu melihat sesuatu perkara daripada perspektif yang berbeza dan berani mengambil risiko apabila telah membuat sesuatu keputusan.

Motivasi kendiri ialah menggunakan hasrat yang paling dalam untuk menggerakan dan menuntun individu menuju sesuatu matlamat, membantu mengambil inisiatif dan selalu bertindak dengan efektif serta sentiasa bertahan dalam menghadapi sebarang kegagalan dan frustrasi (Goleman 1999). Goleman juga menyatakan bahawa individu yang mempunyai motivasi kendiri yang tinggi berupaya menggunakan dorongan suara hati dalam bertindak dan selalu memandu arah mereka dalam mewujudkan sesuatu tujuan. Dengan kata lain boleh juga diertikan dengan 
kecenderungan emosi dalam membimbing atau memudahkan seseorang untuk mencapai sesuatu matlamat. Ia mempunyai empat subdomain iaitu:

a. Dorongan Pencapaian (Achievement Drive) iaitu seseorang yang mempunyai semangat yang tinggi untuk mencapai suatu matlamat atau kecemerlangan. Individu ini, sentiasa meletakkan sasaran yang mencabar dengan risiko tertentu. Individu ini juga mahu menimba maklumat untuk menutupi kekurangan yang ada pada dirinya serta sentiasa mencari jalan untuk melakukan sesuatu dengan lebih baik. Individu ini juga sentiasa belajar cara-cara untuk meningkatkan prestasi dirinya.

b. Komitmen (Commitment) mensejajarkan matlamat peribadi dengan matlamat kumpulan atau organisasi. Individu ini sanggup berkorban demi mencapai matlamat yang lebih besar (matlamat organisasi). Individu ini juga sentiasa mencari makna (sense of purpose) dalam misi yang lebih besar. Menggunakan nilai utama kumpulan dalam membuat keputusan dan menjelaskan pilihan serta pandai memanfaatkan peluang untuk mencapai matlamat kumpulan.

\section{c. Inisiatif (Initiative)}

Seseorang yang menunjukkan sikap proaktif dan sentiasa bersedia merebut peluang yang ada. Melaksanakan tugas melangkaui matlamat yang ditetapkan, iaitu melakukan sesuatu dengan sempurna dan lebih baik. Individu ini berusaha membimbing rakan-rakan dan lain-lain untuk melaksanakan sesuatu tugas bersama-sama dengan cara tersendiri. Individu ini sentiasa berusaha hingga tercapai apa yang dicita-citakan.

\section{d. Optimis (Optimism)}

Seseorang yang berpendirian teguh dalam mencapai cita-cita walaupun terdapat pelbagai macam cabaran dan masalah. Individu yang optimis sentiasa berpandangan "untuk berjaya" dan bukannya berpandangan "untuk gagal" serta lebih melihat masalah sebagai cabaran yang boleh diatasi dan bukannya kelemahan peribadi yang menjadikan diri kurang bersemangat. 


\section{Kompetensi Sosial}

Kompetensi sosial ini menentukan bagaimana seseorang itu mampu menjalin hubungan dengan individu lain. Komptensi sosial mempunyai dua domain iaitu empati dan kemahiran sosial.

\section{i. Empati (Empathy)}

Empati ialah menyedari dan mampu merasakan apa yang dirasakan oleh individu lain (Goleman 1999). Seseorang yang mempunyai empati yang tinggi mampu memahami orang lain daripada perspektif mereka. Individu ini juga mampu menumbuhkan kepercayaan kepada orang lain, dan juga sentiasa mampu menyelaraskan diri dengan individu yang pelbagai. Sifat ini juga boleh menjadi faktor pendorong dan penyubur kemesraan dan keserasian dengan individu dari pelbagai latar belakang. Individu yang mempunyai sifat empati boleh menyelami kepahitan, kesusahan, kekecewaan atau keraguan seseorang terhadap sesuatu perkara (Goleman 1999). Empati ini mengandungi lima subdomain iaitu:

\section{a. Memahami Orang Lain (Understanding Others)}

Kebolehan mengesan perasaan dan perspektif orang lain, serta menunjukkan minat yang mendalam terhadap kepentingan (concern) mereka. Kebolehan memberikan perhatian terhadap tingkah laku emosi dan mendengar secara aktif luahan perasaan oleh seseorang. Menunjukkan sensitiviti dan memahami perspektif orang lain. Di samping itu juga sentiasa sedia membantu untuk memenuhi keperluan dan perasaan orang lain.

b. Mengembangkan Potensi Orang Lain (Developing Others)

Merasakan keperluan mengembangkan potensi orang lain dan berusaha menumbuhkan serta meningkatkan kemampuan mereka. Seseorang yang dapat mengakui dan memberi ganjaran atas ciri-ciri kekuatan dan pencapaian orang lain, menawarkan maklum balas yang berguna dan mengenal pasti keperluan orang lain untuk pengembangan diri. Individu ini juga mampu menjadi pembimbing dan menawarkan tugasan yang mencabar sehingga dapat 
membentuk dan mempertingkatkan kemahiran individu lain. Kebolehan ini adalah salah satu daripada pendekatan kepemimpinan yang efektif (Boyatzis Goleman, \& McKee 2002).

\section{c. Berorientasikan Perkhidmatan (Service Orientation)}

Menjangka, mengenal pasti dan memenuhi keperluan pelanggan. Seorang individu, sama ada guru, pensyarah, peniaga, pekerja komersial ataupun penjawat awam perlu memahami keperluan pelanggannya. Sama ada perkhidmatan yang diberikan telah memenuhi citarasa pelanggan atau belum. Seorang guru ataupun pensyarah, tentunya mereka akan memikirkan sama ada semua pelajar yang mengikuti kelas hari ini mampu menerima, memahami dan mempratikan materi yang telah diajarkan, tanpa ada pilih kasih diantara pelajarnya. Mereka juga sanggup mencari pelbagai kaedah untuk meningkatkan kepuasan dan kesetiaan pelanggan, menghulur bantuan yang sesuai dengan rela. Mereka juga patut memahami perspektif pelanggan dan bertindak sebagai penasihat serta pembimbing yang boleh dipercayai.

d. Mencungkil Kepelbagaian (Leveraging Diversity)

Memupuk peluang melalui pergaulan dengan kepelbagaian individu. Individu perlu menghormati dan membina hubungan baik dengan orang lain daripada berbagai latar belakang. Individu juga perlu memahami berbagai pandangan dunia luar, sensitif terhadap perbezaan kumpulan serta melihat kepelbagaian sebagai peluang. Mampu menciptakan persekitaran yang boleh membuatkan semua orang berkembang maju. Hal ini boleh diwujudkan dengan cara menghakis bias dan memupuk toleransi.

e. Kesedaran Politik (Political Awareness)

Keupayaan membaca emosi kumpulan dan hubunganya dengan pemegang kekuasaan. Mengesan pertalian sosial yang penting, memahami kuasa yang mempengaruhi pandangan dan tindakan klien, pelanggan atau pesaing. Di samping itu, kebolehan memahami realiti organisasi dan luaran. 
Corey dan Corey (1997) juga menyatakan bahawa individu yang berempati mampu menyelami perasaan seseorang dan mampu melihat dunia orang lain tersebut daripada perspektif mereka. Seterusnya Rogers dalam Corey, Corey \& Callahan (1998) pula menyatakan bahawa seseorang yang boleh menunjukkan sifat empati akan lebih mudah berinteraksi dengan orang lain, terutama dalam proses membantu seseorang.

Stein dan Book dalam bukunya Emotional Intelligence and Your Success (2000) memberikan pandangan tentang empati iaitu kemampuan untuk menyadari, memahami dan menghargai perasaan serta fikiran orang lain. dalam laras bahasa yang agak berbeza beliau juga mengemukakan; empati adalah "menyelaraskan diri" mengambil berat terhadap apa, bagaimana, serta memahami latarbelakang perasaan serta fikiran orang lain, sebagaimana orang tersebut merasakan dan memikirkannya. Individu yang mempunyai empati yang tinggi mampu memahami orang lain daripada persepektif individu berkenaan, sangat peduli serta memperlihatkan minat dan perhatian yang tinggi terhadap orang lain.

\section{ii. Kemahiran Sosial}

Kemahiran sosial ialah kemahiran mencetuskan respon yang dikehendaki daripada orang lain. Mampu menagani emosi dengan baik semasa berhubungan dengan orang lain, sentiasa cermat dan teliti dalam membaca situasi-situasi sosial. Mampu berinteraksi dengan lancar dan cekap dalam menggunakan keterampilan-keterampilan mempengaruhi orang lain. Individu ini biasanya mudah untuk bekerja sama dalam kumpulan (Goleman, 1999).

Goleman (1999) juga menyatakan bahawa domain ini membolehkan seseorang mengurus pelbagai emosi secara efektif dalam membina hubungan dengan orang lain. Individu yang mempunyai kemahiran sosial yang baik, mampu mentafsirkan dengan tepat situasi sosial yang berlaku di sekelilingnya serta mempunyai kemahiran untuk menjaga dan memimpin persekitaranya. Individu ini juga mampu menjadi pakar runding yang baik di samping berkebolehan menyelesaikan konflik, serta mampu mewujudkan kerjasama dan semangat berpasukan apabila bekerja dalam sesebuah kumpulan ataupun organisasi. Terdapat lapan subdomain iaitu: 


\section{a. Pengaruh (Influence)}

Menggunakan taktik yang efektif untuk membujuk orang lain. Individu yang mahir mempengaruhi orang lain dengan cara membuat penyampaian idea secara halus untuk menarik minat pendengar. Individu ini pandai menggunakan pelbagai strategi (seperti pengaruh tak langsung) untuk membina konsensus dan sokongan serta mencetuskan suasana yang dramatik untuk menonjolkan idea secara efektif.

\section{b. Komunikasi (Communication)}

Kemampuan seseorang mendengar secara terbuka dan menyampaikan mesej dengan cara yang meyakinkan. Individu yang mempunyai kemahiran berkomunikasi ini sentiasa efektif dalam bertolak ansur dan menyampaikan tanda emosi sejajar dengan mesej yang disampaikan. Individu ini juga suka berterus terang dalam isu yang rumit, mahu mendengar secara aktif, saling memahami dan sangat mengalu-alukan perkongsian maklumat. Mereka juga sentiasa menggalakkan komunikasi terbuka serta setia mendengar berita baik dan buruk.

\section{c. Pengurusan Konflik (Conflict Management)}

Mampu berunding dan menyelesaikan pertikaian. Individu yang berkemahiran dalam pengurusan konflik boleh menangani permasalahan yang sukar dengan bijaksana. Mereka juga boleh mengesan potensi konflik yang terjadi dalam suasana tertentu, mengetengahi percanggahan pendapat secara terbuka dan membantu meredakannya, menggalakkan pembahasan dan perbincangan terbuka serta merancang penyelesaian konflik berkenaan.

\section{d. Kepemimpinan (Leadership)}

Pemimpin berfungsi untuk memberi inspirasi dan membimbing individu dan kumpulan. Pemimpin yang baik melahir dan membangkitkan keghairahan untuk mencapai misi dan visi yang dirangka bersama. Mereka akan melangkah ke hadapan untuk memimpin bila diperlukan tanpa mengira kedudukan, membimbing prestasi orang lain dan pada masa yang sama mempertanggungjawabkan bawahan atas prestasinya masing-masing serta memimpin melalui teladan. 
e. Pemangkin Perubahan (Change Catalyst)

Pemangkin perubahan akan memulakan atau mempekerjakan perubahan yang berlaku dalam suatu organisasi. Seseorang yang mempunyai kecekapan ini mengetahui keperluan untuk berubah. Sentiasa berusaha untuk menghapus halangan dan mencabar keadaan yang boleh mengganggu keperluan untuk berubah. Mereka juga memperjuangkan perubahan secara bersama-sama (collaboration) dengan rakan-rakan setugas yang lain.

\section{f. Pembina Hubungan (Building Bonds)}

Membentuk hubungan yang bermakna dalam sebuah organisasi. Seseorang perlu memupuk dan mengekalkan rangkaian informal yang luas, membina hubungan yang saling memberi faedah, membina hubungan baik serta mengekalkan persahabatan peribadi dalam kalangan rakan sejawat.

\section{g. Kolaborasi dan Kerjasama (Collaborative and Cooperative)}

Bekerjasama dengan orang lain demi mencapai matlamat yang sama berpandukan misi dan visi organisasi. Kebolehan ini dipamerkan dengan mengimbangkan fokus terhadap tugasan serta perhatian terhadap hubungan. Kolaborasi, berkongsi rancangan, maklumat dan sumber serta mewujudkan persekitaran kerja yang positif dan mesra. Individu ini juga perlu mengesan dan memupuk peluang untuk bekerjasama antara rakan sejawat atau orang bawahan supaya matlamat organisasi dapat dicapai secara bersama-sama.

\section{h. Keupayaan Berpasukan (Team Capabilities)}

Mewujudkan sinergi kumpulan dalam mencapai matlamat bersama. Seorang pemimpin (informal atau formal) perlu membentuk ciri kumpulan yang berasaskan hormat menghormati, suka membantu dan bekerjasama. Pemimpin ini juga dapat membawa semua ahli kumpulan bersama-sama aktif dan ghairah dalam membina identiti kumpulan, semangat kekitaan dan komitmen serta memelihara kumpulan dan reputasinya di samping berkongsi penghargaan yang diterima secara bersama.

Menurut Stein dan Book (2000) kemahiran sosial ialah kemampuan seseorang untuk menunjukkan bahawa kita adalah ahli kumpulan dalam masyarakat yang dapat 
bekerja sama, berperan dan konstruktif. Domain EQ ini termasuk juga bertindak secara bertanggung jawab, walaupun mungkin kita secara peribadi tidak mendapatkan keuntungan secara langsung. Individu ini mampu melakukan sesuatu untuk dan bersama orang lain, bertindak sesuai dengan bisikan hati nurani, serta menjujung tinggi norma-norma yang berlaku di dalam masyarakat. Individu yang memiliki kemahiran sosial yang tinggi, memiliki kesedaran sosial dan sangat peduli dengan orang lain. Hal terlihat dalam kemampuannya memikul tanggung jawab hidup berorganisasi dan bermasyarakat. Individu ini juga dapat menerima orang lain, serta dapat memanfaatkan bakat dan potensi orang tersebut untuk kebaikan bersama.

\section{Kerohanian}

Domain kerohanian menggambarkan beberapa perkara seperti keredhaan, rasa tanggungjawab kepada pencipta serta kebolehan menghayati nilai-nilai agama. Keredhaan didefinisikan sebagai kebolehan seseorang untuk menerima dengan hati yang rela peraturan-peraturan tertentu yang digariskan oleh agama masing-masing dan peraturan-peraturan ini dijadikan sebagai garispanduan yang harus diterima dalam menjalani kehidupan. Kesedaran tentang tanggungjawab terhadap penciptanya membantu seseorang untuk melaksanakan tugas tanpa rasa jemu. Seterusnya boleh memberi semangat kepada individu tersebut untuk terus bekerja. Ini menunjukkan bahawa seseorang yang sentiasa aktif bekerja untuk memenuhi tanggungjawabnya sebagai seorang manusia kepada penciptanya akan dapat membina aras kerohanian yang tinggi. Untuk melaksanakan tanggungjawab itu sebaik mungkin, seseorang itu perlu berhubung dengan penciptanya di samping menguasai ilmu-ilmu yang perlu untuk memenuhi tuntutan kerohaniannya. Dalam mengamalkan nilai agama seseorang itu akan sentiasa berfikir dulu sebelum melakukan sesuatu perkara. Kekuatan kerohanian dikaitkan dengan kebolehan seseorang untuk bersabar, beriman, bertakwa dan ikhlas dalam melakukannya (Noriah et al. 2003).

\section{Kematangan}

Noriah et al (2003) telah mendapati bahawa domain kematangan ini merangkumi aspek usia, pengalaman dan pengetahuan seseorang serta kesannya terhadap 
kecerdasan emosi. Dari segi usia, didapati seseorang itu biasanya akan menjadi lebih matang apabila bertambah usia. Sifat kematangan ini digambarkan sebagai kebolehan seseorang untuk mengawal tingkah laku seiring dengan bertambahnya usia. Peningkatan usia dapat membantu seseorang untuk melakukan muhasabah diri untuk mengenal kelemahan dan kekuatan diri masing-masing. Dari aspek pengalaman pula, didapati ianya mempunyai perkaitan yang rapat dengan kecerdasan emosi. Seseorang yang mempunyai pengalaman yang positif tentang dunia pekerjaannya, dapat mengawal emosi dengan baik di tempat kerja berbanding dengan seorang pekerja yang masih kurang berpengalaman. Pengalaman juga boleh membantu seseorang belajar dan seterusnya menggunakan hasil pembelajaran tersebut apabila berada dalam keadaan konflik dengan diri sendiri ataupun orang lain. Mereka sentiasa menjadikan pengalaman-pengalaman lepas sebagai contoh dan tauladan. Peningkatan ilmu pengetahuan juga boleh membantu seseorang meningkatkan kematangan diri. Pengetahuan tersebut boleh diperolehi sama ada melalui pembelajaran secara formal (hasil daripada latihan dalam perkhidmatan atau sebelum perkhidmatan) atau secara tidak formal. Bagaimana pun, kebanyakan pembelajaran berlaku dalam keadaan tidak formal. Individu yang boleh menyerap ilmu pengetahuan secara tidak formal dan menggunakannya dalam kehidupan peribadi atau pekerjaannya secara berkesan akan dapat meningkatkan kepintaran emosinya.

Mayer et al (1999) mentakrifkan kecerdasan emosi sebagai satu domain prestasi manusia yang boleh dikaji dengan mengukur kebolehannya. Menurut Mayer, Caruso dan Salovey (1999) kecerdasan emosi mempunyai empat domain iaitu "kebolehan menerima dan menunjukkan emosi dengan tepat, kebolehan menyesuaikan emosi, kebolehan memahami sesuatu emosi dan mengawal emosi”. Bagaimanapun, kajian ini akan disandarkan pada model kecerdasan emosi (EQ) yang dicadangkan oleh Goleman-Noriah et al. (2004). 


\subsection{DEFINISI ISTILAH}

Definisi operasi atau konsep yang digunakan dalam kajian ini adalah:

\section{i. Modul EQ}

Modul EQ merupakan bahan terancang yang digunakan oleh penyelidik untuk menyampaikan konsep-konsep kecerdasan emosi supaya dapat difahami oleh orang lain (Zuria 2004). Modul EQ yang akan digunakan dalam kajian ini merangkumi tujuh domain EQ seperti yang dicadangkan Noriah-Goleman (2004). Modul tersebut akan dibangunkan berdasarkan model EQ yang dicadang oleh beliau dan juga mengambil kira pandangan-pandangan pakar, yang akan didapatkan melalui temubual mendalam dengan pakar-pakar tersebut.

Dalam kajian ini modul EQ dimaksudkan dengan modul latihan bagi tujuan meningkatkan EQ guru-guru di Malaysia, yang dibina menggunakan konsep EQ yang kemukakan oleh Goleman-Noriah et al (2004) yang menyatakan kecerdasan emosi atau emotional intelligence sebagai satu set kompetensi atau kemahiran berarahkan emosi yang membolehkan seseorang mengurus kehidupan mereka dengan baik. Ianya merangkumi kebolehan menyelami emosi sendiri untuk mengetahui dan menilai keadaan diri, menggunakan kecenderungan emosi untuk membimbing atau memudahkan seseorang mencapai sesuatu matlamat, kebolehan menyedari perasaan keperluan kehendak, dan masalah atau kegusaran orang lain, kebolehan mencetuskan respon yang sesuai daripada seseorang, sedar tentang kepentingan nilai agama sebagai perintis kehidupan, serta menggunakan pengalaman hidup (diri atau orang lain) sebagai panduan dalam menyelesaikan masalah. Justeru seseorang yang mempunyai EQ yang tinggi berkebolehan untuk mengetahui kekuatan dan kelemahan diri mereka, berkebolehan untuk membina motivasi yang tinggi untuk berjaya, boleh berkomunikasi secara berkesan serta perihatin terhadap kesukaran atau komplikasi situasi yang dihadapi oleh orang lain. Mereka juga boleh bekerja dalam satu pasukan, sedar tentang nilai serta pegangan hidup serta boleh menggunakan pengalaman lepas sebagai panduan kehidupan masa kini. 


\section{ii. Kecerdasan}

Kecerdasan mempunyai pelbagai takrifan bergantung kepada pakar atauppun ahli yang memberikan pengertian tentang kecerdasan tersebut. Pendefinisian ke atas kecerdasan juga bergantung kepada tempat dan budaya tertentu (Gardner 1990; Gardner 1991; Krechevsky 1993 \& Sternberg 1996). Justeru, budaya yang berbeza akan memberikan cara berfikir dan kecerdasan yang berbeza pula.

Bagi Wechsler (1958) kecerdasan ditakrifkan sebagai kebolehan seseorang untuk bertindak selari dengan matlamat, berfikir secara rasional serta boleh mengurus persekitaran dengan berkesan. Menurut Ausubel (1968) pula kecerdasan merupakan anugerah pelbagai fungsi yang membolehkan seseorang bertindak balas ke atas berbagai fenomena serta mampu berinteraksi dengan keadaan tertentu. Sedangkan menurut Gardner (1983), kecerdasan diertikan sebagai kemahiran yang dimiliki oleh seseorang dalam menyelesaikan sesuatu masalah yang akhirnya boleh memberikan pengetahuan baru kepada seseorang tersebut. Du Bois, Alverson dan Staley (dlm Syed 2005) pula menyatakan bahawa kecerdasan merupakan konstruk teoritikal untuk menerangkan bentuk kelakuan.

Bar-On (dlm Goleman 2001) menyatakan bahawa kecerdasan sebagai kemampuan seseorang dalam mengurus emosi, pengetahuan sosial dan kebolehan mempengaruhi kesemua kenolehan untuk berhadapan engan keperluan persekitaran secara berkesan. Salovey dan Mayer (dlm Goleman 2001) menyatakan bahawa kecerdasan merupakan kebolehan untuk mengurus perasaan dan emosi sendiri dan orang lain serta boleh membezakannya dalam kalangan mereka dan menggunakan matlamat tersebut untuk memandu pemikiran dan tindakan seseorang tersebut. Gardner (1993) dan Goleman (2001) memberikan gambaran tentang kecerdasan sebagai satu potensi biofizik untuk memproses informasi yang boleh diaktifkan dalam sesebuah budaya bagi menyelesaikan masalah atau menghasilkan sesuatu yang berharga dalam budaya tersebut. Seterusnya Gardner (1993) juga menyatakan kecerdasan sebagai kebolehan untuk menyelesaikan masalah atau menghasilkan produk yang bernilai dalam budaya sendiri, budaya orang lain ataupun dalam komuniti tertentu. 
Pada umumnya definisi kecerdasan yang dikemukakan oleh pakar-pakar di atas memberikan pengertian yang lebih kurang sama, iaitu keupayaan seseorang dalam menerima, memproses dan menilai maklumat dan menggunakan emosi secara terarah bagi mengawal pemikiran, tindakan dan mampu menyelesaikan masalah dalam persekitaran tertentu.

\section{iii. Emosi}

Menurut Mayer, Caruso dan Salovey (dlm Syed 2005), emosi adalah proses dalaman yang memantau serta mengkordinasi subsistem psikologi seperti kesedaran minda dan tindak balas fisiologi. Menurut Woolfolk (2004), reaksi emosi berlaku apabila mengalami sesuatu peristiwa atau melalui pemerhatian (termasuk mendengar dan membaca). Williams (2001) pula melihat emosi sebagai sesuatu ciri manusia yang kompleks dan multidimensi yang merangkumi komponen biologi dan budaya. Menurut beliau, emosi ini wujud atau kelihatan dalam pelbagai konteks hubungan sosial. Faktor persekitaran ini amat mempengaruhi kematangan individu dalam menentukan respons emosi dalam suasana yang berbeza (Saarni 2000). Sehubungan dengan itu, kajian ini melihat emosi daripada perspektif kecerdasan emosi.

iv. Kecerdasan Emosi (EQ)

Menurut Goleman (1999), EQ adalah kebolehan menyedari, mengenal pasti dan mengurus emosinya sendiri serta mampu menjalin hubungan mesra dengan orang lain serta memiliki motivasi kendiri yang tinggi. Ini selari dengan pandangan Mayer et al. (1999) yang mendefinisi EQ sebagai kebolehan individu mengenal pasti makna-makna emosi dan hubung kaitnya dengan perkara-perkara yang lain, termasuk juga kebolehan dalam menaakul dan menyelesai masalah.

Menurut Weisenger (dlm Syed 2005), EQ adalah kemahiran mencorakkan pemikiran dan membentuk tingkah laku dengan menggunakan emosi untuk mencapai sesuatu matlamat. Mayer, Salovey dan Caruso (2000) juga menyatakan EQ sebagai tingkah laku individu dalam menunjukkan emosi dan pemikiran dalam upaya membina hubungan di dalam masyarakat. Definisi ini dikukuhkan lagi oleh McCallum dan Piper 
(2000) yang mentakrifkan EQ sebagai satu konstruk yang mempengaruhi keupayaan individu untuk menguasai cabaran dan tekanan dalam persekitaran. Bagi Woolfolk (2004) pula EQ dinyatakan sebagai keupayaan seseorang dalam memproses maklumat emosi dengan tepat dan efisien. Seterusnya Lynn (2002) juga menyatakan bahawa EQ adalah kebijaksanaan dalam mengurus diri dan berinteraksi dengan orang lain.

\section{v. Kesedaran Kendiri}

Kesedaran kendiri dimaksudkan sebagai menyedari dan mengetahui perasaan sendiri di dalam sesuatu keadaan serta dapat memilih keutamaan dalam mengambil tindakan atau membuat keputusan. Individu ini boleh melakukan penilaian yang tepat ke atas keupayaan diri sindiri dan mempunyai keyakinan diri yang tinggi (Goleman 1999). Duval dan Wicklund (dlm Syed 2005) juga berpandangan yang sama di mana kesedaran dan kefahaman terhadap diri sendiri membolehkan seseorang itu membuat penilaian kendiri yang tepat. Kesedaran terhadap diri sendiri juga boleh membawa perubahan ke atas tingkah laku seseorang.

Weisenger (1998) menyatakan bahawa kesedaran kendiri ialah keupayaan mengawal diri, mengawal tindakan dan tindak balas yang baik dalam mencapai sesuatu matlamat. Bagi Covey (1990) pula kesedaran kendiri didefinisikan sebagai keupayaan untuk berfikir semasa proses pemikiran berlaku. Whitmore (dlm Syed 2005) menyatakan kesedaran kendiri sebagai menyedari bila dan bagaimana emosi diri boleh mengubah persepsi seseorang.

\section{vi. Regulasi Kendiri}

Regulasi kendiri ditakrifkan sebagai kemampuan mengurus emosi dalam melaksanakan kerja agar memudahkan dan tidak mengganggu tugasan tersebut. Kebolehan ini mampu memberikan kekuatan semangat untuk mencapai matlamat . Individu yang memiliki regulasi yang baik biasanya akan cepat pulih daripada tekanan emosi (Goleman 1999). Weisenger (1998) melihat regulasi kendiri sebagai kebolehan memahami emosi tertentu dan menggunakan emosi itu untuk mengawal sesuatu keadaan. 
vii. Motivasi Kendiri

Motivasi bermaksud keupayaan seseorang untuk menggunakan kemahuan diri sebagai pendorong dan panduan untuk mencapai sesuatu tujuan. Motivasi kendiri juga dapat membantu seseorang untuk sentisa berinisiatif, tabah dalam memperbaiki diri, dan menangani cabaran kehidupan (Goleman 1999). Motivasi kendiri juga bermaksud menggunakan emosi untuk merangsang semangat dalam mencapai sesuatu matlamat atau menyelesaikan sesuatu tugasan.

viii. Empati

Empati ialah kebolehan menyedari dan mengenal pasti perasaan orang lain, memahami sesuatu menurut perspektif orang lain serta mampu menimbulkan kemesraan dengan individu lain (Goleman 1999). Menurut Covey (1990) pula, empati adalah kebolehan memahami perasaan seseorang keseluruhannya. Mengikut Muhamad (1993) pula, empati ditakrifkan sebagai kebolehan individu menyelami perasaan seseorang dalam sesuatu keadaan tanpa memberi kemudaratan terhadap emosi sendiri. Empati juga dimaksudkan sebagai kebolehan menyelami perasaan seseorang mengikut persepsi individu tersebut, selalu memahami sebab-sebab seseorang bertindak dan dapat merasai emosi orang lain tersebut (Adler \& Towne 1984; Tangney dalam Tangney \& Fischer 1995; Elias, Tobias \& Friedlander 2002; Syed 2005). Seseorang yang mempunyai sifat empati dapat merasai keadaan emosi, fizikal atau psikologi seseorang. Ianya terdiri daripada komponen kognitif dan afektif, mempunyai keupayaan memahami, membayangkan dan secara afektif berkongsi keadaan emosi, fizikal atau psikologi seseorang (Waxler \& Robinson dalam Tangney \& Fischer 1995).

ix. Kemahiran Sosial

Menurut Goleman (1999), kemahiran sosial adalah kemampuan individu untuk mentafsir dengan tepat keadaan sosial dan dan persekitaranya. Kemahiran ini boleh mengurus pelbagai emosi yang tercetus dengan berkesan dalam sesuatu pergaulan. Individu yang berkemahiran sosial yang baik mampu membujuk, memimpin, berunding serta dapat menyelesaikan konflik bagi mewujudkan persefahaman dan 
mempunyai semangat berpasukan yang tinggi. Hartley (1999) menyatakan bahawa kemahiran sosial adalah keupayaan seseorang untuk memilih perlakuan yang sesuai mengikut keadaan tertentu.

x. Kerohanian

Kerohanian membawa maksud individu yang sentiasa redha dengan ketentuan Tuhan, sentiasa mengingatiNya dalam pelbagai aspek kehidupan, selalu bermuhasabah diri dan mematuhi peraturan agama yang dipercayainya.

\section{xi. Kematangan}

Kematangan merujuk kepada kematangan umur, pengetahuan dan pengalaman. Sehingga individu yang matang mempunyai kemahiran menyelesaikan masalah atau membuat keputusan yang tepat dan bijaksana.

\subsection{RUMUSAN}

Tujuan utama kajian ini adalah untuk membina modul EQ sebagai panduan untuk latihan kecerdasan emosi guru-guru. Dapatan kajian ini diharapkan dapat memberikan sumbangan terhadap guru-guru bagi menyediakan panduan meningkatkan kecerdasan emosi secara bersendirian ataupun melalui latihan-latihan EQ yang dijalankan. 


\section{BAB II}

\section{KAJIAN KEPUSTAKAAN}

\subsection{PENGENALAN}

Dalam bab ini pengkaji membincangkan tentang teori-teori berkaitan dengan kecerdasan, seperti kecerdasan Intelek (IQ), kecerdasan pelbagai (MI), kecerdasan emosi (EQ); EQ Mayer, Caruso dan Salovey, EQ Bar-On, EQ Goleman (1999), dan EQ Goleman-Noriah et al. (2004). Pada bahagian ini juga dibincangkan kajian-kajian berkaitan dengan EQ sama ada luar mahupun dalam negara. Di akhir bab ini pengkaji membincangkan tentang kajian-kajian berkaitan dengan latihan-latihan EQ yang sedia ada.

\subsection{TEORI-TEORI KECERDASAN}

Terdapat beberapa teori yang membincangkan tentang istilah kecerdasan. Penerangan ke atas kecerdasan itu bergantung kepada pakar yang mengemukakan teori tersebut. Untuk memudahkan pemahaman konsep kecerdasan dalam kajian ini, pengkaji cuba membincangkan beberapa konsep kecerdasan yang dilihat dari pelbagai sudut berbeza, seperti; kekerdasan intelektual (IQ), kecerdasan pelbagai (MI) dan kecerdasan emosi (EQ).

\subsubsection{Kecerdasan Intelektual (IQ)}

Manusia adalah makhluk yang cerdas, dan Allah telah melengkapkan manusia dengan domain kecerdasan yang kompleks. Ini ditunjukan oleh sejumlah temuan pakar 
(seperti Martha, Morelock, Feldman Spearman, Cattell, Guilford, Binet \& Wechler) yang mengarah kepada fakta bagi membuktikan bahwa manusia adalah makhluk ciptaan Allah yang paling cerdas. Manusia sentiasa menjadi makhluk yang terbaik apabila mampu mempergunakan kecerdasan yang diberikan secara maksimum.

Pakar-pakar psikologi telah cuba merumuskan maksud cerdas bagi seseorang. Perkataan cerdas atau intelligence telah mula dibincangkan sebelum terciptanya pelbagai ujian yang digunakan untuk mengukur kecerdasan kanak-kanak (Rosadah 2004). Kecerdasan didefinisikan sebagai keupayaan seseorang untuk memahami sesuatu konsep dan seterusnya memanipulasi konsep tersebut (Martha, Morelock \& Feldman 1991; Rosadah 2004). Menurut Spearman, Cattell dan Guilford (dlm Rosadah 2004) kecerdasan ialah sejenis fakulti mental yang dikaitkan dengan keupayaan am seseorang. Keupayaan am (general abilities) itulah yang bertanggungjawab menyerlahkan keistimewaan individu tersebut. Nik Aziz (dlm Rosadah 2004) juga mengemukakan bahawa kecerdasan boleh dikaitkan dengan operasi mental yang digunakan oleh manusia untuk menyelesaikan sesuatu masalah.

Thorndike (dlm Ubaydillah 2004) telah membahagi kecerdasan manusia kepada tiga; (i) kecerdasan abstrak iaitu kemampuan memahami simbol matematik dan bahasa, (ii) kecerdasan konkrit iaitu kemampuan memahami objek nyata dan (iii) kecerdasan sosial iaitu kemampuan untuk memahami dan mengelola hubungan baik sesama manusia. Handy (dlm Ubaydillah 2004) juga mengemukakan beberapa konsep kecerdasan iaitu; (i) kecerdasan logik (menaakul dan mengira), (ii) kecerdasan praktikal (kemampuan untuk mempraktekkan idea), (iii) kecerdasan verbal (kemampuan berbahasa dan berkomunikasi), (iv) kecerdasan muzik, (v) kecerdasan intrapersonal (kemampuan mengenali diri sendiri), (vi) kecerdasan interpersonal (kemampuan membina hubungan mesra dengan orang lain) dan (vii) kecerdasan spasial (kemampuan memahami ruang).

Seterusnya pakar-pakar psikologi juga telah memberikan gambaran yang berbeza tentang kecerdasan. Antaranya ialah Binet s(1916) menggambarkan kecerdasan sebagai keupayaan individu memahami, membuat pertimbangan dan menaakul dengan baik, Wechsler (1939) memberikan gambaran tentang kecerdasan 
sebagai kemampuan individu untuk bermaklum balas selaras dengan tujuan, berfikir rasional, dan mampu mengelola persekitaran dengan baik. Dari beberapa pendapat yang dikemukakan, yang paling menarik perhatian orang ramai ialah gambaran kecerdasan yang dikemukakan oleh Binet dan Simon. Beliau telah berjaya melahirkan satu ujian untuk mengukur kecerdasan seseorang "Stanford-Binet Intelligence Scale". Ujian tersebut kemudian diubahsuai oleh Terman di Amerika Syarikat dan dinamakan Intelligence Quotient "IQ" (Sternberg 1996). Ujian IQ ini mengukur tahap mental otak dalam logik-matematik dan linguistik, dan ianya dilaksanakan secara one-on-one relationship dengan expertise tester. Dapatan ujian ini ditukar kepada konstruk yang dipanggil "Mental Age" dan kemudian dibahagikan dengan umur sebenar dan didarabkan 100.

Bagaimanapun, pada awal tahun 80-an Gardner (1983) cuba mengemukakan satu lagi konsep kecerdasan. Menurut beliau terdapat sekurang-kurangnya tujuh jenis kecerdasan iaitu verbal-linguistik, logik-matematik, spatial, muzik, kinestetik badan, interpersonal dan intrapersonal. Konsep ini disebut sebagai Multiple Intelligence (MI). Pada tahun 1990 pula, Salovey dan Mayer cuba memperkenalkan satu lagi konsep kecerdasan iaitu "Kecerdasan Emosi (EQ)" yang kemudian dipopularkan oleh Goleman pada tahun 1995 melalui buku beliau "Emotional Intelligence”. Kecerdasan emosi yang dikemukakan oleh Goleman merangkumi sekali kecerdasan interpersonal dan intrapersonal, seperti dicadangkan oleh Gardner.

Kajian tentang EQ bermula daripada kajian neurologi, apabila bahagian dalam otak manusia yang dipanggil amygdala dibuang, maka individu tersebut tidak menunjukkan sebarang emosi dalam pelbagai keadaan. demikian juga bila pembedahan otak dibuat dan bahagian lobus prahadapan (prefrontal lobes) kiri dibuang, maka individu tersebut hilang keupayaan untuk membuat keputusan dalam hidup kesehariannya, walaupun IQ individu tersebut tidak terjejas. Ini menunjukkan terdapat satu lagi komponen otak dalam membuat keputusan selepas penaakulan intelek, iaitu pertimbangan emosi (Goleman 1995). 


\subsubsection{Kecerdasan Pelbagai (MI) Gardner}

Gardner (1995) telah mengemukakan konsep baru tentang kecerdasan. Beliau menyatakan bahawa terdapat sekurang-kurangnya lapan jenis kecerdasan bagi menggambarkan potensi seseorang. Jenis-jenis kecerdasan yang beliau maksudkan ialah; (i) verbal-linguistik atau kecerdasan berbahasa, (ii) logik-matematik, (iii) visual spatial atau kecerdasan dalam memahami pandangan-ruangan, (iv) muzik, (v) kinestetik badan, (vi) interpersonal, (vii) intrapersonal dan (viii) kecerdasan dalam memahami alam semulajadi. Kelapan-lapan jenis kecerdasan ini merupakan potensi yang wujud pada setiap individu dalam kadar yang berbeza-beza (Gardner 1983, Nik Aziz 1999; Rosadah 2004). Seseorang mungkin sahaja memiliki kecerdasan linguistik yang menonjol, tetapi memiliki kecerdasan muzik yang rendah dan sebaliknya (Taufik Pasiak 2003).

Permasalahan hari ini adalah, pendidikan di Malaysia walaupun telah mempunyai Falsafah Pendidikan Negara yang jelas iaitu untuk mewujudkan insan yang seimbang dari segi intelek, rohani, emosi dan jasmani, namun sampai sekarang masih terlihat kecenderungan sekolah yang masih berpaksikan akademik dan berorientasikan peperiksaan (Murad 2004), sehingga dalam mempersiapkan tenaga pendidikpun juga cenderung seperti itu. Murad (2004) menyatakan bahawa di sekolah, di maktab dan universiti hampir 90 peratus daripada pelajaran yang diberikan berbentuk pelajaran akademik (intelek) dan 10 peratus sahaja diperuntukan kepada kegiatan kurikulum dan kokurikulum yang boleh membantu mengembangkan potensi pelajar secara seimbang. Calon-calon guru dibekalkan dengan pengetahuan yang akan mereka ajarkan semula kepada pelajar apabila mereka mula berkhidmat di sekolah. Justru, penumpuan kepada aspek-aspek pembinaan karakter tidak dititik beratkan, sehingga sampai saat ini majoriti sekolah di Malaysia masih berorientasikan kepada peperiksaan, dan sebahagian besar pencapaian telah dititik beratkan pada sudut akademik (Murad 2004). Untuk melahirkan guru-guru berkesan tidak cukup hanya dengan keterampilan pengetahuan semata-mata, sebab tugas guru bukan hanya sekadar

menyampaikan ilmu pengetahuan tetapi juga mampu mencungkil pelbagai potensi yang ada pada masing-masing pelajar. Untuk mencungkil kepelbagaian potensi 
tersebut diperlukan seorang guru yang mempunyai kemampuan tentang perkara tersebut.

Kecerdasan pelbagai tidaklah merupakan perkara yang baru, kerana Gardner telah memperkenalkannya lebih kurang 20 tahun yang lepas. Taufik Pasiak (2003) mengemukakan bahawa otak manusia mempunyai peranan penting dalam kecerdasan dan kejayaan. Kejayaan dipandang sebagai pemakaian otak, bagaimanapun selama ini otak manusia belum dikembangkan secara maksimal (whole brin), ini terbukti pada pelaksanaan pendidikan yang masih belum menyeluruh. Beliau juga mengatakan bahawa dalam kepala manusia telah dibekalkan dengan tiga bentuk pemikiran, iaitu (i) pemikiran rasional, (ii) pemikiran emosional dan (iii) pemikiran spritual. Untuk mengembangkan seseorang secara seimbang mestilah menyentuh ketiga-tiga jenis pemikiran tersebut.

Beberapa halanganyang dihadapi sekarang adalah, mampukah kita mengubah minda masyarakat (terutamanya para pendidik) yang begitu yakin dan percaya dengan kecerdasan intelektual (IQ). Sehingga tidak aneh kita mendengar bahawa pelajarpelajar yang mendapatkan keputusan peperiksaan yang kurang baik, dianggap sebagai pelajar yang bodoh, lemah, kurang berjaya dan sebaliknya. Adakah kajian ilmiyah dijalankan bagi menjawab persoalan berkenaan? Adakah mana-mana kajian mendapati bahawa pelajar-pelajar yang cemerlang akademik, mereka juga cemerlang dalam kerjayanya? Ataupun sebaliknya. Pertanyaan-pertanyaan seperti inilah yang mungkin perlu diperolehi jawapannya! sehingga guru-guru tidak mudah membuat kesimpulan untuk mengatakan seseorang itu bodoh, lemah dan tidak berjaya.

\subsubsection{Kecerdasan Emosi (EQ)}

Mayer, Caruso dan Salovey (1999) berpandangan bahawa emosi merupakan satu peristiwa dalaman yang menyelaras subsistem psikologi termasuk tindak balas fisiologi dan kesedaran minda. Seterusnya Mayer et al. (1999) juga mentakrifkan kecerdasan emosi sebagai kebolehan untuk mengenal pasti makna-makna emosi dan hubungkaitnya dengan sesuatu, boleh menaakul dan menyelesaikan masalah berdasarkan emosi tersebut. Weisenger (2000) pula, menyatakan kecerdasan emosi 
sebagai kemampuan menggunakan emosi secara sengaja untuk membentuk tingkah laku dan pemikiran ke arah meningkatkan pencapaian sesuatu matlamat.

Konsep-konsep yang dikemukakan di atas telah dirangkum dalam satu definisi kecerdasan emosi yang dikemukakan oleh Goleman (1999), iaitu keupayaan seseorang menyedari dan mengenal pasti perasaannya dan perasaan orang lain, mempunyai motivasi kendiri, boleh mengurus emosinya sendiri serta mampu menjalin hubungan mesra dengan orang lain. Terdapat lima domain EQ dalam definisi yang dikemukakan oleh Goleman tersebut, iaitu; (i) Kesedaran kendiri, (ii) Regulasi kendiri, (iii) Motivasi kendiri, (iv) empati dan (v) kemahiran sosial. Beliau juga menyatakan bahawa EQ lebih menyumbang ke arah kejayaan seseorang berbanding dengan IQ. Dari kajian yang dijalankan beliau mendapati bahawa EQ telah menyumbang 80 peratus ke atas kejayaan seseorang berbanding IQ yang hanya menyumbang 20 peratus sahaja. Daripada dapatan ini beliau berpandangan bahawa sepatutnya bukan hanya individu yang mesti memiliki EQ malah juga organisasi bagi meningkatkan keuntungan dan produktiviti (Goleman 1999).

Kesedaran kendiri adalah mengetahui perasaan dalam satu-satu situasi dan dapat memilih keutamaan dalam membuat satu keputusan, mempunyai penilaian yang realistik tentang keupayaan diri dan keyakinan diri (Goleman 1999). Duval \& Wicklund (1972) memberi definisi yang hampir sama iaitu kesedaran kendiri adalah sebagai objek yang membolehkan seseorang menyesuaikan tingkah laku berdasarkan konsep kendiri. Kesedaran terhadap diri sendiri dan persekitaran akan membolehkan berlakunya penilaian kendiri. Menurut Weisenger (1998) kesedaran kendiri ialah kebolehan memantau diri, menguasai tindakan dan tindak balas ke arah sesuatu matlamat.

Regulasi kendiri adalah mengurus emosi sendiri supaya lebih mudah, tidak mengganggu dalam menyelesaikan sesuatu tugasan, berhemah dan berusaha menangguhkan perasaan untuk memuaskan hati dalam mengejar matlamat yang dinginkan, serta cepat pulih semula daripada tekanan emosi (Goleman 1999). Bagi Weisenger (1998) pula regulasi kendiri ialah memahami dan menggunakan emosi sendiri secara positif untuk mengawal sesuatu keadaan. 
Motivasi kendiri adalah menggunakan bisikan hati dalam menggerakan dan memandu arah seseorang untuk mewujudkan sesuatu tujuan. Motivasi dapat membantu dalam mengambil inisiatif dan bersungguh-sungguh untuk memperbaiki diri, serta sentiasa sabar dan tabah apabila menghadapi masalah dan kekecewaan (Goleman 1999). Motivasi kendiri juga bermaksud menggunakan emosi sendiri untuk merangsang demi mencapai sesuatu matlamat yang telah ditetapkan.

Empati adalah kebolehan seseorang untuk mengesan perasaan orang lain, boleh melihat dan memahami sudut pandang orang lain dari perspektif mereka, boleh mencetuskan dan menyuburkan kemesraan dengan pelbagai individu yang berlainan latar belakang (Goleman 1999). Bagi Covey (1990) empati ialah melihat sesuatu daripada sudut pandangan seseorang, memahami paradigma dan perasaan mereka dengan penuh emosional dan juga intelektual. Mengikut Muhamad (1993) pula mengemukakan bahawa empati ialah keupayaan untuk menyelami hati dan perasaan seseorang dengan tepat, serta berupaya keluar semula daripada keadaan tersebut tanpa meninggalkan sebarang kesan yang boleh memberikan mudarat kepada dirinya.

Kemahiran Sosial adalah kebolehan seseorang mengurus pelbagai emosi secara efektif dalam membina hubungan dengan orang lain, dan mampu mentafsir dengan tepat situasi sosial yang berlaku, mempunyai kemahiran dalam membujuk dan memimpin, berunding dan menyelesaikan konflik untuk mewujudkan kerjasama dan semangat berpasukan (Goleman 1999). May Lwin et all (2003) dalam bukunya How to Multiply Your Child's Intelligence melaporkan bahawa penyelidik untuk Harvard Review mendapati bahawa pemenang prestasi terbaik AT\&T Bell Labs, iaitu merupakan satu tempat (think tank) bagi engineer-engineer cerdas di New Jersey, bukanlah orang-orang yang mempunyai IQ yang tinggi, tetapi orang-orang yang pandai membina hubungan dengan orang lain, mempunyai rakan sekerja yang baik dan terkenal dalam kalangan kawan-kawan mereka. Faktor utama yang menentukan kejayaan dan kegagalan seorang eksekutif adalah kemampuan mereka dalam membina hubungan, memahami dan bekerja sama dengan orang lain. 80 peratus orang-orang yang tidak berjaya di tempat kerja, adalah kerana keterampilan bersosial yang buruk (Morgan McCall dan Michael Lombardo dalam May Lwin et al. 2003). 
May Lwin et al (2003) juga mengemukakan bahawa Individu yang mempunyai pemahaman yang rendah terhadap diri sendiri, sering tidak stabil secara emosi apabila berdepan dengan tekanan dan penderitaan. Individu sebegini cenderung tidak dapat mengatasi berbagai tantangan hidup, tidak selesa dengan kritikan dan pandangan orang lain, selalu sepi dalam keramaian dan sering tertekan secara emosi serta mudah menyerah. Implikasi dari kecenderungan tersebut, membuatkan individu mudah terpedaya dengan pengaruh-pengaruh negatif, cenderung berprestasi rendah dan tidak bermotivasi dalam mengerjakan sesuatu tugas.

\subsubsection{Kecerdasan Emosi Mayer, Caruso dan Salovey}

Mayer, Caruso dan Salovey (1999) mengemukakan bahawa kecerdasan emosi terdiri daripada empat domain iaitu (i) kebolehan membuat persepsi tentang emosi (emotional perception) iaitu kebolehan menerima, menilai dan menunjukan emosi dengan tepat, (ii) penyesuaian emosi (emotional facilitation of thought), (iii) memahami emosi (urdestanding of emotion) iaitu kebolehan memahami sesuatu emosi dan maklumat yang dibawa, dan (iv) ialah mengawal emosi (managing emotion) iaitu mengawal emosi untuk meningkatkan perkembangan emosi dan intelek. Mayer et al menyatakan bahawa kecerdasan emosi boleh bertambah bila umur dan pengalaman bertambah.

Menurut Weisenger (1998), keempat komponen asas kecerdasan emosi di atas telah dikenal pasti oleh dua ahli psikologi Mayer (University of New Hampshire) dan Salovey (Yale) yang mencipta istilah emotional intelligence. Menurut beliau, setiap komponen mewakili kebolehan tertentu, apabila digabungkan membentuk kecerdasan emosi. Komponen ini tersusun dalam bentuk hierarki dan komponen yang berada pada bahagian atas hirarki adalah gabungan daripada komponen-komponen yang berada pada hirarki bahagian bawah. Empat komponen tersebut ialah, (i) kebolehan menerima, menilai dan menunjukkan emosi dengan tepat, (ii) kebolehan mempamerkan perasaan bila diperlukan, yang mana individu dapat memahami diri sendiri dan orang lain, (iii) kebolehan memahami sesuatu emosi dan maklumat yang dibawa dan (iv) kebolehan mengawal emosi untuk meningkatkan perkembangan emosi dan intelek. 


\subsubsection{Kecerdasan Emosi Bar-On}

Bar-On (2000) mengemukakan bahawa terdapat lima domain kecerdasan emosi iaitu

(i) intrapersonal EQ ialah kemampuan untuk mengenal dan mengendalikan diri sendiri,

(ii) interpersonal EQ iaitu kemampuan invidu untuk bergaul, beriteraksi dengan orang lain, (iii) pengurusan stres EQ iaitu kemampuan untuk sentiasa bertahan dalam menghadapi stres dan mengendalikan impuls, kemampuan untuk sesalu tenang serta konsentrasi, (iv) penyesuaian EQ iaitu keupayaan individu untuk menyesuaian emosi mereka dengan pelbagai kedaan, dan (v) mood umum EQ iaitu kemampuan untuk mempertahankan sikap positif yang realistik terutama sekali ketika berhadapan dengan masa-masa sukar dan kritikal, mampu mensyukuri kehidupan, menyukai diri sendiri dan orang lain, selalu bersemangat serta berghairah dalam melakukan sebarang kegiatan.

Bar-On tcuba mengemukakan sub-sub domain bagi setiap domain yang beliau kemukakan. Intrapersonal EQ terdiri daripada beberapa subdomain iaitu (i) penjagaan diri (self-regard), (ii) kesedaran emosi, (iii) asertif, (iv) berdikari dan (v) peningkatan diri (self-actualization). Interpersonal EQ terdiri daripada 3 subdomain iaitu (i) empati, (ii) tanggungjawab sosial dan (iii) hubungan interpersonal. Pengurusan stres EQ mengandungi dua sub domain iaitu (i) toleran stres (stress tolerance) dan (ii) pengawalan dorongan (impulse control). Penyesuaian EQ pula terdapat 3 subdomain iaitu (i) ujian realiti, (ii) fleksibiliti dan penyelesaian masalah. Sedangkan mood umum EQ mengandungi dua subdomain iaitu (i) optimis dan (ii) kegembiraan.

Definisi bagi setiap subdomain di atas adalah seperti berikut: (i) penjagaan dirikebolehan untuk sedar, faham, menerima dan menghormati diri. (ii) kesedaran emosikebolehan mengenal pasti dan memahami emosi sendiri. (iii) asertif- kebolehan menyatakan perasaan, kepercayaan, pemikiran dan mempertahankan hak diri secara aman. (iv) berdikari- kebolehan melakukan sesuatu tanpa diperintah dan boleh mengawal pemikiran dan tindakan tanpa terpengaruh dengan emosi. (v) peningkatan diri- kebolehan mengetahui potensi diri sendiri dan melakukan sesuatu yang disukai. (vi) empati- kebolehan menyedari, memahami dan menghargai perasaan orang lain. (vii) tanggungjawab sosial- kebolehan menonjolkan diri sebagai seorang yang 
kooperatif dan memberi sumbangan kepada kumpulan. (viii) hubungan interpersonalkebolehan membina dan menjaga hubungan mesra berdasarkan keintiman dan memberi dan menerima kasih sayang. (ix) tolerans stres- kebolehan menghadapi situasi gawat dan intensiti emosi yang tinggi tanpa terjejas. (x) pengawalan dorongankebolehan mengawal dan menunda dorongan atau perasaan ingin bertindak serta mengawal emosi. (xi) ujian realiti- kebolehan menilai apa yang dirasai dengan apa yang sebenarnya berlaku. (xii) fleksibiliti- kebolehan menyesuaikan perasaan, pemikiran dan tingkah laku mengikut situasi. (xiii) penyelesaian masalah- kebolehan mengenal pasti dan mentakrif masalah peribadi dan masalah sosial seterusnya menjana dan melaksanakan penyelesaian yang efektif. (xiv) optimis- kebolehan melihat daripada sudut positif dan mengekalkan sikap positif walaupun dalam situasi sukar; dan (xv) kegembiraan- kebolehan merasakan kepuasan hidup, menikmati hidup memperlihatkan emosi positif.

\subsubsection{Kecerdasan Emosi Goleman}

Sebelum mempopularkan konsep kecerdasan emosi, Goleman, Boyatzis \& Annie Mckee (2002) telah cuba menjalankan satu kajian dan menganalisis lebih kurang 500 model kompetensi daripada beberapa syarikat yang bertaraf antarabangsa. Syarikatsyarikat dimaksudkan adalah seperti IBM, Lucent, PepsiCo, British Airways dan Credit Suisse First Boston serta organisasi-organisasi pelayanan kesihatan, institusi akademik, institusi-institusi kerajaan bahkan juga organisasi-organisasi keagamaan. Bagi menentukan kompetensi-kompetensi yang dominan dalam menentukan kejayaan seseorang, mereka cuba mengelompokan kepada tiga kategori utama, iaitu : (i) keterampilan teknikal tulen, seperti akaunting dan perencanaan keusahawanan, (ii) kemampuan kognitif, seperti pemikiran yang kritis dan analitik, (iii) sifat-sifat yang menunjukkan EQ, seperti kesedaran dan kemahiran bersosialisasi.

Untuk menciptakan beberapa model kompetensi itu, mereka telah berusaha menjalankan kajian melalui "expert interview" ke atas pemimipin-pemimpin syarikat besar di Amerika. Kajian tersebut dijalankan adalah untuk mengenal pasti kompetensikompetensi yang paling menonjol dalam kalangan pemimpin-pemimpin syarikat berkenaan (Goleman, Boyatzis \& Annie Mckee 2002). Pada masa yang sama, 
penyelidik juga melakukan kajian perbandingan, bagi tujuan membezakan corak kepimpinan antara pemimpin yang lebih senior dengan pemimpin yang masih junior, yang belum mempuyai pengalaman kerja yang banyak. Penyelidik telah berusaha melakukan temubual dan menjalankan pelbagai ujian bagi menentukan apakah kompetensi yang menghantarkan mereka kepada puncak kejayaan.

Dari pelbagai cara yang digunakan, mereka telah berjaya mengeluarkan beberapa senarai kompetensi yang menjadikan seseorang sebagai pemimpin yang efektif. Antara kompetensi yang paling menonjol ialah inisiatif, kerjasama (collaboration) dan empati (Goleman, Boyatzis \& Annie Mckee, 2002). Dari pelbagai analisis yang mereka jalankan, sama ada keterampilan-keterampilan kognitif ataupun keterampilan-keterampilan teknikal, didapati kompetensi yang berasaskan EQ lebih berperanan bahkan dianggap lebih penting dalam menjayakan sesebuah organisasi (Goleman, Boyatzis \& Annie Mckee, 2002). Sehingga Goleman et al juga menyatakan bahawa semakin tinggi tingkat organisasi yang dipimpin oleh seseorang maka semakin tinggi pula keperluanya terhadap EQ. Beliau mengatakan perbandingan yang tepat antara EQ dan IQ, sangat bergantung pada bagaimana kedua-duanya itu diukur. Bagaimanapun, berdasarkan pengalaman dan hasil kajian yang dijalankan, beliau mendapati bahawa EQ telah menyumbang 80 sampai 90 peratus ke atas kejayaan sesebuah organisasi. Kompetensi kognitif tulen, seperti keterampilan teknikal, keterampilan spesifik hanya mampu menghantarkan seseorang pada paras kualiti kerja normal, berbanding dengan individu yang memiliki EQ tinggi.

Goleman (1999) memberikan konsep tentang kecerdasan emosi iaitu kemampuan mengenali perasaan sendiri dan perasaan orang lain, kemampuan memotivasi diri sendiri dan kemampuan mengelola emosi sendiri dengan baik serta kebolehan membina hubungan dengan individu lain. Goleman (1999) juga menyatakan bahawa seseorang yang tidak mempunyai keupayaan mengawal emosi, agak sukar untuk berinteraksi dengan orang lain, dan tidak mampu untuk menjalankan pekerjaan yang digelutinya dengan baik. Mereka boleh digolongkan sebagai individu yang kurang berjaya dalam kerjaya yang diceburinya. Peristiwa-peristiwa cetusan emosi yang berlaku saat ini, terutama di tempat kerja, membawa kesan kepada tahap kestabilan dan kematangan emosi individu berkenaan (Goleman 1999). Beliau juga 
menyatakan bahawa EQ adalah satu yang diperlukan oleh seseorang untuk berjaya dalam kerjaya yang digelutinya. Goleman (1995) telah mengemukakan satu idea untuk menerangkan beberapa domain yang mempengaruhi kecerdasan emosi seseorang. Beliau cuba menerangkan penyebab kegagalan dan keberhasilan seseorang dalam kehidupan peribadi dan profesion masing-masing daripada perspektif EQ.

Menurut Goleman (1999), kecerdasan emosi terbahagi kepada dua kecekapan iaitu kecekapan peribadi dan kecekapan sosial. Kedua-dua kecekapan itu membolehkan seseorang mengawal diri sendiri dan berinteraksi dengan baik di tengahtengah masyarakat. Beliau telah mengenal pasti lima domain kecerdasan emosi iaitu kesedaran kendiri (self awareness), kawalan kendiri (self regulation), motivasi kendiri (self motivation), empati (empathy) dan kemahiran sosial (social skills). Beliau juga berpendapat bahawa kecerdasan ini boleh meningkat seiring dengan bertambahnya usia dan pengalaman seseorang, kecerdasan ini juga boleh dipelajari bagi sesiapa sahaja yang mahu mempelajari sepanjang hayatnya.

Goleman cuba memberikan penerangan tentang kepentingan bagi setiap domaian yang dicadangkan. (i) Kesedaran kendiri merupakan domain asas atau prasyarat yang perlu ada sebelum kewujudan domain-domain yang lain di dalam kecerdasan emosi. (ii) Regulasi kendiri dapat menentukan bentuk respons atau tindak balas yang dizahirkan oleh seseorang dalam sesuatu keadaan. (iii) motivasi kendiri merupakan pendorong bagi seseorang untuk mencapai sebarang matlamat yang diimpikan. (iv) empati membolehkan seseorang untuk memahami emosi atau perasaan orang lain sama ada marah, sedih, benci dan sebagainya. Kemampuan ini sangat penting dalam membentuk hubungan yang lebih akrab dengan individu-individu lain di dalam sesebuah organisasi ataupun masyarakat. Tanpa kemahiran ini, maka domain yang kelima iaitu kemahiran bersosial dalam sukar dicapai. Rajah 2.1 menunjukan model EQ yang dikemukakan oleh Goleman (1999). 


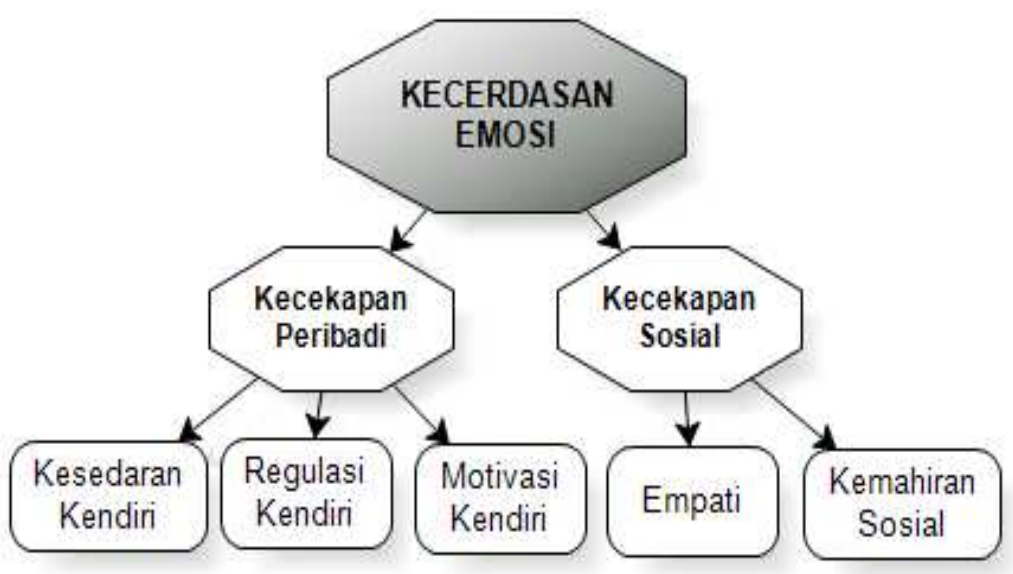

Rajah 2.1 Model EQ Goleman (1999)

\subsubsection{EQ Goleman-Noriah et al. (2004)}

Seperti disentuh sebelum ini Goleman (1999) mencadangkan bahawa EQ boleh dikaitkan dengan dua jenis kompetensi iaitu; kompetensi peribadi dan kompetensi sosial. Kedua-dua kompetensi tersebut diwakili oleh lima domain seperti berikut: kesedaran kendiri (self-awareness), regulasi kendiri (self-regulation), motivasi kendiri (self-motivation), empati (empathy), dan kemahiran bersosial (social skills). Bagaimanapun, kajian Noriah et al. (2004) mendapati wujudnya penambahan dua domain baru yang sangat berperanan dalam meningkatkan EQ seseorang. Dua domain tambahan tersebut adalah kerohanian (spirituality) dan kematangan (maturity). Domain-domain tersebut bersesuaian dengan budaya dan seting tempatan. Konsep ini diistilahkan dengan konsep "EQ Goleman-Noriah (2004)". Goleman-Noriah telah memberikan definisi bagi setiap domain tersebut, seperti berikut:

\section{Kompetensi Peribadi}

Kompetensi ini menentukan bagaimana seseorang itu menguruskan dan berinteraksi dengan diri sendiri. Kompetensi ini diwakili oleh tiga domain iaitu kesedaran kendiri, regulasi kendiri dan motivasi kendiri. 


\section{i. Kesedaran Kendiri}

Kesedaran kendiri adalah kemampuan individu untuk mengetahui perasaan sendiri, berkeupayaan menilai dengan tepat kekuatan dan kelemahan diri sendiri, mampu membina keyakinan diri dan sedar tentang niat dalam diri. Domain ini mempunyai tiga subdomain iaitu:

\section{a. Kesedaran emosi (Emotional Awareness)}

Kesedaran emosi merupakan keupayaan seseorang untuk mengenal pasti emosi yang wujud dalam dirinya dan kesannya terhadap prestasi sendiri. Seseorang yang mempunyai kesedaran emosi yang tinggi boleh merasakan perasaan yang sedang bergejolak di dalam dirinya (sama ada sedang sedih, kecewa, marah dan sebagainya) dan mampu mengaitkan perasaan tersebut dengan perkara yang sedang difikirkan, dilakukan dan diungkapkan. Individu tersebut juga sedar dan dapat menjangka kesan yang akan timbul akibat daripada luahan perasaannya terhadap dirinya dan orang lain. Individu tersebut juga menyedari nilai serta matlamat diri yang dijadikan panduan dalam menilai emosi sendiri.

b. Penilaian kendiri yang tepat (Accurate Self-Assessment)

Penilaian kendiri yang tepat merujuk kepada keupayaan seseorang untuk mengetahui kekuatan dan kelemahan dirinya dalam melakukan sesuatu tugas. Individu yang tahu kekuatan dan kelemahan diri sendiri dapat menghargai kelebihan dan kekurangan orang lain. Justeru, dalam memperbaiki kelemahan diri sendiri, individu ini lebih bersikap terbuka dalam menerima pandangan, dan kritikan daripada sesiapa sahaja. Individu ini juga sentiasa bersikap terbuka dalam menerima maklumbalas dan cuba melihat idea ataupun pandangan baru dari perspektif yang baru. Ini dianggap sebagai pembelajaran sepanjang hayat yang dilakukan untuk mengembangkan potensi diri.

\section{c. Keyakinan Diri (Self Confidence)}

Keyakinan diri menggambarkan keupayaan seseorang untuk menghargai diri sendiri dan percaya dengan kebolehan diri dalam melakukan sesuatu tugas. Individu sedemikian mempunyai nilai diri yang tinggi dan sentiasa berpegang 
kepada prinsip hidupnya. Mereka tidak mudah terpengaruh dengan gaya hidup orang lain. Individu ini juga tidak mengharap bantuan orang lain jika mereka mampu melaksanakan sesuatu tugas yang diamanahkan. Individu ini berani mengeluarkan pendapat dan idea walaupun mungkin tak digemari oleh orang lain. Individu ini boleh membuat keputusan yang tepat walaupun terdapat tekanan dan pandangan yang mengelirukan daripada orang lain.

\section{ii Regulasi Kendiri}

Regulasi kendiri Ialah kemampuan seseorang untuk mengawal perasaan yang sedang bergejolak di dalam dirinya, sentiasa jujur dalam bertindak, bertanggung jawab dalam melakukan sesuatu, fleksibel dengan perubahan yang berlaku dan mahu menerima idea-idea baru dari sesiapa sahaja tanpa diiringi dengan perasaan negatif. Terdapat lima subdomain iaitu:

\section{a. Kawalan Diri (Self Control)}

Keupayaan mengawal naluri dan emosi-emosi yang destruktif. Seseorang itu dapat memantau perasaan dan menghalang cetusan emosi yang negatif sehingga tidak dapat dikesan oleh orang lain. Pengawalan kendiri ini diperlukan terutamanya dalam situasi seperti pertengkaran, dan perdebatan yang memerlukan seseorang itu berada dalam keadaan tenang supaya dapat berfikir dengan jelas dan memberi tumpuan kepada isu yang dibincangkan sebelum membuat sesuatu keputusan.

b. Kebolehpercayaan (Trustworthiness)

Keupayaan mengekalkan kejujuran dan jati diri yang tinggi. Seseorang yang mempunyai kejujuran yang tinggi akan mudah didekati dan disenangi oleh individu-individu lain. Mereka juga sentiasa ikhlas dalam menjalin hubungan dengan orang lain dan juga dalam melaksanakan tugasan yang diamanahkan. Ini dapat dilihat daripada ketulusan mereka mengakui kesilapan sendiri dan keberanian mereka untuk menegur perbuatan orang lain yang kurang beretika. Mereka mempunyai pendirian yang tegas berasaskan prinsip yang dipegang walaupun tidak disukai oleh orang lain. 
c. Bertanggungjawab (Conscientiousness)

Ialah seseorang yang mempunyai tanggungjawab diri yang tinggi ke atas pencapaian peribadi. Individu ini boleh menilai prestasi diri pada setiap masa dan sangat teliti dalam merencanakan sesuatu tugasan, menyelesaikan tugas pada waktunya dan berdisiplin. Kebolehan ini penting dalam mengukur tahap persediaan diri seseorang dalam menjalankan sesuatu tugas yang diberikan.

\section{d. Penyesuaian Diri (Adaptability)}

Seseorang yang sangat luwes (flexible) dalam menangani perubahan. Individu sedemikian cekap dalam menangani pelbagai cabaran, terutama yang melibatkan perubahan yang drastik dan memerlukan respons serta taktik yang selari dengan situasi yang anjal (fluid). Ciri keluwesan ini penting terutama bagi seseorang yang perlu membuat keputusan dalam situasi yang sentiasa berubah. Justeru, kebolehan menyesuaikan diri dalam suasana kerja yang pelbagai boleh membantu seseorang agar lebih mahir dalam menyelesaikan sesuatu tugasan.

\section{e. Inovasi(Innovation)}

Seseorang yang berkebolehan menerima idea-idea baru, pendekatan dan maklumat baru daripada sesiapa sahaja tanpa perasaan negatif. Sentiasa mencari idea-idea baru daripada pelbagai sumber di samping menjana idea-idea baru. Individu sebegini sentiasa melihat sesuatu perkara daripada perspektif yang berbeza dan berani mengambil risiko dalam melakukan sesuatu.

\section{iii. Motivasi Kendiri}

Motivasi kendiri Ialah kecenderungan emosi dalam membimbing seseorang untuk mencapai sesuatu matlamat. Sentiasa bersemangat untuk mencapai kecemerlangan, mempunyai komitmen yang tinggi untuk mencapai matlamat yang telah ditetapkan, mempunyai sikap proaktif dan sentiasa merebut peluang yang ada serta sentiasa istiqamah dalam mewujudkan matlamat, walaupun terdapat pelbagai rintangan dan halangan yang mencabar. Ia mempunyai empat subdomain iaitu: 
a. Dorongan Pencapaian (Achievement Drive) seseorang yang mempunyai semangat untuk mencapai suatu matlamat dan kecemerlangan. Individu ini, meletakkan sasaran yang mencabar dengan risiko tertentu. Individu ini juga menimba maklumat untuk mengurangkan ketidaktentuan dan mencari jalan untuk melakukan sesuatu dengan lebih baik. Mereka juga sentiasa belajar pelbagai cara untuk meningkatkan prestasi ke arah yang lebih baik.

b. Komitmen (Commitment) mensejajarkan matlamat diri dengan matlamat kumpulan ataupun organisasi. Sanggup berkorban demi mencapai matlamat yang lebih besar iaitu matlamat organisasi. Individu juga perlu mencari makna (sense of purpose) dalam misi yang lebih besar. Menggunakan nilai utama kumpulan dalam membuat keputusan dan menjelaskan pilihan serta aktif merebut peluang untuk mencapai misi kumpulan.

\section{c. Inisiatif (Initiative)}

Seseorang yang sentiasa memperlihatkan sikap proaktif dan selalu bersedia merebut peluang yang ada. Melaksanakan tugas melebihi matlamat yang ditetapkan, melakukan sesuatu dengan sempurna dan berkeinginan untuk menjadi yang terbaik. Berupaya mengembleng rakan-rakan untuk melaksanakan sesuatu tugas bersama-sama dengan cara tersendiri. Individu ini sentiasa berusaha hingga tercapainya matlamat dicita-citakan.

\section{d. Optimis (Optimism)}

Seseorang yang beristiqamah dalam mencapai cita-cita walaupun terdapat pelbagai halangan dan masalah. Individu yang optimis melihat dari sudut "harapan untuk berjaya" dan bukannya dari sudut "kemungkinan untuk gagal" serta lebih melihat masalah sebagai rintangan yang boleh diatasi dan bukannya kelemahan peribadi.

\section{Kompetensi Sosial}

Kompetensi sosial merujuk kepada kemampuan seseorang dalam berinteraksi dengan orang lain, sama ada secara langsung mahupun sebaliknya. Setiap individu sentiasa 
berinteraksi dengan orang lain sepanjang masa. Proses berinteraksi ini terkadang dijalankan secara aktif dan terus-menerus. Bagaimanapun, terkadang proses ini dijalankan secara pasif dan secara tidak langsung. Kompetensi sosial ini mempunyai dua domain iaitu empati dan kemahiran sosial. Kompetensi ini juga boleh menentukan bagaimana seseorang menjalin hubungan dengan individu lain.

\section{i. $\quad$ Empati (Empathy)}

Bermaksud menyedari perasaan, keperluan dan kehendak, masalah atau keperihatinan (concern) yang dirasakan oleh orang lain. Mampu mengesan perasaan orang lain daripada perspektif mereka, mengesan keperluan, mengembangkan potensi orang lain, sentiasa berkeinginan untuk memenuhi keperluan orang lain, memupuk peluang melalui kepelbagaian manusia dan berupaya memahami perasaan kumpulan serta pemegang kekuasaan di sesebuah organisasi. Domain empati mempunyai lima subdomain iaitu:

\section{a. Memahami Orang Lain (Understanding Others)}

Kebolehan mengesan perasaan orang lain, perspektif mereka dan menunjukkan minat yang mendalam ke atas kehendak dan masalah (concern) yang dihadapi oleh individu lain. Kebolehan memberikan perhatian terhadap tingkah laku seseorang dan mahu mendengar secara aktif tentang apa sahaja yang dicurahkan oleh seseorang tersebut. Menunjukkan sensitiviti dan memahami orang lain daripada perspektif mereka. Individu ini juga sedia membantu berdasarkan pemahaman tentang keperluan dan perasaan orang lain.

b. Mengembangkan potensi orang lain (Developing Others)

Mampu mengesan keperluan mengembangkan potensi dan meningkatkan kebolehan mereka. Individu ini dapat mengakui dan memberi ganjaran atas kekuatan dan pencapaian orang lain. sentiasa memberikan maklum balas yang berguna dan mengenal pasti keperluan orang lain untuk perkembangan diri mereka. Seseorang juga boleh menjadi pembimbing dan menawarkan tugasan yang mencabar yang dapat membentuk kemahiran individu lain. Kebolehan ini adalah 
salah satu daripada pendekatan kepemimpinan yang efektif (Goleman, Boyatzis \& McKee 2002).

\section{c. Berorientasikan Perkhidmatan (Service Orientation)}

Menjangka, mengenal pasti dan memenuhi keperluan pelanggan. Seseorang individu itu sama ada peniaga, pekerja komersial mahu pun penjawat awam perlu memahami keperluan pelanggan tentang perkhidmatan mahupun produk yang diniagakan. Mereka juga sanggup mencari pelbagai kaedah untuk meningkatkan kepuasan dan kesetiaan pelanggan, menghulur bantuan yang sesuai dengan ikhlas. Mereka juga memahami perspektif pelanggan dan bertindak sebagai penasihat yang boleh dipercayai.

d. Mencungkil Kepelbagaian (Leveraging Diversity)

Memupuk peluang melalui kepelbagaian manusia. Seseorang itu perlu menghormati dan membina hubungan yang baik dengan orang daripada berbagai latar belakang, memahami berbagai pandangan dan sensitif terhadap perbezaan kumpulan serta melihat kepelbagaian sebagai peluang serta mencipta persekitaran dimana semua orang boleh berkembang maju. Seseorang juga perlu menghakis bias dan memupuk toleransi.

\section{e. Kesedaran Politik (Political Awareness)}

Keupayaan membaca emosi kumpulan serta pemegang tampuk kuasa dalam sesuatu hubungan, mengesan rangkaian sosial yang penting, memahami kuasa yang membentuk pandangan dan tindakan klien, pelanggan ataupun pesaing, dan juga mempunyai kebolehan dalam memahami realiti dalaman dan luaran organisasi.

\section{ii Kemahiran Sosial (social skill)}

Ialah kemahiran mencetuskan respons yang dikehendaki daripada orang lain. Menggunakan cara yang efektif untuk memujuk orang lain, mampu menerima dan menyampaikan mesej dengan penuh keyakinan dan berkebolehan menyelesaikan konflik dengan baik. Terdapat lapan subdomain iaitu: 


\section{a. Pengaruh (Influence)}

Menggunakan taktik yang efektif untuk membujuk orang lain, iaitu seseorang yang berkemahiran dalam mempengaruhi orang lain dengan cara menyampaikan idea secara halus untuk menarik minat orang lain. Individu ini pandai menggunakan strategi yang pelbagai (seperti pengaruh tak langsung) untuk membina konsensus dan sokongan, serta mencetus suasana yang dramatik untuk menonjolkan idea secara efektif.

\section{b. Komunikasi (Communication)}

Seseorang yang mendengar secara terbuka dan menyampaikan mesej secara meyakinkan. Individu yang mempunyai kemahiran berkomunikasi ini adalah efektif dalam bertolak ansur dan menyampaikan tanda emosi sejajar dengan mesej yang disampaikan. Mereka juga suka berterus terang dalam isu yang rumit, mendengar secara aktif, saling memahami dan mengalu-alukan perkongsian maklumat sepenuhnya. Mereka juga sentiasa menggalakkan komunikasi terbuka dan setia mendengar berita buruk dan baik.

\section{c. Pengurusan Konflik (Conflict Management)}

Berunding dan menyelesaikan pertikaian. Seseorang yang berkemahiran dalam pengurusan konflik boleh menangani individu yang sukar dihadapi serta boleh menenangkan keadaan yang tegang dengan bijaksana. Mereka juga boleh mengesan potensi konflik berlaku dalam sesuatu kedaan, menyelesaikan percanggahan pendapat secara terbuka dan membantu meredakannya, menggalakkan perbahasan dan perbincangan terbuka serta mampu merancang penyelesaian berbentuk tanpa merugikan salah satu pihak.

\section{d. Kepemimpinan (Leadership)}

Pemimpin berfungsi untuk memberi inspirasi dan membimbing individu dan kumpulan. Pemimpin yang baik melahir dan membangkitkan keghairahan untuk mencapai misi dan visi yang dirangka bersama. Mereka akan melangkah ke hadapan untuk memimpin bila diperlukan tanpa mengira kedudukan, membimbing prestasi orang lain dan pada masa yang sama mempertanggungjawabkan orang bawahan atas prestasi masing-masing, serta memimpin melalui teladan. 
e. Pemangkin Perubahan (Change Catalyst)

Pemangkin perubahan akan memulakan atau mempekerjakan perubahan yang berlaku dalam sesebuah organisasi. Seseorang yang mempunyai kecekapan ini mengetahui keperluan untuk berubah dan berusaha menyingkirkan halangan dan mencabar keadaan yang boleh mengganggu keperluan untuk berubah tersebut. Mereka juga memperjuangkan perubahan secara kolaborasi bersama-sama dengan rakan-rakan setugas yang lain.

\section{f. Membina Hubungan (Building Bonds)}

Membentuk hubungan yang bermakna dalam sesebuah organisasi. Seseorang perlu memupuk dan mengekalkan jaringan informal yang luas, membina hubungan yang saling memberi faedah, membina hubungan baik serta membina dan mengekalkan persahabatan peribadi dalam kalangan rakan sejawat.

\section{g. Kolaborasi dan Kerjasama (Collaboration and Cooperation)}

Bekerjasama dengan orang lain demi mencapai matlamat yang sama berpandukan misi dan visi organisasi. Kebolehan ini ditunjukkan dengan cara menyeimbangkan fokus terhadap tugasan serta perhatian terhadap hubungan. Kolaborasi, berkongsi rancangan, maklumat dan sumber serta mewujudkan persekitaran kerja yang positif dan mesra. Individu ini juga boleh mengesan dan memupuk peluang untuk bekerjasama antara rakan sejawat atau orang bawahan supaya matlamat organisasi dapat dicapai secara bersama-sama.

\section{h. Keupayaan Berpasukan (Team Capabilities)}

Mewujudkan sinergi kumpulan dalam mencapai matlamat bersama. Seorang pemimpin (informal atau formal) perlu membentuk ciri kumpulan yang berasaskan pada saling menghormati, suka membantu dan bekerjasama. Pemimpin ini juga dapat membawa semua ahli kumpulan bersama-sama aktif dan bersemangat dalam membina identiti kumpulan, semangat kekitaan dan komitmen serta memelihara kumpulan dan reputasi yang pernah didapat serta berkongsi penghargaan yang diterima bersama-sama. 


\section{Kerohanian}

Domain kerohanian menggambarkan beberapa perkara seperti keredhaan, rasa tanggungjawab kepada pencipta serta kebolehan menghayati nilai-nilai agama. Keredhaan didefinisikan sebagai kebolehan seseorang untuk menerima dengan hati yang tulus peraturan-peraturan tertentu yang digariskan oleh agama masing-masing. Peraturan-peraturan ini selalu dijadikan garis panduan dalam menjalani kehidupan seharian. Kesedaran tentang tanggungjawab terhadap penciptanya membantu seseorang itu dalam melaksanakan tugas tanpa rasa jemu. Seterusnya keadaan Ini boleh memberi semangat kepada individu untuk terus bekerja.

Ini memberikan implikasi bahawa seseorang yang sentiasa aktif bekerja untuk memenuhi tanggungjawab sebagai seorang manusia kepada penciptanya dapat membina aras keyakinan/kerohanian yang tinggi. Untuk melaksanakan tanggungjawab tersebut, seseorang itu perlu sentiasa berkomunikasi dengan penciptanya, dan pada masa yang sama mereka juga perlu menguasai pelbagai ilmu pengetahuan bagi memenuhi tuntutan kerohaniannya. Dalam mengamalkan nilai-nilai agama seseorang itu akan sentiasa berfikir dulu sebelum melakukan sesuatu perkara. Kekuatan kerohanian dikaitkan dengan kebolehan seseorang untuk bersabar, beriman, bertakwa dan ikhlas dalam melaksanakanya.

Gambaran tentang keredhaan yang dikemukakan oleh Noriah et al di atas disokong oleh Sholihin dan Anwar (2002), yang menyatakan bahawa keredhaan ialah menerima dengan ikhlas segala sesuatu yang dianugerah Allah SWT. Seseorang yang mempunyai sifat redha mampu melihat hikmah dan kebaikan di sebalik cubaan dan tantangan yang diberikan kepada mereka, dan tidak pernah berprasangka buruk terhadap ketentuan yang Maha kuasa. Bahkan pada masa yang sama ia mampu melihat keagungan, kebesaran, dan kemahasempurnaan zat yang memberikan cubaan tersebut, sehingga ia tidak pernah mengeluh dan merasa tersakiti dengan cubaan yang diberikan.

Abdul Halim dalam Sholihin\&Anwar (2002) juga mengemukakan bahawa redha dapat mendorong manusia agar bersuha sekuat tenaga untuk mendapatkan apa yang dicintai Allah dan rasul-Nya. Namun sebelum mendapatkanya ia harus menerima 
dan merelakan akibatnya dengan cara apapun yang disukai Allah SWT. Sikap mental redha ini merupakan kelanjutan rasa cinta atupun perpaduan dari mahabah dan sabar. Seterusnya Abdul Halim juga menyatakan bahawa redha juga mengandung pengertian menerima dengan lapang dada dan hati terbuka ke atas segala sesuatu yang datang daripada Allah SWT. sama ada dalam menerima mahupun dalam melaksanakan ketentuan-ketentuan agama yang berkaitan dengan masalah nasib dirinya. Hal ini dapat dimunculkan dengan adanya rasa cinta yang diperkuat dengan ketabahan, sehingga boleh menimbulkan kelapangan hati, kesediaan yang tulus ikhlas untuk berkorban, dan melakukan apa sahaja yang diperintahkan oleh yang dicintai. Dengan kata lain; rela menuruti apa yang dikehendaki oleh Allah SWT. tanpa rasa terpaksa, serta tidak pernah terlintas di dalam fikiran untuk menyesali nasib yang dialami.

Clinebell dalam Hawari (1999), dalam persidangan pertama "Pan Fasific on Drugs and Alkholism" mengemukakan dalam kertas kerjanya yang bertajuk "The Role of Religion in the Prevention and treatment of Additions the Growth Counseling Perspective” bahawa, pada dasarnya setiap diri manusia terdapat keperluan asas kerohanian (basic spiritual need) bukan hanya bagi manusia yang beragama, tetapi juga bagi manusia yang tidak memeluk agama sekalipun (sekuler).

Istilah kerohanian berasal daripada akar kata roh, secara amnya, istilah roh (kerohanian) sering diertikan dengan nyawa (Sholihin\&Anwar 2002). Namun jika diertikan secara terperinci, istilah roh (kerohanian) merujuk kepada dua makna. Pertama adalah roh yang bersumber dalam hati jasmani. Roh ini memancarkan cahaya ke seluruh tubuh manusia melalui urat nadi, pembuluh darah. Pancaran cahayanya memberikan kehidupan bagi manusia. Ia ibarat pelita di dalam sesebuah rumah yang menerangi seluruh sudut rumah tersebut. Jika pelitanya mati, maka mati pula cahaya di sekitar rumah berkenaan. Demikian juga dengan roh, jika mati maka mati pula kehidupan manusia. Dalam istilah perubatan, roh dalam pengertian pertama ini disebut dengan istilah "nyawa jasmani yang halus yang terbit dari panas gerak hati jasmani". Sedangkan dalam pandangan keagamaan (syari'at), istilah roh seperti itu tidaklah mempunyai kaitan dengan pengertian roh yang sebenar. 
Makna kedua, roh merupakan bisikan rabbani, yang dapat mengetahui segala sesuatu dan dapat menangkap segala pengertian. Bagaimanapun dalam pengertian yang kedua ini, roh tidak dapat diketahui hakikat sebenarnya. Inilah yang dimaksudkan oleh Allah di dalam Al-Isra' ayat 85;

Seandainya mereka bertanya tentang roh, maka katakanlah (Muhammad) bahawa roh itu adalah urusan tuhanku(QS. Al-Isra': 85).

Dari itu penyelidikan tentang roh dilarang di dalam agama. Sholihin dan Anwar menambahkan bahawa, yang boleh diketahui daripada roh itu adalah bahawa ianya merupakan satu esensi tidak terpisahkan yang masuk ke dalam dunia titah (amr), bahawa ia tidak berasal dari sesuatu yang abadi, melainkan diciptakan. Bagaimanapun, pemahaman tentang kerohanian yang dikemukakan dalam perbincangan ini, hanyalah pada lingkup fenomena-fenomena (accident) yang dihasilkan daripada aktiviti roh tersebut dalam diri manusia.

Hawari (1999) mengemukakan bahawa sebenarnya fitrah manusia sama ada disedari atau tidak, mereka sangat merindukan Tuhan Maha pencipta ataupun pelindungnya. Keperluan asas kerohanian sudah merupakan fitrah, dan suara fitrah itu muncul terdengar dan sentiasa menjerit memanggil Tuhannya manakala manusia berhadapan dengan berbagai malapetaka, kesukaran dan permasalahan hidup ataupun ditimpa sesuatu penyakit. Dalam keadaan sedemikian manusia akan tunduk, patuh, bertawakal dan tidak mengingkari Tuhannya. Bagaimanapun, sering juga terlihat pada sesetengah manusia apabila diberikan nikmat kepadanya, ketika itu mereka sering lalai dan seolah-olah tidak perlu kepada pertolongan Maha pencipta. Oleh itu, hendaknya manusia sentiasa berada pada jalan (agama) yang lurus, agar keperluan asas kerohanianya selalu terpenuhi.

Dari beberapa kajian yang telah dijalankan oleh pakar, antaranya adalah Clinebell dalam Hawari (1999) telah memperolehi 10 iventarisasi keperluan asas kerohanian manusia iaitu;

1. Keperluan ke atas kepercayaan dasar (basic trust) yang sentiasa secara teratur terus-menerus diulang guna membangkitkan kesedaran bahawa hidup ini adalah 
ibadah, maka manusia tidak perlu merasa takut apabila satu masa mereka mengalami kesusahan, kesedihan, ataupun kehilangan sesuatu yang sangat dicintai, kerana semua itu hanyalah cubaan keimanan dan keyakinan. Sebaliknya apabila diberi kenikmatan hendaknya manusia pandai mensyukurinya. "Apabila sedang senang jangan lupa daratan dan apabila sedang susah jangan lupa ingatan".

2. Keperluan ke atas makna hidup, manusia diciptakan membawa dua misi utama, iaitu sebagai pemimpin dimuka bumi (khalifah fil ardh) dan pada masa yang sama manusia juga sebagai hamba ('abdun) yang harus mengabdi kepada Tuhannya.

3. Keperluan ke atas komitmen peribadatan dan hubungkaitnya dengan hidup seharian. Setiap ibadah yang dilakukan hendaknya mempunyai pengaruh yang nyata dalam kehidupannya.

4. Keperluan ke atas pengisian keimanan dengan cara selalu mengadakan hubungan dengan Tuhan. Hal ini dimaksudkan agar kekuatan iman dan taqwa seseorang tidak melemah.

5. Keperluan ke atas bebas daripada rasa bersalah dan berdosa. Kedaan sebegini akan menjadi beban mental bagi seseorang, sehingga boleh menjejaskan kesihatan jiwa.

6. Keperluan ke atas penerimaan diri dan harga diri (self acceptence and self-estem). Setiap diri ingin dihargai dan diterima oleh persekitarannya, serta tidak ingin diremeh dan dipulaukan.

7. Keperluan ke atas rasa aman, terjamin dan keselamatan terhadap harapan masa hadapan.

8. Keperluan ke atas tercapainya derajat dan martabat yang semakin tinggi sebagai peribadi yang utuh (integrated personality).

9. Keperluan ke atas terpeliharanya dengan alam dan sesama manusia. Ini menunjukkan bahawa manusia tidak mampu untuk hidup sendirian, sangat memerlukan keberadaan orang lain dan persekitarannya. 
10. Keperluan ke atas hidup bermasyarakat yang penuh dengan nilai-nilai agama. Woodhouse dalam Hawari (1999) mengatakan bahawa bila anda tidak menginginkan wujudnya berbagai penyakit psikososial di dalam masyarakat, maka hendaknya dipegang teguh tiga jati diri, iaitu; (i) Masyarakat yang bergama, (ii) eksistensi keluarga, (3) sifat saling tolong-menolong diantara sesama dan tidak mementingkan diri sendiri.

Sepuluh inventarisasi yang kemukakan oleh Clinebell tersebut selari dengan ayat al qur'an: Afahasibtum annamaa kholaqnaakum 'abatsan wa 'annakum ilainaa laa turja'unn (Q.S. Annuur: 115) yang bermaksud;

Apakah kamu mengira bahawa sesungguhnya kami menjadikan kamu tidak akan kembali kepada kami semula? (Q.S.al-Nur: 115).

Dalam Islam, perkara-perkara yang berhubungkait dengan kerohanian seperti konsistensi (istiqamah), rendah hati (tawadhu'), berusaha dan berserah diri (tawakal), ketulusan (ikhlas), totaliti (kaffah), keseimbangan (tawazun), integriti dan penyempurnaan (ihsan), kesemuanya itu dipanggil dengan "akhaluqul karimah" (ginanjar, 2002). Seseorang yang memiliki sifat-sifat seperti ini akan sentiasa mengontrol dirinya ke arah yang disenangi oleh orang lain dan penciptanya. Sebenarnya perkara-perkara inilah yang menjadi asas utama dalam kecerdasan emosi.

Al-ghazali dalam Othman (1987) mengemukanan bahawa setiap manusia menerima sifat kerohanian langsung daripada Allah SWT. Kerohanian tersebut ada disaat embrio telah siap dan sesuai untuk menerima. Ketika terjadi pertemuan antara roh dan badan, terbentuklah makhluk baru, iaitu manusia. Perkara yang membezakan manusia dengan makhluk lainya ialah sifat dari kerohanianya yang disamakan dengan inti daripada manusia tersebut. Karakteristik daripada badannya adalah berasal daripada peribadinya sebagai hasil dari pertemuan antara roh dengan badanya. Kesemuanya itu merupakan kejadian yang memang sewajarnya dalam usaha untuk mencapai keyakinan. Dorongan untuk mencapai keyakinan ini bersandar pada sifat kerohanian manusia tersebut. Dorongan ini bukanlah merupakan permasalahan pilihan, tetapi merupakan suatu kenyataan yang sewajarnya dari sifat kerohanian yang dimiliki 
oleh seseorang. Alasan utama bagi Allah untuk memberikan sifat kerohanian kepada setiap manusia adalah, supaya manusia ketika berada di dunia memperolehi pengetahuan dengan menggunakan akal fikiran badaniyahnya untuk mengetahui ciptaan Allah, dan melalui sifat ini tersebut akhirnya manusia akan dapat mengenal tuhannya.

Al-ghazali juga mengatakan bahawa setiap insan yang dilahirkan wajib mengenal Allah, inilah yang dimaksudkan dalam agama dengan istilah fitrah. Usaha untuk mencari kebenaran merupakan usaha untuk memuaskan kerohanian manusia. Usaha sedemikian ialah bagi memperolehi kedamaian hidup dalam diri sendiri. Kedamaian ini akan dapat terwujud apabila seseorang mengalami dan mengetahui seluruh tingkatan yang ada. Iaitu ianya berusaha untuk mengatasi pelbagai masalah yang boleh menghalanginya untuk mengenal dunia asalnya. Mereka akan berusaha dengan gigih untuk melawan, menjahui dan menyingkirkan semua perkara yang menyebabkan dirinya terasing dari dunia kerohanian.

Seterusnya al-Ghazali juga mengatakan bahawa, diantara seluruh sifat-sifat manusia, hanya kerohanian yang mendapatkan kesenangan di dalam pemahaman kebenaran. Pertentangan pendapat di dalam peribadi seseorang adalah diakibatkan oleh sifat-sifat lain yang wujud pada manusia tersebut. Disiplin peribadi mengandung erti menguasai semua sifat-sifat yang ada dalam diri manusia untuk memuaskan kerohaniannya. Pengusaan tersebut bukan bererti pengingkaran, seperti menjalani hidup menyendiri (menjauhkan diri dari orang ramai), tetapi adalah untuk mengembangkan keseimbangan organis. Tidak satupun di dalam diri manusia yang harus dilupuskan, terkecuali gejala-gejala yang berlebihan yang terdapat di beberapa bahagian daripada peribadinya yang memberikan kesenangan kepada keinginankeinginan yang agak aneh, yang menjauhkan manusia dari peranan yang harmonis.

Pencapaian tingkat integrasi secara keseluruhan di bawah dominasi kerohanian, adalah merupakan langkah utama untuk mendapatkan satu pengetahuan tertentu. Proses pertumbuhan menuju integrasi diri diperlukan untuk memahami perkaraperkara tertentu daripada fenomena dunia. Perkara tersebut juga merupakan prasyarat untuk menggosok cermin pengertian dan mempersiapkan agar dapat memahami 
tingkatan-tingkatan yang lebih tinggi. Satu pengetahuan tertentu memerlukan satu proses perubahan diri yang panjang dan melelahkan, dimana ketentuan-ketentuan yang dinamis di dalam keperibadian manusia menjadi matang, yang pada setiap tahap belajar untuk memainkan peranan di dalam hubunganya dengan keseluruhan aspek, guna melayani sepenuhnya hala tuju kerohanian. Hanya selepas tahapan tersebut, cahaya kesedaran diri akan terpantul ke dalam hati, dan Allah dapat dikenal jauh ke dalam diri-Nya dan segala sesuatu dapat difahami inti patinya. Ini tentunya merupakan satu keadaan dimana pengetahuan dapat diketahui secara langsung, kerana adanya kenikmatan istimewa daripada kerohanian. Juga merupakan satu keadaan dimana tingkah laku moral menjadi biasa dan terlaksanakan dengan mudah.

Suharsono (2004) dalam bukunya optimalkan IQ, EQ \& SQ, mengatakan bahawa kerohanian akan dapat terpelihara apabila seseorang memelihara fitrahnya (potensi ketuhanan yang telah ada pada masing-masing manusia) dengan baik, tanpa mengotori dengan perilaku buruk, egoisme dan pelbagai sifat tercela lainya. Sepatutnya dengan fitrah inilah manusia cuba mempresepsi, berinteraksi dan mengatasi semua permasalahan yang muncul di dalam kehidupan mereka. Beliau cuba mencontohkan dengan kehidupan rasullah saw. yang semenjak kecilnya adalah sebagai seorang yang ummi, tidak mampu membaca dan menulis. Namun rasulullah adalah merupakan seorang yang paling cerdas kerohanianya, sama ada sebelum menjadi rasul, apatah lagi setelah menjadi rasul Allah SWT. Ini ditunjukan dengan pelbagai kebijaksanaan yang beliau tunjukkan ketika mahu menyelesaikan pelbagai permasalahan umat manusia yang dikenal dengan masyarakat jahiliyah. Rasulullah SAW. dihina, dicerca, dipulaukan, dimusuhi dan diperangi. Namun dengan kekuatan kerohanian yang dimiliki, beliau dapat menghadapi dan menyelesaikan semua permasalahan ini dengan baik.

Pasca Rasulullah s.a.w Suharsono (2004) juga cuba mencontohkan dengan kehidupan para wali songo atau orang-orang suci dan mukmin. Sebagaimana diketahui bahawa kepulauan Nusantara pada masa pemerintahan Majapahit terkenal dengan masyarakatnya yang majoriti pemeluk agam Hindu. Dalam masa yang tidak begitu lama kerajaan Majapahit dapat digantikan dengan kerajaan Islam. Kenapa ini boleh berlaku? Jawapanya, kerana para wali tersebut mempunyai kekuatan kerohanian untuk 
menundukan kerajaan Majapahit yang begitu besar, dan pada masa yang sama mereka juga mampu menaklukan kesedaran msyarakatnya.

Seseorang yang mempunyai kekuatan kerohanian, memandang dan menginterpretasikan sesuatu masalah bukan hanya berasaskan fakta dan fenomena, tetapi ia cuba melangkah lebih jauh dan mendalam. Iaitu cuba untuk memasuki pada aras epistimik dan subtansi. Jalaluddin dalam Suharsono (2004) mengemukakan bahawa, seseorang yang mempunyai kekuatan kerohanian memiliki pengetahuan yang didasarkan kepada inspirasi Ilahi. Beliau menyatakan bahawa pengetahuan ini sangat berharga berbanding pengetahuan mental semata-semata. Seseorang yang memiliki kekuatan kerohanian, mereka tidak hanya berfikir secara melintang (horizontal), akan tetapi pada masa yang sama mereka juga mampu berfikir secara menegak (vertikal) dengan memohon petunjuk dan mengembalikan segala sesuatunya kepada sang khaliqnya. Selalunya individu seperti ini akan memiliki dedikasi kerja yang lebih tulus, ikhlas, dan tidak suka mementingkan diri sendiri (egoisme), apatah lagi untuk menzalimi orang lain. Motivasi-motivasi yang mendorongnya untuk melakukan sesuatu juga sangat khas iaitu pengetahuan dan kebenaran.

Hawari (2003) juga mengemukakan bahawa, seseorang yang mempunyai kerohanian yang tinggi bukan hanya sekadar beragama, tetapi juga beriman dan bertaqwa kepada Allah s.w.t. Seseorang yang beriman adalah seorang yang betul-betul percaya bahawa allah itu ada, maha mendengar, maha melihat, dan maha mengetahui segala yang diucapkan serta yang terniat di dalam hati manusia. Selain daripada itu mereka juga percaya adanya malaikat yang selalu mengawasi setiap niat dan perbuatan yang dilakukan, sama ada yang baik mahupun yang buruk. Individu seperti ini sentiasa memegang amanah, konsisten (istiqanah), dan setiap tugasan yang dipercayakan kepadanya dipandang sebagai satu ibadah kepada Tuhannya. Oleh kerana itu setiap sikap dan tindakan yang diambil selalu berpandukan pada nilai-nilai moral dan etika agama, selalu memohon taufiq dan hidayah Allah., dalam melaksanakan amanah yang dipercayakan kepadanya. Hawari juga menyatakan bahawa, seseorang itu sangat perlu mempunyai kerohanian yang tinggi, kerana perkara tersebut dapat menjadikan dirinya bermanafaat bagi orang lain. Pada dasarnya setiap individu akan diminta untuk 
mempertanggungjawabkan setiap tugasan dan amanah yang diberikan oleh Allah s.w.t. Ini selari dengan hadis Rasulullah s.a.w. yang bermaksud;

Setiap kamu adalah pemimpin. Dan setiap pimpinan akan diminta pertanggungjawapannya terhadap apa yang dipimpinya (H.R. Bukhari dan Muslim).

Individu yang mempunyai kerohanian yang tinggi juga mempunyai rasa kasih sayang diantara sesama. Hal ini selari juga dengan hadis Rasulullah SAW. yang bermaksud;

Belumlah sempurna Iman seseorang, apabila tidak menyayangi orang lain sebagaimana ia menyayangi dirinya sendiri.

Seterusnya individu ini juga tidak termasuk ke dalam orang-orang yang mendustakan agama. Firman Allah yang bermaksud;

Tahukah kamu orang-orang yang mendustakan agama? Maka itulah orangorang yang menelantarkan anak yatim dan tidak menyuruh (manusia) memberi makan orang miskin" (QS. al-Ma'un, 107: 1-3).

Seseorang yang mempunyai kerohanian yang tinggi, selalu mengambil berat tentang kehidupan orang lain. Mereka tidak pernah membeza-bezakan status yang dimiliki orang lain tersebut, sama ada ianya yatim, orang miskin, kaya, berilmu, tidak berilmu dan sebagainya. Mereka memandang orang-orang berkenaan adalah sama dan tidak ada yang perlu dibeza-bezakan.

Khairul, Dimitri\&Agus (2003) mengemukakan bahawa, kerohanian adalah kemampuan manusia untuk memberikan makna ke atas segala sesuatu yang pernah dialami dan dijalani. Beliau mengatakan bahawa kerohanian bukanlah sekadar agama (religion). Terlepas daripada agama, manusia juga dapat memberi makna melalui pelbagai macam keyakinan. Sebahagian orang ada yang merasa hidupnya bermakna dengan menyimpan benda-benda yang diyakini mempunyai kekuatan. Sebahagian lagi ada yang merasa hidupnya bermakna dengan melakukan aktiviti kegemarannya. Bahkan ada yang merasakan hidupnya bermakna dengan melakukan perkara-perkara yang menyusahkan dirinya, seperti seorang perenang Malik Maidin yang telah 
bertungkus lumus merenangi beberapa benua yang sangat membahayakan dirinya, sama ada bahaya cuaca mahupun bahaya-bahaya binatang buas yang ada di dalam lautan yang sedang ia renangi. Bagaimanapun Khairul et al. mengatakan bahawa kebanyakan orang meyakini bahawa kecintaan pada Tuhan adalah merupakan sumber nilai kerohanian yang sejati. Wujud daripada kerohanian ini adalah sikap moral yang dipandang luhur oleh pelakunya. Kerana manusia dapat merasa memiliki makna dari berbagai perkara, agama akan mengarahkan manusia untuk mencari makna dengan pandangan lebih jauh dan bermakna di hadapan Tuhan.

Bagi Khairul et al. seseorang yang memiliki kerohanian yang tinggi mampu memaknakan seluruh fenomena yang dialami dalam kerangka berfikir positif dan sangat optimis tentang semesta. Beliau cuba mengemukakan beberapa formula bagi meningkatkan kekuatan kerohanian seseorang:

1. Sentiasa mengucapkan Alhamdulillah (memuji kepada Maha pencipta).

Dalam hal ini beliau cuba mengemukakan satu contoh bagi seseorang yang sentiasa mengucapkan alhamdulillah. Seorang perempuan yang sangat sederhana, tidak seberapa cantik, hidup sangat miskin, namun mempunyai perilaku yang lembut dan berbudi pekerti yang luhur. Mungkin sudah taqdir daripada Allah dia juga dipertemukan dengan suami yang miskin yang berprofesi sebagai penarik beca, tentunya mempunyai penghasilan yang tidak seberapa. Bersamaan dengan kemiskinan yang ia jalani bersama suaminya, beliau dikaruniakan tujuh orang anak, empat dari tujuh orang anak-anaknya meninggal sebelum menginjak usia dewasa. Yang paling menyedihkan lagi, dengan keadaan perekonomian yang sedemikiani, suami beliaupun masih berkesempatan untuk beristeri dua. Namun beliau tidak pernah bertengkar sama ada dengan suaminya mahupun dengan isteri mudanya. Kata-kata yang selalu keluar dari mulutnya adalah alhamdulillah, mungkin ini merupakan takdir dari pada Allah, masih banyak lagi orang yang lebih menderita daripada saya. 
2. Kemurahan hati yang tulus

Kemurahan hati yang tulus merupakan sumber kerohanian yang membuat diri sendiri dan orang lain menjadi lebih bahagia. Kemurahan hati akan muncul apabila seseorang seseorang sentiasa bersyukur dengan apa yang ia dapatkan. Seseorang yang memiliki kerohanian yang tinggi, sangat memahami hukum kemurahan hati yang tulus ini. Bukan hanya itu, malahan dia berusaha untuk menyebarkan pada persekitarannya, sama ada dalam bentuk materi ataupun bukan materi.

3. Kerendahan hati untuk tidak cepat menilai

Khairul et al (2003) mengemukan bahawa berdasarkan hasil tinjauan yang mereka jalankan, didapati bahawa diantara berbagai masalah yang dihadapi, ternyata yang betul-betul merupakan masalah hanyalah 7 peratus, selebihnya 93 peratus adalah masalah yang diciptakan oleh kecerdasan manusia. Kecerdasan yang dimiliki oleh seseorang seringkali menjadikanya subjektif dalam menilai sesuatu masalah yang terjadi. Seseorang yang mempunyai kerohanian yang tinggi, tidak mudah terperangkap dengan penilaian subjektif ke atas peristiwa-peristiwa yang menimpa dirinya. Kekuatan seseorang dalam mengendalikan fikiran, sehingga tidak mudah stres dan bersedih kerana sesuatu yang tidak sesuai dengan penilaian, juga menunjukkan tingginya tingkat kerohanian dalam diri seseorang tersebut. Dia akan berfikir bahawa Tuhan itu sangat indah dan menciptakan segala sesuatu itu indah. Tidak satupun akan terjadi, sejelek apapun menurut penilaian diri kita, kecuali atas Izin yang maha kuasa. Terkadang kita begitu mudah membuang kotoran yang sangat menjijikan pada hal di dalamnya ada terselip mutiara yang sangat berharga. Terkadang kita begitu mudah meluahkan makanan yang pahit ketika dimakan, padahalnya ia merupakan ubat bagi penyakit yang terkandung dalam badan. Individu yang memiliki kekuatan kerohanian sentiasa sedar bahawa penilaian yang mutlak hanyalah penilaian Tuhan, sedangkan penilaianya atas peristiwa ataupun yang ditunjukkan orang lain sentiasa memiliki ruang kemungkinan untuk salah.

Dari pelbagai pendapat yang dikemukakan di atas dapat ditarik satu kesimpulan bahawa untuk meningkatkan kekuatan kerohanian, dapat dilakukan dengan menghayati serta mengamalkan nilai-nilai agama, iaitu rukun iman dan rukun islam. Seseorang 
yang mempunyai kekuatan kerohanian yang tinggi akan mudah mengontrol dan mengawal pelbagai kesukaran dan permasalahan hidup yang dihadapinya. Sehingga dapat dikatakan bahawa kerohanian merupakan domain utama dalam pembentukan kecerdasan emosi seseorang (Noriah et al 2003; Syafrimen 2004, Syed Najmuddin 2005).

\section{Kematangan}

Domain kematangan ini menggambarkan aspek usia, pengalaman dan pengetahuan seseorang dan kesannya ke atas EQ. Dari segi usia, didapati seseorang itu biasanya akan menjadi lebih matang apabila bertambah usia. Sifat kematangan ini digambarkan sebagai kebolehan seseorang untuk mengawal tingkah laku apabila usia bertambah. Peningkatan usia membantu seseorang untuk melakukan muhasabah diri untuk mengenal kelemahan dan kekuatan diri masing-masing. Dari aspek pengalaman pula, didapati ianya mempunyai perkaitan yang rapat dengan EQ. Seseorang yang mempunyai pengalaman positif tentang dunia pekerjaannya, dapat mengawal emosi dengan baik di tempat kerja berbanding dengan seorang pekerja yang masih kurang berpengalaman di dunia pekerjaan. Pengalaman juga boleh membantu seseorang belajar dan seterusnya menggunakan hasil pembelajaran tersebut apabila dalam keadaan konflik dengan diri atau orang lain. Pengalaman lepas dianggap sebagai contoh atau tauladan. Peningkatan ilmu pengetahuan juga boleh membantukan seseorang meningkatkan kematangan diri. Pengetahuan tersebut boleh diperolehi sama ada melalui pembelajaran secara formal (hasil daripada latihan dalam perkhidmatan atau sebelum perkhidmatan) atau secara tidak formal. Bagaimana pun, kebanyakan pembelajaran berlaku dalam keadaan tidak formal. Individu yang boleh menyerap ilmu pengetahuan secara tidak formal dan menggunakannya dalam kehidupan peribadi atau pekerjaannya secara berkesan dapat meningkatkan kecerdasan emosinya. Rumusan tentang konsep EQ Goleman-Noriah et al. (2004) tersebut dapat di rujuk pada Rajah 2.2 selepas perenggan di bawah ini.

Model EQ yang dicadangkan oleh Goleman-Noriah et al. (2004) ini telah dijadikan asas kepada kajian ini. Selari dengan beberapa kajian sebelum ini (Noriah 2004; Syafrimen 2004; Syed Najmuddin 2005; Rorlinda 2008 dan Wan Ashibah 
2004), yang melihat bahawa model ini selari dengan konteks budaya tempatan. Dalam seting pendidikan, model ini juga selari dengan Falsafah Pendidikan Negara (FPN) yang juga menyentuh aspek emosi, sekaligus aspek kerohanian yang menjadi ciri utama masyarakat tempatan. Justeru, pembinaan modul EQ yang diasaskan kepada FPN dan model EQ tersebut dapat memberikan satu pencerahan dan nuansa baru kepada guru-guru supaya dapat melihat lebih jelas lagi hasrat FPN dalam memandu halatuju pendidikan di negara ini.

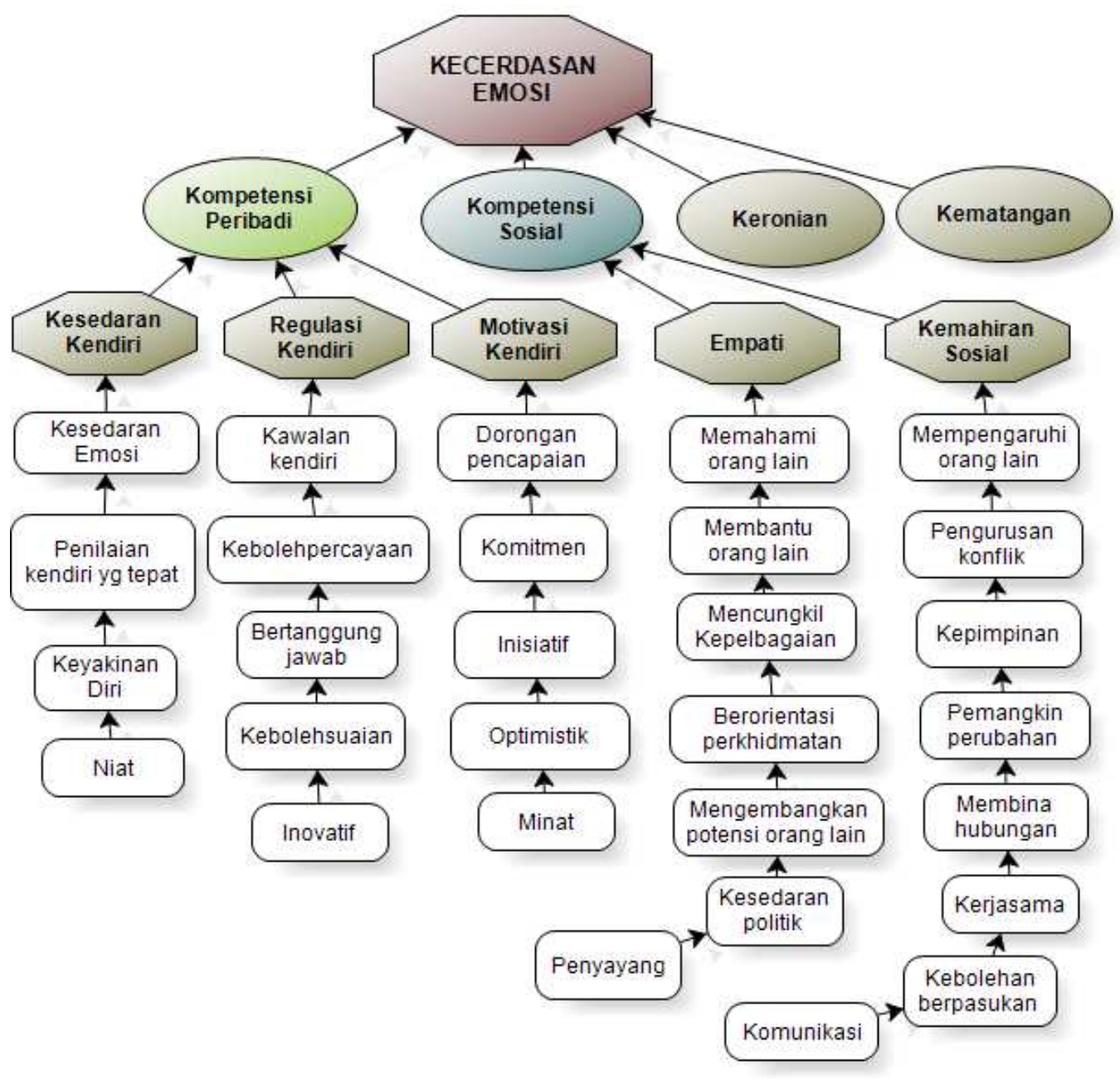

Rajah 2.2 Model EQ Noriah-Goleman (2004) 


\subsection{KAJIAN-KAJIAN BERKAITAN}

Kajian tentang kecerdasan emosi (EQ) telah banyak dijalankan di luar negara, seperti EQ dalam dunia usaha, pendidikan dan sebagainya Bagaimanapun, kajian EQ dalam pendidikan (khususnya kajian tentang guru-guru) sangat terbatas dan agak sukar ditemukan berbanding dengan EQ dalam bidang-bidang yang lain . Apatah lagi kajian tentang keberkesanan latihan modul EQ ke atas guru-guru. Perkara ini kemungkinan disebabkan oleh sejarah EQ yang masih baru lagi. Kajian EQ mula-mula ditemukan ketika Bar-On cuba melaporkan rahasia kejayaan individu-individu berjaya dalam usaha mereka, seterusnya dipopulerkan oleh Goleman tahun 1995.

\subsubsection{Kajian-Kajian Di Luar Negara}

Terdapat beberapa kajian tentang pembinaan modul dan aktiviti latihan EQ yang dijalankan di luar negara, seperti kajian yang dijalankan oleh Lewkowicz (1999) dan Lynn (2002). Beliau telah mencadangkan beberapa aktiviti pembinaan EQ ke atas individu. Aktiviti pembinaan EQ yang beliau cadangkan merangkumi kedua-dua kompetensi EQ "personal dan sosial” seperti yang dicadangkan oleh Goleman (1999) dan Goleman-Noriah (2004). Antara aktiviti yang dicadangkan oleh Lynn (2002) ialah "Champion or Chump, Importance Meter, Rank Order Your Employees, Ask for Feedback, Personality Contest, Coming Through, Listening Habits, Genuine Listening, I Was Appreciated, A Grateful Heart, Common Mistakes with gratitute, A Note of Thanks". Saranan aktiviti tersebut difokuskan bagi meningkatkan domain kesedaran kendiri, regulasi kendiri, empati dan kemahiran sosial. Menurut Lynn (2002) aktivitiaktiviti EQ ini secara tidak langsung juga dapat membina kemahiran komunikasi, kerja berpasukan, kemahiran interpersonal dan kebolehan memimpin, mengurus serta menyelia.

Lynn (2002) telah menyediakan garis panduan lengkap bagi setiap aktiviti yang dicadangkan (seperti; aspek objektif, peruntukan masa, bahan-bahan, tahap kesukaran, tips-tips, arahan aktiviti dan soalan latihan) yang boleh digunapakai oleh jurulatih khasnya di institusi-institusi pendidikan guru. Memandangkan sistem pendidikan dan latihan guru hari ini lebih berorientasikan pengetahuan dan kemahiran, maka aktiviti- 
aktiviti "hands on" yang disarankan bukan sahaja dapat meningkatkan EQ guru-guru, bahkan dapat mewujudkan suasana pembelajaran yang menyeronokan. Menurut Lynn (2002) selepas satu-satu aktiviti dijalankan, pengalaman yang dilalui itu boleh memberi manafaat kepada individu tersebut dan dapat dikongsi dengan orang lain bagi meningkatkan EQ masing-masing.

Seterusnya Lewkowicz (1999) menyatakan bahawa EQ boleh dibina menerusi domain-domain tertentu, seperti; kesedaran kendiri, pengurusan emosi, konsep kendiri dan perhubungan, empati, kemahiran membina hubungan dan kawalan kendiri. Beliau telah mencadangkan beberapa langkah pembinaan EQ bagi setiap domain tersebut. Misalnya bagi pembinaan EQ menerusi kesedaran kendiri, aktiviti yang boleh dilibatkan perlu merangkumi aspek membuat pilihan, membina keputusan pilihan mengikut kumpulan, menentukan pelbagai perasaan dan memahami kepelbagaian andaian. Seterusnya bagi pembinaan EQ menerusi pengurusan emosi pula, beliau mencadangkan beberapa aktiviti yang meliputi aspek penilaian dan pengurangan kebimbangan, perkongsian perasaan, menangani kemarahan, menilai dan menerima tanggungjawab serta memilih kegembiran.

Lewkowicz (1999) telah menyenaraikan aspek-aspek sasaran domain, sasaran kecerdasan pelbagai dan bidang kurikulum yang sesuai bagi setiap aktiviti yang dicadangkan. Sebagai contoh bagi aktiviti pengurusan marah, sasaran domain emosi yang difokuskan ialah kesedaran kendiri, pengurusan emosi, kawalan kendiri, empati dan menangani hubungan. Sasaran kecerdasan pelbagainya pula meliputi kecerdasan verbal/linguistik, visual/spatial, kinestetik, logikal matematik, intrapersonal, interpersonal, muzik dan naturalis. Seterusnya aktiviti ini juga sesuai digunakan dalam bidang yang melibatkan kurikulum pendidikan seperti kesihatan, pembelajaran sosial, seni bahasa, matematik, sains dan muzik. Di samping menghuraikan langkah-langkah aktiviti tersebut, beliau juga mencadangkan beberapa cara modifikasi aktiviti untuk disesuaikan dengan tahap pendidikan tertentu seperti sekolah rendah, sekolah menengah rendah dan menengah atas. Kaedah pengajaran EQ yang dicadangkan oleh Lewkocicz nampaknya disusun secara terperinci dan komprehensif bagi memudahkan pelatih-pelatih EQ menggunakan modul pengajaran tersebut dalam latihan pembinaan EQ guru-guru. 
Hartel dan Hooper (2002) pembinaan skala kecerdasan emosi kerja kumpulan dan hubunganya ke atas keberkesanan proses berpasukan dan fokus matlamat oleh Jordan, Ashkanasy, Kajian ini melibatkan 448 pelajar ijazah yang memasuki kursus kemahiran pengurusan dan komunikasi. Sampel kajian terdiri daripada pelajar yang berusia antara 17-50, dengan purata umur 19.7 tahun. 56.3 peratus terdiripada wanita dan 95 peratus melaporkan sama ada mereka terikat dengan pekerjaan sepenuh masa dan separoh masa, atau pernah bekerja pada masa lalu. Satu per empat daripada sampel dilaporkan berasal daripada negara Asia. Kajian ini menggunakan skala Workgroup EI Profil Version3 (WEIP-3) untuk kajin perhubungan diantara EQ dan dua pengukuran prestasi pasukan (keberkesanan proses pasukan dan fokus matlamat kumpulan).

Hasil dapatan mencadangkan ahli kumpulan yang mempunyai tahap EQ yang sederhana, telah digambarkan dalam prestasi kumpulan diperingkat awal. Dalam kajian ini, kumpulan yang mempunyai tahap kecerdasan emosi yang rendah menunjukan pretasi yang rendah berbanding pasukan yang mempunyai tahap emosi yang tinggi. walau bagaimanapun, dari semasa kemasa, kumpulan yang mampunyai EQ yang rendah didapati meningkatkan prestasi untuk dipadankan dengan kumpulan yang mempunyai tahap EQ yang tinggi.

Dulewicz dan Higgs (2004) telah menjalankan beberapa kajian bagi melihat sama ada EQ boleh dibina ataupun sebaliknya. Kajian tersebut telah melibatkan pengurus, penyelia, ketua, dan pekerja daripada perlumbaan kayak sedunia. Beliau telah menggunakan dua set instrument bagi melihat EQ subjek berkenaan, iaitu Emotional Intelligence Questionnaire (EIQ) yang dibina oleh Dulewicz dan Higgs (2000) dan instrument Emotional Quotient inventory (EQi) oleh Bar-On (1997). Kajian ini beliau jalankan bagi meneroka sama ada terdapat perubahan skor EQ setelah latihan dijalankan ataupun tidak. Laporan kajian beliau adalah seperti berikut:

Kajian pertama: Kajin ini adalah sebahagian daripada kajian besar (Slaski dan Cartwright 2002) untuk menilai hubungan EQ, tekanan, kesejahteraan dan prestasi seseorang. Kajian tersebut terfokus untuk menilai efikasi program untuk membina EQ. Subjek kajian terdiri melibatkan 59 orang pengurus kelas menengah (middle managers) yang berumur dalam lingkungan 36.3 tahun. 61 peratus terdiri daripada 
pengurus lelaki dan 25.4 peratus memiliki ijazah. Latihan intervensi EQ dijalankan sekali dalam seminggu yang dilaksanakan selama 4 minggu. Bagi setiap sesi latihan ditangguhkan selama satu minggu, untuk memberi peluang kepada subjek mempraktikkan dan menghayati latihan-latihan yang telah diikuti. Latihan tersebut menunpukan kepada perkembangan kesedaran kendiri, regulasi emosi, mengenal pasti emosi orang lain dan kesan tingkah laku individu kepada seseorang. Teknik yang digunakan dalam latihan tersebut adalah berbentuk latihan, perbincangan, video, dialog, main peranan, catatan diari dan maklum balas antara perorangan. Penguruspengurus tersebut diuji semula 6 bulan selepas hari terakhir latihan. Instrumen "Performance Ratings of job performance" juga digunakan bagi mengukur prestasi pengurus-pengurus yang terlibat (Dulewicz et al 2003). Hasil analisis ujian $t$ berpasangan (paired sample t-test) mendapati bahawa terdapat peningkatan EQ yang signifikan dalam kalangan pengurus tersebut. Lima daripada tujuh domain yang dikaji berada pada tahap sig 0.001. Perubahan didapati pada domain kesedaran emosi, sensitifiti interpersonal, pengaruh, motivasi dan daya tahan emosi. Dua domin yang tidak menunjukan perubahan ialah intuitif dan ketelitian.

Kajian kedua telah dijalankan ke atas ketua-ketua projek di dalam sebuah syarikat. Tujuh belas projek telah dibentuk untuk melihat jenis-jenis permasalahan daripada pelbagai isu seperti komunikasi, peningkatan proses dan kawalan dokumentasi. Setiap projek diketuai oleh ketua pasukan yang telah melalui latihanlatihan khusus bagi memimpin projek-projek berkenaan. Sebelum projek tersebut dimulakan, setiap ketua pasukan telah dinilai menggunakan instrumen EIQ. Seterusnya kumpulan kawalan juga dibentuk (tujuh belas orang) dan menjawab instrumen yang sama. Mereka telah dipilih berdasarkan kesamaan umur, pengalaman dan sebahagian besar berijazah, tetapi tidak menduduki sebarang latihan dan tidak memimpin projekprojek yang istimewa. Intervensi awal mendapati bahawa tiada subjek yang mengambil sebarang tindakan perkembangan bagi memperbaiki EQ mereka dalam masa tempoh intervensi. Bagaimanapun, kumpulan rawatan didapati mengambil bahagian dalam beberapa latihan perkembangan untuk memperbaiki EQ mereka secara berterusan (Dulewicz dan Higgs,2000). Bagaimanapun, hasil ujian t berpasangan mendapati bahawa tidak terdapat perbezaan yang signifikan dalam skor EIQ atau pada enam domain $\mathrm{EQ}$, tetapi ujian ini mendapati wujudnya perbezaan yang signifikan 
(pada aras 0.001) bagi domain bertanggungjawab. Analisis seterusnya mendapati bahawa domain bertanggung jawab bagi kumpulan rawatan bertambah baik berbanding dengan kumpulan kawalan. Oleh itu Dulewicz dan Higgs menyimpulkan bahawa wujud kesan yang baik daripada latihan yang diberikan.

Kajian ketiga melibatkan 14 orang ketua-ketua pelumba kayak sedunia. Dapatan kajian menunjukkan wujud perbezaan skor EIQ pada domain intuitif dalam kalangan ketua-ketua tersebut. Perbezaannya adalah signifikan pada tahap 0.03 dan menunjukan peningkatan menerusi perlumbaan kayak berkenaan. Bagaimanapun, dapatan kajian menunjukkan wujud penurunan skor yang signifikan pada dua domain "sensitifiti dan penguruh". Secara keseluruhan dua kajian awal mendapati bahawa terdapat peningkatan dalam skor EQ setelah sample kajian melalui pelbagai bentuk latihan. Bagaimanapun kajian yang ketiga tidak menunjukan sebarang peningkatan. Pengkaji menyatakan kemungkinan perkara ini disebabkan oleh faktor-faktor peribadi.

Seterusnya kajian yang dijalankan oleh Bagsaw (2000) yang menyatakan bahawa pemikiran logik (IQ) tidak mencukupi dalam persekitaran kerja. Individu perlu bertindak dengan EQ bagi mengelakkan konfrantasi dan situasi negatif. Beliau juga menyatakan bahawa EQ boleh dipelajari. Seseorang yang memiliki EQ yang tinggi berkebolehan dalam menangani pelbagai tekanan, mampu membuat pilihan, mempunyai daya tahan, berempati, memiliki kesedaran kendiri dan kawalan kendiri. Bagsaw (2000) juga menyatakan bahawa terdapat tiga pra syarat bagi mempelajari pengetahuan tentang EQ. Prasyarat dimaksudkan adalah subjek mesti bersedia, mesti menentukan apa yang diperlukan, dan perlu latihan secara berterusan.

Walupun terdapat banyak kajian tentang faktor-faktor yang menyumbang kepada perkembangan EQ seseorang (Ciarrochi, Frank \& Stephen 2002; Noriah et al. 2003; Holm 1997; Ghosn 1999; McDowelle \& Bell 1997, Slaski 2000; Marlow \& Inman 2002, Constantine \& Gainor 2001; Hargreaves 2000), namun masih terlalu kurang kajian yang dijalankan untuk pembinaan latihan EQ yang berkesan. Melalui literatur yang dijalankan sedikit sekali kajian yang dijalankan untuk menilai kesan latihan EQ bagi membantu peningkatan EQ seseorang. Sharp (2001), Lynn (2002) and Lewkowicz (1999), mencadangkan bahawa untuk kejayaan dalam kehidupan individu 
perlu berupaya untuk belajar bagaimana mengenal pasti dan memahami emosi di samping mengurus dan meluahkan emosi dengan sesuai. Memandangkan kemahiran bukan kebolehan atau bakat semula jadi, oleh itu kebolehan ini perlu dipelajari menerusi proses latihan.

\subsubsection{Kajian-Kajian Dalam Negara}

Beberapa kajian EQ berkaitan dengan konteks pendidikan tempatan telahpun mula dijalankan seawal tahun 2000, sama ada kajian EQ yang dikaitkan dengan pelajar mahupun kajian-kajian EQ yang dikaitkan dengan guru. Bagaimanapun, kajian yang dijalankan ke atas guru-guru sangatlah terbatas dan masih berbentuk kajian tinjauan. Sepanjang tinjauan kepustakaan yang dijalankan sampai sekarang, pengkaji belum mendapati adanya kajian tentang latihan EQ ke atas guru-guru di Malaysia. Beberapa kajian EQ yang telah dijalankan di Malaysia ialah seperti kajian kajian Faizah (2004), Norlida (2004) ke atas pelajar-pelajar sekolah menengah. Seterusnya kajian yang dijalankan oleh Najib (2000) yang cuba melihat kestabilan emosi pensyarah-pensyarah di universiti tempatan. Kajian beliau mendapati bahawa EQ pensayarah berada pada tahap yang sederhana atau tidak terlalu menonjol.

Abdul Hamid et al. (2005) juga telah menjalankan kajian ke atas 280 orang pelajar di Fakulti Sains kesihatan dan perubatan UiTM, Selangor. Kajian beliau cuba melihat hubungan antara persepsi pelajar ke atas EQ pensyarah dengan pencapaian akademik pelajar tersebut. Dapatan kajian menunjukkan wujudnya hubungan yang signifikan antara EQ pensyarah dengan pencapaian akademik pelajar. Kajian beliau juga mendapati bahawa antara lima belas sub-kategori domain EQ, domain interpersonal adalah paling menyumbang ke atas pencapaian akademik pelajar. Justru, pencapaian akademik pelajar diandaikan sentiasa bolehmeningkat apabila mereka dibimbing oleh pensyarah-pensyarah yang mempunyai EQ tinggi.

Seterusnya kajian EQ ke atas guru-guru di Malaysia juga telah dijalankan oleh Najib (2000), Zuria dan Noriah (2003), Noriah, Syed Najmuddin dan Syafrimen (2003), Syafrimen (2004), Wan Ashibah (2004) dan Syed (2005). Kajian Zuria dan Noriah (2003) ke atas guru-guru MRSM, guru sekolah berasrama penuh (SBP) dan 
guru-guru sekolah menengah harian mendapati bahawa guru-guru MRSM dan SBP memiliki kelima-lima domain EQ (kesedaran kendiri, regulasi kendiri, motivasi kendiri, empati dan kemahiran sosial) seperti EQ yang dicadangkan Goleman (1995, 1999). Kajian beliau juga mendapati wujudnya penambahan domain baru iaitu kerohanian dan kematangan yang sangat membantu dalam meningkatkan EQ seseorang. Penemuan aspek kerohanian ini diandaikan bahawa kerjaya sebagai guru sangat berkait rapat dengan nilai-nilai kerohanian yang syarat dengan keikhlasan untuk membantu pelbagai latar belakang pelajar. Sedangkan dapatan tentang domain kematangan pula, memberikan gambaran bahawa guru-guru tersebut sepatutnya memiliki kematangan dari segi ilmu pengetahuan dan pengalaman.

Kajian yang sama juga dijalankan ke atas 1004 orang guru oleh Noriah, Siti Rahayah, \& Zuria (2003). Beliau cuba meneroka dan membina profil EQ guru-guru tersebut dengan mengambil kira jantina, pengalaman mengajar dan tempat bertugas. EQ guru-guru terbabit telah dilihat menggunakan Inventori Kepintaran Emosi Malaysia (IKEM) yang merangkumi ketujuh-tujuh domain EQ (kesedaran kendiri, regulasi kendiri, motivasi kendiri, empati, kemahiran sosial, kerohanian dan kematangan) seperti yang dinyatakan di atas. Kajian beliau mendapati bahawa secara keseluruhan skor EQ guru-guru relatif rendah pada domain kesedaran kendiri, kemahiran sosial dan empati. Seterusnya kajian beliau juga mendapati skor EQ yang sederhana pada domain motivasi dan regulasi kendiri. Sedangkan bagi domain kerohanian dan kematangan didapati memperolehi skor tertinggi dalam kajian beliau. Dapatan kajian beliau juga menunjukkan wujudnya perbezaan bagi kumpulan guruguru yang dikaji di dalam domain-domain EQ tertentu,seperti empati dan kemahiran sosial.

Kajian secara kualitatif juga dijalankan ke atas ciri populasi yang sama oleh Wan Ashibah (2004) ke atas 30 orang guru (MRSM, Sekolah Menengah Berasrama Penuh dan Sekolah Menengah Harian). Dapatan kajian menunjukkan wujudnya domain-domain EQ bagi konteks guru-huru tempatan seperti yang dicadangkan oleh Goleman (1995). Tema dan sub tema yang muncul didapati selari dengan tema dan sub tema EQ yang dikemukakan oleh Goleman (1995). Bagaimanapun, kajian beliau memperkokohkan lagi dapatan kajian Noriah et al. (2003) yang mendapati 
penambahan dua domain baru"kerohanian dan kematangan". Kajian yang dijalankan oleh Wan juga melaporkan bahawa kestabilan emosi guru-guru sangat membantu mereka dalam proses pengajaran dan pembelajaran.

Seterusnya kajian oleh Noriah et al, Syed Najmuddin \& Syafrimen (2004), Noriah \& Siti Rahayah (2003), Noriah, Syed \& Syafrimen (2003) ke atas guru-guru Maktab Rendah Sains MARA dan sekolah menengah harian biasa. Kajian-kajian tersebut juga mendapati bahawa guru-guru memperolehi skor yang tinggi pada domain kerohanian dan kematangan dan diikuti oleh lima domain yang lain. Kajian yang dijalankan oleh Noriah dan Siti Rahayah (2003) mendapati bahawa skor EQ yang rendah bagi domain regulasi kendiri dan kemahiran sosial. Sementara kajian Noriah, Syed \& Syafrimen (2003) mendapati bahawa guru sekolah berasrama penuh mempunyai EQ yang lebih tinggi berbanding guru-guru sekolah harian. Noriah et al. (2003) juga melihat kepentingan EQ bagi guru dan pelajar untuk membantu mereka mewujudkan suasana pembelajaran yang kondusif. Beliau menyatakan bahawa wujud kepentingan EQ dalam melahirkan guru dan pelajar yang berkesan. Justeru, latihan secara berterusan sangat diperlukan bagi meningkatkan EQ dalam kalangan guru-guru tersebut.

\subsection{LATIHAN-LATIHAN EQ SEDIA ADA}

Sehingga ke hari ini telah banyak ditubuhkan program-program training EQ yang dikendalikan oleh training-training center di luar negara. Sebagai contoh, pertama: Institute for Health and human potential oleh Pawliw, Bill Benjamin, Elizabeth Pawliw dan Blair Steinbach. Training ini telah ditawarkan di tiga tempat iaitu Canada, US dan Australia. Training-training yang dikendalikan adalah (i) emotional intelligence for leadership, (ii) Sales performance, Advanced leadership dan (iv) Coacing effectiveness. Cara-cara pendekatan training yang dilakukan oleh institut ini adalah (i) an interactive two-day training program, (ii) powerful one-on-one or group coaching session, (iii) a self-derected e-learning program, and to finish dan a one-day advanced program in emotional intelligence (http://www.ihhp.com). 
Kedua: six seconds the emotional intelligence network training oleh Anabel Jensen dan Joshua Fredman. Training ini juga ditawarkan di beberapa tempat iaitu, Singapura, Italy dan menlo Park, CA (near Stanford). Adapun matlamat (goals) daripada training adalah, (i) learn how to develop and deliver EQ learning experience, (ii) understand the know yourself, choose yourself, give yourself model an how to apply it for learning and teaching, (iii) learn the most current research on the brain, emotion, behavior and learning, (iv) identify specipic action to increase EQ for self, community, work, or family, (v) enrich toolbox of teaching/training tecniques and approaches dan (vi) receive recommendantions of many resourches, ideas, books, movies dan sebagainya. Training ini mempunyai kadar bayaran yang cukup lumayan iaitu US\$2395/orang (http://www.6seconds.org/training).

Ary Ginanjar mencadangkan satu bentuk training yang telah beliau lakukan semenjak tahun 2002 sehingga sekarang. Training tersebut menggunakan pndekatan spiritual "Emotional Spiritual Quotient Training (ESQ)". Training ini diasaskan kepada 1 ihsan, 6 rukun iman dan 5 rukun Islam, yang dipanggil dengan istilah ESQ way 165. Training ini dibagikan kepada beberapa peringkat, iaitu (i) training untuk eksekutif, (ii) training untuk profesional, (iii) training untuk guru-guru, (iv) training untuk remaja dan (v) training untuk kanak-kanak. Bagi setiap peringkat training yang dijalankan, Ary Ginanjar cuba menyentuh dalaman (kesedaran spiritual) individu yang dijadikan sebagai asas untuk pembangunan kecerdasan emosi seseorang. Bagi beliau apabila seseorang mempunyai kesedaran spiritual yang bagus, akan memudahkan untuk membangun EQ mereka, sebab EQ sangat berkait rapat dengan dalaman seseorang.

Ketiga: Emotional Intelligence Development Programmes oleh Andy Smith di Manchester. Training ini dikendalikan secara berperingkat (peringkat pertama dan peringkat kedua). Setiap peringkat hanya dikuti oleh kumpulan kecil, iaitu maksimum 24 orang pada peringkat pertama dan maksimum 16 orang pada peringkat kedua. Sedang proses training dijalankan selama 20 hari (http://www.practicaleq.com).

Keempat: Training Emotional Intelligence yang dikendalikan oleh Australian Business training (Peter Sullivan) di Australia. Beberapa kompitensi yang cuba 
disentuh di dalam training ini adalah, (i) self awareness, (ii) mastering negative emotion, (iii) attitude of optimism, (iv) reading the emotions of others dan (v) teaming up with others (http://www.australianbusinesstraining.com.au).

Bagaimanapun, keempat-empat program training di atas, tidak memberikan penerangan yang lengkap tentang siapakah kumpulan sasaran daripada training berkenaan. Majoriti daripada training berkenaan lebih menjurus kepada kepada pembentukan karakter secara umum yang boleh diikuti oleh pelbagai kumpulan, dan tidak didapati kumpulan-kumpulan sasaran tertentu. Seterusnya, masing-masing training tersebut tentunya dibangunkan dengan matlamat mereka tersendiri. Bila diperhatikan, kebanyakan daripada training ini lebih bersifat komersial daripada pembinaan EQ kumpulan sasaran. Perkara sebegini tentunya akan menyukarkan guruguru kita untuk mendapatkan latihan yang bersesuaian dengan budaya dan Falsafah Pendidikan Negara.

\subsection{RUMUSAN}

Bahagian ini telah membincangkan teori-teori tentang kecerdasan (IQ, MI dan EQ). Pengkaji juga telah membincangkan konsep-konsep EQ yang dipaparkan oleh beberapa pakar, seperti; Mayer, Caruso dan Salovey (1999), Bar-On (2000), Goleman (1995 \& 1999), dan Goleman-Noriah 2004). Pada bahagian ini juga pengkaji membincangkan tentang kajian-kajian EQ yang dijalankan di dalam dan mahupun di luar negara. Pada akhir bahagian ini pengkaji juga telah membincangkan tentang aktiviti-aktiviti pembinaan EQ yang telah dijalankan oleh pengkaji-pengkaji terdahulu, dan juga latihan-latihan EQ sedia ada. 


\section{BAB III}

\section{METODOLOGI KAJIAN}

\subsection{PENGENALAN}

Kajian ini dijalankan untuk membina modul latihan EQ yang boleh digunakan sebagai panduan dalam latihan kecerdasan emosi guru-guru. Bahagian ini cuba membincangkan tentang reka bentuk kajian, subjek kajian, instrumen kajian, dan kaedah pengumpulan dan penganalisisan data.

\subsection{REKA BENTUK KAJIAN}

Kajian ini dijalankan melalui tiga fasa, iaitu fasa pertama menggunakan pendekatan kuantitatif, dan fasa kedua menggunakan pendekatan kualitatif. Sedangkan fasa ketiga adalah penggabungan antara fasa pertama dan fasa kedua (explanatory mixed methods desings). Penggabungan dua pendekatan ini membolehkan pengkaji mendapatkan data yang lebih komprehensif bagi tujuan pembinaan modul EQ yang menjadi matlamat utama kajian ini (Creswell 2007; Wiersma 2000). Penggabungan pendekatan dalam sesebuah penyelidikan juga dapat memberikan gambaran yang lebih terperinci tentang sesuatu masalah yang dikaji (Creswell 2005; Mils \& Airasian 2006; Creswell 2007). Mereka juga menyatakan bahawa penggunaan kaedah gabungan ini mempunyai kelebihan tersendiri dalam mengumpul dan menganalisis data yang dapat menghasilkan sesebuah penyelidikan yang lebih kukuh dan berkualiti. Gambaran tentang rekabentuk kajian yang digunakan adalah seperti ditunjukkan pada Rajah 3.1 di bawah ini. 


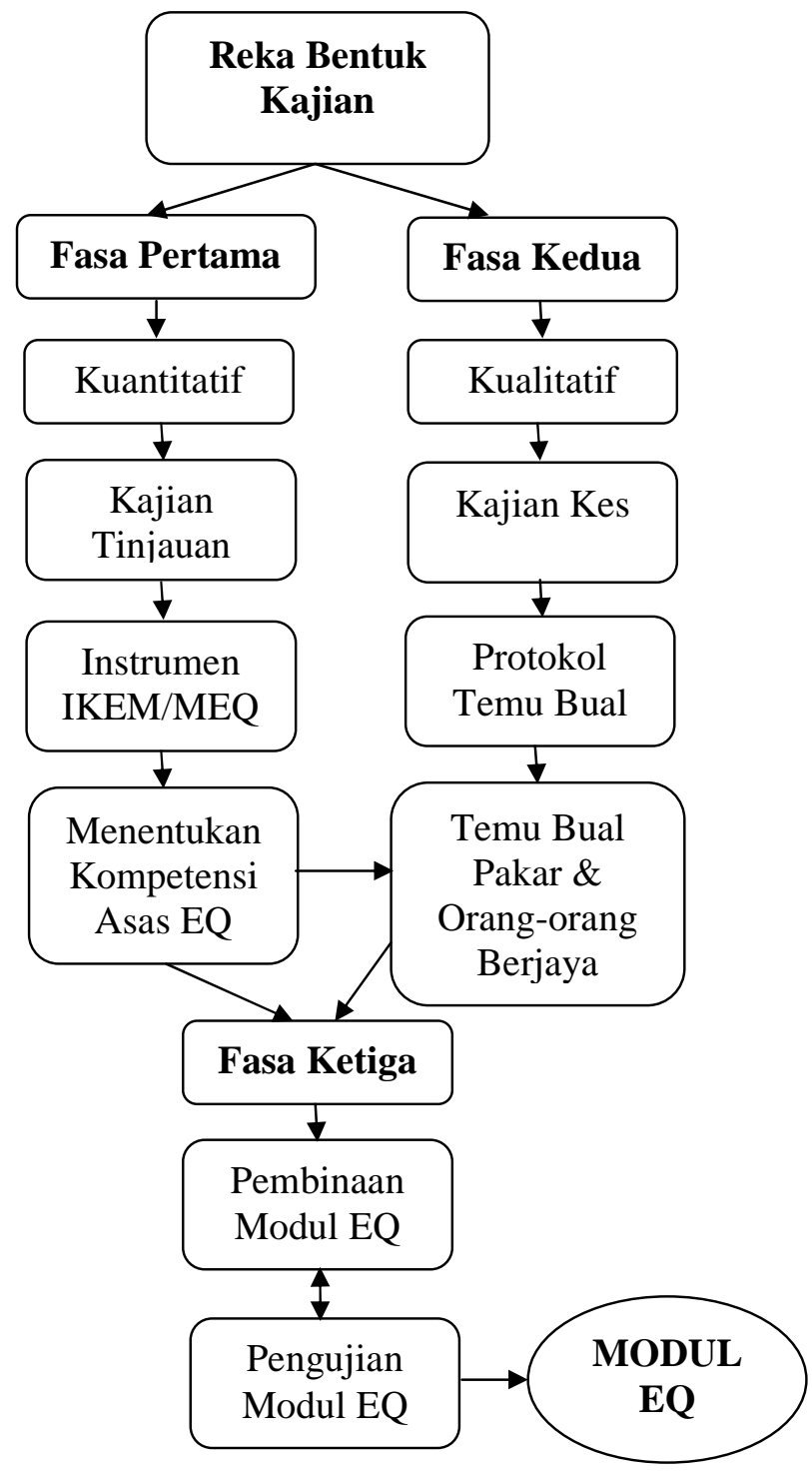

Rajah 3.1 Reka bentuk kajian

Fasa pertama kajian ini dijalankan menggunakan kaedah tinjauan (Cross Sectional Survey Designs), iaitu data dikumpulkan daripada subjek kajian untuk tujuan menentukan komponen-komponen kritikal (kompetensi asas) yang perlu diberikan tumpuan dalam latihan EQ. Melalui kajian tinjauan pengkaji dapat mengumpulkan maklumat terperinci tentang kompetensi asas ataupun komponenkomponen kritikal EQ yang perlu diberikan tumpuan terhadap guru-guru yang menjadi subjek kajian ini (Creswell 2007; Mils \& Airasian 2006; Mohd Majid 2005; Sidek 2002; Wiersma 2000). Dalam versi lain, pakar metodologi penyelidikan juga menyatakan bahawa kajian tinjauan sesuai digunakan untuk mengenal pasti 
pemboleh ubah-pemboleh ubah yang berkaitan dengan sesuatu fenomena tanpa menyoal mengapa pemboleh ubah tersebut wujud dalam fenomena berkenaan (Cohen dan Manion 1985; Creswell 2007; Gay, Mils \& Airasian 2006; Wiersma 2000). Mereka juga menyatakan bahawa kaedah tinjauan sesuai digunakan apabila penyelidik berkeinginan untuk melibatkan jumlah sampel yang agak ramai. Justeru, untuk menjimatkan masa, tenaga dan juga kos maka penggunaan soal selidik adalah satu cara yang lebih praktikal dalam pengumpulan data sesebuah kajian. Perbincangan tentang jumlah sampel yang dilibatkan pada fasa pertama ini, serta instrumen yang digunakan, dibincangkan secara khusus selepas ini.

Setelah mendapatkan kompetensi asas EQ yang perlu diberikan tumpuan dalam latihan EQ pada fasa pertama, kajian diteruskan dengan fasa kedua. Fasa kedua, kaedah kajian kes (case study research design) digunakan, iaitu satu rekabentuk kajian yang membolehkan pengkaji menggunakan kaedah yang komprehensif, dengan cara menggabungkan pelbagai strategi dalam mengumpul dan menganalisis data (Yin 1994). Menurut Yin rekabentuk kajian ini sesuai digunakan pada kajian yang melibatkan sesuatu fenomena yang tidak terpisah dengan konteks persekitaran. Kaedah ini juga dapat membantu penyelidik memahami permasalahan yang kompleks dalam konteks yang agak luas (Burhan Bungin 2003; Denzin \& Lincoln 1994). Mohd. Majid Konting (2005), menyatakan bahawa kajian kes merupakan satu penyelidikan yang dilakukan secara intensif ke atas satu unit sosial yang kecil, seperti individu, satu keluarga, satu kampung, satu kelab ataupun satu sekolah. Sementara Sidek (2002) pula menyatakan bahawa kajian kes merupakan satu reka bentuk kajian untuk mengenalpasti secara intensif tentang latar belakang status semasa serta interaksi persekitaran suatu unit sosial, sama ada melibatkan individu, kumpulan, institusi ataupun komuniti. Beliau berpandangan bahawa walaupun unit yang terlibat dalam kajian kes agak kecil tetapi maklumat yang diperolehi sangat mendalam. Kaedah kajian kes yang digunakan dalam kajian ini adalah multi-case multi-site exploratory case study. Multi-case merujuk kepada lebih daripada satu unit analisis, manakala multi-site merujuk kepada beberapa tempat kajian (Yin 1993).

Pada fasa kedua ini pengkaji mendapatkan maklumat terperinci daripada pakar dan orang-orang yang berjaya dalam bidang yang mereka ceburi. Pemilihan pakar dan orang-orang yang berjaya ini adalah untuk mengetahui perkara-perkara penting yang 
menjadi amalan mereka sehingga mereka menjadi seorang pakar dan seorang yang berjaya dalam bidang mereka. Kajian menunjukkan pakar dan orang-orang yang berjaya dikaitkan dengan EQ yang tinggi (Goleman 1995). Maklumat yang dikongsikan oleh pakar dan orang-orang yang berjaya tersebut, seterusnya dijadikan dalam bentuk aktiviti dalam pembinaan modul EQ pada fasa ketiga kajian ini. Untuk mendapatkan maklumat daripada pakar dan orang-orang yang berjaya tersebut, pengkaji telah melakukan penerokaan melalui temubual mendalam (indepth interview) dan temubual berkumpulan (group interview). Pakar dan orang-orang berjaya dimaksudkan adalah (i) individu yang berjaya dalam bidang yang diceburi, (ii) individu-individu yang pernah mendapatkan anugerah kenamaan, (iii) pakar psikologi, (iv) dan (v) pakar dalam bidang agama.

Setelah mendapatkan kompetensi EQ yang perlu diberikan intervensi pada fasa pertama, dan mendapatkan maklumat-maklumat penting daripada pakar dan orangorang berjaya pada fasa kedua, selanjutnya pembinaan draf modul EQ dilakukan pada awal fasa ketiga. Secara lebih terperinci tentang pelaksanaan kajian ini seperti ditunjukkan pada Rajah 3.2 di bawah ini.

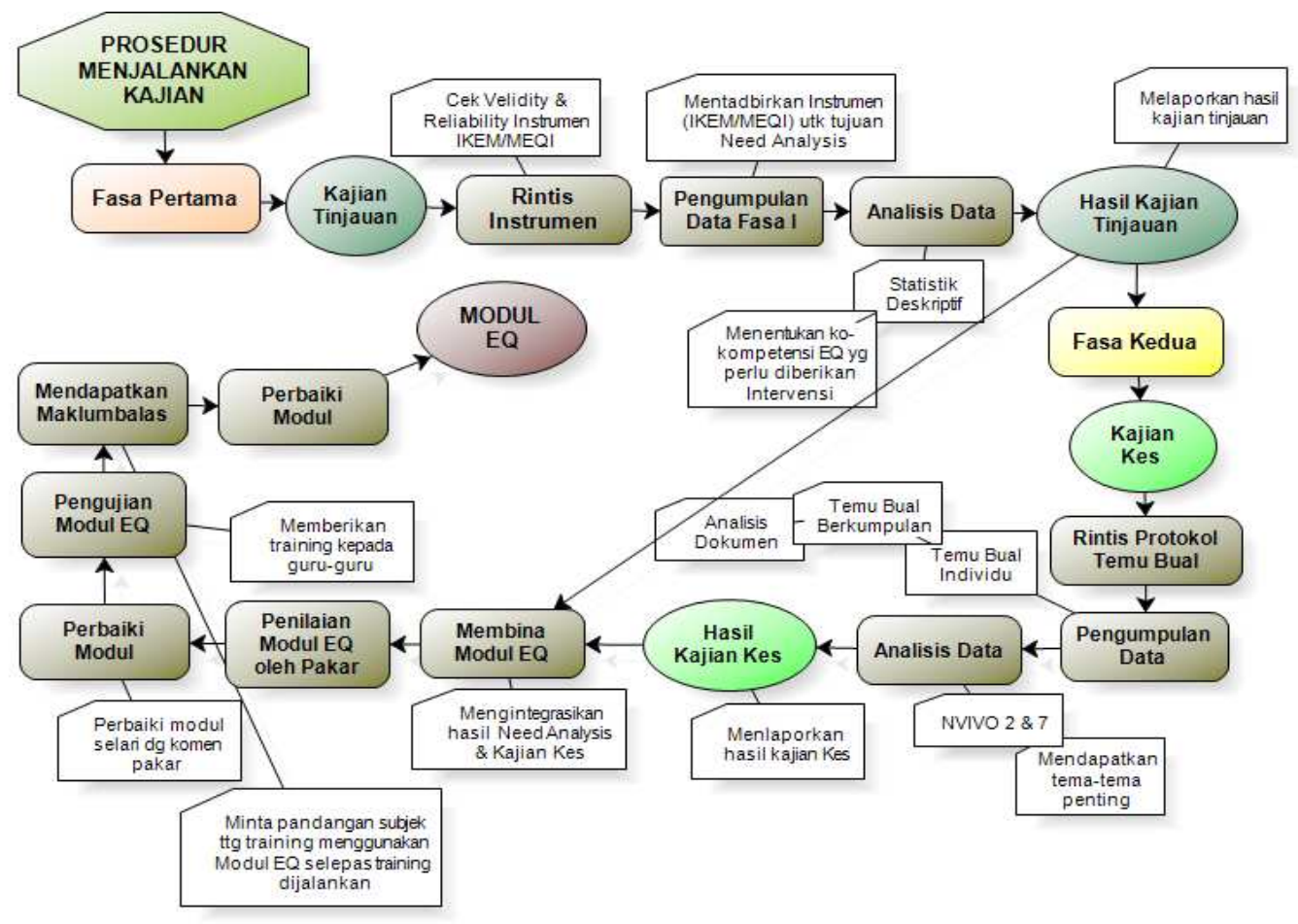

Rajah 3.2 Prosedur menjalankan kajian 


\subsection{SUBJEK KAJIAN}

Fasa pertama kajian ini melibatkan guru-guru yang berkhidmat di bawah Kementerian Pelajaran Malaysia, yang sedang melanjutkan pendidikan peringkat Master dan doktor falsafah di Fakulti Pendidikan, Universiti Kebangsaan Malaysia. Fasa kedua melibatkan lapan orang pakar (pakar psikologi/kaunseling, pakar agama, pakar pendidikan orang dewasa, dan 24 orang-orang yang berjaya dalam kerja yang mereka ceburi. Pemilihan pakar dan orang-orang berjaya tersebut secara terperinci dibincangkan selepas ini. Manakala fasa ketiga pula melibatkan sekumpulan guru-guru yang dipilih daripada kumpulan guru-guru yang terlibat pada fasa pertama kajian ini.

\subsubsection{Subjek Kajian Fasa Pertama}

Fasa pertama kajian ini melibatkan 112 orang guru yang berkhidmat di bawah Kementerian Pelajaran Malaysia, yang sedang melanjutkan pendidikan Master dan doktor falsafah di Fakulti Pendidikan, Universiti Kebangsaan Malaysia. Memandangkan kajian ini merupakan kajian awal dalam pembinaan modul EQ untuk guru-guru, maka kajian ini cuba dijalankan dalam skala yang tidak terlalu besar, kerana hasil kajian ini bukannya untuk tujuan generalisasi kepada seluruh guru-guru di Malaysia, tetapi untuk mendapatkan gambaran tentang kompetensi asas EQ yang perlu diberikan intervensi dalam kalangan guru-guru yang terlibat dalam kajian ini. Berdasarkan kompetensi asas EQ yang diperolehi, pengkaji cuba memikirkan bentuk modul EQ yang sesuai digunakan dalam intervensi EQ bagi guru-guru berkenaan, yang boleh dikembangkan oleh pengkaji selepas ini kepada skop yang lebih besar. Harapan pengkaji adalah apabila pembinaan modul ini berjaya dilakukan, pengkaji berikutnya dapat menguji keberkesanan modul yang dihasilkan untuk tujuan latihan EQ dalam kalangan guru-guru. Satu perkara lagi yang memotivasikan pengkaji melibatkan guruguru ini ialah kerana mereka datang daripada pelbagai sekolah di bawah Kementerian Pelajaran yang tersebar hampir seluruh Malaysia. Kepelbagaian ini dijangkakan dapat memberikan data yang komprehensif yang dapat menggambarkan kompetensi asas EQ

guru-guru tersebut. Perkara ini sangat penting untuk panduan dalam pembinaan modul EQ yang menjadi tujuan utama kajian ini. 
Menurut Krejcie dan Morgan (dlm Wiersma 2000) semakin besar saiz populasi semakin besar pula saiz dan nisbah sampel yang diperlukan untuk mewakili populasi tersebut. Beliau telah memberikan satu panduan bagi menentukan jumlah sampel yang sesuai dalam sesebuah kajian. Sampel seramai 384 orang adalah mencukupi untuk populasi 100,000 orang dan seterusnya. Neuman (2000) juga menyatakan bahawa 300 orang subjek (lebih kurang 30 peratus) daripada populasi yang berjumlah 1000 orang adalah mencukupi untuk mendapat ketepatan yang sesuai dalam sesebuah kajian. Manakala menurut Wiersma (2000) pula menyatakan bahawa saiz sampel antara 200500 responden adalah memadai untuk menjalankan sesebuah kajian. Bagaimanapun, untuk tujuan kajian ini pengkaji tidak mengambil kira nisbah pengambilan subjek kajian seperti yang dicadangkan oleh pakar-pakar tersebut, kerana kajian ini tidak bertujuan untuk membuat generalisasi kepada seluruh populasi guru di Malaysia. Walaubagaimanapun pengkaji cuba mendapatkan jumlah subjek yang bersesuaian untuk mendapatkan data yang komprehensif bagi tujuan pembinaan modul latihan EQ. Pemilihan 112 orang guru seperti yang dinyatakan di atas telah dilakukan menggunakan kaedah sampel bertujun (porposive sampling), iaitu teknik pemilihan subjek dengan cara mengambil kira ciri-ciri tertentu. Ciri-ciri dimaksudkan di sini adalah subjek yang dipilih diandaikan dapat memberikan data yang komprehensif untuk kajian ini.

\subsubsection{Subjek Kajian Fasa Kedua}

Pada fasa kedua (kajian kes) pula pemilihan subjek merujuk kepada "social situation" (Sugiono 2005). Situasi sosial ini merujuk kepada tempat (place), pelaku (actors) dan aktiviti (activity) yang berinteraksi secara bersinergi. Situasi sosial di dalam kajian ini merujuk kepada situasi sekolah, aktornya adalah guru-guru dan aktivitinya adalah pendidikan. Walaubagaimanapun, untuk tujuan mendapatkan data yang komprehensif dan berkualiti, pengkaji tidak mengambil guru-guru sepenuhnya, tetapi juga melibatkan pakar dan orang-orang yang dianggap berjaya untuk berkongsi pengalaman dalam mendapatkan pandangan untuk pembinan satu modul latihan yang sesuai digunakan pada seting sekolah, iaitu modul yang sesuai untuk meningkatkan EQ guruguru. 
Pemilihan subjek fasa kedua ini juga dilakukan menggunakan kaedah "porposive sampling” iaitu teknik pengambilan subjek kajian dengan mengambil kira pertimbangan-pertimbangan tertentu seperti yang telah disentuh sebelum ini. Pertimbangan dimaksudkan dalam kajian ini adalah subjek yang dipilih dianggap pakar dalam bidang kajian yang sedang dijalankan, dan subjek yang dipilih dijangkakan dapat memberikan data secara komprehensif untuk kajian ini. Untuk kajian ini, pengkaji memerlukan pengalaman beberapa orang pakar dan orang-orang yang dianggap berjaya dalam bidang yang mereka ceburi. Pengalaman yang dikongsikan oleh pakar dan orang-orang berjaya tersebut sangat penting untuk pembinaan modul EQ bagi meningkatkan kompetensi asas EQ di kalangan guru-guru yang dihasilkan pada fasa pertama kajian ini.

Pemilihan pakar dan orang-orang berjaya tersebut juga mengambil kira beberapa kajian sebelum ini, yang menyatakan bahawa orang-orang tersebut dikaitkan dengan EQ yang tinggi. Dari itu pengalaman mereka sangat bermakna dikongsi dengan orang lain dalam bentuk latihan yang bersesuaian, dalam hal ini pengkaji cuba menyusun dalam bentuk modul EQ. Teknik "porposive sampling” ini termasuk ke dalam nonprobality sampling iaitu pengambilan subjek kajian bergantung kepada pengkaji melihat subjek tersebut, adakah mereka dapat memberikan data sepenuhnya ataupun sebaliknya (Sugiyono 2005). Justeru, penentuan pemilihan subjek melalui kaedah tersebut sebenarnya bergantung kepada penyelidik dalam melihat kesesuaian subjek yang akan dilibatkan dalam kajian yang dijalankan.

Kriteria pemilihan subjek yang dilibatkan dalam kajian ini ditetapkan oleh pengkaji sendiri dengan mengambil kira pelbagai pertimbangan seperti yang telah dilaporkan pada perenggan sebelum ini. Pemilihan pakar adalah atas pertimbangan akademik yang boleh dikongsi oleh pakar-pakar tersebut yang boleh digunakan untuk meningkatkan kompetensi asas EQ guru yang terlibat dalam kajian ini, kerana mereka memiliki pelbagai pengalaman signifikan dalam mewujudkan kejayaan dirinya, dan sangat berharga untuk dikongsi dengan orang lain. Sedangkan pemilihan subjek berdasarkan kejayaan pula, dengan alasan bahawa orang-orang yang berjaya kebiasaan mempunyai teknik-teknik dan cara-cara tersendiri yang boleh menghantarkan dirinya kepada kejayaan. Orang-orang berjaya kebiasaanya memiliki cara yang unik dan 
berbeza dengan kebiasaan orang-orang yang biasa (normal). Teknik dan cara-cara mereka tersebut dicungkil oleh pengkaji melalui temubual mendalam, dan seterusnya ditransletkan ke dalam bentuk aktiviti yang dibuat dalam bentuk modul latihan, agar dapat membantu orang lain berjaya seperti mereka, dalam hal ini aktiviti dan modul tersebut ditunjukan untuk keperluan guru-guru yang menjadi sasaran kajian ini.

Untuk jumlah subjek yang diperlukan pada fasa kedua ini, Lincoln dan Guba (dlm Sugiono 2005) menyatakan bahawa "naturalistic sampling is, then, very difference from conventional sampling. It is base on informational, not statistical, consideration. Its purpose is to maximize information, not to facilitate generalization. Justeru, pemilihan subjek dalam kajian kualitatif tidak berasaskan kepada jumlah ataupun kuantiti sampel seperti dalam kajian kuantitatif, yang paling penting adalah subjek yang dipilih dapat memberikan maklumat ataupun data secara maksimum, dan subjek yang terlibat memberikan maklumat yang lebih kurang sama (sampai pada peringkat ketepuan data). Lincoln dan Guba (dlm Sugiono 2005) juga menyatakan bahawa "If the purpose is to maximize information, then sampling is terminated when no new information is fourth-coming from newly sampled units; thus redundancy is the primary criterion". Nasution (dlm Sugiyono 2005) pula menyatakan bahawa penentuan jumlah subjek dianggap mencukupi apabila data yang diperolehi telah sampai pada tahap "redundancy" ataupun telah sampai pada tahap ketepuan data. Maknanya, walaupun pengkaji menambahkan subjek yang baru namun tidak lagi memberikan maklumat dan penambahan data.

Pemilihan subjek yang akan dilibatkan dalam sesebuah kajian, Bungin (2003) mencadangkan tiga tahapan pemilihan subjek tersebut, iaitu (i) pemilihan subjek awal yang mesti berhubungkait dengan fokus penyelidikan, (ii) pemilihan subjek lanjutan bagi memperluas maklumat dan mencari variasi yang mungkin muncul dari subjek berikutnya dan (iii) menghentikan pengambilan subjek apabila tidak ditemukan lagi variasi maklumat daripada subjek-subjek yang telah ditemubual. Bagaimanapun, pemilihan subjek awal menjadi prioriti utama bagi mendapatkan maklumat yang sesuai dengan kajian ini, kerana ianya boleh mempengaruhi kelancaran dalam mengumpulkan maklumat-maklumat penting berikutnya. 
Spradley (1980) juga mencadangkan beberapa kriteria untuk pemilihan subjek kajian kualitatif, iaitu: (i) subjek yang dipilih mestilah berpengalaman, memahami sepenuhnya tentang fenomena yang dikaji, (ii) subjek yang dipilih masih aktif dalam bidang yang dikaji, (iii) mempunyai masa yang cukup untuk memberikan maklumat kepada penyelidik semasa temubual dijalankan, dan (iv) subjek mestilah dapat memberikan maklumat yang selari dengan fakta. Beliau juga menambahkan, yang terpenting daripada subjek-subjek yang dipilih adalah memiliki predikat "key informan".

Pemilihan pakar dan orang-orang yang berjaya dalam bidang yang mereka ceburi, adalah selari dengan pandangan Goleman, Mayer, Salovey dan Bar On yang menyatakan bahawa kebanyakan daripada individu yang berjaya mempunyai EQ yang tinggi. Kajian yang dijalankan oleh Goleman (1999) mendapati bahawa 80\% kejayaan seseorang disumbangkan oleh EQ yang mereka miliki dan 20\% sahaja disumbangkan oleh IQ. Sebaliknya Goleman (1999) juga menyatakan bahawa individu yang tidak berkebolehan mengawal emosi apabila berinteraksi dengan orang lain tidak dapat menjalankan tugasan dengan baik. Justeru, beliau mencadangkan bahawa di samping kebolehan yang lain, juga diperlukan EQ yang tinggi. Pemilihan subjek berdasarkan kepakaran pula, merujuk kepada kajian Noriah et al. (2004), Syafrimen (2004), Syed Najmuddin (2005) \& Wan Ashibah (2004) yang mendapati bahawa "kematangan dan kerohanian" sangat berpengaruh dalam meningkat EQ seseorang. Kematangan dimaksudkan adalah kematangan ilmu pengetahuan, umur dan pengalaman. Individu yang matang dalam sesuatu disiplin ilmu adalah dianggap pakar dalam bidang berkenaan.

\subsubsection{Subjek Kajian Fasa Ketiga}

Fasa ketiga ini melibatkan 33 orang guru yang dipilih daripada 112 orang guru yang memberikan respons terhadap instrumen IKEM/MEQI pada fasa pertama kajian ini. Mereka dipilih berdasarkan hasil analisis terhadap data yang mereka berikan pada fasa pertama berkenaan. Merujuk kepada cara interpretasi instrumen EQ yang dicadangkan oleh Noriah (2008), yang menyatakan bahawa individu yang memperolehi skor Min di bawah 80 peratus, menunjukkan individu berkenaan perlu kepada latihan untuk 
memperkukuhkan lagi kompetensi EQ yang terdapat pada individu berkenaan. Justeru, 33 orang guru yang dipilih dan dilibatkan pada fasa ketiga ini adalah guru-guru yang memperolehi skor di bawah 80 peratus tersebut. Guru-guru yang dilibatkan pada fasa ini adalah untuk tujuan pengujian modul EQ yang dibina. Pemilihan mereka juga dibuat bagi memudahkan pengkaji untuk melihat kesesuaian modul EQ yang dibina, iaitu dengan cara membandingkan skor mereka pada fasa pertama tersebut dengan skor yang mereka perolehi selepas mereka mengikuti latihan EQ menggunakan modul EQ yang dibina.

\subsection{INSTRUMEN KAJIAN}

Kajian ini menggunakan dua set instrumen iaitu (i) Inventori Kepintaran Emosi Malaysia (IKEM) atau Malaysian Emotional Quotient Inventory (MEQI) yang disusun oleh Noriah dan rakan-rakan (2004) yang digunakan pada fasa pertama. (ii) Protokol temubual yang disusun sendiri oleh pengkaji, digunakan pada fasa kedua. Selain dua instrumen tersebut, pengkaji juga menggunakan "borang kebenaran responden (consent leter)". Borang kebenaran ini sangat penting diberikan kepada semua subjek untuk mengetahui sama ada mereka ikhlas sebagai peserta kajian ataupun sebaliknya. Borang ini biasanya diberikan sebelum mereka memberikan maklumbalas ke atas instrumen yang diberikan, ataupun sebelum temubual dijalankan dalam kajian kualitatif.

\subsubsection{Instrumen Fasa Pertama}

Fasa pertama kajian ini menggunakan satu set instrumen Kepintaran Emosi MalaysiaDewasa (IKEM-D) atau Malaysian Emotional Quotient Inventory-Adult (MEQI-A) yang dibina oleh Noriah et al. (2004). Noriah et al. telah membina instrumen ini daripada tahun 2002, dan telah mengalami beberapa kali revisi, sehingga tahun 2007. Instrumen berkenaan dimulakan dalam bentuk kertas dan pensil dengan jumlah item yang agak banyak (263 item), dan setelah mengalami beberapa kali revisi akhirnya jumlah item telah berkurang menjadi 182 item serta tersedia dalam dua pilihan, iaitu dalam bentuk kertas dan pensil dan di atas talian yang boleh dijawab secara online. Sehingga sekarang instrumen ini telah diterjemahkan ke dalam lima bahasa, iaitu 
bahasa Inggeris, bahasa Mandarin, Bahasa Korea, bahasa Arab dan bahasa Indonesia. Termasuk bahasa Melayu, maknanya instrumen tersebut telah tersedia dalam enam bahasa.

Instrumen ini telah dinilai di peringkat Universiti, peringkat kebangsaan dan beberapa kali di peringkat antarabangsa. Hasil penilaian tersebut, masing-masing memperolehi pingat emas di peringkat Universiti tahun 2004, pingat perak di peringkat kebangsaan tahun 2005, mendapat anugerah hasil penyelidikan terbaik kategori sains sosial di peringkat antarabangsa di Seoul Korea Selatan pada tahun 2006, dan memperolehi pingat perak pada pertandingan hasil penyelidikan peringkat antarabangsa "ITEX" di Kuala Lumpur pada tahun 2008. Instrumen ini juga telah dipamerkan oleh UKM sebagai hasil inovasi penyelidikan yang memiliki nilai komersial yang tinggi pada tahun 2008 di Geneva dan April 2009 di Jerman.

Instrumen tersebut telah dibangunkan melalui peruntukan projek IRPA (International Research Priority Area) yang ditaja oleh Kementerian Alam Sekitar Malaysia pada tahun 2002. Kajian awal pembinaan instrumen berkenaan diasaskan kepada konsep EQ yang dicadangkan oleh Goleman (1995) yang mengandungi lima domain EQ iaitu, kesedaran kendiri, regulasi kendiri, motivasi kendiri,empati dan kemahiran sosial. Bagaimanapun setelah kajian dijalankan kepada seluruh penjawat Awam di Malaysia, seperti polis, pegawai penjara, pegawai imegresyen dan juru rawat, dapatan kajian menunjukkan wujudnya penambahan dua domain EQ baru yang dinyatakan oleh masyarakat tempatan, iaitu kerohanian dan kematangan. Maka pembinaan instrumen EQ tersebut telah dibuat berdasarkan tujuh domain EQ mengikut konteks tempatan.

Instrumen ini terdiri dari dua bahagian utama iaitu (i) bahagian maklumat dan latar belakang responden, seperti umur, jantina, organisasi dan pengalaman bekerja. (ii) bahagian kedua adalah pernyataan-pernyataan yang mengukur setiap domain dan sub domain EQ seperti yang dinyatakan oleh Goleman-Noriah et al. (2004), iaitu kesedaran kendiri, regulasi kendiri, motivasi kendiri, empati, kemahiran sosial, kerohanian dan kematangan. Untuk menjadikan instrumen ini lebih berkesan, cara pengukurannya telah dipecahkan kepada dua bahagian iaitu, pengukuran dalam bentuk 
pernyataan persepsi dan pengukuran dalam bentuk pernyataan prestasi ataupun pencapaian (performance test). Bagaimanapun, secara keseluruhan domain dan sub domain EQ tersebut lebih banyak diukur melalui penyataan-pernyataan persepsi. Sedangkan pernyataan-pernyataan berbentuk pencapaian digunakan untuk membantu penyelidik memastikan sama ada subjek kajian menjawab instrumen tersebut dengan betul ataupun secara sambil lewa. Daripada tujuh domain EQ yang dikenal pasti oleh Noriah et al. (2004) hanya empat domain sahaja (kesedaran kendiri, regulasi kendiri, motivasi kendiri dan empati) yang diukur melalui pernyataan persepsi dan pencapaian tersebut. Sedang tiga domain yang lain (kemahiran sosial, kerohanian dan kematangan) hanya diukur melalui pernyataan-pernyataan dalam bentuk persepsi (Rujuk myeq.net.my).

Item-item yang dinyatakan dalam bentuk persepsi, direspons oleh subjek kajian melalui skala likert lima-mata, iaitu 1- Sangat Tidak Setuju, 2- Tidak Setuju, 3- Tidak Pasti, 4- Setuju dan 5- Sangat Setuju. Setiap item yang dinyatakan merujuk kepada perasaan dan tingkah laku peribadi subjek yang menjawab instrumen tersebut. Tiada jawapan benar dan salah pada setiap pernyataan yang diberikan, yang pentingnya adalah subjek mestilah menjawab secara ikhlas dan jujur setiap pernyataan yang diberikan.

Sedangkan bahagian pencapaian pula dinyatakan melalui dua keadaan, iaitu soalan terbuka (open ended question) dan dalam bentuk senario (seperti foto emosi, gambar/lanskap dan maze). Subjek memberikan maklumbalas mereka terhadap soalan terbuka, foto/gambar dan maze tersebut sesuai dengan apa yang dirasainya apabila melihat senario yang dinyatakan. Contoh soalan terbuka, dinyatakan dalam situasi pelbagai “mengapa saya perlu mengetahui perasaan saya sendiri?" subjek akan menjawab secara bertulis dalam bentuk tindak balas dengan menyatakan alasan kenapa dirinya perlu mengawal perasaan sendiri. Untuk foto dan gambar/landskap, subjek disuguhkan dengan contoh foto-foto dan gambar/landskap dengan warna semula jadi. Subjek diminta memberikan maklumbalas mereka sesuai dengan skala yang diberikan apabila melihat foto dan gambar/landskap tersebut. Contoh subjek diberikan contoh foto wajah seorang perempuan dalam keadaan murung, subjek akan menyatakan 
maklumbalas mereka terhadap foto tersebut (1- tidak sedih, 2- sedikit sedih, 3- tidak pasti, 4- sedih dan 5- sangat sedih).

Demikian juga dengan gambar/landskap, subjek ditunjukkan contoh pemandangan sebuah pulau yang indah di tengah laut, kemudian mereka akan memberikan respons bagaimana keamatan perasaan yang dialami oleh dirinya (1sangat rendah, 2- rendah, 3- tidak pasti, 4- tinggi dan 5- sangat tinggi). Sedangkan untuk bahagian maze pula (jalan berliku) subjek diberikan bentuk maze yang paling mudah sehingga bentuk maze yang paling sukar. Di tengah-tengah maze tersebut terdapat satu benda yang perlu dikeluarkan mengikut liku-liku jalan sesuai dengan maze yang disediakan. Subjek diminta untuk mencari jalan keluar yang betul dengan cara memberikan coretan pada jalan keluar yang mereka kenal pasti, seterusnya subjek diminta untuk menandakan tahap motivasi dirinya ketika mencari jalan keluar tersebut (1-sangat rendah, 2- rendah, 3- sederhana, 4- tinggi dan 5- sangat tinggi).

Seperti dinyatakan pada perenggan sebelumnya, instrumen ini mengukur tujuh domain EQ iaitu kesedaran kendiri, regulasi kendiri, motivasi kendiri, empati, kemahiran sosial, kerohanian dan kematangan. Terdapat empat bahagian item pada domain kesedaran kendiri, iaitu (i) kesedaran emosi, ii) penilaian kendiri yang tepat, (iii) keyakinan diri dan (iv) kejujuran. Terdapat lima bahagian item pada domain regulasi kendiri, iaitu (i) kawalan kendiri, (ii) kebolehpercayaan, (iii) responsibility, (iv) kebolehsuaian dan (v) inovasi. Terdapat empat bahagian item pada domain motivasi kendiri, iaitu (i) dorongan pencapaian, (ii) komitmen, (iii) (inisiatif dan (iv) minat. Bagi domain empati pula terdapat tujuh bahagian item iaitu (i) memahami orang lain, (ii) membantu orang lain, (iii) leveraging diversity, (iv) berorientasi perkhidmatan, (v) mengembangkan potensi orang lain, (vi) kesedaran politik, dan (vii) perasaan kasih sayang. Bagi domain kemahiran sosial pula terdapat 8 bahagian item iaitu (i) mempengaruhi orang lain, (ii) pengurusan konflik, (iii) kepemimpinan, (iv) pemangkin perubahan, (v) menjalin hubungan, (vi) kerjasama, (vii) keupayaan dalam kerja berpasukan, dan (viii) komunikasi. Sedangkan untuk domain kerohanian (spiritualiti) dan kematangan (maturity) tidak terdapat bahagian-bahagian item seperti lima domain EQ sebelumnya. 


\section{i. Bahagian Kesedaran Kendiri}

a. Item-item bahagian kesedaran emosi mengukur sejauh mana subjek peka terhadap emosi yang wujud di dalam dirinya. Contoh: "saya boleh memaafkan diri sendiri setelah melakukan kesilapan”.

b. Item-item bahagian penilaian kendiri yang tepat pula mengukur ketepatan subjek menilai kekuatan dan kelemahan diri sendiri. Contoh: "kesilapan yang saya lakukan tidak memberi kesan berpanjangan terhadap perasaan saya”.

c. Bahagian keyakinan diri pula mengukur tentang sejauh mana subjek merasa yakin dengan dirinya sendiri. Contoh: "Saya tidak malu memberikan pandangan walaupun berbeza daripada orang lain”.

d. Sedangkan bahagian kejujuran pula melihat sejauh mana subjek dapat melihat perubahan perasaan yang berlaku di dalam dirinya. Contoh: "saya dapat merasakan perubahan perasaan apabila melakukan sesuatu dengan tujuan tertentu".

\section{ii. Bahagian Regulasi Kendiri}

a. Item-item bahagian kawalan kendiri adalah melihat kekuatan subjek mengawal pelbagai emosi negatif yang muncul di dalam dirinya. Contoh:"Saya tidak mudah tersinggung apabila orang lain mengata saya".

b. Bahagian kebolehpercayaan, menilai kejujuran dan integriti diri responden. Contoh: "Saya sentiasa menepati waktu temu janji".

c. Bahagian responsibility mengukur sikap dan rasa tanggungjawab yang dimiliki oleh subjek . Contoh: "Saya akan menyelesaikan semua tugasan dengan sempurna".

d. Bahagian kebolehsuaian diri adalah menilai tentang kemampuan subjek dalam menyesuaikan diri dalam sesuatu keadaan. Contoh: "Saya boleh menyesuaikan diri dengan mudah dalam pelbagai situasi”.

e. Bahagian inovasi pula menilai tentang keupayaan subjek dalam menerima sesuatu perubahan inovasi. Contoh: "Saya sentiasa bersikap terbuka kepada idea baru". 


\section{iii. Bahagian Motivasi Kendiri}

a. Item-item bahagian dorongan pencapaian mengukur tentang kekuatan dorongan subjek untuk mencapai kecemerlangan. Contoh: "Saya sentiasa memastikan prestasi saya di tahap cemerlang”.

b. Bahagian komitmen mengukur kesepaduan keupayaan subjek untuk menjaga dan melakukan sesuatu komitmen yang diberikan kepadanya. Contoh: "Saya akan menyiapkan semua tugasan sehingga selesai”.

c. Bahagian inisiatif mengukur tentang kesediaan subjek untuk merebut peluang yang ada. Contoh: “ Saya suka menawarkan diri untuk mengikuti kursus-kursus yang boleh meningkatkan kecemerlangan saya".

d. Bahagian minat pula menilai tentang minat yang ada pada diri subjek dalam menjalankan sesuatu tugas. Contoh: "Saya tidak cepat bosan bila melakukan sesuatu tugasan”.

\section{iv. Bahagian Empati}

a. Item-item bahagian memahami orang lain mengukur sejauh mana subjek dapat mengesan dan memahami perasaan orang lain dengan tepat. Contoh: "Saya tahu apabila seseorang cuba menyembunyikan perasaannya."

b. Membantu orang lain mengukur sejauhmana subjek dapat memberikan pertolongan kepada orang lain. Contoh: "Saya akan membantu orang lain belajar menyelesaikan masalah mereka."

c. Bahagian leveraging diversity menilai keupayaan subjek mewujudkan peluangpeluang daripada pelbagai keadaan. Contoh: "Saya cuba membina persekitaran yang selesa apabila melakukan sesuatu tugasan bersama rakan-rakan”.

d. Bahagian berorientasikan perkhidmatan mengukur tentang keupayaan subjek dalam menjangka, mengenal pasti dan memenuhi keperluan orang lain. Contoh: "Saya gembira apabila orang berpuas hati dengan pertolongan saya".

e. Bahagian mengembangkan potensi orang lain adalah menilai kebolehan subjek dalam mengesan dan mengembangkan potensi yang dimiliki oleh orang lain. Contoh: "Saya suka membantu orang lain yang ingin berubah". 
f. Bahagian kesedaran politik mengukur kebolehan subjek dalam membaca sesuatu keadaan, dan dapat mengenal pasti pihak yang berpengaruh dalam kumpulan tersebut. Contoh: "Saya tahu siapa yang paling berpengaruh dalam kalangan rakan-rakan".

g. Bahagian penyayang ataupun caring menilai sejauh mana subjek dapat berinteraksi dengan orang lain dengan perasaan kasih sayang yang tulus dan ikhlas. Contoh: "Saya tidak suka melihat orang lain menderita".

\section{v. Bahagian Kemahiran Sosial}

a. Item-item bahagian mempengaruhi orang lain mengukur tentang kemahiran subjek dalam mempengaruhi orang lain secara berhemah dan berkesan. Contoh: "Rakan-rakan tidak pernah menolak pandangan saya".

b. Bahagian pengurusan konflik menilai kebolehan subjek dalam menyelesaikan konflik yang dihadapi oleh orang lain. Contoh: "Saya cuba mewujudkan situasi dimana semua individu yang berkonflik akan mendapat faedah bersama ".

c. Bahagian kepemimpinan mengukur tentang keupayaan subjek dalam membimbing individu dan kumpulan ke arah kecemerlangan. Contoh: "Saya mencari kaedah yang paling sesuai untuk membantu rakan-rakan menyelesaikan sesuatu tugas yang sukar".

d. Bahagian pemangkin perubahan mengukur tentang keupayaan subjek dalam memulakan sesuatu perubahan. Contoh: "Saya tahu apa yang perlu diubah untuk meningkatkan kecemerlangan diri”.

e. Bahagian menjalin hubungan mengukur kebolehan subjek dalam membina hubungan yang berkesan dengan orang lain. Contoh: "Saya mudah membina hubungan mesra dengan siapa sahaja"

f. Bahagian kerjasama mengukur tentang kemampuan subjek dalam membina kerjasama dalam satu pasukan. Contoh: "Saya boleh melakukan aktiviti berkumpulan dengan sesiapa sahaja”.

g. Bahagian keupayaan berpasukan mengukur tentang keupayaan subjek dalam mewujudkan kerjasama berpasukan yang efektif dalam mewujudkan matlamat 
sesebuah organisasi. Contoh: "Saya boleh mewujudkan semangat kerjasama dalam kalangan rakan-rakan".

h. Bahagian komunikasi menilai tentang kemahiran subjek dalam berkomunikasi dengan orang lain. Contoh: "Saya sedia mendengar pandangan orang lain”.

\section{vi. Bahagian Spiritualiti/Kerohanian}

Item-item bahagian kerohanian ini adalah mengukur tentang tahap kerohanian yang wujud dalam diri subjek. Contoh: "Saya suka melihat orang lain berjaya".

\section{vii. Bahagian Kematangan}

Item-item bahagian ini adalah untuk mengukur tentang kemahiran subjek dalam menjadikan pengalaman yang pernah dialami untuk meningkatkan kematangan hidup mereka. Contoh: "Saya banyak belajar dari kesukaran hidup yang pernah dialami”.

\subsubsection{Instrumen Fasa Kedua}

Fasa kedua kajian ini menggunakan dua set soalan protokol, iaitu soalan protokol temubual mendalam (indepth interview) dan soalan protokol temubual berkumpulan (focus group interview). Kedua-dua soalan protokol ini digunakan sebagai panduan untuk mendapatkan data daripada pakar dan orang-orang yang dianggap berjaya dalam bidang yang mereka ceburi. Data-data yang diperolehi daripada pakar dan orang-orang berjaya tersebut dijadikan sebagai asas dalam pembinaan modul latihan EQ yang menjadi tujuan utama kajian ini. Menurut Morgan (1997) melalui temubual pengkaji boleh mendapatkan data yang lebih komprehensif tentang sesuatu perkara yang dikaji. Beliau juga menyatakan pengumpulan data melalui temubual ini dapat memberikan peluang yang lebih besar kepada subjek untuk memberikan pendapat secara bebas dan terbuka tanpa dipengaruhi oleh pandangan orang lain.

Soalan protokol tersebut dibina oleh pengkaji berdasarkan garis panduan yang dicadangkan oleh Krueger (1994). Soalan protokol individu dan soalan protokol 
berkumpulan dibina lebih kurang sama, hanya terdapat sedikit perbezaan pada soalan pembuka. Soalan pembuka pada soalan protokol temubual individu terus ditujukan kepada individu yang ditemubual, sedang soalan pembuka pada temubual berkumpulan cuba menanyakan kepada subjek tentang persamaan dan perbezaan mereka berada dalam kumpulan tersebut. Melalui temubual secara individu pengkaji mendapatkan maklumat secara mendalam daripada individu yang dilibatkan. Sedangkan melalui temubual berkumpulan pula subjek dapat memberikan pelbagai maklumat kepada pengkaji, untuk melihat kepelbagaian interaksi terhadap perkara yang dibincangkan pada satu masa (Morgan 1997; Krueger 1994). Soalan yang dikemukakan dalam protokol ini berbentuk soalan terbuka dan ianya dijalankan dalam bentuk diskusi (sama ada temubual individu mahupun temubual berkumpulan). Subjek bebas menyatakan pandangan mereka tentang perkara yang sedang dibincangkan dalam temubual yang sedang dijalankan. Walaubagaimanapun, perjalanan perbincangan tersebut tetap berpandukan kepada soalan protokol yang digunakan(Yin 1994).

Soalan protokol tersebut mengandungi lima jenis soalan, iaitu soalan pembuka, soalan pengenalan, soalan transisi, soalan kunci dan soalan penutup (Krueger 1994). Kebiasaannya sebelum memberikan soalan pembuka, dalam masa beberapa saat subjek diberi peluang untuk memperkenalkan diri mereka masing-masing. Untuk soalan protokol temubual berkumpulan, bahagian soalan pembuka memberikan peluang kepada subjek untuk mengenal pasti persamaan dan perbezaan mereka berada dalam kumpulan temubual tersebut. Soalan ini sebenarnya bertujuan untuk "ice-breaking" ataupun pembuka tirai perbincangan kepada subjek agar mereka selesa untuk menyampaikan pandangannya dalam perbincangan berikutnya. Pada bahagian ini semua subjek diberikan masa selama 10-20 saat untuk mengenal pasti persamaan dan perbezaan identiti dalam kalangan peserta kumpulan.

Contoh soalan: Boleh tuan/puan terangkan tentang diri dan pengalaman tuan/puan sepanjang kerjaya tuan/puan, sehingga tuan/puan berada pada tahap sekarang ini? 
Soalan pengenalan pula digunakan untuk memperkenalkan tema perbincangan kepada subjek yang terlibat dalam kumpulan. Bahagian ini memberi peluang kepada subjek untuk mengimbas semula pengalaman yang pernah mereka lalui dan diminta mengaitkan pengalaman tersebut dengan topik yang sedang dibincangkan. Soalan ini bertujuan untuk memberikan gambaran kepada subjek tentang isu-isu penting yang menjadi topik perbincangan dalam temubual berkumpulan yang dilaksanakan. Bahagian soalan pengenalan pula bertujuan untuk memperkenalkan secara umum tentang topik perbincangan di dalam temubual tersebut. Selanjutnya melalui soalan transisi pengkaji cuba memandu subjek kepada topik perbincangan ataupun maklumatmaklumat penting yang diperlukan daripada subjek yang terlibat.

Contoh soalan: (i) Pernahkah tuan/puan mengikuti sebarang kursus ataupun latihan tertentu yang dapat membantu tuan/puan menjalankan tugas dengan baik? (ii) Boleh tuan/puan kongsikan, apakah bentuk-bentuk latihan tersebut? Bagainakah pandangan tuan/puan tentang latihan itu?

Sedangkan soalan kunci pula merupakan soalan-soalan inti untuk mencungkil data daripada subjek-subjek yang ditemubual. Melalui soalan-soalan kunci inilah maklumat-maklumat penting diperolehi oleh pengkaji yang akan dijadikan sebagai asas pembinaan modul EQ. Contoh soalan:

\section{a. Kesedaran Kendiri}

Kesedaran kendiri adalah salah satu domain penting dalam membangunkan EQ seseorang. Kesedaran kendiri ini adalah kemampuan individu untuk: (i) mengetahui perasaan sendiri, (ii) berkeupayaan menilai dengan tepat kekuatan dan kelemahan diri sendiri, (iii) mampu membina keyakinan diri dan (iv) sedar tentang niat dalam diri.

1. Berdasarkan pengalaman tuan/puan adakah elemen-elemen tersebut berperanan dalam mencapai kejayaan sekarang ini?

2. Bagaimana tuan/puan mengaitkanya dengan kejayaan yang telah tuan/puan perolehi sekarang? 
3. Apakah yang tuan/puan lakukan untuk membina kesedaran tersebut, sehingga ianya sentiasa wujud dalam diri tuan/puan?

4. Melalui pengalaman tuan/puan, apakah yang telah tuan/puan lakukan untuk mengetahui:

i. Perasaan sendiri

ii. Menilai dengan tepat kekuatan dan kelemahan diri

iii. Membina keyakinan diri

iv. Dan sentiasa sedar tentang niat di dlam diri?

\section{b. Regulasi Kendiri}

Menggambarkan tentang kemampuan seseorang untuk mengawal perasaan yang sedang bergejolak dalam dirinya, sentiasa jujur dalam bertindak, bertanggung jawab dalam melakukan sesuatu, fleksibel dengan perubahan yang berlaku dan mahu menerima idea-idea baru dari sesiapa sahaja tanpa diiringi dengan perasaan negatif.

1. Berdasarkan pengalaman tuan/puan adakah elemen tersebut membantu dalam kejayaan tuan/puan?

2. Bagaimana tuan/puan mempergunakan elemen-elemen tersebut, sehingga ianya memberikan impak terhadap kejayaan yang tuan/puan dapatkan sekarang ini?

3. Melalui pengalaman yang telah dilalui selama ini, bagaimana tuan/puan memupuk elemen-elemen tersebut, sehingga ianya bersebati di dalam diri tuan/puan?

\section{c. Motivasi Kendiri}

1. Bagaimana tuan/puan memotivasikan diri sendiri untuk mewujudkan kejayaan seperti sekarang ini?

2. Pada pengalaman tuan/puan, bagaimana tuan/puan membina motivasi tersebut sehingga ianya sentiasa menjadi pendorong dalam mewujudkan kejayaan tuan/puan?

3. Apakah yang tuan/puan lakukan untuk memotivasikan diri sehingga berjaya? 


\section{d. Empati}

1. Boleh tuan/puan berkongsi pandangan apakah yang tuan/puan faham tentang empati?

2. Mungkin tuan/puan boleh berkongsi pengalaman tentang bagaimana tuan/puan cuba:

(i) Memahami perasaan orang lain?

(ii) Memahami keperluan orang lain?

(iii) Memahami masalah orang lain?

(iv) Dan memahami keperihatinan yang dirasakan oleh orang lain?

3. Kalau tuan/puan melihat ahli keluarga/kakitangan yang mempunyai potensi yang boleh dikembangkan, apakah yang tuan/puan lakukan?

4. Apakah yang tuan/puan lakukan untuk membantu kakitangan tuan/puan sekiranya mereka tidak dapat melihat peluang dalam kerjaya mereka?

\section{e. Kemahiran sosial}

Ialah kemahiran mencetuskan respons yang dikehendaki daripada orang lain. Menggunakan cara yang efektif untuk membujuk orang lain, mampu menerima dan menyampaikan mesej dengan penuh keyakinan dan berkebolehan menyelesaikan konflik dengan baik.

1. Bagaimanakah tuan/puan membina hubungan dengan individu lain? Kenapa Tuan/puan mengatakan begitu?

2. Melalui pengalaman tuan/puan, bagaimakah tuan/puan mempengaruhi orang lain untuk mengikuti cadangan dan idea tuan/puan?

3. Bagaimanakah tuan/puan menyampaikan maklumat kepada orang lain, sehingga orang lain dapat menerima dengan baik?

4. Dalam sesebuah organisasi terkadang berlaku konflik luaran dan dalaman yang mungkin boleh membawa kepada kelemahan sistem sesebuah organisasi, jika tuan/puan berada dalam situasi konflik sedemikian, apakah yang tuan/puan lakukan? 


\section{f. Kerohanian}

1. Pada pengalaman tuan/puan selama ini, bagaimana tuan/puan mengaitkan kerjakerja harian tuan/puan dengan nilai-nilai kerohanian yang tuan/puan yakini?

2. Bagaimana cara tuan/puan menghayati nilai-nilai kerohanian tersebut, sehingga ianya boleh menjadi pendorong kepada kejayaan yang tuan/puan raih sekarang?

3. Bagaimanakah tuan/puan melaksanakan kerja-kerja harian tuan/puan sehingga ianya dipandang sebagai satu amanah yang mesti dikerjakan dengan penuh keikhlasan?

\section{g. Kematangan}

1. Apakah persamaan dan perbezaan yang tuan/puan rasakan ketika mula-mula menceburkan diri dalam kerjaya, dimana tuan/puan telah lama berada di dalam kerjaya tersebut?

2. Apakah faktor-faktor yang membawa kepada kejayaan dalam diri tuan/puan?

3. Untuk sampai pada peringkat sekarang ini, tentunya tuan/puan mempunyai pelbagai pengalaman, bagaimana agaknya tuan/puan mempergunakan pengalaman tersebut untuk memperbaiki keadaan yang tuan/puan hadapi sekarang?

4. Setelah melalui pelbagai rintangan dalam kerjaya, apakah yang tuan/puan rasakan pada saat ini?

Manakala soalan penutup pula merupakan rumusan daripada perbincangan yang dijalankan. Sekiranya masih terdapat perkara-perkara penting yang perlu dikongsikan oleh subjek tentang topik perbincangan yang tidak tertanya oleh pengkaji, maka pada bahagian penutup ini subjek dapat menyampaikan perkara tersebut. Selepas soalan penutup pengkaji mengucapkan terima kasih atas kesediaan dan masa yang diluangkan oleh subjek. Pengkaji menyatakan kepada subjek, sekiranya hasil temubual ini selesai dibuat dalam bentuk transkripsi, maka pengkaji meminta tolong semak semula hasil transkripsi yang dibuat bagi memastikan data-data yang diberikan sesuai dengan yang dimaksudkan oleh subjek-subjek yang memberikan pandangan. 
Contoh soalan: (i) Kita telah berbincang lama, secara umumnya apakah pandangan tuan/puan tentang perkara-perkara yang telah kita bincang tadi? (ii) Adakah perkaraperkara yang tertinggal atau yang ingin tuan/puan tambahkan dalam perbincangan kita tadi?

\subsection{KAJIAN RINTIS}

Kajian rintis merupakan perkara penting dalam sesebuah kajian, bagi menentukan kesahan dan kebolehpercayaan instrumen yang digunakan dalam kajian tersebut. Dalam penyelidikan ini, kajian rintis telah dilakukan terhadap kedua-dua instrumen yang digunakan (IKEM/MEQI dan protokol temubual). Maklumbalas daripada kajian rintis tersebut telah digunakan untuk memurnikan dan memantapkan lagi item-item yang terdapat dalam instrumen dan soalan-soalan protokol temubual yang telah dibina. Kajian rintis IKEM/MEQI telah dilakukan pada pertengahan bulan Ogos 2007, sedangkan kajian rintis untuk protokol temubual dilaksanakan pada ujung bulan November 2007. Bilangan responden yang terlibat dalam kajian rintis instrumen IKEM/MEQI adalah seramai 55 orang, sedangkan untuk kajian rintis protokol temubual telah dilakukan kepada dua orang pakar.

\subsection{KESAHAN DAN KEBOLEHPERCAYAAN INSTRUMEN}

Kesahan (validity) dan kebolehpercayaan (reliability) instrumen merupakan dua isu yang berbeza yang perlu diperhatikan oleh pengkaji sebelum menggunakan instrumen tersebut dalam kajian sebenar. Kesahan sesebuah instrumen merujuk kepada sejauh mana instrumen digunakan itu dapat mengukur apa yang sepatutnya diukur dalam sesebuah kajian yang sedang dijalankan (Alias Baba 1997; Hair, Anderson, Tatham \& Black 1998; Majid Konting 2005; Mohd. Krueger 1994; Sidek Mohd Noah 2002; Wiersma 2000). Sedangkan kebolehpercayaan instrumen pula merujuk kepada ketekalan ataupun konsistensi sesebuah instrumen yang digunakan (Alias Baba 1997; Hair, Anderson, Tatham \& Black 1998; Wiersma 2000). Satu instrumen kajian dikatakan mempunyai kebolehpercayaan yang tinggi, apabila skor yang sama 
diperolehi oleh individu yang sama apabila menjawab satu set instrumen pada masa yang berbeza (Majid Konting 2005; Sidek Mohd. Noah 2002; Wiersma 2000).

Untuk tujuan kajian ini pengkaji menggunakan kedua-dua kaedah berkenaan bagi memastikan kesahan dan kebolehpercayaan instrumen yang digunakan. Untuk menentukan kesahan instrumen IKEM/MEQI pengkaji telah menggunakan kaedah factor analysis (varimax rotation), untuk melihat kebolehpercayaan pula pengkaji menggunakan kaedah "Cronbach Alpha" ataupun ujian ketekalan dalaman (internal consistancy). Sedangkan untuk melihat kesahan protokol temubual pula, pengkaji telah meminta beberapa orang pakar untuk menilai dan menyemak soalan protokol yang telah siap dibina oleh pengkaji. Penilaian dan komen yang diberikan oleh pakar-pakar tersebut telah dijadikan landasan untuk memperbaiki semula soalan protokol tersebut. Sedangkan untuk melihat kebolehpercayaan hasil temubual menggunakan soalan protokol yang telah disahkan oleh pakar kaedah pengiraan "Indeks Kebolehpercayaan Cohen Kappa” digunakan.

\subsubsection{Kesahan Instrumen IKEM/MEQI}

Semenjak instrumen ini dibangunkan dari tahun 2002 oleh Noriah et al. proses penambahbaikan instrumen ini terus dilakukan sehingga tahun 2008. Proses penambahbaikan ini merangkumi pelbagai aspek, mulai daripada penggunaan ayat dalam pernyataan, bentuk tampilan instrumen dan juga kesahan dan kebolehpercayaan instrumen. Untuk penggunaan ayat, Noriah et al. telah menggunakan perkhidmatan pakar bahasa (Melayu, Inggeris, Mandarin, Korea Arab dan Indonesia) kerana instrumen ini telah wujud dalam enam bahasa. Untuk reka bentuk tampilan instrumen Noriah et al. telah menggunakan perkhidmatan konsultan tempatan yang pakar dalam bidang ICT. Kesahan muka dan kesahan kandungan instrumen juga dilakukan dengan mengambil kira pandangan individu yang dianggap pakar dalam bidang ini.

Untuk melihat kesahan konstruk dan kebolehpercayaaan instrumen pula, semenjak instrumen ini mula dibangunkan sehingga tahun 2008 telah melibatkan lebih daripada 20.000 orang sampel dewasa daripada pelbagai kalangan, seperti calon-calon kakitangan dan calon pensyarah UKM, Tentera Laut Diraja Malaysia (TLDM), 
kakitangan Institut Sosial Malaysia (ISM), guru-guru, serta kakitangan pelbagai syarikat swasta yang ada di Malaysia. Bagaimanapun, memandangkan kajian ini difokuskan kepada guru-guru maka kesahan konstruk instrumen IKEM/MEQI menggunakan data-data yang diberikan oleh guru-guru dilakukan lagi sekali, bagi memastikan instrumen tersebut dapat mengumpulkan data-data yang berkesan di dalam kajian ini. Untuk melihat kesahan konstruk tersebut ujian faktor analisis (Varimax rotation) telah dijalankan.

Menurut Hair et al. (1998), factor analysis dapat dilakukan apabila bilangan sampel sekurang-kurangnya lima kali ganda berbanding faktor (variable) yang ingin dikaji, ataupun bilangan sampel tidak kurang daripada 50 orang. Untuk tujuan kajian ini pengkaji telah mengambil jumlah sampel lebih ramai daripada yang dicadangkan oleh Hair et al. tersebut, iaitu pengkaji telah melibatkan seramai 55 orang sampel.

Seterusnya untuk pemilihan item yang dianggap tepat untuk mengukur konstruk yang dikaji, kaedah practical significance telah digunakan. Hair et al. (1998) menyatakan bahawa nilai $\mathbf{0 . 3 0}$ adalah nilai yang boleh diterima dalam analisis faktor. Memandangkan item-item instrumen ini agak banyak, analisis faktor dijalankan melalui beberapa tahap, iaitu tahap pertama pengkaji telah menggugurkan mana-mana item yang memperolehi skor di bawah $\mathbf{0 . 3 0}$ bagi setiap konstruk yang terdapat di dalam instrumen ini. Faktor analisis diteruskan ke tahap berikutnya sehingga tiada lagi item-item yang memperolehi skor di bawah 0.30 yang perlu digugurkan. Dengan perkataan lain ujian analisis faktor tidak diteruskan lagi, apabila hasil ujian menunjukan kesemua item yang tinggal memperolehi nilai loading $\mathbf{0 . 3 0}$ dan ke atas. Item-item inilah yang digunakan untuk mengumpulkan data dalam kajian sebenar.

Jadual 3.1 di bawah menunjukkan hasil ujian Analisis faktor (varimax rotation) untuk melihat kesahan (validity) instrumen IKEM/MEQI yang digunakan di dalam kajian ini. Instrumen tersebut mengandungi tujuh domain utama, iaitu (i) kesedaran kendiri, (ii) regulasi kendiri, (iii) motivasi kendiri, (iv) empati (v) kemahiran sosial, (vi) kerohanian, dan (vii) kematangan. 
Jadual 3.1 Kesahan konstruk instrumen IKEM/MEQI

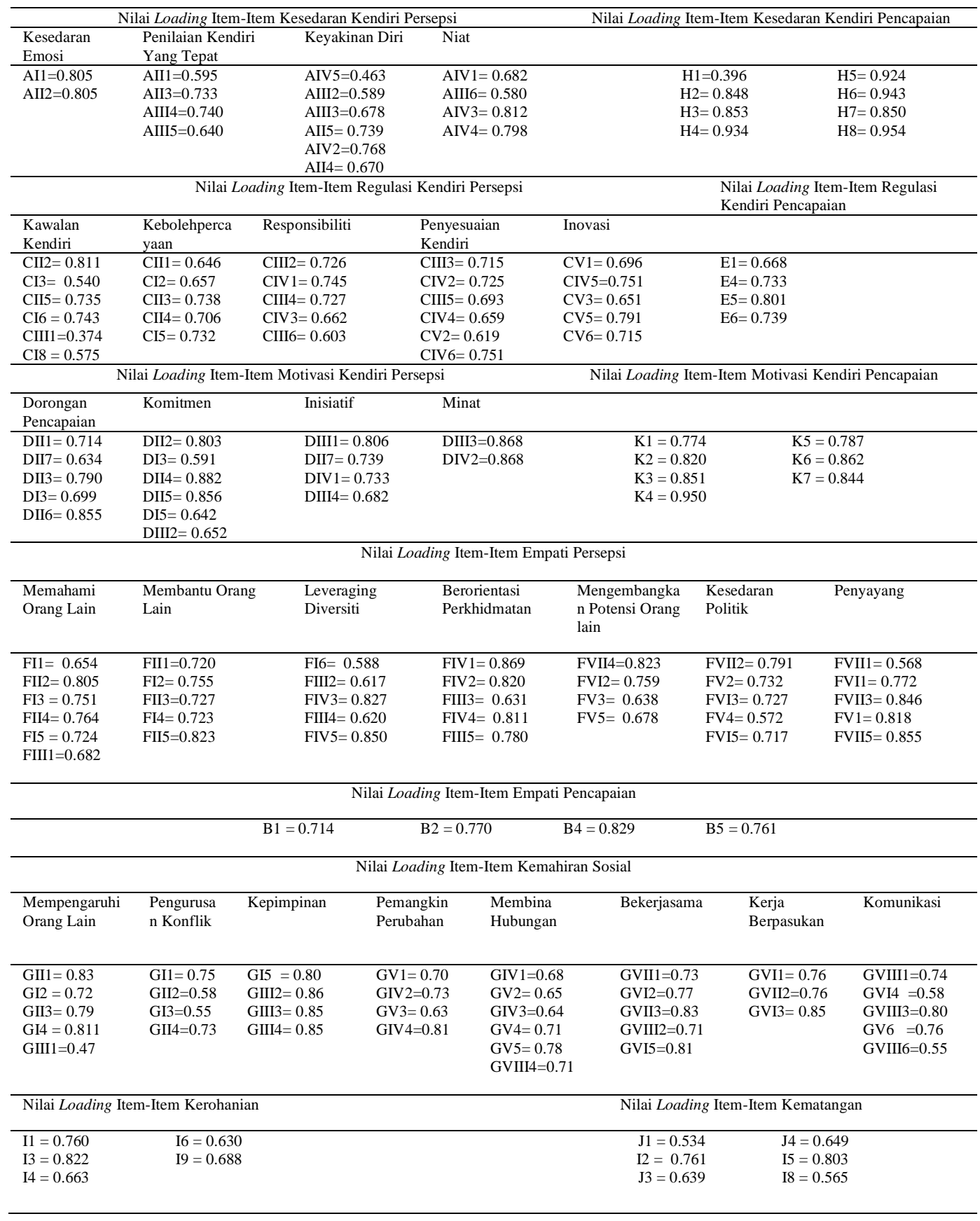

Daripada analisis yang dijalankan didapati 16 memperolehi nilai loading di bawah 0.30, iaitu 13 item pada bahagian soalan persepsi dan dan $\mathbf{3}$ item pada bahagian pencapaian. Keseluruhan item tersebut telah digugurkan daripada instrumen ini sebelum analisis data sebenar dilakukan. Secara keseluruhan 13 item pada bahagian soalan persepsi tersebut adalah; (i) 4 item pada domain kesedaran kendiri, iaitu 1 item 
pada sub domain penilaian kendiri yang tepat $(\mathrm{Ai} 2=-0.122)$, dan 3 item pada sub domain kejujuran (Aiii1=0.043, Aiv6=0.226, Aiv7=0.205). (ii) 3 item pada domain regulasi kendiri, iaitu 1 item pada sub domain kawalan kendiri $(\mathrm{Cv} 4=0.290), 1$ item pada sub domain responsibiliti $(\mathrm{Ci} 7=0.047)$ dan 1 item pada sub domain inovasi $(\mathrm{Ci} 4=$ 0.225). (iii) 1 item pada domain motivasi kendiri, iaitu pada sub doamain komitmen (Di1= 0.034). (iv) 1 item pada domain empati, iaitu pada sub domain mengembangkan potensi orang lain $(F v i 4=0.028)$, dan (v) 4 item pada domain kerohanian $(j 2=0.045$, $\mathrm{J} 5=0.091, \mathrm{I} 7=-0.013, \mathrm{~J} 6=0.055)$. Sedangkan 3 item pada bahagian pencapaian pula didapati 2 item pada domain regulasi kendiri $(E 2=0.050$, dan $E 3=0.236)$, dan 1 item pada domain empati $(\mathrm{B} 3=0.066)$.

\subsubsection{Kesahan Protokol Temubual}

Seperti yang telah disentuh juga sebelum ini, kesahan protokol temubual telah dilakukan dengan cara meminta perkhidmatan beberapa orang pakar untuk menyemak protokol temubual tersebut. Sebaik sahaja pengkaji dapat menyusun protokol temubual berkenaan, pengkaji meminta perkhidmatan enam orang pakar untuk menyemak dan memberikan komen terhadap protokol temubual tersebut. Keenam-enam pakar tersebut adalah, empat orang pakar dalam bidang psikologi dan kaunseling, dan dua orang pakar dalam bidang penyelidikan kualitatif. Setelah keenam-enam pakar berkenaan memberikan pandangan dan komen tentang protokol yang dibina, pengkaji telah memperbaiki semula sesuai dengan komen-komen yang mereka berikan. Bagi memastikan protokol temubual tersebut dapat digunakan dengan baik dan berkesan, pengkaji telah melakukan rintis terlebih dahulu kepada dua orang subjek sebelum protokol tersebut digunakan untuk tujuan temubual sebenar. Melalui rintis tersebut pengkaji dapat mengenal pasti sama ada soalan-soalan dalam protokol tersebut dapat difahami dengan baik oleh subjek kajian atau sebaliknya. Daripada rintis yang dijalankan, sememangnya menghadapi kesukaran untuk memahami beberapa soalan yang diajukan kepada mereka, maka pengkaji telah membincangkan semula dengan penyelia, dan mengubah soalan-soalan tersebut untuk digunakan di dalam mengumpulkan data sebenar. 


\subsection{KEBOLEHPERCAYAAN INSTRUMEN}

Sama halnya dengan kesahan instrumen, kebolehpercayaan juga dilakukan terhadap kedua-dua instrumen yang digunakan dalam kajian ini, iaitu instrumen IKEM/MEQI pada fasa pertama dan soalan protokol pada fasa kedua. Untuk melihat kebolehpercayaan instrumen IKEM/MEQI ujian Cronbach Alpha digunakan. Sedangkan untuk melihat kebolehpercayaan protokol temubual pula, pengkaji telah meminta tujuh orang penilai (Inter-rater reliability) untuk menilai hasil analsis kualitatif yang telah dilakukan. Penilaian yang diberikan oleh masing-masing rater tersebut dikira menggunakan Formula Cohen Kappa $(\mathrm{K})=(\mathrm{fa}-\mathrm{fc}) /(\mathrm{N}-\mathrm{fc})$ seperti yang dicadangkan oleh Yin (1994). Menurut Yin $\mathrm{fa}=$ kekerapan persetujuan penilai, $\mathrm{fc}=$ kekerapan kebarangkalian manakala $\mathrm{N}=$ jumlah item yang disediakan dalam skema pengekodan.

\subsubsection{Kebolehpercayaan Instrumen IKEM/MEQI}

Kebolehpercayaan instrumen IKEM/MEQI sebenarnya telah dilakukan banyak kali. Semenjak instrumen ini dibangunkan pada tahun 2002 oleh Noriah et al. ujian kebolehpercayaan instrumen telah dilakukan kepada sekumpulan sampel guru-guru. Seterusnya ujian kebolehpercayaan juga telah dilakukan oleh beberapa orang pengkaji berikutnya yang menggunakan instrumen tersebut, diantaranya adalah Syafrimen (2004) yang menjalankan kajian terhadap guru-guru sekolah menengah di Malaysia, Syed Najmuddin (2005) yang menjalankan kajian terhadap guru-guru Maktab Rendah Sains MARA (MRSM), Iskandar (2008) yang menjalankan kajian terhadap pensyarah Institut Agama Islam Negeri "Sultan Taha” Jambi Indonesia, dan Rorlinda (2008) yang menjalankan kajian terhadap guru-guru kaunseling di Selangor Malaysia. Masingmasing kajian mendapati kebolehpercayaan instrumen tersebut secara keseluruhan adalah 0.9 ke atas. Bagaimanapun untuk tujuan kajian ini pengkaji cuba melihat kebolehpercayaan instrumen lagi sekali bagi memastikan konsistensi instrumen tersebut. Memandangakan instrumen IKEM/MEQI terbahagi kepada dua bahagian (persepsi dan pencapaian), maka ujian kebolehpercayaan instrumen dilihat bagi kedua-

dua bahagian berkenaan. Ujian kebolehpercayaan bagi setiap domain dan sub domain yang terdapat pada masing-masing bahagian juga dilakukan. 
Jadual 3.2 memaparkan kebolehpercayaan instrumen IKEM/MEQI bahagian persepsi dan juga domain dan sub domain yang terdapat pada bahagian tersebut. Daripada analisis yang dijalankan, nilai alpha IKEM/MEQI secara keseluruhan untuk bahagian persepsi tersebut adalah $\mathbf{0 . 9 8}$. Sedangkan nilai alpha bagi setiap domain yang terkandung pada bahagian ini pula adalah (i) domain kesedaran kendiri $\mathbf{0 . 8 1}$, dan nilai alpha bagi setiap sub domain adalah antara $\mathbf{0 . 6 0}$ sehingga $\mathbf{0 . 7 3}$. (ii) Domain regulasi kendiri pula 0.89, dan nilai alpha bagi setiap sub domain ini adalah antara 0.70 sehingga 0.78. (iii) Domain motivasi kendiri $\mathbf{0 . 9 3}$, dan nilai bagi setiap sub domain pula adalah antara $\mathbf{0 . 6 7}$ sehingga $\mathbf{0 . 8 2}$. (iv) Domain empati 0.94, dan nilai alpha bagi setiap domain pula adalah antara $\mathbf{0 . 7 0}$ sehingga 0.84. (v) Domain kemahiran sosial 0.94, dan bagi setiap domain pula adalah antara 0.60 sehingga 0.86. (vi) Domain kerohanian 0.76, dan (vi) domaian kematangan adalah 0.94. Secara lebih terperinci nilai alpha yang diperolehi bagi masing-masing domain dan sub domain yang terdapat dalam instrumen IKEM/MEQI bahagian persepsi tersebut, adalah seperti pada Jadual 3.2 di bawah ini.

Jadual 3.2 Nilai Kebolehpercayaan alpha cronbach instrumen IKEM-MEQI persepsi

\begin{tabular}{|c|c|c|}
\hline Domain & Sub Domain & Nilai Alpha \\
\hline IKEM/MEQI Keseluruhan & & 0.98 \\
\hline \multirow[t]{5}{*}{ Kesedaran Kendiri Persepsi } & & 0.81 \\
\hline & - Kesedaran emosi & 0.60 \\
\hline & $\begin{array}{l}\text { - Penilaian kendiri yang } \\
\text { tepat }\end{array}$ & 0.61 \\
\hline & - Keyakinan diri & 0.73 \\
\hline & - Kejujuran & 0.70 \\
\hline \multirow[t]{6}{*}{ Regulasi Kendiri } & & 0.89 \\
\hline & - Kawalan kendiri & 0.70 \\
\hline & - Kebolehpercayaan & 0.73 \\
\hline & - Responsibiliti & 0.73 \\
\hline & - Kebolehsuaian & 0.78 \\
\hline & - Inovasi & 0.77 \\
\hline \multirow[t]{5}{*}{ Motivasi Kendiri } & & 0.93 \\
\hline & - Dorongan pencapaian & 0.80 \\
\hline & - Komitmen & 0.82 \\
\hline & - Inisiatif & 0.72 \\
\hline & - Minat & 0.67 \\
\hline
\end{tabular}


...sambungan

Empati

- Memahami orang lain $\quad 0.82$

- Membantu orang lain $\quad 0.81$

- Leveraging diversiti 0.74

- Berorientasi 0.84 perkhidmatan

- Mengembangkan $\quad 0.70$ potensi orang lain

- Kesedaran politik 0.75

- Penyayang 0.83

$\begin{array}{ll}\text { Kemahiran Sosial } & \mathbf{0 . 9 4}\end{array}$

- Mempengaruhi orang $\quad 0.77$ lain

- Pengurusan konflik $\quad 0.60$

- Kepimpinan 0.86

- Pemangkin perubahan $\quad 0.70$

- Membina hubungan $\quad 0.80$

- Bekerjasama 0.82

- Kerja berpasukan $\quad 0.70$

- Komunikasi 0.72

$\begin{array}{ll}\text { Kerohanian } & \mathbf{0 . 7 6}\end{array}$

$\begin{array}{lc}\text { Kematangan } & 0.94\end{array}$

Jadual 3.3 di bawah ini pula memaparkan nilai kebolehpercayaan instrumen IKEM/MEQI bahagian pencapaian. Nilai kebolehpercayaan secara keseluruhan untuk bahagian pencapaian adalah $\mathbf{0 . 6 5}$, dan nilai kebolehpercayaan bagi setiap domain yang terkandung pada bahagian ini adalah domain kesedaran kendiri $\mathbf{0 . 9 4}$, regulasi kendiri 0.71, motivasi kendiri $\mathbf{0 . 9 4}$, dan domain empati $\mathbf{0 . 7 6}$.

Jadual 3.3 Nilai Kebolehpercayaan alpha cronbach instrumen IKEM- MEQI pencapaian

\begin{tabular}{llc}
\hline & Domain & Nilai Alpha \\
\hline IKEM/MEQI Keseluruhan & & $\mathbf{0 . 6 5}$ \\
& Kesedaran Kendiri & 0.94 \\
& Regulasi Kendiri & 0.71 \\
& Motivasi Kendiri & 0.94 \\
& Empati & 0.76 \\
\hline
\end{tabular}

Menurut Hair, Anderson, Tatham dan Black (1998), nilai kebolehpercayaan adalah antara $\mathbf{0}$ hingga 1, dan nilai $\mathbf{0 . 6 0}$ hingga $\mathbf{0 . 7 0}$ merupakan nilai terendah dan 
masih boleh diterima. Robinson, Shaver, dan Wrightsman (1991) dalam Hair et al. (1998) menyatakan nilai minimum Cronbach Alpha dalam kajian eksplorasi ialah 0.60. Sedangkan menurut Mohd Majid Konting (2005) pula nilai alpha yang melebihi 0.60 sering digunakan. Sidek Mohd. Noah (2002) pula menyatakan untuk ujian kebolehan seperti mengukur kebolehan mental umum mestilah mempunyai kebolehpercayaan 0.90 ke atas. Untuk Typcal Performance Test, Nilai keboleh percayaan boleh $\mathbf{0 . 8 5}$ hingga 0.90. Bila dirujuk kepada beberapa pandangan di atas, secara umumnya nilai kebolehpercayaan yang diperolehi adalah pada tahap yang boleh digunakan. Dengan perkataan lain instrumen tersebut boleh dikatakan konsisten dan boleh dipercayai.

\subsubsection{Kebolehpercayaan Soalan Protokol}

Kebolehpercayaan protokol temubual dilihat melalui dua cara iaitu, pertama dengan cara menjalankan rintis temubual kepada dua orang subjek, iaitu untuk mengetahui sama ada soalan protokol tersebut konsisten ataupun tidak. Melalui rintis juga dapat diketahui sama ada subjek yang ditemubual faham dengan soalan-soalan yang dibina ataupun sebaliknya.

Kedua, kebolehpercayaan hasil temubual individu dan temubual berkumpulan telah dilihat menggunakan kaedah Indeks Kebolehpercayaan Cohen Kappa (K) menggunakan formula yang dicadangkan oleh Yin (1994) iaitu:



Pengkaji telah memberikan jadual pengekodan tema-tema yang diperolehi kepada lima orang yang dianggap pakar untuk menilai pengekodan tema-tema tersebut. Setelah proses analisis data dijalankan pengkaji telah memperolehi sebanyak 43 tema yang dikongsikan oleh subjek kajian untuk pembinaan 11 kompetensi asas EQ yang telah dikenal pasti pada fasa pertama kajian ini. Secara keseluruhan 43 tema tersebut 
adalah seperti ditunjukkan pada Rajah 3.3, Rajah 3.4, Rajah 3.5 dan Rajah 3.6 di bawah ini.

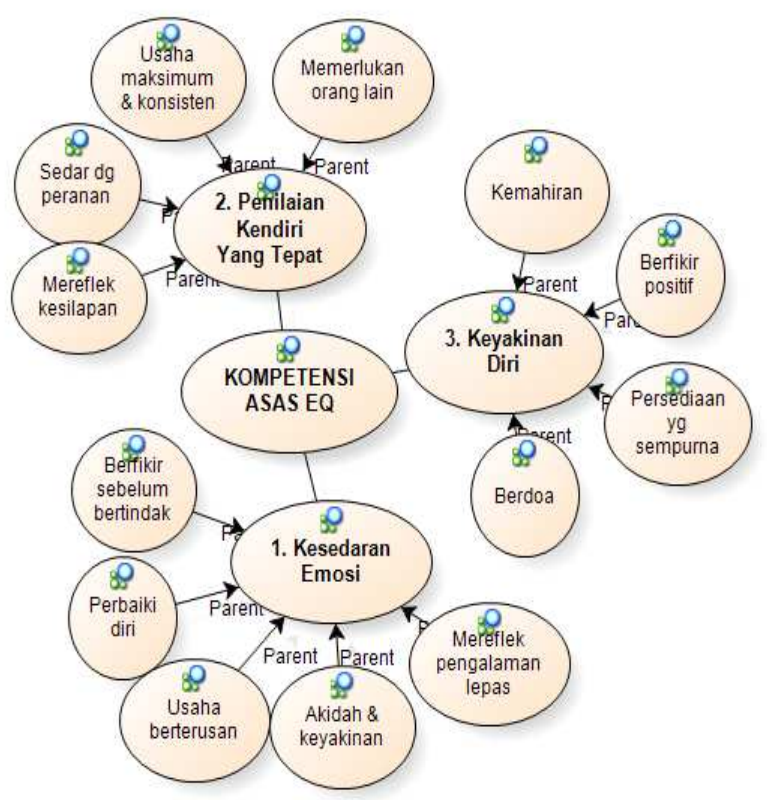

Rajah 3.3 Tema kesedaran emosi, penilaian kendiri yang tepat dan keyakinan diri

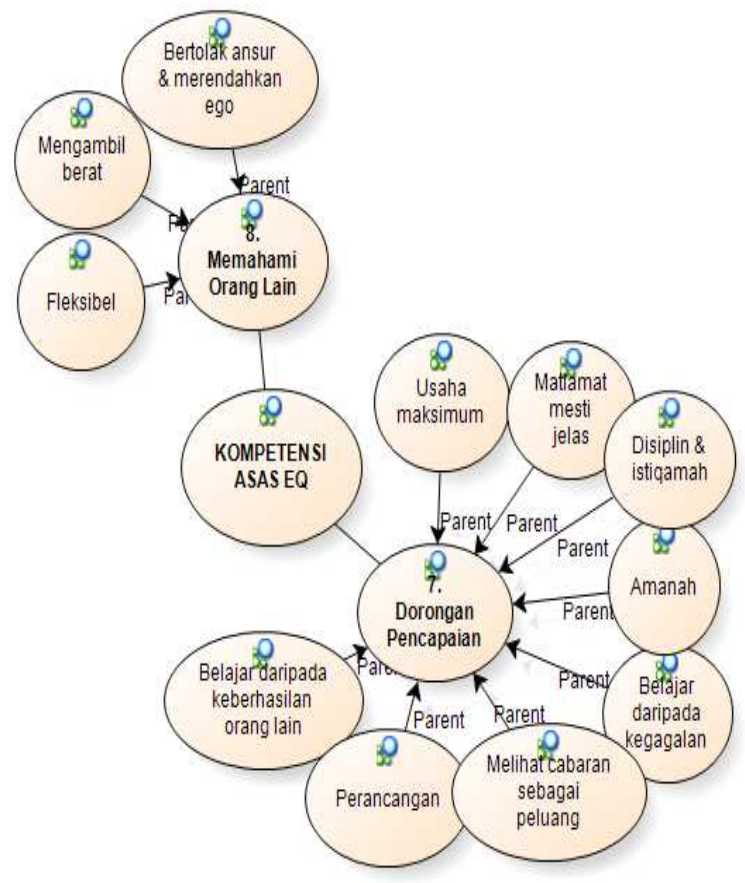

Rajah 3.5 Tema dorongan pencapaian dan memahami orang lain

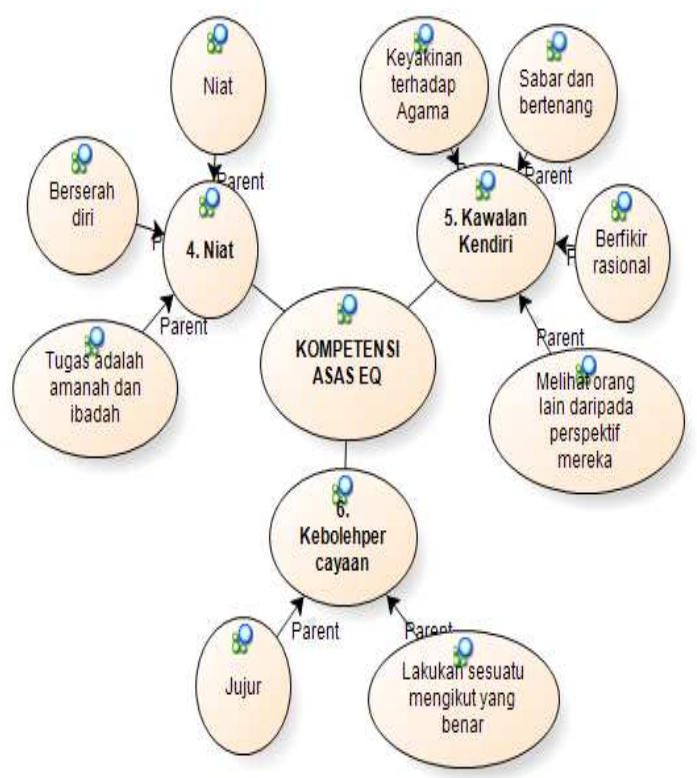

Rajah 3.4 Tema niat, kawalan kendiri dan kebolehpercayaan

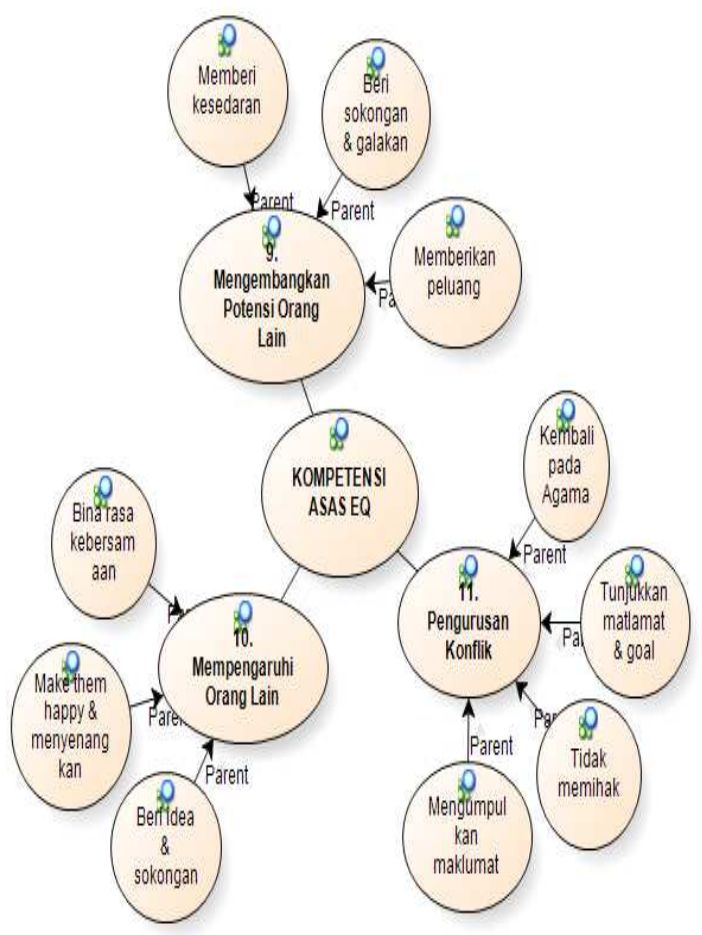

Rajah 3.6 Tema mengembangkan potensi orang lain, mempengaruhi orang lain dan pengurusan konflik 
Setelah kelima-lima orang pakar memberikan persetujuan mereka terhadap proses koding yang dilakukan berdasarkan tema-tema yang diperolehi, seterusnya pengkaji mengira indeks kebolehpercayaan proses koding tersebut. Proses pengiraan indeks Cohen Kappa seperti ditunjukkan pada Jadual 3.4 di bawah ini.

Jadual 3.4 Nilai persetujuan Cohen Kappa

\begin{tabular}{|c|c|c|c|c|c|}
\hline Pakar 1 & Pakar 2 & Pakar 3 & Pakar 4 & Pakar 5 & $\begin{array}{c}\text { Nilai Kohen Kappa } \\
\text { Keseluruhan }\end{array}$ \\
\hline $\mathrm{K}=\underline{41-21.5}$ & $\mathrm{~K}=\underline{42-21.5}$ & $\mathrm{~K}=\underline{40-21.5}$ & $\mathrm{~K}=\underline{42-21.5}$ & $\mathrm{~K}=\underline{41-21.5}$ & $\mathrm{~K}=$ \\
\hline$\overline{43-21.5}$ & $\overline{43-21.5}$ & $\overline{43-21.5}$ & $\overline{43-21.5}$ & $\overline{43-21.5}$ & $\underline{0.90+0.95+0.86+0.95+0.9}$ \\
\hline$K=\underline{19.5}$ & $K=\underline{20.5}$ & $K=\underline{18.5}$ & $K=\underline{20.5}$ & $K=\underline{19.5}$ & $\underline{0}$ \\
\hline 21.5 & 21.5 & $\overline{21.5}$ & 21.5 & $\overline{21.5}$ & 5 \\
\hline$K=0.90$ & $K=0.95$ & $K=0.86$ & $K=0.95$ & $K=0.90$ & $K=0.91$ \\
\hline
\end{tabular}

Peroses pengiraan indeks Cohen Kappa yang dipaparkan pada Jadual 3.4 di atas menujukkan bahawa daripada 43 tema yang diperolehi melalui proses koding yang dilakukan, didapati masing-masing pakar telah memberikan persetujuan mereka terhadap proses koding tersebut. Pakar 1 telah bersetuju terhadap $41(\mathrm{fa}=41)$ proses koding yang dilakukan mengikut tema-tema yang diperolehi, dan dua proses koding dianggap tidak bersesuaian dengan tema yang didapatkan, pakar 2 bersetuju 42 tema $(\mathrm{fa}=42)$ dan satu tema tidak bersetuju, pakar 3 bersetuju 40 tema $(\mathrm{fa}=40)$ dan tiga tema tidak bersetuju, pakar 4 bersetuju 42 tema $(\mathrm{fa}=42)$ dan satu tema tidak bersetuju, dan pakar 5 bersetuju 41 tema $(\mathrm{fa}=41)$ dan tidak bersetuju dua tema.

Setelah mengira hasil persetujuan pakar tersebut menggunakan formula yang dicadangkan, nilai indeks Cohen Kappa yang diperolehi adalah; pakar $1 \mathrm{~K}=0.90$, pakar $2 \mathrm{~K}=0.95$, paka3 $\mathrm{K}=0.86$, pakar $4 \mathrm{~K}=0.95$ dan pakar $5 \mathrm{~K}=0.90$. Sedangkan indeks Cohen Kappa secara keseluruhannya adalah K= 0.91. Landis dan Koch (1977) telah mencadangkan cara interpretasi nilai yang diperolehi menggunakan formula Cohen Kappa iaitu, nilai keboleh percayaan yang melebihi 0.75 adalah menunjukkan persetujuan yang kuat ataupun menunjukkan tahap konsistensi pengekodan data yang dilakukan oleh pengkaji adalah tinggi. Nilai 0.41 hingga 0.75 menunjukkan tahap persetujuan yang sederhana, dan nilai di bawah 0.40 menunjukkan tahap persetujuan yang lemah. Merujuk kepada cara interpretasi yang ditunjukkan tersebut boleh 
dikatakan bahawa proses koding yang dilakukan terhadap data-data yang diperolehi dalam kajian ini boleh dianggap konsisten.

\subsection{PROSEDUR PENGUMPULAN DATA}

Memandangkan kajian ini dijalankan melalui tiga fasa, maka pengumpulan data dilakukan melalui kaedah yang berasingan. Fasa pertama data dikumpulkan melalui soal selidik "Iventori Kepintaran Emosi Malaysia" (IKEM) atau "Malaysian Emotional Quotient Inventory” (MEQI). Fasa kedua, data dikumpulkan melalui temubual mendalam, temubual berkumpulan dan analisis dokumen. Manakala fasa ketiga (selepas pengujian modul EQ) data dikumpulkan semula menggunakan soal selidik IKEM/MEQI dan temu bual. Data yang dikumpulkan melalui soal selidik adalah untuk mendapatkan gambaran tentang profil kompetensi EQ selepas latihan dijalankan. Sedangkan pengumpulan data melalui temu bual pula adalah untuk mendapatkan pandangan subjek tentang latihan EQ menggunakan modul EQ yang dibangunkan.

Fasa pertama kajian ini melibatkan 112 orang guru-guru yang sedang menuntut peringkat Sarjana dan Doktor falsafah di Fakulti Pendidikan Universiti Kebangsaan Malaysia. Untuk memudahkan proses menjalankan kajian, permohonan kelulusan menjalankan kajian dengan pihak fakulti dan juga pensyarah-pensayah yang terlibat mengajar guru-guru tersebut telah dilakukan terlebih dahulu. Secara umumnya 112 orang guru-guru yang terlibat adalah mereka yang sedang mengikuti perkuliahan Kaedah Penyelidikan I dan Kaedah Penyelidikan II di fakulti Pendidikan. Mereka dipilih agar proses pengumpulan data dapat dilakukan dengan lebih cepat dan berkesan, kerana mereka terkumpul dalam satu kelas setiap minggu untuk mengikuti perkuliahan tersebut. Setelah mendapatkan kelulusan daripada pihak fakulti, pengkaji juga mendapatkan kelulusan daripada penyelaras kursus masing-masing. Seterusnya surat kebenaran (Consent Latter) diberikan kepada guru-guru tersebut bagi memastikan ketulusan dan keikhlasan mereka mengambil bahagian dalam kajian ini. Setelah semua perkara tersebut selesai dilakukan, barulah proses pengumpulan data pada fasa pertama ini dilakukan. 
Data fasa pertama dikumpulkan menggunakan satu set instrumen "IKEM/MEQI" yang disusun oleh Noriah dan rakan-rakan daripada tahun 2002 (perbincangan terperinci mengenai instrumen telah dilaporkan pada bahagian instrumen kajian). Peserta kajian telah memberikan maklum balas sepenuhnya terhadap instrumen yang diberikan. Daripada maklum balas berkenaan pengkaji telah mengenal pasti kopetensi asas EQ yang perlu diberikan latihan dalam kalangan guruguru yang mengambil bahagian dalam kajian ini.

Fasa kedua pula iaitu kajian kes, langkah pertama yang dilakukan adalah mengenal pasti terlebih dahulu subjek (pakar dan orang-orang berjaya) yang dapat memberikan data secara komprehensif kepada kajian ini. Untuk menentukan pakar dan orang-orang yang dianggap berjaya dalam bidang masing-masing, pengkaji telah duduk dengan beberapa orang pakar untuk membincangkan kriteria pemilihan pakar dan orang-orang berjaya dimaksudkan. Seterusnya pengkaji juga merujuk kepada beberapa dokumen untuk menentukan kriteria pakar dan orang-orang yang dianggap berjaya tersebut.

Setelah kriteria pakar dan orang-orang berjaya tersebut didapatkan, pengkaji telah menulis surat secara rasmi kepada orang-orang berkenaan untuk meminta kesediaan mereka berkongsikan maklumat tentang pelbagai perkara yang menyumbang kepada kepakaran dan kejayaan mereka. Untuk memudahkan proses ini, surat yang dihantarkan kepada pakar dan orang-orang berjaya tersebut telah disertakan gambaran secara ringkas tentang tujuan kajian ini dijalankan. Pengkaji disokong oleh penyelia juga telah menceritakan tentang kepentingan kenapa mereka dipilih dan dilibatkan dalam kajian ini. Secara umumnya pakar-pakar dan orang-orang berjaya yang mengambil bahagian dalam kajian ini telah memberikan kerjasama sepenuhnya untuk berkongsi pengalaman mereka. Pengalaman tersebut sangat diperlukan sebagai panduan dalam pembinaan modul EQ yang menjadi tujuan utama kajian ini. Pada fasa ini lapan temubual individu dengan pakar, dan dua kelompok temu bual berkumpulan kepada 24 orang-orang berjaya telah dilakukan.

Pada masa temubual dijalankan pengkaji mengambil kira pandangan Fantana dan Frey (1994) yang mencadangkan bahawa semasa temubual dijalankan pengkaji 
penting mempertimbangkan perkara-parkara berikut; (i) menerangkan kajian yang dijalankan menggunakan keterangan yang sama bagi semua peserta temua bual, (ii) urutan soalan (pengenalan, urutan soalan dan penuturan soalan mestilah sama, (iii) jawapan sepenuhnya diberikan kepada subjek temubual bukannya penemubual, (iv) penemubual tidak mencadangkan jawapan kepada subjek, (v) penemubual tidak mentafsirkan jawapan yang diberikan oleh subjek mengikut penafsiran sendiri dan (vi) tidak menambah dan mengurangi soalan protokol yang telah dibina.

Pengumpulan data pada fasa ketiga pengkaji tidak lagi melakukan prosedur seperti pada fasa pertama dan kedua, memandangkan subjek kajian fasa ketiga ini adalah guru-guru yang terlibat pada fasa pertama. Pengumpulan data pada fasa ini dilakukan selepas pengujian modul EQ dilakukan. Selepas pengujian modul, pengkaji memberikan soal selidik kepada subjek kajian yang terlibat pada fasa ini semula untuk mendapatkan perbandingan data dengan data fasa pertama. Perbandingan data fasa pertama dan ketiga ini sangat penting untuk melihat profil kompetensi EQ sebelum dan selepas mereka mengikuti latihan menggunakan modul EQ yang dibina. Pada fasa ini juga pengkaji cuba mendapatkan maklum balas daripada subjek-subjek yang terlibat pada fasa ketiga ini dengan cara mendapatkan pandangan mereka tentang latihan yang mereka ikuti menggunakan modul EQ tersebut. Pandangan mereka ini sangat penting untuk melihat respons mereka secara jujur sepanjang mengikuti latihan menggunakan modul EQ berkenaan.

\subsection{TATACARA PENGANALISISAN DATA}

Data-data yang dikumpul pada fasa pertama menggunakan instrumen IKEM/MEQI dianalisis menggunakan SPSS windows versi 15 (Statistical Package for Social Science Version 15). Sebelum analisis dijalankan pembersihan data dilakukan terlebih dahulu. Perkara ini sangat penting dilakukan kerana kemungkinan terdapat kesilapan semasa memasukan data ke dalam program SPSS. Kesilapan memasukan data boleh mempengaruhi hasil analisis yang dilakukan (Choakes 2005; Julie Pallant 2004). Setelah data-data yang diperolehi selesai dibersihkan barulah proses analisis dijalankan. Statistik deskriptif digunakan untuk menganalisis data-data yang diperolehi pada fasa pertama tersebut. Statistik deskriptif (kekerapan dan peratusan) telah 
digunakan untuk menerangkan profil responden kajian yang terlibat dalam kajian ini. Sedangkan statistik deskriptif (min dan sisihan piawai) digunakan untuk menentukan kompetensi asas EQ yang perlu diberikan intervensi dalam kalangan guru-guru yang terlibat di dalam kajian ini.

Data yang diperolehi pada fasa kedua (kajian kes) pula dianalisis menggunakan secara tematik menggunakan perisian NVivo 2 dan NVivo 7 iaitu jenis perisian terkini yang dibina khas untuk memudahkan dalam menganalisis dan mengorganisasikan data-data kualitatif. Sebelum data-data temubual dianalisis menggunakan perisian tersebut, semua hasil temubual sama ada temubual individu mahupun temubual berkumpulan, didengarkan semula dan ditranskripsikan satu persatu-persatu dalam bentuk dialog ataupun verbatim. Seterusnya sebelum hasil transkripsi tersebut dimasukan ke dalam perisian NVivo, semua hasil transkripsi dipastikan bersih terlebih dahulu iaitu dengan cara meminta tolong semak semula oleh subjek-subjek yang terlibat dalam temubual tersebut. Setelah semua langkah tersebut dilakukan, barulah proses mengimport ataupun memasukan data ke dalam perisisan NVivo dilakukan.

Langkah selanjutnya adalah membina tema-tema yang bersesuaian, agar petikan-petikan temubual dapat dikeluarkan bagi mendapatkan pengalaman dan pandangan subjek-subjek yang ditemubual, untuk tujuan pembinaan modul EQ yang menjadi tujuan utama kajian ini. Satu persatu hasil temubual tersebut telah dikodkan berdasarkan tema-tema yang dibina. Proses pengekodan telah dilakukan bagi setiap data temubual yang didapatkan. Seperti dibincangkan sebelum ini, kajian ini melibatkan lapan orang pakar dan 24 orang-orang yang dianggap berjaya dalam bidang yang mereka ceburi. Secara lebih terperinci cara penganalisisan data mengikut persoalan kajian seperti ditunjukkan pada Jadual 3.5 di bawah ini. 
Jadual 3.5 Tatacara analisis data mengikut persoalan kajian

\begin{tabular}{|c|c|c|c|c|}
\hline No & Persoalan Kajian & $\begin{array}{c}\text { Pengumpulan } \\
\text { Data }\end{array}$ & $\begin{array}{l}\text { Analisis } \\
\text { Data }\end{array}$ & $\begin{array}{l}\text { Perisian Yg } \\
\text { Digunakan }\end{array}$ \\
\hline $\mathrm{i}$ & $\begin{array}{l}\text { Apakah kompetensi EQ yang perlu } \\
\text { diberikan intervensi dalam kalangan } \\
\text { guru-guru? }\end{array}$ & IKEM/MEQI & $\begin{array}{c}\text { Statistik } \\
\text { Deskriptif }\end{array}$ & SPSS 15.0 \\
\hline ii & $\begin{array}{l}\text { Bagaimanakah pandangan pakar dan } \\
\text { orang-orang berjaya tentang cara } \\
\text { pembinaan kompetensi tersebut? }\end{array}$ & $\begin{array}{c}\text { Temubual } \\
\text { mendalam \& } \\
\text { berkumpulan }\end{array}$ & Tematik & $\begin{array}{c}\text { NVivo } 2 \& \\
\text { Nvivo } 7\end{array}$ \\
\hline iii & $\begin{array}{l}\text { Apakah kaedah yang sesuai } \\
\text { digunakan bagi melatih kompetensi } \\
\text { tersebut? }\end{array}$ & Analisis Dokumen & Tematik & NVivo 7 \\
\hline iv & $\begin{array}{l}\text { Apakah profil kopetensi EQ guru- } \\
\text { guru sebelum dan selepas latihan } \\
\text { menggunakan modul EQ yang } \\
\text { dibina? }\end{array}$ & IKEM/MEQI & $\begin{array}{l}\text { Statistik } \\
\text { Deskriptif }\end{array}$ & SPSS 15.0 \\
\hline $\mathrm{v}$ & $\begin{array}{l}\text { Bagaimanakah pandangan guru-guru } \\
\text { tentang latihan EQ menggunakan } \\
\text { mudul latihan yang EQ dibina? }\end{array}$ & $\begin{array}{l}\text { Maklumbalas } \\
\text { peserta latihan }\end{array}$ & Tematik & NVivo 7 \\
\hline
\end{tabular}

\subsection{RUMUSAN}

Kajian ini dijalankan menggunakan kaedah gabungan antara kuantitatif dan kualitatif (explanatory mixed method designs), yang dijalankan melalui tiga fasa. Fasa pertama diawali dengan kajian tinjauan melibatkan 112 orang guru, menggunakan satu set instrumen EQ (IKEM/MEQI), bagi tujuan menentukan kompetensi asas EQ yang perlu diberikan intervensi pada fasa ketiga. Fasa kedua dijalankan menggunakan kajian kes, melibatkan 8 orang pakar, 24 orang-orang berjaya, dan 12 dokumen. Manakala fasa ketiga melibatkan 33 orang guru yang dipilih daripada 112 orang guru yang terlibat pada fasa pertama. Satu set protokol temubual digunakan sebagai panduan pengumpulan data fasa kedua. Data fasa pertama dan fasa kedua telah dianalisi secara berasingan, dan hasil analisis daripada kedua-dua fasa tersebut telah dijadikan asas pembinaan modul pada fasa ketiga kajian ini. Data-data yang dikumpulkan menggunakan soal selidik telah dianalisis menggunakan statistik deskriptif berbantukan perisian SPSS 15.0. sedangkan data-data yang diperolehi melalui temu bual dan analisis dokumen dianalisis secara tematik berbantukan perisian NVivo 2 dan NVivo 7. 


\section{BAB IV}

\section{DAPATAN KAJIAN}

\subsection{PENGENALAN}

Pada bahagian ini pengkaji melaporkan semua dapatan kajian yang disusun mengikut persoalan kajian. Sebagaimana yang telah dibincangkan dalam bab 1 sebelumnya, kajian ini mempunyai beberapa objektif, iaitu; (i) mengenalpasti kompetensi EQ yang perlu diberikan intervensi dalam kalangan guru-guru, (ii) mengenal pasti pandangan pakar dan orang-orang berjaya untuk pembinaan kompetensi asas EQ yang telah dikenal pasti, (iii) mengenal pasti kaedah yang sesuai digunakan dalam latihan, (iv) mengenal pasti profil kompetensi EQ guru-guru sebelum dan selepas latihan menggunakan modul EQ yang dibina, dan (v) mengenal pasti pandangan guru-guru tentang latihan EQ menggunakan modul latihan yang EQ dibina.

Dua pendekatan analisis data telah digunakan untuk memaparkan hasil kajian tentang kelima-lima objektif kajian tersebut. Untuk objektif kajian pertama dan keempat kaedah analisis data secara kuantitatif, iaitu analisis deskriptif (Min dan sisihan Piawai) telah digunakan. Kaedah statistik deskriptif (kekerapan dan peratusan) juga digunakan untuk melaporkan profil subjek yang terlibat di dalam kajian ini. Objektif kajian kedua, ketiga dan kelima menggunakan kaedah analisis secara kualitatif menggunakan perisian Nvivo. 2 dan Nvivo 7 telah digunakan.

Melalui analisis statistik deskriptif pengkaji melaporkan dapatan kajian tentang kompetensi asas EQ yang perlu diberikan intervensi ataupun latihan menggunakan modul EQ yang dibina. Statistik deskriptif juga digunakan untuk mendapatkan gambaran tentang profil kompetensi asas EQ guru-guru setelah mengikuti latihan 
menggunakan modul EQ yang dibina. Sedangkan kaedah analisis kualitatif menggunakan perisian Nvivo 2 dan Nvivo 7 (assayscope, matrix intersection dan model) pula digunakan untuk menganalisis data-data yang diperolehi melalui temubual (individu dan berkumpulan), dan juga data-data yang diperolehi melalui analisis dokumen. Melalui analisis ini pengkaji cuba melaporkan hasil kajian dan membina satu model berkaitan dengan komponen-komponen penting yang perlu wujud di dalam modul EQ bagi tujuan intervensi, untuk meningkatkan kompetensi asas EQ yang telah dikenal pasti. Perisian ini juga digunakan untuk melaporkan pandangan guru-guru tentang latihan EQ menggunakan modul EQ yang dibina.

\subsection{PROFIL SUBJEK KAJIAN}

Untuk lebih mudah memahami profil subjek yang terlibat di dalam kajian ini, pengkaji melaporkan profil subjek berdasarkan fasa-fasa kajian yang dijalankan, iaitu (i) melaporkan profil subjek yang terlibat semasa ujian keperluan (need analisis) dan mendapatkan profil EQ sebelum latihan EQ dijalankan, (ii) melaporkan profil subjek yang terlibat di dalam latihan EQ, dan (iii) melaporkan profil subjek kajian yang mengambil bahagian dalam kajian kes.

\subsubsection{Profil Subjek Analisis Keperluan (Need Analysis)}

Sebelum pembinaan modul EQ dilakukan, analisis keperluan dijalankan terlebih dahulu untuk mengenal pasti kompetensi asas EQ yang perlu diberikan latihan. Merujuk kepada beberapa hasil kajian yang dijalankan sebelum ini (seperti kajian Noriah 2004, Syafrimen 2004 dan Syed Najmuddin 2005) mendapati peserta kajian agak rendah pada beberapa domain $\mathrm{EQ}$, namun bila dilihat kepada analisis yang mereka tunjukkan secara terperinci mengikut sub-sub domain tertentu, didapati tidak semua sub domain EQ mempunyai nilai yang rendah ataupun dikategorikan sebagai sub domain yang kritikal.

Analisis keperluan ini juga penting bagi mendapatkan gambaran untuk menyediakan garis panduan dalam membina modul EQ yang lebih spesifik. Memandangkan modul latihan ini dibina untuk keperluan intervensi dalam kalangan 
guru-guru, justeru pengkaji perlu mendapatkan gambaran secara autentik yang berasaskan kepada data untuk keperluan latihan EQ dalam kalangan guru-guru tersebut. Namun, setelah modul ini selesai dibina, bukan bermakna ianya tidak boleh dijalankan ke atas sampel ataupun populasi selain daripada guru. Modul ini menjadi fleksibel penggunaanya apabila sampel ataupun populasi selain daripada guru mempunyai kompetensi asas EQ yang lebih kurang sama dengan populasi yang dikaji.

Analisis keperluan melibatkan 112 orang guru yang sedang melanjutkan pengajian di peringkat Sarjana dan juga doktor falsafah di fakulti Pendidikan, Universiti Kebangsaan Malaysia. Profil mereka yang terlibat dalam analisis keperluan tersebut adalah seperti ditunjukkan dalam jadual 4.1 di bawah ini.

Jadual 4.1 Profil subjek kajian untuk analisis keperluan

\begin{tabular}{llcc}
\hline Profil Responden & & Kekerapan & Peratus \\
Umur & 30 Tahun Ke Bawah & 36 & $32.1 \%$ \\
& 31-40 Tahun & 53 & $47.3 \%$ \\
& Di Atas 40 Tahun & 23 & $20.5 \%$ \\
& Total & 112 & $100 \%$ \\
Jantina & Lelaki & 43 & $38.4 \%$ \\
& Perempuan & 69 & $61.6 \%$ \\
Bangsa & Total & 112 & $100 \%$ \\
& Melayu & 103 & $92.0 \%$ \\
& Cina & 2 & $1.8 \%$ \\
Status Perkahwinan & India & 112 & $6.3 \%$ \\
& Total & 69 & $100 \%$ \\
& Berkahwin & 32 & $61.6 \%$ \\
& Bujang & 11 & $28.6 \%$ \\
& Mising & 112 & $100 \%$ \\
\hline
\end{tabular}

Daripada 112 orang guru yang terlibat dalam analisis keperluan tersebut, 36 orang $(32.1 \%)$ guru berumur 30 tahun ke bawah, 53 orang (47.3\%) guru berumur 3140 tahun dan 23 orang (20.5\%) dalam kalangan mereka berumur di atas 40 tahun. Sedangkan berdasarkan jantina didapati 43 orang (38.4\%) adalah daripada guru-guru lelaki dan 69 orang $(61.6 \%)$ daripada guru-guru perempuan. Manakala berdasarkan bangsa pula majoriti dalam kalangan guru-guru yang terlibat adalah daripada guru- 
guru Melayu (103 orang, 92.0\%), dua orang (1.8\%) daripada guru berbangsa Cina dan tujuh orang $(6.3 \%)$ daripada mereka adalah berbangsa India. Latar belakang guru-guru berdasarkan status perkahwinan pula didapati 69 orang $(61.6 \%)$ di dalam kalangan mereka telah berkahwin dan 32 orang (28.6\%) masih bujang. Data kajian ini juga menunjukkan terdapat 11 orang $(9.8 \%)$ dalam kalangan mereka yang tidak menyatakan status perkahwinan mereka.

Jadual ini menunjukkan bahawa dari segi latar belakang umur ramai dalam kalangan guru-guru yang terlibat adalah guru-guru yang berumur 31 hingga 40 tahun, dari segi jantina pula jumlah guru perempuan lebih ramai berbanding dengan guruguru lelaki, dari segi latar belakang bangsa secara umumnya berketurunan Melayu dan dari segi status perkahwinan pula lebih ramai dalam kalangan mereka yang telah berkahwin berbanding dengan jumlah guru-guru yang bujang.

\subsubsection{Profil Subjek Yang Terlibat Dalam Latihan EQ}

Daripada 112 orang guru yang mengambil bahagian dalam analisis keperluan seramai 33 orang guru telah dipilih untuk diberikan latihan menggunakan modul EQ yang dibina. Pemilihan guru-guru tersebut adalah berasaskan kepada hasil ujian EQ yang telah mereka lalui pada analisis keperluan yang dilakukan. Secara umumnya guru-guru tersebut didapati mempunyai kompetensi asas EQ yang lebih kurang sama dengan kompetensi asas EQ yang diperolehi secara keseluruhan. Selari dengan pandangan Goleman (1995) bahawa biasaanya EQ seseorang akan meningkat selari dengan peningkatan usia dan pengalaman mereka. Justeru, pemilihan guru-guru tersebut juga telah mengambil kira pengalaman bekerja mereka. Profil guru-guru tersebut adalah seperti ditunjukkan pada Jadual 4.2 di bawah ini.

Jadual 4.2 Profil subjek yang terlibat di dalam latihan EQ

\begin{tabular}{llcc}
\hline Profil Responden & Kekerapan & Peratus \\
\hline Umur & 30 Tahun Ke Bawah & 5 & $15.2 \%$ \\
& 31-40 Tahun & 8 & $24.2 \%$ \\
& Di Atas 40 Tahun & 20 & $60.6 \%$ \\
& Total & 33 & $100 \%$
\end{tabular}

bersambung... 
...sambungan

\begin{tabular}{llcc} 
Jantina & Lelaki & 15 & $45.5 \%$ \\
& Perempuan & 18 & $54.5 \%$ \\
Bangsa & Total & 33 & $100 \%$ \\
& Melayu & 30 & $90.9 \%$ \\
& Cina & 2 & $6.1 \%$ \\
\multirow{3}{*}{ Status Perkahwinan } & India & 1 & $3.0 \%$ \\
& Total & 33 & $100 \%$ \\
& Berkahwin & 28 & $84.8 \%$ \\
& Bujang & 5 & $15.2 \%$ \\
& Total & 33 & $100 \%$ \\
\hline
\end{tabular}

Daripada 33 orang guru-guru yang terlibat di dalam latihan EQ yang dijalankan, 20 orang $(60.6 \%)$ dalam kalangan mereka berumur di atas 40 tahun. Seramai lapan orang (24.2\%) mereka berumur 31-40 tahun dan lima orang (15.2\%) berumur 30 tahun ke bawah. Data ini menunjukkan bahawa sebahagian besar daripada guru-guru yang terlibat dalam latihan EQ tersebut adalah lingkungan umur di atas 40 tahun. Profil mereka berdasarkan jantina pula didapati 15 orang (45.5\%) daripada guru-guru lelaki dan 18 orang (54.5\%) daripada guru-guru perempuan. Profil guruguru berdasarkan bangsa pula, didapati secara umumnya iaitu 30 orang (90.9\%) dalam kalangan guru-guru yang terlibat adalah berbangsa Melayu, dua orang (6.1\%) berbangsan Cina dan satu orang (3.0\%) berbangsa India. Sedangkan berdasarkan status perkahwinan pula didapati secara umumnya iaitu 28 orang $(84.8 \%)$ dalam kalangan guru-guru tersebut telah berkahwin dan lima orang (15.2\%) dalam kalangan mereka masih bujang.

\subsubsection{Profil Subjek Kajian Kes}

Secara umumnya latar belakang subjek kajian yang terlibat dalam kajian kes ini dikelompokkan kepada empat kategori utama iaitu latar belakang berdasarkan umur, pendidikan, pengalaman bekerja, dan berdasarkan kursus-kursus yang pernah mereka ikuti. Dari segi latar belakang umur didapati keseluruhan subjek yang teribat adalah berumur di atas 40 tahun (100\%). Berdasarkan latar belakang pendidikan pula, subjeksubjek yang terlibat di dalam temubual berkumpulan keseluruhanya mempunyai latar belakang diploma pendidikan (100\%), dan mereka sedang dalam proses mendapatkan Ijazah melalui Program Khas Pensiswazahan Guru (PKPG) di fakulti Pendidikan 
UKM. Subjek-subjek yang terlibat dalam temubual individu keseluruhannya (100\%) berkelulusan doktor falsafah sama ada di dalam mahupun luar negara, bahkan mereka telahpun mendapatkan gelaran Profesor Madya dan Profesor penuh dalam bidang kepakaran masing-masing.

Seterusnya latar belakang subjek berdasarkan pengalaman pula, subjek yang terlibat di dalam temubual individu didapati secara keseluruhanya mereka telah mempunyai pengalaman kerja di atas 10 tahun (100\%). Sedangkan yang terlibat di dalam temubual berkumpulan pula, didapati ada yang berpengalaman kerja 10-20 tahun (82\%), bahkan ada dalam kalangan mereka yang mempunyai pengalaman lebih daripada 20 tahun (18\%). Sedangkan latar belakang subjek berdasarkan kursus-kursus yang pernah mereka ikuti pula (selain daripada kursus formal), secara umumnya (100\%) mereka tidak pernah mengikuti kursus-kursus yang spesifik berkaitan dengan EQ. Bagaimanapun terdapat sebahagian mereka yang pernah mengikuti kursus motivasi, kemahiran generik, andragogi dan juga kursus-kursus yang berkaitan dengan kemahiran untuk membantu di dalam pekerjaan mereka masing-masing, seperti kursus komputer, kursus penyelidikan dan kursus penggunaan perisian yang berkaitan dengan analisis data di dalam penyelidikan, sama ada di dalam dan luar negara. Secara umumnya, subjek kajian menyatakan bahawa walaupun mereka tidak mengikuti kursus yang spesifik tentang EQ namun pengalaman yang mereka lalui dan kursus-kursus yang mereka ikuti sangat membantu di dalam kerjaya mereka. Profil mereka secara terperinci seperti ditunjukan pada Jadual 4.3 di bawah ini.

Jadual 4.3 Profil subjek untuk kajian kes

\begin{tabular}{lllcc}
\hline Responden & & & Kekerapan & Peratus \\
\hline $\begin{array}{l}\text { Temubual } \\
\text { Individu }\end{array}$ & Umur & Diatas 40 tahun & 8 & $100 \%$ \\
& & & & \\
& Pendidikan & Doktor falsafah & 8 & $100 \%$ \\
& Pengalaman & Diatas 10 tahun & 8 & $100 \%$ \\
& Latihan & Tiada latihan spesifik & 8 & $100 \%$ \\
Temubual & Umur & Diatas 40 tahun & 22 & $100 \%$ \\
Berkumpulan & & & & \\
& Pendidikan & Diploma pendidikan & 22 & $100 \%$ \\
& Pengalaman & $10-20$ tahun & 18 & $82 \%$ \\
& & Lebih 20 tahun & 4 & $18 \%$ \\
& Latihan & Tiada latihan & 22 & $100 \%$ \\
\hline
\end{tabular}




\subsection{KOMPETENSI ASAS EQ YANG PERLU DIBERIKAN INTERVENSI}

Seperti yang telah dibincangkan dalam bab 2 sebelumnya iaitu EQ mempunyai tujuh domain utama iaitu (i) kesedaran kendiri, (ii) regulasi kendiri, (iii) motivasi kendiri, (iv) empati, (v) kemahiran sosial, (vi) kerohanian dan (vii) kematangan. Terkecuali domain kerohanian dan kematangan, lima domain utama yang lainnya masing-masing mempunyai sub domain tertentu. Secara keseluruhan terdapat 29 sub domain yang terkandung dalam kelima-lima domain tersebut, seperti ditunjukkan pada jadual 4.1.

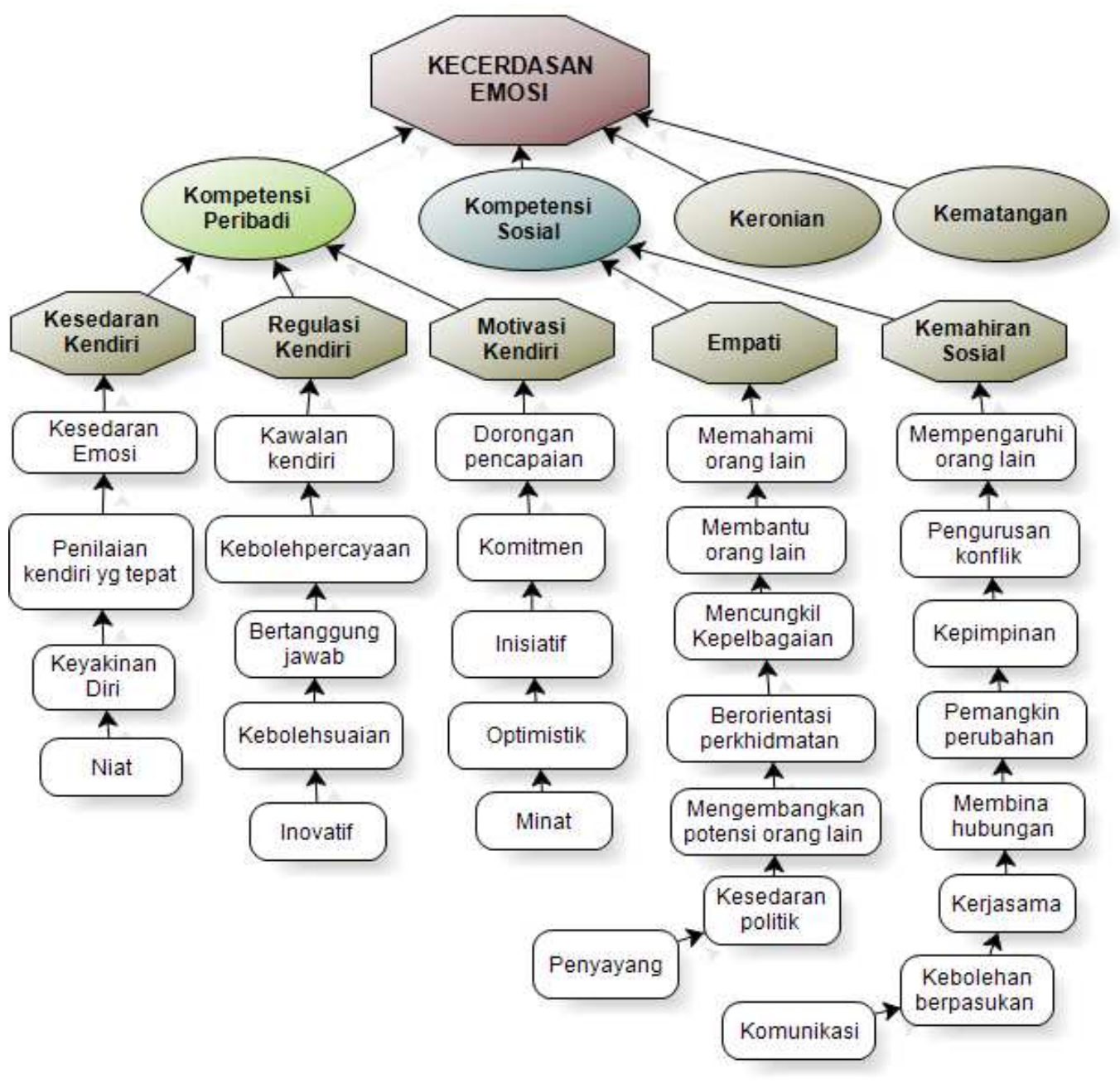

Rajah 4.1 Domain dan sub domaian EQ

Untuk keperluan membina modul EQ dalam kajian ini, pengkaji telah melakukan ujian awal (need analysis) bagi tujuan menentukan kompetensi asas EQ (critical component) yang perlu diberikan intervensi menggunakan modul EQ yang 
dibina. Untuk menentukan komponen kritikal tersebut seramai 112 orang guru yang sedang menuntut di peringkat sarjana dan doktor falsafah di fakulti Pendidikan telah dilibatkan. Guru-guru tersebut telah diberikan satu ujian menggunakan satu set instrumen EQ “Malaysian Emotional Quotient Inventory” bagi tujuan menentukan kompetensi kritikal tersebut. Maklum balas yang diberikan oleh guru-guru terbabit telah dianalisis menggunakan statistik deskriptif (Min dan sisihan piawai), nilai min yang mereka perolehi diinterpretasikan berdasarkan EQ Index Interpretation oleh Noriah (2007).

Noriah (2007) telah membahagikan cara interpretasi skor min EQ yang diperolehi oleh individu ataupun kumpulan yang menggunakan instrumen EQ sebagai alat ujian kepada empat bahagian, iaitu; Min kurang daripada 40 menunjukkan individu lemah pada komponen tersebut ataupun individu berkenaan beranggapan komponen tersebut tidak penting bagi mereka. Menurut Noriah individu ataupun kumpulan yang memperolehi skor sebegini kurang dapat berfungsi dengan semestinya, mereka perlu mencari cara yang efektif untuk meningkatkan komponen tersebut.

Skor 41-60 menunjukkan bahwa kadang-kadang individu ataupun kumpulan menyedari wujudnya kompetensi EQ tersebut, namun kompentensi berkenaan belum sebati dengan perilaku individu ataupun sesebuah kumpulan berkenaan. Noriah mencadangkan supaya individu ataupun kumpulan yang memperolehi skor sedemikian mencari kaedah tertentu untuk meningkatkan kompentensi berkenaan. Beliau juga berpandangan bahawa sekiranya individu atau kumpulan tersebut mampu melakukan hal sedemikian, kemungkinan mereka akan memperolehi kemajuan yang signifikan.

Skor 61-80 menunjukkan bahawa kompetensi tersebut boleh dianggap baik dan telah dimiliki oleh individu ataupun kumpulan, tambahan lagi apabila skor yang diperolehi adalah antara 70-80. Bagaimanapun kompetensi tersebut masih belum konsisten dalam amalan individu dan kumpulan berkenaan. Oleh itu Noriah mencadangkan bahawa prestasi individu tersebut akan lebih baik apabila kompetensi berkenaan dapat ditingkatkan. Tindakan tersebut akan lebih membantu dalam mengembangkan potensi individu ataupun kumpulan berkenaan. 
Skor 81-100 menunjukkan individu memperolehi skor yang baik. Apabila skor yang diperolehi antara 90-100 maka skor tersebut adalah lebih tinggi daripada purata ataupun norm kajian-kajian yang dilakukan sebelum ini. Individu dalam kumpulan ini telah menyedari tentang kompetensi yang dimiliki, bagaimanapun individu tersebut belum dapat menghayati kompetensi berkenaan dalam keadaan-keadaan tertentu. Namun, apabila kompetensi ini dapat dibaiki lagi ia akan menjadi suatu yang lebih bersifat semula jadi dalam diri seseorang. Tambahan lagi dalam situasi tertentu kompentensi yang sama akan menjadi kekuatan yang bersebati dengan diri individu berkenaan. Individu tersebut hanya perlu mengekalkan kompetensi tersebut dari segi amalan dalam kehidupan mereka. Tindakan ini dapat membantu meningkatkan peluang dan boleh meningkatkan kecenderungan ke arah kejayaan. Justeru, Noriah mencadangkan individu dalam kumpulan ini hanya perlu lebih konsisten dalam bertingkah laku dan mempertahankan kompetensi itu dalam pelbagai situasi. Kekuatan kompetensi yang ada pada diri individu tersebut dapat membantu dirinya mengambil peluang yang dapat menghantarkannya kepada keberhasilan. Noriah juga mencadangkan bahawa individu yang memperolehi skor sebegini supaya sentiasa berusaha konsisten dan memaksimumkan potensi ini. Merujuk kepada cara interpretasi yang diberikan oleh Noriah tersebut. Untuk tujuan kajian ini kompetensi EQ yang mempunyai skor di bawah $80 \%$ telah dikategorikan sebagai kompetensi yang perlu diberikan intervensi. Secara terperinci cara interpretasi yang diberikan oleh Noriah dapat dirujuk pada lampiran $\mathrm{C}$.

Daripada analisis keperluan yang dijalankan, terdapat 11 kompetensi asas EQ yang perlu diberikan perhatian untuk intervensi. Secara keseluruhan 11 kompetensi tersebut adalah semua sub domain kesedaran kendiri iaitu; (i) kesedaran emosi, (ii) penilaian kendiri yang tepat, (iii) keyakinan diri, dan (iv) niat. Dua sub domain regulasi kendiri iatu; (v) kawalan kendiri dan (vi) kebolehpercayaan. Satu sub domain motivasi kendiri iaitu; (vii) dorongan pencapaian. Dua sub domain empati iaitu; (viii) membantu orang lain dan (ix) membina potensi orang lain, dan dua daripada sub domain kemahiran sosial iaitu; (x) mempengaruhi orang lain dan (xi) pengurusan konflik, seperti yang digambarkan di dalam rajah 4.2 di bawah ini; 


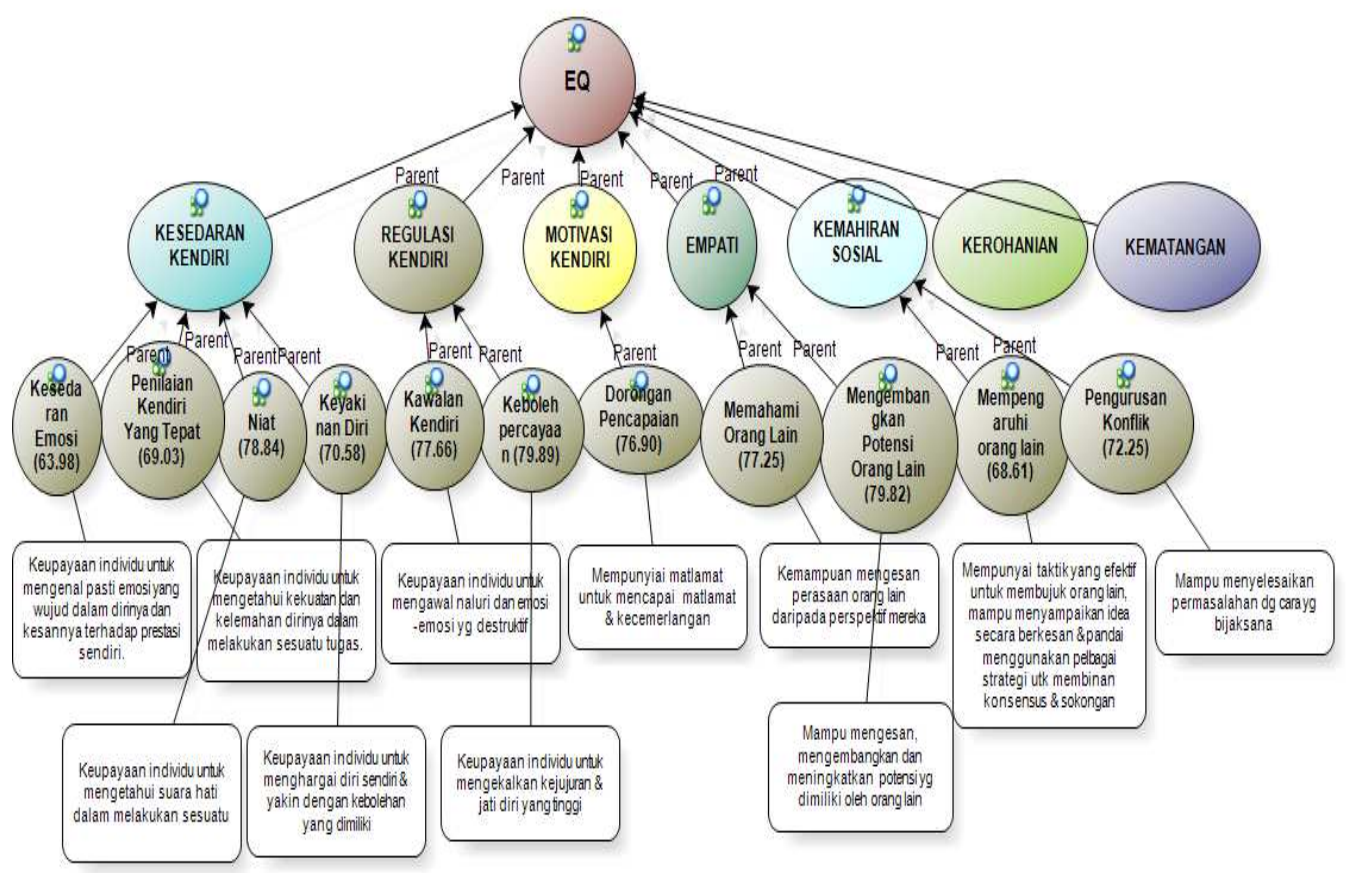

Rajah 4.2 Kompetensi asas EQ yang perlu diberikan intervensi

Skor min yang diperolehi bagi setiap kompetensi tersebut adalah seperti yang ditunjukkan pada rajah 4.3 di bawah ini.

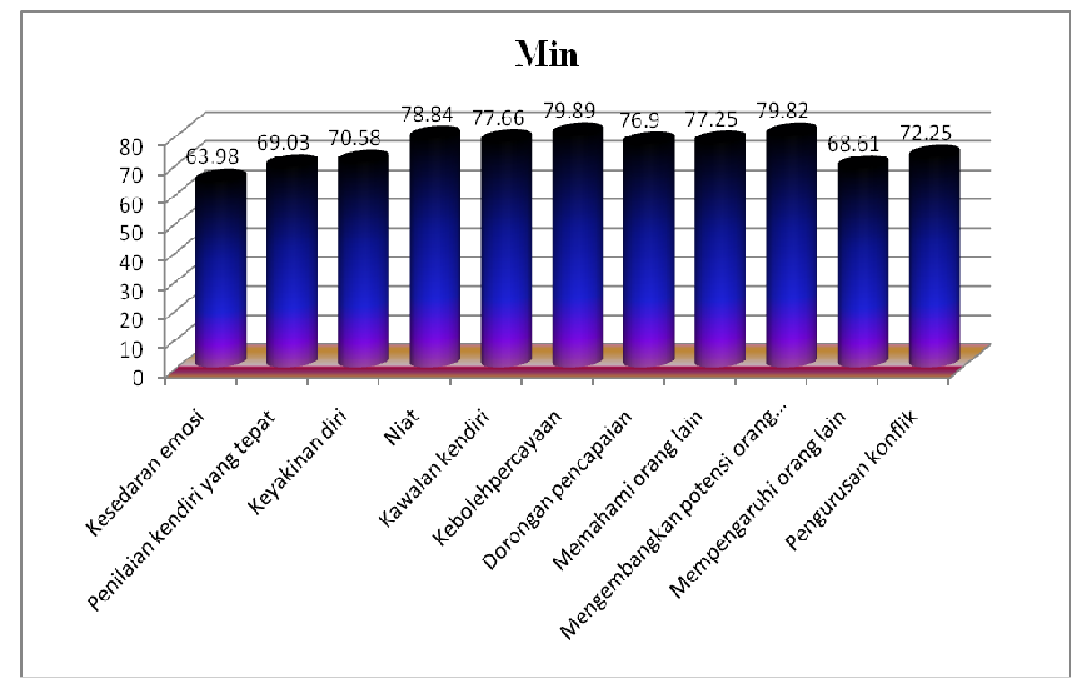

Rajah 4.3 Min yang diperolehi bagi setiap kompetensi asas EQ

Seperti yang dipaparkan pada rajah 4.2 dan rajah 4.3, skor min yang diperolehi bagi setiap kompetensi asas EQ tersebut adalah; (i) Sub domain kesedaran kediri iaitu; 
kesedaran emosi $(\mathrm{Min}=63.98, \mathrm{SP}=15.50)$, penilaian kendiri yang tepat $(\mathrm{Min}=69.03$, $\mathrm{SP}=8.67)$, keyakinan diri $(\mathrm{Min}=70.58,8.67)$ dan niat $(\mathrm{Min}=78.84, \mathrm{SP}=7.39)$. (ii) $\mathrm{Sub}$ domain regulasi kendiri iaitu; kawalan kendiri (Min= 77.66, $\mathrm{SP}=8.90$ ) dan kebolehpercayaan (Min= 79.89, $\mathrm{SP}=10.73$ ) (iii) Seterusnya sub domain motivasi kendiri iaitu dorongan pencapaian ( $\mathrm{Min}=76.90, \mathrm{SP}=22.23$ ). (iv) Sub domain empati iaitu; memahami orang lain ( $\mathrm{Min}=77.25, \mathrm{SP}=8.60)$ dan mengembangkan potensi

orang lain $(\mathrm{Min}=79.82, \mathrm{SP}=9.56)$. (v) sedangkan sub domain kemahiran sosial pula iaitu; mempengaruhi orang lain $(\mathrm{Min}=68.61, \mathrm{SP}=10.84)$ dan pengurusan konflik $(\mathrm{Min}=72.25, \mathrm{SP}=11.73)$.

Bila dirujuk kepada indeks interpretasi EQ yang dicadangkan oleh Noriah (2007) di atas, nilai-nilai ini sebenarnya sudah boleh dikategorikan baik. Pengertian baik yang dimaksudkan oleh Noriah adalah individu ataupun kumpulan telah menyedari kepentingan kompetensi tersebut, bagaimanapun individu tersebut masih belum konsisten atau tekal menunjukkan kompetensi tersebut dalam tingkahlaku mereka. Untuk menjadikan kompetensi berkenaan bersebati dan konsisten dalam diri mereka, justeru beliau mencadangkan agar diberikan latihan secara berterusan sehingga individu berkenaan lebih yakin tentang kepentingan kompetensi berkenaan dalam meningkatkan kecemerlangan diri mereka.

\subsection{PANDANGAN PAKAR DAN ORANG-ORANG BERJAYA UNTUK PEMBINAAN KOMPETENSI ASAS EQ}

Pembinaan modul EQ di sini merujuk kepada 11 kompetensi asas EQ seperti yang telah dibincangkan sebelum ini (rujuk rajah 4.2), iaitu (i) empat sub domain di dalam kesedaran kendiri (kesedaran emosi, penilaian kendiri yang tepat, keyakinan diri dan niat). (ii) dua sub domain di dalam regulasi kendri iaitu (kawalan kendiri dan kebolehpercayaan). (iii) satu sub domain di dalam motivasi kendiri (dorongan pencapaian). (iv) dua sub domain empati (memahami orang lain dan mengembangkan potensi orang lain) dan (v) dua sub domain di dalam kemahiran sosial (mempengaruhi orang lain dan pengurusan konflik). Untuk pembinaan modul tersebut, temubual secara mendalam dan temubual secara berkumpulan kepada pakar dan orang-orang yang dianggap berjaya di dalam bidang yang diceburi telah dijalankan. Daripada temubual tersebut pengkaji telah mencungkil pelbagai pengalaman yang menjadi teras 
kepada kejayaan orang-orang tersebut. Pengalaman-pengalaman yang dikongsikan telah diubah dalam bentuk aktiviti yang disusun di dalam bentuk modul latihan EQ.

Temubual mendalam telah dijalankan kepada lapan orang subjek dan temubual berkumpulan kepada dua kumpulan, masing-masing kumpulan seramai 12 orang subjek. Masing-masing subjek telah berkongsi pengalaman tentang perkara-perkara yang mereka lakukan sehingga mereka menjadi seorang pakar dan seorang yang berjaya di dalam bidan dan kehidupan mereka. Pengalaman-pengalaman yang dikongsikan oleh subjek tersebut telah dirumuskan dan kemudian dioperasikan ke dalam bentuk modul EQ untuk meningkatkan kompetensi asas EQ yang telah dikategorikan sebagai komponen kritikal seperti yang telah dibincangkan sebelum ini.

Untuk mengoperasikan pengalaman-pengalaman berkenaan ke dalam bentuk modul EQ, pengkaji telah memilih pengalaman-pengalaman signifikan yang mempunyai peratusan tertinggi terlebih dahulu sebelum menggunakan pengalamanpengalaman lain yang didapati mempunyai peratusan yang agak rendah. Bagaimanapun sekiranya pengalaman yang mereka kongsikan mempunyai peratusan yang lebih kurang sama, maka pengkaji mengambil dan merumuskan secara keseluruhan pengalaman-pengalaman tersebut untuk dijadikan asas pembinaan modul EQ tersebut. Memandangkan temubual ini dijalankan oleh pengkaji sendiri, semasa sesi perbincangan dijalankan pengkaji dapat melihat, menilai dan merasakan cara subjek menyampaikan pengalaman mereka, sama ada pengalaman itu betul-betul pengalaman yang signifikan bagi mereka ataupun tidak. Untuk itu pengkaji juga mengambil kira perkara berkenaan untuk dioperasikan dalam pembinaan modul EQ ini.

\subsubsection{Pembinaan Kesedaran Emosi}

Rajah 4.4 memaparkan pengalaman subjek tentang komponen-komponen penting yang mereka lakukan dalam pembinaan kesedaran emosi. Daripada lapan temubual mendalam dan dua temubual berkumpulan dijalankan didapati mereka menyatakan lima komponen penting untuk pembinaan kesedaran emosi tersebut. Kelima-lima komponen tersebut adalah; (i) perbaiki diri, (ii) berfikir sebelum bertindak, (iii) usaha 
berterusan, (iv) akidah/keyakinan dan (v) mereflek pengalaman lepas. Kekerapan dan peratusan subjek mengemukakan masing-masing komponen tersebut, didapati peratusan tertinggi adalah pada komponen memperbaiki diri (80\%) dan komponen mereflek pengalaman lepas $(80 \%)$. Seterusnya diikuti oleh komponen usaha berterusan (60\%) dan komponen berfikir sebelum bertindak (50\%). Sedangkan komponen akidah hanya dikemukakan oleh dua orang subjek sahaja (20\%).

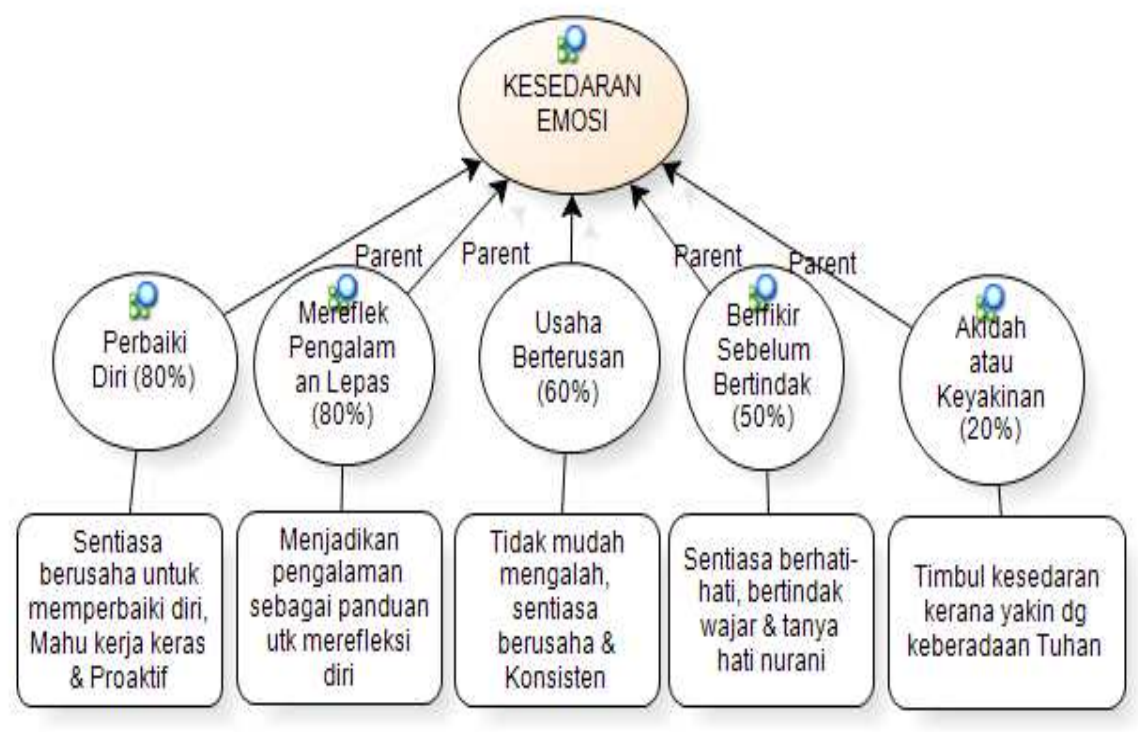

Rajah 4.4 Pengalaman subjek dalam pembinaan kesedaran emosi

Dapatan ini menunjukkan bahawa daripada lima komponen tersebut, terdapat empat komponen yang memperolehi peratusan yang tinggi (perbaiki diri, mereflek pengalaman lepas, usaha berterusan dan berfikir sebelum bertindak) selalu digunakan dalam pembinaan kesedaran emosi oleh subjek-subjek yang dikaji. Justeru lebih baik sekiranya kelima-kelima komponen tersebut dapat diambil kira secara keseluruhan. Dengan perkataan lain subjek melihat bahawa untuk pembinaan kesedaran emosi pada diri seseorang dapat dilakukan dengan cara memberikan kesedaran agar seseorang tersebut sentiasa memperbaiki diri, menimbulkan kesedaran supaya sentiasa mereflek pengalaman lepas yang mungkin pernah mereka alami. Subjek juga berpandangan bahawa usaha pembinaan kesederan emosi sepatutnya dilakukan secara berterusan dan ianya juga dapat dilakukan dengan cara sentiasa berfikir rasional sebelum bertindak melakukan sesuatu. Ianya akan lebih kukuh lagi apabila diasaskan pada aspek akidah ataupun keyakinan yang mantap. 
Seterusnya bila diperhatikan pada hasil analisis matrix intersection terhadap pandangan yang dikongsikan oleh subjek melalui temubual berkumpulan dan temubual secara mendalam (rujuk Jadual 4.4), didapati tiga diantara kelima-lima komponen tersebut iaitu berfikir sebelum bertindak, perbaiki diri dan mereflek pengalaman lepas dikongsikan oleh subjek dalam temubual berkumpulan dan juga temubual secara individu. Bagaimanapun perkongsian mereka tentang komponen-komponen tersebut didapati lebih banyak muncul melalui temubual secara individu berbanding dengan temubual secara berkumpulan.

Jadual 4.4 Matrix intersection kesedaran emosi

\begin{tabular}{lcc}
\hline Matrix Nodes & F.Group & Individu \\
\hline Berfikir Sebelum Bertindak & 1 & 4 \\
Perbaiki Diri & 2 & 6 \\
Mereflek Pengalaman Lepas & 2 & 6 \\
Usaha Berterusan & 0 & 6 \\
Akidah & 0 & 2 \\
\hline
\end{tabular}

Berikut ini perkongsian yang dikemukakan oleh subjek tentang kelima-lima komponen tersebut. Untuk memudahkan memahami perkongsian yang dikemukakan, pengkaji menggunakan kod-kod berikut bagi seluruh laporan hasil temubual yang dijalankan. Kod-kod tersebut adalah seperti ditunjukkan dalam Jadual 4.5 di bawah ini:

Jadual 4.5 Kod yang digunakan untuk melaporan hasil temubual

\begin{tabular}{cr} 
Kod & Keterangan Kod \\
\hline FG 2 & Temubual Berkumpulan Group 2 \\
FG 1 & Temubual Berkumpulan Group 1 \\
TBI 1 & Temubual Mendalam dengan Subjek 1 \\
TBI 2 & Temubual Mendalam dengan Subjek 2 \\
TBI 3 & Temubual Mendalam dengan Subjek 3 \\
TBI 4 & Temubual Mendalam dengan Subjek 4 \\
TBI 5 & Temubual Mendalam dengan Subjek 5 \\
TBI 6 & Temubual Mendalam dengan Subjek 6 \\
TBI 7 & Temubual Mendalam dengan Subjek 7 \\
TBI 8 & Temubual Mendalam dengan Subjek 8 \\
\hline
\end{tabular}


Perkongsian subjek tentang pembinaan kesedaran emosi menggunakan komponen "memperbaiki diri” digambarkan menerusi "sikap berdikari”. Sikap tersebut diperlihatkan oleh dua orang subjek dalam temubual individu (TBI 3, TBI5). Mereka telah berkongsi pengalaman tentang perlunya usaha memperbaiki diri menerusi tindakan yang menggambarkan kemahuan untuk sentiasa bekerja keras, belajar lebih rajin dan mahu mencuba. Bagaimanapun, antara ke dua subjek kajian tersebut terdapat perbezaaan dari segi motivasi dan kebolehan melihat ke dalam diri untuk mencari celik akal bagi tujuan menimbulkan kesedaran emosi masing-masing. Motivasi belajar yang ditunjukkan oleh subjek TBI3 lebih bersifat luaran kerana ibu menjadi punca kesedaran emosi untuk bergerak ke arah kecemerlangan. Sedangkan subjek TBI5 pula mempunyai kesedaran emosi yang bersifat dalaman. Justeru, wujud kepelbagaian punca kesedaran emosi yang ditunjukkan oleh kedua-dua subjek tersebut, seperti dalam petikan di bawah ini:

TBI3 : ... jadi bila pergi ke sana itu memang rasa perlu kerja keraslah, supaya balik belajar dapat menyara mak dan sebagainya. So bila saya sampai di sana, kalau dibandingkan dengan pelajar-pelajar lain saya rajinlah. Sampai saya ambil dictionary tengok makna dan sebagainya. Macam kawan-kawan lain mereka nak enjoy dulu di tempat yang baru kan. Walaupun penguasaan bahasa saya kurang baik berbanding dengan pelajar-pelajar perempuan tapi saya cubalah.

TBI5 : Saya bekerja kuat sebab saya fikir saya adalah orang yang lemah, masukpun kelayakan kurang kan. Saya orang yang lemah saya mesti bekerja kuat. Rupanya kerja kuat yang kita jangkakan hanya untuk meluluskan, membuat saya melonjak lebih daripada yang dijangkakan.

Selain daripada sikap berdikari subjek juga mengaitkan usaha memperbaiki diri dengan kecenderungan untuk "bertindak lebih proaktif". Ini dapat dilihat menerusi perkongsian pengalaman yang dinyatakan oleh subjek TBI3, TBI6 dan TBI8 seperti ditunjukan pada petikan di bawah ini:

TBI3 : ...cara saya belajar saya sentiasa ke hadapan, saya tidak tunggu guru mengajarkan dulu. Maksudnya saya dah baca lima atau tiga bab lebih awal daripada apa yang ingin diajarkan oleh guru. Jadi bila diajar saya faham. Kalau saya tak faham saya akan tanya kepada guru yang mengajar itu. Macam itu juga dengan tugasan-tugasan saya, kadang-kadang bila terfikir satu topik saya pergi jumpa pensyarah, saya kata kalau saya nak buat macam ini macamana? Walaupun tajuk tugasan belum keluar, jadi maksudnya saya sentiasa proaktiflah, dan saya suka buat sesuatu kreatif. 
TBI6 : ...misalnya masa buat $\mathrm{PhD}$ tu saya belajar, bila kita buat kajian kita tahu nak perlukan statistik, so belajar sendirilah. Jumpa orang, bila ada iklan untuk mengadakan kursus saya pergi menghadiri kursus tersebut... maknanya itu semua memudahkan kerja sayalah.

TBI8 : Katakanlah saya tak memahami satu-satu aspek, kita boleh menilai diri kita sama ada kita faham atau tidak, saya akan mencari. Katakanlah dalam bidang kaunseling, bindang kaunseling merupakan minat saya sejak lepas master lagi. Saya memang berminat dalam bidang kaunseling. Jadi saya berusaha sebenarnya, sebelum saya buat $\mathrm{PhD}$ lagi saya sudah berusaha.

Untuk menimbulkan kesedaran kendiri dengan cara "melakukan refleksi terhadap pengalaman lepas" pula subjek telah mengemukakan pelbagai pengalaman mereka bahawa pengalaman-pengalaman yang dilalui sangat membantu dirinya untuk menilai diri yang sebenar. Bagaimanapun pengalaman yang dilalui oleh masingmasing subjek tersebut tidaklah sama, namun memberikan makna tersendiri kepada diri mereka, seperti ditunjukkan dalam petikan berikut ini:

FG2 : ... yang paling banyak membantu adalah pengalaman kerja, bagi saya kursus tidak terlalu banyak membantu tetapi penglaman yang paling penting. Pengalaman memang memainkan peranan yang amat penting untuk melatih kemahiran, tetapi ilmu yang kita dapat bila kita pergi kursus, itu menguatkan lagi dan memastikan apa yang kita buat.

TBI2 : Saya rasa pengalaman saya mungkin sedikit sebanyak memang ada kaitan dengan beberapa aspek ... bagaimana kita menganalisis diri, mengawal emosi, bagaimana berinteraksi dan seterusnya, dari segi pengalaman lah. Saya rasa kalau aspek-aspek itu yang mungkin menjadi landasan kepada pengalaman saya.

... saya nampak daripada kecil saya memang seorang yang menonjol dari segi kepimpinan di sekolah dan sebagainyalah, mungkin di situ ada kelihatan dari segi aspek pengalaman yang membawa aspek kemenonjolan yang mungkin kemudiannya menonjolkan diri sayalah

TBI6 : ...tapi bila datang untuk tujuan kenaikan pangkat baru kita tahu, o... tak cukup ini.. kemudian barulah kita usahakan, Itu baru datang kesedaran. Mungkin itu peringkat gifted juga tetapi bukanlah gifted itu tinggi sangat tetapi maknanya cukup belajar, so maknanya maksud saya itu sedarlah bahawa saya ini silap. Saya rasa macam anugerah yang diberi oleh Tuhan kepada sayalah. Setengah orang belajar bila dia gagal dulu baru dia sedar (TBI 6). 
Pembinaan kesedaran emosi melalui "usaha berterusan" pula juga dinyatakan oleh subjek menerusi pengalaman mereka masing-masing. Usaha berterusan tersebut telah dicontohkan melalui pengalaman mereka masing-masing. Seperti yang diterangkan oleh TBI3 yang menyatakan bahawa apabila dirinya mempunyai sesuatu idea yang dirasa bermanfaat untuk orang lain, dia akan berusaha menunjukkan idea tersebut walaupun orang lain kurang bersetuju dengan idea yang dibawanya. Bagi dirinya perkara sebegini sebenarnya untuk mengingatkan dirinya sendiri bahawa untuk membuktikan sesuatu yang baik sememangnya diperlukan usaha secara berterusan, dan tidak berhenti sekiranya terdapat sedikit halangan untuk mewujudkanya. Pengalaman yang hampir sama dikongsikan TBI 4 yang menyatakan bahawa beliau menyedari tentang kedaan dirinya sendiri. Bagi dirinya untuk mewujudkan sesuatu perlu dilaksanakan secara berkesinambungan dan konsisten walaupun perlahan. Namun dia memastikan dirinya sentiasa berusaha, seperti dipaparkan pada petikan di bawah ini:

TBI3 : ... dalam mesyuarat-mesyuaratpun saya suka kemukakan idea saya. Kalau saya ada idea tapi kalau orang tidak sokong, saya tidak akan berhenti, saya akan buat dan saya akan tunjukkan bahawa idea saya itu ada manfaat kepada orang lain.

TBI4 : ... daripada masa persekolah dulu saya tak boleh laju, saya tak kuat tapi cross coutry saya boleh bertahan. Kalau cross country jarak jauhpun saya boleh bertahan. Walaupun letih saya cuba juga. Dah letih, tak larat dah nafas macam dah nak putus saya cuba juga. Saya ingat dalam apapun, dalam pengurusan, dalam research dan pekerjaan, itu cara sayalah. Saya tidak laju tapi saya konsisten. Saya terus jalan, kalau tak boleh itu saya cuba cari jalan lain sampai boleh. Walaupun dah tak tahan sangat tapi saya cuba terus, berdo'a banyaklah, akhirnya saya dapat habis....

Perkongsian peserta temubual tentang pembinaan kesedaran emosi dengan cara "berfikir sebelum bertindak" pula telah dinyatakan dalam pelbagai perkongsian oleh subjek kajian, sama dalam temubual berkumpulan mahupun subjek temubual individu. Salah seorang subjek dalam FG1 menyatakan bahawa berdasarkan pengalaman beliau sebagai seorang pendidik dan pentadbir, yang sentiasa berhadapan dengan pelbagai karenah guru dan pelajar, memerlukan kehati-hatian dalam bertindak. Bagi dirinya setiap tindakan yang dilakukan perlu dilaksanakan dengan penuh tanggungjawab, dan mestilah dijalankan dalam keadaan sedar dan tidak bertidak sewenang-wenang. Cara 
sedemikian mengingatkan dirinya bahawa dia adalah sebagai seorang pemegang amanah yang mesti berfikir sebelum melakukan sesuatu.

Peserta temubual individu pula TBI1 menceritakan pengalamanya tentang berfikir sebelum bertindak dalam pembinaan kesedaran emosi. Bagi beliau sekiranya muncul perasaan negatif di dalam dirinya yang mendorong untuk melakukan sesuatu, dirinya akan memikirkan tentang kewajaran fikiran tersebut terlebih dahulu, kenapa dirinya boleh berfikiran sedemikian. Pengalaman beliau sambil berfikir tentang kewajaran berperasaan sedemikian terkadang beliau bercakap dengan diri sendiri kenapa beliau berfikiran sedemikian. Perkara tersebut secara tidak langsung telah membuatkan dirinya sentiasa sedar sebelum sesuatu tindakan diambil. Perkongsian kedua-dua orang subjek tersebut seperti ditunjukkan pada petikan berikut ini:

FG1 : ...kita perlu berhati-hati dengan tanggungjawab, contohnya tandatangan kita laku, jadi jangan sewenang-wenangnya kita menanda tangani apa-apa sahaja dokumen. Lebih-lebih lagi sesuatu yang kosong. Cek kosong, ataupun kertas kosong, jangan sekali-sekali dilakukan. Jadi perkara ini boleh membimbing kepada kerjaya yang lebih professional.

TBI1 : ...kita boleh memikirkan kembali dari segi kewajaran kita berperasaan begitu. Misalnya kalau anak degil kita marah, $i$ think that ok untuk kebaikan tapi kalau kita marah sampai mencederakan anak dah tak baik, sebab kalau kita tak marah anak menganggap perbuatan tersebut tidak salah, jadi saya ingat itu penting. Kena pikir sekejaplah, dan kadang-kadang bercakap pada diri sendiri. Kalau itu merupakan satu keluhan, bercakap mengadu kepada Allah S.W.T. Saya suka berfikir sebelum melakukan sesuatu.

Pengalaman berfikir sebelum bertindak dalam pembinaan kesedaran emosi juga dikongsikan oleh TBI2, TBI3 dan TBI8 yang menyebut istilah berkenaan dengan bertindak melakukan sesuatu dengan batas tertentu, dalam melakukan sesuatu tindakan beliau tidak melulu, menunjukan bahawa dirinya dalam keadaan sedar melakukan perkara tersebut, seperti dinyatakan dalam petikan di bawah ini:

TBI2 : ... kita dah ada had lah maknanya kita punya agama, saya rasa itulah yang menjadikan kita sesuatu, menjadikan kita untuk dapat reflek dan dengan sendirilah kita sedar, so kita tahu bagaimana nak berhenti, sedar, jadi kita boleh menilai perasaan kita...

TBI3 : Sebelum saya manivestasikan idea saya, saya akan buat kajian terlebih 
dahulu, saya akan lihat ada tak orang buat. Jadi bila kita buat sesuatu yang menjangkaui masa, maksudnya kita buat sesuatu yang barulah. Contohnya di Malaysia belum ada, jadi kita boleh ke hadapan sikitlah...

TBI8 : Contohnya saya dimintak untuk bentang kertas kerja, saya akan tengok di situ tajuk tu relevan atau tidak dengan saya. Kemudian saya ada banyak bahan atau tidak untuk menulis tajuk itu. Kalau saya nampak dia kurang relevan dan sayapun kurang banyak bahan saya mungkin mintak berikan kepada orang lain.

Pembinaan kesedaran emosi melalui komponen "akidah" pula TBI6 menceritakan pengalamannya untuk sentiasa sedar dengan keadaan yang berlaku di dalam dirinya, sentiasa menggunakan pendekatan agama untuk membantu menyedarinya. Bagi beliau sentiasa berusaha secara tidak langsung memang dapat melihat perkara-perkara yang ada dalam dirinya, namun beliau yakin dalam usaha tersebut terdapat kekuatan lain yang membantu dirinya yang dipanggil dengan istilah akidah ataupun keyakinan. Perkara yang sama juga dikongsikan oleh TBI7 iaitu untuk menimbulkan kesedaran seseorang perlukan kepada agama. Sebagai contoh untuk menimbulkan kesedaran kepada guru-guru, perlu disentuh tentang shalatnya, alQur' anya dan Qiyamulailnya, seperti dapat dilihat dalam perkongsian berikut ini:

TBI6 : Saya yang ketara sekali bila saya buat $\mathrm{PhD}$, bila kebetulan saya balik kali kedua boleh dikatakan setiap malam saya akan sembahyang tahajud, do'a, sembahyang hajat. Maknanya benda tu memang kita hendak sangat dan kita rasa kita tidak guarantee kita dapat. So, usaha tetap usaha tetapi selepas itu sentiasa berdoa. So maknanya menyerahkan sepenuhnya pada yang maha kuasa.

TBI7 : Jadi maknanya akhlak ini dalaman dulu. Lepas itu baru ditunjuk dengan yang nampak. Ini yang sebut dengan nawaitu tadi, inilah dia. Kalau ini tak beres, jadi tak bolehlah. Jadi kita kena latihanlah guru-guru kita al-qur'anya, shalatnya, qiyamullailnya. Kalau tak ada yang itu macam mana nak buat yang ini (TBI7).

\subsubsection{Pembinaan Penilaian Kendiri Yang Tepat}

Penilai kendiri yang tepat merupakan sub domain kedua di dalam kesedaran kendiri.

Rajah 4.5 di bawah memaparkan tentang pandangan subjek dalam pembinaan penilaian kendiri yang tepat. Terdapat empat komponen penting yang mereka 
kongsikan oleh subjek dalam pembinaan penilaian Kediri yang tepat tersebut iaitu; (i) sedar dengan peranan "role fungtion", (ii) memerlukan orang lain untuk memberikan pandangan tentang diri mereka, (iii) usaha maksimum dan konsisten dan (iv) merefleksi kesilapan yang pernah dilakukan. Bila dilihat kekerapan dan peratusan subjek mengemukakan pandangan mereka terhadap masing-masing komponen tersebut, didapati peratusan tertinggi adalah pada komponen sedar dengan peranan "role function" (70\%) dan komponen memerlukan orang lain memberikan pandangan tentang diri mereka (70\%). Diikuti oleh komponen merefleksi kesilapan (40\%) dan komponen usaha maksimum dan konsisten (20\%).

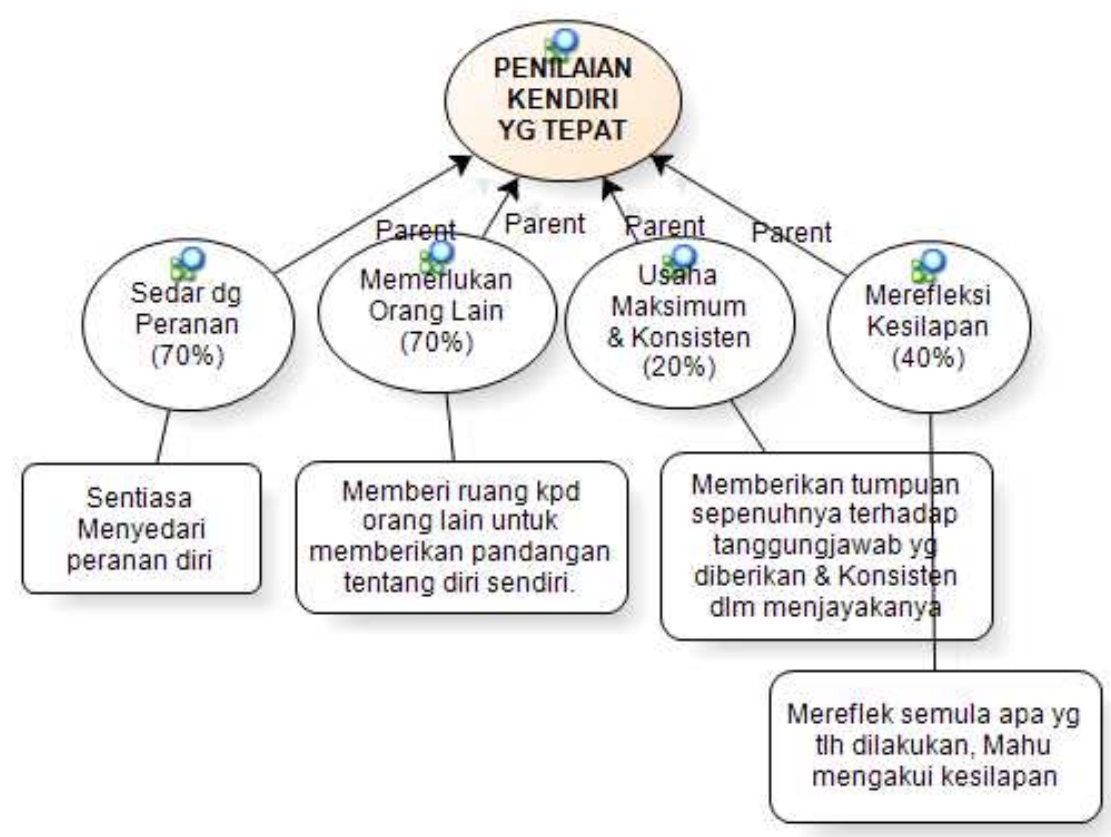

Rajah 4.5 Pengalaman subjek dalam pembinaan penilaian kendiri yang tepat

Dapatan ini menunjukkan daripada keempat-empat komponen tersebut, terdapat tiga komponen yang memiliki peratusan yang tinggi iaitu (sedar dengan peranan, memerlukan orang lain untuk memberikan pandangan terhadap diri mereka dan merefleksi kesilapan yang pernah dilakukan). Bagaimanapun menurut mereka menjadi lebih baik sekiranya kesemua komponen tersebut diambil kira secara keseluruhan. subjek melihat untuk pembinaan penilaian kendiri yang tepat, mereka menyedari tentang peranan diri mereka (role function). Mereka juga menyatakan terkadang mereka memerlukan orang lain untuk memberikan maklumbalas tentang 
dirinya. Pengalaman menarik juga mereka kongsi adalah perlunya merefleksi kesilapan yang pernah dilakukan. Mereka menyatakan mengimbas semula kesilapan yang pernah dilakukan dapat memberi ruang kepada dirinya untuk menilai semula kekuatan dan kelemahan yang ada pada dirinya. Komponen-komponen tersebut akan lebih mantap apabila diusahakan secara maksimum dan konsisten.

Apabila bila dirujuk kepada Matrix Intersection terhadap pandangan yang dikemukakan melalui temubual berkumpulan dan temubual secara individu (rujuk Jadual 4.6) oleh responden, didapati tiga daripada empat komponen yang dikemukakan (sedar dengan peranan, memerlukan orang lain dan merefleksi kesilapan) adalah dikemukakan oleh subjek melalui temubual berkumpulan dan temubual secara individu. Sedangkan untuk komponen usaha maksimum dan konsisten hanya dikemukakan melalui temubual individu sahaja. Bagaimanapun perkongsian mereka tentang keempat-empat komponen tersebut lebih banyak muncul melalui temubual individu berbanding dengan temubual berkumpulan, seperti ditunjukkan di bawah ini.

Jadual 4.6 Matrix intersection penilaian kendiri yang tepat

\begin{tabular}{lcc}
\hline Matrix Nodes & F.Group & Individu \\
\hline Sedar dengan Fungsi Peranan & 2 & 5 \\
Memerlukan Orang Lain & 2 & 5 \\
Merefleksi Kesilapan & 1 & 3 \\
Usaha Maksimum \& Konsisten & 0 & 2 \\
\hline
\end{tabular}

Berikut ini adalah pengalaman yang dikongsikan oleh peserta temubual tentang perkara-perkara yang mereka lakukan untuk pembinaan penilaian kendiri yang tepat bagi diri mereka. Untuk komponen sedar dengan peranan "role function" terdapat beberapa istilah yang mereka gunakan untuk menerangkan komponen tersebut. Ada yang menyebutkan "sedar dengan role function" secara jelas dan ada juga yang menyatakan dengan istilah yang agak berlainan namun mempunyai pengertian yang lebih kurang sama. Seperti yang diceritakan oleh peserta temubual individu TBI1, beliau menyatakan untuk penilaian kendiri beliau sentiasa cuba "sedar dengan role function" (peranan dirinya). 
Istilah lain pula yang digunakan oleh subjek adalah perkataan "sedar dan faham" namun masih merujuk kepada pengertian yang sama dengan "sedar dengan role function". Seperti yang ditunjukkan dalam perkongsian oleh beberapa orang subjek (FG2 dan FG1). Seorang subjek dalam kumpulan FG2 menyatakan sebagai seorang pemimpin mestilah menyedari bahawa dirinya adalah pemimpin sebab setiap perkataan, perbuatan dan tingkah laku akan menjadi perhatian dan contoh bagi orang lain, seperti yang ditunjukkan dalam perkongsian di bawah ini:

TBI1 : ...sedar tentang peranan "role function" jadi kalau di rumah kita sedar peranan kita sebagai bapa, kalau dengan anak-anak kita dapat menyesuaikan hubungan bapa dengan anak. Bila berhadapan dengan rakan sekerja, tidak adalah hubungan itu antara bapa dengan anak lagi sebab ini antara rakan sekerja...

FG2 : Di sekolah kita akan pastikan dapat mengawal diri kita sebaik yang mungkin memandangkan kita adalah seorang pemimpin. Apa yang kita cakap, semua tindakan kita, senyum kita ikut prosedur yang dan standart sebab kita sebagai seorang model di sekolah.

Pandangan yang hampir sama juga dikongsikan oleh peserta temubual individu. Seperti yang dinyatakan oleh TBI3 dan TBI5 bagaimana mereka cuba "menyedari" tentang peranannya sebagai seorang pendidik, bagi dirinya sedar dengan role function bermakna dapat memberikan komitmen sepenuhnya terhadap tanggungjawab yang telah diamanahkan. Yang paling menarik daripada perkongsian ini adalah beliau mampu memperoleh kejayaan dalam bidang yang diceburi lebih cepat berbanding dengan rakan-rakan yang lain. Bagi beliau sedar dengan role function menjadikan dirinya fokus dengan bidang dan kerjaya yang digeluti, seperti perkongsian di bawah ini:

TBI3 : ...Jadi saya tengok dalam akademik ini apa dia punya tangga-tangga dialah, mula-mula pensyarah, kemudian disyahkan di dalam jawatan, and then masa itu tidak ada pensyarah kanan, Prof. Madya dan Profesor. Saya tengok Profesor-Profesor di fakulti, dah nak pencen baru dia jadi Profesor. Saya kata kalau macam itu teruklah saya. So saya balik kaji lah, saya tengok, apa yang diperlukan untuk nak dapatkan Prof. Madya dan nak jadi Profesor. O... rupanya penerbitan, reserch, jadi saya fokuslah.

TBI5 : ...kata dalam tugas kita kena buat sesuatu diarah diminta untuk membuat sesuatu, bila nak buat itu saya akan homework. Saya kena menyelia tesis sebagai contoh kan, saya akan meneroka tentang tesis. Saya baca buku-buku 
tentang cara menulis. Saya baca buku tentang bagaimana membuat tesis, bagaimana membuat research, begitu maksudnya, bagaimana menulis esei.

Komponen kedua yang dikemukakan oleh peserta temubual tentang pembinaan penilaian kendiri yang tepat adalah "memerlukan orang lain" untuk mengingatkan. Perkongsian pengalaman tentang penilaian kendiri yang tepat menggunakan kaedah "memerlukan orang lain" untuk mengingatkan, subjek menyatakan melalui beberapa kaedah, iaitu ada diantara mereka yang "meminta secara langsung agar orang lain memberikan pandangan terhadap dirinya", sama ada dalam bentuk lisan mahupun tulisan. Ada juga dalam kalangan mereka yang mengkategorikan pandangan orang lain tersebut "melalui tugasan ataupun pekerjaan lebih yang diberikan kepada dirinya". Mereka melihat tugasan-tugasan yang diberikan kepada dirinya sebagai pesanan bahawa dirinya mempunyai kekuatan tentang perkara tersebut. Ada juga diantara mereka yang "menjadikan orang lain sebagai idola" sebagai ingatan kepada dirinya.

Seperti yang dikongsikan oleh salah seorang subjek dalam temubual berkumpulan FG2 yang menceritakan pengalamannya meminta pandangan orang lain secara terus. Bagi dirinya memberikan penilaian terhadap diri sendiri merupakan perkara yang agak susah. Melalui pengalamannya sebagai seorang pentadbir di sekolah, beliau sentiasa memberikan ruang seluas-luasnya kepada kakitangannya untuk menilai dan memberikan pandangan secara terbuka tentang dirinya. Pandangan yang hampir sama dikongsi juga subjek TBI1 yang menyatakan terkadang dirinya tidak sedar dengan kekuatan dan kelemahan yang ada pada diri sendiri. Bagi dirinya pandangan orang lain sangat bererti untuk menunjukkan kekuatan dan kelemahan yang dimiliki, seperti dinyatakan dalam petikan di bawah ini:

FG2 : ...memang susah untuk memahami perasaan diri kita sebenarnya namun begitu apa yang saya lakukan adalah pada setiap minggu saya akan mengadakan KMK. Di akhir KMK itu setiap sesi KMK itu saya memberi peluang kepada guru untuk bercakap apa sahaja mengenai pentadbiran saya, kedudukan sekolah yang tidak sesuai bagi mereka. Saya buat open, mereka bebas mengemukakan pendapat tetapi tidak boleh menggunakan bahasa yang tidak baik, gunakan bahasa yang membina dan cadangan-cadangan untuk penambah baikan. Dan saya akan catat, malah kita minitkan.

TBI1 : ...menilai kelemahan dan kekuatan diri secara tepat, kadang kala memerlukan orang lain membantu kita mengenal kelemahan, kadang- 
kadang kita tak nampak kelemahan-kelemahan kita. Kadang kala kekuatan yang kita adapun kita tak sedar, orang lain kata.. o... you macam ni lah, so kita tak perasan "tak awer" yang sebenarnya dipandang oleh orang...

Kaedah berikutnya pula iaitu mengingatkan diri "melalui tugasan ataupun pekerjaan lebih yang diberikan", seperti yang dikongsi oleh salah seorang subjek temubual berkumpulan dalam FG1 yang menceritakan bahawa pada peringkat awal dirinya tidak menyedari, sebenarnya "kerja-kerja yang diberikan kepada dirinya" adalah untuk persediaan dirinya yang diamanahkan sebagai pentadbir sekarang ini. Beliau sendiri tidak melihat awalnya akan memegang jawatan tersebut, namun pimpinan seolah-olah telah mempersiapkan dirinya untuk memikul amanah berkenaan. Akhirnya beliau menyedari secara tidak langsung pimpinan beliau telah memberikan pesanan bahawa dirinya mempunyai potensi untuk memimpin di peringkat sekolah, Beliau sebenarnya tidak menyedari bahawa dirinya boleh memimpin, namun perkara tersebut terserahlah apabila ada orang lain yang menonjolkan dirinya, seperti yang dinyatakan dalam petikan temubual berikut ini:

FG1 : ...sama ada kerja-kerja aktiviti luar seperti sukan, perkemahan pengakap, kemudian pertandingan-pertandingan saya yang dihantar walaupun ini bukan tugas saya. Kemudian tugas-tugas pejabat tu disuruh saya buat. Kewangan ada kerani di suruh saya buat, hingga pada satu peringkat pernah dia datang berjumpa saya, masa itu saya mengajar dia kata Cikgu berhenti mengajar sekarang, naik pejabat saya ganti tempat Cikgu. Pergi jumpa kerani mintak kerja dengan dia. Apa yang saya dah arahkan kerani Cikgu kerjakan. Jadi pada masa itu memang saya rasa tertekan terlalu banyak kerja yang dibuat selain daripada mengajar. Tapi bila saya dah menjawat sebagai jawatan guru besar baru saya terfikir, sedar bahawa itu adalah nilai yang paling berharga pada saya. Jadi ketika orang lain mempunyai masalah kerana tidak mempunyai latihan menjadi guru besar, alhamdulillah saya dah boleh buat kerja.

Salah satu kaedah lagi adalah menjadikan "orang lain sebagai idola" untuk ingatan kepada diri. Seperti yang dikongsi oleh subjek TBI4 yang menyatakan beliau tidak meminta orang lain untuk memberikan pandangan tentang diri beliau, tetapi beliau mula menyedari dan membina kekuatan yang ada pada dirinya apabila di universiti tempat dia menuntut, melihat seorang pensyarah yang sangat baik di matanya. Pensyarah tersebut dijadikan sebagai idola untuk dirinya bergerak ke hadapan. Pandangan yang hampir sama dikongsi oleh TBI8 yang menyatakan bahawa 
dirinya merasa perlu meraih kejayaan apabila dimotivasikan oleh guru-guru ketika menuntut di peringkat sekolah menengah, seperti yang dikongsikan beriku ini:

TBI4 : ... Bila masuk UTM dulu di situlah agaknya mula develop benda-benda macam inilah. Sebab ada seorang pensyarah yang ada hubungan keluarga dengan kami lagi dan dia memang very active, sampai dia terlibat dengan penubuhan ABIM dulu. Dia itu macam saya punya idola.

TBI8 : ... saya rasa mungkin sebab saya sekolah di asrama penuh ya, jadi motivasi gurulah yang kuat. Motivasi guru, suasana pembelajaran yang memang cukup kondusif untuk kita, jadi kita semua sama-sama belajar untuk mendapat kejayaan.

Komponen ketiga pula yang diperolehi untuk pembinaan penilaian kendiri yang tepat adalah "merefleksi kesilapan" yang pernah dilakukan. Merefleksi kesilapan yang pernah dilakukan dikongsikan oleh subjek dalam beberapa bentuk penyampaian namun mempunyai makna yang lebih kurang sama. Seperti yang dikongsi oleh salah seorang subjek dalam kumpulan FG 1 yang sentiasa memikirkan apakah yang telah dia lakukan untuk hari ini. Beliau juga menyatakan sekiranya telah melakukan kesilapan, beliau tidak merasa segan dan malu untuk mengakui kesilapan yang telah dilakukan tersebut. Pandangan yang hampir sama juga dikongsikan oleh TBI6 yang menyatakan dirinya sentiasa memikirkan dan mengimbas semula perkara-perkara yang telah beliau abaikan selama ini, seperti dalam perkongsian berikut ini:

FG1 : Bagi saya, saya tiap-tiap hari ada berfikir apakah yang telah saya lakukan hari ini, dan ada apa komen daripada rakan-rakan dan orang lain tentang diri saya.... yang paling penting adalah jangan malu nak mengaku dalam kesilapan kita. Jangan malu nak menarik kesilapan yang kita lakukan. Jangan kita berdolak-daliklah.

TBI6 : ...yang saya abaikan dulu saya tingkatkan balik..., saya rasa itu penting supaya tidak ada pengabaian. Maknanya sentiasa chek and balance jugalah kan.

Komponen keempat yang dikongsikan oleh subjek adalah "usaha berterusan dan konsisten" namun peratusan terhadap komponen ini didapati agak rendah berbanding dengan tiga komponen sebelumnya. Usaha berterusan dan konsisten di sini ditunjukkan dengan istilah "tidak mengabaikan dan ingin standing dengan orang-orang yang terkemuka". Seperti yang dikongsikan oleh subjek TBI 6 yang menyatakan bahawa dirinya memang tidak suka mengabaikan pelajaran dan sentiasa memberikan 
tumpuan sepenuhnya terhadap pelajaran semasa beliau menuntut sama ada di sekolah menengah sehinggalah ke Institusi Pengajian Tinggi. Keingininan untuk standing dengan orang-orang terkemuka di dunia dalam bidang yang diceburi menunjukkan usaha berterusan dan konsisten dalam mewujudkan kecemerlangan dalam bidang yang diceburi, seperti dinyatakan dalam perkongsian di bawah ini:

TBI6 : ...Cumanya saya memang suka bila dah belajar ini saya memang tak abaikan pelajaran. Itulah yang saya lakukan sampai ke peringkat universitilah. So, orang kata beri perhatian penuhlah pada pelajaran.

TBI1 : ...Saya ingat kalau saya tengok apa yang saya dapat hari ini mungkin juga disebabkan oleh keserasian minat dan juga dorongan keluarga. Mungkin juga keinginan dan cita-cita sayalah nak setanding dengan penyelidikpenyelidik terkemuka di luar Negara.

\subsubsection{Pembinaan Keyakinan Diri}

Rajah 4.6 memaparkan tentang pandangan subjek dalam pembinaan keyakinan diri (Sub domain ke-3 dalam kesedaran kendiri). Hasil temubual mendapati terdapat empat komponen penting yang dikongsikan oleh subjek dalam pembinaan keyakinan diri mereka. Keempat-empat komponen tersebut adalah; (i) kemahiran ataupun kemahiran, (ii) persediaan yang sempurna, (iii) berfikiran positif, dan (iv) berdoa. Bila dilihat kekerapan dan peratusan subjek menyatakan pandangan mereka didapati peratusan tertinggi adalah pada komponen berfikir positif (50\%), diikuti oleh tiga komponen berikutnya, iaitu persediaan yang sempurna (40\%), kemahiran ataupun kemahiran (40\%) dan berdoa (40\%). Dapatan ini menggambarkan bahawa untuk pembinaan keyakinan diri, subjek telah mengambil kira keempat-empat komponen tersebut. Bagaimanapun mereka telah meletakkan komponen berfikir positif pada urutan pertama. Ini menunjukkan bahawa berfikiran positif tersebut sangat penting dalam membina keyakinan diri mereka. 


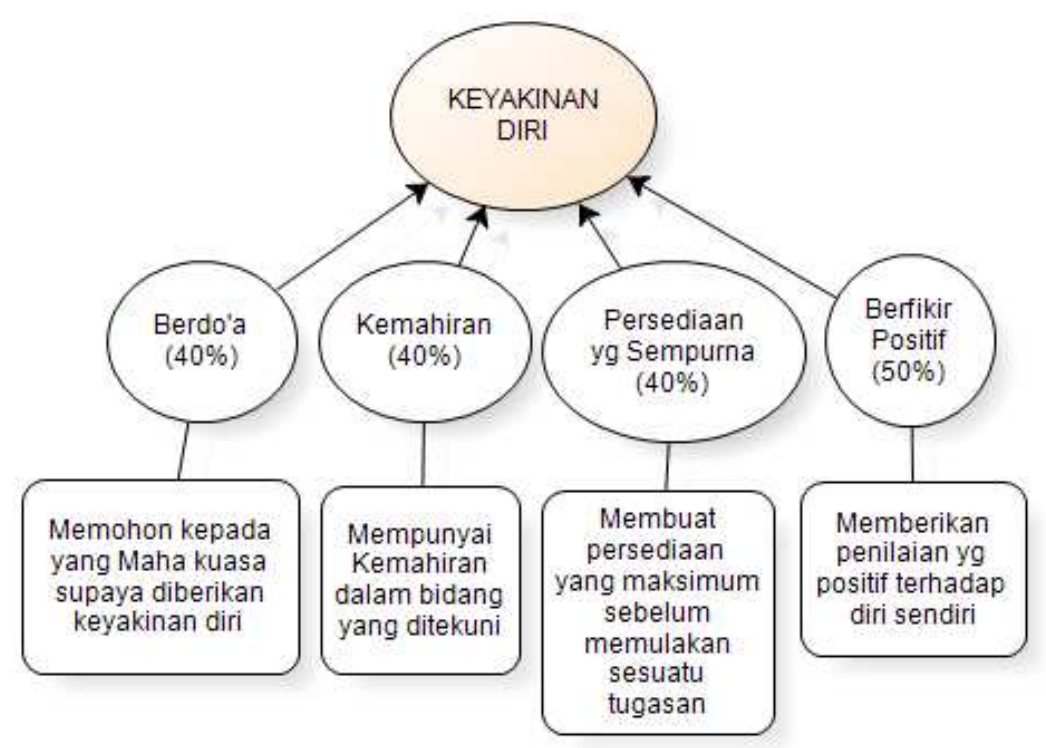

Rajah 4.6 Pengalaman subjek dalam pembinaan keyakinan diri

Apabila bila diperhatikan kepada Matrix Intersection terhadap pandangan subjek tersebut (rujuk jadual 4.7) didapati kempat-empat komponen tersebut (berfikir positif, skill ataupun kemahiran, persediaan yang sempurna dan berdo'a) dikemukakan oleh subjek melalui kedua-dua kaedah temubual yang dilakukan (temubual berkumpulan dan temubual individu). Bagaimanapun perkongsian mereka lebih banyak diperolehi melalui temubual individu berbanding dengan temubual secara berkumpulan.

Jadual 4.7 Matrix intersection keyakinan diri

\begin{tabular}{lcc}
\hline Matrix Nodes & F.Group & Individu \\
\hline Berfikir Positif & 1 & 4 \\
Kemahiran & 1 & 3 \\
Persediaan Sempurna & 2 & 2 \\
Berdo'a & 1 & 3 \\
\hline
\end{tabular}

Perkongsian pengalaman subjek tentang perkara-perkara yang mereka lakukan untuk membina keyakinan diri mereka secara terperinci dilaporkan di bawah ini. Untuk komponen "berfikir positif" salah seorang peserta temubual dalam FG1 menyatakan berfikir positif tersebut dengan cara "membandingkan dirinya dengan orang lain". Apabila mendapatkan sesuatu yang boleh melemahkan semangat dirinya, 
dia cuba meyakinkan diri semula dengan menyatakan kepada dirinya "kemungkinan orang lain lebih teruk daripada dirinya". Dengan cara sebegini dirinya berasa yakin semula dengan kekuatan yang dimiliki.

Pandangan lebih kurang sama dikemukakan oleh TBI5 yang menyatakan berfikir positif dengan cara "melihat kekuatan yang ada pada diri sendiri”. Berdasarkan beberapa ujian psikologi yang diambil, dirinya mendapati sebenarnya dia adalah seorang yang rendah diri ataupun tidak seberapa yakin dengan diri sendiri. Namun pada masa yang sama dia merasakan mempunyai "kekuatan tersendiri" (berfikir positif), kekuatan itulah yang dipergunakan untuk menonjolkan diri beliau ke hadapan. Perkongsian tersebut dikukuhkan lagi oleh TBI 8 yang menyatakan berfikiran positif dengan istilah "tidak ingin menunjukkan kelemahan diri", dia ingin menunjukkan bahawa dirinya adalah "seorang yang pandai dan yakin boleh buat" (berfikir positif), seperti yang dikongsikan berikut ini:

FG1 : Selalunya saya kalau keyakinan diri ini, katalah saya ini dapat satu benda yang tidak baguslah, selalunya saya nak yakin diri saya, saya selalu bandingkan diri kita dengan orang lain. Mungkin orang lain lebih teruk daripada saya, itu cara saya menguatkan semangat. Diri kita kurang, orang lain ada lagi yang kurang daripada kita...

TBI5 : ...saya pernah mengikuti banyak-banyak ujian, ujian itu menunjukkan kepada saya memang saya rendah diri. Tak nak buat itu, takut buat ini (tidak berapa confidence kan). Cuma saya di dalam tidak confidence itu saya ada kekuatan iaitu saya pandai bercakap. Saya tahu kalau saya bercakap, saya nampak kalau saya bersuara semua orang dengar, itu dululah sekarang mungkin sudah berkurang. Saya nampak ada kekuatan, jadi kekuatan itu menimbulkan keyakinan.

TBI8 : ... saya memang tak nak tunjuk saya bodoh kan? Saya nak tunjuk saya pandai,... saya boleh buat, saya bukan orang tak boleh buat kan? Saya rasa dalaman...

Seterusnya membina keyakinan diri melalui kaedah "berdoa" pula, subjek kajian menceritakan pelbagai pengalaman mereka berkaitan dengan perkara tersebut. Seperti dikongsikan oleh TBI1, TBI4 dan salah seorang subjek dalam FG2 yang menyatakan bahawa dalam keadaan cemas dan kurang yakin diri dalam menghadapi situasi tertentu mereka sentiasa berdo'a untuk mengurangkan rasa cemas tersebut dan 
memohon kekuatan agar diberikan kekuatan untuk mengatasinya, seperti dinyatakan pada perkongsian berikut ini:

TBI1 : ... Ya Allah mudah-mudahan tak ada apa-apa...walaupun cemas ketika itu, memang sewajarnya cemas... Jadi kita nak mententramkan diri, ya Allah selamatkan anak saya.., macam tu. So perkara itu boleh melegakan sebab ada tempat mengadu yang Maha Kuasa.

TBI4 : ... saya tidaklah berapa confidence sangat, kadang-kadang saya menggeletar juga (kecut perut), tapi saya atasi dengan banyak berdoalah kan. Saya selalu gunakan doa-doa kalau nak jumpa orang ataupun bagi ceramah dan bentang paper di peringkat antarabangsa. Selalu saya baca doa nabi Musa dalam menghadapi Fir' aun tu kan.

FG1 : Biasanya kalau ada propgram-program yang ingin saya jalankan, saya akan shalat hajat dua ataupun tiga kali untuk mintak petunjuk daripada Allah S.W.T, untuk melakukan sesuatu pekerjaan tersebut. Dan sayapun selalu galakan cikgu-cikgu saya untuk melakukan sholat hajat.

Membina keyakinan diri melalui kemahiran ataupun "kemahiran" pula, subjek juga telah menyatakan pelbagai pengalaman mereka. Seperti dikongsikan oleh salah seorang subjek dalam FG1 yang menyatakan pengalaman beliau untuk menimbulkan keyakinan diri melalui kemahiran ataupun kemahiran tersebut dirinya berusaha untuk memahirkan diri dengan pelbagai keperluan dalam bidang yang digelutinya. Perkara yang hampir sama juga dikongsikan oleh subjek TBI1 dan TBI5 yang menyatakan bahawa untuk pembinaan keyakinan diri melalui kemahiran tersebut, beliau selalu bersedia mengikuti pelbagai kursus, agar kemahiran yang diperolehi dapat menambahkan lagi keyakinan dirinya. Perkongsian yang ditunjukkan oleh masingmasing subjek tersebut seperti ditunjukkan di bawah ini:

FG1 : ... saya boleh membina alat bantu mengajar ... dalam bentuk power poin yang agak bagus. Bila saya buat, saya dedahkan kepada cikgu, kata cikgu ini cukup bagus, boleh buatkan saya cikgu? Jadi ini memberikan keyakinan lagi kepada diri saya...

TBI1 : Jadi kursus yang saya hadiri itu menambah keyakinan saya tentang keupayaan saya untuk menjalankan penyelidikan dengan lebih baik dan juga mungkin mematangkan saya...

TBI5 : ... Jadi saya pelbagai itu agaknya membuat saya rasa salah satu yang mebuat saya jadi confidence dalam kehidupan. Di universiti ini, saya nak pergi kat manapun ada orang yang saya kenal. Itu agaknya yang membina tapi yang utama sekali ialah skill. Kita kena ada kemahiran yang kita tengok orang lain tidak ada. 
Seterusnya pembinaan keyakinan diri melalui "persediaan yang sempurna" pula, dinyatakan oleh subjek dalam pelbagai istilah. Diantara istilah yang mereka gunakan adalah "membaca, persediaan yang sempurna, persediaan yang baik, belajar, berorganisasi" dan sebagainya. Seperti yang dikongsikan oleh salah seorang subjek dalam FG2 yang menyatakan pengalaman beliau bahawa untuk pembinaan keyakinan diri dia telah membiasakan dirinya dengan banyak membaca. Subjek lain pula dalam FG2 menyatakan bahawa untuk pembinaan keyakinan diri beliau sentiasa membuat persediaan yang sempurna. Perkongsian mereka tentang perkara tersebut seperti ditunjukkan di bawah ini:

FG2 : Banyak perkara yang membuatkan self confidence kita, melalui pembacaan... tak lengkap melalui pembacaan sahaja sebenarnya, banyaklah perkara-perkara yang boleh membantu.

FG2 : Bagi saya kalau nak meningkatkan keyakinan,... saya selalu membuat persediaan yang sempurna. Bila saya buat persediaan yang sempurna saya merasakan telah membuat yang terbaik. Jadi saya sangat berkeyakinan... dan saya selalu positive thinking .

TBI5 dan TBI8 juga menyatakan bahawa mereka membina keyakinan diri melalui self study, kebiasaan dalam berorganisasi dan mempersiapkan diri sebelum menghadapi sesuatu situasi yang dijangkakan berlaku. Keadaan tersebut telah menjadikan mereka lebih yakin dalam melakukan sesuatu.

TBI5 : self study ... boleh membina kemahiran, Saya sebenarnya terus aktif dalam gerakan masyarakat, tadi saya kata masa sebelum masuk universiti saya start belia, kemudian saya sambung dalam pemuda UMNO, dalam UMNO, saya rasa itu semua menambah confidence ... Sampai tua macam ini orang hendak lagi...

TBI8 : ... Saya set diri saya untuk mengahadapi situasi itu, itu yang saya dapat. So dalam suasana belajarpun macam tu juga, saya dah set diri saya dalam situasi itu. Jadi saya cuba bayangkan dulu, apa situasi yang akan hadapi, dan saya cuba set untuk menghadapi... itulah yang saya buat.

\subsubsection{Pembinaan Niat}

Rajah 4.7 memaparkan pandangan subjek dalam pembinaan niat (Sub domain ke-4 dalam kesedaran kendiri). Dapatan kajian menunjukkan terdapat tiga komponen utama yang selalu diberikan perhatikan dalam pembinaan niat tersebut. Ketiga-tiga 
komponen itu adalah; (i) melihat tugasan sebagai amanah dan ibadah, (ii) sentiasa berserah diri, dan (iii) sentiasa ikhlas dalam melakukan sesuatu pekerjaan. Bila dilihat kepada kekerapan dan peratusan subjek menyatakan pandangan tersebut, didapati peratusan tertinggi adalah pada komponen tugas adalah amanah dan ibadah (40\%). Seterusnya diikuti oleh komponen berserah diri (20\%), dan komponen niat ikhlas $(10 \%)$.

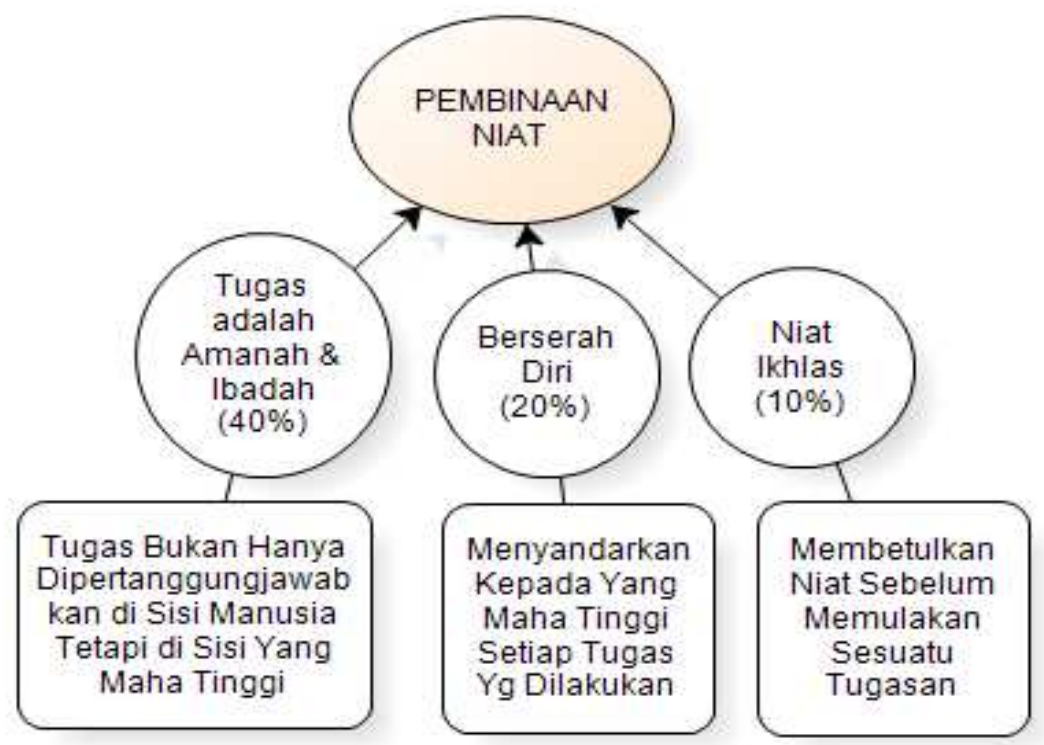

Rajah 4.7 Pandangan subjek dalam pembinaan niat

Dapatan tersebut menunjukkan untuk pembinaan niat bagi subjek yang dikaji, perkara utama yang mereka fikirkan adalah melihat tugasan yang sedang mereka lakukan adalah sebagai "amanah dan ibadah” kepada Yang Maha Tinggi. Seterusnya mereka juga melihat dalam menjalankan amanah dan ibadah tersebut mereka perlu "berserah diri" dan "sentiasa mempunyai niat yang ikhlas" dalam melakukannya.

Apabila bila diperhatikan hasil Matrix Intersection terhadap pengalaman yang dikongsikan oleh subjek berkenaan (rujuk Jadual 4.8), didapati ketiga-tiga komponen tersebut (tugas adalah amanah dan ibadah, berserah diri dan niat ikhlas) dikemukakan melalui kedua-dua temubual yang dijalankan. Namun dapatan kajian menunjukkan, perkongsian lebih banyak didapati melalui temubual individu berbanding dengan temubual berkumpulan. Bagaimanapun sedikit perbezaan di dalam sub domain ini 
berbanding dengan sub domain yang lain adalah peserta temubual tidak terlalu banyak menceritakan pengalaman mereka dalam pembinaan niat ini.

Jadual 4.8 Matrix intersection pembinaan niat

\begin{tabular}{lcc}
\hline Matrix Nodes & F.Group & Indiviu \\
\hline Berserah Diri & 1 & 1 \\
Niat Ikhlas & 0 & 1 \\
Tugas Adalah Amanah \& Ibadah & 0 & 4 \\
\hline
\end{tabular}

Berikut ini dapat dilihat perkongsian pengalaman yang dinyatakan oleh subjek tentang perkara-perkara yang mereka lakukan untuk pembinaan niat tersebut. Pertama, komponen "tugas adalah amanah dan ibadah", subjek menyatakan dalam beberapa istilah, seperti "rasa komplesen, Allah suka bila kita buat yang terbaik, tidak melihat ganjaran sesaat, memberikan sumbangan yang signifikan dan sebagainya". Seperti yang dinyatakan oleh TBI3 dan TBI4, sebagai seorang Islam sepatutnya melakukan pekerjaan dengan sempurna, dengan baik kerana menurut beliau melakukan pekerjaan dengan cara sedemikian adalah sebahagian daripada ibadah. Mereka juga menyatakan bahawa dalam melakukan sesuatu tugasan sepatutnya tidak hanya memikirkan ganjaran yang akan didapatkan selepas pekerjaan itu selesai dilakukan tetapi perlu merasakan bahawa ada Yang Maha Tinggi yang sentiasa memberikan penilaian terhadap pekerjaan tersebut, seperti dinyatakan pada petikan di bawah ini:

TBI3 : Tapi saya rasa sebagai orang Islamlah terutamanya kita tak sepatutnya rasa komplesen, maksudnya kita kena sentiasa melakukan sesuatu yang baik, melakukan sesuatu yang murni, saya rasa memang Allah suka bila kita buat sesuatu buat secara yang terbaik, secara yang paling elok, bermakna itupun sebahagian daripada ibadah juga.

TBI4 : ... duit bukan saya punya matlamat, tapi something yang saya buat itu ada sumbangan sayalah kepada masyarakat, saya nak tengok yang itu, bukan sembarang buat-buat sahajalah. Macam KL kan saya buat something yang very significance, saya nampak satu kebanggaan, ada contribution saya di sana.

TBI7 dan TBI8 mengukuhkan lagi perkongsian tersebut yang menyatakan bahawa dalam melakukan pekerjaan mereka memastikan pekerjaan tersebut dapat "memberikan sumbangan yang signifikan" kepada orang lain. Mereka memastikan setiap pekerjaan yang dilakukan sesempurna yang mungkin, dan melakukannya tanpa 
mengharapkan ganjaran daripada orang lain ataupun bos di tempat kerja, seperti dinyatakan di bawah ini:

TBI7 : Kalau nak jadi guru kena faham apa dia guru? Guru ini maknanya ibadahlah. Saya jumpa you kerana ibadah sahaja, bukan saya kenal you. Maknanya saya menjalankan tugas, ibadah ini kita buat kerana Tuhanlah. Ini yang dah tak ada sekarang ini.

TBI8 : ... saya cuba untuk memenuhi segala keperluan-keperluan yang diperlukan sebagai seorang pensyarah. Maknanya mana lobang yang kosong saya mesti isikan, ... kalau ikut prestasi saya sentiasa cemerlanglah... Kemudian bila saya buat sesuatu saya tidak mengharapkan apa-apa, saya tidak mengharapkan ganjaran, paling kurang apa yang saya buat tu orang dapat merasai.

Seterusnya untuk komponen "berserah diri" pula, subjek menyatakan dengan beberapa istilah "memohon doa restu kepada Allah", supaya pekerjaan tersebut dapat membantu orang lain sebagaimana yang diharapkan. Seperti yang dinyatakan oleh TBI8 dan salah seorang subjek dalam FG1 yang menyatakan sebagai seorang pendidik, setiap mengawali pekerjaan rutin harian dirinya sentiasa berserah diri kepada Yang Maha Tinggi terlebih dahulu agar kerjaanya dimudahkan dan diberkati, seperti yang dinyatakan dalam petikan di bawah ini:

TBI8 : ... saya buat ini apa manfaatnya yang orang lain boleh dapat, kata saya bagi ceramah, selepas saya bagi ceramah apa yang terjadi dengan orang yang dengar ceramah saya. Adakah mereka dapat mengambil apa yang sampaikan, adakah berlaku perubahan di dalam diri mereka atau bagaimana? Jadi bila saya nak buat sesuatu saya memang mintak doa kepada Tuhan, bila saya buat sesuatu biarlah memberi kesan kepada orang lain.

FG1 : Saya tiap-tiap pagi bila nak keluar pergi sekolah saya berniat Ya Allah ya Tuhan ku redhailah pekerjaan ku ini, aku nak mendidik anak-anak muridku supaya nak menjadi orang-orang yang berilmu, beriman... itulah yang saya niatkan setiap hari. Kemudian saya kata, apa yang saya kerjakan ini akan berbalik kepadaku, jadi redhailah pekerjaan aku ini dan limpahi rezeki ku supaya dapat menampung keluarga ku dan berkahilah.

Sedangkan tentang "niat ikhlas" pula TBI1 menyatakan bahawa dirinya selalu mengaitkan niat dalam melakukan sesuatu dengan keikhlasan. Beliau menyatakan dirinya cuba sentiasa menyedari tentang apa yang diniatkannya, seperti dinyatakan dalam petikan berikut ini: 
TBI1 : ...kadang kala saya mengambil kira soal niat saya katakan dengan keikhlasan, betul ke saya nak pergi ke sana ni kerana kawan dia saya atau memang betul-betul nak tolong, itu ada di dalam pertimbangan. Dan biasanya saya sedar tentang intention itu. Biasanya dia datang dengan sendirinya dan link kepada thinking supaya saya dapat buat keputusan sama ada nak teruskan ataupun tidak.

\subsubsection{Pembinaan Kawalan Kendiri}

Rajah 4.8 di bawah memaparkan tentang pengalaman subjek dalam pembinaan kawalan kendiri (sub domain 1 dalam regulasi kendiri). Dapatan kajian menunjukkan terdapat empat komponen penting yang dikongsikan oleh subjek dalam pembinaan kawalan kendiri mereka. Keempat-empat komponen berkenaan adalah; (i) melihat orang lain daripada perspektif mereka, (ii) sentiasa berfikir secara rasional (iii), sentiasa bersabar dan bertenang, (iv) dan keyakinan terhadap agama. Bila dilihat kepada kekerapan dan peratusan subjek menceritakan tentang komponen tersebut, didapati peratusan tertinggi adalah pada komponen melihat orang lain daripada perspektif mereka (70\%) dan berfikir rasional (70\%), diikuti oleh komponen sabar dan bertenang $(60 \%)$, dan komponen keyakinan terhadap agama (30\%).

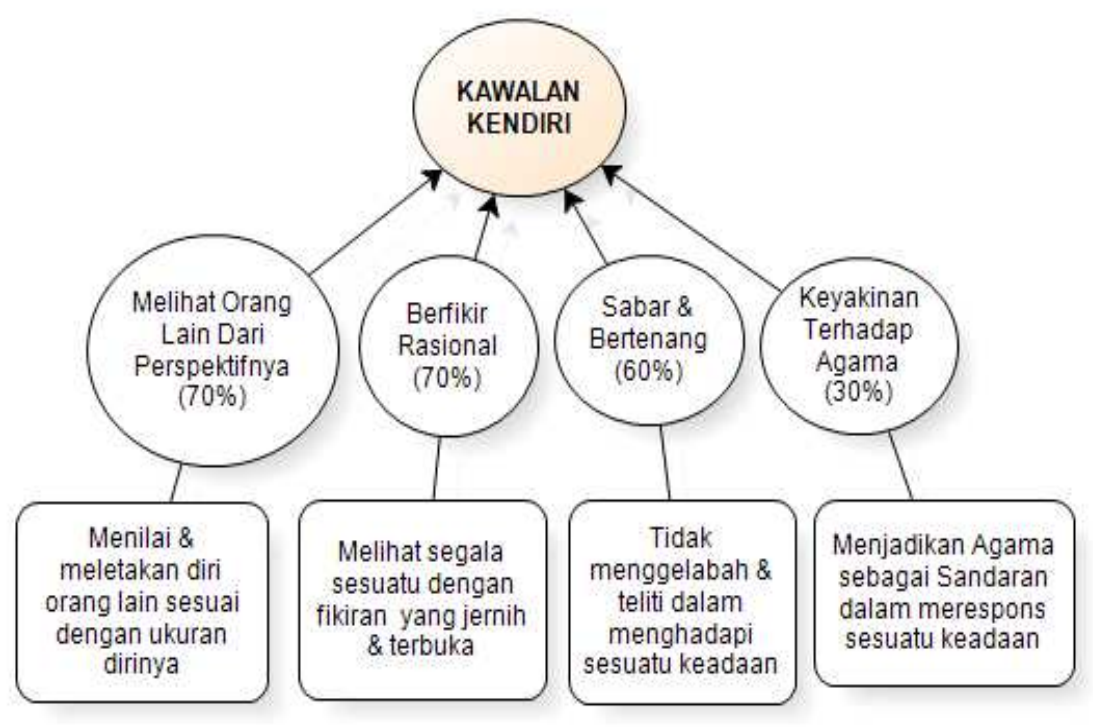

Rajah 4.8 Pengalaman subjek dalam pembinaan kawalan kendiri

Dapatan ini menunjukkan tiga daripada empat komponen tersebut (melihat orang lain daripada perspektif mereka, berfikir rasional, serta sentiasa sabar dan 
bertenang) merupakan komponen penting dan sentiasa diambil berat oleh subjek untuk mengawal diri mereka sebelum mengambil sesuatu tindakan. Walaupun peratusan keyakinan terhadap agama nampak agak kecil (30\%), namun mereka melihat aspek berpegang pada agama juga berperanan dalam membantu mereka untuk mengawal diri mereka masing-masing. Dengan perkataan lain pengendalian diri mereka menjadi lebih mantap apabila mereka dapat mengambil kira keempat-empat komponen tersebut.

Apabila bila dilihat kepada Matrix Intersection terhadap perkongsian subjek tersebut (rujuk Jadual 4.9), didapati keempat-empat komponen tersebut (melihat orang lain daripada perspektif mereka, berfikir rasional, sabar dan bertenang dan keyakinan pada agama) dikemukakan melalui kedua-dua kaedah temubual yang dijalankan (temubual berkumpulan dan temubual individu). Bagaimanapun dapatan kajian juga menunjukkan maklumat daripada perkongsian melalui temubual individu lebih banyak berbanding dengan temubual secara berkumpulan.

Jadual 4.9 Matrix intersection kawalan kendiri

\begin{tabular}{lcc}
\hline Matrix Nodes & F.Group & Individu \\
\hline Melihat Orang Lain Daripada Perspektif Mereka & 2 & 5 \\
Berfikir Rasional & 1 & 6 \\
Sabar \& Bertenang & 2 & 4 \\
Berpegang Pada Agama & 1 & 2 \\
\hline
\end{tabular}

Di bawah ini dapat dilihat pengalaman yang dikongsikan oleh subjek tentang perkara-perkara yang mereka lakukan untuk pembinaan kawalan kendiri mereka. Pertama adalah "melihat orang lain daripada perspektif" mereka. Beberapa istilah yang digunakan oleh subjek untuk menyatakan perkara berkenaan adalah "melihat orang daripada sudut pandangan dia, rasional dalam membuat keputusan, tidak ego dengan diri sendiri, merasa diri yang paling betul, melihat kekuatan yang ada pada diri orang lain, terbuka dengan pandangan orang lain, fleksibel dan menerima orang seadanya". Seperti pandangan yang dikongsi oleh TBI5 yang menyatakan beliau sentiasa melihat orang lain daripada perspektif orang berkenaan. Salah seorang subjek dalam FG 1 juga menyatakan terkadang seseorang perlu "merendahkan ego diri sendiri dan cuba melihat orang lain daripada perspektif mereka". Bagi beliau melihat seseorang jangan 
hanya dilihat kelemahannya tetapi cuba lihat kelebihan atupun kekuatan yang ada pada diri orang tersebut, seperti dinyatakan pada petikan berikut ini:

TBI5 : Melihat orang daripada sudut pandangan dia lah, saya agak masa saya muda jenis pemarah juga, kemampuan mengawal perasaan itu bukan dari tidak boleh marah. Tetapi kemampuan untuk rasional dalam membuat keputusankeputusan atau fleksibel dalam membuat keputusan. Artinya bersedia untuk mendengar pandangan orang dan juga akur.

FG1 : ... kita jangan ego dengan diri kita sendiri, kita kena bercermin diri, kita muhasabah diri dan jangan merasa diri kita selalu betul. Kita sentiasa melihat orang lain, tapi satu kita melihat orang jangan melihat kelemahan tapi cuba lihat kelebihan orang lain. Saya dengan cikgu-cikgu saya bercakap, saya tengok you, apakah kelebihan dan kekuatan you. Kalau kita mencari kelemahan kita akan nampak kelemahanlah, tapi kalau kita mencari kekuatan ... kita akan sportive dengan kekuatan itu.

Selanjutnya TBI1 juga menyatakan pengalaman beliau tentang melihat orang lain daripada perspektif mereka dengan istilah "terbuka pada pandangan orang lain". Dirinya berprinsip bahawa pemikiran yang dikemukan oleh satu orang tidak akan sama dengan pemikiran yang dikemukakan oleh banyak orang. Perkongsian tersebut dikukuhkan lagi oleh TBI5 yang menyatakan pandangan beliau dengan istilah "fleksibel dan boleh menerima orang lain seadanya", seperti dapat dilihat pada petikan di bawah ini:

TBI1 : ... Terutama kita terbuka pada pandangan orang lain, one brain tidak akan sama dengan many brain. Jadi kita bersikap terbuka pada pandangan orang lain yang mungkin maklumat yang lebih berpengalaman, kalau saya tidak bersikap terbuka secara tidak langsung saya tidak memberi peluang kepada diri saya sendiri untuk berkongsi pandangan dengan orang lain.

TBI5 : Saya sangat fleksibel, boleh menerima orang seadanya, saya tidak ada paksa orang, kamu mesti macam ini. ... saya akur, saya cuma memberi pandangan yang berbeza. Kotak tidak semestinya empat segi mungkin boleh bulat...

Seterusnya pembinaan kawalan kendiri menggunakan pendekatan "berfikir rasional" pula didapati subjek menggunakan beberapa istilah iaitu "mudah marah, bersikap positif dan berfikiran positif”. Seperti yang dikongsikan oleh subjek TBI1 dan TBI4 menyatakan apabila dirinya merasa marah, mereka sentiasa cuba mengawal kemarahannya, berfikir bahawa marah itu sebenarnya ada campur tangan Syetan yang 
akan memperburuk lagi keadaan. Satu pengalaman menarik yang juga dikongsikan oleh TB1 adalah beliau masih boleh berfikir secara rasional apabila walaupun dalam keadaan marah. Bagi TBI4 pula marah tidak dapat menyelesaikan masalah. Sekiranya beliau merasa geram dan marah dengan seseorang, beliau akan menggunakan pendekatan membujuk orang berkenaan, seperti dinyatakan dalam petikan di bawah ini:

TBI1 : Saya tak mudah marah, Ini saya apply semasa di rumah dengan isteri, sedar bahawa o.....tak boleh marah ni, sebab marah ini ada campur tangan syetan yang akan menambah buruk keadaan. So kadang-kadang saya relate dengan prinsip Islam bahawa orang yang kuat ini sebenarnya adalah orang menahani marah bukan orang yang meluahkan kemarahan. Kalau saya rasa nak marah saya masih lagi boleh berfikir, saya tak akan marah ketika itu, saya cuba berfikir...

TBI4 : ...saya tahu marah itu tidak akan pergi ke mana, tidak menyelesaikan masalah, bagus kita bujuk dia...Kadang-kadang saya bila dah terlalu marah sangat saya pergi bilik air dan ambil wudhuk.

Seterusnya TBI6, TBI8 dan FG1 juga menceritakan pengalaman beliau tentang pembinaan kawalan kendiri melalui kaedah berfikir secara rasional tersebut. Mereka menyatakan berfikir rasional dengan istilah "bersikap dan berfikir positif". TBI6 menyatakan apabila tidak dapat mengawal kemarahan, sebenarnya itulah yang menyebabkan seseorang jadi panik dan tertekan. Seseorang yang dapat berfikir secara positif tidak akan menggelabah dan sentiasa berhemah dalam menyelesaikan sesuatu masalah. TBI8 pula menyatakan bahawa apabila dirinya merasa marah dia tidak akan meluahkan seketika itu tetapi cuba mengasingkan diri seketika dan memikirkan kenapa perkara tersebut boleh berlaku. Perkongsian tersebut dikukuhkan lagi oleh salah seorang subjek dalam FG1 yang menyatakan sekiranya dirinya merasa tertekan dengan sesuatu pekerjaan, beliau cuba bertindak secara rasional, iaitu dengan cara berkongsi dan bertukar fikiran dengan rakan-rakan sekerja. Petikan pengalaman subjek tersebut seperti ditunjukkan di bawah ini:

TBI1 : ... kita berfikiran positif, maknanya...menerima itu sebagai satu ketentuan Allah "redha". Bila kita terima itu sebagai ketentuan Allah kita tidak tension. ...Bila kita terima itu sebagai ketentuan Allah, kita tak marahmarah, kita tak ada rasa apa-apa. Sebenarnya marah itu yang membuatkan kita jadi tension. 
TBI8 : Kalau marah di ofice saya akan masuk dalam bilik dan saya akan buat kerja saya, dan saya akan cuba untuk mengasingkan diri beberapa ketika daripada orang-orang tertentu. Sebenarnya saya buat seperti itu supaya orang buat kepada saya itu dia sedar dengan kesilapan yang dia lakukan...

FG1 ...bila kita menghadapi apa-apa cabaran ataupun menghadapi masalah yang susah ataupun sukar nak menyelesaikannya. Yang penting bagi saya adalah positive tinking dan selalu bertenang, sabar. Kemudian saya berbincang, tanya pendapat dari rakan saya yang lebih senior...

Perkongsian subjek dalam pembinaan kawalan kendiri dengan kaedah "sabar dan bertenang" pula didapati subjek menggunakan beberapa istilah seperti "sabar dan bertenang" dan "menerima kenyataan". Seperti yang dinyatakan oleh salah seorang subjek dalam FG1dan TBI4 menyatakan pengalaman mereka dalam mengawal diri dengan cara sentiasa sabar dan bertenang apabila merasa terekan dan menghadapi sebarang masalah. Bagi mereka sekiranya dirinya terlalu marah melihat sesuatu keadaan mereka akan cuba membujuk orang-orang yang terlibat dalam keadaan tersebut dengan cara bersabar dan bertenang, seperti perkongsian di bawah ini:

FG1 : ... kalau misal kata kita tertekan dia sebenarnya memberi infak kepada kekuatan kita. Misalnya hari ini saya sangat letih sebab hari ini kerja terlalu banyak, stress. Pada masa itu yang saya buat adalah perlu bertenang. Seboleh-bolehnya masa stress itu kita jangan buat banyak kerja, kita banyak bertenang.

TBI4 : ... kadang-kadang bila saya nak marah sangat sebab semua orang tidak jalan menjalankan kerja kan. Katalah macam projek IRPA yang lepas saya dapat 2.7 billion dan bekerja dengan banyak orang. Saya tengok sini tidak jalan, sanapun tak jalan, jadi kadang dah nak marah sangat, itu kena sabar kan, lepas itu kena bujuk orang dan Tanya...

TBI6 pula menyatakan pengalaman beliau tentang pembinaan kawalan kendiri tersebut dengan kaedah sabar dan bertenang, beliau menggambarkan istilah sabar dan bertenang tersebut dengan istilah "menerima kenyataan". Bagi dirinya apabila menerima kenyataan dalam hidup seseorang akan merasakan ketenagan dan tidak bertindak secara agresif yang mungkin boleh mengakibatkan perkara yang tidak baik kepada diri sendiri, seperti dinyatakan dalam petikan di bawah ini 
TBI6 : So memang saya rasa menerima kenyataan itu kita akan merasa tenang, kalau ada kesusahan, dapat masalah kita masih mampu bertenang. Akhirnya akan ada kesenangan. Kita sedar memang Allah itu Maha Pengasih dan Maha Penyayang kan. Apa yang dia buat itu ada hikmahnya, ... Allah kata, Rasulullah kata "jangan seseorang itu mengaku beriman sebelum dia lulus ujian”. Kadang sesetengah orang bila susah dia langsung marah-marah.

Sedangkan pembinaan kawalan kendiri dengan cara "berpegang pada Agama" pula subjek kajian TBI1 dan TBI2 menyatakan dirinya sentiasa mengaitkan dengan shalat yang dia lakukan sehari-hari. Menurut mereka shalat yang betul menjadikan seseorang dapat mengenal diri sendiri. Apabila seseorang dapat mengenal dirinya maka senang baginya untuk mengawal diri sendiri. TBI2 juga menyatakan bahawa sekiranya individu berpegang betul-betul pada agama maka dirinya akan merasakan kenikmatan agama tersebut dan berpengaruh dalam kehidupan seharian, seperti petikan berikut ini:

TBI1 : Mungkin pendekatan saya ini lain sikit biasanya saya membetulkan shalat saya. Saya yakin salah satu buah penting daripada shalat ini akhlak. Jadi saya ingat kalau kita mengerjakan shalat dengan tertib dan sempurna dia secara tidak langsung membentuk kematangan emosi kita. Jadi boleh mengawal dirilah... semakin boleh kenal diri dan semakin mudah mengawal diri...

TBI2 : ...Tapi asasnya saya nampak agamalah, kalau kita faham agama yang sebenarnya kita akan dapat dia punya tu...,saya rasa insya Allah...

\subsubsection{Pembinaan Kebolehpercayaan}

Rajah 4.9 memaparkan pandangan dan pengalaman subjek dalam pembinaan kebolehpercayaan (sub domain ke-2 dalam regulasi kendiri) dalam diri mereka. Dapatan kajian menunjukkan terdapat dua komponen penting yang menjadi amalan subjek dalam pembinaan kebolehpercayaan tersebut. Kedua-dua komponen berkenaan adalah (i) melakukan sesuatu mengikut yang benar dan (ii) sentiasa jujur dalam melakukan sesuatu. Kekerapan dan peratusan subjek menyatakan komponen tersebut, didapati "melakukan sesuatu mengikut yang benar (30\%)" dan "sentiasa jujur dalam melakukan sesuatu (20\%)". Walaupun peratusan kedua-dua komponen tersebut agak rendah, namun subjek melihat bahawa kedua-dua komponen berkenaan bermakna bagi mereka dalam dalam pembinaan kebolehpercayaan di dalam diri mereka. 


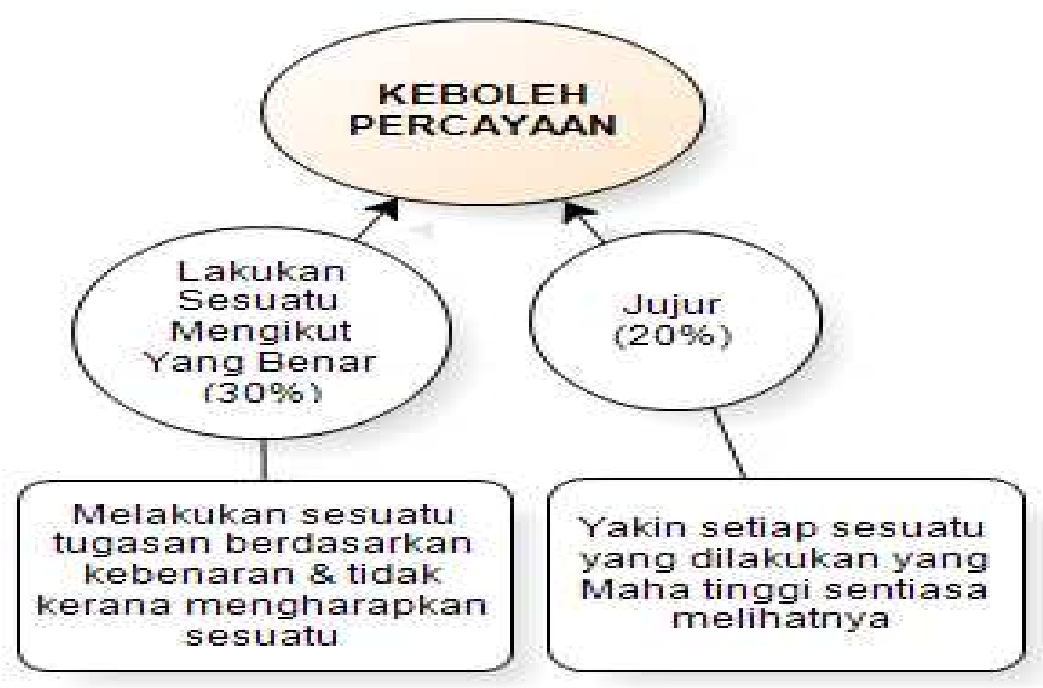

\section{Rajah 4.9 Pengalaman subjek dalam pembinaan Kebolehpercayaan}

Apabila bila dilihat pada Matrix Intersection terhadap perkongsian subjek dalam kedua-dua komponen tersebut (rujuk Jadual 4.10) didapati kedua-duanya dikemukakan melalui kedua-dua kaedah temubual yang dijalankan. Bagaimanapun dapatan kajian menunjukkan maklumat yang diperolehi melalui perkongsian temubual individu masih lagi lebih banyak berbanding dengan temubual secara berkumpulan.

Jadual 4.10 Matrix intersection kebolehpercayaan

\begin{tabular}{lcc}
\hline Matrix Nodes & F.Group & Individu \\
\hline Jujur & 0 & 2 \\
Lakukan Sesuatu Mengikut Yang Benar & 1 & 2 \\
\hline
\end{tabular}

Perkongsian subjek secara lebih terperinci dapat dilihat pada petikan-petikan temubual di bawah ini. Pertama pembinaan kebolehpercayaan dengan cara "melalukan sesuatu mengikut yang benar", subjek kajian menyatakan dengan beberapa istilah, seperti; "buat dengan betul, tanggungjawab dan Allah sentiasa menilai apa yang dilakukan”. Seperti yang dikongsikan oleh salah seorang subjek dalam FG1, TBI7 dan TBI8 yang menyatakan mereka sentiasa berusaha untuk melakukan pekerjaan mengikut yang benar dan betul, dan juga sentiasa jujur dan ikhlas dalam melaksanakan sesuatu pekerjaan tersebut. TBI8 menyatakan perkara tersebut dengan istilah 
“tanggungjawab". Bagi dirinya amanah yang diberikan kepada dirinya dilihat sebagai tanggungjawab yang sepatutnya dikerjakan dengan sebaik yang mungkin. Perkongsian subjek-subjek tersebut seperti dinyatakan di bawah ini:

FG1 : ... kita buat dengan betul walaupun kita tertekan, jangan sekali-kali buat salah. Kita buat secara jujur, secara ikhlas dan bersabar.

TBI7 : ... yang memberi kekuatan saya itu adalah yakin kepada kebenaran...

TBI8 : ... Saya sedar bahawa anak itu adalah amanah dan tanggungjawab saya..., itu yang saya buat. Yang penting apa yang saya buat ini saya tahu benda ini ada penilaian daripada Allahlah, maknanya saya buat benda ini betul...

Pembinaan keboleh percayaan melalui "kejujuran" pula didapati subjek TBI5 dan TBI8 menyatakan kejujuran tersebut dengan sentiasa melakukan sesuatu pekerjaan mengikut yang betul. TBI8 juga menyatakan bahawa apabila dirinya perlu keluar semasa waktu pejabat, beliau sentiasa memberi tahu kemana beliau pergi kepada orang-orang yang sepatutnya mengetahui di mana beliau berada ketika itu, beliau tidak ingin nanti orang lain tercari-cari kemana beliau pergi, seperti perkongsian berikut ini:

TBI5 : Tentang kejujuran saya cuba melakukan pekerjaan mengikut yang betul.

TBI8 : ... saya pergi ke manapun saya akan bagi tahu pihak-pihak tertentu yang mereka perlu tahu kemana saya pergi. Specialy kalau waktu bekerja saya akan bagi tahu dengan kerani, ataupun dengan PA kepada ketua jabatan, supaya kalau pelajar cari, atau sesiapa cari mereka tahu saya berada di mana, itu yang saya buat secara jujur lah.

Seterusnya TBI8 juga mengaitkan kejujuran tersebut dengan pandangan yang Maha melihat, segala sesuatu yang dilakukan Allah akan mengetahuinya. Beliau mencontohkan dalam kerjaya sebagai ahli akademik yang aktif dalam membuat penyelidikan, apabila dalam sesebuah penulisan mengambil idea orang lain maka tidak sepatutnya menjadikan orang lain tersebut sebagai idea sendiri dan mesti dinyatakan bahawa idea tersebut diambil daripada orang lain. Perkongsian TBI8 tentang kejujuran juga dinyatakan bahawa dirinya memastikan di dalam pekerjaan sentiasa berlaku jujur. Sekiranya beliau tidak datang ke pejabat maka beliau tidak akan melakukan look in daripada luar agar dirinya masih dianggap datang ketika itu, seperti dinyatakan pada petikan di bawah ini: 
TBI8 : ...kalau kita buat kerja tu memang kita sentiasa ingatlah bahawa segala sesuatu yang kita buat tu, mesti dikenakan balasan oleh Allah kan. ...katakanlah kita menulis, kalau kita ambik maklumat daripada orang lain, kita kena tulislah bahawa itu maklumat daripada orang lain. Kalau kita rasa orang tak tahupun tapi Tuhan tahu.

TBI8 : ... Contoh saya tak datang ofice, tiba-tiba saya nak pergi look in, saya pikir buat apa saya nak look in ya pada hal saya tak datang office, orang mesti nampak kan. Mungkin disebabkan perasaan seperti itu saya tidak berani untuk melakukan sesuatu yang tidak jujurlah...

\subsubsection{Pembinaan Dorongan Pencapaian}

Rajah 4.10 di bawah ini memaparkan pengalaman subjek dalam pembinaan dorongan pencapaian (sub domain pertama dalam motivasi kendiri). Dapatan kajian menunjukkan terdapat lapan komponen penting yang dikongsikan oleh subjek agar mereka sentiasa bersemangat ataupun terdorong untuk mewujudkan matlamat mereka. Kelapan-lapan komponen tersebut adalah; (i) melihat cabaran sebagai peluang, (ii) perancangan, (iii) disiplin dan istiqamah, (iv) usaha maksimum, (v) belajar daripada keberhasilan orang lain, (vi) belajar daripada kegagalan, (vii) matlamat mesti jelas dan (viii) amanah.

Bila dilihat kepada kekerapan dan peratusan subjek menceritakan pengalaman mereka tentang komponen tersebut, didapati peratusan tertinggi pada komponen melihat cabaran sebagai peluang (70\%), diikiuti oleh perancangan $(60 \%)$, disiplin dan istiqamah (60\%), usaha maksimum (60\%), belajar daripada keberhasilan orang lain (50\%), belajar daripada kegagalan (40\%), matlamat mesti jelas (30\%) dan amanah $(10 \%)$. 


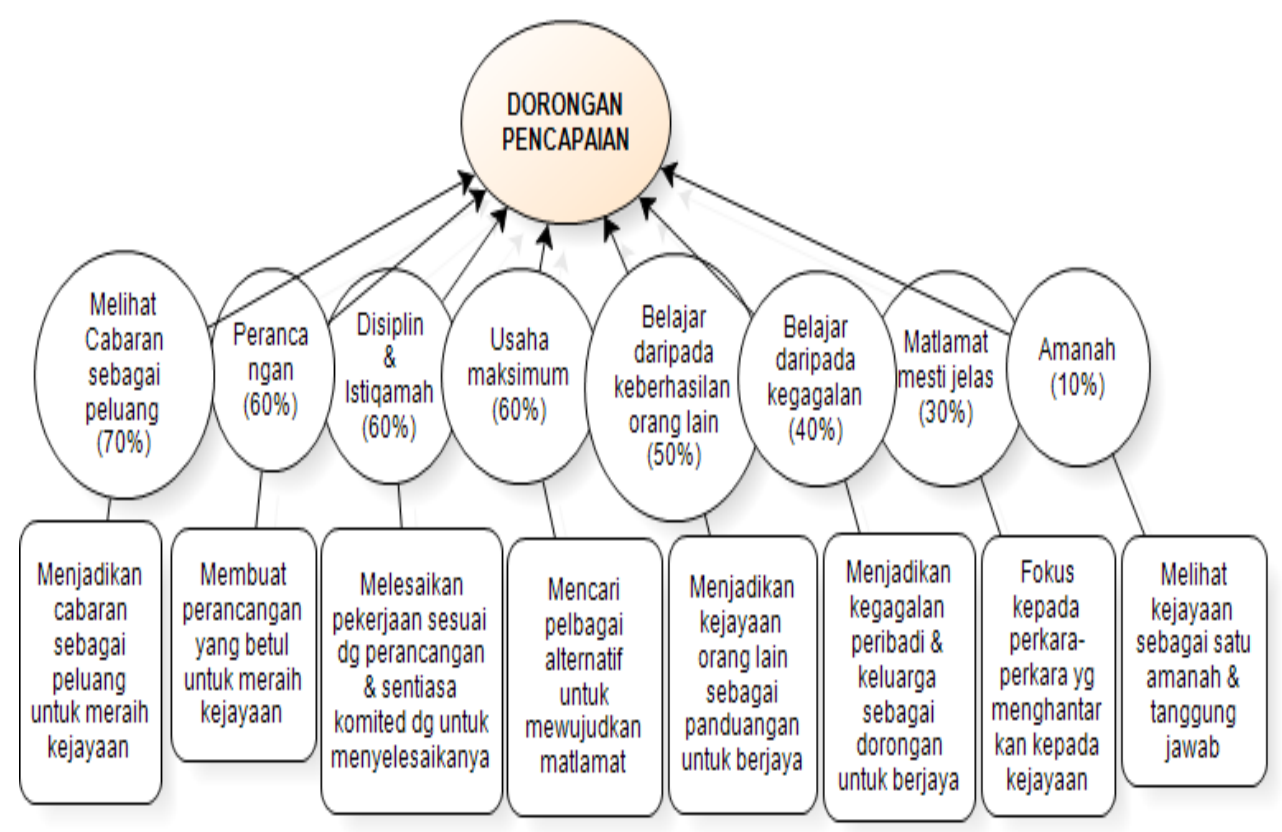

Rajah 4.10 Pengalaman subjek dalam pembinaan dorongan pencapaian

Dapatan di atas menunjukkan enam daripada lapan komponen tersebut, iaitu melihat cabaran sebagai peluang, perancangan, disiplin dan istiqamah, usaha maksimum, belajar daripada keberhasilan orang lain, dan belajar daripada kegagalan merupakan komponen penting dan sentiasa menjadi perhatian bagi subjek dalam membangkitkan semangat mereka agar sentiasa terdorong untuk mewujudkan kejayaan. Walaupun peratusan dalam komponen matlamat mesti jelas (30\%) dan amanah (10\%) nampak agak kecil, namun subjek masih melihat kepentingan keduadua komponen tersebut membantu mereka dalam mewujudkan kejayaan. Dengan perkataan lain dorongan mereka untuk mewujudkan sesuatu matlamat menjadi lebih mantap apabila mengambil kira kelapan-lapan komponen berkenaan.

Apabila bila diperhatikan pada Matrix Intersection terhadap perkongsian subjek dalam kelapan-lapan komponen tersebut (rujuk Jadual 4.11), didapati secara keseluruhannya dikongsikan melalui temubual secara berkumpulan dan juga temubual secara individu. Bagaimanapun, dapatan kajian menunjukkan perkongsian subjek melalui temubual individu didapati juga lebih banyak berbanding dengan temubual secara berkumpulan. 
4.11 Matrix intersection dorongan pencapaian

\begin{tabular}{lcc}
\hline Matrix Nodes & F. Group & Individu \\
\hline Melihat Cabaran Sebagai Peluang & 2 & 5 \\
Perancangan & 1 & 5 \\
Disiplin \& Istiqamah & 1 & 5 \\
Usaha Maksimum & 0 & 6 \\
Belajar Daripada Keberhasilan Orang Lain & 2 & 3 \\
Belajar Daripada Kegagalan & 1 & 3 \\
Matlamat Mesti Jelas & 0 & 3 \\
Amanah & 0 & 1 \\
\hline
\end{tabular}

Perkongsian subjek tentang kelapan-lapan komponen berkenaan, secara lebih terperinci dapat dilihat pada petikan-petikan temubual di bawah ini. Pertama adalah pembinaan dorongan pencapaian dengan cara "melihat cabaran sebagai peluang". Seperti yang dikongsikan oleh salah seorang peserta temubual berkumpulan FG1 menyatakan bahawa dirinya lebih terdorong untuk mencipta kejayaan kerana pelbagai pengalaman pahit yang pernah dialami sebelumnya. Perkara sama juga dikongsi oleh TBI3 yang menyatakan bahawa dirinya sentiasa melihat secara positif pelbagai cabaran dan tamparan yang dihadapi dalam mewujudkan sesuatu yang diyakini memberikan manfaat kepada orang lain. Bagi TBI3 dirinya mempunyai satu falsafah iaitu melakukan sesuatu bukan kerana orang bercakap baik, tetapi dia melakukan kerana dirinya yakin bahawa pekerjaan itu memberi manfaat kepada orang lain. Perkongsian subjek tersebut seperti pada petikan di bawah ini:

FG1 : Sebelum itu saya pergi ke SK yang teruk yang tidak ada apa-apa, pegawai tidak ada, kerani tidak ada. Jadi sayalah yang jadi kerani, PK koko, PKHEM, PK 1 dan guru besar. Jadi kerja saya betul-betul mentadbir sekolah termasuk gaji guru-guru. Jadi alhamdulillah sekolah tersebut boleh berubah dan mendapat sekolah yang berjaya.

TBI3 : Ok saya normaly bila saya buat saya tidak memikirkan sangatlah cemohan, to me ini adalah satu idea, bagi saya idea itu adalah satu amanah, sesuatu yang boleh saya sebar kepada orang lain. So, kalau orang kata ini tidak ada bendalah kan, saya cuba ambik yang positiflah. Ataupun kalau dia komen teruk... ok tak apa. Prinsip hidup saya jangan hidup buat sesuatu kerana orang cakap baik... kalau orang bagi pandangan saya terima, kalau pandangan itu boleh bantu saya ambil kira. Kalau pandangan itu sekadar untuk mengkritik dan sebagainya, dia tidak akan melemahkan semangat saya... 
Seterusnya TBI4 juga menyatakan bahawa kejayaan dirinya pada hari ini, adalah merupakan sumbangan daripada rasa sakit yang beliau lalui semasa beliau belajar dulu. Pandangan tersebut dikukuhkan lagi oleh TBI6 yang menyatakan bahawa beliau tidak mahu lari daripada kesusahan, beliau akan cuba menggandakan usaha semaksimum yang yang boleh dan akhirnya diserahkan kepada yang maha kuasa, seperti petikan di bawah ini:

TBI4 : ... Masa buat master di UKM saya buat by research, lepas itu pensyarah itu pula terlalu stric, dia bagi saya scop tujuh bulan saya dah habis, tambahnya lagi scop, setahun saya habis, tambah lagi scop (tiga kali tambah), jadi dua tahun saya baru boleh habiskan. Tapi walaupun saya rasa sakit pada waktu itu, dia tambah-tambah scop kan, tapi selepas daripada itu saya boleh tulis buku. Dan saya dapat compute self of modeling technical lah. ... Walaupun mula-mula saya merasa saya tertekan tetapi akhirnya saya berjaya dan dapat melihat keseluruhan modelling...

TBI6 : ...yang susah tu saya akan cuba, saya tidak melarikan diri dari kesusahan, saya akan cuba. Bahasa Ingris saya ikuti, orang mungkin baca sekali, saya akan baca tiga kali. Maknannya kita tahu kelemahan kita dan kita gandakan usaha. Dan saya yakin usaha itupun tidak akan berhasil juga kalau tanpa izin Allah juga, so, alhamdulillah berkat kegigihan saya dan dengan keizinan Allah saya berjaya juga dapat $\mathrm{PhD}$.

Pembinaan dorongan pencapaian menggunakan aspek "perancangan" pula didapati pelbagai perkongsian yang dinyatakan oleh subjek kajian. Perkongsian mereka dinyatakan dalam beberapa istilah seperti "sentiasa membuat perancangan, planing" terdapat juga yang menggunakan istilah lain namun memberikan maksud yang hampir sama "membuat persediaan, dan ada target". Seperti dinyatakan oleh TBI1 bahawa dirinya sentiasa "membuat perancangan" apabila ingin memulakan sesuatu pekerjaan. Perancangan yang dibuat memberikan motivasi tersendiri kepada dirinya dalam mewujudkan kejayaan.

Perkara yang sama juga dikongsi oleh subjek TBI5 yang menyatakan bahawa dirinya sentiasa melengkapkan diri dengan pelbagai persediaan terlebih dahulu sebelum memulakan sesuatu pekerjaan yang ingin dilakukan. Perkongsian tersebut dikukuhkan lagi oleh TBI8 yang menyatakan bahawa untuk memotivasikan dirinya menyelesaikan sesuatu tugasan, dirinya sentiasa membuat perancangan masa dan menentukan target tertentu bila sepatutnya tugasan tersebut mesti dihabiskan. 
Perkongsian subjek-subjek tersebut seperti dinyatakan pada petikan temubual berikut ini:

TBI1 : Saya ingat pertama sekali perancangan, planning mesti ada. Dalam planning kita ada matlamat untuk dicapai dan sela masa yang kita perlukan, jangka masa kita boleh mencapai matlamat tersebut, itu saya ingat penting dalam mewujudkan kejayaan. Keduanya, dari segi kesungguhanlah nak mencapai itu. Tidak boleh sambil lewa. Mesti istiqamah dalam mengerjakannya...

TBI5 : ... Jadi kita buat persediaan, persediaan kalau ada kemungkinan..., antaranya ambik klas TOFEL, saya buat persendirian. Jadi sahaja ambil kursus-kursus itu untuk melengkapkan diri supaya kalau boleh nanti dapatlah masuk ke UKM balik...

TBI8 : ... saya rasa time management, yang kedua saya memang ada target. Saya ada target, katakanlah kalau PhD target saya dua tahun sahaja, kalau master tu, sebab buat fully research kan, saya target satu tahun, saya hanya lambat sebab pemeriksaan, external examiner lambat...

Membina dorongan pencapaian dengan kaedah "disiplin dan istiqamah" pula TBI4 menyatakan bahawa untuk menjadi seorang yang berjaya usaha mestilah melebihi kebiasaan yang orang lain, dan tidak banyak membuang masa. Keadaan sebegini telah mendorong dirinya untuk sentiasa hidup berdisiplin dan melaksanakan pekerjaan sesuai dengan matlamat yang telah ditetapkan. Pandangan tersebut dikukuhkan lagi oleh TBI5 yang menyatakan dirinya merasa resah sekiranya tidak dapat melaksanakan pekerjaan sesuai dengan kerangka masa kerja yang telah ditetapkan, seperti ditunjukkan pada petikan di bawah ini:

TBI4 : Dari segi disiplin, mungkin saya lebih daripada everage oranglah, saya tak banyak buang masa. Macam di rumah tu TV pun saya tidak tengok sangat... sembang-sembang saya memang kurang.

TBI5 : ... saya seorang yang sangat berdisiplin... resah kalau time frame pukul 8.00 am hingga pukul 10.00 malam tidak mengulang kaji. Bila ke universiti saya kekal macam tu, malah saya tambah 8.00 am hingga 12.00 malam. Saya resah kalau duduk di kedai kopi ke, jalan ke...mesti nak duduk di tempat study...

Subjek kajian juga menyatakan tentang pembinaan dorongan pencapaian dengan cara "berusaha maksimum" iaitu mencari pelbagai alternatif untuk mewujudkan sesuatu matlamat. Seperti dinyatakan oleh TBI1 dirinya sentiasa 
membina hubungan dengan orang-orang yang dilihatnya boleh membantu mewujudkan impian dirinya. Pandangan tersebut dimantapkan lagi oleh TBI 3 yang menyatakan untuk menjadi terbaik perlu diusahakan secara maksimum dan bukannya sambil lewa, seperti akan dinyatakan di dalam petikan berikut ini:

TBI1 : ... saya sendiri yang membuat jalinan net work dengan penyelidik terkemuka di luar negara. Dengan menghadiri seminar saya aproach mereka sendiri memberi kad dan sebagainya. Dari situ saya nampak keinginan saya untuk setanding dengan mereka menyebabkan saya tidak malu-malulah untuk ke depan walaupun rasa masih kerdil...

TBI3 : ... sesuatu yang baik itu perlu diusahakan... pokok yang baik itu perlu disiram dengan air, letak baja kan. Macam itu juga saya rasa dengan diri manusia ini, untuk menjadi yang terbaik kita perlu berusaha dan kita perlu ada macam saya kata tadilah, kita tidak boleh komplesen

Satu lagi perkara menarik yang dikongsi oleh subjek kajian dalam pembinaan dorongan pencapaian adalah "belajar daripada keberhasilan orang lain". Untuk menjadi seorang yang berjaya terkadang didorong oleh kejayaan yang diperolehi orang lain. Seperti dinyatakan oleh salah seorang subjek dalam FG2, dirinya banyak belajar daripada pembacaan sejarah tokoh-tokoh yang berjaya. Keadaan sedemikian telah mendorong dirinya untuk menerokai secara lebih mendalam tentang perkara-perkara yang menyumbang kepada kejayaan tokoh-tokoh yang dibaca. Perkara sedemikian juga dirasakan oleh TBI1 yang menyatakan bahawa dirinya menjadi terangsang apabila melihat orang-orang yang serius dalam melaksanakan pekerjaannya. Perkongsian pengalaman mereka seperti ditunjukkan pada petikan di bawah ini:

FG2 : ... Di samping itu juga melalui pengalaman-pengalaman dan pembacaan tokoh-tokoh yang telah berjaya. Berkongsi pengalaman dengan orang-orang yang telah melalui pengalaman tersebut. Jadi belajar daripada kejayaan yang telah diperolehi oleh orang lain.

TBI1 : ... Misalnya saya pergi attachment di US baru-baru ini, saya perhatikan mereka sangat serius dalam bekerja. Perkara ini merangsang saya. Sebab kalau nak jadi pakar tidak boleh main-main. Ini menjadikan saya bersemangat... jadi saya terpengaruh untuk menjadi komited, echievement oriented, maknanya terdorong untuk membuat yang terbaiklah.

Perkongsian yang lebih kurang sama juga dinyatakan oleh TBI2 dan TBI4, iaitu dirinya merasa terdorong apabila melihat kawan-kawan yang sama telah berjaya 
berbanding dirinya. Mereka juga menyatakan bahawa dirinya banyak belajar daripada orang-orang yang dekat dengannya, seperti ditunjukkan dalam peritikan berikut ini:

TBI2 : ... Kesedaran itu timbul apabila kita melihat kawan-kawan kita yang sama dengan kita ini dia orang ini sudah tak ada disekolah..., mose of them ambik di PPIPM,...di situ kita macam rasa tercicir, jadi daripada situlah kita itu balik...menimbulkan kesedaran...

TBI4 : ...Saya ingat mungkin semangat itu daripada datuk-datuk sayalah. Mungkinlah tanpa saya sedari semasa saya kecil lagi, ... Macam atuk saya tu kebun dia banyak, kebun dia luas. Masa itu saya selalu ikut dia ke kebun, dia arahkan orang bekerja, semua nampak kan... Macamana dia handle dia punya pekerja, staf dia kan, kedai-kedai dia semua...

Subjek kajian juga menyatakan tentang pembinaan dorongan pencapaian melaui "belajar daripada kegagalan". Salah seorang subjek dalam FG1, TBI1 menyatakan bahawa mereka banyak belajar daripada kesilapan yang pernah dilakukan, kesilapan tersebut telah mendorong dirinya untuk menjadi seorang yang lebih baik. TBI1 juga menyatakan bahawa dirinya banyak didorong oleh latar belakang kehidupan keluarga yang susah, kesusahan tersebut telah menjadi pembakar semangat kepada dirinya untuk menjadi cemerlang sehingga keadaan tersebut tidak berulang. TBI2 mengukuhkan lagi perkongsian subjek tersebut yang menyatakan bahawa kesedaran untuk merebut kejayaan telah timbul apabila dirinya teringat dengan kegagalan yang pernah dilakukan. Petikan perkongsian pengalaman mereka seperti ditunjukkan di bawah ini:

FG1 : ...saya belajar melalui kesilapan yang saya lakukan. Jadi ketahanan jiwa memang adalah dari segi emosi. Di samping itu juga saya banyak aktif di dalam aktiviti sosial.

TBI1 : ... untuk self motivation ini mungkin lebih kepada factor silam kehidupan keluarga yang susah mungkin membantu saya untuk terus membuatkan bersikap ingin cemerlang. Tak mahu kesusahan keluarga berulang untuk keluarga yang saya ada sekarang ini. So itu menjadi faktor pendorong...

TBI2 : ... saya nampak kesedaran itu datang daripada kegagalanlah, ... Jadi kegagalan itu menjadi pengajaran yang betul-betul bermakna... saya rasa kegagalanlan, sebab kalau kita compare keluarga kita dengan keluarga orang satu kan, ...lepas itu kita compare kita ini dengan orang lain, kita gagalkan, dari segi harta ke, dari segi semualah... 
Perkara yang tidak kalah pentingnya dikongsikan oleh subjek dalam membina dorongan pencapaian kepada diri mereka adalah "matlamat mesti jelas". TBI3 menyatakan dalam kehidupan jangan melihat apa yang berlaku hari ini tetapi mesti mempunyai visi yang jelas ke hadapan. Pandangan tersebut dikukuhkan oleh TBI8 yang menyatakan dirinya sentiasa meletakkan target lebih awal sebelum memulakan sesuatu. Beliau telah melatakan satu piawai dalam kehidupanya supaya tidak menurun dari segi grafik kecemerlangan. Sekiranya tidak dapat meningkat prestasi, paling tidak dapat mempertahankan apa yang telah diperolehi. Perkongsian subjek tersebut seperti dinyatakan di bawah ini:

TBI3 : ... dalam hidup ini kita kena ada visionlah jangan hidup ini sekadar apa yang berlaku hari ini. Maksudnya the day to day. Jadi dalam hidup ini kita kena ada satu target, apa yang kita nak capai dalam kehidupan yang singkat ini. So bila kita ada target kita akan lebih terfokus, dan untuk nak capai target kita itu kita boleh fikirkan cara ataupun proses untuk itu.

TBI8 : Saya ada target awal lagi lah, katakanlah dari segi prestasi kerja, saya nak saya kekal, kalau saya boleh dapat 94 tahun ini, tahun depan saya nak lebih dari 94. ... supaya dia tidak menurun saya akan pastikanlah, apa kerja yang saya dah buat, apa kerja yang saya belum buat. Kalau ada kerja-kerja yang belum buat saya pasti akan siapkan.

Terakhir sekali yang dikongsikan oleh subjek kajian dalam pembinaan dorongan pencapaian adalah dengan cara hidup memegang prinsip “Amanah". Seperti yang dikongsikan oleh TBI3, dalam melakukan sesuatu pekerjaan dirinya telah didorong oleh prinsip "amanah" yang menjadi pegangan dirinya. Beliau melihat pekerjaan yang dilakukan adalah satu amanah yang akan dipertanggungjawabkan. Bagi dirinya bekerja bukannya untuk mencari kemasyhuran tetapi dia melakukan pekerjaan supaya memberikan manfaat kepada orang lain, seperti dinyatakan di bawah ini:

TBI3 : ...yang mendorong saya untuk menyatakan bahawa kita buat bukan supaya kita nak dipuji orang, sebab pada saya idea ini satu amanah, jadi kalau kita simpan rugilah. Tapi kalau idea ini boleh kita manivestasikan, sebarkan, kalau orang tidak dapat manfaatpun sekurang-kurangnya kita dapat manfaatkan kerana kita berjaya merealisasikan idea kita. 
TBI3 : Saya rasa bukan untuk mencari kemashuran tapi kalau kita buat sesuatu yang orang lain boleh manfaatkan,... Jadi sekarang ini benda yang saya buat ini tak ada masalahlah, sebab bila on the net semua orang boleh baca kan. Bila pihak surat kabar dah tahu, jadi sekali-sekali dia orang hubungi sayalah. Sebab saya rasa itu cara yang paling cepat berkembang.

\subsubsection{Pembinaan Memahami Orang Lain}

Rajah 4.11 memaparkan tentang amalan subjek dalam memahami orang lain, iaitu sub domain pertama dalam empati.

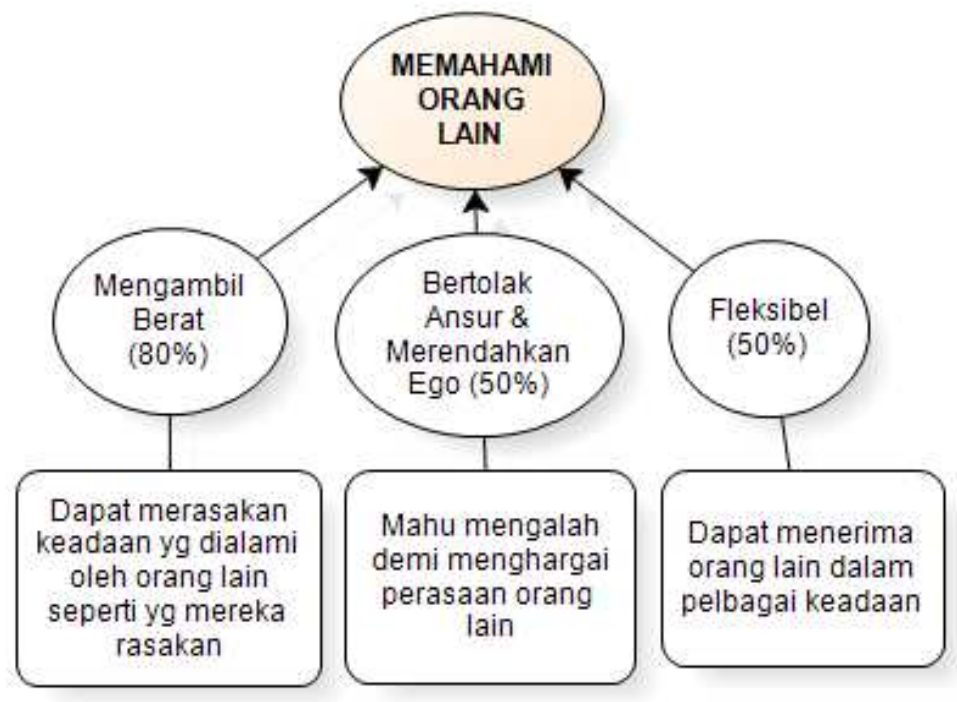

Rajah 4.11 Pengalaman subjek dalam memahami orang lain

Dapatan tersebut menunjukkan terdapat tiga komponen penting yang dikongsikan oleh subjek agar mereka sentiasa dapat memahami orang lain. Ketiga-tiga komponen tersebut adalah; (i) mengambil berat, (ii) bertolak ansur dan merendahkan ego dan (iii) fleksibel. Mengambil berat merujuk kepada kemampuan individu untuk merasakan keadaan yang dirasakan oleh orang lain seperti apa yang mereka rasakan. Sedangkan bertolak ansur dan merendahkan ego pula merujuk kepada kebolehan individu untuk mengalah demi menghargai perasaan orang lain. Manakala fleksibel pula merujuk kepada kesanggupan untuk menerima orang lain dalam pelbagai keadaan. Bila dilihat kepada kekerapan dan peratusan subjek menyatakan pengalaman mereka tentang komponen tersebut didapati peratusan tertinggi adalah pada komponen mengambil berat (80\%), dikiuti oleh bertolak ansur dan merendahkan ego (50\%) dan 
fleksibel (50\%). Dapatan ini menunjukkan ketiga-tiga komponen tersebut merupakan komponen penting dan sentiasa menjadi amalan subjek dalam memahami orang lain.

Apabila bila diperhatikan pada Matrix Intersection terhadap perkongsian subjek dalam ketiga-tiga komponen berkenaan (rujuk Jadual 4.12), didapati secara keseluruhan dikongsikan melalui kedua kaedah temubual yang dikalukan, iaitu temubual secara berkumpulan dan juga temubual secara individu. Bagaimanapun, perkongsian subjek melalui temubual individu didapati lebih banyak berbanding dengan temubual secara berkumpulan.

Jadual 4.12 Matrix intersection memahami orang lain

\begin{tabular}{lcc}
\hline Matrix Nodes & F.Group & Individu \\
\hline Mengambil Berat & 2 & 6 \\
Bertolak ansur \& Meredahkan Ego & 2 & 3 \\
Fleksibel & 2 & 3 \\
\hline
\end{tabular}

Perkongsian subjek tentang ketiga-tiga komponen tersebut, secara lebih terperinci dapat dilihat pada petikan-petikan hasil temubual di bawah ini. Pertama adalah memahami orang lain dengan cara "menambil berat" tentang orang tersebut. Pernyataan subjek tentang mengambil berat disampaikan dalam dalam pelbagai pernyataan, seperti "perihatin, mendahulukan orang dan carring". Seperti dikongsikan oleh salah seorang subjek dalam FG2 yang menyatakan sebagai seorang ketua beliau selalu memastikan orang-orang di bawahnya untuk memperhatikan pelajar-pelajar yang berada di sekolah, ini menunjukkan bahawa sebagai seorang guru mestilah mengambil berat tentang pelajar.

TBI4 pula menyatakan beliau cuba memahami orang lain dengan cara mendahulukan kepentingan orang tersebut. Bagi beliau menjadi seorang ketua tidak ubahnya menjadi seorang ayah yang sentiasa mendahulukan kepentingan orang-orang di bawah jagaannya, seperti dinyatakan pada petikan di bawah ini:

FG2 : ...saya mintak kepada guru-guru agar diperhatikan ada tak pelajar-pelajar yang tidak makan pagi, yang miskin tidak makan pagi. Ada tak kita tengok kanak-kanak yang datang dengan pakaian yang tidak rapi, comok... Ada 
cikgu saya yang kejar budak dalam hutan untuk bawa anak itu datang ke sekolah. Maknanya beginilah kita mendidik. Kita memanusiakan manusia kena perihatin.

TBI4 : ... saya akan dulukan orang dulu, saya rasa kita ketua ni macam bapa kan, kalau kita makan dulu anak kita kelaparan... Macam ketika saya jadi ketua jabatan dulu ada banyak reserch groups, sesetengah tu reserch grant tak ada... Jadi kalau mintak duit banyak dan pada mesyuarat tu boleh agre kan, oklah, saya tidak dapatpun tak apalah...

Pandangan yang lebih kurang sama dinyatakan oleh TBI8, iaitu dirinya akan mendahulukan kepentingan orang lain terlebih dahulu sekiranya menurut pandanganya orang tersebut lebih memerlukan terlebih dahulu daripada dirinya di saat itu. Pandangan tersebut dikukuhkan oleh TBI7 yang menyatakan istilah mengambil berat dengan istilah carring. TBI7 mencontohkan dalam dunia pendidikan, menurut beliau untuk menjadi seorang pendidik mesti mampu menjadi seorang ayah ataupun ibu kepada pelajar-pelajar, seperti dinyatakan pada petikan berikut ini:

TBI8 : ...contoh adik saya telepon minta bantuan kewangan kerana dia amergency perlukan duit lebih dan dia minta pinjam sekejap. Jadi saya rasa pada masa itu walaupun saya ada keperluan pribadi saya tapi saya memikirkan keperluan dia amat genting, jadi saya akan berikan duit saya pada dia waktu itu...

TBI7 : ...sebelum kita menjadi guru kita mesti menjadi ayah kepada murid kita. Maknanya kita tak boleh jadi guru melainkan you ada sifat seorang ayah, kalau perempuan seorang ibu baru you boleh jadi guru ... bila kita ada dua sifat itu dia akan timbul dua sifat yang mengandungi nilai moralah iaitu "carring dengan adil". ...Jadi saya nampak di situlah, kalau you tak ada sifat keibubapaan you tak akan jadi carring.

Kaedah berikutnya yang dikonsikan oleh subjek dalam memahami orang lain adalah dengan cara "bertolak ansur dan merendahkan ego". Salah seorang subjek dalam FG2 menyatakan dirinya lebih mudah mengalah apabila berhadapan dengan orang lain, dalam konteks sebagai seorang pentadbir beliau mencontohkan perhubungan beliau dengan guru-guru di bawah jagaan beliau. Perkongsian tersebut dikukuhkan lagi oleh TBI1 yang menyatakan untuk memahami orang lain adalah dengan cara "lebih sensitive" dengan perasaan orang tersebut. Bagi beliau keadaan sedemikian dapat lebih menyuburkan lagi rasa empati terhadap orang lain. Petikan perkongsian subjek berkenaan seperti ditunjukkan di bawah ini: 
FG2 : Saya sendiri saya sebenarnya lebih mudah mengalah... kalau ada diantara cikgu-cikgu menceritakan kelemahan saya, saya kata tak apa, saya terbuka. Saya pernah buat soal selidik untuk diri saya... jadi saya mengakui di mana kelemahan saya...

TBI1 : ...kesediaan untuk memahami perasaan orang lain, sensitif dengan perasaan orang lain. Saya ingat itu perlu bersamanya dengan kerendahan ego. Kalau kita ada ego yang tinggi, kita tak mahu memamahami perasaan orang lain. ...merendah ego kita dan bersifat ingin memberikan kebaikan kepada orang lain, jadi itu akan membantu menyuburkan empati.

Satu perkara lagi yang dikongsi oleh subjek dalam memahami orang lain adalah melalui kaedah "fleksibel" iaitu dapat menerima orang lain dalam pelbagai keadaan. Seperti dinyatakan subjek dalam FG2 bahawa sebagai seorang pentadbir dirinya tidak terlalu banyak protokol. Dalam konteks ini beliau mencontohkan dirinya sebagai seorang pentadbir yang sentiasa bermesra dengan kakitangannya dalam pelbagai kedaan. TBI8 pula cuba mencontohkan dalam kehidupan berkeluarga, seperti dinyatakan pada petikan temubual berikut ini:

FG2 : Saya sebenarnya protokol saya kurang, saya banyak berada di ruangan guru, di kantin dan di mana-mana saya akan berbual. Saya tidak ada masalah makan bersama-sama dengan guru-guru, duduk di bilik guru. Ini memudahkan saya untuk berinteraksi dan menyelesaikan masalah dengan guru-guru saya...

TBI8 : ... contohnya anak-anak saya dia perlukan masa untuk makan bersama-sama dengan saya, sedangkan pada masa yang sama saya nak segera pergi ke tempat lain seperti office contohnya. Jadi waktu itu saya akan bagi tahu pada dia, sekian-sekian waktu saya kena berada di sana. Jadi makan nanti mungkin saya tak sempat bersama, kalau sempat mungkin saya akan makan bersama, so macama mana? Dia kata ok... ok. Tapi kalau dia kata tak saya akan duduk juga makan dengan dia sikit lepas itu saya akan cakap dengan dia, saya terpaksa minta diri dulu kerana ada program penting yang mesti dilaksanakan. Itu saya lakukan dengan anak sebab masa mereka dengan saya terlalu singkat.

\subsubsection{Mengembangkan Potensi Orang Lain}

Rajah 4.12 memaparkan tentang pengalaman subjek dalam mengembangkan potensi orang lain, iaitu sub domain kelima dalam domain empati. Mengembangkan potensi orang lain merujuk kepada bagaimana seseorang itu melihat potensi dan kekuatan yang 
ada pada diri seseorang untuk diserlahkan sehingga boleh membawa mereka kepada kejayaan.

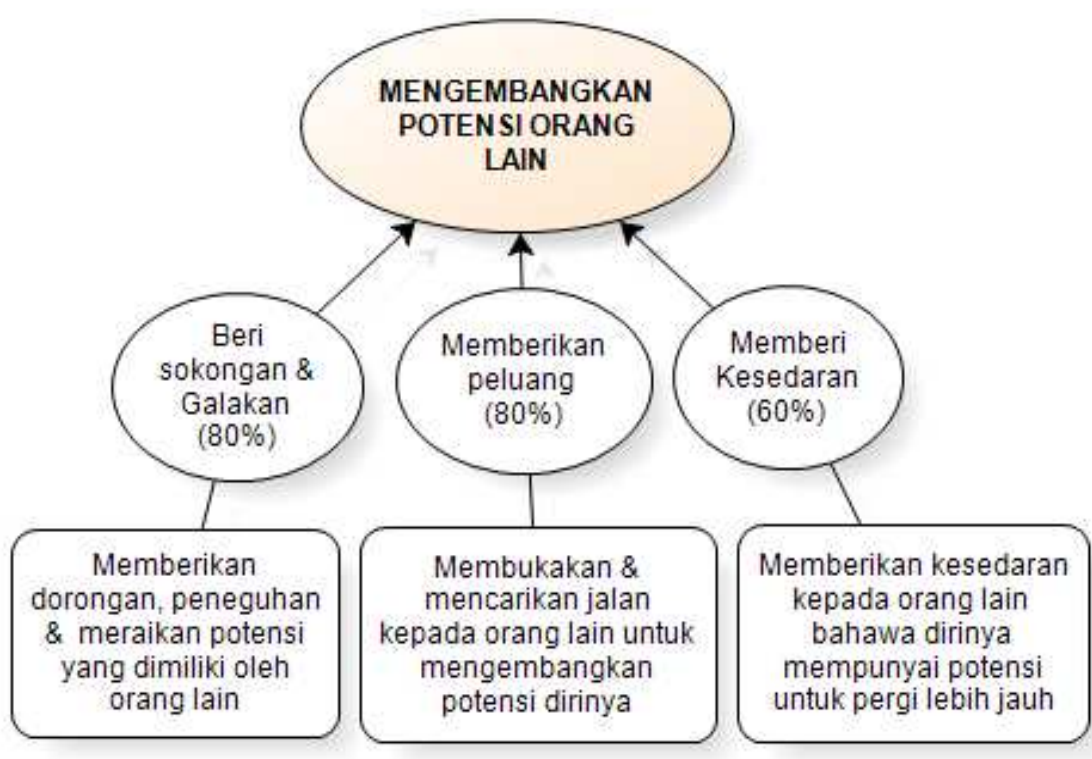

Rajah 4.12 Pengalaman subjek dalam mengembangkan potensi orang lain

Dapatan kajian yang dipaparkan pada Rajah 4.12 di atas juga menunjukkan terdapat tiga komponen penting yang dikongsikan oleh subjek dalam mengembangkan potensi orang lain. Ketiga-tiga komponen tersebut adalah; (i) beri sokongan dan galakan, (ii) memberikan peluang, dan (iii) memberikan kesedaran. Memberi sokongan merujuk kepada kemampuan individu untuk memberikan dorongan, peneguhan dan meraikan potensi yang dimiliki oleh seseorang. Sedangkan memberi peluang pula merujuk kepada kemampuan individu untuk mencarikan peluang ataupun jalan kepada orang lain bagi mengembangkan potensi yang ada pada dirinya. Manakala memberi kesedaran pula merujuk kepada kemampuan seseorang dalam memberikan kesedaran kepada orang lain untuk menyatakan bahawa orang tersebut mempunyai potensi untuk pergi lebih jauh daripada apa yang didapatkan sekarang ini.

Bila dilihat kepada kekerapan dan peratusan subjek menyatakan pengalaman mereka tentang ketiga-tiga komponen tersebut, didapati peratusan tertinggi adalah pada komponen beri sokongan dan galakan (80\%), memberikan peluang (80\%) dan memberikan kesedaran (60\%). Dapatan ini menunjukkan ketiga-tiga komponen 
tersebut merupakan komponen penting dan sentiasa menjadi amalan subjek dalam mengembangkan potensi orang lain.

Apabila dirujuk pada Matrix Intersection terhadap perkongsian subjek dalam ketiga-tiga komponen tersebut (rujuk Jadual 4.13), didapati ketiga-tiganya dikongsikan melalui kedua kaedah temubual yang dilakukan, iaitu temubual berkumpulan dan temubual individu. Bagaimanapun, perkongsian subjek melalui temubual individu didapati lebih banyak berbanding dengan temubual berkumpulan.

Jadual 4.13 Matrix intersection mengembangkan potensi orang lain

\begin{tabular}{lcc}
\hline Matrix Nodes & F.Group & Indivdu \\
\hline Beri Sokongan \& Galakan & 2 & 6 \\
Memberikan Peluang & 2 & 6 \\
Memberi Kesedaran & 2 & 4 \\
\hline
\end{tabular}

Perkongsian subjek tentang ketiga-tiga komponen berkenaan, secara lebih terperinci dapat dilihat pada petikan hasil temubual berikut ini. Pertama adalah mengembangkan potensi orang lain dengan cara "memberi sokongan dan galakan". Seperti dikongsikan oleh peserta temubual dalam FG2 yang menyatakan pengalaman beliau sebagai pentadbir di sekolah. Sebagai seorang pentadbir beliau sentiasa memperhatikan individu-individu yang mempunyai potensi untuk dikembangkan. Tidak cukup hanya dengan memperhatikan, beliau juga sentiasa memberikan galakan kepada individu tersebut supaya dapat melakukan yang terbaik, agar dirinya lebih berjaya daripada sekarang ini. Pengalaman yang sama juga dinyatakan oleh TBI1 dan TBI7 yang sentiasa cuba membantu rakan-rakan sekerja dengan cara berbagi pengalaman yang dimiliki kepada rakan-rakan tersebut. Bagi TBI1 kejayaan adalah untuk semua dan tidak yang dirahasiakan, sekiranya dirinya mempunyai sesuatu kelebihan yang boleh dikongsikan dengan orang lain beliau akan melakukan perkara tersebut dengan rakan-rakan secara terbuka. TBI7 pula menyatakan untuk membantu orang lain, terkadang beliau terpaksa push sehingga orang tersebut dapat melihat kekuatan yang dimiliki dalam dirinya. Bagi beliau perkara sebegini sangat penting, kerana bila seseorang dah nampak potensi dirinya senang untuk bergerak ke hadapan. Perkongsian kedua-dua subjek tersebut seperti dinyatakan pada petikan di bawah ini: 
FG2 : Beri sokongan dan galakan, di sekolah saya ada beberapa orang... saya kata dengan mereka cikgu tunjukan yang terbaik, saya tahu bahawa cikgu ada potensi. Buatlah yang terbaik, dan saya memang sentiasa war-warkan bila ada cikgu-cikgu saya yang mempunyai potensi.

TBI1 : ...Misalnya rakan sekerja yang minat dalam satu-satu bidang, saya cuba membantu dari segi pengalaman yang adalah. Misalnya saya bagi ceramah kepada pensyarah-pensyarah baru, bagaimana boleh menjadi seorang akademik? Tanpa menyimpan sebarang rahasia saya kongsi bersama. Saya nak mereka boleh berjaya dalam bidang masing-masing. Saya ingat soal dengki ini patut dihapuskan.

TBI7 ... Kadang sampai kita push dia, dia tidak nampak lagi, bila dah nampak tu... alhamdulillah. Biasanya kumpulan yang macam ini saya akan jumpa secara personal....

Satu cara lagi yang dilakukan oleh subjek untuk mengembangkan potensi orang lain adalah dengan cara "memberikan peluang" kepada orang tersebut. Memberikan peluang kepada orang lain dinyatakan dalam pelbagai keadaan, seperti "memberikan projek untuk dijalankan, memberikan kerja lebih, mengajak bekerja bersama-sama dan senang melihat orang lain berjaya". Seperti dikongsi oleh subjek dalam FG1 dan TBI4. Seorang subjek dalam FG1 menceritakan penglamannua bahawa dia cuba mengembangkan potensi orang-orang di bawah jagaannya dengan cara memberikan satu-satu projek untuk dijayakan. TBI 4 pula menyatakan bahawa untuk mengembangkan potensi orang lain kebiasaanya beliau memberikan pekerjaan lebih ataupun memberikan pekerjaan yang lebih mencabar kepada orang tersebut, seperti dinyatakan pada perkongsian berikut ini:

FG1 : ... saya masing-masing guru saya bagi menjalankan satu projek, jadi dia akan mengendalikan masing-masing projeklah. Agar projek dia diikuti oleh orang lain, maka dia perlu mengikuti projek-projek yang dianjurkan oleh guru yang lain...

TBI4 : ...biasanya kalau dalam bidang saya, saya akan cuba bagi dia lebih banyak kerja. Kalau bukan bidang saya ... biasanya saya akan bagi dia tugas yang lebih mencabarlah yang boleh menonjolkan bakat dia. ...tapi yang lemahlemah inipun kena tolong juga, bagi dia peluang jugalah dan mereka kena beri perhatian lebih juga...

Pengalaman yang lebih kurang sama juga dikongsikan oleh TBI6 dan TBI8 yang menyatakan cara memberikan peluang kepada orang lain untuk mengembangkan dirinya adalah dengan cara melibatkan individu tersebut bekerja secara bersama-sama 
dengan dirinya. TBI8 cuba mencontohkan dirinya sebagai seorang ahli akademik, perkongsian dilakukan dalam bentuk melakukan penyelidikan bersama, membuat kertas kerja bersama dan menulis jurnal bersama seperti dinyatakan pada petikan di bawah ini:

TBI6 : Dan satu cara lagi ialah dengan cara terlibat bersama dalam research, ...sentiasa menanya hal, mintak maklum balas, beri perhatian. Itu saya lakukan pada semua orang, tidak memilihlah. Kadang semua sekali saya jumpa ramai-ramai.

TBI8 : Saya akan ajak dia bersama dengan saya, kalau research saya akan ajak dia bersama. Saya tak akan buat research sorang, saya akan ajak dia bersama kalau saya nampak dia ada potensi. ...Saya ajak dia menulis bersama, buat kertas kerjapun saya akan ajak.

Perkara ketiga yang dinyatakan oleh subjek dalam mengembangkan potensi orang lain adalah dengan cara "memberikan kesedaran" kepada orang tersebut. Terkadang tidak semua orang dapat melihat bahawa dirinya mempunyai potensi yang sebenarnya mereka boleh pergi lebih jauh, mereka memerlukan orang lain untuk menyatakan potensi yang dimiliki. Beberapa kaedah dalam memberi kesedaran yang dikongsi oleh subjek adalah "memberi tahu secara langsung, menjadikan diri sebagai contoh, dan berperanan sebagai pembimbing".

Seperti perkongsian yang dinyatakan subjek dalam FG2, untuk memberikan kesedaran kepada orang lain agar mereka dapat mengembangkan diri kepada yang lebih baik, biasanya beliau akan memanggil langsung orang tersebut dan menyatakan kepada orang tersebut bahawa dirinya mempunyai potensi yang besar untuk lebih berjaya. Perkara sama dikongsikan oleh TBI6 yang menyatakan bahawa untuk memberikan kesedaran kepada orang lain kebiasaanya beliau mengingatkan orang tersebut, seperti dinyatakan pada petikan berikut ini:

FG2 : Biasanya saya akan panggil mereka dan saya akan bagi tahu potensi beliau bahawa beliau boleh pergi jauh. ...saya akan memberikan nasihat kepada semua... supaya menjaga prestasi, jaga kejayaan sekolah...

TBI6 : Saya ingatkan mereka, tapi memanglah manusia ini tak sama kan, so memang saya gerakan semua, semua itu adalah di bawah tanggungjawab saya. So saya tidaklah selectively individu tertentu sahaja untuk saya bantu. Tapi saya dalam mensyuaratpun memang sentiasa mengingatkan dan beri perhatian pada semua. 
Satu cara lagi yang kongsi oleh subjek dalam memberikan kesedaran kepada orang lain agar mereka dapat mengembangkan potensi diri sendiri adalah dengan cara menjadikan diri sendiri sebagai contoh. Seperti dinyatakan oleh TBI2 dan TBI5 kadang beliau cuba menjadikan dirinya sebagai contoh kepada orang lain, ataupun memberikan contoh kepada orang-orang yang berjaya di persekitaranya. Keadaan sebegini dapat membuka minda orang lain untuk menyedarkan diri mereka, bahawa dirinya juga mempunyai potensi yang sama untuk berjaya seperti orang-orang berjaya tersebut. TBI5 juga menyatakan bahawa terkadang tidak semua orang dapat melihat potensi yang dimiliki tetapi beliau boleh nampak bahawa orang tersebut mempunyai potensi yang baik untuk berjaya, beliau berusaha untuk menjadi leader kepada orang tersebut, seperti dinyatakan pada petikan di bawah ini:

TBI2 : ...kadang-kadang saya cuba jadikan diri saya sebagai contohlah, ...jadikan diri kita sebagai contoh untuk dia orang melonjak ke depan. Specialy dalam bidang akademik, ... sebab kita contoh yang paling dekat dengan dia orang. ... atau pun orang-orang yang sudah berjaya di lingkungan kita boleh juga dijadikan contoh.

TBI5 : Kadang-kadang dia tidak nampak tapi saya nampak, dia ini sepatutnya menuju ke sini, ...jadi saya lead dia supaya pergi kepada jalan yang lebih baik yang dapat mengantarkan dia kepada kejayaan.

\subsubsection{Pembinaan Cara Mempengaruhi Orang Lain}

Rajah 4.13 memaparkan tentang amalan subjek dalam mempengaruhi orang lain, iaitu sub domain pertama dalam kemahiran sosial. Mempengaruhi orang lain merujuk kepada kemampuan seseorang untuk meyakinkan orang lain agar dapat menerima sesuatu idea yang disampaikan. 


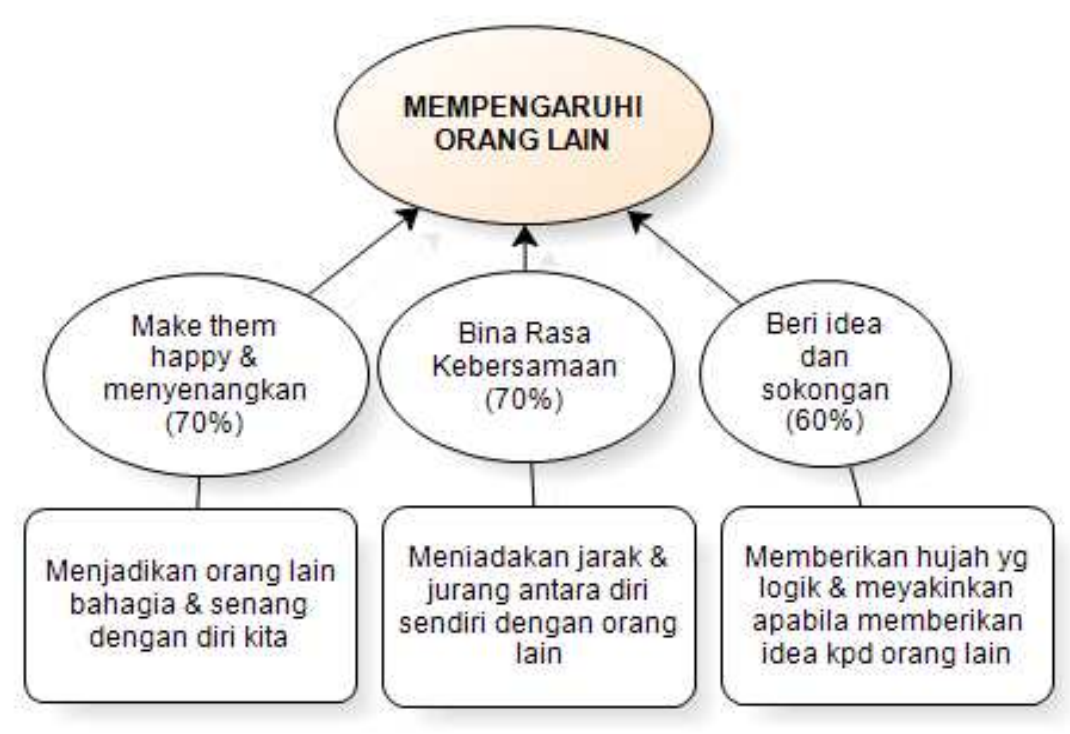

\section{Rajah 4.13 Pengalaman subjek dalam mempengaruhi orang lain}

Dapatan ini menunjukkan terdapat tiga komponen penting yang dikongsikan oleh subjek dalam mempengaruhi orang lain. Ketiga-tiga komponen tersebut adalah; (i) make them happy dan menyenangkan, (ii) membina rasa kebersamaan, dan (iii) berikan idea beserta sokongan. Make them happy dan menyenangkan merujuk kepada kemampuan individu untuk membuat orang lain menjadi bahagia dan senang dengan dirinya. Sedangkan membina rasa kebersamaan merujuk kepada kemampuan individu untuk menunjukkan rasa kebersamaan, dan mampu merapatkan jurang antara diri sendiri dengan orang lain. Manakala memberikan idea beserta sokongan merujuk kepada kemampuan individu dalam memberikan hujah dan logik yang meyakinkan apabila menyampaikan idea kepada orang lain.

Bila dilihat kepada kekerapan dan peratusan subjek menyatakan pengalaman mereka tentang ketiga-tiga komponen tersebut, didapati dua komponen memperolehi peratusan yang sama, iaitu make them happy dan menyenangkan (70\%), membina kebersamaan (70\%). Seterusnya diikuti oleh komponen beri idea dan sokongan (60\%). Dapatan ini juga menunjukkan bahawa ketiga-tiga komponen tersebut adalah merupakan komponen penting dan sentiasa menjadi amalan subjek dalam mempengaruhi orang lain. 
Apabila dirujuk pada Matrix Intersection terhadap perkongsian subjek dalam ketiga-tiga komponen tersebut (rujuk Jadual 4.14), didapati ketiga-tiganya dikongsikan melalui kedua kaedah temubual yang dilakukan, iaitu temubual berkumpulan dan temubual individu. Bagaimanapun, perkongsian subjek melalui temubual individu didapati masih lagi lebih banyak berbanding dengan temubual berkumpulan.

Jadual 4.14 Matrix intersection mempengaruhi orang lain

\begin{tabular}{lcc}
\hline Matrix Nodes & F.Group & Individu \\
\hline Make Them Happy \& Menyenangkan & 2 & 5 \\
Rasa Kebersamaan & 2 & 5 \\
Beri Idea \& Sokongan & 1 & 5 \\
\hline
\end{tabular}

Perkongsian subjek tentang ketiga-tiga komponen tersebut secara lebih terperinci dapat dilihat pada petikan temubual di bawah ini. Pertama adalah mempengaruhi orang lain dengan cara "membuat orang lain gembira dan menyenangkan". Seperti dikongsikan oleh TBI8 dan FG1 yang menyatakan bahawa beliau suka membuat orang lain gembira (make them happy) iaitu dengan cara mendekati orang lain dengan kasih sayang. Prinsip beliau adalah cuba memberikan yang terbaik kepada orang lain dan memberikan pekerjaan sesuai dengan kemampuan orang tersebut, seperti beliau nyatakan pada petikan di bawah ini:

TBI8 : ... saya suka bagi orang gembiralah (make them happy), dekati mereka dengan kasih sayang. Saya berpegang pada satu prinsip "I try my best". Dengan sesiapa sahaja saya buat macam tu,...maknanya saya percaya kita ini bukan hanya ada ikatan fizikal sahaja tetapi juga ada ikatan roh...

FG1 : ... bagi saya, saya selalu meletakkan diri saya di tempat guru itu, tengok berdasarkan kemampuan dia, dan saya cuba meringkaskan pekerjaan yang berikan kepada mereka.

Perkongsian pengalaman di atas dikukuhkan lagi oleh TBI2 dan TBI4. TBI4 menyatakan bahawa belaiu sentiasa mendekatai orang lain selari dengan kemampuan berfikir orang tersebut. Beliau mencontohkan sebagai seorang ahli akademik, sepatutnya cuba menyampaikan sesuatu berdasarkan kefahaman orang yang menjadi audien. TBI4 pula menyatakan pengalaman beliau untuk membuat orang lain gembira 
adalah dengan cara mendahulukan kepentingan orang tersebut, seperti dinyatakan pada petikan di bawah ini:

TBI2 : ... kita aproach orang ni ikut dia punya kemampuan dia berfikirlah ...kena ikut level the their of understanding lah kan. Jadi kalau orang asli ni kadangkadang benda-benda yang remeh-remeh aja, ...yang simple-simple. Jadi kita kena guna logik-logik mudah lah ... kita kena ikut logik dia bercakap dengan bahasa yang mudah ...

TBI4 : ... saya bagi semua kepada staf-staf sayalah. That the way saya buat kerja saya bagi orang lain dulu. Saya kata, saya tidak dapatpun tidak ada masalah...

Cara kedua yang dikongsikan oleh subjek dalam mempengaruhi orang lain adalah dengan "membina rasa kebersamaan". Seperti dinyatakan oleh TBI1, beliau cuba memberikan keyakinan kepada orang lain dengan cara memberikan sumbangan pemikiran kepada orang lain tersebut, agar mereka dapat merasakan kepentingan idea yang beliau sampaikan, sehingga idea tersebut dapat dilihat sebagai kepentingan bersama oleh orang-orang berkenaan. TBI3 mengukuhkan lagi perkongsian tersebut yang menyatakan bahawa dirinya sentiasa membina konsep berkawan dengan semua orang. Konsep sebegini memudahkan dirinya apabila menyampaikan sesuatu idea kepada orang-orang tersebut, seperti dinyataka pada petikan berikut ini:

TBI1 : Membangkitkan rasa yang sama ataupun apa yang saya rasa kepada orangorang yang cuba saya yakinkan. Jadi mereka merasa bahawa perkara tersebut adalah penting. Peringkat itu yang agak sukarlah, supaya samasama merasa bahawa benda itu penting...

TBI3 : Jadi konsep saya berkawan dengan semua orang dan kalau boleh jangan bermusuh dengan siapa-siapa, tapi untuk kebenaran tiada kompromi...

Satu perkara yang dikongsikan oleh subjek dalam mempengaruhi orang lain adalah dengan cara "memberi idea beserta sokongan". Seperti ditunjukkan oleh perkongsian TBI1, TBI4 dan TBI8 yang menyatakan bahawa apabila beliau menyampaikan idea kepada orang lain beliau berusaha untuk menunjukkan bukti kenapa idea tersebut penting. TBI4 mencontohkan bahawa untuk meyakinkan orang lain beliau sentiasa melakukan dengan cara menunjukkan senarai kebaikan kepada orang tersebut tentang idea-idea yang dicadangkan, sehingga orang dapat menerima dengan baik sesuatu idea yang beliau dikongsikan. Demikian juga dengan TBI8 apabila beliau memberikan keyakinan kepada orang lain tentang kebaikan sesuatu idea 
yang ingin disampaikan, beliau sentiasa menunjukkan bukti dan contoh sehingga orang lain dapat menerima pandangan beliau tanpa dikeragui. Perkongsian subjek-subjek tersebut seperti ditunjukkan pada petikan di bawah ini:

TBI1 : ...bagaimana kita nak memberi keyakinan kepada pihak lain supaya menerima idea kita? tentunya sekali dengan adanya sokongan-sokongan dan bukti, pada masa yang sama kita bukan mendesak tetapi memberikan keyakinan bagaimana perlunya idea yang dibawa tersebut. Saya memberikan justifikasi kanapa, tetapi bukan dengan jalan mendesak.

TBI4 : ...tapi saya kemukakan dengan angka beberapa senarai kebaikanya, jadi dia tidak boleh menolaklah...

TBI8 : Selalunya saya akan bawa bukti, saya tak akan bagi idea sesuatu tanpa ada contoh ataupun ada bukti yang lain. Sebab saya rasa sukar untuk meyakinkan orang lain kalau tak ada contoh dan tak ada bukti. Jadi bila saya bagi satu-satu pandangan berasaskan kepada fakta dan bukti biasanya mudah untuk diterima oleh orang lain.

\subsubsection{Pembinaan Cara Pengurusan Konflik}

Rajah 4.14 memaparkan tentang pengalaman subjek dalam pengurusan konflik, iaitu sub domain kedua dalam kemahiran sosial. Pengurusan konflik merujuk pada kemampuan individu untuk mencari jalan penyelesaian terhadap diri sendiri dan juga orang-orang yang sedang berkonflik.

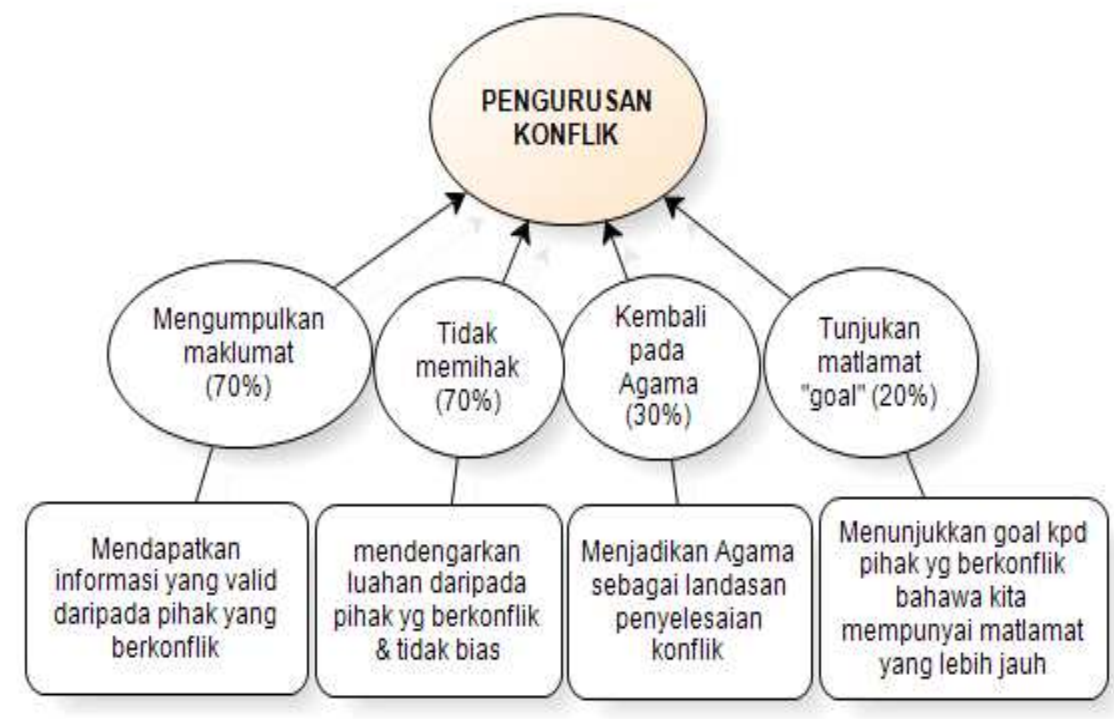

Rajah 4.14 Pengalaman subjek dalam pembinaan pengurusan konflik 
Dapatan kajian seperti yang dipaparkan pada Jadual 4.14 di atas menunjukkan terdapat empat komponen penting yang dikongsi oleh subjek dalam pengurusan konflik tersebut. Keempat-empat komponen tersebut adalah; (i) mengumpulkan maklumat, (ii) tidak memihak, (iii) kembali pada agama, dan (iv) tunjukan matlamat ataupun goal. Mengumpulkan maklumat merujuk kepada kemahiran individu untuk mendapatkan maklumat yang sah dari pelbagai pihak dalam menyelesaikan koflik yang berlaku. Tidak memihak pula menggambarkan tentang kemahiran individu dalam mendengarkan luahan daripada pihak-pihak yang berkonflik, tidak bias dalam mendengar dan mencermati pelbagai maklumat yang diberikan oleh pihak-pihak yang berkonflik. Sedangkan kembali kepada agama pula merujuk kepada kemahiran seseorang untuk menjadikan agama sebagai landasan dalam penyelesaian konflik. Manakala tunjukkan matlamat dan goal pula merujuk kepada kemahiran individu untuk menyatakan, bahawa terdapat satu matlamat yang lebih penting yang mesti dicapai. Matlamat tersebut tidak mungkin dapat dicapai sekiranya orang-orang yang akan menjayakan dalam keadaan berkonflik.

Bila dilihat kepada kekerapan dan peratusan subjek menyatakan pengalaman mereka tentang keempat-empat komponen tersebut, didapati dua komponen memperolehi peratusan yang sama, iaitu mengumpulkan maklumat (70\%), tidak memihak (70\%). Diikuti oleh komponen kembali pada agama (30\%) dan tunjukan matlamat dan goal (20\%). Dapatan ini menunjukkan dua komponen yang memperolehi peratusan tertinggi iaitu mengumpulkan maklumat dan tidak memihak adalah merupakan dua komponen penting dan sentiasa menjadi amalan subjek dalam menyelesaikan sesuatu konflik. Bagaimanapun peratusan yang agak rendah pada komponen kembali pada agama dan tunjukan matlamat dan goal juga membantu dirinya dalam menyelesaikan sesebuah konflik.

Apabila dirujuk pada Matrix Intersection terhadap perkongsian subjek dalam keempat-empat komponen tersebut (rujuk Jadual 4.15) didapati dua komponen iaitu "mengumpulkan maklumat dan tidak memihak" dikongsikan melalui kedua kaedah temubual yang dilukan, iaitu temubual berkumpulan dan temubual individu. Sedangkan dua komponen lagi iaitu "kembali pada agama dan tunjukan matlamat dan goal" hanya dikongsikan oleh subjek melalui temubual secara individu. 
Jadual 4.15 Matrix intersection menyelesaikan konflik

\begin{tabular}{lcc}
\hline Matrix Nodes & F.Group & Individu \\
\hline Mengumpul Maklumat & 2 & 5 \\
Tidak Memihak & 1 & 5 \\
Kembali Pada Agama & 0 & 2 \\
Tunjukan Goal & 0 & 1 \\
\hline
\end{tabular}

Perkongsian subjek tentang keempat-empat komponen tersebut, secara lebih terperinci dapat dilihat pada petikan temubual di bawah ini. Pertama adalah menguruskan konflik dengan cara "mengumpulkan maklumat". Pelbagai istilah digunakan oleh subjek dalam mengumpulkan maklumat tersebut seperti; "cek satu persatu, mendengar, mengenal pasti punca konflik dan mempertemukan orang yang berkonflik". Seperti dikongsikan oleh salah seorang subjek dalam FG2 yang menyatakan untuk menyelesaikan konflik menurut beliau kena cek satu persatu dan kena buat step by step sehingga dapat menyelami apakah yang menyebabkan konflik tersebut berlaku. Mengumpulkan maklumat menggunakan kaedah mendengar pula dikongsikan oleh subjek dalam FG1 yang menyatakan bahawa beliau sentiasa menggunakan kaedah mendengar dengan baik terlebih dahulu daripada orang-orang yang berkonflik, sebelum beliau membantu menyelesaikan orang-orang yang berkonflik tersebut, seperti dinyatakan pada petikan berikut ini:

FG2 : Untuk menyelesaikan konflik ini saya rasa kita kena cek satu persatu, kita kena buat step by step sehingga ketika itu saya boleh menyelami hati nurani dan saya tahu kelemahan dan kekuatan dia, dan yang penting sekali adalah bertolak ansur.

FG1 : ...saya ada banyak pengalaman untuk menyelesaikan konflik di banyak sekolah, ...biasanya saya gunakan cara mendengar, mendengar masalah masing-masing dan bersimpati pada mereka, dengar luahan perasaan mereka. Kemudian cuba beri tahu mereka bahawa niat kita untuk berbaikbaiklah.

Mengumpulkan maklumat dengan cara mengenal pasti punca-punca konflik pula dikongsikan oleh TB1 dan TBI5. TBI1 menyatakan pengalaman beliau dalam menyelesaikan konflik dengan cara mengenal pasti punca-punca konflik tersebut. Bagi beliau mengumpulkan maklumat sebanyak yang mungkin tentang perkara-perkara yang menyumbang kepada berlakunya konflik sangat mustahak sebelum mula mencari penyelesaian ke atas konflik berkenaan. TBI5 pula menyatakan bahawa setelah 
mendapatkan maklumat yang cukup daripada kedua belah pihak yang berkonflik, kedua-dua pihak berkenaan cuba dipertemukan, seperti dinyatakan pada petikan berikut ini:

TBI1 : ...biasa saya ingin supaya punca-punca konflik itu di kenal pasti. ...memulakan penyelesaian konflik itu dengan jalan mendapat maklumat sebanyak mungkin yang berkaitan dengan konflik tersebut. Punca-puncanya, siapa yang terlibat, kenapa boleh terjadi macam ini, agak-agak apa yang menyumbang kepada berlakunya konflik dan cuba bersifat objektiflah.

TBI5 : ...Saya panggil ini... saya panggil ini... saya buat kesimpulan... saya temukan, ...pelajar macam tu juga, tapi saya dengar dia dulu, saya dengar dia dulu kemudian kalau perlu disatukan dalam satu pertemuan...

Kaedah kedua yang dikongsikan oleh subjek dalam pengurusan konflik adalah dengan cara "tidak memihak" kepada mana-mana pihak. Seperti dinyatakan oleh subjek dalam FG1, TBI 8 dan TBI5 pula berkongsi pengalaman mereka dalam pengurusan konflik dengan menggunakan kaedah tidak memihak. TBI8 menyatakan pengalaman beliau bahawa beliau cuba menjadi pendengar yang baik kepada keduadua belah pihak yang berkonflik, namun pendekatan unik yang digunakan oleh beliau adalah kedua-dua pihak yang sedang berkonflik tidak mengetahui bahawa beliau telah mendapatkan maklumat daripada kedua-dua belah pihak tersebut. TBI5 pula menyatakan bahawa beliau menggunakan pendekatan secara personal dalam membantu menyelesaikan konflik diantara dua individu. Bagi beliau dalam pengurusan konflik, tidak boleh hanya mempercayai satu pihak sahaja. Perkongsian subjek tersebut seperti dinyatakan pada petikan berikut ini:

FG1 : ...pertama sekali kita hendaklah berada di tengah-tengah. Kemudian kenalpasti apa konflik itu... study puncanya...study situasi konflik itu... kemudian siapa yang terlibat. Akhirnya secara halus menanganinya... jangan menggunakan kaedah yang tidak menyenangkan...

TBI8 : ...orang ni jumpa saya dan orang ni jumpa saya, kedua-duanya tak tahu. Jadi bila yang ini datang, saya dengar dan saya akan bagi cerita apa-apa yang boleh memantapkan emosi dia dan pendirian dia sehingga dia boleh bekerja semula...

TBI5 : ...dalam masalah disiplin dan penyelesaian konflik, agaknya mesejnya sama iaitu individual aproach, berjumpa sorang-sorang dan bincang, cari yang terbaik, jangan percaya mana-mana pihak dulu... akhirnya mencampurkan... 
Kembali pada Agama adalah kaedah ketiga yang dikongsikan oleh responden, walaupun kaedah ini mempunyai peratusan yang rendah berbanding dua komponen sebelum ini, namun subjek menyatakan kepentingan perkara tersebut dalam membantu untuk pengurusan konflik. Seperti yang dikongsikan oleh TBI4, berdasarkan pengalamanya sebagai seorang pentadbir, dirinya sentiasa berhadapan dengan pelbagai konflik dalam kalangan orang-orang di bawah jagaanya. Untuk pengurusan konflik tersebut, dirinya sentiasa menggunakan pendekatan agama dalam menguruskan konflik berkenaan. Bagi dirinya apapun bentuk usaha yang dilakukan dalam menyelesaikan konflik, baginya pertolongan yang Maha Kuasa adalah segala-galanya. Perkongsian tersebut dikukuhkan oleh TBI7 yang menyatakan bahawa bila manusia telah kembali kepada agama perbezaan tidak mungkin wujud kerana manusia mempunyai matlamat yang sama, seperti dinyatakan pada petikan di bawah ini:

TBI4 : Terutamanya kalau sebelum mesyuarat saya selalu berdo'alah supaya Allah cucuri rahmat, hidayahnya dalam mesyuarat itu. Biasalah kita start saya baca doa dan mula dengan alfatihah ... setiap kali mesyuarat kita baca Hadis , Qur'an yang ada kaitan dengan kerja...

TBI7 : ...bila kita hendak kepada agama, mana ada beza? Kaya ataupun miskin sama sahaja. ... sembang tentang masalah dia, saya dengar...

Satu perkara unik juga yang dikongsikan oleh subjek dalam pengurusan konflik ini adalah dengan cara "menunjukkan matlamat dan goal". Seperti yang dikongsi oleh TBI 4 pada petikan di bawah ini:

TBI4 : ... Jadi masa dekat departemen dulu saya gunakan pendekatan bahawa kita ada satu matlamat nak di capai..., ...kita ada goal nak jadi the best engineering school in the world ... Kita nampak goal yang jauh ke depan dan masing-masing berusaha untuk mencapai itu. Jadi perbezaan dalam kumpulan itu jadi berkuranglah...

\subsection{KAEDAH YANG DIGUNAKAN DALAM LATIHAN EQ}

Untuk mencari kaedah yang sesuai digunakan di dalam latihan EQ, analisis dokumen telah dilakukan kepada beberapa dokumen seperti yang ditunjukkan di dalam jadual 4.16 di bawah ini: 
Jadual 4.16 Dokumen yang dianalisis untuk mencari kaedah yang sesuai dalam latihan EQ

\begin{tabular}{|c|c|c|c|c|}
\hline No & Dokumen & Pengarang & Penerbit & Tahun \\
\hline 1. & $\begin{array}{l}\text { Al-Quranul Karim \& } \\
\text { Terjemahan }\end{array}$ & $\begin{array}{l}\text { Lajnah Pentarjih Al- } \\
\text { Qur'an, Departemen } \\
\text { Agama Repoblik } \\
\text { Indonesia }\end{array}$ & $\begin{array}{l}\text { Departemen } \\
\text { Agama Repoblik } \\
\text { Indonesia }\end{array}$ & 2004 \\
\hline 2. & $\begin{array}{l}\text { The emotional intelligence } \\
\text { activity book ( } 50 \text { activity for } \\
\text { promoting EQ at work }\end{array}$ & Adele B. Lynn & $\begin{array}{l}\text { American } \\
\text { Management } \\
\text { Association } \\
\text { (AMACOM). } \\
\text { USA }\end{array}$ & 2002 \\
\hline 3. & $\begin{array}{l}\text { Emotional Intelligence in } \\
\text { Action; latihan and coacing } \\
\text { activities for leaders and } \\
\text { managers }\end{array}$ & $\begin{array}{l}\text { Maricia Hughes, L. } \\
\text { Bonita Patterson and } \\
\text { James Bradford } \\
\text { Terrel, forewod by } \\
\text { Reuven Bar-On }\end{array}$ & $\begin{array}{l}\text { Pfeifer (Essential } \\
\text { resources for } \\
\text { latihan and HR } \\
\text { professionals. } \\
\text { USA }\end{array}$ & 2005 \\
\hline 4. & $\begin{array}{l}\text { Emotions at work; theory } \\
\text { researc and applications for } \\
\text { management }\end{array}$ & $\begin{array}{l}\text { Roy L. Payne and } \\
\text { Cary L. Cooper }\end{array}$ & $\begin{array}{l}\text { Jhon Wiley \& } \\
\text { Sons, Ltd. England }\end{array}$ & 2001 \\
\hline 5. & $\begin{array}{l}\text { Emotional Intelligence } \\
\text { achieving academic and Career } \\
\text { axcelence }\end{array}$ & $\begin{array}{l}\text { Darwin B. Nelson \& } \\
\text { Gary R. Low }\end{array}$ & $\begin{array}{l}\text { Prentice Hall. New } \\
\text { Jersey Columbus, } \\
\text { Ohio }\end{array}$ & 2003 \\
\hline 6. & Social Intelligence & Daniel Goleman & $\begin{array}{l}\text { PT. Gramedia. } \\
\text { Jakarta }\end{array}$ & 2006 \\
\hline 7. & $\begin{array}{l}\text { Akselerasi Intelegensi; } \\
\text { Optimalkan IQ, EQ \& SQ }\end{array}$ & Suharsono & $\begin{array}{l}\text { Inisiasi Press. } \\
\text { Jakarta }\end{array}$ & 2004 \\
\hline 8. & Meledakkan IESQ & Mas Udik Abdullah & $\begin{array}{l}\text { Zikrul Hakim. } \\
\text { Jakarta }\end{array}$ & 2005 \\
\hline 9. & $\begin{array}{l}\text { Rahasia sukses membangun } \\
\text { kecerdasan emosional dan } \\
\text { spiritual (ESQ); the ESQ way } \\
165 \text {, New Edition }\end{array}$ & $\begin{array}{l}\text { Ary Ginanjar } \\
\text { Agustian }\end{array}$ & ARGA. Jakarta & 2005 \\
\hline 10. & $\begin{array}{l}\text { Rahasia sukses membangkitkan } \\
\text { ESQ power; sebuah inner } \\
\text { journey melalui al-ihsan }\end{array}$ & $\begin{array}{l}\text { Ary Ginanjar } \\
\text { Agustian }\end{array}$ & ARGA. Jakarta & 2003 \\
\hline 11. & $\begin{array}{l}\text { Pendidikan dan pembangunan } \\
\text { manusia; pendekatan bersepadu }\end{array}$ & $\begin{array}{l}\text { Tajul Ariffin } \\
\text { Noordin \& Nor' } \\
\text { Aini Dan }\end{array}$ & $\begin{array}{l}\text { Assabab Media. } \\
\text { Selangor, D.E }\end{array}$ & 2002 \\
\hline 12. & $\begin{array}{l}\text { Andragogi; mengajar orang } \\
\text { dewasa }\end{array}$ & $\begin{array}{l}\text { Azhar Abdul hamid, } \\
\text { Paimah Atoma, } \\
\text { Muhamed Fauzi } \\
\text { Othman \& Mohd } \\
\text { Nasir Markom }\end{array}$ & $\begin{array}{l}\text { PTS Publication \& } \\
\text { Distributor SDN. } \\
\text { BHD. Pahang, } \\
\text { Darul Makmur }\end{array}$ & 2004 \\
\hline
\end{tabular}


Rajah 4.15 di bawah menunjukkan hasil analisis dokumen tentang kaedah yang sesuai digunakan dalam latihan EQ. Hasil analisis menunjukkan terdapat empat kaedah yang bersesuaian digunakan dalam latihan EQ tersebut, iaitu; (i) latihan mesti mempunyai model yang dijadikan sebagai sandaran ataupun landasan. (ii) Mesti dilaksanakan dengan cara hikmah, iaitu dengan cara memandu peserta untuk dapat mengenali dan merenungi diri sendiri kerana EQ merupakan aspek dalaman masingmasing individu. (iii) Pembelajaran semestinya berlaku melalui pengalaman dan perbuatan, iaitu peserta dapat belajar sendiri melalui aktiviti-aktiviti yang dilakukan di dalam latihan, dan (iv) Latihan dilakukan secara berterusan, iaitu memberikan kemahiran kepada peserta agar mereka dapat berlatih secara berterusan.

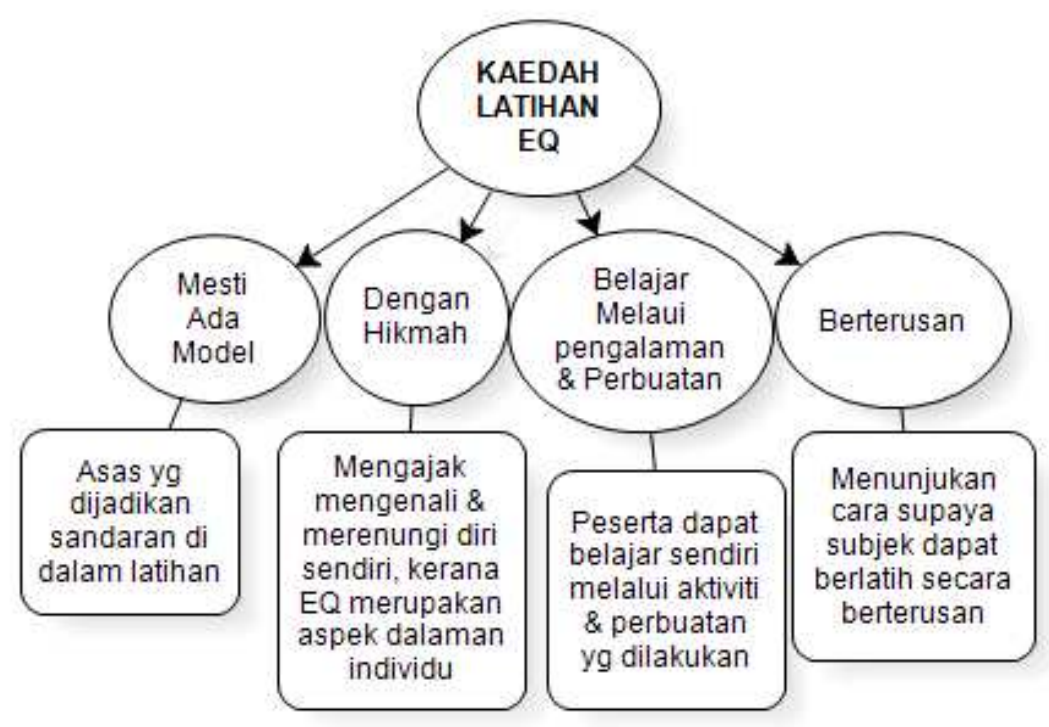

Rajah 4.15 Kaedah yang sesuai digunakan dalam latihan EQ

Secara terperinci bentuk-bentuk pernyataan yang diperolehi daripada analisis dokumen tentang kaedah latihan yang digunakan di dalam latihan EQ tersebut dapat dilihat pada petikan-petikan di bawah ini. Pertama, latihan mestilah dilaksanakan berlandaskan "satu model yang kukuh". Seperti dinyatakan dalam dokumen 9, 10 dan 12 pada petikan di bawah ini:

Dk9\&10 : ..latihan mesti ada model yang jelas untuk dijadikan sebagai sandaran kepada pelaksanaan latihan tersebut. 
Dk12 : Pembelajaran dewasa memerlukan rangsangan dan tindakbalas bagi mengukuhkan pembelajaran yang sedang dilakukan. Pembelajaran perlu menitikberatkan kepada pemerolehan pengetahuan danpengalaman, dimana sebelum memulakan aktiviti pembelajaran fasilitator (trainer) perlu mengambil kira latar belakang peserta supaya tidak membosankan. Selanjutnya pembelajaran juga memerlukan permodelan, iaitu fasilitator (trainer) adalah model kepada para perserta dalam mewujudkan matlamat hidup mereka.

Kepentingan tentang perlunya sesebuah model dalam sesebuah latihan juga disentuh oleh dokumen1 yang menyatakan bahawa orang-orang yang mengajar (dalam hal ini adalah trainer) perlu menjadi model kepada peserta-peserta latihanya. Selanjutnya dokumen 11 juga menyatakan bahawa bahawa pendidikan untuk menusia adalah merujuk kepada definisi manusia itu sendiri. Dokumen 11 menyatakan bahawa seorang pendidik perlu memahami monsep manusia tersebut dengan makna yang betul. Petikan dokumen-dokumen tersebut tentang perlunya model dalam sesebuah latihan sepeti ditunjukkan di bawah ini:

Dk1 : Sesungguhnya telah ada pada diri Rasulullah itu suri teladan yang baik bagimu (model) bagi orang yang mengharap rahmat Allah dan kedatangan hari kiamat, dan dia sentiasa menyebut Allah.

Dk11 : Seorang guru "trainer" perlu memahami konsep manusia, khususnya daripada perspektif al-Qur'an. Manusia adalah insan, insan berperanan sebagai khalifah untuk membina kesejahteraan hidup di dunia dan di akhirat. Di dalam memberikan pendidikan guru (trainer) perlu memahami konsep insan tersebut.

Perkara kedua yang diperolehi daripada analisis dokumen adalah latihan perlu dilaksanakan dengan cara "hikmah" Pelaksanaan latihan dengan cara hikmah adalah merujuk kepada kebijaksanaan trainer dalam menyampaikan materi latihan, iaitu dengan mengambil kira siapakah yang menjadi sasaran latihan, bagaimana bahanbahan sepatutnya dipersembahkan dan sebagainya. Seperti disentuh oleh dokumen 1 yang menyatakan bahawa mengajak ataupun memberikan pelajaran kepada manusia perlulah dengan cara yang bijaksana (hikmah). Bijaksana yang dimaksudkan oleh dokumen ini adalah merangkumi semua perkara yang berkaitan dengan kejayaan sesebuah pembelajaran tersebut. Kaedah hikmah juga merujuk kepada kemampuan trainer untuk membangunkan potensi peserta-peserta latihan, sekiranya perkara 
sebegini gagal dilaksanakan menunjukkan satu kegagalan kepada latihan tersebut, seperti dinyatakan pada petikan di bawah ini:

Dk1 : Serulah manusia kepada jalan Tuhan-mu dengan hikmah dan pelajaran yang baik, dan bantahlah mereka dengan cara yang baik...

Dk7 : Manusia yang tidak memiliki pengetahuan tentang potensi, dan kemampuan diri sendiri, serta tidak mampu menemukan visi dan tujuan hidup, akan menjadi manusia-manusia yang kerdil.

Perkara ketiga yang didapatkan daripada analisis dokumen adalah, peserta latihan sepatutnya "belajar melalui pengalaman (exprencial learning)". Ini merujuk kepada kemahiran trainer dalam merancang pelbagai aktiviti di dalam menyampaikan materi latihan, sehingga peserta latihan dapat belajar secara mandiri melalu mesejmesej yang dibawa melalui aktiviti tersebut. Seperti yang disentuh dalam dokumen 5 yang menyatakan bahawa untuk meningkatkan kemahiran kecerdasan emosi seseorang sepatutnya melalui proses pembelajaran dengan sendirinya, proses pembelajaran tersebut dapat dilakukan dengan cara belajar melalui pengalaman dan perbuatan. Dokumen 5 juga menyentuh bahawa pembelajaran tentang kecerdasan emosi adalah berbeza dengan cara pembelajaran yang biasa diikuti secara tradisional. Dokumen 5 menyatakan bahawa pembelajaran kecerdasan emosi perlu dilaksanakan melalui proses tertentu, seperti dinyatakan dalam petikan di bawah ini;

Dk5 : Emotional learning that results in increased self-awaresness, improved behaviors, and the acquisition of new skills must actively engage the individual in the learning process. Learning by doing and expriencing is the key to learning emotional intelligence skills.

Dk5 : Emotional and experience based learning is differentiate from traditional academic content learning. The emotional learning system based on: Self Assessment"Explore"Self-Awareness"Identify", Self-Knowladge "Understand", Self-Development "Learn", and Self-Improvement "Apply and model.

Pembelajaran melalui pengalaman juga disentuh oleh dokumen1 yang menyatakan dengan istilah qiasan iaitu sebenarnya al-Qur'an adalah ayat-ayat yang nyata di dalam dada orang-orang yang diberi ilmu. Dokumen ini memaksudkan bahawa orang-orang yang memiliki pengetahuan sepatutnya sentiasa menyedari 
bahawa di dalam kehidupan mereka sebenarnya terbentang pelbagai perkara yang boleh dijadikan pengajaran yang amat berharga. Pada bahagian lain dokumen 1 juga menyatakan bahawa pembelajaran tersebut juga terbentang luas di dalam kitab yang menjadi pegangan masing-masing individu. Dalam hal ini dokumen satu menyentuh melalui ayat sindiran, iaitu walaupun pembelajaran tersebut terbentang luas di dalam ayat-ayat yang terdapat di dalam kitab yang menjadi pegangan seseorang, namun ianya hanya menjadi suatu i'tibar bagi mereka-mereka yang mempergunakan fikiran dengan baik, seperti dinyatakan dalam petikan di bawah ini:

Dk1 : Sebenarnya al-Qur'an adalah ayat-ayat yang nyata dalam dada orang-orang yang diberi ilmu, dan tidak ada yang mengingkari ayat-ayat kami kecuali orang-orang yang Zalim (Al-Ankabuut 29: 49).

Dk1 : Ini adalah sebuah kitab yang kami turunkan kepadamu penuh dengan berkah supaya mereka memperhatikan ayat-ayat-Nya dan supaya mendapat pelajaran bagi orang-orang yang berfikir (Shaad 38; 29).

Pembelajaran yang paling hampir cuba disentuh oleh dokumen 1 adalah perkara-perkara yang terdapat di dalam diri masing-masing individu. Dokumen 1 menyatakan bahawa "dan di dalam diri kita sendiri, apakah kamu tidak memperhatikan". Sebenarnya terdapat pengetahuan yang perlu diterokai, agar individu dapat menyedari siapakah dirinya sebenar. Pembelajaran melalui pengalaman tersebut juga dikukuhkan oleh dokumen 9 yang menyatakan bahawa kesuksesan itu bakanlah satu tujuan tetapi perjuangan untuk memperolehinya. Ayat yang dikemukakan oleh dokumen 9 ini perlu ditafsir untuk menangkap makna yang tersirat di sebalik ayat tersebut. Melalui pengalaman perjuangan untuk mewujudkan satu tujuan, tentunya individu mempunyai sejarah dan perjuangan masing-masing. Sejarah dan perjuangan inilah merupakan pengalaman yang sangat berharga untuk diri sendiri, mahupun untuk dikongsikan dengan orang lain. Petikan dokumen 1 dan dokumen 9 tersebut seperti dinyatakan di bawah ini:

Dk1 : ... dan juga di dalam dirimu sendiri, apakah kamu tidak memperhatikan?... (Adz-Dzariyaat 51:21).

Dk9 : Success is not a destination but a journey, justeru kesuksesan itu bukanlah satu tujuan tetapi perjuangan untuk mendapatkanya. 
Perkara keempat pula yang didapatkan melalui analisis dokumen adalah latihan "perlu dilaksanakan secara berterusan". Memandangkan EQ merupakan dalaman individu, maka kaedah berterusan ini merujuk kepada kemahiran trainer untuk memotivasikan peserta latihan, agar mereka sentiasa dapat belajar melalui pengalaman kehidupan yang pernah dilalui. Seperti dinyatakan oleh dokumen 7 bahawa EQ yang dimiliki seseorang tidak matang dengan sendirinya selari dengan perkembangan biologisnya, sebaliknya EQ tersebut akan menjadi mantap melalui proses latihan secara berterusan. Perkara yang sama juga disentuh oleh dokumen 12 yang menyatakan bahawa pembelajaran EQ tidak berlaku secara spontan, ianya berlaku melalui pembelajaran di dalam kehidupan seharian. Ini menunjukkan bahawa individu perlu sentiasa peka dengan keadaan persekitaran yang mungkin boleh dijadikan sebagai pembelajaran dalam kehidupanya, sehingga boleh membawa pada kematangan individu tersebut, seperti dinyatakan pada petikan berikut ini:

Dk7 : EQ yang dimiliki oleh seseorang tidak matang dengan sendirinya selari dengan perkembangan biologis dan usia individu tersebut, sebaliknya EQ bergantung pada proses latihan dan pendidikan secara berterusan.

Dk12 : ...bukanya berlaku secara spontan, pembelajaran berlaku dari hari ke hari di dalam kehidupan individu "deliberate learning" iaitu pembelajaran yang disengajakan yang berlaku secara perlahan-lahan.

Latihan ataupun pembelajaran secara berterusan juga disentuh oleh dokumen 1 yang menyatakan bahawa individu perlu sentiasa membaca. Membaca di sini merujuk kepada membaca apa sahaja, sama ada membaca dalam pengertian biasa (seperti membaca buku, membaca majalah, membaca kitab-kitab tertentu dan sebagainya) mahupun membaca keadaan alam semesta, sehingga dapat memberikan kefahaman dan keyakinan kepada individu berkenaan. Pada bahagian lain dokumen 1 juga menyatakan bahawa Allah akan meninggikan orang-orang yang beriman dan orangorang yang diberi ilmu beberapa derajat. Ini mengisyaratkan bahawa untuk mendapatkan darjat yang tinggi seperti yang dijanjikan oleh Allah itu, tentunya bukan satu perkara yang mudah, ianya memerlukan usaha yang gigih dan berterusan sehingga darjat tersebut dapat diperolehi, seperti di sentuh oleh petikan di bawah ini:

Dk1 : Bacalah dengan menyebut nama Tuhanmu yang menciptakan (1), Dia telah menciptakan manusia dari segumpal darah (2), bacalah, dan Tuhanmulah 
yang Maha Pemurah (3), Yang mengajar manusia dengan perantaran kalam (4), Dia mengajar kepada manusia apa yang tidak diketahuinya (5).

Dk1 : ...Allah akan meninggikan orang-orang yang beriman di antaramu dan orang-orang yang diberi ilmu pengetahuan beberapa derajat dan Allah Maha mengetahui apa yang kamu kerjakan.

Berkaitan dengan pelaksanaan latihan pula hasil analisis menunjukkan bahawa latihan EQ perlu diawali dengan cara memandu peserta untuk menerokai diri mereka masing-masing. Setelah masing-masing peserta memperolehi kemahiran menerokai diri mereka, langkah seterusnya adalah mengenal pasti emosi yang dirasai. Setelah peserta dapat mengetahui emosi yang sedang mereka rasakan, seterusnya peserta diminta memahami sepenuhnya kenapa emosi sedemikian boleh wujud dalam diri mereka, apa yang akan berlaku sekiranya emosi sedemikian selalu menguasai dirinya. Apabila peserta telah melalui langkah-langkah tersebut, selanjutnya peserta diminta untuk mempelajari membina dan mengekalkan emosi-emosi yang positif, mengontrol emosi-emosi negatif yang menguasai diri. Terakhir peserta mempraktikan dalam kehidupan mereka dengan cara sentiasa menunjukkan peningkatan emosi positif dalam kehidupan.

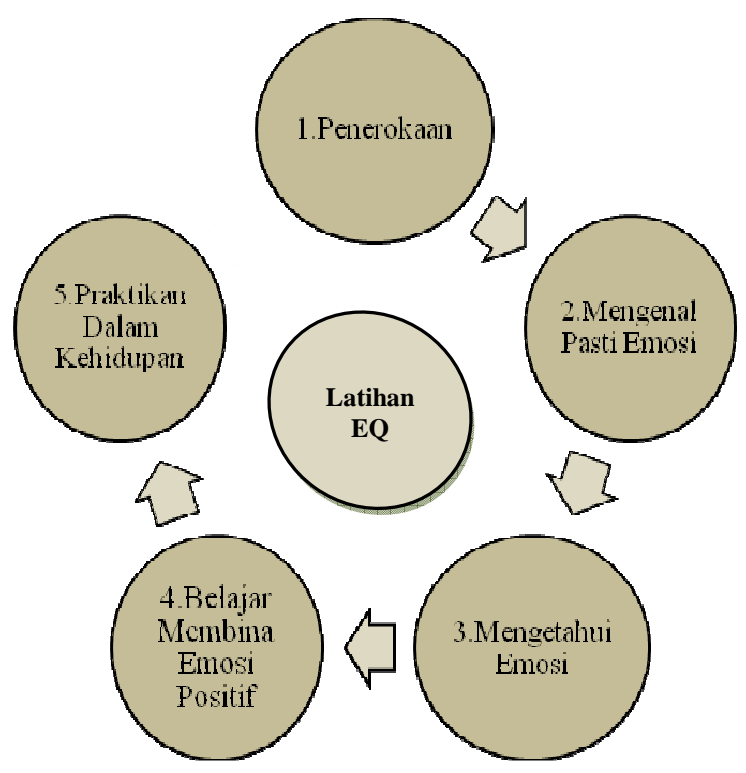

Rajah 4.16 Cara pelaksanaan latihan EQ 


\subsection{MODEL PEMBINAAN MODUL EQ}

Pembinaan modul EQ dimaksudkan adalah daripada pengintegrasian dapatan kajian fasa pertama (need analysis) dan kajian fasa kedua (case study). Proses pembinaan tersebut adalah seperti digambarkan pada rajah 4.17 .

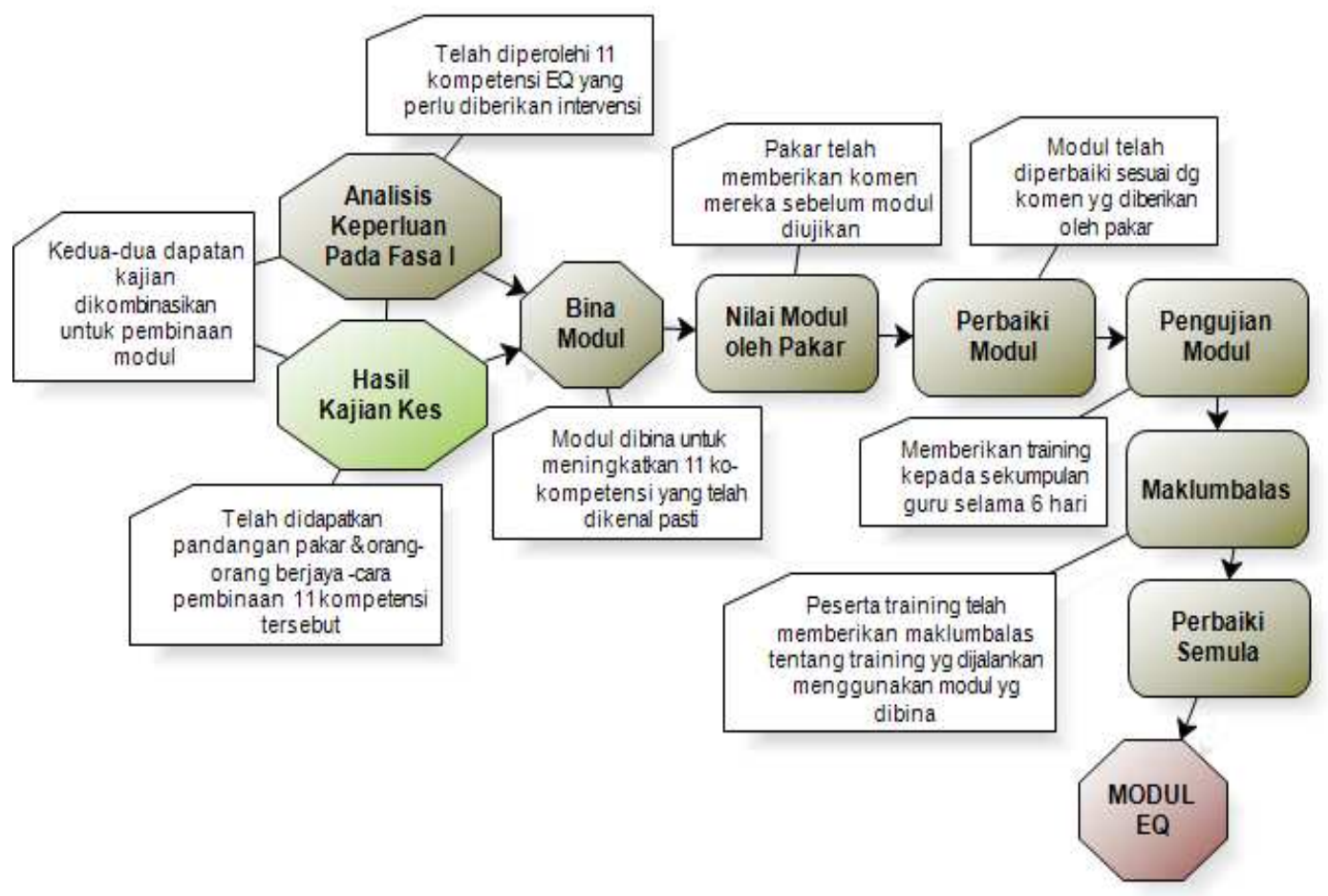

Rajah 4.17 Proses pembinaan modul EQ

Seperti yang ditunjukkan pada Rajah 4.17 di atas, pada fasa pertama kajian ini pengkaji telah memulakan dengan kajian tinjauan, untuk tujuan membuat analisis keperluan bagi memastikan kompetensi asas EQ yang perlu diberikan intervensi ataupun latihan EQ dalam kalangan guru-guru yang terlibat dalam kajian ini. Daripada analisis keperluan pengkaji telah memperolehi 11 kompetensi asas EQ yang perlu diberikan intervensi seperti ditunjukkan pada Rajah 4.1 sebelum ini. Setelah mendapatkan kompetensi asas EQ tersebut, pengkaji telah meneruskan kajian ini dengan kajian kes, dan telah menggunakan kaedah temubual secara perseorangan dan juga berkumpulan, bagi mendapatkan pengalaman pakar dan orang-orang berjaya dalam membina 11 kompetensi asas yang telah dikenal pasti pada fasa pertama. 
Seterusnya analisis dokumen juga telah dilakukan bagi mendapatkan kaedah yang sesuai untuk latihan EQ tersebut.

Selanjutnya pengkaji mengitegrasikan kedua-dua dapatan kajian tersebut untuk dijadikan panduan dalam pembinaan modul EQ. Dengan perkataan lain modul EQ dibina untuk meningkatkan 11 kompetensi asas EQ yang telah dikenal pasti pada fasa pertama, cara pembinaan 11 kompetensi tersebut adalah mengambil kira pandangan pakar, orang-orang berjaya, dan hasil analisis dokumen yang telah dilakukan. Pandangan pakar dan orang-orang berjaya tersebut telah diubahsuai ke dalam bentuk aktiviti yang digunakan dalam latihan EQ. Perkongsian pengalaman oleh pakar dan orang-orang berjaya tersebut, secara keseluruhannya boleh dilihat dalam dua aspek, iaitu isi kandungan modul EQ dan kaedah yang sesuai untuk latihan EQ tersebut.

Pengkaji telah merumuskan pengalaman yang dikongsikan oleh pakar dan orang-orang berjaya tersebut kepada 11 aktiviti, iaitu 1 aktiviti untuk menyentuh 1 kompetensi asas EQ yang telah dikenal pasti. Falsafah pemilihan aktiviti tersebut selari dengan perkongsian pengalaman pakar dan orang-orang berjaya yang diperolehi pada fasa kedua kajian ini. Aktiviti-aktiviti tersebut seperti ditunjukkan pada jadual 4.17 di bawah ini. Penerangan terperinci untuk setiap aktiviti tersebut dapat dirujuk pada (lampiran A).

Jadual 4.17 Aktiviti-aktiviti dalam latihan EQ
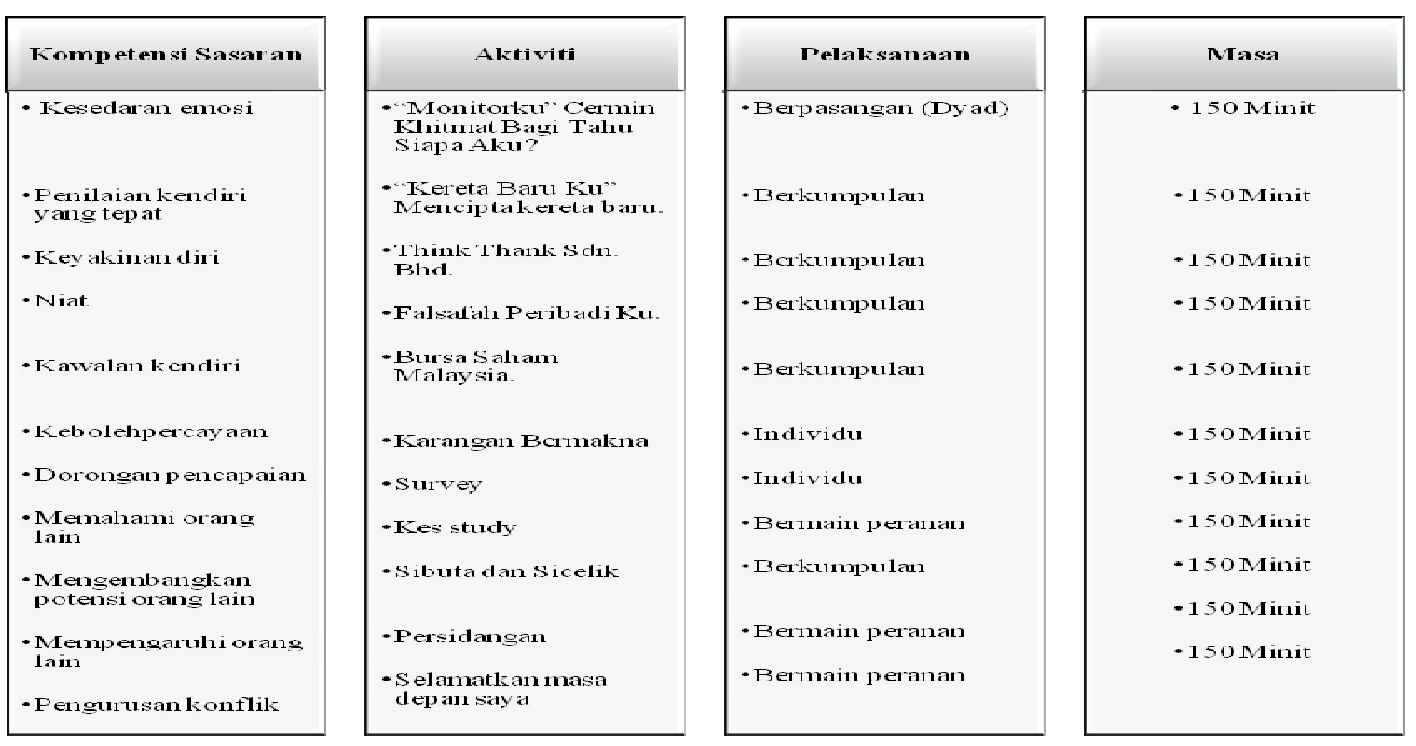


\subsection{KOMPETENSI EQ GURU-GURU SEBELUM DAN SELEPAS MENGIKUTI LATIHAN MENGUNAKAN MODUL EQ}

Seperti yang telah dibincangkan pada bahagian analisis keperluan, iaitu kajian ini melibatkan 112 orang guru yang sedang melanjutkan pendidikan peringkat Sarjana dan Doktor falsafah di Fakulti Pendidikan UKM. Daripada 112 orang guru-guru tersebut, 33 orang dalam kalangan mereka telah dipilih untuk diberikan latihan menggunakan modul latihan EQ yang dibina. Pemilihan 33 orang guru tersebut adalah berdasarkan maklumbalas dan skor yang mereka perolehi terhadap instrumen EQ yang diberikan. Daripada maklumbalas tersebut pengkaji telah mendapatkan profil kompetensi EQ guru-guru berkenaan sebelum latihan menggunakan modul EQ yang dibina.

Seterusnya pengkaji telah mengumpulkan guru-guru tersebut pada satu tempat untuk diberikan latihan intensif selama empat hari menggunakan modul EQ yang dibina. Latihan yang diberikan kepada guru-guru berkenaan adalah untuk tujuan pengujian modul EQ yang dibina tersebut. Selepas empat hari latihan diberikan, pengkaji cuba melihat profil kompetensi EQ guru-guru tersebut semula, berdasarkan maklumbalas mereka terhadap instrumen EQ yang diberikan pada hari terakhir latihan. Pada hari terakhir ini juga pandangan dan komen mereka diminta berkenaan dengan modul latihan yang telah digunakan (dilaporkan secara terperinci pada bahagian 4.8).

Rajah 4.18 di bawah menunjukkan profil kompetensi asas EQ guru-guru sebelum diberikan latihan menggunakan modul EQ yang dibina. Dapatan kajian menunjukkan secara umumnya skor yang diperolehi oleh guru-guru bagi setiap kompetensi tersebut adalah pada tahap yang masih perlu dipertingkatkan, agar kompetensi berkenaan dapat bersebati dengan diri mereka, sehingga mereka boleh pergi lebih jauh daripada yang mereka perolehi sekarang ini. Penentuan kompetensi tersebut adalah merujuk kepada cara tafsiran skor min EQ yang dicadangkan oleh Noriah et al (2008).

Daripada analisis yang dijalankan skor yang diperolehi bagi setiap kompetensi tersebut adalah; kesedaran emosi (Min= 63.88), penilaian kendiri yang tepat (Min= 67.71), keyakinan diri (Min= 65.22), niat (Min= 77.77), kawalan kendiri (Min= 71.87), kebolehpercayaan $(\mathrm{Min}=73.03)$, dorongan pencapaian $(\mathrm{Min}=70.22)$, memahami orang lain $($ Min= 70.72), mengembangkan potensi orang lain $($ Min= 70.75), 
mempengaruhi orang lain $(\mathrm{Min}=62.36)$, pengurusan konflik $(\mathrm{Min}=68.03)$. Secara terperinci adalah seperti ditunjukkan pada rajah 4.18 berikut ini.

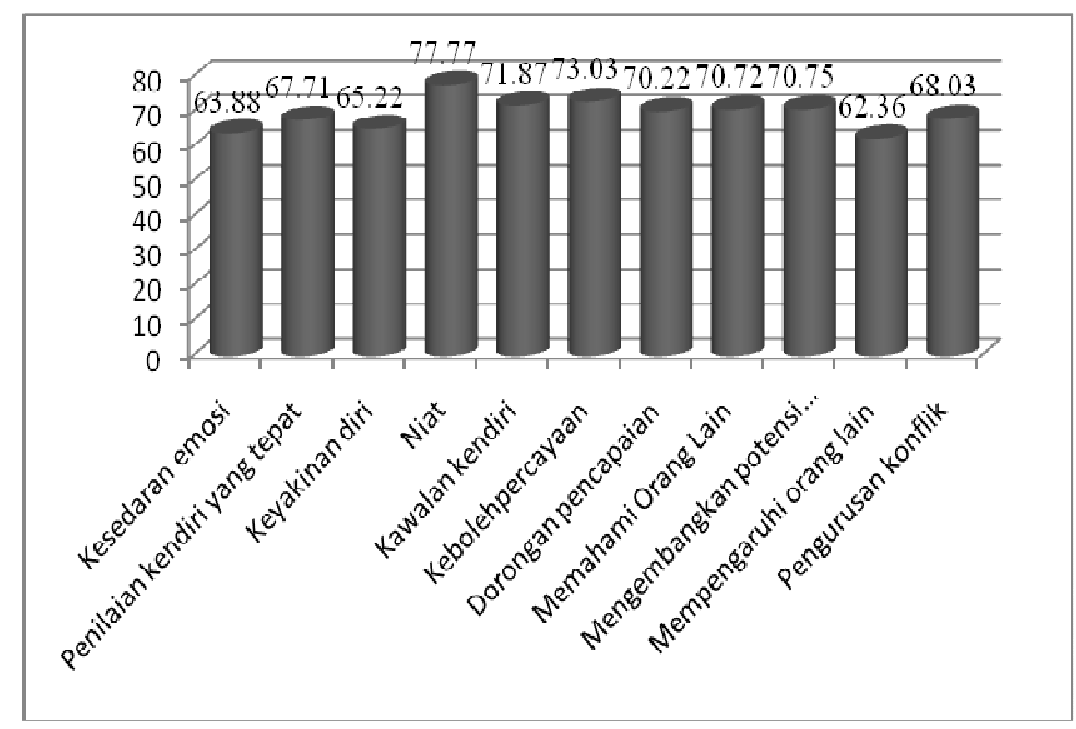

Rajah 4.18 Profil kompetensi EQ guru-guru sebelum diberikan latihan

Rajah 4.19 di bawah ini pula menunjukkan profil kompetensi asas EQ guru-guru setelah diberikan latihan menggunakan modul EQ yang dibina. Setelah diberikan latihan secara intensif selama empat hari, dapatan kajian menunjukkan terdapat peningkatan pada keseluruhan kompetensi asas EQ tersebut. Skor yang diperolehi bagi setiap kompetensi tersebut adalah kesedaran emosi (Min=94.12), penilaian kendiri yang tepat $($ Min= 88.74), keyakinan diri $($ Min= 95.13), niat $(M i n=95.08)$, kawalan kendiri (Min=93.15), kebolehpercayaan (Min= 98.63), dorongan pencapaian (Min= 92.91), memahami orang lain (Min= 96.52), mengembangkan potensi orang lain (Min= 89.47), mempengaruhi orang lain (Min= 98.10) dan pengurusan konflik (Min= 90.26). Secara terperinci adalah seperti ditunjukkan pada rajah 4.19 di bwah ini. 


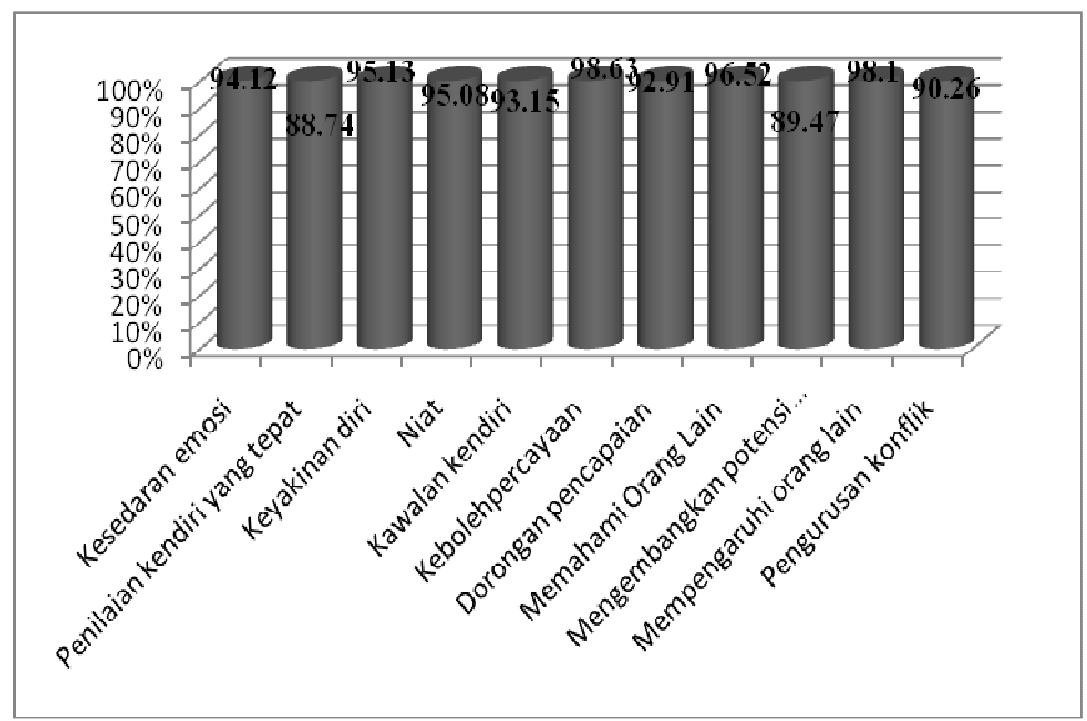

Rajah 4.19 Profil kompetensi EQ guru-guru selepas diberikan latihan

Untuk lebih jelas perbandingan skor min yang diperolehi oleh guru-guru terbabit sebelum dan selepas mengikuti latihan menggunakan modul EQ yang dibina adalah seperti ditunjukkan pada rajah 4.20 berikut ini.

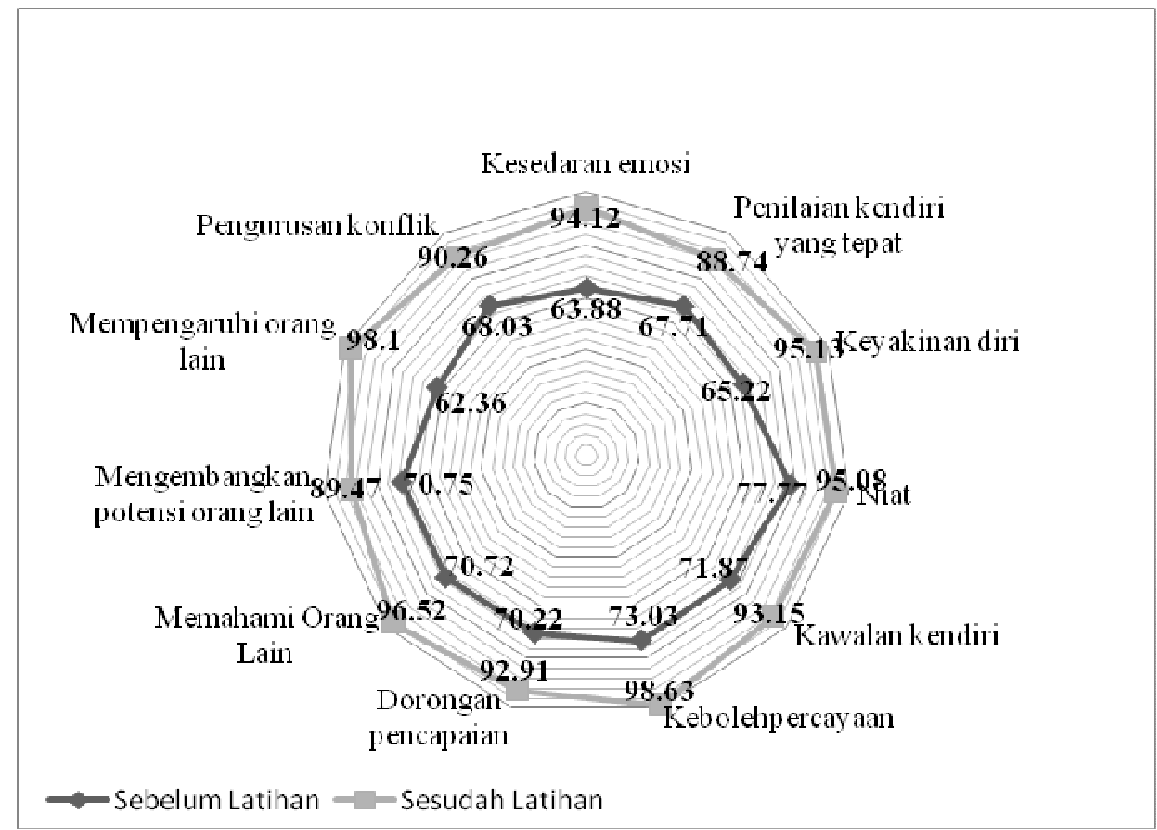

Rajah 4.20 Profil kompetensi EQ sebelum dan selepas latihan 


\subsection{PANDANGAN SUBJEK TERHADAP LATIHAN KECERDASAN EMOSI MENGGUNAKAN MODUL EQ YANG DIBINA}

Untuk mengetahui pandangan subjek tentang latihan EQ menggunakan modul latihan EQ yang dibina, maklumbalas daripada subjek yang mengikuti latihan EQ tersebut telah didapatkan selepas latihan dilaksanakan. Maklumbalas tersebut diperolehi melalui penilaian spontan yang diberikan oleh subjek pada hari terakhir pelaksanaan latihan berkenaan. Secara keseluruhan subjek yang terlibat di dalam latihan tersebut telah memberikan pandangan mereka masing-masing. Pandangan-pandangan subjek berkenaan telah dirakamkan dalam bentuk vidio, dan kemudian dijadikan transkripsi sebagaimana layaknya menjalankan kajian kes, dan seterusnya dianalisis menggunakan perisian Nvivo7.

Rajah 4.21 di bawah memaparkan hasil analisis tentang pandangan subjek tersebut. Secara umumnya pandangan subjek terhadap latihan EQ menggunakan modul latihan EQ yang dibina, dapat dirumuskan ke dalam tiga kategori utama iaitu (i) $70 \%$ subjek menyatakan bahawa latihan yang dilaksanakan menggunakan modul latihan EQ telah memberikan perubahan kepada diri mereka (ii) 60\% dalam kalangan subjek menyatakan bahawa latihan tersebut telah memberikan pengetahuan baru kepada mereka, dan (iii) $40 \%$ menyatakan bahawa latihan berkenaan telah memberikan kesedaran kepada diri mereka. Perubahan yang dimaksudkan oleh subjek adalah mereka dapat melihat diri mereka dengan lebih positif dan dapat mereka praktikan dalam kehidupan seharian. Sedangkan memberikan pengetahuan pula, yang mereka maksudkan adalah latihan tersebut dapat memberikan kefahaman kepada mereka tentang perkara-perkara yang berkaitan dengan emosi. Manakala memberikan kesedaran yang mereka maksudkan adalah latihan tersebut dapat memberikan kesedaran tentang perubahan yang berlaku di dalam diri mereka, serta dapatan mengarahkan perubahan tersebut kepada perkara-perkara yang lebih positif. Secara terperinci dapat dirujuk pada rajah 4.21 di bawah ini. 


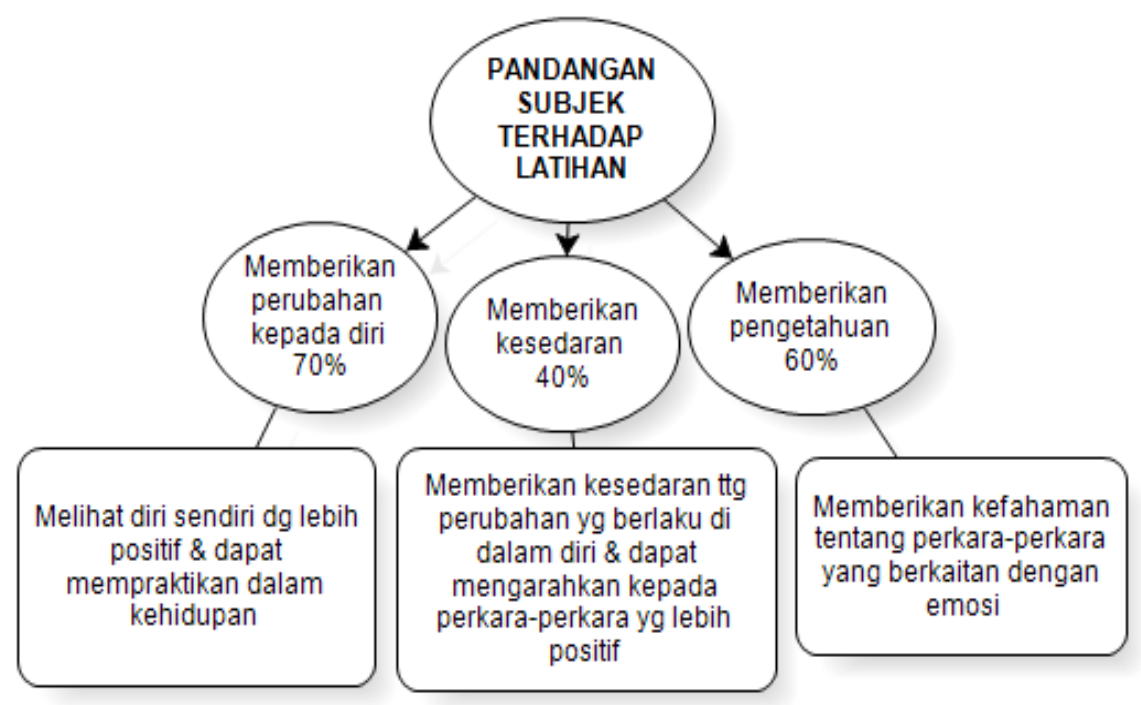

Rajah 4.21 Pandangan subjek terhadap latihan menggunakan modul EQ yang dibina

Perkongsian subjek tentang ketiga-tiga pandangan berkenaan, secara lebih terperinci dapat dilihat pada petikan di bawah ini. Pertama adalah latihan yang dilaksanakan dapat "memberikan perubahan kepada diri subjek". Seperti dikongsikan oleh Subjek 3 yang menyatakan bahawa beliau mendapatkan banyak perkara daripada latihan yang diikuti, seperti beliau dapat mengekspresikan emosi sendiri yang sebelum ini sering disembunyikan. Perkongsian yang lebih kurang sama oleh subjek 10 yang menyatakan bahawa beliau dapat merasakan satu perubahan kepada dirinya, iaitu sebelum ini beliau merasakan bahawa dirinya adalah seorang yang kurang pandai bercakap, kurang yakin dalam menyampaikan idea. Namun beliau merasakan satu perubahan sebaliknya setelah berlatih melalui latihan EQ, seperti dinyatakan berikut ini:

Sb3 : Bila saya lalui daripada semalam sehingga ke hari ini, banyak perkaralah saya dapat, seperti macamana kita nak ekspresikan kita punya real emotion yang selama ini kita lihat, kita suka menyembunyikan perasaan itu. Saya dapat rasakan bahawa diri saya ini penuh dengan kasih sayang, saya nak curahkan kepada siapapun saya macam tidak tahu...

Sb10 : Sebenarnya saya bukan orang pandai bercakap, lepas itu tidak boleh ke depan, tapi tadi ada kawan puji dan kata nampak saya ada perubahan. Jadi saya rasa saya ada keyakinan untuk ke hadapan dan pertama sekali bila 
dalam mesyuarat memang saya... dah berapa tahun dah saya bekerja... saya bukanlah guru yang kemukakan idea... saya adalah seorang guru yang bila mesyuarat saya datang mesyuarat, ikut apa yang disuruh kemudian buat... dan tadi bila disuruh buat argument saya rasa macam panik, bila dibahagi saya mic, saya tidak boleh cakap. Jadi di sini dia membina keyakinan saya dan mudah-mudahan saya lebih konfidenlah untuk bercakap.

Perkongsian di atas dikukuhkan lagi oleh Subjek14 yang menyatakan bahawa perubahan yang beliau rasakan adalah, setiap kali beliau nak marah beliau dapat berfikir sekejap dan boleh control kemarahan yang sedang beliau rasakan, seperti dinyatakan di bawah ini:

Sb14 : Apa yang saya dapat daripada program ini... setiap kali... kadang saya marah... setiap kali saya nak marah saya berhenti sekejap teringat pasal EQ lepas itu slow sikit... maknaya saya boleh kontrolah sekarang ini. Contohnya masa saya diminta untuk mengajar... kalau dulu pelajar-pelajar buat saya macam itu... tugang baliklah kelas ini... tapi saya senyum sahaja saya dengar sahaja apa yang dia orang buat. Yes... saya akan apply ini di dalam kehidupan saya.

Perkara kedua yang dikongsikan oleh subjek tentang latihan ini adalah "mereka memperolehi pengetahuan". Seperti dikongsikan oleh subjek 8 yang menyatakan beliau mendapatkan satu pengetahuan baru daripada latihan berkenaan. Subjek 9 pula menyatakan bahawa beliau banyak belajar tentang diri sendiri, dan beliau mendapatkan satu pengalaman bahawa dirinya sebenarnya memiliki kemahiran untuk menggunakan otak beliau secara seimbang antara otak kiri dan otak kanan. Perkongsian tersebut dikukuhkan lagi oleh subjek 1 yang menyatakan bahawa daripada latihan yang diikuti dirinya mendapatkan banyak ilmu baru yang selama ini mungkin kurang disedari keberadaanya. Perkongsian pengalaman mereka seperti dinyatakan pada petikan di bawah ini:

Sb8 : Saya datang ke sini saya dapat satu pengetahuan baru bahawa apa yang saya lakukan itu bukanlah satu kesalahan cumanya pengetahuan berikut yang saya dapatkan adalah saya perlu bijak cara nak meluahkan emosi tersebut,... Jadi itu yang saya dapat... apa yang saya dapat selama ini adalah benar tetapi saya perlu berhemah macamana cara untuk meluahkan emosi tersebut bilah berhadapan dengan orang lain. 
Sb9 : ... Saya banyak belajar tentang diri saya sendiri, selama ini saya ingatkan saya sebagai seorang guru yang hebat, rupa-rupanya tidak hebatpun. When I feel to controll the class yesterday memberikan tamparan yang agak hebat untuk diri saya..., and than saya belajar benda baru juga, rupa-rupanya saya boleh menggunakan kedua-dua belah otak saya, rupa-rupanya saya seorang yang buat kerja secara sistematik yang selama ini saya jenis yang hentam kromo sahaja...

Sb1 : ...dari bengkel ini saya dapat banyak ilmu baru... saya tidak patut malu untuk meluahkan emosi saya tidak kira kepada siapa yang terlibat. Dan juga bengkel ini dapat membantu saya dalam pengurusan emosi...

Perkara ketiga yang dikongsikan oleh subjek tentang latihan ini adalah “memberi kesedaran kepada mereka”. Seperti dinyatakan oleh subjek11 bahawa beliau dapat menyedari keberadaan EQ di dalam dirinya. Subjek 7 pula menyatakan bahawa satu perkara yang beliau rasakan daripada latihan yang beliau ikuti adalah sedar tentang pentingnya kenal dengan diri sendiri. Perkongsian tersebut dikukuhkan lagi oleh subjek1 yang menyatakan bahawa beliau baru sahaja menyedari tentang kesilapan yang beliau lakukan selama ini, iaitu dirinya sering munafik dengan diri sendiri. Perkongsian mereka seperti ditunjukkan di bawah ini:

Sb11 : Sebenarnya saya rasa ciri-ciri EQ itu ada dalam diri saya dan kini saya sedar kepentingan EQ itu buat diri saya, dan saya boleh gunakan ciri-ciri EQ itu untuk meneruskan kerjaya dengan lebih cemerlang lagi.

Sb7 : Apa yang saya dapati daripada latihan ini, sedar tentang pentingnya kenal dengan diri sendiri... bila kita dah tahu tentang itu baru kita boleh kenal ataupun fahan tentang emosi orang lain...

Sb1 : ... Bila masuk bengkel ini saya rasa apa yang sangka sebenarnya silap. Bagi saya orang yang tidak kesah ini tiada perasaan sayang, ...Saya perlu salahkan diri saya, sebab saya terkadang munafik terhadap diri sendiri. Kalau saya suka, saya kata tidak suka, saya macam buat biasa sahaja. Kalau saya marah, saya macam buat tak tahu sahaja. Tapi bila saya masuk latihan EQ ini, saya rasa saya patut luahlah, kalau saya marah saya patut kata marah, kalau saya suka saya patut bagi tahu bahawa saya suka...

Sebenarnya masing-masing subjek telah memberikan pandangan mereka berkaitan dengan latihan EQ yang mereka ikuti. Namun pengkaji tidak melaporkan secara keseluruhan, memandangkan pandangan mereka hampir sama. Perkara-perkara 
yang dilaporkan di atas ungkapan-ungkapan perkongsian yang dinyatakan hampir sama oleh keseluruhan subjek yang mengikuti latihan EQ tersebut.

\subsection{RUMUSAN}

Kajian ini telah berjaya mengenal pasti 11 kompetensi asas EQ yang perlu diberikan latihan kepada guru-guru yang terlibat di dalam kajian ini. Daripada temubual individu dan berkumpulan telah didapati pelbagai kaedah yang dikongsikan oleh pakar dan orang-orang yang berjaya tentang teknik-teknik untuk meningkatkan kompetensi asas tersebut. Daripada analisis dokumen juga telah diperolehi tentang pelaksanaaan latihan yang bersesuian kepada guru-guru yang terlibat dalam kajian ini. Bila bila dirujuk pada ujian yang diberikan setelah latihan dilaksanakan kepada guru-guru yang terlibat, didapati wujudnya peningkatan pada keseluruhan kompetensi berkenaan. Apabila diperhatikan pada maklumbalas yang diberikan oleh guru-guru selepas latihan dilaksanakan, didapati mereka telah memperolehi manfaat daripada latihan yang dijalankan terhadap mereka menggunakan modul EQ yang dibina. 


\section{BAB V}

\section{RUMUSAN DAN IMPLIKASI KAJIAN}

\subsection{PENGENALAN}

Bab ini membentangkan rumusan hasil kajian yang diperolehi pada bab empat, iaitu menyentuh tentang kompetensi EQ yang perlu diberikan intervensi dalam kalangan guru-guru, pandangan pakar dan orang-orang berjaya untuk pembinaan kompetensi tersebut, kaedah yang sesuai digunakan dalam latihan EQ, profil kompetensi EQ guruguru sebelum dan selepas latihan menggunakan modul EQ yang dibina, dan pandangan guru-guru tentang latihan EQ menggunakan modul latihan yang EQ dibina.

\subsection{RUMUSAN HASIL KAJIAN}

Rumusan hasil kajian dilaporkan berdasarkan fasa-fasa kajian ini, iaitu dimulakan dengan ujian keperluan (need analysis) bagi menentukan kompetensi EQ yang perlu diberikan intervensi dalam kalangan guru-guru, diteruskan dengan kajian kes, iaitu temu bual individu dan temu bual berkumpulan untuk melihat pandangan pakar dan orang-orang berjaya dalam pembinaan kompetensi EQ tersebut. Dalam fasa kajian kes juga, dilaporkan hasil analisis dokumen untuk menentukan kaedah yang sesuai digunakan dalam latihan EQ terhadap guru-guru yang terlibat dalam kajian ini. Selanjutnya diikuti dengan proses pembinaan modul, pengujian modul dan melihat pandangan subjek tentang latihan menggunakan modul yang dibina.

Daripada analisis keperluan yang dilakukan, dapatan kajian menunjukkan terdapat 11 kompetensi EQ yang perlu diberikan perhatian untuk diberikan intervensterhadap sub domain kesedaran kendiri (kesedaran emosi, penilaian kendiri yang tepat, 
keyakinan diri dan niat). Dua sub domain regulasi kendiri (kawalan kendiri dan kebolehpercayaan). Satu sub domain motivasi kendiri iaitu dorongan pencapaian. Dua sub domain empati (membantu orang lain dan mengembangkan potensi orang lain). Dua sub domain kemahiran sosial iaitu mempengaruhi orang lain dan pengurusan konflik. Secara keseluruhan 11 sub domain berkenaan memperolehi skor antara 60.00 sehingga 79.89. Menurut Noriah (2008) skor sebegini sememangnya sudah boleh dianggap baik, memandangkan individu ataupun kumpulan yang memperolehinya telahpun memiliki kompetensi berkenaan. Bagaimanapun kompetensi ini masih belum konsisten dalam amalan individu dan kumpulan tersebut. Menurut beliau akan menjadi lebih baik apabila kompetensi ini dapat dipertingkatkan, sehingga lebih membantu dalam mengembangkan potensi individu terbabit.

Pandangan pakar dan orang-orang berjaya untuk pembinaan kompetensi tersebut, didapati wujud kaedah-kaedah tertentu yang dikongsikan oleh subjek untuk meningkatkan masing-masing kompetensi itu. Pertama adalah empat subdomain yang terdapat dalam domain kesedaran kendiri (kesedaran emosi, penilaian kendiri yang tepat, kayakinan diri dan niat). Untuk pembinaan kesedaran emosi dapatan kajian menunjukkan terdapat lima kaedah yang dikongsikan iaitu dengan cara memperbaiki diri sendiri, merefleksi pengalaman-pengalaman hidup yang pernah dilalui, berusaha secara berterusan, berfikir sebelum bertindak dan kembali kepada akidah ataupun keyakinan masing-masing. Memperbaiki diri sendiri di sini merujuk kepada kemahuan seseorang untuk sentiasa memperbaiki dirinya, sentiasa bekerja keras dan proaktif dalam kehidupan. Merefleksi pengalaman lepas pula merujuk kepada kemampuan seseorang untuk menjadikan pengalaman yang pernah dilalui sebagai panduan untuk memuhasabah diri sendiri. Usaha berterusan pula menggambarkan tentang konsistensi seseorang dalam berusaha. Sedangkan berfikir sebelum bertindak menunjukkan ketelitian seseorang dalam melakukan sesuatu tindakan. Dengan perkataan lain individu sebegini sentiasa bertanya kepada hati nurani sebelum mengambil sesatu tindakan. Manakala akidah dan keyakinan pula menunjukkan timbulnya kesedaran kerana yakin dengan keberadaan Yang Maha Tinggi dalam kehidupanya.

Untuk pembinaan penilaian kendiri yang tepat, dapatan kajian menunjukkan terdapat empat kaedah yang dikongsikan oleh subjek iaitu dengan cara menyedari 
peranan diri sendiri dalam satu-satu keadaan. Memberikan ruang kepada orang lain untuk memberikan penilaian tentang diri kita. Selanjutnya dengan cara merefleksi kesilapan yang pernah dilakukan, dan terakhir sekali dengan cara berusaha dengan maksimum dan konsisten, iaitu memberikan tumpuan sepenuhnya terhadap sesuatu tangungjawab yang diamanahkan kepada kita.

Untuk keyakinan diri pula, subjek kajian juga menyatakan empat perkara yang sentiasa mereka lakukan untuk pembinaan keyakinan diri mereka, iaitu sentiasa berfikir positif, persediaan yang sempurna apabila melakukan sesuatu, mesti ada kemahiran yang kukuh tentang sesuatu pekerjaan yang hendak dilakukan dan setiasa berdoa kepada Yang Maha Kuasa agar diberikan keyakinan diri dalam melakukan sesuatu pekerjaan yang diamanahkan. Sedangkan untuk pembinaan niat pula, dapatan kajian menunjukkan tiga perkara penting yang dikongsikan oleh subjek, iaitu sentiasa melihat tugasan sebagai satu amanah dan ibadah daripada Yang Maha Kuasa, sentiasa membersihkan diri daripada unsur-unsur yang tidak baik ataupun menyandarkan sesuatu perkara yang dilakukan kepada Yang Maha Kuasa, dan sentiasa meluruskan niat sebelum memulakan sesuatu tugasan yang diberikan.

Kedua adalah dua subdomain regulasi kendiri (kawalan kendiri dan kebolehpercayaan). Untuk pembinaan kawalan kendiri hasil kajian menunjukkan terdapat empat perkara penting yang dikongsikan oleh subjek kajian iaitu melihat orang lain daripada pespektif diri mereka, sentiasa berfikir secara rasional, sentiasa bersabar dan bertenang dalam menyikapi sesuatu perkara dan keyakinan terhadap agama. Manakala untuk pembinaan kebolehpercayaan pula didapati dua perkara penting yang dikongsikan oleh subjek kajian iaitu sentiasa melakukan sesuatu mengikut yang benar dan sentiasa bersikap jujur dalam melakukan pekerjaan yang diberikan.

Ketiga, adalah satu subdomain motivasi kendiri iaitu dorongan pencapaian. Dalam pembinaan dorongan pencapaian ini terdapat lapan kaedah yang dikongsikan oleh subjek kajian iaitu melihat cabaran sebagai peluang untuk berjaya, perancangan yang baik, disiplin dan istiqamah dalam melakukan pekerjaan, berusaha secara maksimum, belajar daripada keberhasilan orang lain, belajar daripada kegagalan diri 
sendiri, matlamat mesti jelas dan sentiasa melihat kejayaan itu sebagai satu amanah daripada Yang Maha Kuasa yang perlu direbut oleh individu.

Keempat adalah dua subdomain empati (memahamai orang lain dan mengembangkan potensi orang lain). Subjek kajian menyatakan bahawa terdapat tiga perkara yang menyebabkan diri mereka sentiasa peka dengan keadaan orang lain, perkara-perkara tersebut adalah sentiasa mengambil berat tentang keadaan yang dirasakan oleh orang lain, mahu bertolak ansur dan merendahkan ego apabila berhadapan dengan orang lain, dan bersikap fleksibel ataupun mahu menerima orang lain dalam pelbagai keadaan. Sedangkan untuk mengembangkan potensi orang lain pula, dapatan kajian menunjukkan tiga perkara penting yang dikongsikan oleh subjek kajian iaitu sentiasa memberikan sokongan dan galakan kepada orang lain, memberikan peluang kepada orang lain untuk meneroka dan mengembangkan diri mereka serta memberikan kesedaran kepada orang lain berkenaan agar mereka dapat melihat dirinya dengan lebih positif dan boleh berjaya sama seperti orang lain.

Kelima adalah dua subdomain kemahiran sosial (mempengaruhi orang lain dan pengurusan konflik). Untuk mempengaruhi orang lain, hasil kajian mendapati tiga perkara penting yang perlu diperhatikan oleh seseorang iaitu sentiasa membuat orang lain senang terhadap diri kita (make them happy), membina rasa kebersamaan ataupun merapatkan jurang antara diri sendiri dengan orang lain, dan sentiasa memberikan idea beserta sokongan yang kukuh apabila berhadapan dengan orang lain. Terakhir adalah pembinaan cara pengurusan konflik, subjek kajian menyatakan terdapat empat perkara penting yang perlu diperhatikan dalam pengurusan konflik, iaitu mengumpulkan maklumat terlebih dahulu daripada individu ataupun kumpulan yang berkonflik, tidak memihak dalam membantu menyelesaikan konflik tersebut, kembali kepada Agama, dan menunjukkan matlamat dalam organisasi apabila yang berkonflik itu adalah individu-individu dalam satu pasukan.

\subsection{PERBINCANGAN HASIL KAJIAN}

Untuk lebih menarik, perbincangan kajian ini dibuat mengikut sususan objektif dan persoalan kajian, iaitu (i) kompetensi EQ yang perlu diberikan intervensi dalam 
kalangan guru-guru, (ii) pandangan pakar dan orang-orang berjaya untuk pembinaan kompetensi EQ, (iii) kaedah yang sesuai digunakan dalam latihan EQ, (iv) profil kopetensi EQ guru-guru sebelum dan selepas latihan menggunakan modul EQ yang dibina, dan (v) pandangan guru-guru tentang latihan EQ menggunakan modul latihan EQ yang dibina. Masing-masing dapatan dibincangkan dan disokong dengan pelbagai teori dan hasil kajian-kajian lepas yang dilakukan oleh pengkaji-pengkaji sebelumnya.

\subsubsection{Kompetensi Asas EQ Yang Perlu Diberikan Intervensi dalam Kalangan Guru-Guru}

Untuk mendapatkan gambaran tentang kompetensi EQ yang perlu diberikan intervensi dalam kalangan guru-guru yang terlibat dalam kajian ini, analisis keperluan telah dilakukan terlebih dahulu. Analisis keperluan ini sangat penting dilakukan bagi mendapatkan gambaran tentang kesesuaian modul yang dibangunkan, dan seterusnya digunakan dalam latihan untuk membantu meningkatkan kompetensi EQ yang telah dikenal pasti.

Guru merupakan profesyen yang sangat mulia iaitu berperanan untuk memanusiakan manusia. Untuk memanusiakan manusia, guru perlu memiliki ciri-ciri tersendiri yang mungkin tidak sama dengan profesyen lain. Pertama, guru perlu mengusai ilmu dalam bidang kepakaranya dengan cemerlang. Kedua, guru perlu menguasai ilmu dan kemahiran mengenai kaedah yang boleh membuat suasana pengajaran yang lebih berkesan (McNergney dan Herbert 1998; Mohd. Sani 2002; Kamarul Azmi \& Ab. Halim 2008). Justeru, ciri kedua ini mengisyaratkan bahawa untuk menjadi seorang guru yang berkesan, guru perlu kepada ilmu-ilmu kejiwaan ataupun lebih dikenal dengan ilmu psikologi, agar tugas memanusiakan manusia dapat dilaksanakan dengan lebih berkesan. Memandangan perubahan tingkah laku manusia (pelajar) menunjukkan paten yang berbeza mengikut perkembangan zaman, maka individu yang memilih profesion sebagai seorang pendidik sepatutnya sentiasa mengikuti perkembangan ilmu psikologi tersebut, agar peranan mereka dalam memanusiakan manusia tidak terjejas akibat kekurang fahaman mereka dalam memahami pelajar-pelajar mereka. 
Falsafah Pendidikan Negara (FPN) mempunyai ciri-ciri yang lengkap ke arah itu. Menurut FPN guru berkesan adalah guru yang sentiasa berupaya membina keunggulan sahsiah pelajarnya dan keunggulan suasana pengajaran dan pembelajaran. Justeru, guru tidak hanya mementingkan pencapaian akademik pelajar, tetapi mereka perlu mengambil berat terhadap keseimbangan antara pengisian penghayatan Agama dan moral dengan penguasaan kemahiran dalam bidang yang mereka ajarkan (Tajul Arifin \& Nor 'Aini Dan 2002; Kamarul Azmi \& Ab. Halim 2008). Pengetahuan yang diperolehi oleh pelajar, sepatutnya dapat direfleksikan dalam kehidupan seharian mereka dalam bentuk akhlak yang baik, sama ada dengan Sang Penciptanya mahupun dengan persekitaranya. Dengan perkataan lain, semakin banyak ilmu yang diperolehi oleh seseorang, sepatutnya lebih mendekatkan dirinya kepada penciptanya, dan lebih mengenal tujuan hidup mereka di dunia ini. Guru profesional sentiasa bersedia untuk meningkatkan kualiti dan prestasi diri menerusi latihan-latihan profesionalisme perguruan (Tajul Arifin \& Nor 'Aini Dan 2002; Rohaty 2002; Mohd. Sani, Izham \& Jainabee 2008). Justeru, guru yang sentiasa berpijak pada landasan FPN, mereka tidak mudah menggelabah dalam menghadapi perubahan tingkah laku pelajar seperti yang digambarkan sebelum ini.

Matlamat FPN adalah ingin melahirkan insan yang seimbang dari segi Jasmani, Emosi, Rohani dan Intelek. Untuk melahirkan insan seimbang tersebut, tentunya perlu dipersiapkan guru-guru yang boleh membimbing ke arah itu. Peranan guru tidak hanya memindahkan ilmu pengetahuan kepada pelajar sehingga memperolehi pencapaian akademik yang cemerlang, tetapi guru juga bertanggungjawab membimbing pelajar supaya dapat hidup seimbang seperti dicita-citakan FPN tersebut. Justeru, pembinaan guru secara seimbang perlu dilakukan terlebih dahulu untuk mewujudkan cita-cita mulia FPN berkenaan. Rohaty (2002) menggariskan beberapa ciri personaliti yang perlu dimiliki oleh seorang guru untuk membantu mereka mewujudkan cita-cita tersebut, seperti guru mestilah bersikap mesra, boleh humor, memiliki sifat empati, suka belajar, amanah, bertanggungjawab dan mempertahankan etika profesinya.

Wan Mohd Zahid (1993) menyatakan terdapat 8 ciri penting yang perlu dipenuhi oleh guru bagi membantu menjayakan FPN, iaitu peranan guru dalam menjayakan perpaduan rakyat, gaya pengurusan dan kepimpinan yang berkesan, 
perkhidmatan penyayang, empowerment, sistem pengesanan, budaya ilmu, sekolah penyayang dan budaya kecemerlangan. Bila dikaitkan dengan kajian-kajian psikologi (Ary Ginanjar 2005; Goleman 1995,1999; Skovholt \& D'rozario 2000; Mohd Najib 2000; Noriah et al. 2001; Noriah, Syed Najmuddin \& Syafrimen 2003; Noriah \& Siti Rahayah 2003; Zuria \& Noriah 2003, Noriah et al. 2004; Syafrimen 2004; Syed Najmuddin 2005 \& Zurinah 2007; Wan Ashibah 2004) menunjukkan kemahiran guru dalam aspek psikologi, seperti kemahiran EQ perlu dipertingkatkan, bagi memperkukuhkan ciri-ciri tersebut. Kemahiran EQ dimaksudkan adalah seperti kesedaran kendiri, regulasi kendiri, motivasi kendiri, empati dan kemahiran sosial. Sebagai contoh untuk mewujudkan perpaduan serta pengurusan dan kepimpinan yang berkesan guru-guru perlu kepada kesedaran kendiri dan kemahiran sosial yang tinggi, untuk perkhidmatan penyayang guru-guru perlu kepada empati yang tinggi, dan untuk sekolah penyayang dan budaya cemerlang guru-guru perlu memiliki sifat empati dan motivasi kendiri yang tinggi.

Menurut Dadang Hawari (2003) pendidik yang memiliki EQ yang tinggi mampu mengendalikan diri dengan baik, sabar dalam mendidik, tekun, tidak mudah bertindak secara agresif apatah lagi sampai mencederakan pelajar, serta sentiasa berfikiran positif dalam menjalankan tugas pendidikan. Menurut beliau untuk memperolehi EQ yang tinggi individu sepatutnya telah didedahkan semenjak daripada awal lagi, cara yang paling sederhana adalah melalui contoh teladan yang ditunjukkan oleh ibubapa. Ketika memasuki alam persekolahan, murid dan pelajar banyak menghabiskan masa mereka di sekolah, untuk itu guru-guru sepatutnya tidak hanya memindahkan ilmu pengetahuan tetapi juga dapat memberikan contoh teladan yang baik kepada murid-murid dan pelajar-pelajar mereka (Kamarul Azmi \& Ab. Halim 2008; Tajul Ariffin \& Nor'Aini Dan 2002). Justeru, guru yang memiliki EQ tinggi sentiasa dapat mengawal tingkah laku yang dapat merugikan diri sendiri dan juga orang lain (Dadang Hawari 2003; Noriah, Syed Najmuddin \& Syafrimen 2003; Syed Najmuddin 2005).

Al-Ghazali cuba mengelompokan manusia kepada empat kelompok besar, dalam penulisan ini dikaitkan dengan senario sebagai seorang pendidik. Pertama, adalah "guru yang tahu, dan dia tahu kalau dirinya tahu". Menurut Ghazali individu 
seperti ini sememangnya sangat sesuai memilih profesion sebagai guru. Kedua, "guru yang tidak tahu, dan tahu kalau dirinya tidak tahu". Menurut beliau ini adalah menunjukkan personaliti guru yang arif. Guru seperti ini mempunyai peluang untuk menjadi seorang guru yang cemerlang, kerana sentiasa mahu belajar perkara-perkara yang tidak diketahui. Ketiga, guru yang tahu tetapi dia tidak tahu kalau dirinya tahu”. Guru seperti ini perlu diingatkan bahawa dirinya mempunyai potensi yang baik yang boleh dimanfaatkan untuk mendidik dengan lebih berkesan. Guru sebegini kebiasaanya memerlukan sokongan daripada persekitaran agar dapat menggunakan potensi yang dimiliki sepenuhnya. Keempat, "guru yang tidak tahu tetapi dia tidak tahu kalau dirinya tidak tahu" ini adalah kategori guru yang ego yang sentiasa melihat dirinya sebagai seorang yang hebat, tidak mahu menerima pandangan orang lain, dan tidak tahu dengan kekurangan yang terdapat dalam dirinya. Guru pertama dan kedua merupakan ciri-ciri guru yang memiliki EQ yang tinggi. Guru ketiga adalah guru yang telah memiliki ciri EQ tetapi masih memerlukan latihan agar mereka dapat mengenal pasti potensi yang dimiliki dalam dirinya. Sedangkan guru keempat adalah guru yang menunjukkan ciri EQ yang rendah, sekiranya tidak dapat disedarkan, kemungkinan kelompok sebegini kurang dapat memberikan subangan secara maksimum dalam profesion mereka sebagai seorang pendidik (Noriah, Siti Rahayah 2008).

Kajian ini menunjukkan terdapat 11 kompetensi dalam kelima-lima domain EQ seperti yang disebutkan sebelum ini, yang perlu diberikan perhatian untuk diberikan intervensi dalam kalangan guru-guru, memandangkan kompetensi tersebut merupakan kompetensi penting yang mesti dimiliki oleh seorang guru (Abd. Rahman 2002; Kamarul Azmi \& Ab. Halim 2008; Noriah 2004 et al; Tajul Ariffin \& Nor'Aini Dan 2002; Rohaty 2002 \& Wan Mohd Zahid 1993) . 11 kompetensi tersebut adalah kesedaran emosi, penilaian kendiri yang tepat, keyakinan diri, niat, kawalan kendiri, kebolehpercayaan, dorongan pencapaian, memahami orang lain, mengembangkan potensi orang, mempengaruhi orang lain dan pengurusan konflik. Secara umumnya kompetensi EQ tersebut selari dengan himbauan Kementerian Pendidikan Malaysia (2002) dan Kamarul Azmi \& Ab. Halim (2008) iaitu setiap warga pendidik haruslah mempunyai sifat-sifat luhur, bertanggungjawab, dan sentiasa meningkatkan keprofesionalan ke tahap yang lebih tinggi. 
Kompetensi tersebut sejajar dengan etika kerja guru seperti amanah, benar, bijaksana, bersyukur, dedikasi, ikhlas dan penyayang (Abd. Rahman 2002). Amanah merujuk kepada sifat sentiasa bertanggungjawab dalam menjalankan tugas yang diberikan, dan tidak menyalahgunakan kuasa yang diberikan. Benar merujuk kepada sentiasa berniat baik dan jujur dalam menjalankan tugasan, serta mahu menerima dan berkongsi pandangan dengan orang lain. Bijaksana pula merujuk kepada sentiasa menggunakan pemikiran yang bijak dalam membuat keputusan dan tindakan, serta dapat menggunakan seluruh potensi dan kepakaran untuk menjayakan tugasan profesion. Bersyukur pula menggambarkan tentang kemampuan insan guru dalam menghargai segala sesuatu yang diterima, dan mahu memberi pengiktirafan kepada individu lain yang patut menerima penghargaan yang sama seperti dirinya. Dedikasi pula menggambarkan tentang kesiapan guru untuk mengorbankan masa dan tenaga bagi menghasilkan pendidikan yang berkualiti. Sedangkan ikhlas menggambarkan tentang ketulusan guru untuk menghasilkan kerja yang berkualiti tanpa mengharapkan sebarang ganjaran. Manakala penyayang pula menunjukkan sikap yang sentiasa memahami, menghargai, mengambil berat dan tidak berdendam, sama ada dengan pelajar mahupun dengan persekitaran.

Secara tidak langsung dapatan kajian ini menggambarkan masih wujud dalam kalangan guru yang belum mengamalkan sepenuhnya etika kerja profesion perguruan yang menjadi pilihan kerjaya mereka. Pertanyaan yang boleh dimunculkan adalah, apakah yang akan berlaku sekiranya guru kurang menyedari bahawa dirinya adalah sebagai seorang guru? Apakah yang akan berlaku sekiranya guru kurang memiliki keyakinan diri, tidak boleh dipercayai, kurang sensitif dengan keadaan orang lain dan tidak dapat mengembangkan potensi orang lain dengan baik.... dan seterusnya? Kamarul Azmi \& Ab. Halim (2008) menyatakan bahawa guru perlu berusaha meletakan diri mereka pada kedudukan yang lebih baik dan terhormat di kalangan murid, ini kerana guru tersebut merupakan contoh teladan, bukan hanya kepada muridmurid mereka, malah kepada ibu bapa dan masyarakat sekitarannya (Tajul Ariffin \& Nor'Aini Dan 2002).

Dalam mendidik terkadang guru berdepan dengan pelbagai cabaran yang boleh menggugat emosi ataupun perasaan, kemungkinan boleh membawa kesan negatif 
kepada guru dan murid yang mereka didik. Guru yang profesional sepatutnya mereka tidak terlalu hanyut dengan perasaan negatif yang sedang mereka alami, kerana boleh memberikan kesan yang kurang baik kepada diri dan juga pelajarnya. Justeru, untuk mengelakan berlakunya keadaan sedemikian, guru perlu memperkukuhkan kompetensi yang masih pada tahap perlu dipertingkatkan. Dengan perkataan lain, guru-guru sepatutnya tidak perlu merasa enggan untuk memperbaiki keadaan tersebut dengan cara berlatih secara berterusan.

Sekiranya guru tidak dapat menyedari dan menilai dengan baik bahawa dirinya adalah sebagai seorang guru, ini menunjukkan guru tersebut kurang dapat membuat penilaian kendiri yang tepat terhadap dirinya. Akibat daripada ketidakbolehan ini kemungkinan boleh menjejaskan tugas hakiki sebenar guru berkenaan. Guru sepatutnya memahami sepenuhnya bahawa peranan mereka adalah sebagai pendidik (Tajuk Ariffin \& Nor 'Aini Dan 2002; Rohaty 2002; Robiah Sidin 2002). Sebagai pendidik tugas guru bukan hanya sekedar mengajarkan ilmu, pada masa yang sama guru merupakan pendidik kepada ibu bapa, ahli masyarakat dan seluruh rakyat. Justeru jalan keluar yang ditawarkan dalam kajian ini adalah memberikan bimbingan dan latihan secara berterusan kepada guru-guru yang menghadapi masalah sebegini.

Satu perkara penting juga yang perlu dimiliki oleh seorang guru adalah mempunyai dorongan pencapaian yang tinggi, iaitu sentiasa ingin membawa pelajarnya ke tahap cemerlang. Guru tidak sepatutnya terperangkap dengan-kerja-kerja rutin yang membosankan pelajar. Untuk mengelakan diri daripada perkara tersebut, guru perlu sentiasa memikirkan dan mencuba pendekatan baru supaya lebih menarik dan berkesan. Dorongan pencapaian di sini juga dikaitkan dengan kemampuan guru untuk membuat perubahan (self renewal) terhadap dirinya sendiri (Rohaty 2002) agar sentiasa bermotivasi dan tidak membosankan. Guru profesional sepatutnya sentiasa meneroka dan mengemaskini ilmu pegetahuan agar dirinya lebih ke hadapan daripada pelajarnya. Sentiasa meningkatkan pengetahuan dan pengalaman supaya dapat dijadikan panduan untuk mendidik yang lebih berkesan. Sentiasa melibatkan diri dalam aktiviti pembelajaran seperti bengkel, seminar malah melanjutkan pengajian ke peringkat yang lebih tinggi, agar mereka dilihat sebagai seorang model yang cinta 
kepada ilmu pengetahuan oleh pelajar-pelajar mereka (Rohaty 2002; Kamarul Azmi \& Ab. Halim 2008).

Menurut Tajul Ariffin (2008) guru sepatutnya dapat berperanan sebagai seorang ayah ataupun ibu kepada murid-murid mereka. Ini menggambarkan perlunya sifat kasih sayang dimiliki oleh guru tersebut (Kamarul Azmi \& Ab. Halim 2008; Rohaty 2002;). Kasih sayang yang ditunjukkan oleh seorang guru kepada pelajarpelajarnya adalah kasih saya yang tulus, ikhlas sebagaimana mereka memberikan kasih sayang kepada anak-anak mereka sendiri di rumah (Tajul Ariffin 2008). Dengan perkataan lain agak sukar bagi seorang guru untuk menjayakan pendidikan sekiranya mereka tidak memiliki sifat kasih sayang tersebut.

Kajian ini juga mendapati guru-guru yang terlibat dalam kajian ini menunjukkan skor yang agak rendah pada dua subdomain kemahiran sosial, iaitu kompetensi mempengaruhi orang lain dan pengurusan konflik. Dua kompetensi ini merupakan kompetensi yang sangat kritikal bagi seorang guru. Pelajar-pelajar yang datang ke sekolah tentunya daripada pelbagai latar belakang. Kepelbagaian pelajar tersebut menuntut guru-guru memiliki seni yang baik untuk mendekati pelajar-pelajar mereka, agar mereka merasa selesa dengan guru, dan dapat mencurahkan pelbagai permasalahan sekiranya mereka menghadapi sebarang masalah dalam pembelajaran ataupun dalam kehidupan peribadi.

Dapatan tersebut selari dengan pandangan Mennin and Farach (2007), Sloan and Kring (2007), Suveg, Southam-Gerow, Goodman, and Kendall (2007), Zeman, Klimes-Dougan, Cassano, and Adrian (2007) yang menyatakan bahawa kemahiran EQ (kemahiran mempengaruhi orang lain dan pengurusan konflik) merupakan perkara penting yang menunjukkan seseorang itu memiliki EQ yang tinggi. Menurut mereka kemahiran EQ tersebut merupakan satu kemahiran yang holistik yang dapat diperolehi melalui proses pembelajaran, perubahan tingkah laku dan pelbagai pengalaman hidup dalam kehidupan peribadi mahupun sosial. Pandangan lebih kurang sama juga dinyatakan oleh Christine (2007) yang menyatakan bahawa kemahiran sosial merupakan perkara penting yang perlu ada dalam sesebuah pengurusan (pengurus syarikat, pendidik, dan sebagainya). Beliau juga menyatakan bahawa kemahiran 
tersebut boleh dibina, bukan hanya melalui latihan secara formal tetapi juga dapat dipelajari melalui proses dan pengalaman hidup yang dilalui oleh seseorang.

\subsubsection{Pandangan Pakar Dan Orang-Orang Berjaya Dalam Pembinaan Kompetensi Asas EQ}

Dapatan kajian menunjukkan terdapat kaedah-kaedah tertentu yang dinyatakan oleh subjek untuk pembinaan kompetensi EQ yang dikenal pasti melalui analisis keperluan. Hasil temu bual individu mahupun kumpulan menunjukkan satu paten yang dapat dikatakan sebagai satu kaedah yang dilakukan oleh subjek untuk pembinaan kompetensi EQ mereka. Di bawah ini dibincangkan hasil dapatan kajian tersebut dengan pelbagai kajian lain yang telah dilakukan oleh penyelidik-penyelidik dalam bidang yang hampir bersamaan.

\section{(i) Pembinaan Kesedaran Emosi}

Kompetensi pertama yang perlu diberikan intervensi adalah "kesedaran emosi". Kesedaran emosi merujuk kepada keupayaan seseorang untuk mengenal pasti emosi yang wujud dalam dirinya, dan dia dapat mengenal pasti kesan emosi tersebut terhadap dirinya sendiri. Individu ini biasanya sentiasa sedar dan dapat menjangka kesan yang akan terjadi akibat daripada luahan perasaan yang dia lakukan, sama ada terhadap dirinya mahupun orang lain. Individu ini juga sentiasa menjadikan nilai yang terdapat dalam dirinya sebagai panduan untuk menilai emosi sendiri. Skovholt dan D'Rozario (2000), Saadi (2001) menyatakan bahawa guru yang mampu menguasai emosi mereka dapat mewujudkan pembelajaran yang menyenangkan. Justeru guru yang pandai mengurus dan mengawal emosi sendiri, dan memahami perasaan yang bermain dalam dirinya lebih disenangi oleh pelajar (Goleman 1995, 1999).

Menurut Semmel (1986) terkadang seseorang secara tidak sedar sering tidak melayani emosi sendiri. Menurut beliau seseorang yang tidak pandai melayani emosi sendiri dapat dikatakan mengalami kerugian dalam kehidupan mereka, kerana dia tidak dapat memberi makna kepada emosi-emosi yang pernah dilalui (sama ada emosi yang positif nahupun emosi yang negatif). Menurut beliau pengalaman emosi tersebut dapat 
mempengaruhi kehidupan seseorang. Seseorang yang tidak pandai melayani emosi sendiri kemungkinan boleh menimbulkan penyakit fizikal kepada dirinya, kerana ketika seseorang cuba untuk meniadakan emosinya secara psikologis badan sering menjadi mangsa pelayan emosi tersebut, inilah yang menyebabkan badan menjadi sakit.

Semmel (1986) juga menyatakan bahawa menerima emosi, dan memilih cara yang konstruktif untuk memanfaatkan emosi tersebut sememangnya bukan perkara yang mudah. Seseorang perlu berjuang untuk menguasai emosi sendiri. Kemampuan seseorang untuk menguasai emosi sendiri dapat menciptakan hidup yang lebih menyenangkan dan dapat bertindak secara waras dalam menjalankan tugas sebagai insan dan khalifah Allah di bumi ini. Untuk pembinaan kompetensi ini, dapatan kajian menunjukkan terdapat lima perkara penting yang dikongsikan oleh subjek. Perkaraperkara tersebut adalah memperbaiki diri, mengimbas pengalaman lepas, usaha secara berterusan, berfikir sebelum bertindak, dan kembali kepada akidah ataupun keyakinan.

Memperbaiki diri merujuk kepada kemampuan individu untuk sentiasa bekerja keras, proaktif, serta selalu berusaha memperbaiki diri sendiri. Pembinaan kesedaran emosi melalui pendekatan ini yang dimaksudkan adalah individu perlu bekerja keras dan sentiasa berusaha untuk memperbaiki diri terlebih dahulu, sehingga akhirnya mereka mengenal keadaan dirinya sendiri. Dapatan kajian ini selari dengan pandangan Bar-On (2000) yang menyatakan bahawa that EI is learned through life experience. Santoso (2004) juga menyatakan bahawa kecerdasan emosi (EQ) sememangnya tidak berkembang secara semulajadi selari dengan perkembangan umur dan kematangan fizikal seseorang. Justeru kematangan EQ sangat bergantung pada proses latihan dan pendidikan secara berterusan (Cakan \& Altun 2005; Punia 2002; Click 2002; Moriarty \& Buckley 2003). Dadang Hawari (2003) pula menyatakan perkembangan EQ berkait rapat dengan perkembangan personaliti (personality development) dan kematangan personaliti (maturity of personality). Justeru, pengalaman-pengalaman hidup yang dilalui dapat membantu individu menjadi seorang memiliki EQ yang tinggi.

Memperbaiki diri merupakan satu usaha untuk mengetahui diri sendiri, usaha sebegini sebenarnya memberi kesan terhadap kejayaan di tempat kerja dan juga dalam 
kehidupan seseorang (Ainon 2005). Menurut beliau individu yang mempunyai sifat sebegini didapati lebih berjaya dalam kerjaya dan kehidupan mereka. Dengan perkataan lain semakin tinggi tahap kefahaman seseorang terhadap dirinya kemungkinan mereka untuk berjaya adalah lebih besar berbanding dengan orang lain yang tidak dapat mengenal pasti siapakah dirinya sebenar. Ini adalah merupakan salah satu ciri psikologi yang membezakan seseorang yang cepat naik ke tangga kejayaan, sama ada di tempat kerja mahupun dalam kehidupan berbanding dengan orang lain (Longhorn 2004; Fatt 2002; Bennis 2001; Bar-On and Parker 2000; Chen et al. 1998; Dulewicz and Higgs 1998; Goleman 1998).

Sebaliknya individu yang tidak mahu memperbaiki diri dikaitkan dengan individu yang gagal. Kegagalan ini boleh jadi kerana dirinya tidak terbuka terhadap maklum balas yang diberikan oleh orang-orang yang beriteraksi dengan dirinya, terutamanya apabila maklum balas yang diberikan oleh orang lain berbentuk kritikan kepada dirinya. Individu yang mempunyai kesedaran emosi yang tinggi menerima dengan fikiran terbuka dan dapat menjadikan kritikan yang diberikan oleh orang lain tersebut sebagai ingatan terhadap dirinya bagi membuat refleksi kendiri supaya dapat diperbaiki untuk meraih kehidupan yang lebih baik.

Kemampuan subjek yang sentiasa bekerja keras untuk memperbaiki diri seperti ditunjukkan dalam kajian ini sememangnya boleh membawa mereka pada kejayaan. Kejayaan dimaksudkan di sini adalah, kejayaan untuk melihat ke dalam diri sendiri, sehingga dapat menjadi pendorong untuk menciptakan peluang kejayaan dalam kehidupan mereka, sama ada untuk diri sendiri mahupun orang lain (Dulewicz and Higgs 2000; Mandell and Pherwani 2003). Individu yang sentiasa menjadikan pengalaman sebegini untuk memperbaiki diri, sememangnya lebih cenderung untuk memperoleh kejayaan dalam kehidupan (Dulewicz \& Higgs 1998; Weisinger 1998). Kebiasaanya individu seperti ini lebih bijak menilai pengalaman hidup mereka (Jordan et al. 2002), sehingga apabila diberikan peluang untuk memimpin, kecenderungan mereka untuk berjaya adalah lebih tinggi berbanding dengan orang-orang yang tidak mahu membuka diri ataupun menerima pandangan orang lain (Higgs and Rowland, 2002; Prati et al. 2003). Individu sebegini juga mempunyai budaya kerja yang lebih efektif dan mudah menyesuaikan diri dengan persekitarannya. Menurut Nikolaou \& 
Tsaousis (2002), Bar-On et al. (2000) individu sebegini juga memiliki strategi yang mantap kerana sentiasa belajar daripada pengalaman hidup yang pernah dia lalui.

Seperti yang telah dilaporkan sebelum ini dapatan kajian menunjukkan terdapat beberapa perkara yang dilakukan oleh subjek untuk memperbaiki diri mereka, seperti bekerja keras, muhasabah diri, membuka peluang kepada orang lain untuk memberikan pandangan terhadap dirinya dan sebagainya. Perkara-perkara yang dilakukan oleh subjek tersebut selari dengan pandangan Ainon (2005) yang menyatakan beberapa cara yang boleh dilakukan untuk mengenali diri sendiri. Pertama adalah mendengar pandangan orang lain berkenaan dengan diri kita, kerana dengan cara sebegini seseorang dapat menilai dan memperbiki diri sendiri daripada perspektif orang lain. Individu yang memiliki kesedaran emosi yang tinggi selalu peka dengan pandangan orang lain terhadap dirinya. Dia berpandangan bahawa dirinya akan lebih mudah untuk mengenal pasti perkara-perkara yang perlu diperbaiki apabila mendapat maklum balas daripada orang lain. Cara kedua adalah sengaja meminta pandangan orang lain berkaitan dengan diri kita sendiri. Selanjutnya sentiasa berlatih untuk melihat ke dalam diri sebagaimana orang lain melihat diri kita. Cara terakhir adalah dengan cara mendedahkan lebih banyak maklumat tentang diri kita yang kemungkinan selama ini dijadikan rahasia sendiri.

Kedah-kaedah seperti itu sememangnya banyak dikongsikan oleh subjek yang terlibat dalam kajian ini, tanpa mereka sedari kedaan ini banyak memberikan sumbangan kepada kejayaan yang mereka perolehi. Justeru Jamali, Sidani \& Abu-Zaki (2006) mencadangkan bahawa agar pembinaan terhadap cara-cara memperbaiki diri tersebut perlu dilakukan secara berterusan sama ada oleh individu mahupun organisasi. Dalam kajian beliau dinyatakan bahawa:

...EI should be a major focus in training and development efforts at all organizational levels and for both genders. This is particularly true if organizations realize the value of nurturing a critical mass of EI competencies for superior performance. 
Pandangan hampir sama juga dinyatakan oleh Ashkanasy \& Daus (2005) menyatakan bahawa:

...It is also important to popularize the notion that while EI may indeed touch on individual differences, it tends to grow over time and can be improved and harnessed through proper training and development initiatives.

Perkara kedua yang ditunjukkan oleh hasil kajian adalah pembinaan kesedaran emosi dengan cara "mereflek pengalaman lepas". Mereflek pengalaman lepas ini merujuk kepada kemampuan seseorang untuk menjadikan pengalaman sebagai panduan untuk memuhasabah diri. Mereflek pengalaman lepas sememangnya dapat memberikan kesedaran terhadap seseorang yang mahu belajar daripada pengalaman tersebut. Keadaan inilah yang cuba digambarkan oleh Abu Sangkan (2006) yang menyatakan bahawa "Al-Qur'an merupakan lukisan jiwa manusia". Sejarah telah menceritakan bahawa Al-Qur'an diturunkan secara beransur-ansur kepada Muhammad saw. Ini kerana Allah Maha tahu bahawa Al-Qur'an tersebut merupakan perjalanan fitrah jiwa manusia, sehingga mereka dapat lebih mudah mengetahui kebenaranya melalui pelbagai peristiwa yang menjadi penyebab turunya Al-Qur'an tersebut, peristiwa inilah yang disebut dengan pengalaman.

Bukti kejayaan Rasulullah belajar melalui pengalaman telah ditunjukkan dengan melekatnya Al-Qur'an dalam dirinya, malah dalam beberapa hadis diriwayatkan bahawa Al-Qur'an merupakan akhlaknya. Kenapa ini boleh terjadi? Kerana dirinya telah mengalami dan merasakan perkara-perkara yang berkaitan dengan sebab-musabab diturunkan Al-Qur'an kepada dirinya. Inilah yang disebut oleh pakar tafsir dengan istilah asbabun nuzul, yang sifatnya adalah membenarkan dan meluruskan pengalaman yang telah dilalui oleh Rasulullah saw.

Kajian ini juga mendapati bahawa salah satu perkara yang dikongsikan oleh subjek untuk mewujudkan kesedaran emosi adalah sentiasa "belajar daripada pengalaman". Secara tidak langsung sebenarnya mereka telah menyatakan bahawa belajar daripada pengalaman itu merupakan kaedah terbaik bagi diri mereka. Sememangnya cara ini yang ditunjukkan oleh Allah swt untuk mengajar Rasulnya 
Muhammad saw. Rasulullah dikatakan sebagai seorang yang ummi (tidak boleh membaca dan menulis), namun beliau telah menjadi idola umat sehingga ke hari ini (Hart 2005), kerana dirinya mampu menunjukkan yang terbaik, kerana sentiasa belajar melalui pengalaman. Pertanyaannya adalah, kenapa orang-orang seperti ini sering memperolehi kejayaan? Jawapanya adalah kerana mereka sebenarnya telah mengkuti perjalanan fitrah yang ditunjukkan oleh Maha guru yang mengatur alam semesta ini. Seperti yang dinyatakan dalam Surah Al-Furqan, ayat 32 berikut ini.

... mengapa al-Qur'an tidak diturunkan kepadanya sekaligus...?... demikianlah, supaya kami perkuat hatimu denganya... (QS. al-Furqan, ayat 32).

Pengalaman sememangnya merupakan guru yang sangat berharga dalam kehidupan manusia. Covey (2002) memaparkan pelbagai kisah benar dalam bukunya Living The 7 Habitts tentang kejayaan orang-orang yang belajar daripada pengalaman. Salah satu kisah nyata yang sangat menyayat hati diceritakan oleh Covey adalah pengalaman hidup seorang bapa, kaki minum dan mabuk yang akhirnya membawa kehancurkan dalam kerjaya dan kehidupan keluarga mereka. Namun apabila bapa tersebut dapat belajar daripada pengalaman-pengalaman yang membawa pada kehancuran kehidupanya, akhirnya dia dapat bangkit dan berjaya semula. Yang lebih menarik lagi adalah pengalaman yang dilalui bukan hanya dijadikan pengajaran untuk diri sendiri, namun dijadikan peluang untuk dapat membantu orang lain supaya tidak mengalami nasib sama seperti dirinya.

Berman, Evan \& Jonathan ( 2008) juga mendapati dalam kajian mereka bahawa pengurus-pengurus syarikat yang sentiasa belajar daripada pengalaman, sama ada pengalaman yang membawa kepada keberhasilan mahupun pengalaman kegagalan, didapati mempunyai keupayaan yang lebih baik dalam menilai dirinya sendiri dan juga orang lain. Kajian mereka juga menunjukkan bahawa pengurus-pengurus tersebut dapat menilai kekuatan dan kelemahan dirinya dengan baik, serta bijak dalam menangani emosi-emosi negatif yang bergejolak dalam dirinya. Keupayaan pengurus tersebut belajar daripada pengalaman juga memberi kesan terhadap cara mereka menyesuaikan diri, cara mereka berkomunikasi dan membina hubungan dengan orang lain. Justeru mereka menyatakan bahawa; 
...Feedback and mentoring processes are directly associated with increased perceptions of EI, while other practices such as training, selection and policy development are only indirectly associated with perceptions of EI.

Mennin and Farach (2007) dalam kajian beliau menyatakan bahawa seseorang yang belajar daripada pengalaman yang pernah mereka lalui akan melihat hidupnya lebih bermakna, kerana terdapat pelbagai pengetahuan yang tersirat di sebalik pengalaman tersebut.

...This finding is consistent with Teasdale and Barnard's (1993) discussion of implicational meaning, which posits that people have better access to all components of a higher-order meaning structure when they are in the emotional state connected to that structure. It also resonates with cognitive research on mood-dependent memory, which often finds that people more readily access self-generated meaning when in the same emotional state that they were in when they originally constructed it (e.g., Eich, 1995).

Langkah selanjutnya yang dilakukan oleh subjek untuk meningkatkan kesedaran emosi mereka adalah dengan cara "berusaha secara berterusan dan berfikir sebelum bertindak". Usaha secara berterusan menunjukkan kepada ketahanan diri subjek untuk sentiasa berusaha secara konsisten untuk mempelajari dirinya sendiri. Berfikir sebelum bertindak pula menggambarkan tentang kehati-hatian diri dalam melakukan sesuatu. Kehati-hatian, bertindak secara wajar dan sentiasa bertanya kepada hati nurani telah membantu mereka untuk mengetahui siapa diri mereka sebenarnya. Sehingga keadaan ini dapat membantu mereka untuk bertindak lebih wajar dan tidak agresif dalam melakukan tindakan.

Terakhir yang dikongsikan oleh subjek dalam pembinaan kesedaran emosi mereka adalah dengan cara "kembali kepada akidah ataupun keyakinan". Akidah dan keyakinan merujuk pada kesedaran tentang keberadaan Tuhan dalam kehidupan mereka. Seperti dinyatakan oleh subjek: 
... So, usaha tetap usaha tetapi selepas itu sentiasa berdoa, so maknanya menyerahkan sepenuhnya pada Yang Maha Kuasa.

Dapatan ini menunjukkan tentang kecenderungan fitrah jiwa manusia terhadap kekuatan yang berada diluar dirinya. Kekuatan di luar diri di sini merujuk kepada keyakinan seseorang tersebut, keyakinan inilah yang sebut oleh Ary Ginanjar dengan istilah pusat orbit yang terdapat dalam diri seseorang. Pusat orbit tersebut sentiasa menarik dirinya untuk berjalan pada garis kebenaran.

Ary Ginanjar (2005) menyatakan bahawa pusat orbit yang terdapat dalam diri seseorang persis sama dengan susunan Galaksi Bima Sakti, yang dijadikan sebagai garis orbit maha luas yang memiliki daya tarik (gravitasi) yang sangat kuat seperti dinyatakan oleh Newton. Pada Galaksi Bima Sakti terdapat titik tengah yang sentiasa menjangkar dan menarik seluruh benda-benda angkasa dalam jangkauan gravitasinya agar tetap berada pada garis orbitnya, ini adalah untuk tujuan agar berlaku keharmonisan dalam perjalanan alam semesta. Beliau menyatakan bahawa, demikian juga halnya dengan pusat gravitasi jiwa seseorang yang terletak pada pusat jiwa. Pakar-pakar psikologi sering menyebut pusat jiwa tersebut dengan istilah "fikiran bawah sadar", iaitu satu kekuatan dalam diri seseorang yang sentiasa menarik dirinya ke arah titik pusat tersebut. Tititk pusat ini bersifat universal, maknanya berlaku dan menjangkau seluruh umat manusia, siapapun mereka dan apapun jenis pegangan dan keyakinanya, mereka sentiasa tertarik menuju gaya tarik titik pusat itu, Ary Ginanjar menyebutnya dengan istilah "spiritual".

Titik pusat spiritual ini merupakan pusat kekuatan yang mengatur peredaran hidup seseorang. Apabila ada yang mencuba untuk keluar daripada garis orbit tersebut (off line) niscaya akan terjadi reaksi jiwa dan reaksi sosial yang sangat hebat. Sebagai contoh, kita pernah dikejutkan dengan insiden guru mengetuk kepada pelajar dengan kasut sehingga berdarah, pelajar membuli rakan-rakanya sehingga menimbulkan kecederaan, dah bahkan sampai meninggal dunia. Pelbagai reaksi tidak baik telah keluar untuk menantang tindakan guru dan pelajar-pelajar tersebut. Kita juga pernah mendengar oknum guru sebagai pengedar dadah, pelbagai reaksi muncul untuk mengecam perbuat guru tersebut. Apabila ditanya kepada masing-masing peribadi 
yang melakukan perbuatan berkenaan, mereka juga merasa resah dengan perbuatan yang telah mereka lakukan. Ini adalah salah satu contoh kecil orang-orang yang coba keluar daripada garis orbit kehidupannya.

Demikian juga sebaliknya, kita selalu mendengar dan melihat guru-guru yang mendapatkan anugerah cemerlang, bagaimanakah reaksi masyarakat terhadap diri mereka? Walaupun bukan dirinya yang memperolehi kecemerlangan tetapi mereka ikut berbangga dengan guru-guru seperti ini. Pelbagai pujian dan komen positif keluar daripada mulut orang ramai tentang guru tersebut. Ini adalah salah satu contoh kepada orang-orang yang sentiasa berada pada garis orbit, semua orang merasakan kedamaian dan ketenagan dengan perbuatan yang dia lakukan. Secara umumnya sama ada cepat atau lambat manusia akan kembali kepada garis orbitnya semula, tunduk pada kehendak nilai-nilai spiritual yang terdapat dalam dirinya (Ary Ginanjar 2007). Apabila ada individu yang degil untuk keluar daripada garis orbitnya (off line), akan lahir energi gravitasi, energi elektromagnetik dan energi atomik yang akan menghancurkan dirinya akibat kedegilan tersebut, serta mengembalikanya pada garis orbit semula. Inilah yang disebut dengan hukum alam "sunnatullah"

Seseorang yang berjalan pada garis orbit bermakna mereka hidup dalam keteraturan. Sedangkan seseorang yang keluar daripada garis orbit, bermakna mereka hidup dalam keadaan yang tidak seimbang yang akhir boleh membawa padah terhadap diri sendiri dan juga orang lain. Apabila seseorang dapat meletakan dirinya tepat pada posisi garis orbit tersebut, maka ini adalah langkah yang penuh kekuatan dan keseimbangan, dan inilah yang disebut dengan langkah "Ihsan" iaitu kemampuan individu untuk mengikuti dan memanfaatkan energi spiritual pada garis orbitnya. Manusia yang sentiasa berjalan pada garis orbit sentiasa merasa melihat dan dilihat oleh Maha Pencipta. Bila dikaitkan dengan dapatan kajian ini, subjek kajian kembali kepada keyakinan untuk pembinaan kesedaran emosi diri mereka. Seperti yang telah disentuh sebelum ini, individu yang mempunyai kesedaran emosi yang tinggi sentiasa dapat menyedari perubahan emosi yang berlaku dalam dirinya dan dapat menyalurkan emosi tersebut dengan cara-cara yang lebih positif sehingga tidak menimbulkan kesan terhadap dirinya dan juga orang lain. Kenapa mereka berjaya membina kesedaran emosi menggunakan pendekatan ini? Kerana mereka dapat menyedari peranan dirinya 
yang sebenar, dan pertolongan Tuhan sangat dekat dengan orang-orang yang sentiasa mendekatkan diri kepadanya, seperti dinyatakan pada petikan Al-Qur'an di bawah ini:

Siapa yang berpaling daripada peringatan-Ku, maka sesungguhnya baginya kehidupan yang sempit, dan kami akan mengumpulkanya pada hari kiamat dalam keadaan buta (Thaha 20; 124). Maka hadapkanlah wajahmu dengan mantap kepad agama, menurut fitrah Allah yang telah menciptakan fitrah itu pada manusia. Tiada dapat diubah (hukum-hukum) ciptaan Allah. Itulah agama yang benar, tetapi kebanyakan manusia tidak mengetahuinya (Ar-Ruum $30 ; 30)$.

\section{(ii) Pembinaan Penilaian Kendiri Yang Tepat}

Hasil kajian menunjukkan pembinaan penilaian kendiri yang tepat dilakukan melalui empat kaedah iaitu, sedar dengan peranan, memerlukan orang lain, usaha maksimum dan konsisten, dan merefksi kesilapan yang pernah dilakukan. Sedar dengan peranan merujuk menunjukkan tentang kemampuan seseorang untuk menyedari apakah peranan dirinya dalam kehidupan sama ada dalam keluarga, di tempat kerja mahupun dalam kehidupan bermasyarakat. Memerlukan orang lain pula merujuk kepada kemampuan individu untuk membuka peluang kepada orang lain untuk memberikan penilaian terhadap dirinya. Sedangkan usaha maksimum dan konsisten menunjukkan kemampuan individu untuk memberikan tumpuan sepenuhnya terhadap tanggungjawab yang diberikan kepada dirinya. Manakala merefleksi kesilapan merujuk kepada kemahiran seseorang untuk menjadikan kesilapan yang pernah dilakukan untuk menilai kekuatan dan kelemahan yang terdapat dalam dirinya.

Ary Ginanjar (2005) menggunakan istilah ketangguhan peribadi (personal atrength) terhadap istilah "sedar dengan peranan" yang didapati dalam kajian ini. Menurut beliau personal atrength dapat diperolehi oleh seseorang apabila dirinya memiliki prinsip hidup yang kukuh dan jelas. Seseorang dikatakan mempunyai prinsip yang kukuh apabila dirinya tidak mudah terpengaruh dengan persekitaran yang sentiasa berubah dengan pantas. Dirinya tidak menjadi korban daripada perubahan persekitaran yang mungkin dapat merobah prinsip hidup dan cara berfikir seseorang. Seseorang yang memiliki personal strength dapat mengambil satu keputusan yang bijaksana dengan menyelaraskan prinsip yang diyakini dengan keadaan persekitaran, 
dia tidak akan menggadaikan prinsip hidupnya semata-semata hanya ingin nampak dilihat moden oleh sesetengah orang. Individu sebegegini sentiasa dapat mengawal fikiran sendiri apabila berhadapan dengan pelbagai tekanan yang wujud pada persekitaran dirinya.

Dapatan ini juga selari dengan pandangan Danah Zohar \& Ian Marshall (2002) yang menyatakan bahawa penilaian kendiri yang tepat (sedar dengan peranan) merupakan satu ciri tertinggi bagi seseorang untuk mewujudkan kesedaran kendiri yang tinggi. Seseorang yang mempunyai kesedaran kendiri yang tinggi menurut beliau merupakan ciri tertinggi daripada kecerdasan emosi dan kecerdasan spiritual. Menurut beliau satu kelemahan sistem pendidikan di Amerika adalah mulai daripada alam persekolahan individu sentiasa diajarkan untuk melihat keluar daripada dirinya bukanya ke dalam dirinya. Individu sentiasa dibawa untuk memusatkan perhatian pada fakta dan masalah praktis yang bersifat lahiriyah untuk berorientasi pada tujuan tertentu. Pendidikan Barat tidak mendorong individu untuk merenungkan diri sendiri, kehidupan batin, dan motif ataupun tujuan hidup yang sebenar (Danah Zohar \& Ian Marshall 2002). Individu sentiasa didorong untuk mengalirkan daya kritikal tetapi tidak diseimbangkan dengan kekuatan dalaman, sehingga banyak di kalangan mereka mencari perkara-perkara yang bersifat luaran sekiranya mereka menghadapi sebarang masalah dalam kehidupan mereka.

Cooper \& Ayman Sawaf (1998) menyatakan bahawa meluangkan masa selama dua atau tiga minit, dan bangun dari tidur lima minit lebih awal daripada biasanya, kemudian duduk dengan tenang, gunakan indera telinga dan hati, keluarlah daripada fikiran kemudian masuk ke dalam hati, yang paling penting adalah menulis segala sesuatu yang dirasakan. Berdasarkan pemerhatian beliau cara-cara sebegini secara tidak langsung dapat mendatangkan kejujuran emosi dalam diri seseorang. Cara ini juga menurut beliau dapat menghadirkan nilai-nilai kebijaksanaan, dan menghantarkanya seseorang sehingga dapat menggunakan pengalaman tersebut secara efektif. Kemampuan seseorang untuk belajar daripada kesilapan yang pernah dilakukan memberikan "makna" tersendiri dalam kehidupan seseorang tersebut. Justeru menurut beliau, ini adalah salah satu kaedah yang dapat dilakukan oleh seseorang agar dapat melihat dirinya dengan lebih tepat. 
Dalam islam, cara ataupun kaedah yang dicadangkan oleh Cooper \& Ayman Sawaf tadi iaitu kaedah untuk "masuk ke dalam hati dan keluar dari fikiran" dikenal dengan istilah "Solat Khusyu" yang intinya adalah menyelami ke dalam diri untuk menemukan jati diri yang sebenar. Menurut Cooper \& Ayman Sawaf (1998) teknik seperti ini adalah salah satu teknik yang didapati berkesan yang setiasa digunakan oleh Deborah Killey iaitu salah seorang pengurus pada Arthur Andersen and Andersen Consulting (Ary Ginanjar 2005).

Seseorang yang dapat melihat dirinya dengan tepat berdasarkan prisip yang kukuh mempunyai visi yang jelas dalam mewujudkan tujuan hidupnya, tetap fleksibel dan bijaksana dalam menghadapi pelbagai relaliti kehidupan yang nyata. Individu ini tidak hanya mampu melihat dirinya secara bersendirian, tetapi juga mampu keluar dari dalam dirinya untuk melihat dirinya dari luar, sehingga mampu bersikap adil dan terbuka pada dirinya dan juga orang lain. Inilah yang menyebabkan individu ini dapat belajar daripada kesilapan yang pernah dia lakukan, dan mahu berusaha secara maksimum serta konsisten menunjukkan bahawa dirinya mempunyai kekuatan untuk melihat ke dalam dirinya sendiri. Dia juga memerlukan pandangan daripada orang lain untuk memberikan penilaian yang terhadap dirinya, menunjukkan dirinya juga terbuka dengan orang di luar dirinya. Kaedah-kaedah yang ditunjukkan oleh subjek untuk penilaian kendiri mereka, seperti yang didapati dalam kajian ini, rasanya tidak menghairankan kerana sememangnya perkara ini juga merupakan kunci kejayaan yang sentiasa dilakukan oleh kebanyakan orang-orang berjaya (Goleman 1996; Mortiboys 2005; Ary Ginanjar 2005).

\section{(iii) Pembinaan Keyakinan Diri}

Untuk pembinaan keyakinan diri dapatan kajian juga menunjukkan terdapat empat kaedah yang dikongsikan oleh subjek kajian, iaitu berfikir positif, persediaan yang sempurna, kemahiran, dan sentiasa berdoa. Berfikir positif menggambarkan tentang kemahiran individu untuk melihat dirinya daripada pelbagai aspek yang positif, bukanya melihat perkara-perkara yang negatif. Persediaan yang sempurna menggambarkan tentang keupayaan seseorang untuk mempersiapkan segala sesuatu

dengan matang apabila memulakan sesuatu tugasan. Kemahiran merujuk kepada 
persediaan keterampilan yang mantap dalam menjalankan sesuatu pekerjaan yang diamanahkan kepadanya. Manakala berdoa'a pula menggambarkan tentang keyakinan individu terhadap kekuatan yang berada di luar dirinya yang sentiasa membantu dirinya apabila dia memohon secara sungguh-sungguh kepada kekuatan tersebut. Bagaimanapun individu ini berkeyakinan bahawa pertolongan tersebut akan datang apabila dirinya telah melakukan usaha secara maksimum untuk menampakan keyakinan dirinya. Dengan perkataan lain usaha dirinya adalah merupakan perkara yang mustahak, namun dirinya berkeyakinan bahawa usaha tersebut akan menjadi lebih mantap sekiranya selari dengan kehendak yang Maha Kuasa.

Dapatan ini selari dengan pandangan Dawson (1997) yang menyatakan bahawa untuk pembinaan keyakinan diri maka seseorang mesti mengubah dirinya terlebih dahulu. Beliau juga menyatakan apabila seseorang menginginkan perubahan maka mereka mesti mengembangkan sikap hidup yang positif (berfikir positif), menentukan tujuan yang akan mengarahkan hidup mereka dengan lebih baik (Persediaan yang sempurna dan skill), dan menguatkan keyakinan dalam diri sendiri yakin dengan kejayaan (berdoa). Pandangan ini selari juga dengan pandangan Al-Qur'an yang bermaksud;

Sesungguhnya Allah tidak akan merubah nasib suatu kaum kecuali dia sendiri yang akan mengubah dirinya (QS. al Ra'du: 11)

Injil juga menyatakan;

Berubah oleh pembaharuan budimu”.

Tolstoy dlm Taufiq Pasiak (2007) juga menyatakan bahawa banyak orang berfikir bagaimana mengubah dunian ini, tetapi hanya sedikit yang memikirkan bagaimana mengubah diri sendiri. Justeru untuk pembinaan keyakinan diri, seseorang perlu melihat dirinya secara positif, agar dapat mempergunakan segala kekuatan yang dimiliki, seterusnya juga dapat memperbaiki segala kekurangan yang dikenal pasti.

Dapatan ini juga selari dengan pandangan Ainon Mohd (2005) yang menyatakan bahawa untuk meningkatkan keyakinan diri seseorang perlu melihat dirinya secara 
positif dan pandai menghormati diri sendiri. Empat kaedah pembinaan kayakinan diri yang dihasilkan oleh kajian ini, selari dengan beberapa kaedah yang beliau katakan sebagai bukti individu menghormati dirinya sendiri. Menurut beliau individu yang menghoramati diri sendiri adalah: mencari lebih banyak kejayaan walaupun kejayaan itu kecil, menggunakan bahasa yang positif apabila bercakap dengan diri sendiri, sentiasa bercakap dengan nada yang optimis, tidak takut mengambil risiko, sentiasa menambah ilmu pengetahuan, sentiasa belajar kemahiran-kemahiran baru, menghargai dan bangga dengan hasil kerja sendiri, memimpin diri sendiri, sentiasa menggunakan imageri visual positif, dan berpakaian secara rapi dan profesional.

Berfikir positif, persediaan yang sempurna, memiliki kemahiran yang mantap dan sentiasa berdoa kepada Maha Pencipta sememangnya merupakan langkah-langkah yang dapat membawa perubahan kepada diri seseorang. Melalui fikiran positif seseorang yang kurang yakin dengan diri sendiri kemungkinan mearasa yakin, kerana dia melihat pelbagai aspek positif yang terdapat dalam dirinya. Individu yang sentiasa berfikiran positif, sekiranya dia tahu dengan kekurangan dirinya, maka dia akan berusaha untuk membuat persediaan dengan sempurna, persediaan ini akan membuatkan dirinya menjadi lebih mahir dalam sesuatu pekerjaan yang akan dilakukan. Keyakinan berdoa kepada yang Maha Kuasa lebih memperkukuhkan lagi keyakinan diri individu sebegini. Justeru, individu seperti ini sentiasa melakukan perubahan-perubahan positif terhadap dirinya untuk mewujudkan kecemerlangan diri.

Taufiq Pasiak (2007) menyatakan terdapat tiga kecenderungan asas yang menjadi pemicu perubahan dalam diri seseorang. Menurut beliau ketiga-tiga kecenderungan tersebut merupakan cetak birunya dalam diri manusia, iaitu: kecenderungan kepada kebaikan, kesempurnaan, dan kesenangan. Bagi beliau perubahan yang dilakukan oleh seseorang sepatutnya membawa dirinya kepada pemenuhan ketiga-tiga kecenderungan tersebut. Menurutnya tiga hal tersebut mesti diletakkan pada bahagian awal bagi seseorang yang ingin memulakan perubahan dalam dirinya, sehingga ekoran daripada perubahan tersebut dapat melahirkan beberapa perkara iaitu: (i) Happiness iaitu merasa seronok dengan perubahan yang dilakukan, (ii) Achievement adalah setiap tindakan yang dilakukan mestilah merupakan satu pencapaian yang baik, (iii) significance iaitu bagaimana semua perkara yang 
dilakukan terhadap diri sendiri memberikan manafaat kepada orang lain. Dengan perkataan lain dorongan melakukan perubahan untuk diri sendiri, memberikan ilham dan motivasi kepada orang lain untuk melakukan perkara yang sama ataupun lebih baik daripada yang dilakukan, dan (iv) legacy adalah mewariskan sesuatu yang bermakna kepada generasi yang akan datang.

Kaedah-kaedah yang didapati dalam kajian ini tentang pembinaan keyakinan diri merupakan dorongan yang muncul daripada dalam diri seseorang, iaitu dorongan dari dalam ke luar bukanya daripada luar ke dalam. Pembinaan keyakinan diri yang muncul kerana dorongan dari dalam diri sememangnya memberikan kesan yang lebih bermakna berbanding dengan dorongan daripada luaran (Ary Ginanjar 2005). Dorongan pembinaan keyakinan yang datang dari dalam kebiasaanya menjadikan seseorang nampak lebih percaya diri, kerana dia dapat menguasai dirinya dengan baik apabila berhadapan dengan pelbagai keadaan. Menurut Ary Ginanjar (2005) keyakinan diri sebegini timbul kerana prinsip yang kukuh, iaitu ingin memperbaiki diri ke arah yang lebih baik. Seseorang yang memiliki keyakinan diri sebegini kebiasaanya memiliki kepercayaan diri yang kukuh, dan mampu mengendalikan serta menjaga keyakinan yang ada dalam dirinya. Individu sebegini kebiasaanya dapat memberikan perubahan kepada persekitaranya (Ary Ginanjar 2005). Justeru, dirinya tidak terlalu terpengaruh dengan persekitaran yang ada di luar dirinya dalam mewujudkan kejayaan yang dia yakini boleh dicapai.

\section{(iv) Pembinaan Niat}

Dapatan menunjukkan terdapat tiga kaedah yang dikongsikan oleh subjek untuk pembinaan niat dalam diri mereka, kaedah-kaedah tersebut adalah sentiasa melihat tugasan sebagai "amanah dan ibadah". Dalam menjalankan amanah dan ibadah tersebut mereka sentiasa "berserah diri dan sentiasa mempunyai niat yang ikhlas". Amanah dan ibadah merujuk kepada bagaimana seseorang itu melihat tugasan yang diberikan kepadanya, bukan hanya dipertanggungjawabkan di sisi manusia tetapi juga di sisi Yang Maha Melihat. Berserah diri merujuk kepada kemampuan individu untuk menyandarkan setiap tugasan yang dilakukan kepada yang Maha Tinggi. Manakala 
keikhlasan pula merujuk kepada usaha seseorang untuk sentiasa meluruskan niat mereka sebelum memulakan sesuatu tugasan yang diberikan.

Inilah sebenarnya yang disentuh oleh surah Al-Fatihah ayat kelima, yang bermaksud " Hanya kepada-Mu kami mengabdi dan hanya kepada-Mu kami memohon pertolongan". Prinsip mengabdi dan memohon pertolongan adalah menunjukkan ketulusan dan keikhlasan seseorang dalam melakukan sesuatu pekerjaan yang diamanahkan, iaitu prinsip tunggal kepada Yang Maha Esa. Bekerja dengan bersungguh-sungguh dan selalu bersikap jujur. Memiliki komitmen dan selalu konsisten dalam mewujudkan matlamat, dan merasakan bahawa diri selalu dalam pantauan Sang Maha Pencipta. Mempunyai piawai dan pencapain kerja yang tinggi kerana yakin bahawa prinsip tersebut adalah sesuatu yang mesti dijaga dan dipegang. Siap menghadapi pelbagai cabaran dan tantangan sebagai prinsip sentiasa mengejar kemenangan dan kejayaan. Pembinaan niat melalui ketiga-tiga kaedah tersebut selari dengan konsep ayat tersebut (Q.S. al-Fatihah: 5).

Melihat tugasan sebagai satu tanggungjawab adalah merupakan nilai tertinggi dalam kehidupan seseorang (Danah Zohar \& Ian Marshall 2002), pandangan ini selari dengan Hadits Rasullah saw yang bermaksud "Sesungguhnya sesuatu pekerjaan itu diawali dengan niat, dan seseorang akan memperolehi hasil pekerjaanya seperti yang diniatkannya". Menurut Danah Zohar \& Ian Marshall (2002) seseorang sepatutnya sensitif dan sentiasa memanfaatkan bisikan murni yang terdapat dalam dirinya, untuk merespons secara jujur pelbagai situasi yang dihadapi dalam persekitaran. Menurut beliau hanya individu yang dapat memberikan makna terhadap sesuatu yang terjadi kepada dirinya. Justeru, niat baik ataupun sebaliknya dalam melakukan sesuatu hanya individu tersebut yang mengetahuinya.

Pembinaan niat melalui kaedah ikhlas yang ditunjukkan oleh kajian ini juga menggambarkan tentang keredhaan untuk menerima kemungkinan-kemungkinan hasil yang akan diperolehi, kerana telah melakukan tugasan sebagai satu amanah, dan sentiasa berserah diri dalam melakukan tugasan tersebut. Apapun bentuk hasil yang akan diperolehi, diterima dengan hati yang ikhlas. Ini tidak bermakna hanya menyerah kepada takdir ataupun nasib, tetapi sentiasa bekerja secara maksimum dan teliti. 
Sekiranya gagal, sentiasa mempelajari dimanakah punca kegagalan tersebut. Sikap ikhlas sememangnya dapat membantu individu daripada tekanan psikologis yang disebut dengan istilah perfectionist iaitu merasa resah dan tertekan kerana belum tercapainya matlamat yang ditetapkan. Sebenarnya prinsip inilah yang disebut dengan istilah kaizen oleh orang Jepun. Pertanyaanya sekarang adalah, kenapa orang-orang berjaya menggunakan kaedah ini untuk pembinaan niat dalam diri mereka? Kerana sememangnya kaedah ini sebenarnya dirindui oleh seluruh manusia di dunia ini. Orang berjaya bekerja secara sungguh-sungguh kerana melihat pekerjaan sebagai satu perbuatan yang perlu dipertanggungjawabkan. Bekerja dengan niat yang ikhlas, kerana yakin dengan keikhlasam melakukan peluang pertolongan akan datang tanpa disangkasangka. Kemungkinan inilah yang menyebabkan tiga kaedah ini muncul sebagai hasil kajian ini.

\section{(v) Pembinaan Kawalan Kendiri}

Kajian ini mendapati terdapat empat kaedah yang dikongsikan oleh subjek kajian untuk pembinaan kawalan kendiri, iaitu melihat orang lain daripada perspektif mereka, berfikir rasional, sabar dan bertenang, dan keyakinan terhadap agama. Bagaimanapun tiga kaedah pertama merupakan kaedah unggulan bagi subjek yang terlibat dalam kajian ini. kajian ini mendapati walaupun peratusan keyakinan terhadap agama nampak agak kecil (30\%), namun subjek masih melihat berpegang pada agama tersebut juga berperanan dalam membantu mereka dalam mengawal diri. Dengan perkataan lain pengendalian diri mereka menjadi lebih mantap apabila mereka dapat mengambil kira keempat-empat komponen tersebut.

Dalam melaksanakan tugas sebagai guru, banyak perkara yang boleh menggugat emosi. Guru tentunya mempunyai niat yang baik untuk membimbing pelajar-pelajarnya, agar mereka dapat mencapai kejayaan kelak. Bagaimanapun, pelajar yang datang ke sekolah terdiri daripada pelbagai latar belakang, kemungkinan tidak semua dapat mentafsirkan niat baik yang ada dalam fikiran gurunya. Terdapat daalam kalangan pelajar terkadang mempunyai pandangan sinis terhadap guru, memberikan gelaran yang tidak baik, dan bahkan ada yang sampai melawan guru. Keadaan sebegini terkadang boleh menimbulkan hilangnya kawalan kendiri guru yang 
berhadapan dengan pelajar tersebut. Kemungkinan inilah yang menyebabkan pelbagai insiden berlaku di sekolah-sekolah. Walaubagaimanapun, guru yang dapat melihat pelajar daripada perspektif pelajar berkenaan, terkadang berjaya mendekati pelajar seperti ini. Kejayaan itu dikuti dengan kemampuan guru tersebut untuk cuba berfikir secara rasional, kanapa pelajarnya bertingkah laku sedemikian? Dan dia cuba menghadapi pelajar tersebut dengan pendekatan sabar dan bertenang, sehingga guru tersebut dapat menyampaikan mesej dengan cara yang lebih berkesan kepada muridmuridnya. Kalau diperhatikan di sekolah-sekolah, kemungkinan guru-guru seperti ini menjadi guru idola kepada pelajar.

Apabila dikaitkan dengan dapatan kajian ini, kemampuan seseorang untuk dapat melihat orang lain daripada perspektif dirinya, sentiasa berfikir secara rasional sebelum melakukan sesuatu tindakan, sentiasa bertindak dengan sabar dan bertenang, apatah lagi diiringi dengan kayakinan terhadap Agama yang menjadi pegangan mereka, sememangnya menjadikan seseorang dapat bertindak secara waras ataupun dapat mengawal tindakannya. Ini kerana dalam diri seseorang itu telah diberikan potensi emosi yang dapat mendorong dirinya untuk melakukan sesuatu yang kurang baik, dan juga potensi emosi sebaliknya yang dapat mendorong dirinya untuk melakukan sesuatu perbuatan yang baik (Mas Udik Abdullah 2005). Seseorang yang sentiasa mengikuti dorongan emosi ke arah yang baik, inilah yang disebut dengan individu yang memiliki kawalan kendiri yang tinggi. Justeru, individu sebegini sentiasa dapat mengawal dorongan-dorongan emosi negatif yang sebenarnya akan menimbulkan kesan negatif terhadap diri sendiri dan juga orang lain.

Dapatan kajian ini selari dengan pandangan Mas udik Abdullah (2005) menyatakan bahawa pembinaan kawalan kendiri, memang dituntut peranan akal yang sihat dan ketenangan batin seseorang. Menurut beliau terdapat lima kaedah yang dapat membantu mengendalikan diri seseorang, iaitu Bersikap tenang, berfikir sebelum bertindak, memperlakukan orang lain seperti memperlakukan diri sendiri (melihat orang lain daripada perspektif mereka) seperti yang ditunjukkan dalam kajian ini, sabar, dan menundukan hawa nafsu. 
Seseorang yang memiliki sikap tenang memiliki kemampuan berfikir yang jernih sehingga dapat menentukan kesesuaian tindakan yang akan dilakukan. Ia juga dapat menyedari bahawa secara naluriah manusia sama-sama memerlukan kasih sayang. Inilah yang menyebabkan dirinya sentiasa dapat mengawal sesuatu tindakan yang akan dilakukan. Ini juga selari dengan Hadits Rasulullah saw yang bermaksud;

Apabila hendak mengerjakan sesuatu maka fikirkan dulu akibatnya. Apabila baik, kerjakanlah. Apabila buruk, tinggalkanlah" (H.R. Ibnu Mubarak).

Dalam riwayat lain juga dinyatakan yang bermaksud;

Fikirkan terlebih dahulu sebelum mengerjakan sesuatu. Apabila melihat akibatnya baik, maka kerjakanlah, dan apabila kuatir tersesat, maka tahanlah dirimu" (H.R. Abdul Razzaq dari Anas ra).

Memperlakukan orang lain seperti memperlakukan diri sendiri (melihat orang lain daripada perspektif mereka) merupakan salah satu kaedah untuk pembinaan kawalan kendiri yang diperolehi dalam kajian ini. Ini juga selari dengan pandangan Rasulullah seperti yang dinyatakan oleh Thabrani daripada Ibnu Umar yang bermaksud

Bersikap kasih sayang terhadap orang lain merupakan sebahagian daripada Akal" (H.R. Al-Thabrani dari Ibnu Umar).

Menurut beliau salah satu tanda individu yang memiliki emosi yang tinggi adalah apabila dia dapat bersikap kepada orang lain seperti bersikap terhadap dirinya sendiri. Adalah merupakan fitrah manusia agar dirinya dapat diterima dengan baik, difahami dan tidak dizhalimi. Bukhari menyatakan bahawa yang bermaksud;

Tidaklah beriman seseorang diantara kamu, sehingga ia menyukai saudaranya seperti menyukai dirinya sendiri”.

Dalam riwarat lain Bukhari Muslim juga menyatakan;

Orang Islam adalah orang yang menjaga umat islam lainya selamat dari lisan dan tanganya. Dan orang yang berhijrah adalah orang yang meninggalkan segala sesuatu yang dilarang oleh Allah swt”. 
Selanjutnya sabar dan bertenang menggambarkan tentang ketidak gelabahan seseorang dalam mengambil satu tindakan. Sifat menggelabah sering membuat seseorang terlupa. Maksud terlupa adalah kemungkinan seseorang tidak sempat memikirkan kesan negatif daripada tindakan yang dia dilakukan. Ianya perasan setelah melihat kesan daripada tindakan tersebut dilakukan. Sebagai contoh, dulu kita pernah dikejutkan dengan tindakan agresif seorang guru yang mengetuk kepala pelajar dengan tumit kasutnya, sehingga menimbulkan kecederaan kepada pelajar berkenaan. Pertanyaanya adalah, mungkinkah perkara ini dilakukan sekiranya guru itu cuba bertenang dan berfikir sejenak, apakah kesan sekiranya dia mengetuk kepala pelajar dengan kasutnya? Yang terjadi adalah kemungkina guru berkenaan perasan apabila dia melihat kepala muridnya berdarah akibat perbuatanya, dan kemungkinan dia menyesal kerana ibu bapa pelajar tersebut juga tidak senang dengan tindakan yang dilakukan oleh guru itu. Inilah makna daripada hasil kajian ini tentang pembinaan kawalan kendiri melalui kaedah-kaedah yang telah dibincangkan tadi.

\section{(vi) Pembinaan Kebolehpercayaan}

Untuk pembinaan kebolehpercayaan, dapatan kajian menunjukkan terdapat dua kaedah yang dikongsikan oleh subjek, iaitu melakukan sesuatu mengikut yang benar, dan sentiasa jujur dalam melakukan sesuatu. Melakukan sesuatu mengikut yang benar, merujuk kepada kebolehan seseorang untuk melakukan sesuatu tugasan berdasarkan kebenaran, bukanya kerana adanya sesuatu yang diharapkan di sebalik pekerjaan tersebut. Manakala jujur pula menunjukkan ketulusan dan keyakinan seseorang bahawa setiap tugasan yang dilakukan sentiasa dilihat oleh Yang Maha Tinggi.

Kebenaran dan kejujuran merupakan aspek dalaman manusia yang setiasa mendorong dirinya ke arah kebaikan. Semua orang di dunia ini sentiasa menginginkan kebenaran dan kejujuran tersebut. Kajian yang dijalankan oleh Stanley terhadap 733 orang jutawan dunia mendapati bahawa faktor utama yang menyumbang kepada kejayaan mereka adalah selalu memegang prinsip kebenaran dan kejujuran. Seterusnya dikuti oleh beberapa faktor lain, seperti disiplin, membina hubungan baik dengan orang lain, memiliki pasangan yang sentiasa menyokong kerjaya mereka, dan ketekunan bekerja yang berbeza dengan orang lain. Kenapa kebenaran dan kejujuran 
tanpa disedari muncul sebagai penyumbang utama kepada kajayaan mereka? Q.S Thaha: 124 menyatakan:

Siapa yang berpaling daripada peringatan-Ku, maka sesungguhnya baginya kehidupan yang sempit, dan kami akan mengumpulkan mereka pada hari kiamat dalam keadaan buta(QS. Thaha: 124).

Individu yang sentiasa menegakan kebenaran dan kejujuran merupakan individu yang sentiasa berjalan pada garis orbitnya. Seperti yang disentuh sebelum ini, semakin dekat seseorang kepada pusat orbitnya maka semakin tinggi tingkat kejayaan yang akan diperolehi. Jawapan yang tepat adalah kedua-dua faktor tersebut terletak pada pusat orbit manusia.

Hart (2005) telah meletakan nabi Muhammad sebagai tokoh paling berpengaruh sepanjang masa diantara 100 tokoh terkemuka yang dia kaji. Beliau menyatakan kemungkinan orang seluruh dunia bertanya kenapa Nabi Muhammad diletakan pada senarai paling atas dalam kalangan tokoh yang paling berpengaruh sepanjang masa? Hasil penyelidikan beliau mendapati Nabi Muhammad merupakan tokoh yang paling berjaya dalam urusan Agama dan urusan dunia sehingga ke hari ini. Agama yang dibawanya merupakan Agama terbesar di dunia, beliau mampu menyebarkan pengaruhnya ke seluruh pelosok dunia dalam masa yang tidak terlalu lama. Dalam sejarah Islam hanya dalam masa 22 tahun 22 bulan 22 hari, iaitu semenjak dirinya dilantik sebagai Rasulullah sehingga menjelang akhir hayatnya. Dalam urusan dunia beliau berpenampilan sederhana namun sangat disegani bukan hanya oleh orang-orang yang menyenanginya, malah oleh orang-orang yang berseberangan dengan ideologi yang dibawa. Tidak ada yang dapat menandingi beliau dalam urusan politik, ekonomi, kepimpinan, pentadbiran negara dan segala perkara yang berkaitan dengan kehidupan peribadi mahupun kehidupan sosial. Apakah yang membuatkan dirinya disenaraikan sebagai seorang yang paling berpengaruh? Terdapat empat ciri utama yang melekat pada dirinya, iaitu selalu berpegang pada prinsip kebenaran (siddiq), selalu menyampaikan kebenaran kepada orang lain (tabligh), dijuluki sebagai al-Amin kerana sentiasa jujur dalam semua tindakan (amanah), dan memiliki kecerdasan yang tinggi (Fathanah). Orang berjaya dalam kajian ini mencadangkan kaedah yang sama dengan kaedah yang dilakukan oleh Rasulullah, 
justeru kaedah ini sememangnya telah terbukti berjaya digunakan beberapa abad yang lepas, dan sangat relevan sehingga ke hari ini.

\section{(vii) Pembinaan Dorongan Pencapaian}

Dapatan kajian menunjukkan terdapat lapan kaedah yang dikongsikan oleh subjek untuk pembinaan dorongan pencapaian dalam kehidupan mereka. Kelapan-lapan kaedah tersebut adalah melihat cabaran sebagai peluang, perancangan, disiplin dan istiqamah, usaha maksimum, belajar daripada keberhasilan orang lain, belajar daripada kegagalan, matlamat mesti jelas, dan amanah. Bagaimanapun bila dilihat pada kekerapan subjek menggunakan pengalaman tersebut didapati peratusan tertinggi adalah pada komponen melihat cabaran sebagai peluang, dikiuti oleh perancangan, disiplin dan istiqamah, usaha maksimum, belajar daripada keberhasilan orang lain, belajar daripada kegagalan, dan matlamat mesti jelas. Sedangkan amanah merupakan peratusan terendah yang mereka kongsikan. Namun mereka masih melihat sekiranya seseorang melihat kejayaan itu sebagai satu amanah dalam kehidupan dirinya, maka perkara tersebut boleh menjadi pendorong dalam mewujudkan kecemerlangan.

Jika dikaitkan dapatan kajian ini dengan realiti yang berlaku dalam kehidupan, sememangnya kebanyakan dalam kalangan orang-orang berjaya memiliki ciri-ciri tersebut (Ginanjar 2005; Goleman 1999; Ratna Sulistami \& Erlinda Manah Mahdi 2006). Ratna Sulistami \& Erlinda Manah Mahdi (2006) menyebut komponenkomponen itu dengan istilah Trait, Motive, self-concept, dan self-controll yang merupakan bahagian daripada keperibadian seseorang. Kajian-kajian terkini dan juga realiti kehidupan menunjukkan kemahiran seseorang dalam mengurus komponenkomponen berkenaan didapati lebih berjaya dalam pelbagai sisi kehidupan mereka (pendidikan, kerjaya, keluarga, dan juga kehidupan sosial). Realiti inilah yang dibangkitkan oleh Goleman (1995) yang menyatakan bahawa kebanyakan orang-orang berjaya bukanya kerana memiliki IQ yang tinggi tetapi kerana memiliki ciri-ciri yang ditunjukkan oleh dapatan kajian ini, yang dipanggilnya dengan istilah EQ. Seseorang yang mempunyai dorongan pencapaian yang tinggi, sentiasa berupaya menggunakan kehendak hati yang utama untuk mencapai kejayaan (Goleman 1999). Menurut beliau dorongan pencapaian yang dimiliki oleh seseorang dapat membantu dirinya dalam 
mengambil sesuatu kebijakan, dan bersungguh-sungguh untuk memperbaiki diri. Goleman (1999) juga menyatakan bahawa dorongan pencapaian yang dimiliki juga membolehkan individu lebih bijaksana untuk berhadapan dengan pelbagai cabaran yang dihadapi, dengan perkataan lain individu ini dapat menjadikan cabaran tersebut sebagai peluang untuk merebut kejayaan dalam kehidupannya.

Pandangan tersebut dikukuhkan oleh Stolz (2000) yang memperkenalkan istilah Adversity Question iaitu kemampuan seseorang untuk menjadikan cabaran sebagai peluang. Beliau menyatakan kebanyakan orang berjaya adalah kerana dirinya tidak cepat gibab, tidak mudah kalah apabila berhadapan dengan pelbagai cabaran hidup, sebaliknya dapat menarik makna di sebalik cabaran tersebut. Dalam istilah lain juga disebut dengan ketahanan menghadapi pelbagai dugaan, kemahiran seseorang menjadikan cabararan sebagai peluang untuk menciptakan kecemerlangan. Asmawati Desa (2006) juga menyatakan seseorang yang memiliki dorongan pencapaian yang tinggi selalu berkeinginan untuk memenuhi keperluan hidupnya, dan ianya akan lebih bersemangat untuk memotivasikan diirinya apabila melihat kejayaan orang lain.

Garfield, salah seorang penyelidik Barat telah mengkaji ciri-ciri yang dimiliki oleh orang-orang yang memperolehi prestasi tinggi, seperti atlit-atlit peringkat antarabangsa dan calon-calon angkasawan dunia. Kajian beliau mendapati ciri-ciri unik yang dimiliki oleh orang-orang tersebut adalah mereka mempunyai dorongan pencapaian yang sangat tinggi. Ini terbukti pada pemerhatian yang beliau dilakukan tentang cara-cara atlit dan angkasawan tersebut berlatih untuk mewujudkan impian mereka. Beliau mendapati orang-orang tersebut mempunyai cara yang jauh berbeza dengan cara-cara normal seperti yang banyak dilakukan orang-orang yang hanya berprestasi secara normal.

Salah satu kaedah yang diperolehi dalam kajian ini untuk pembinaan dorongan pencapaian adalah dengan cara belajar daripada kegagalan. Kajian dan realiti hari ini semangkin banyak menemukan orang-orang berjaya kerana sentiasa belajar daripada kegagalan yang pernah mereka lakukan, sama ada kegagalan itu oleh diri sendiri mahupun kegagalan yang disebabkan oleh faktor-faktor lain. Dapatan ini selari dengan pandangan Krishna (2006) yang menyatakan bahawa dorongan pencapaian yang 
dimiliki oleh seseorang juga tercermin pada penerimaanya terhadap kegagalan dan kekecewaan yang pernah diperolehi. Menurut beliau bangsa-bangsa besar di dunia hari ini adalah kerana mereka memiliki dorongan pencapaian yang tinggi, dan setiasa menjunjung tinggi nilai-nilai yang dipegang oleh bangsa tersebut. Mustahil seseorang memperolehi kejayaan yang menyerlah sekiranya tidak mempunyai dorongan pencapaian yang tinggi. Justeru, individu sebegini selalu dikaitkan dengan prestasi cemerlang, mempunyai daya kreativiti yang tinggi untuk menjadikan kegagal tersebut sebagai guru yang amat berharga untuk menciptakan peluang kejayaan di masa hadapan (Boyartzit 2000; Gorge 2000; Bedwell 2001; McClelland 2007).

\section{(viii) Pembinaan Cara Memahami Orang Lain}

Dapatan kajian menunjukkan terdapat tiga kaedah yang dikongsikan oleh subjek untuk dapat memahami orang lain, iaitu mengambil berat, bertolak ansur dan merendahkan ego, serta fleksibel. Mengambil berat merujuk kepada kemampuan individu untuk merasakan keadaan yang dirasakan oleh orang lain seperti apa yang mereka rasakan. Sedangkan bertolak ansur dan merendahkan ego pula merujuk kepada kebolehan individu untuk mengalah demi menghargai perasaan orang lain. Manakala fleksibel pula merujuk kepada kesanggupan untuk menerima orang lain dalam pelbagai keadaan.

Mengambil berat keadaan orang lain sememangnya merupakan asas bagi seseorang untuk dapat memahami orang lain. Mustahil bagi seseorang dapat merasakan apa yang diarasakan oleh orang lain sekiranya dia tidak dapat mengambil berat tentang orang tersebut. Mengambil berat bukan hanya sekadar dapat merasakan apa yang dirasakan oleh orang lain, tetapi cuba melakukan sesuatu untuk membantu orang tersebut daripada permasalahan yang sedang dihadapi sesuai dengan kemampuan diri sendiri. Seseorang yang memiliki sifat mengambil berat tentang keadaan orang lain, dia berusaha mencari jalan penyelesaian walaupun terkadang perlu melibatkan orang-orang di luar dirinya. Ini selari dengan pandangan Goleman (1999) yang menyatakan bahawa seseorang yang mempunyai sifat mengambil berat dalam dirinya mempunyai kepekaan yang tinggi terhadap persekitaran sosial, dan dia dapat mentafsir dengan tepat situasi yang berlaku pada persekitaran tersebut. Individu ini 
tidak berhenti sampai disini, malah cuba melihat peluang apakah yang boleh disumbangkan terhadap persekitaran tersebut sekiranya ada sesuatu yang perlu diperbetulkan. Bila dikaitkan dengan profesion sebagai seorang guru, mengambil berat tentang keadaan orang lain sebenarnya merupakan asas yang sangat penting untuk menjadikan guru tersebut menjadi seorang guru yang berkesan (Chernis 1998; Corey, Corey \& Callahan 2003; Goleman 1999; Katzenbach 2000; Muhibbin Syah 1995; Tajudin Ninggal 2003; Shahbani 2005).

Kajian yang dijalankan Taufiq Pasiak (2007) mendapati bahawa seseorang yang sentiasa mengambil berat orang lain, menjadikan hatinya lebih baik dan lebih sensitif dengan keadaan orang lain. Menurut beliau dari segi kesihatan juga didapati individu sebegini lebih sihat berbanding dengan individu yang kurang sensitif dengan keadaan orang lain, individu yang hanya sibuk memikirkan diri sendiri dan tidak peduli dengan persekitaran. Kenapa perkara ini boleh berlaku? Kajian beliau mendapati individu yang sensitif dengan keadaan orang lain sentiasa memperbaiki diri mereka terlebih dahulu sebelum mengulurkan bantuanya kepada orang lain. Dia dilihat sebagai seorang yang mempunyai nilai tinggi oleh persekitaranya. Nilai tersebut merupakan obat yang paling hebat untuk meningkatkan kekebalan pada tubuh seseorang. Keadaan inilah yang menyumbang terhadap kesihatan mereka. Realiti kehidupan sememangnya menunjukkan sekiranya seseorang merasa tidak bernilai ataupun tidak berguna dalam persekitaranya. Keadaan ini kemungkinan boleh menimbulkan rasa tertekan pada diri seseorang. Apabila seseorang selalu dalam keadaan tertekan maka penyakit lain mudah menyerang (Taufiq Pasiak 2007; Zinah Ahmad \& Hamdan Mohd. Ali 2006).

Jika dikaitkan dengan pandangan Islam mengambil berat tentang keadaan orang lain sememangnya dinilai sebagai perbuatan yang sangat baik dan boleh mendatangkan pertolongan Sang Khaliq terhadap individu yang memiliki sifat tersebut. Seperti dinyatakan dalam al-Qur'an yang bermaksud:

Sesiapa yang menolong Agama Allah maka Allah akan menolong mereka. 
Orang-orang yang menolong Agama Allah yang dimaksudkan oleh ayat ini adalah termasuk orang yang mengambil berat tentang urusan hamba-hamba Allah yang bertugas sebagai khalifah di muka bumi ini. Jikalau Allah menghendaki, sesuatu yang tidak terfikirkan oleh akal kita boleh sahaja terjadi, kerana Dia Yang Maha tahu, dan Dia Boleh melakukan sesuatu mengikut kehendaknya, yang kemungkina tidak terjangkau oleh akal fikiran manusia.

Selanjutnya bertolak ansur dan merendahkan ego juga didapati membantu seseorang untuk memahami orang lain. Individu yang selalu melihat dirinya lebih daripada orang lain, ataupun sering dikatakan sebagai individu yang egois, dalam realiti kehidupan sememangnya sering dilihat kurang sensitif ataupun kurang peka dengan keadaan orang lain. Individu sebegini biasanya mempunyai hati yang keras, berat bagi dirinya untuk berada pada posisi yang sejajar dengan orang lain, apatah lagi pada posisi di bawah orang lain. Dia merasakan dirinya lebih hebat, lebih berkeupayaan berbanding dengan orang lain. Keadaan ini yang menjadikan dirinya sukar untuk memahami apa yang dirasakan oleh orang lain. Ciri individu yang mudah bertolak ansur dan merendahkan ego selalunya mudah memberikan penghargaan kepada orang lain, memberikan perhatian yang tulus, mau mendengarkan orang lain apabila bercerita tentang dirinya, sentiasa membuat orang lain penting di hadapanya, mudah meminta maaf apabila merasa bersalah, ringan lidahnya untuk mengucapkan terima kasih kepada orang lain, mudah memberikan pujian kepada orang lain, dan sentiasa berusaha memahami perasaan orang lain (Ary Ginanjar 2005). Individu yang memiliki ciri-ciri seperti ini tentunya sangat mudah memahami orang lain, kerana dia melihat orang lain sangat berharga di hadapannya, menyayangi orang lain sama seperti menyayangi diri sendiri.

Individu yang mudah bertolak ansur dan merendahkan ego kebiasaanya memiliki prinsip sentiasa memberi dan mengawali (Ary Ginanjar 2005). Prinsip memberi dan mengawali merupakan prinsip Bismillah. Kalau diperhatikan dalam AlQur'an semua awal-awal surah diawali dengan bismillahirrahmanirrahiim. Kalimat ini bermaksud "dengan nama Allah yang Maha pengasih lagi Maha penyayang" Pengasih dan penyayangnya Allah tidak ada dapat menandingi, Allah tidak hanya mengasihi dan menyayangi umat Islam tetapi Allah mengasihi semua makhluk ciptaanya. Dengan 
perkataan lain tidak pilih kasih. Kasih dan sayang Allah adalah kasih dan sayang yang tulus, ikhlas yang tiada tandingnya, dan tidak pernah meminta dibalasi kasih sayang yang diberikan. Inilah yang dimaksudkan dengan prinsp Bismillah iatu prinsip sentiasa memberi dan memulakan. Kenapa orang-orang yang memegang pripsip ini memperolehi kejayaan?. Disedari ataupun tidak sememangnya Allah telah menjanjikan bahawa Dia akan membalasi setiap perbuatan yang dilakukan oleh hamba-hambanya. Seperti dinyatakan berikut ini:

... maka barangsiapa yang melakukan kebaikan walaupun sebesar biji Zarah, Ia pasti akan melihatnya! Dan barang siapa melakukan kejahatan walaupun sebesar biji Zarah, Ia juga pasti akan melihatnya (QS. al-Zalzalah: 7-8).

Kemungkinan perkara inilah yang membantu kejayaan orang-orang yang terlibat dalam kajian ini, sehingga secara tidak langsung mereka menyatakan bahawa bertolak ansur dan merendahlan ego sangat membantu mereka untuk memahami orang lain.

Kaedah terakhir yang didapati dalam kajian ini untuk pembinaan memahami orang lain adalah fleksibel, iaitu kesediaan seseorang untuk menerima orang lain dalam pelbagai keadaan. Dalam istilah lain sering juga disebut menerima orang lain tanpa syarat. Dalam realiti kehidupan sememangnya dapat dibuktikan bahawa seseorang yang dapat menerima orang lain tanpa syarat, sangat mudah untuk memahami keadaan orang lain, kerana individu sebegini melihat orang lain bukan menurut ukuran dirinya tetapi dia cuba memahami orang lain mengikut keadaan orang tersebut. Inilah yang menyebabkan dirinya sangat mudah untuk memahami orang lain. Ini selari dengan pandangan Goleman (1999) yang menyatakan bahawa individu yang memiliki sifat fleksibel berkebolehan untuk mengesan perasaan orang lain daripada perspektif orang tersebut. Menunjukkan minat yang mendalam terhadap kehendak dan masalah yang dihadapi oleh orang lain. Menurut beliau individu ini sangat sensitif terhadap tingkah laku yang ditunjukkan oleh seseorang, dan berminat mendengarkan pelbagai masalah yang dicurahkan seseorang kepadanya. 


\section{(ix) Pembinaan Cara Mengembangkan Potensi Orang Lain}

Dapatan menunjukkan terdapat tiga kaedah yang dikongsikan oleh responden dalam pembinaan mengembangkan potensi orang lain iaitu beri sokongan dan galakan, memberikan peluang, dan memberikan kesedaran. Memberi sokongan merujuk kepada kemampuan individu untuk memberikan dorongan, peneguhan dan meraikan potensi yang dimiliki oleh seseorang. Sedangkan memberi peluang pula merujuk kepada kemampuan individu untuk mencarikan peluang ataupun jalan kepada orang lain untuk mengembangkan potensi yang ada pada dirinya. Manakala memberi kesedaran pula merujuk kepada kemampuan seseorang dalam memberikan kesedaran kepada orang lain untuk menyatakan bahawa orang tersebut mempunyai potensi untuk pergi lebih jauh daripada apa yang didapatkan sekarang ini.

Dapatan ini selari dengan pandangan Goleman, Boyatzis \& McKee 2002 yang menyatakan bahawa untuk mengembangkan potensi orang lain sememangnya digalakan bagi individu untuk memberikan sokongan dan galakan terhadap individu yang hendak dibantu. Menurut mereka yang memiliki kemahiran memberikan sokongan dan galakan kepada orang lain, mampu mengesan keperluan dan potensi yang dapat dikembangkan pada orang lain tersebut. Individu ini memiliki cara tersendiri untuk memberikan ganjaran atas kekuatan dan pencapaian orang lain berkenaan. Ciri yang unik pada individu ini boleh menjadi pembimbing kepada orang lain, sentiasa menawarkan tugas yang mencabar kepada seseorang bagi tujuan membentuk dan mengembangkan kemahiran individu berkenaan.

Individu yang sentiasa melihat kepentingan mengembangkan potensi orang lain ini berprinsip bahawa kejayaan yang diperolehi oleh seseorang sekiranya tidak memberikan pengaruh kepada orang lain, maka individu tersebut belumlah dianggap berjaya. Dengan perkataan lain, individu yang berjaya adalah individu yang dapat membantu orang lain berjaya bersama-sama dengan dirinya, inilah yang disebut dalam konsep Islam sebagai "Rahmatan Lil 'Aalamin" iaitu satu prinsip kecemerlangan untuk semua orang. Individu yang memiliki prinsip ini, merasa resah sekiranya orang-orang di sekitarnya tidak dapat dia bantu untuk memperolahi kecemerlangan secara bersamasama. Inilah yang dimaksudkan oleh Q.S. al-Qashas: 84 yang bermaksud; 
Sesiapa yang membawa kebaikan, pahalanya adalah lebih baik daripada kebaikan yang dia lakukan...(QS. al-Qashas: 84 )

Kajian Gardner mendapati hasil pemikiran secara berkumpulan jauh lebih baik daripada hasil pemikiran secara bersendirian. Beliau membuktikan kajian ini melalui eksperimen melalui belajar secara berkumpulan dalam satu mata kuliah. Hasil kajian membuktikan bahawa hasil kerja berkumpulan adalah lebih baik berbanding kerja sendirian. Menurut beliau kerja secara berkumpulan bukan hanya berpengaruh kepada skor yang diperolehi oleh pelajar, tetapi juga membawa kebaikan kepada cara berkomunikasi dan berinteraksi dalam kalangan pelajar tersebut. Dalam kerja secara berkumpulan masing-masing individu akan menyumbangkan fikiran untuk kumpulan tersebut. Setiap fikiran yang disampaikan kemungkinan melihat satu-satun isu daripada perspektif yang berbeza, sehingga melahirkan kepelbagaian pandangan dalam kumpulan berkenaan. Kepelbagaian yang ditunjukkan oleh masing-masing ahli dalam kumpulan, secara tidak langsung merupakan wadah latihan bagi individu untuk menghargai pandangan orang lain. Menghargai pandangan orang lain bermakna meraikan, menyokong dan memberikan galalakan serta memberikan peluang kepada orang tersebut untuk memberikan pandangan mereka pada isu-isu yang lain. Inilah persamaan pandangan Gardner tersebut dengan dapatn kajian ini.

Memberikan peluang kepada orang lain juga merupakan satu kaedah yang dikongsikan oleh subjek untuk mengembangkan potensi orang lain. Memberikan peluang kepada orang lain secara tidak langsung telah memberikan keyakinan kepada orang tersebut untuk membuktikan kebolehan yang dia miliki. Seseorang yang diberikan peluang untuk bertanggungjawab terhadap sesebuah pekerjaan, cara penerimaan dan cara mereka melaksanakan pekerjaan tersebut akan berbeza daripada mereka bekerja di bawah kawalan orang lain. Secara tidak langsung cara seperti ini merupakan kaedah untuk mengembangkan potensi orang lain. Menurut Gray (2001) memberikan peluang kepada orang lain untuk mencuba sesuatu bagi tujuan mengembangkan potensi diri mereka sebenarnya merupakan tanggungjawab bagi setiap orang. Bagi beliau apabila seseorang merasakan bahawa mengembangkan potensi orang lain merupakan tanggungjawab, maka dirinya akan merasa bangga dan bahagia melihat orang lain berjaya. Justeru, individu sebegini lebih bahagia melihat orang lain bahagia dan berjaya. 
Apabila seseorang bahagia melihat kejayaan yang diperolehi oleh orang lain, kebahagiaan itu sebenarnya adalah kebahagiaan dirinya sendiri kerana individu ini melihat orang lain adalah bahagian daripada dirinya yang mesti dibantu sebagaimana membantu dirinya sendiri (Gray 2001). Menurut beliau kejayaan peribadi adalah rasa bahagia yang dimiliki oleh seseorang, dan berkuasa dalam proses melaksanakan sesuatu perkara yang ingin dilakukan. Berkuasa dalam proses melakukan perkara yang ingin dilakukan bukan bermakna hidup tanpa aturan, maknanya di sini adalah bertindak berdasarkan prinsip kebenaran. Justeru, apabila seseorang memberikan peluang kepada orang lain untuk membantu mengembangkan potensi dirinya sebenarnya dia telah memberikan kebahagiaan kepada dirinya sendiri, kerana ini merupakan fitrah semula jadi manusia.

Kaedah ketiga yang didapati oleh kajian ini untuk mengembangkan potensi orang lain adalah dengan cara memberikan kesedaran. Seperti yang telah disentuh pada bahagian awal bab ini, al-Ghazali telah mengelompokan manusia kepada empat kelompok besar, salah satunya adalah "kelompok orang yang tahu, tetapi dia tidak tahu bahawa dirinya tahu". Dalam relaliti kehidupan sememangnya sering dilihat kelompok orang seperti ini. Orang seperti ini memerlukan orang lain untuk mengingatkan mereka, kerana dia tidak menyedari bahawa dirinya mempunyai potensi untuk berkembang lebih baik daripada apa yang telah dia perolehi. Menurut Goleman (1999) individu seperti ini dikaitkan dengan individu yang rendah kesedaran kendiri ataupun kurang memiliki kreativiti untuk menilai kekuatan dan kelemahan diri sendiri. Justeru, individu sebegini memerlukan ingatan daripada orang lain untuk memberikan kesedaran kepada dirinya supaya dia dapat melihat semula potensi yang dimiliki dalam dirinya.

Dalam Islam kaedah ini menjadi unggulan Rasulullah saw untuk membina umatnya sama-sama menuju kecemerlangan. Seperti dinyatakan dalam Q.S. Ali-Imran: 104 yang bermaksud

Dan hendaklah diatara kamu ada segolongan orang yang menyeru kepada kebajikan, menyuruh kepada yang ma'ruf dan mencegah dari yang mungkar, dan mereka itulah orang-orang yang beruntung(QS. Ali Imran: 104). 
Menyeru kepada kebajikan dimaksudkan oleh ayat ini adalah termasuk memberikan ingatan kepada orang-orang yang tidak dapat melihat potensi dirinya dengan baik. Individu yang menggunakan pendektan ini dikaitkan dengan keberuntungan. Keberuntungan dimaksudkan adalah kecemerlangan kejayaan individu tersebut mengingatkan semula individu yang selama ini kurang melihat potensi yang dimiliki dalam dirinya. Ketiga-tiga kaedah yang didapati dalam kajian ini sememangnya selari dengan langkah-langkah yang dilakukan oleh orang-orang yang berjaya membantu mengembangkan potensi orang lain.

\section{(x) Pembinaan Cara Mempengaruhi Orang Lain}

Hasil kajian mendapati terdapat tiga kaedah yang dikongsikan oleh subjek untuk mempengaruhi orang lain, iaitu make them happy dan menyenangkan, membina rasa kebersamaan, dan berikan idea beserta sokongan. Make them happy dan menyenangkan merujuk kepada kemampuan individu untuk membuat orang lain menjadi bahagia dan senang dengan dirinya. Sedangkan membina rasa kebersamaan merujuk kepada kemampuan individu untuk menunjukkan rasa kebersamaan, dan mampu merapatkan jurang antara diri sendiri dengan orang lain. Manakala memberikan idea beserta sokongan merujuk kepada kemampuan individu dalam memberikan hujah dan logik yang meyakinkan apabila menyampaikan idea kepada orang lain.

Menurut Goleman (1999) mempegaruhi orang lain merupakan asas bagi seseorang untuk membina hubungan sosial. Individu yang memiliki kemahiran sosial yang tinggi dapat membaca persekitaranya dengan baik, dan mampu mencetuskan pelbagai respons yang sesuai dengan keperluan persekitaran tersebut, menerusi kemahiran ataupun teknik-teknik mempengaruhi yang dimiliki. Individu sebegini pandai menggunakan pelbagai taktik yang efektif untuk membujuk orang lain, memiliki cara yang berkesan dalam menyampaikan idea, sehingga dapat menarik minat orang lain terhadap idea yang disampaikan. Individu ini juga pandai menggunakan strategi yang pelbagai untuk membina konsensus dan sokongan, serta mencetus suasana yang dramatik untuk menonjolkan idea yang ingin dikongsikan dengan seseorang. 
Membuat orang lain merasa senang dan gembira sememangnya memudahkan seseorang untuk mempengaruhi orang lain. Apabila seseorang merasa senang dan gembira dengan diri kita akan memudahkan kita untuk menyampaikan sesuatu idea yang perlu dikongsikan dengan orang tersebut (Goleman 1999). Menurut beliau salah satu kemahiran EQ adalah kemampuan seseorang untuk memahami keadaan orang lain. Sekiranya seseorang mahu jujur dengan suara hatinya, kunci EQ adalah pada suara hati tersebut. Suara hati yang murni sememangnya menginginkan orang lain sentiasa merasa senang dan gembira daripada setiap tindakan yang dilakukan. Justeru, orang-orang yang mengikuti suara hati tersebut memudahkan dirinya untuk mempengaruhi orang lain. Inilah yang dimaksudkan oleh Q.S. Al-'Alaq yang bermaksud:

Bacalah dengan menyebut nama Tuhan-mu yang meciptakan. Dia telah menciptakan manusia daripada segumpal darah. Bacalah dan Tuhanmu yang Maha pemurah.Yang menjarkan manusia perkara-perkara yang tidak diketahuinya (QS. al-Alaq: 1-5)

Setiap orang menginginkan supaya orang lain melakukan sesuatu yang menyenangkan untuk dirinya, untuk itu seseorang perlu pandai membaca pelbagai perkara yang boleh membuatkan orang lain menjadi senang.

Goleman (2007) menyatakan seseorang yang pandai menyenangkan hati orang lain dapat mengubah persepsi negatif terhadap dirinya menjadi persepsi positif yang menyebabkan dirinya dapat diterima oleh orang lain tersebut. Dalam relaliti kehidupan, apabila seseorang mempunyai seseatu idea yang ingin dikongsikan dengan orang lain, kemungkinan wujud pelbagai reaksi orang lain dalam menerima idea tersebut sebagai satu idea yang baik. Individu yang melontarkan ideanya kemungkinan akan mendapatkan maklum balas negatif yang boleh mencabar dirinya ataupun sebaliknya. Bagaimanapun, individu yang pandai menyenangkan hati orang lain, dia tidak akan membalas maklum balas negatif tersebut dengan balasan yang sama, tetapi dia boleh menjadikan persepsi negatif tersebut untuk membuat orang lain dapat menerima idea yang ingin dia kongsikan. Kemampuan seseorang untuk membuat orang lain menjadi senang, Goleman menyebutnya dengan istilah social intelligence iaitu kepekaan individu untuk menjadikan orang lain merasa senang dengan dirinya. 
Bagi beliau terdapat dua perkara penting yang perlu diperhatikan dalam mempengaruhi orang lain, iaitu kesedaran sosial dan fasiliti sosial. Kesedaran sosial menggambarkan tentang apa yang dirasakan oleh seseorang tentang orang lain, dan fasiliti sosial pula menggambarkan tentang apa yang perlu dilakukan dengan kesedaran terhadap orang lain tersebut. Justeru, individu yang memiliki kemahiran ini sangat mudah bagi mereka untuk mempengaruhi orang lain, kerana orang merasa selesa dengan pendekatan yang dia lakukan.

Goleman (2007) juga menyatakan bahawa membuat orang lain senang dan bahagia, secara tidak langsung seseorang telah melayani dengan baik kehandak hati orang lain. Covey (2001) menamakan istilah ini dengan berusaha mengerti orang lain terlebih dahulu baru minta orang lain mengerti dengan diri kita. Menurut Covey ini merupakan prinsip pertama dalam membangunkan kemahiran sosial (mempengaruhi orang lain). Goleman (2007) menyatakan kemampuan ini adalah merupakan kemampuan yang dimiliki oleh orang-orang yang didapati lebih menonjol dalam memimpin sesebuah organisasi berbanding dengan orang yang tidak memiliki kemahiran sedemikian. Individu seperti ini sentiasa meluangkan masa untuk melayani perasaan orang lain terlebih dahulu sebelum dirinya menyatakan hasratnya kepada orang lain tersebut. Beliau menyatakan justeru, individu sebegini didapati lebih berjaya berbanding dengan orang lain.

Dapatan kajian juga menunjukkan mempengaruhi orang lain dengan cara membina kebersamaan. Individu yang memiliki kemahiran untuk mewujudkan kebersamaan sememangnya mudah bagi dirinya untuk mempengaruhi orang lain. Sebagai contoh, individu sebegini apabila ingin menyampaikan sesuatu kepada orang lain, kebiasaanya dia berusaha menjadikan idea yang ingin disampaikan itu menjadi sebahagian daripada idea orang-orang yang akan dipengaruhinya. Dengan perkataan lain, dia akan memberikan keyakinan kepada orang lain bahawa idea tersebut penting untuk bersama. Kalau kita lihat dalam realiti kehidupan, kaedah ini sebenarnya banyak digunakan oleh orang-orang berniaga menggunakan pendekatan Multi Level Marketing. Dia menggunakan kaedah membina rasa kebersamaan dalam untuk mempengaruhi orang lain, dalam mewujudkan kejayaan perniagaan mereka. Seseorang yang memiliki kemahiran seperti ini dalam dunia kerjaya, Goleman (2007) mengaitkan 
individu seperti ini dengan pelbagai istilah bagi menggambarkan kejayaan individu tersebut, seperti penesihat yang paling cerdik, ahli politik dipilih rakyat, jurujual yang paling produktif, guru yang paling berjaya, dan terapis yang paling berwawasan.

Menurut Goleman (1999) membina semangat kebersamaan merupakan asas penting bagi seseorang agar lebih mudah mempengaruhi orang lain. Menurut beliau individu yang memiliki kemahiran sebegini sememangnya dapat membina hubungan bermakna dan membina semangat kerjasama dalam mewujudkan sesuatu matlamat. Menurut Syed Najmuddin (2005) dalam budaya Asia sifat kerjasama serta mementingkan masyarakat melebihi kepentingan individu. Pada pandangan beliau ini merupakan ciri budaya Asia yang sentiasa ditekankan dalam pendidikan keluarga mahupun sekolah. Dalam realiti kehidupan didapati masing-masing individu telah dilatih untuk mengaambil tanggungjawab dalam kehidupan keluarga mereka, seperti menjaga adik dan membantu ibu di rumah bagi kanak-kanak perempuan (Noriah 1999; Syed Najmuddin 2005). Daripada kecil telah diajarkan untuk menghormati dan membantu orang lain terutamanya seseorang yang lebih tua.

Syed Najmuddin (2005) berpandangan bahawa pembinaan tingkah laku sentiasa menghormati orang lain, secara tidak langsung telah mengajarkan seseorang untuk mengawal diri daripada tindakan kurang sopan terhadap orang lain, menjalin dan mengukuhkan persaudaraan dan persahabatan, dan prihatin serta mengambil berat keadaan yang dihadapi oleh orang lain. Dalam kehidupan bermasyarakat justeru individu sebegini dilihat sebagai individu yang mempunyai keperibadian dan nilai yang tinggi. Bila dikaitkan dengan dapatan kajian ini, Kemungkinan pengaruh budaya dan didikan sejak kecil ini menjadi salah satu pendorong terhadap munculnya dapatan tersebut. Kemungkinan seseorang telah dapat melihat makna kebersamaan tersebut melalui pengajaran dan pengalaman hidup mereka, sehingga mereka melihat kebersamaan itu boleh diaplikasikan dalam pelbagai aspek kehidupan. Subjek yang memberikan pandangan dalam kajian ini adalah individu-individu yang dianggap berjaya dalam kehidupan, kemungkinan mereka telah membuktikan sendiri melalui pengalaman hidup bahawa dengan membina kebersamaan mereka dapat lebih mudah untuk berurusan dengan orang lain. 
Kaedah ketiga yang didapati dalam kajian ini untuk mempengaruhi orang lain adalah dengan cara memberikan idea beserta sokongan. Bagi memberikan keyakinan kepada orang lain sememangnya diperlukan bukti-bukti dan sokongan yang mantap terhadap sesuatu idea yang ingin disampaikan. Kemahiran seseorang dalam memberikan hujah tentang sesuatu idea yang dikongsikan, kemungkinan menjadikan orang lain lebih percaya dengan idea tersebut. apatah lagi kalau idea tersebut hendak dikongsikan dengan orang-orang yang lebih mahir dan lebih matang dalam bidang berkenaan. Berhadapan dengan orang-orang yang lebih mahir dan lebih mengusai bidang yang akan dikongsikan lebih diperlukan lagi bukti-bukti dan sokongan yang mantap tentang idea yang akan dikongsikan tersebut. Justeru, kemahiran individu dalam mengemukan hujjah dan bukti akan menjadikan orang lain lebih mudah untuk menerima idea yang mahu dikongsikan tersebut. Malah dalam Q.S Ali-Imran: 159 dinyatakan untuk mempengaruhi orang lain bukan hanya pandai berhujjah tetapi juga perlu teknik-teknik tertentu sehingga orang lain berminat dengan idea yang dibawa tersebut. seperti dinyatakan:

...berlaku lemah lembutlah terhadap mereka. Sekiranya kamu bersikap keras lagi berhati kasar, tentulah mereka menjauhkan diri dari sekelilingmu...(QS. Ali-Imran: 159)

Ini mengisyaratkan bahawa seseorang juga perlu memiliki cara yang berkesan untuk menyampaikan sesuatu idea yang dirasakan penting untuk dikongsikan dengan orang lain.

\section{(xi) Pembinaan Cara Pengurusan Konflik}

Dapatan kajian menunjukkan terdapat empat kaedah yang dikongsikan oleh subjek dalam pengurusan konflik, mengumpulkan maklumat, tidak memihak, kembali pada agama, dan tunjukan matlamat ataupun goal. Mengumpulkan maklumat merujuk kepada kemahiran individu untuk mendapatkan maklumat yang kukuh dari pelbagai pihak dalam menyelesaikan koflik yang berlaku. Tidak memihak menggambarkan tentang kemahiran seseorang dalam mendengarkan luahan daripada pihak-pihak yang berkonflik, individu ini tidak bias dalam mendengar dan mencermati pelbagai maklumat yang diberikan oleh kedua belah pihak yang berkonflik. Sedangkan kembali 
kepada agama pula merujuk kepada kemahiran seseorang untuk menjadikan Agama sebagai landasan dalam penyelesaian konflik. Manakala tunjukkan matlamat dan goal merujuk kepada kemahiran individu untuk menyatakan, bahawa terdapat satu matlamat yang lebih penting yang mesti dicapai. Matlamat tersebut tidak mungkin dapat dicapai sekiranya orang-orang yang akan menjayakan dalam keadaan berkonflik.

Menurut Goleman (1999) pengurusan konflik merujuk kepada kemahiran seseorang dalam menyelesaikan sesuatu perselisihan. Seseorang yang berkemahiran dalam pengurusan konflik dapat menangani individu yang sukar dihadapi serta boleh menenangkan keadaan yang tegang dengan bijaksana. Individu ini juga dapat mengesan potensi konflik berlaku dalam sesuatu kedaan. Individu yang memiliki kemahiran menyelesaikan konflik juga dapat menyelesaikan dan meredakan percanggahan pendapat diantara dua kubu yang berkonflik dengan kaedah menangmenang. Individu sebegini menggalakan penyelesaian dan perbincangan secara terbuka, dan mampu merancang penyelesaian konflik yang berlaku tanpa merugikan salah satu pihak.

Alfarisi (2005) menyatakan seseorang yang akan membantu menyelesaikan konflik memang sepatutnya mengumpulkan semua maklumat yang berkaitan dengan konflik yang berlaku, seterusnya meneliti maklumat-maklumat yang telah diperolehi daripada pelbagai aspek untuk memastikan kesesuaian maklumat yang diperolehi dengan konflik yang berlaku. Maklumat-maklumat yang bersesuaian akan digunakan untuk membantu menyelesaikan konflik, sedangkan maklumat-maklumat yang tidak bersesuaian dibuangkan supaya tidak mempengaruhi jalanya penyelesaian konflik dengan baik. Sebab maklumat-maklumat yang tidak sesuai itu boleh menyebabkan bias dalam mengambil keputusan sekiranya individu yang mengendalikan konflik tidak hati-hati dengan keadaan seperti ini. Dalam Islam langkah-langkah penyelesaian konflik seperti ini telah diabadikan dalam surah al-An'am: 74-79, dalam ayat ini Allah telah menceritakan bagaimana Nabi Ibrahim yang sedang berkonflik dengan dirinya sendiri, kemudian dia mendapatkan jalan penyelesaian terbaik, dan seterusnya dapat meluruskan jalan orang-orang yang mahu mendengarkan seruanya (Q.S al-An'am 7479). 
Tidak memihak merupakan langkah bijaksana dalam penyelesaian konflik. Dalam realiti kehidupan kaedah penyelesaian konflik sebegini memang didapati terbukti berjaya dan menyenangkan kedua-dua belah pihak, kerana kedua belah pihak merasa tidak dirugikan. Kaedah ini telah dibuktikan berjaya oleh Rasulullah saw ketika beliau menangani konflik antara dua Qabilah di Mekkah. Dua kelompok ini berkonflik kerana masing-masing mereka merasakan lebih berhak untuk meletakan Hajar Ashwat semula ke tempat asalnya. Untuk meredakan konflik ini Rasulullah telah menggunakan kaedah menang-menang (tidak memihak), iaitu dengan cara melibatkan kedua-dua kelompok tersebut bersama-sama dengan Rasulullah untuk meletakan Hajar Ashwat itu semula pada tempatnya. Justeru, masing-masing mereka tidak merasa dirugikan oleh pendekatan yang digunakan oleh Rasulullah tersebut.

Kaedah tersebut telah diabadikan dalam al-Qur'an untuk dijadikan panduan penyelesaian konflik sehingga ke hari ini. Seperti dinyatakan dalam surah al-Nisa': 35 yang bermaksud:

Wahai orang-orang yang beriman, jadilah kamu orang yang benar-benar penegak keadilan, menjadi saksi karena Allah biarpun terhadap dirimu sendiri atau ibu bapa dan kaum kerabatmu. Jika ia kaya ataupun miskin, maka Allah lebih tahu kemaslahatannya. Maka janganlah kamu mengikuti hawa nafsu karena ingin menyimpang dari kebenaran. Dan jika kamu memutar balikkan (kata-kata) atau enggan menjadi saksi, maka sesungguhnya Allah adalah Maha Mengetahui segala apa yang kamu kerjakan. Dalam ayat lain (surah AlMaidah: 8) juga dinyatakan yang bermaksud "Hai orang-orang yang beriman hendaklah kamu jadi orang-orang yang selalu menegakkan (kebenaran) karena Allah, menjadi saksi dengan adil. Dan janganlah sekali-kali kebencianmu terhadap sesuatu kaum, mendorong kamu untuk berlaku tidak adil. Berlaku adillah, karena adil itu lebih dekat kepada takwa. Dan bertakwalah kepada Allah, sesungguhnya Allah Maha Mengetahui apa yang kamu kerjakan (QS. alNisa': 35)

Thomas Merton mengungkapkan "jika kau sendiri merasa damai, setidaknya ada sedikit kedamaian di dunia. Kemudian bagilah rasa damaimu dengan seтиa orang, dan semua orang akan merasa damai (Dyer 2005). Jauh daripada konflik (mewujudkan kedamaian) merupakan sunnatullah ataupun inti sari alam semesta. Jauh daripada konflik merupakan kasih sayang yang tak terbatas, kerana tidak ada rasa marah, rasa takut, keserakahan, kedengkian ataupun iri hati. Jauh daripada konflik bermakna mewujudkan samudera kedamaian yang luas, kerana tiada konflik dengan 
orang lain. Secara spiritual kedamaian adalah selaras dengan sifat-sifat ketuhanan (Dyer 2005).

Dyer (2005) menyatakan bahawa kebencian merupakan sumber kepada individu yang berkonflik. Peringkat awal mungkin seseorang agak sukar untuk menerima kenyataan ini, kerana kemungkinan mereka akan beralasan bahawa mereka berkonflik kerana wujudnya ketidak selarasan diantara kedua belah pihak. Kalau difikirkan dengan hati terbuka tanpa didorong dengan rasa benci ketidak selarasan di antara kedua belah pihak itu tidak akan menjadi konflik diantara mereka. Justeru, untuk penyelesaian konflik tersebut beliau mencadangkan agar setiap individu memilih jalan keluar spiritual, selari dengan hasil kajian ini, seperti yang dicadangkan oleh kebanyakan subjek kajian iaitu menyelesaiian konflik dengan cara kembali kepada agama.

Seseorang yang membenci adalah kerana merasa dibenci oleh orang lain, akhirnya dia meluahkan kebencian tersebut kepada orang yang dilihatnya membenci dirinya, inilah yang medorong berlakunya konflik. Kaedah yang dicadangkan oleh Dyer (2005) untuk menyelesaikan konflik tersebut adalah dengan penuh kasih sayang, kerana Tuhan mengasihi manusia tanpa syarat, walaupun manusia tidak mengetahuinya. Seperti dibincangkan sebelum ini konflik wujud kerana adanya kebencian, untuk itu salah satu pihak mesti menggunakan pendekatan kasih sayang.

Kaedah keempat yang dikongsikan oleh subjek dalam penyelesaian konflik adalah dengan cara menunjukkan goal atapun matlamat. Kaedah ini nampaknya lebih sesuai untuk menyelesaikan konflik yang berlaku dalam sebuah oraganisasi. Sesebuah organisasi tentunya mempunyai satu matlamat iaitu matlamat organisasi. Seseorang yang berkhidmat dalam organisasi tersebut sepatutnya memahami apakah yang menjadi matlamat oragnisasi. Sekiranya ada diantara kakitangan yang berkhidmat dalam organisasi tersebut, kurang memahami matlamat organisasi, maka individu yang bertanggungjawab memimpin organisasi tersebut mesti berani mengingatkan tentang matlamat organisasi. Sekiranya wujudnya konflik yang boleh mengganggu perjalanan menuju matlamat tersebut, maka senang untuk menunjukkan semula bahawa dalam organisasi ada satu matlamat yang mesti didahulukan. Pemberian kesedaran sebegini 
kebiasaanya memang berkesan untuk menyelesaikan konflik pada organisasi tersebut. Justeru, keempat-empat kaedah yang dihasilkan dalam kajian ini telah terbukti berjaya dalam menyelesaikan pelbagai konflik yang berlaku.

\subsubsection{Kaedah Yang Sesuai Dalam Latihan EQ}

Kajian ini mendapati empat kaedah yang sesuai digunakan dalam memberikan latihan EQ terhadap guru-guru, iaitu; (i) mesti mempunyai model yang jelas untuk dijadikan landasan dalam latihan. (ii) dilaksanakan dengan cara hikmah, iaitu dengan cara memandu peserta latihan agar dapat mengenali dan mempelajari diri sendiri, kerana EQ merupakan aspek dalaman seseorang, (iii) Pembelajaran dalam latihan berlaku melalui pengalaman dan perbuatan, iaitu peserta dapat belajar sendiri melalui aktivitiaktiviti yang dilakukan dalam latihan,dan (iv) Mestilah berterusan, iaitu memberikan kemahiran kepada peserta agar mereka dapat berlatih secara berterusan, bukan semasa latihan diberikan sahaja.

Memberikan latihan kepada individu mahupun kumpulan tentunya diharapkan berlakunya satu perubahan, perubahan yang diharapkan selari dengan matlamat latihan yang diberikan. Untuk menentukan matlamat sesuatu latihan itu tentunya diperlukan panduan yang jelas, kemana peserta latihan hendak diarahkan. Untuk tujuan itulah diperlukan satu model yang mantap yang boleh dijadikan panduan dalam latihan yang dijalankan. Model tersebut bukan hanya sebagai panduan tetapi juga merupakan resipi untuk mewujudkan cita rasa pada latihan berkenaan. Kajian ini mendapati, cita rasa tersebut (model) merupakan perkara penting yang mesti wujud dalam latihan EQ. Sekiranya tidak ada model yang mantap dijadikan sebagai landasan ataupun boleh dikatakan sebagai resipi latihan, kemungkinan latihan tersebut akan menghasilkan pelbagai cita rasa terhadap orang-orang yang mengikuti latihan yang diberikan. Dengan perkataan lain latihan yang dilakukan tidak mempunyai arah yang jelas, apakah bentuk hasil yang ingin dikeluarkan daripada latihan tersebut.

Resipi kebiasaanya banyak dijual dimana-mana, demikian juga halnya dengan model-model yang ditawarkan untuk pembangunan insan, dalam hal ini khasnya adalah guru-guru. Pelbagai model dijual dipasaran, namun satu pertanyaan penting 
yang perlu dijawab adalah, adakah model tersebut sesuai dengan cita rasa ataupun keperluan di Malaysia? Inilah yang dimaksudkan oleh kajian ini bahawa latihan mesti ada model yang mantap untuk dijadikan sebagai panduan. Untuk tujuan latihan ini resipi yang diberikan adalah resipi EQ sebagai penyedap rasa kepada guru-guru untuk membantu pelajar-pelajar menjadi insan cemerlang. Untuk melahirkan murid-murid cemerlang, sudah tentu guru-guru mesti cemerlang terlebih dahulu. Bagi memastikan model yang sesuai untuk keperluan latihan tersebut, pengkaji telah menggunakan model EQ yang bersesuaian keperluan tempatan, yang dihasilkan melalui penyelidikan menggunakan data-data yang diperolehi daripada konteks tempatan. Memandangkan latihan ini ditujukan kepada guru-guru, maka model EQ yang digunakan sepatutnya membawa guru-guru tersebut agar dapat merasakan lagi kepentingan Falsafah Pendidikan Negara yang mesti dijadikan panduan dalam menjayakan pendidikan di negara ini (Tajul Ariffin \& Nor'aini Dan 2002). Seperti disentuh sebelum ini, FPN berhasrat melahirkan insan yang seimbang dari segi Jasmani, Emosi, Rohani dan Intelek. Dengan demikian Model EQ yang dijadikan panduan dalam latihan ini adalah berorientasikan kepada menjayakan hasrat FPN tersebut.

Perkara kedua yang didapati oleh kajian ini adalah latihan mesti dilaksanakan dengan cara hikmah. Memandangkan EQ merupakan aspek dalaman seseorang, maka hikmah di sini merujuk kepada modul yang dibina dan orang yang akan memberikan latihan tersebut. Pembinaan modul mesti selari dengan kompetensi yang akan dilatih, dan individu yang akan melaksanakan latihan itu mestilah memiliki kemahiran untuk mengendalikan latihan menggunakan modul EQ tersebut, supaya dapat memberikan kesedaran kepada peserta latihan agar mereka dapat melihat ke dalam diri mereka sendiri, untuk melakukan yang terbaik kepada diri mereka (Mennin and Frank Farach 2007; Barbuti 2006; Lynn 2002). Menurut Mennin and Frank Farach diantara teknik yang bersesuaian untuk latihan EQ adalah behavioral and cognitive therapies, psychodynamic therapies (emotion experience and expression as deterministic), experiential therapies, dan emotions serve functions.

Al-Ghazali menyebut aspek dalaman tersebut dengan istilah Qalb. Qalb diertikan dalam dua bentuk, iaitu qalb daripada sisi spitual dan qalb secara fizikal. Daripada sisi fizikal qalb diertikan dengan hati ataupun jantung. Dari sisi spiritial Qalb 
merujuk kepada ruh manusia yang membawa amanah daripada Allah swt yang dihiasi dengan ilmu pengetahuan-Nya, ilmu pengetahuan yang dilandasi dengan fitrah asas manusia tersebut. Ruh selalu mengumandangkan keesaan Allah, sebab ruh tersebut merupakan asal usul utama daripada eksistensi manusia dan merupakan makhluk terakhir yang akan tetap ada pada hari kebangkitan (Muhammad Izzuddin Taufiq 2006). Justeru, cara latihan secara hikmah, iaitu pemilihan pendekatan yang bersuaian dalam menyampaikan latihan tersebut akan mengingatkan seseorang pada makna dirinya yang paling dalam. Surah al-Ra'du: 28 menyatakan:

...Ingatlah, hanya dengan mengingat Allahlah hati menjadi tenteram...(QS. al Ra'du: 28)

Menurut al-Ghazali hati yang tenang adalah hati yang lembut, penuh cahaya ilahi, dan penuh kekuatan spiritual. Hati yang lembut inilah yang menunjukkan identiti seseorang yang sebenar. Dengan kelembutan inilah seseorang dapat mengenal dirinya sendiri semula. Beliau juga menyatakan bahawa hati inilah sebenarnya memberikan pancaran dalam kehidupan seseorang. Seperti dinyatakan dalam hadits Rasulullah saw yang bermaksud:

Dalam tubuh manusia terdapat seketul daging, apabila baik daging tersebut maka baiklah seluruh tubuhnya, dan apabila daging itu rosak maka rosaklah seluruh tubuhnya. Inilah yang disebut dengan hati.

Al-Ghazali juga menyatakan bahawa hati (Qalb) merupakan sumber ilmu pengetahuan. Menurut beliau semua perkara yang dipelajari diolah dan diperjelas dalam hati. Al-Ghazali menyatakan ilmu pengetahuan adalah makna paling dalam daripada hati seseorang, yang didalamnya terdapat pelbagai maklumat yang boleh mengingatkan manusia semula kepada asalnya. Justeru beliau menyatakan hati akan memproses ilmu pengetahuan melalui tiga tahapan, iaitu peringkat keyakinan orang ramai, keyakinan ahli mutakallimin, dan keyakinan al-`arifin iaitu orang-orang yang benar-benar mengetahui hakikat dirinya. Justeru, cara hikmah itulah yang akan menghantarkan seseorang kepada tangga 'arifin tersebut.

Kaedah ketiga yang diperolehi dalam kajian ini adalah latihan EQ mestilah mampu membuatkan peserta dapat belajar melalui pengalaman sendiri melalui aktiviti- 
aktiviti yang dilakukan semasa latihan. Dapatan ini selari dengan pandangan Azhar et al. (2004) pembelajaran mestilah berasaskan kepada tiga kriteria penting iaitu, pembelajaran mestilah menampakan perubahan dalam tingkah laku, pembelajaran mestilah melibatkan pemikiran, dan pembelajaran mesti menghasilkan perubahan melalui pengalaman dan latihan. Justeru, latihan yang berkesan mestilah mengambil kira ketiga-tiga aspek tersebut. Seseorang yang mendapatkan pengetahuan melalui pengalaman sendiri lebih berkesan berbanding dengan pengetahuan yang didapatkan melalui pembelajaran daripada orang lain. Menurut Azhar et al. (2004) latihan yang diberikan perlu menggalakan dan mengekalkan minat peserta berkembang bagi mengembangkan dan memperluaskan pengalaman mereka serta menggalakan mereka menyertai dan mengambail bahagian secara aktif dalam proses latihan yang diberikan. Kaedah akan memandu mereka untuk dapat belajar melalui pengalaman sendiri sepanjang hayat.

Memandangkan EQ mengandungi aspek-aspek yang berkaitan dengan kehidupan peribadi dan sosial, maka latihan yang diberikan sememangnya akan lebih menarik sekiranya latihan tersebut dapat dikaitkan pelbagai pengalaman peserta dan mengambil kira ciri-ciri peribadi seperti umur, kehidupan dan status sosial, pekerjaan dan pelbagai latar belakang kehidupan lainya. Azhar et al. (2004) menyatakan bahawa pengalaman hidup seseorang merupakan instrumen budaya yang membolehkan mereka memainkan peranan diri sendiri dan fasilitator sebagai proses pembelajaran dalam latihan yang mereka ikuti. Justeru, kaedah ini akan memudahkan fasilitator dalam menyampaikan mesej yang hendak disampaikan dalam sesebuah latihan yang dijalankan.

Kaedah keempat yang diperolehi dalam kajian ini adalah kaedah latihan secara berterusan. Latihan secara berterusan tidak bermakna seseorang mesti duduk mengikuti latihan setiap hari untuk menjadikan mereka matang dalam kompetensi yang perlu dipertingkatkan. Latihan secara berterusan bermakna menunjukan kaedah latihan kepada seseorang agar mereka dapat melakukan latihan secara madiri menerusi pelbagai pengalaman dalam kehidupan mereka. Ini selari dengan pandangan Mc Clusky yang menyatakan bahawa perubahan berterusan memerlukan pembelajaran yang berterusan. Pembelajaran berterusan adalah merupakan proses pendidikan 
semenjak manusia itu dilahirkan sehingga tamat riwayat hidup mereka, menerusi pendidikan sama ada secara formal, informal dan non formal (Azhar et al. 2004). Ini selari dengan pandangan Bar-On (2000) yang menyatakan bahawa EQ semamangnya dipelajari menerusi pengalaman hidup seseorang. EQ seseorang tidak berkembang secara semulajadi selari dengan perkembangan umur dan kematangan fizikalnya tetapi bergantung pada proses pembelajaran dan latihan secara berterusan (Cakan \& Altun2005; Santoso 2004; Punia; 2002; Click 2002; Moriarty \& Buckley 2003). Pandangan tersebut dikukuhkan lagi oleh Dadang Hawari (2003) yang menyatakan bahawa perkembangan EQ berkait rapat dengan perkembangan personaliti (personality development) dan kematangan personality (maturity of personality). Justeru, pengalaman hidup yang dilalui seseorang sepanjang hayat mereka dapat membantu dirinya memiliki kematangan EQ tersebut.

Pembelajaran berterusan sememangnya dapat meningkatkan kemahiran seseorang, pengetahuan dan pengalaman dan setrusnya dapat dipraktikan dalam kehidupan seharian, yang akhirnya berobah menjadi karakter seseorang. Pembelajaran secara berterusan dapat meningkatkan kualiti hidup seseorang. Kaedah ini sebenarnya selari dengan kehendak semula jadi manusia yang sentiasa menginginkan perubahan kea rah kebaikan sepanjang hayat mereka. Melalui proses pembelajaran sepanjang hayat seseorang dapat menyesuaikan diri dengan perubahan yang berlaku dan dapat mengenal pasti dengan tepat potensi dirinya. Justeru melalui pembelajaran sepanjang hayat seseorang dapat mewujudkan perubahan yang diinginkan sesuai dengan kekuatan potensi yang dimiliki. Prinsip ini selari dengan prinsip Islam seperti diabadikan dalam Al-Qur'an yang menyuruh manusia untuk belajar sepanjang hayat. Pelbagai istilah digunakan dalam Al-Qur'an tentang pembelajaran sepanjang hayat tersebut, seperti menyeruh manusia untuk sentiasa membaca (surah al-`Alaq 1-5). Juga dinyatakan bahawa:

... Allah akan mengangkat derajat orang-orang yang beriman dan berilmu beberapa derajat..." (Q.S. al-Mujadilah: 11).

Al-Qur'an juga menyatakan dalam bentuk pertanyaan kepada manusia agar mereka dapat memikirkan makna di sebalik pertanyaan tersebut: 
Adakah kamu mengira bahawa orang-orang yang mengetahui sama dengan orang yang tidak mengetahui, sesunggiuhnya orang yang berakalah yang dapat menerima pelajaran" (surah al-Zumar: 9).

Semua ini sebenarnya mendorong manusia untuk sentiasa belajar sepanjang hayat, kerana melalui pembelajaran mereka akan memperolehi pelbagai pengetahuan, yang membezakan mereka dengan orang-orang yang tidak berilmu, dan akhirnya derajat mereka akan terangkat oleh ilmu pengetahuan tersebut, kerana ini merupakan janji Allah s.w.t. Justeru, pembinaan EQ secara berterusan seperti yang dicadangkan oleh kajian ini sememangnya membawa kepada keberhasilan, kerana kaedah tersebut bukan hanya satu keperluan dalam kehidupan manusia, tetapi ianya juga merupakan janji Allah swt yang pasti akan terbukti kebenarnya.

\subsubsection{Profil Kompetensi Asas EQ Guru-Guru Sebelum dan Selepas Latihan Menggunakan Modul EQ Yang Dibina}

Dapatan kajian menunjukkan terdapat peningkatan skor terhadap kompetensi EQ yang diberikan intervensi menggunakan modul EQ yang dibina dalam kajian ini. Peningkatan skor tersebut dapat dilihat berdasarkan perbandingan hasil ujian yang diperolehi oleh subjek sebelum dan setelah mendapatkan latihan. Dapatan ini menggambarkan tentang manfaat latihan yang diberikan kepada subjek menggunakan modul yang dibina. Latihan yang diberikan kepada subjek adalah mengambil kira pelbagai aspek yang telah dikongsikan oleh pakar dan orang-orang berjaya tentang pembinaan sesebuah modul dan pelaksanaan sesebuah latihan. Kemungkinan perkara inilah yang menyumbang terhadap kejayaan latihan yang diberikan kepada subjek tersebut. Sebagai contoh untuk menimbulkan kesedaran emosi subjek, dalam latihan telah ditunjukan apakah sepatutnya yang perlu dilakukan agar mereka dapat melihat ke dalam diri mereka sendiri, untuk merasakan dan mengenal pasti emosi yang sedang mereka rasakan? Latihan sebegini didapati membuatkan subjek dapat menyedari keperluan mereka mengenal pasti keadaan emosi mereka, yang sebelumnya kurang mereka sedari kepentinganya. Seperti dinyatakan oleh salah seorang subjek:

... Saya banyak belajar tentang diri saya sendiri, selama ini saya ingatkan saya sebagai seorang guru yang hebat, rupa-rupanya tidak hebatpun. When I feel to controll the class yesterday memberikan tamparan yang agak hebat untuk diri saya..., and than saya belajar benda baru juga, rupa-rupanya saya boleh 
menggunakan kedua-dua belah otak saya, rupa-rupanya saya seorang yang buat kerja secara sistematik yang selama ini saya jenis yang hentam kromo sahaja...".

Demikian juga dengan kompetensi-kompetensi yang lain, masing-masing aktiviti yang bersesuaian telah digunakan untuk menyentuh subjek supaya mendapatkan celik akal, dan merasakan kepentingan setiap kompetensi tersebut sehingga mereka sendiri merasakan bahawa mereka perlu meningkatkan kompetensi EQ yang mereka miliki untuk memperbaiki kehidupan mereka, sama ada dalam kehidupan peribadi mahupun kehidupan sosial, seprti dinyatakan oleh salah seorang subjek;

Apa yang saya dapati daripada training ini, sedar tentang pentingnya kenal dengan diri sendiri... bila kita dah tahu tentang itu baru kita boleh kenal ataupun fahan tentang emosi orang lain...".

Kemungkinan keadaan inilah yang menyumbang terhadap peningkatan skor setiap kompetensi yang disentuh dalam latihan tersebut. Dapatan ini selari dengan kajian Chrusciel, Don (2006) yang menyatakan bahawa sesebuah latihan akan memberikan pengaruh yang positif apabila latihan tersebut dapat menyentuh peserta dengan kaedah yang berkesan.

Melatih kebiasaan kognitif umumnya lebih mudah berbanding melatih kecerdasan emosi (Ary Ginanjar 2005; Goleman Boyatzit 1999). Melatih seseorang untuk mempergunakan sebuah peralatan seperti komputer, alat menghitung, menghafal angka-angka dan sebagainya yang menyangkut dengan kebiasaan kognitif mempergunakan otak kiri kebiasaanya lebih mudah, walaupun masa yang diperlukan bagi setiap orang tidak sama untuk mempelajari perkara-perkara tersebut. Berbeza dengan melatih keterampilan EQ seperti melatih seseorang menjadi individu yang konsisten dalam kehidupan (menyelaraskan antara ucapan dengan perlakuan), melatih seseorang untuk menjadi individu yang mempunyai komitmen yang tinggi, bersikap jujur, memiliki keyakinan diri yang tinggi dan sebagainya. Untuk melatih keterampilan ini tidak cukup hanya dengan berupa pelatihan kognitif tetapi seseorang perlu merasakan sendiri pengalaman tersebut sehingga berkesan bagi mereka. Justeru, 
latihan yang dilakukan dalam kajian ini telah mengambil kira sepenuhnya pandangan ini, menerusi data-data yang diperolehi sebelum latihan dimulakan.

Kebiasaan yang sering berlaku dalam sesebuah latihan adalah kesan latihan yang diberikan hanya sesaat, semasa latihan seakan-akan seseorang mendapatkan energi baru daripada latihan tersebut, namun kesan latihan itu akan beransur berkurang seiring dengan perjalanan masa. Justeru, latihan yang hanya menyentuh aspek kognitif cenderung berdampak seperti itu. Seperti yang telah disentuh sebelumnya untuk keterampilan EQ diperlukan latihan secara berterusan sehingga menjadi satu kebiasaan dan akhirnya menjadi satu budaya yang tidak mungkin dapat dipisahkan dengan kehidupan seseorang. Menurut Ary Ginanjar (2005) apabila sikap baru telah tercipta dalam diri seseorang, ianya akan menggantikan kebiasaan buruk yang selama ini menjadi amalan dirinya. Goleman (1999) menyatakan kecekapan merupakan sekumpulan kebiasaan yang terkoordinasi antara apa yang difikirkan, dirasakan dan kerjakan agar sesuatu tugas dapat terlasana dengan baik. Juteru Covey (2001) merumuskan satu istilah yang menggambarkan tentang internalisasi sesuatu pengalaman baru menjadi satu kebiasaan dalam kehidupan "taburlah gagasan, petiklah perbuatan, taburlah perbuatan, petiklah kebiasaan, taburlah kebiasaan petiklah tingkah laku (karakter), taburlah karakter, petiklah nasib. Pandangan ini menunjukkan untuk pembinaan keterampilan EQ memerlukan latihan secara berterusan seperti didapati dalam kajian ini. Justeru, latihan ini telah mengambil kira aspek-aspek tersebut untuk menjadikan latihan ini dapat memberikan kesan berpanjangan. Sebagai contoh yang dilakukan dalam latihan ini adalah membudayakan senyum dalam kehidupan, dimulakan pada hari pertama latihan, terus dilakukan sepanjang latihan. Seterusnya dinyatakan apakah faedah senyuman tersebut dalaman kehidupan, kemudian ditunjukkan bagaimana senyuman tersebut dipraktikan, sehingga peserta latihan dapat menjadikan senyum menjadi karakter diri mereka, dan akhirnya menjadi satu budaya yang tidak dapat dipisahkan daripada kehidupan mereka.

Goleman (1999) kecerdasan emosi dapat dipelajari bila-bila masa sepanjang hayat seseorang. Beliau menyatakan bahawa seseorang yang selama ini pemarah, pemalu, kurang keyakinan diri, sukar berkomunikasi dengan orang lain, dan sebagainya, dengan usaha dan keyakinan bersungguh-bersungguh kebiasaan negatif 
tersebut dapat dirobah kepada sifat-sifat positif. Justeru, latihan yang dilandasi dengan kesedaran yang tinggi, sesuai dengan bisikan nurani semua manusia merupakan jalan yang telah dipilih sebagai metode dalam latihan ini, sehingga seseorang dapat berlatih secara berterusan untuk menjadikan kehidupan lebih bermakna. Iaitu berusaha semaksimum yang mungkin untuk menerapkan nilai-nilai positif, dan mengurangi, bahkan menghilangkan kebiasaan negatif dalam kehidupan akan menghantarkan seseorang pada tujuan tersebut.

\subsubsection{Pandangan Subjek Tentang Latihan Kecerdasan Emosi Menggunakan Modul EQ Yang Dibina}

Hasil kajian menunjukkan secara umumnya subjek menyatakan latihan yang dilaksanakan menggunakan modul latihan EQ telah memberikan perubahan kepada diri mereka, memberikan pengetahuan baru kepada mereka, dan memberikan kesedaran kepada diri mereka. Perubahan dimaksudkan oleh subjek adalah mereka dapat melihat diri mereka dengan lebih positif dan dapat mereka aplikasikan dalam kehidupan seharian. Sedangkan memberikan pengetahuan pula menunjukkan latihan tersebut dapat memberikan kefahaman kepada mereka tentang perkara-perkara yang berkaitan dengan emosi sendiri dan juga orang lain. Manakala memberikan kesedaran pula menunjukkanlatihan tersebut dapat memberikan kesedaran tentang perubahan yang berlaku dalam diri mereka, serta dapatan mengarahkan perubahan tersebut kepada perkara-perkara yang lebih positif.

Latihan yang berkesan sepatutnya dapat memberikan perubahan, kesedaran dan pengetahuan kepada peserta latihan yang diberikan. Perubahan yang diharapkan adalah perubahan secara berkesinambungan dan bukanya perubahan sesaat yang mudah pudar setelah beberapa minggu latihan dijalankan. Dengan mengambil kira kesedaran peserta latihan tentang kompetensi yang dibangunkan, dan dengan cara-cara latihan secara mandiri, mudah-mudahan kesan berpanjangan tersebut akan diperolehi oleh subjeksunjek yang mengambil bahagian dalam kajian ini. Penggunaan teknik latihan sepanjang hayat dan belajar melalui pengalaman sendiri sememangnya dapat membantu menimbulkan kesedaran pada peserta latihan, dan memberikan pengetahuan yang berkesan kepada mereka. Kerana latihan sebegini sebenarnya selari dengan keperluan seseorang sepanjang hayat mereka. Seperti dinyatakan dalam al-Qur'an; 
...Hatinya tidak mendustakan apa yang dilihatnya (QS. al-Najm 53: 23).

Ini menggambarkan bahawa sebenarnya seseorang sentiasa terdorong untuk memperbaiki dirinya, namun terkadang sering bterhalang kerana wujudnya halangan pada pendorong hati nurani yang menjadi pendorong dalam kehidupan seseorang tersebut.

Hasil kajian Thomas Stanley dalam bukunya The Millionaire of Mind kepada 733 multi millionaire telah menyenaraikan beberapa faktor penting yang mendorong kepada keberhasilan millionaire tersebut, iaitu kejujuran kepada semua orang, disiplin diri yang tinggi, sentiasa bergaul secara baik dengan orang lain, memiliki suami dan isteri yang sentiasa menyokong kerjaya dan bekerja lebih kuat berbanding dengan orang lain. Kelima-lima faktor tersebut adalah terletak pada pusat orbit manusia. Justeru, keupayaan seseorang untuk sentiasa berjalan berada pada pusat orbit tersebut akan memberikan makna yang lebih baik daripada proses pembelajaran sepanjang hayat yang mereka lakukan. Kerana semakin seseorang mendekati pusat orbit maka semakin tinggi peluang untuk sukses akan diperolehi (Ari Ginanjar 2007). Ini selari dengan kaedah yang dilakukan oleh Rasulullah saw 15 abad yang lepas, namun beliau tetap tersenarai di bahagian paling atas dalam kajian dunia terhadap orang-orang yang dianggap paling berpengaruh di seluruh dunia sehingga ke hari ini. Resipi yang beliau gunakan adalah sentiasa berjalan pada garis orbit, iaitu; honest/Siddiq (sentisa bersikap jujur), accountablelamanah (sentiasa dapat dipercayai), cooperative/tabligh (sentiasa bertanggungjawab menyampaikan kebenaran), smart intelligent fathanah (memiliki kecerdasan).

Pandangan tersebut juga selari dengan firman Allah swt yang menyatakan:

Sesunguhnya beruntunglah orang-orang yang mensucikan jiwanya, dan merugilah orang-orang yang mengotorinya (Asy-Syams: 9-10). Dalam ayat lain Allah juga menyatakan "Sesungguhnya telah ada pada (diri) Rasulullah itu suri tauladan yang baik bagimu, iairu bagi orang-orang yang mengharap (rahmat) Allah dan kedatangan hari kiamat dan dia banyak menyebut nama Allah (QS: al-Ahzaab: 21).

Michael Persinger (1990) seorang pakar saraf juga telah berjaya membuktikan tentang keberadaan God Spot (pusat spiritual) pada otak manusia. Diperkukuhkan lagi 
oleh Ramachandran dari Calivornia University (1997) yang menyatakan bahawa god spot ataupun pusat spiritual telah built in pada otak manusia. Wolf Singer seorang pakar saraf Australia (1996) menemukan istilah "The Binding Problem" yang menyatakan bahawa dalam otak manusia terdapat proses saraf yang mempersatukan dan memberi makna pada pengalaman hidup manusia. Jaringan saraf tersebut mengikat pengalaman signifikan manusia, dan mendorong manusia untuk hidup lebih bermakna. Bila disesuaikan dengan kehidupan orang-orang berjaya sama ada mereka sedari ataupun tidak sebenarnya yang menghantarkan pada kejayaan mereka adalah nilai-nilai spritual (seperti kasih sayang, kejujuran, keprihatinan dan kebersamaan), ataupun sentiasa berjalan pada garis orbit. Justeru, keadaan inilah sebenarnya kemungkinan kenapa subjek-subjek kajian ini memberikan pandangan sedemikian terhadap latihan yang diberikan kepada mereka.

\subsection{IMPLIKASI AMALAN}

Pengkaji melaporkan implikasi kajian berdasarkan gambaran dapatan kajian secara keseluruhan. Kajian pembinaan modul kecerdasan emosi (EQ) dilihat sebagai satu kajian penting dijalankan sekarang ini, memandangkan telah banyak kajian berbentuk tinjauan dijalankan sebelumnya untuk mengenal pasti profil EQ dalam perspektif pendidikan mahupun bidang kerjaya selain pendidikan. Dalam perspektif pendidikan sama ada pelajar, guru-guru mahupun pentadbir sekolah banyak dihasilkan. Secara umumnya para penyelidik telah berjaya mengenal pasti kekuatan dan kelemahan yang dimiliki oleh masing-masing subjek kajian. Untuk itu menurut pengkaji sudah sepatutnya penyelidik-penyelidik yang berminat dalam bidang yang sama memikirkan bentuk-bentuk latihan yang bersesuaian untuk memperbaiki pelbagai kelemahan yang telah dikenal pasti, dan mempertingkatkan lagi kompetensi EQ yang dilihat penting dalam seting profesion masing-masing, supaya nampak kesinambungan usaha untuk memperbaiki dapatan kajian yang telah dihasilkan. Satu catatan penting yang perlu dipertimbangkan adalah pembinaan sesebuah modul selayaknya dimulakan dengan ujian keperluan, supaya modul yang dibina lebih spesifik tentang kompetensi yang perlu diambil tindakan dalam sesebuah latihan. 
Konsep pembelajaran sepanjang hayat sangat bersesuaian dalam pembinaan EQ, memandangkan EQ tersebut dapat diperbaiki sepanjang hayat seseorang. Pembinaan secara berterusan penting dilakukan memandangkan EQ tidak matang dengan sendirinya selari dengan perkembangan umur ataupun kematangan fizikal sesorang, melainkan dilakukan latihan secara berterusan, menerusi pengalaman hidup yang dilalui sepanjang hayat tersebut. Kaedah ini akan dapat mewujudkan individu yang lebih bijak mengenal pasti keadaan emosi sendiri dan juga emosi orang lain, sehingga akhirnya akan menjadi dirinya sebagai individu yang memiliki kecerdasan emosi yang tinggi. Justeru, dalam seting pendidikan kaedah ini dapat dimulakan semenjak kanak-kanak mula belajar pada peringkat pendidikan paling rendah sekali. Kedaan tersebut dapat terus dikembangkan sehingga generasi yang telah terdidik dapat mewariskan budaya tersebut pada generasi-generasi seterusnya. Jika keadaan ini dapat diwujudkan barulah kita dapat melihat keseimbangan dan merasakan keharmosnisan dalam kehidupan seperti yang dicita-citakan oleh Falsafah Pendidikan Negara.

Melalui latihan berterusan secara mandiri oleh guru-guru dapat meningkatkan kecerdasan mereka sendiri dan pada masa yang sama dapat meningkatkan kualiti pengajaran dan pembelajaran yang menyenakan kepada pelajar. Suasana persekitaran sekolah yang positif dan kondusif dapat membantu guru-guru dan pelajar memantapkan kecerdasan emosi mereka. Justeru, suasana sedemikian sepatutnya menjadi prioriti bagi pentadbir sekolah bagi mewujudkan budaya sekolah penyayang, yang akan melahirkan insan-insan berilmu, berbudi dan berakhlak mulia. Bagi memastikan perkara tersebut berjaya, maka pemilihan guru perlu mengambil kira aspek-aspek kecerdasan emosi sebagai satu daripada kriteria yang wajib dimiliki. Sebagaimana dicadangkan oleh Sarason (dlm Syed Najmudin 2005) yang menyatakan bahawa reformasi pendidikan akan berjaya apabila kaedah pemilihan dan latihan guru diubah.

\subsection{IMPLIKASI TEORI}

Satu perkara penting yang perlu diambil kira dalam pembinaan sesebuah modul adalah teori yang digunakan. Teori tersebut mestilah dapat merefleksikan seting budaya pendidikan tempatan. Dalam isu pembinaan kecerdasan emosi di kalangan 
pendidik tidak dapat dipisahkan dengan Falsafah Pendidikan Negara (FPN) yang menjadi tunjang kepada pendidikan negara. Pelbagai konsep dan teori kecerdasan emosi terus berkembang di dunia luar, namun pengkaji tempatan perlu bijak mempelajari teori tersebut, apakah ianya selari dengan konteks pendidikan di negara ini ataupun sebaliknya. Justeru, penggunaan konsep yang dihasilkan berdasarkan budaya tempatan lebih sesuai digunakan sebagai landasan untuk mengkaji dan menerangkan senario pendidikan dalam negara.

\subsection{SUMBANGAN KAJIAN KEPADA ILMU}

Pembinaan modul kecerdasan emosi menggunakan konsep EQ yang digambarkan melalui 7 domain EQ iaitu kesedaran kendiri, regulasi kendiri, motivasi kendiri, empati, kemahiran sosial, kerohanian dan kematangan diantara modul yang awal dalam aspek pembinaan kecerdasan emosi mengkut konteks tempatan. Pembinaan modul EQ berdasarkan konsep tersebut tentunya agak berbeza dengan konsep EQ Goleman (1995, 1999), Mayer dan Salovey (1990) dan Bar-on (2000).

\subsection{SUMBANGAN KAJIAN KEPADA MASYARAKAT}

Modul yang dibangunkan dapat digunakan untuk keperluan intervensi yang sesuaian bagi masing-masing profesion dalam negara ini. Salah satu sumbangan nyata daripada kajian ini buat masa sekarang adalah, sebahagian kandungan modul telah digunakan untuk memberikan latihan kecerdasan emosi dan pembentukan "positive attitude" dalam pembinaan modal insan pada kakitangan Institut Sosial Malaysia, dan latihan kecerdasan emosi dan pembentukan "positive attitude" dalam pembinaan modal insan kepada pelajar-pelajar Kolej MARA Banting.

\subsection{CADANGAN UNTUK KAJIAN LANJUTAN}

Kajian ini baru berjaya membangunkan modul EQ berdasarkan ko-kompetensi EQ yang diperolehi daripada kajian tinjauan yang dijalankan pada bahagian awal kajian ini, dan komponen-komponen penting yang didapatkan melalui kajian kes melalui fasa keduanya. Dan diakhir kajian ini pengkaji baru dapat melaporkan pandangan subjek 
terhadap modul yang dibangunkan. Kajian-kajian berikutnya kemungkinan boleh menguji semula keberkesanan modul ini digunakan sebagai panduan mmberikan latihan kecerdasan emosi dalam profesion perguruan ataupun profesyen-profesyen yang lain yang memiliki ciri yang lebih kurang sama.

\subsection{RUMUSAN}

Bab ini telah merumuskan hasil kajian dan membincangkan hasil kajian secara menyeluruh berdasarkan hasil kajian yang diperolehi oleh pengkaji-pengkaji sebelumnya. Pelbagai kaedah tentang pembinaan kompetensi EQ yang diperolehi juga dibincangkan berdasarkan realiti kehidupan dan beberapa kajian yang memperkukiuhkan lagi dapatan kajian ini. Di akhir kajian, implikasi dan cadangan kajian lanjutan telah dibentangkan. 


\section{RUJUKAN}

Al-Quran

Abdul Hamid, A. Atoma, P. Fauzi, M. O \& Nasir, M. 2004. Andragogi: mengajar orang dewasa. Pahang: PTS Publication \& Distributor Sdn. Bhd.

Abu Sangkan. 2006. Menghidupkan kecerdasan emosional dan spiritual: berguru kepada Allah. Jakarta: Yayasan Shalat Khusyu'.

Ainon, M. 2005. Kejayaan dari dalam: ciri-ciri psikologi lebih menentukan siapa yang akan berjaya dan siapa yang akan gagal. Dengan mengubah psikologi, kita dapat mengubah kegagalan menjadi kejayaan. Kuala Lumpur: PTS Publication \& Distributors Sdn. Bhd.

Al-Asqalani. Mohd. Ali. 1994. Fathul Bari sarah Saheh Bukhari. Beirut: darul Kutub.

Al-farisi, M. Z. 2005. Psikologi dalam Al-Qur'an terapi dalam menyembuhkan gangguan kejiwaan. Bandung: Pustaka Setia.

Alias Baba. 1997. Statistik penyelidikan dalam pendidikan dan sains sosial. Bangi: Universiti Kebangsaan Malaysia.

Antoniou, A.S. 2000. Sources of stress and profesional burnout of teachers of special education needs in greece. Kertas kerja yang dibentangkan di International Special Education Congress. University of Manchester.

Ashkanasi, N. \& Daus, C. 2005. Rumors of the death of emotional intelligence in organizational behavior are vastly exaggerated. Journal of Organizational Behavior, Vol. 26 No. 4, pp. 441-52.

Asmawati Desa. 2006. Persekitaran keluarga dan motivasi pencapain pelajar. Dlm Rohany Nasir \& Fatimah Omar. (pnyt.). Kesejahteraan manusia perspektif psikologi. Bangi: Universiti Kebangsaan Malaysia.

Atan Long. 1980. Pedagogi kaedah Am mengajar. Kuala Lumpur: Fajar Bakti Sdn. Bhd.

Barbuti, J. 2006. The inside gide to training as a teacher, a practical survival guide. New York: Continuum International Publishing Group.

Bar-On, R. 2000. Emotional and social intelligence: insights from the emotional quotient inventory (EQ-I), in Bar-On, R. and Parker, J. (Eds), The Handbook of Emotional Intelligence, Jossey-Bass, San Francisco, CA, pp. 363-88. 
Bar-On, R., Brown, J., Kirkcaldy, B. and Thome, E. 2000. Emotional expression and implications for occupational stress: an application of the emotional quotient inventory (EQ-I), Personality and Individual Differences, Vol. 28, pp. 1107-18.

Bar-On, R. and Parker, J.D.A. 2000. The handbook of emotional intelligence. San Francisco: Jossey-Bass.

Bennis, W. 2001. The emotional intelligent workplace. Foreword, San Francisco: Jossey-Bass.

Berita Harian. 2005. Pengurusan sistem pendidikan kita terbaik di dunia ketiga. 31 Mei.

BPG. 2003. Sukatan pelajaran ilmu pendidikan pengajian profesional. Kuala Lumpur: Kementerian Pendidikan Malaysia.

BPG. 2004. Sukatan pelajaran kemahiran generik: Kompetensi kecerdasan emosi. Putera Jaya: Kementrerian Pendidikan Malaysia.

Bungin, B. 2003. Analisis data penelitian kualitatif: Pemahaman filosofis dan metodologis ke arah pengusaan model aplikasi. Jakarta: P.T. Raja Grafindo Persada.

Cakan, M. and Altun, S.A. 2005. Adaptation of an emotional intelligence scale for Turkish educators, International Education Journal, Vol. 6 No. 3, pp. 367-72.

Chen, W., Jacobs, R. and Spencer, L. 1998. Calculating the competencies of stars, working with emotional intelligence. New York: Bantam Books.

Choakes, S.J. 2005. SPSS version 12.0 for windows analysis without anguish. Australia: National Library of Australia.

Corey, M. S. \& Corey, G. 1997. Groups: Process and practice. Ed. Ke-5. Pcific Grove: Brooks/Cole Publishing Company.

Corey, Corey dan Callanan. 2003. Issue and ethics in helping profession, $5^{\text {th }}$ Brookes/Cole Pub. Co. Pacific Grove.

Creswell, J. W. 2005. Research design: qualitative and quantitave approaches. Thousand Oaks: SAGE Publication.

Covey, S.R. 1990. The 7 habits of highly effective people. New York: A Fireside Book.

Chua, B.S. \& Adi, F. 2002. Tekanan pekerjaan, kepuasan kerja, dan implikasinya tehadap proses pengajaran-pembelajaran di sekolah: satu kajian ke atas guruguru sekolah menengah di kota Kinabalu, Sabah. Prosiding seminar kebangsaan profession pergurun. Bangi: Fakulti Pendidikan Universiti Kebangsaan Malaysia. 
Christine R. Dreyfus. 2007. Identifying competencies that predict effectiveness of $R \& D$ managers.www.emeraldinsight.com/0262-1711.htm.Philadelphia, Pennsylvania, USA.

Chrusciel, D. 2006. Considerations of emotional intelligence (EI) in dealing with change decision management. Management Decision, Volume 44, Number 5, 2006 , pp. 644-657(14). Emerald Group Publishing Limited.

Click, H.S. 2002. An exploration of emotional intelligence scores among students in educational administration endorsement programs, unpublished doctoral dissertation, East Tennessee State University, Johnson City, TN.

Danah Zohar \& Ian Marshall. 2000. Spitual intelligence- the ultimate intelligence. Britain: Bloomsbury.

N., \& Lincoln,Y. 1994. Handbook of qualitative research. Thousand Oaks: SAGE publication.

DuBois, N. F., Alverson, G.F. \& Staley, R.K. 1979. Educational psychology and instructional decisions. Homewood, Illinois: The Dorsey Press.

Dulewicz,V.\& Higgs, M. 2004. Can emotional intelligence be developed? Journal of Human Ressource management. 15:95-111.

Dulewicz, V. and Higgs, M. 2000. Emotional intelligence: a review and evaluation study, Journal of Managerial Psychology, Vol. 15 No. 4, pp. 341-72.

Dulewicz, V. and Higgs, M. 1998. Can emotional intelligence be measured and developed. Leadership \& Organization Development Journal, Vol. 20 No. 5, pp. 242-52.

Duval, S. \& Wicklund, R.A. 1972. A theory of objective self awareness. New York: Academic Press.

Dyer, W. W. 2001. Ada jalan keluar spiritual bagi setiap masalah. Terj. Jakarta: PT. Gramedia Pustaka Utama.

Fantana, A. \& Frey, J.S. 1994. Interviewing: The art of science. Dlm Denzin, N.K. \& lincoln, Y.S. (pnyt.). handbook of Qualitative research, Thousand Oaks: SAGE publication.

Fatt, J.P. 2002. Emotional intelligence: implications for human resource managers. Management Research News, Vol. 25 No. 11, pp. 57-74.

Gardner, H. 1983. Frames of mind. London: William Heiemann Ltd.

Gardner, H. 1993. Multiple Intelligence: the theory in practice. New York: Basic Books.

Ginanjar, A. A., 2005. Rahasia sukses membangun kecerdasan emosional dan spiritual (ESQ); the ESQ way 165, New Edition. Jakarta: Arga. 
Ginanjar, A. A., 2003. Rahasia sukses membangkitkan ESQ power: sebuah inner journey melalui al-ihsan. Jakarta: Arga.

Goleman. D. 1995. Emotional intelligence: Why it can matter more than IQ. New York: Bantam Books.

Goleman. D. 1996. Emotional intelligence: Why it can matter more than IQ. New York: Bantam Books.

Goleman, D. 1998. Working with Emotional Intelligence. New York: Bantam Books.

Goleman. D. 1999. Working with emotional intelligence. New York: Bantam Books.

Goleman. D. 1999. Kecerdasan emosi untuk mencapai puncak prestasi. Terj. Alex Trikantojo Widodo. 1999. Jakarta: PT.Gramedia Utama.

Goleman. D. 2001. Emotional intelligence: Issues in paradigm building. Dlm Cherniss, C. dan Goleman, D. (pnyt.) 2001. The emotionally intelligent workplace (atas talian) [28 Mac 2002].

Goleman. D. 2001. Emotional intelligence: issues in paradigm building. Dlm. Cherniss, C. \& Goleman, D. (pnyt.). The emotionally intelligent workplace. San Francisco: Jossey-Bass.

Goleman, D. 2007. Social Intellice: ilmu baru tentang hubungan antar manusia. Jakarta: PT. Gramedia.

Goleman. D., Boyatzis, R. \& Mckee, A. 2002. The new leaders: Transforming the art of leadership into the science of results. London: A Little, Brown Book.

Gray, J. 1999. Bagaimana mendapatkan yang anda inginkan dan menyukai yang anda dapatkan. Terj. Hermaya, T. 2001. Jakarta: Gramedia Pustaka Utama.

Hair, J. F., Anderson, R. E., Tatham, R. L. dan Black W. C. 1998. Multivariate data analysis. Edisi Kelima. New Jersey: Prentice Hall.

Hart, H. M. 100 tokoh paling berpengaruh sepanjang masa. Batam: Karisma Publishing Group.

Harian Metro. 2005. Guru disyaki edar dadah. 19 Mei.

Harian Metro. 2005. Guru belasah murid kerana hilang RM 5. Jumat 17 Juni.

Hartley, P. 1999. Interpersonal communication. Ed. Ke-7 London: Routladge.

Hawari, D. 1999. Alqur'an ilmu kedokteran jiwa dan kesehatan jiwa. Yokyakarta: PT. Dana Bhakti Prima Yasa

Hawari, D. 2003. IQ, EQ, CQ \& SQ. Kriteria sumber daya manusia (pemimpin) berkualaitas. Jakarta: Fakultas Kedokteran Universitas Indonesia. 
Higgs, M. and Rowland, D. 2002. Does it need emotional intelligence to lead change?, Journal of General Management, Vol. 27, pp. 62-76.

Inday, S. 2000. Emotional intelligence development differences in boys and girls between 4 to 6 years of age (MS) Universiti Putra Malaysia.

Jackson, J. 2005. Divine Interventions: Needs analysis for post-graduate academic literacy and curricuium development, in a south african school of theology. Applied Language Studies, Sctiool of Language, Cultureand Communication, Vol. 19, No.1. Pietermaritzburg; University of KwaZuiu-Natal.

Jordan, P., Ashkanasy, N. and Hartel, C. 2002. Emotional intelligence as a moderator of emotional and behavioral reactions to job insecurity, Academy of Management Review, Vol. 27, pp. 361-71.

Kamarul Azmi, J. \& Ab. Halim, T. 2008. Pendidikan islam kaedah pengajaran dan pembelajaran. Johor: Universiti Teknologi Malaysia.

Kartono, K. 1993. Kamus lengkap psikologi. Jakarta: PT. Raja Grafindo Persada.

Krueger, R.A. 1994. Focus group: a practical guide for applied research. Ed. Ke-2. Thousand Oaks: SAGE Publications.

Lewkowicz, A.B. 1999. Teaching emotional intelligence: Making informed choices. IL: SkyLight Training and Publishing Inc.

Lynn, A.B 2002. The emotional intelligence activity book: 50 activities for developing EQ at work. New York; American Management Association.

Pallant, J. 2004. SPSS survival manual. Crow Nest, NSW: Allen \& Unwin.

Parson, M \& Stephenson, M. 2005. Developing reflective in student teachers: collaboration and critical partnerships.

Prati, L., Douglas, C., Ferris, G., Ammeter, A. and Buckley, M. 2003. Emotional intelligence, leadership effectiveness and team outcomes, The International Journal of Organizational Analysis, Vol. 11, pp. 21-40.

Pusat perkembangan kurikulum. 2004. Falsafah pendidikan kebangsaan, matlamat dan misi. Kuala Lumpur; Kementerian Pendidikan Malaysia.

Mahathir. 2005. Perdana Menteri minta guru cungkil kebolehan murid. http://www.cikgu.net.my/malay/berita/moreberita.php3 [27 Mei 2005].

Majid Konting, M. 2005. Kaedah penyelidikan pendidikan. Kuala umpur: Dewan Bahasa dan Pustaka.

Mandell, B. and Pherwani, S. 2003. Relationship between emotional intelligence and transformational leadership style: a gender comparison, Journal of Business and Psychology, Vol. 17 No. 3, pp. 387-404. 
Maricia Hughes, L. Bonita Patterson and James Bradford Terrel, forewod by Reuven Bar-On. 2005. Emotional Intelligence in Action; training and coacing activities for leaders and managers. USA; Essential Resources for Training and HR Professionals.

Mas Udik, A. 2005. Meledakkan IESQ. Jakarta: Zikrul Hakim.

Mayer, J.D., Caruso, D.R. \& Salovey, P. 1999. Emotional intelligence meets traditional standards for an intelligence. (atas talian) http:// www.eqi.org/fulltxt1.htm [18 Julai 2002]

May Lwin et all. 2003. How to multiply your child's intelligence; A pratical guide for parents of seven-year-olds and below. Alih bahasa: Christine Sujana. 2005. cara mengembangkan berbagai komponen kecerdasan. Jakarta: PT. INDEKS kelimpok GRAMEDIA.

Mcnergney, R.F. \& Herbert, J.M. 1998. Foundation of Education. USA: Allyn \& Bacon.

Mennin, D., \& Farach, F. 2007. Emotion and evolving treatments for adult psychopathology. Clinical Psychology: Science and Practice, 14, 329-352.

Mohd Najib Ghafar. 2000. Kestabilan emosi guru: perbandingan antara pensyarah dan pelajar. Jurnal Teknologi 32 (E): 1-10.

Mohamed Sani. 2001. Perkembangan profesionalis guru: satu tuntutan dan satu kemestian. Kertas kerja dalam seminar Nasional 10 pengurusan dan kepimpinan pendidikan . Genting Highland: Institut Aminudin Baki.

Mohd. Sani Ibrahim. 2002. Etika perkhidmatan guru. Selangor: Fakulti Pendidikan, Universiti Kebangsaan Malaysia.

Mok Soon,S. 1992. Panduan latihan UKELP bahagian am. Kuala Lumpur: Kumpulan Budiman. SDN. BHD.

Moriarty, P \& Buckley, F. 2003. Increasing team emotional intelligence through process. Journal of European Industrial Training. 27, 2-4. ABI/INFORM Global pg. 98.

Mortiboys, A. 2005. Teaching with emotional intelligence: A step-by-step guide for higher and further eduacation professionals. Newyork: Routledge.

Muhammad Izzuddin Taufiq. 2006. Panduan lengkap dan praktis psikologi islam. Jakarta: Gema Insani.

Muhamad Jantan. 1993. Membina ibu bapa profesional dalam konteks psikologi keibubapaan. Kuala Lumpur: Nurin Enterprise.

Nordin, A.B. \& Othman, I. 2003. Falsafah pendidikan negara dan kurikulum. Kuala Lumpur: Quantum books. 
Noriah Mohd. Ishak, Shaharuddin Ahmad, Kadderi Mohd. Desa, Roslina Tan Abdullah. 2008. Kepintaran emosi sebagai faktor peramal pencapaian akademik Pelajar IPTA: Implikasi terhadap kebolehpasaran. Jurnal Personalia. Vol. 11. Selangor: Universti Kebangsaan Malaysia.

Noriah, M.I. 1994. Pola pemilihan respons menangani ketegangan dan hubungannya dengan punca ketegangan di kalangan guru-guru. Tesis Sarjana.Universiti Kebangsaan Malaysia.

Noriah, M.I., dan Aliza, A., 2002. Kecenderungan menghadapi tekanan dan implikasinya terhadap kesihatan mental guru-guru. Prosiding seminar kebangsaan profession pergurun 2002, Bangi: Fakulti Pendidikan Universiti Kebangsaan Malaysia.

Noriah, M.I., Zuria,M, Siti Rahayah, A. dan Manisah M.A. 2003. Hubungan antara Tanggungjawab Kepada Diri, Pelajaran, Pelajar dan Masyarakat di Kalangan Guru-guru. Prosiding seminar kebangsaan profession pergurun 2003. Bangi: Fakulti Pendidikan Universiti Kebangsaan Malaysia.

Noriah, M.I., Zuria,M, Siti Rahayah.A., dan Manisah, M.A. 2002. Hubungan antara tanggungjawab kepada diri, pelajaran, pelajar dan masyarakat di kalangan guru-guru. Jurnal Pendidikan. Jilid 24: 548-555.

Noriah M.I., Zuria, M. 2003. Kepintaran Emosi di Kalangan Pekerja di Malaysia. Prosiding IRPA-RMK-8 Kategori EAR. Jilid 1: 184-187.

Noriah, M.I., Nor Sakinah. M. 2003. Pola pertautan guru- pelajar dan komitmen terhadap profesyen perguruan di kalangan guru-guru pelatih. VirTEC Journal. Volume 3, No.1, May 2003.

Noriah, M.I., Syed Najmuddin, S.H. dan Syafrimen. 2004. Guru dan kepintaran emosi: Implikasi ke atas kebolehan guru dalam menangani masalah sosial pelajar. Prosiding seminar kebangsaan ke-3 psikologi dan masyarakat. Bangi: Pusat penerbitan dan teknologi pendidikan Universiti Kebangsaan Malaysia.

Noriah, M.I. 2005. Pengurusan kecerdasan emosi (EQ) dan pembangunan kendiri pelajar. Prosiding seminar kepengetuaan kebangsaan ke-4. Kuala Lumpur; Universiti Malaya.

Nelson, B.D \& Low, G. R. 2003. Emotional Intelligence achieving academic and Career axcelence. New Jersey Columbus, Ohio; Prentice Hall.

Neuman, W.L. 2000. Social Research methods: qualitative and quantitative approaches. Ed. ke-4. Boston: Allyn and Bacon.

Newton, D. P. \& Newton, L.D. 2001. Choosing and judging teachers: what heads and student teachers think matter. Research in Education 66: 54-64.

Nikolaou, I. and Tsaousis, I. 2002. Emotional intelligence and occupational stress, The International Journal of Organizational Analysis, Vol. 10 No. 4, pp. 327-42. 
Othman dan Ali Issa. 1987. Manusia menurut alghazali. Bandung: Perpustakaan Salman Institut tegnologi Bandung.

Payne, R.L. \& Cooper, C. L. 2001. Emotions at work; theory researc and applications for management. England; Jhon Wiley \& Sons, Ltd.

Polloway, E.A., Patton, J.R., \& Serna, L. 2001. Strategies for teaching learners with special needs. Ed. ke-7. Upper Saddle River, New Jersey: Merrill PrenticeHall Inc.

Punia, B.K. 2002. Emotional intelligence and leadership behavior in indian executives: an exploratory study, unpublished manuscript, Guru Jambheshwar University, Hisar.

Robiah, S. 2002. Konsep guru profesional. Kertas Kerja Prosiding Seminar Profesion perguruan. Selangor: Fakulti Pendidikan Universiti Kebangsaan Malaysia.

Rohaty, M. 2002. Identiti guru; Isu cabaran dan halatuju. Kertas Kerja Prosiding Seminar Profesion perguruan. Selangor: Fakulti Pendidikan Universiti Kebangsaan Malaysia.

Saadi, I. 2001. An attitudes to school for primary school children. Research in Education. 66: 65-75.

Saarni, C. 2000. Emotional competence: a developmental perspective. Dlm Bar-On., R. \& Parker, J.D.A. (pnyt). The handbook of emotional intelligence: theory, development, assessment, and application at home, school, and in the workplace, hlm.68-91. San Francisco: Jossey-Bass.

SCTV. Pensiunan guru perkosa cucu sendiri. (atas talian) http:// www.liputan6.com [4 April 2004].

SCTV. Pemimpin pondok pesantren khulafar rasyidin di Pontianak, Kalimantan Barat mencabuli lima santri perempuan. (atas talian) http:// www.liputan6.com [25 Ogos 2003].

Semmel, R. A. 1986. Emosi bagaimana mengenal, menerima dan mengarahkanya. Yokyakarta: Kanisus.

Sidani \& Abu-Zaki. 2006. Emotional intelligence and management development implications insights from the lebanese context Lebanon: Olayan School of Business, American University of Beirut. www.emeraldinsight.com/02621711.htm.

Sidek Mohd Noah. 2002. Reka bentuk penyelidikan faslafah, teori dan praktis. Selangor: Universiti Putera Malaysia.

Skovholt, T. \& D'Rozario, V. 2000. Portraits of outstanding and inadequate teachers in Singapore: The impact of emotional intelligence. Teaching and Learning. 21(1): 9-17. 
Sloan, D. M., \& Kring, A. M. 2007. Measuring changes in emotion during psychotherapy: Conceptual and methodological issues. Clinical Psychology: Science and Practice, 14, 307-322.

Solomon, R. C. 2002. Back to basics: On the very idea of basic emotions. Journal for the Theory of Social Behavior, 32, 115-144.

Spradley, J.P. 1980. Participant Observation. Holt Reinhart and Winston.

Stein, J. Steven \& Book, M.D Howar 2000. Emotional Inttelligence and Your Success. Toronto: Stoddart Publishing.

Sternberg, R.J. 1996. Successful intelligence. New York: Simon \& Schuster.

Suara Pembaharuan Daily. 2005. www. Suara pembaharuan. com.

Sugiyono. 2005. Memahami penelitian kualitatif. Bandung: CV. Alfabeta.

Suharsono. 2004. Akselarasi intelegensi optimalkan IQ, EQ \& SQ. Jakarta: Inisiasi Press.

Sulistami, R \& Erlinda Manah Mahdi. 2006. Universal intelligence, tonggak kecerdasan untuk menciptakan strategi dan solusi menghadapi perbedaan. Jakarta: P.T. Gramedia Pustaka Utama.

Suveg, C., Southam-Gerow, M. A., Goodman, K. L., \& Kendall, P. C. 2007. The role of emotion theory and research in child therapy development. Clinical Psychology: Science and Practice, 14, 358-371.

Syafrimen. 2004. Profil kecerdasan emosi guru-guru sekolah menengah Zon Tengan Semenanjung Malaysia. Kertas Projek Sarjana. Universiti Kebangsaan Malaysia.

Syed Najmuddin, S. H. 2005. Hubungan antara faktor kecerdasan emosi,nilai kerja dan prestasi kerja di kalangan guru Maktab Rendah Sains Mara. Tesis Doktor Falsafah. Universiti Kebangsaan malaysia.

Tajul Ariffin, N \& Nor' Aini, D. 2002. Pendidikan dan pembangunan manusia; pendekatan bersepadu. Selangor; Assabab Media.

Taniza. S.T. 2002. Masalah Burnout di kalangan guru serta hubungannya dengan keperluan perkhidmatan kaunseling. Prosiding seminar kebangsaan profession pergurun. Bangi: Fakulti Pendidikan Universiti Kebangsaan Malaysia.

Tangney, J. P. 1995. Shame and guilt in interpersonal relationship. Dlm Tangney, J.P. \& Fischer, K.W. (pynt.). Self-conscious emotion: the psychology of shame, guilt, embarassment and pride, hlm. 114-142. New York: The Guildford Press.

Taufiq Pasiak. 2007. Brain management for self improvement. Bandung: P.T. Mizan.

Ubaydillah. 2004. Selayang pandang IQ, EQ dan SQ. www.e-psikologi.com 
Utusan Malaysia. 2005. Guru sedia berkhidmat penuhi aspirasi negara. 31 Mei.

Wan Ashiba. 2003. Kecerdasan emosi di kalangan guru sekolah menenga berasrama penuh dan sekolah harian. Kertas projek Sarjana. Universiti Kebangsaan Malaysia.

Wan Mohd Zahid Mohd Nordin. 1993. Pengisian wawasan pendidikan. Persidangan Pendidikan Nasional.

Wechler, D. 1958. The measurement and appraisal of adult intelligence. Ed. ke-4. Baltimore: The Williams and Wilkins Company.

Wiersma, W. 2000. Research metodh in education: an introduction. Needham Heights: Allyn and Bacon.

Weisenger, H. 1998. Emotional intelligence at work. San Francisco: Jossey-Bass.

Weisenger, H. 2000. Emotional intelligence at work. San Francisco: Jossey-Bass.

Woolfolk, A. 2004. Educational Psychology. Ed. ke-9 Boston: Pearson Education, Inc.

Williams, S. J. 2001. Emotion and social theory: corporeal reflections on the (ir) rational. London: SAGE Publication.

Yin, R. K. 1993. Applications of case study research. Newbury Park: SAGE Publications.

Zinah Ahmad, Z. \& Hamdan Mohd. Ali 2006. Tekanan kerja dan kesihatan pekerja. Dlm Rohany Nasir \& Fatimah Omar. (pnyt.). Kesejahteraan manusia perspektif psikologi. Bangi: Universiti Kebangsaan Malaysia.

Zeman, J., Klimes-Dougan, B., Cassano, M., \& Adrian, M. 2007. Measurement issues in emotion research with children and adolescents. Clinical Psychology:

Science and Practice, 14, 377-401.

Zuria Mahmud. 2004. Perjumpaan Personal. Fakulti Pendidikan Universi Kebangsaan Malaysia.

Zurinah, I. 2005. Profil kepintaran emosi dalam kalangan guru pelatih. Kertas kerja yang dibentangkan dalam Seminar Pendidikan Khas, Universiti Kebangsaan Malaysia, Bangi. 


\section{LAMPIRAN A}

\section{MODUL LATIHAN \\ KECERDASAN EMOSI GURU-GURU}

\section{A. Objektif Latihan}

Memberikan kemahiran kepada peserta agar:

i. Dapat mengenalpasti secara mandiri tentang kompetensi penting yang mesti wujud dalam diri seorang guru, seperti: kesedaran kendiri, penilaian kendiri yang tepat, keyakinan diri, kawalan kendiri, kebolehpercayaan, dorongan pencapaian, memahami orang lain mengembangkan petensi orang lain, mempengaruhi orang lain, dan pengurusan konflik.

ii. Menganalisa dan memahami isu-isu penting yang menyebabkan terbelenggunya kompetensi tersebut.

iii. Membina dan mengekalkan kompetensi tersebut dalam profesyen dan kehidupan seharian.

\section{B. Aktiviti Berkenalan}

1. Untuk mencairkan kebekuan dalam kumpulan training dan membawa peserta melalui pengalaman sendiri untuk berkenalan dan berkomukasi secara efektif (elemen EQ) sebelum masuk ke sesi training yang sebenar.

\begin{tabular}{|l|l|}
\hline Aktiviti & $\begin{array}{l}\text { Mencari Kenalan Baru } \\
\text { (CD ku) }\end{array}$ \\
\hline Masa & Minit \\
\hline Objektif & $\begin{array}{l}\text { Berkenalan dan membina hubungan dengan lebih berkesan } \\
\text { dengan rakan-rakan baru }\end{array}$ \\
\hline Prosedur & $\begin{array}{l}\text { Setiap peserta diberikan sehelai kertas berbentuk sekeping } \\
\text { CD yang dibahagikan kepada empat bahagian } \\
\text { Peserta diminta untuk menulis empat soalan kreatif (satu } \\
\text { soalan untuk setiap bahagian CD) yang akan mereka } \\
\text { tanyakan kepada rakan baru mereka. Contoh soalan kreatif: } \\
\text { Apakah kegemaran, minat, harapan impian hidup, } \\
\text { lagu\&muzik kesukaan, tempat-tempat yang selalu } \\
\text { dikunjungi. }\end{array}$ \\
\hline
\end{tabular}




\begin{tabular}{|c|c|}
\hline & $\begin{array}{l}\text { - Peserta diberi masa } 10 \text { minit untuk mendapatkan maklumat } \\
\text { rakan-rakan baru mereka dengan soalan-soalan kreatif } \\
\text { tersebut. } \\
\text { - Selepas sepuluh minit, peserta diminta berkumpul semula } \\
\text { dan fasilitator meminta peserta untuk memperkenalkan diri } \\
\text { masing-masing. } \\
\text { - Fasilitator meminta untuk menambahkan maklumat tentang } \\
\text { diri peserta yang sedang berkenalan kepada peserta yang } \\
\text { menanya tadi. } \\
\text { - Perkara yang sama dilakukan oleh fasilitator sehingga semua } \\
\text { peserta habis berkenalan. } \\
\text { Peserta yang mengumpulkan maklumat terbanyak tentang } \\
\text { rakan baru mereka akan diberikan hadiah menarik dari } \\
\text { trainer. } \\
\text { Tindakan trainer: } \\
\text { - Trainer meminta pandangan peserta tentang apakah yang } \\
\text { dirasakan oleh peserta ketika sedang berkenalan } \\
\text { - Trainer cuba menanya apakah yang telah dilakukan oleh } \\
\text { peserta untuk mencari kenalan dan mendapatkan informasi } \\
\text { tentang rakan baru tersebut } \\
\text { - Trainer membuat satu rumusan (mengaitkan dengan EQ) } \\
\text { tentang makna permainan "mencari kenalan baru". } \\
\text { Note: Permainan diiringi dengan alunan muzik yang } \\
\text { menyeronokan peserta untuk bermain. }\end{array}$ \\
\hline Bahan & Kertas dan Pensil/Pen \\
\hline Falsafah & $\begin{array}{l}\text { Peserta menggunakan pelbagai kreativiti, kemahiran membina } \\
\text { hubungan dan cara-cara mempengaruhi orang lain untuk } \\
\text { mendapatkan maklumat tentang rakan-rakan yang baru }\end{array}$ \\
\hline
\end{tabular}

2. Menggiring peserta melalui Falsafal Pendidikan Peribadi (FPP) kepada Falsafah Pendidikan Negara dan Profesyen (Fokus kepada EQ)

\begin{tabular}{|l|l|}
\hline Aktiviti & $\begin{array}{l}\text { Falsafah Peribadi Ku } \\
\text { (Puzzle) }\end{array}$ \\
\hline Masa & 1.15 Minit \\
\hline Objektif & $\begin{array}{l}\text { Mengenalpasti perlunya menghayati Falsafah Pendidikan dan } \\
\text { Profesyen }\end{array}$ \\
\hline $\begin{array}{l}\text { Prosedur } \\
\text { Activiti: }\end{array}$ & $\begin{array}{l}\text { Fasilitator menunjukkan bentuk kepingan "Puzzle" Pada } \\
\text { scren paparan di hadapan } \\
\text { Fan masing-masing kumpulan diberi sehelai kertas berbentuk }\end{array}$ \\
\hline
\end{tabular}




\begin{tabular}{|c|c|}
\hline & $\begin{array}{l}\text { kepingan "puzzle" yang terdapat pada scren paparan. } \\
\text { - Fasilator memberikan arahan, bahawa masing-masing ahli } \\
\text { dalam kumpulan adalah merupakan kepingan-kepingan } \\
\text { "puzzle seperti yang terdapat pada screen. } \\
\text { - Fasilitator meminta peserta untuk mengisi Falsafah Peribadi } \\
\text { pada kepingan "puzzle" masing-masing, seterusnya } \\
\text { ditampalkan pada kepingan "Puzzle" kumpulan. } \\
\text { Cara permainan: } \\
\text { - Permainan dimulakan dengan membaling anak dadu } \\
\text { - Fasilitator meminta wakil kumpulan secara bergiliran untuk } \\
\text { membaling anak dadu (sebanyak tiga kali), untuk } \\
\text { mendapatkan apakah kepingan "puzzle" yang keluar. } \\
\text { - Apabila wakil kumpulan berjaya membaling anak dadu } \\
\text { sesuai dengan kepingan "puzzle" yang dimiliki, maka } \\
\text { kumpulan tersebut akan menampalkan kepingan "puzzle } \\
\text { mereka pada "Puzzle" yang berada di paparan hadapan. } \\
\text { - Prosedur yang sama akan dilakukan sehingga sebanyak yang } \\
\text { mungkin "Puzzle" kumpulan dapat ditampal pada "puzzle" di } \\
\text { hadapan. } \\
\text { Tindakan Trainer: } \\
\text { - Trainer memerhati peserta sepanjang permainan dijalankan } \\
\text { - Trainer membacakan Falsafah Peribadi yang ditulis pada } \\
\text { kepingan Puzzle yang ditampal di hadapan } \\
\text { - Trainer meminta pandangan peserta, apakah yang mereka } \\
\text { fikirkan ketika mengisi kepingan "puzzle" masing-masing } \\
\text { - Trainer cuba menanyakan, apakah yang dirasakan oleh } \\
\text { peserta ketika berjaya dan tidak berjaya membaling anak } \\
\text { dadu Trainer membuat satu rumusan (mengaitkan dengan } \\
\text { kepentingan EQ dalam FPN) daripada permainan "Puzzle" } \\
\text { yang dilakukan } \\
\text { Dengan mengelapkan suasana dalam ruangan training dan } \\
\text { diiringi dengan muzik yang menyentuh hati, trainer cuba } \\
\text { membawa peserta untuk merasakan "apakah yang berlaku } \\
\text { kepada diri dan pelajar-pelajar" seandainya Falsafah Peribadi } \\
\text { tidak selari dengan Falsafah profesyen dan FPN. }\end{array}$ \\
\hline Bahan & $\begin{array}{l}\text { - Kertas yang telah digunting dalam bentuk kepingan Puzzle } \\
\text { - Pensil/pen } \\
\text { - Dadu } \\
\text { - Puzzle besar }\end{array}$ \\
\hline Falsafah & $\begin{array}{l}\text { - Melaui pengalaman sendiri setiap individu mengenal sifat } \\
\text { pendidik yang tulen dan berkesan } \\
\text { - Keterbukaan } \\
\text { - Menyelaraskan Falsafah Pendidikan Peribadi dengan } \\
\text { Falsafah Pendidikan Negara dan Profesyen } \\
\text { - Menjana daya usaha }\end{array}$ \\
\hline
\end{tabular}




\section{Kompetensi EQ Yang Disentuh Dalam Latihan}

\section{(i) Kesedaran Emosi}

Dapat memafkan diri sendiri setelah melakukan kesilapan yang dilakukan, kesilapan yang dilakukan tersebut tidak memberi kesan berpanjangan terhadap perasaan peribadi.

\begin{tabular}{|c|c|}
\hline Aktiviti & $\begin{array}{l}\text { "Monitor ku" } \\
\text { Cermin Khidmat Bagi Tahu Siapa Aku? } \\
\text { Dyad (berpasangan) }\end{array}$ \\
\hline Masa & 1.45 Minit \\
\hline Objektif & $\begin{array}{l}\text { Umum: } \\
\text { - Mengenali emosi/perasaan sendiri dan orang lain } \\
\text { Peserta dapat: } \\
\text { (a) merasai dan menamakan emosi/perasaan yang dialami } \\
\text { (b) menerima dan mengakui kesan emosi/perasaan pada diri } \\
\text { sendiri dan orang lain } \\
\text { (c) mengenalpasti faktor penyebab tercetusnya } \\
\text { emosi/perasaan tersebut. } \\
\text { (d) Mengenalpasti kepentingan untuk jujur emosi pada diri } \\
\text { sendiri. }\end{array}$ \\
\hline $\begin{array}{l}\text { Prosedur } \\
\text { Activiti: }\end{array}$ & $\begin{array}{l}\text { Permulaan } \\
\text { Aktiviti ini dumulakan dengan penanyangan Flm Cermin } \\
\text { Hikmat P.Ramlee (5 minit)! } \\
\text { (a) Setiap peserta diberi sekeping cermin muka, kertas A4 } \\
\text { yang dimasukan ke dalam sampul surat. } \\
\text { (b) Aktiviti dilaksanakan bermula pada waktu pagi hari } \\
\text { pertama training, tengahari dan petang. } \\
\text { (c) Aktiviti yang sama dilakukan sehingga ke penghujung } \\
\text { training EQ. } \\
\text { Perlaksanaan aktiviti } \\
\text { Langkah satu: } \\
\text { Peserta diminta mencabut nama pasangan (Buddy) yang akan } \\
\text { bersamanya dalam aktiviti "monitorku". } \\
\text { - Fasilitator meminta peserta menulis nama pada sehelai } \\
\text { kertas, dilipat dan dimasukkan ke dalam kotak yang } \\
\text { disediakan. } \\
\text { - Fasilitator membuat undian bertuah untuk mendapatkan }\end{array}$ \\
\hline
\end{tabular}




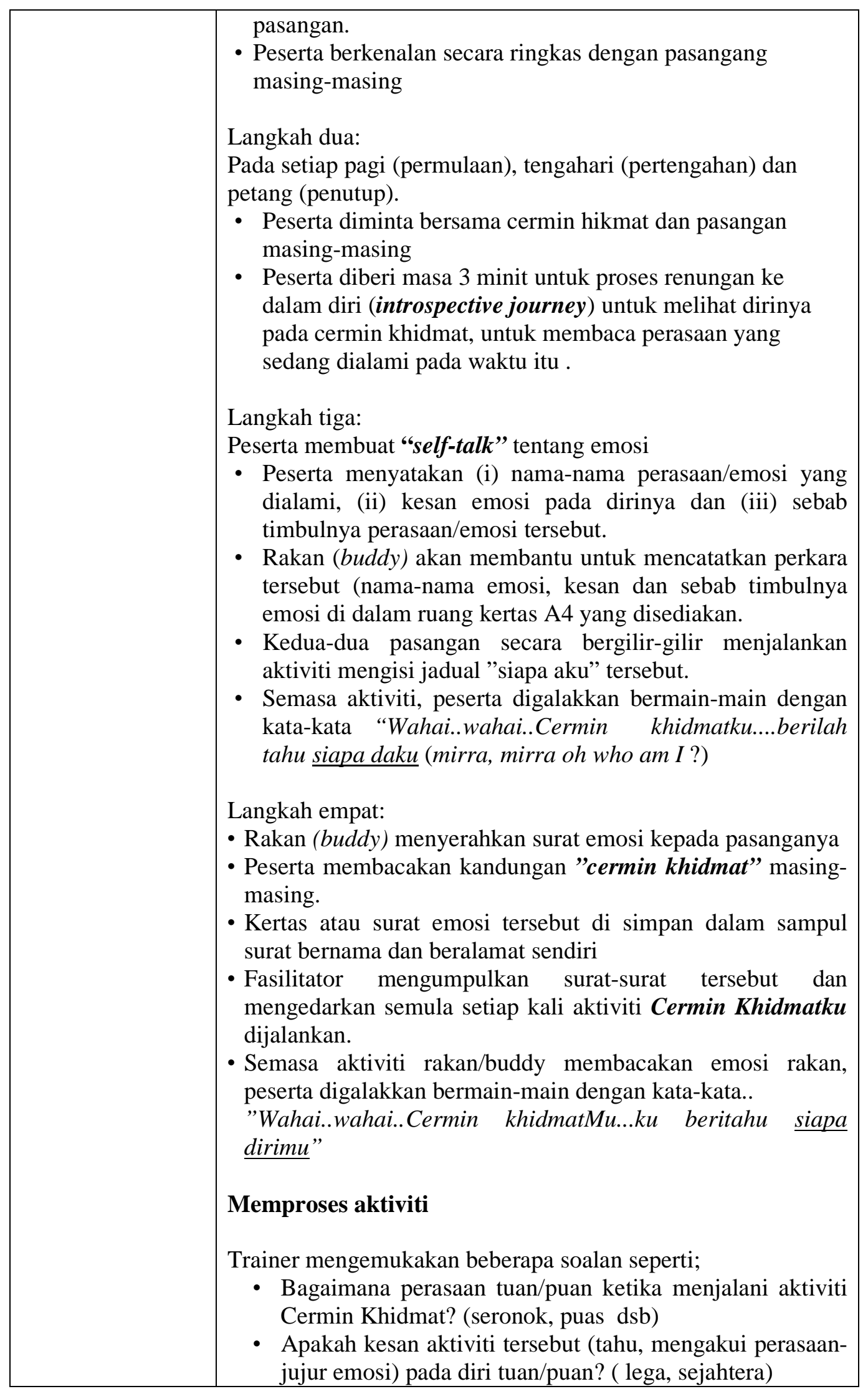




\begin{tabular}{|c|c|}
\hline & $\begin{array}{l}\text { - Apakah kesan aktiviti tersebut pada teman/rakan anda? } \\
\text { (ketelusan/lebih kenali) } \\
\text { - Siapakah yang lebih mengenali perasaan tuan/puan? } \\
\text { - Apakah kepentingan jujur dengan emosi pada diri sendiri } \\
\text { dan orang lain? } \\
\text { - Bagaimanakah cara terbaik tuan/puan melayani } \\
\text { perasaan/emosi (positif atau negatif) yang dialami? } \\
\text { - Seterusnya lampu dalam ruangan training digelapkan, } \\
\text { diringi dengan muzik lembut dan pemandangan yang } \\
\text { indah pada screen di hadapan, trainer akan membawa lagi } \\
\text { peserta untuk menyelami perasaan sebenar di dalam } \\
\text { dirinya, dengan mengajukan soalan-soalan yang } \\
\text { menyentuh perasaan. } \\
\text { - Sesi berakhir dengan menyalakan lampu ruangan training } \\
\text { semula. } \\
\text { Peringatan Berikutnya: } \\
\text { - Ulangi aktiviti cermin khidmat setiap pagi, selepas makan } \\
\text { tengahari dan sebelum pulang. } \\
\text { Ia boleh dijalankan secara tidak formal namun mengikut } \\
\text { langkah-langkah yang sama (boleh diubahsuai). Apa yang } \\
\text { PENTING ialah mencatat nama-nama emosi yang dialami. } \\
\text { - Pastikan selepas mengisi surat emosi, rakan/buddy } \\
\text { menyimpan semula surat tersebut ke dalam kotak yang } \\
\text { disediakan. } \\
\text { Di akhir progam, trainer akan memulangkan surat emosi } \\
\text { kepada setiap peserta untuk tujuan refleksi. }\end{array}$ \\
\hline Bahan & $\begin{array}{l}\text { - Cermin muka } \\
\text { - Kertas } \\
\text { - Sampul surat } \\
\text { - Pensil/pen }\end{array}$ \\
\hline Falsafah & $\begin{array}{l}\text { a. Memupuk sifat jujur emosi, mengambil berat dan } \\
\text { bertanggungjawab pada kesejahteraan diri sendiri dan } \\
\text { orang lain. } \\
\text { b. Memupuk sifat memahami dan menerima perasaan sendiri } \\
\text { dan orang lain (be kind to our feelings) } \\
\text { c. Sesuatu tindakan yang dilakukan dalam keadaan sedar dan } \\
\text { dengan penuh ketulusan akan membuahkan hasil yang di } \\
\text { luar jangkauan serta berkekalan (terkesan dalam } \\
\text { jangkamasa panjang) } \\
\text { d. Mendidik diri untuk jujur emosi (emotional honest) } \\
\text { e. Setiap manusia merasa selesa untuk "jujur emosi" dalam } \\
\text { suasana selamat, selesa, memberi kepuasan, penuh } \\
\text { penghormatan \& percaya serta produktif. Safe, satisfying, } \\
\text { caring and productive environment } \\
\text { f. Kebijaksaan menyalur atau mengurus emosi membina } \\
\text { kefungsiaan / keberkesanan diri dan persekitaran }\end{array}$ \\
\hline
\end{tabular}




\section{(ii) Penilaian Kendiri yang Tepat}

Tahu apabila berfikir secara negatif terhadap diri (tidak yakin, tidak mampu, tidak bersemangat dsb). Boleh menceritakan dengan tepat apa yang dialami kepada orang lain, Boleh merasai perubahan fikiran apabila dirangsang oleh sesutu perkara/peristiwa, Merasa berpuas hati apabila mengetahui kekuatan diri sendiri, dan Tahu kesan tingkah laku ke atas orang lain.

\begin{tabular}{|c|c|}
\hline Aktiviti 1 & $\begin{array}{l}\text { Menciptakan Kereta Baru } \\
\text { (Kereta Baru Ku) }\end{array}$ \\
\hline Masa & 90 Minit \\
\hline Objektif & $\begin{array}{l}\text { Dapat menilai kekuatan dan kelemahan diri sendiri: } \\
\text { - Menghargai kepentingan diri sendiri } \\
\text { - Dapat mengenal pasti dan mempergunakan kekuatan diri } \\
\text { untuk meningkatkan produktiviti. } \\
\text { - Dapat mngenal pasti kelemahan diri sendiri untuk } \\
\text { diperbaiki }\end{array}$ \\
\hline $\begin{array}{l}\text { Prosedur } \\
\text { Activiti: }\end{array}$ & 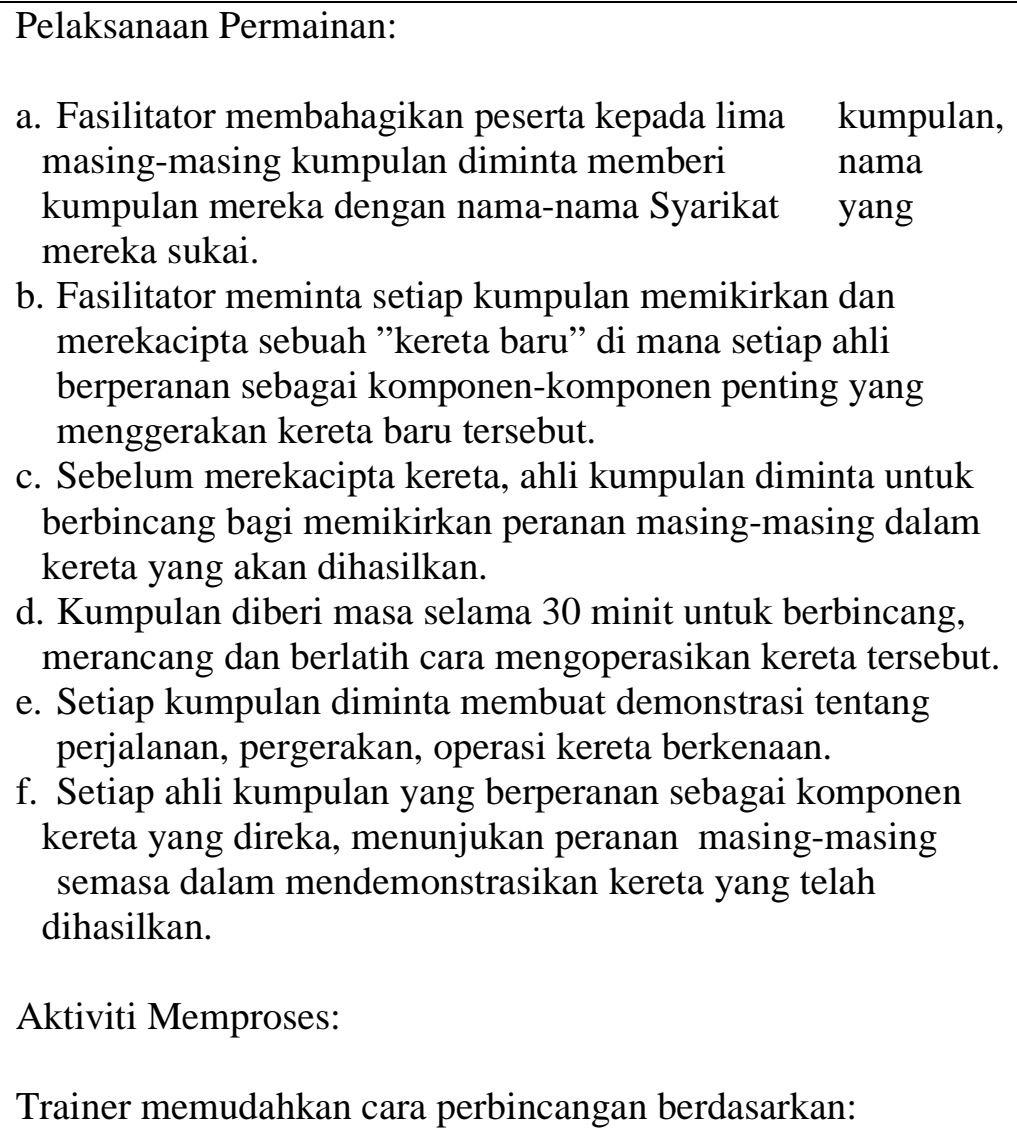 \\
\hline
\end{tabular}




\begin{tabular}{|c|c|}
\hline & $\begin{array}{l}\text { - Bagaimanakah perasaan tuan/puan berperanan sebagai } \\
\text { komponen sebuah kereta yang direka? } \\
\text { - Apakah kepentingan setiap komponen yang wujud dalam } \\
\text { kereta yang tuan/puan hasilkan? } \\
\text { - Apakah kekuatan dan kelemahan masing-masing komponen } \\
\text { yang ada dalam kereta tang tuan/puan hasilkan? } \\
\text { - Apakah yang akan berlaku sekiranya komponen tersebut } \\
\text { rosak ataupun tidak berfungsi? } \\
\text { - Apakah faktor yang membawa kejayaan tugas kumpulan } \\
\text { tuan/puan? } \\
\text { - Apakah pembelajaran yang dapat tuan/puan ambil daripada } \\
\text { permainan yang kita lakukan? } \\
\text { Note } \\
\text { - Semasa merekacipta kereta, diiringi dengan muzik yang } \\
\text { menyeronokan peserat untuk bekerja } \\
\text { - Semasa demonstrasi, peserta dihiburkan dengan muzik } \\
\text { yang boleh meningkat semangat untuk medemonstrasikan } \\
\text { kereta mereka masing-masing. }\end{array}$ \\
\hline Bahan & $\begin{array}{l}\text { - Kertas sebak } \\
\text { - Alat tulis } \\
\text { - Gam } \\
\text { - Crayon } \\
\text { - Plastersin } \\
\text { - Majalah } \\
\text { - Akhbar (yang ada gambar) }\end{array}$ \\
\hline Falsafah & $\begin{array}{l}\text { - } \text { Masing-masing individu menyedari kekuatan dan } \\
\text { kelemahan untuk menjayakan sesebuah projek } \\
\text { - Pentingnya peranan individu dan sokongan ahli yang saling } \\
\text { bermotivasi dalam menjayakan sesuatu projek. } \\
\text { - Bersatu kita teguh, bercerai kita roboh }\end{array}$ \\
\hline
\end{tabular}

\begin{tabular}{|l|l|}
\hline Aktiviti 2 & $\begin{array}{l}\text { Saya Adalah Pendidik } \\
\text { (Pendidik Berjaya) }\end{array}$ \\
\hline Masa & 90 minit \\
\hline Objektif & $\begin{array}{l}\text { Dapat menilai kekuatan dan kelemahan diri sendiri dan } \\
\text { menyedari fungsi mereka sebagai pendidik. } \\
\text { - Menghargai kepentingan diri sendiri sebagai seorang } \\
\text { pendidik. }\end{array}$ \\
$\begin{array}{l}\text { Dapat mengenalpasti dan mempergunakan kekuatan diri } \\
\text { untuk meningkatkan imej profesyen. } \\
\text { Dapat mengenalpasti kelemahan diri sendiri untuk } \\
\text { diperbaiki ke arah yang lebih baik. }\end{array}$ \\
\hline
\end{tabular}




\begin{tabular}{|c|c|}
\hline $\begin{array}{l}\text { Prosedur } \\
\text { Activiti: }\end{array}$ & $\begin{array}{l}\text { - Dimulakan dengan filem "Cikgu Fauziah" bahagian } 1 \text { (5 } \\
\text { minit) untuk melihat situasi di dalam kelas yang } \\
\text { dikendalikan oleh Cikgu Fauziah. } \\
\text { - Selepas melihat film Cikgu Fauziah bahagian 1, trainer } \\
\text { akan berinteraksi dengan peserta, dengan mengajukan } \\
\text { beberapa pertanyaan yang berkaitan dengan perasaan yang } \\
\text { dirasakan oleh peserta ketika melihat karenah pelajar- } \\
\text { pelajar Cikgu Fauziah ketika beliau masuk ke dalam kelas } \\
\text { untuk mengajar. } \\
\text { - Film Cikgu Fauziah akan dimainkan sehingga bahagian ke } \\
3 \text { dan proses berinteraksi antara trainer dengan peserta } \\
\text { akan berterusan. } \\
\text { - Diringi dengan muzik lembut dan menyentuh hati, trainer } \\
\text { akan membawa peserta untuk merasakan di di dalam diri } \\
\text { masing-masing "apakah yang akan berlaku sekiranya } \\
\text { guru-guru hari ini mempunyai sifat yang sama dengan } \\
\text { "Cikgu fauziah"? }\end{array}$ \\
\hline Bahan & $\begin{array}{l}\text { - CD Cikgu Fauziah } \\
\text { - Multi Media }\end{array}$ \\
\hline Falsafah & $\begin{array}{l}\text { Masing-masing dapat menyedari peranan mereka sebagai } \\
\text { seorang pendidik. }\end{array}$ \\
\hline
\end{tabular}

\section{(iii) Kawalan Kendiri}

Tidak cepat naik marah, Mampu bertindak dengan tenang, Mampu mengawal perasaan, Sentiasa bertenang walaupun dalam keadaan tertekan, Boleh menenagkan diri dengan cepat apabila dalam keadaan marah, Tidak mudah tersinggung, Dan tidak kecil hati apabila dikritik.

\begin{tabular}{|l|l|}
\hline Aktiviti & Bursa Saham Malaysia \\
\hline Masa & 90 Minit \\
\hline Objektif & $\begin{array}{l}\text { Membolehkan peserta supaya berfikir sebelum melakukan } \\
\text { sesuatu, sabar \& bertenang dalam suasana tertekan, mampu } \\
\text { melihat orang daripada perspektif mereka dan mampu berfikir } \\
\text { secara rasional. }\end{array}$ \\
\hline
\end{tabular}




\begin{tabular}{|c|c|}
\hline $\begin{array}{l}\text { Prosedur } \\
\text { Activiti: }\end{array}$ & $\begin{array}{l}\text { - Fasilitator membahagikan peserta kepada lima kumpulan. } \\
\text { Setiap kumpulan terdiri dari enam orang ahli. } \\
\text { - Setiap kumpulan dikehendaki menamakan kumpulan } \\
\text { dengan satu nama syarikat yang disepakati oleh ahli-ahli } \\
\text { kumpulan } \\
\text { - Fasilitator meminta masing-masing syarikat untuk melantik } \\
\text { A : Pengarah urusan } \\
\quad \text { B : Pengarah Eksekutif } \\
\text { C : Pegawai penganalisis saham syarikat } \\
\text { Aktiviti: } \\
\text { - Pegawai bursa saham memainkan peranan penting dalam } \\
\text { mengawal proses jual beli saham X \& Y. } \\
\text { - Pegawai Bursa Saham akan memberikan pilihan kepada } \\
\text { masing-masing Syarikat, apakah pilihan saham (Y atau X) } \\
\text { syarikat tersebut untuk hari ini. } \\
\text { - Pegawai bursa saham akan memaparkan harga saham } \\
\text { semasa pada skrin paparan. } \\
\text { - Aktiviti jual beli saham dilakukan sebanyak tiga kali oleh } \\
\text { pegawai Bursa Saham. }\end{array}$ \\
\hline Bahan & $\begin{array}{l}\text { - Kertas } \\
\text { - Pensil/pen }\end{array}$ \\
\hline Falsafah & $\begin{array}{l}\text { Melalui permainan Bursa Saham peserta dapat memahami } \\
\text { betapa pentingya mengawal emosi dalam bertindak }\end{array}$ \\
\hline
\end{tabular}

CONTOH PAPARAN HARGA BURSA SAHAM MALAYSIA DARI SEMASA KE SEMASA

HARGA BURSA SAHAM PUSINGAN 1

\begin{tabular}{|c|c||c|}
\hline JUAL BELI & SAHAM X & SAHAM Y \\
\hline $6 \mathrm{X}$ & - RM1000 & \\
\hline $4 \mathrm{X} 2 \mathrm{Y}$ & RM1500 & - RM1000 \\
\hline $\mathbf{3 X ~ 3 Y}$ & - RM2000 & RM2000 \\
\hline $2 \mathrm{X} \mathrm{Y}$ & RM3000 & - RM1000 \\
\hline $6 \mathrm{Y}$ & & RM1000 \\
\hline
\end{tabular}


HARGA BURSA SAHAM MALAYSIA PUSINGAN 2

\begin{tabular}{|c|c|c|}
\hline JUAL BELI & SAHAM X & SAHAM Y \\
\hline $6 \mathrm{X}$ & & $-\mathrm{RM} 1000$ \\
\hline $4 \mathrm{X} 2 \mathrm{Y}$ & $\mathrm{RM} \mathrm{5000}$ & $-\mathrm{RM} 10000$ \\
\hline $\mathbf{3 X \quad 3 Y}$ & $-\mathbf{R M ~ 1 5 0 0 0}$ & $\mathbf{R M 1 2 0 0 0}$ \\
\hline $2 \mathrm{X} \mathrm{Y}$ & RM 25000 & -RM18000 \\
\hline $6 \mathrm{Y}$ & RM50000 & \\
\hline
\end{tabular}

HARGA BURSA SAHAM MALAYSIA HARI 3

\begin{tabular}{|c||c|c|}
\hline JUAL BELI & SAHAM X & SAHAM Y \\
\hline $6 X$ & - RM2000 & \\
\hline $4 X \quad 2 Y$ & RM 16000 & - RM12000 \\
\hline $3 X \quad 3 Y$ & - RM 18000 & RM 25000 \\
\hline $2 X \quad Y$ & RM 40000 & -RM15 000 \\
\hline $6 Y$ & & RM 75000 \\
\hline
\end{tabular}

\section{(iv) Keyakinan Diri}

Keyakinan diri menggambarkan keupayaan seseorang untuk menghargai diri sendiri dan percaya dengan kebolehan diri dalam melakukan sesuatu tugas. Individu ini mempunyai nilai diri yang tinggi dan sentiasa berpegang kepada prinsip hidupnya. Mereka tidak mudah terpengaruh dengan gaya hidup orang lain. Individu ini juga tidak mengharap bantuan orang lain jika mereka mampu melaksanakan sesuatu tugas yang diamanahkan. Berani mengeluarkan pendapat dan idea walaupun mungkin tak digemari oleh orang lain. Individu ini boleh membuat keputusan yang tepat walaupun terdapat tekanan dan pandangan yang mengelirukan daripada orang lain.

\begin{tabular}{|l|l|}
\hline Aktiviti 1 & Think Tank Sdn. Bhd. \\
\hline Masa & 90 Minit \\
\hline Objektif & $\begin{array}{l}\text { Peserta dapat menunjukkan keyakinan diri menerusi ciri-ciri } \\
\text { keyakinan diri seperti yang dinyatakan dalam konsep }\end{array}$ \\
\hline
\end{tabular}




\begin{tabular}{|c|c|}
\hline & keyakinan diri di atas \\
\hline $\begin{array}{l}\text { Prosedur } \\
\text { Activiti: }\end{array}$ & 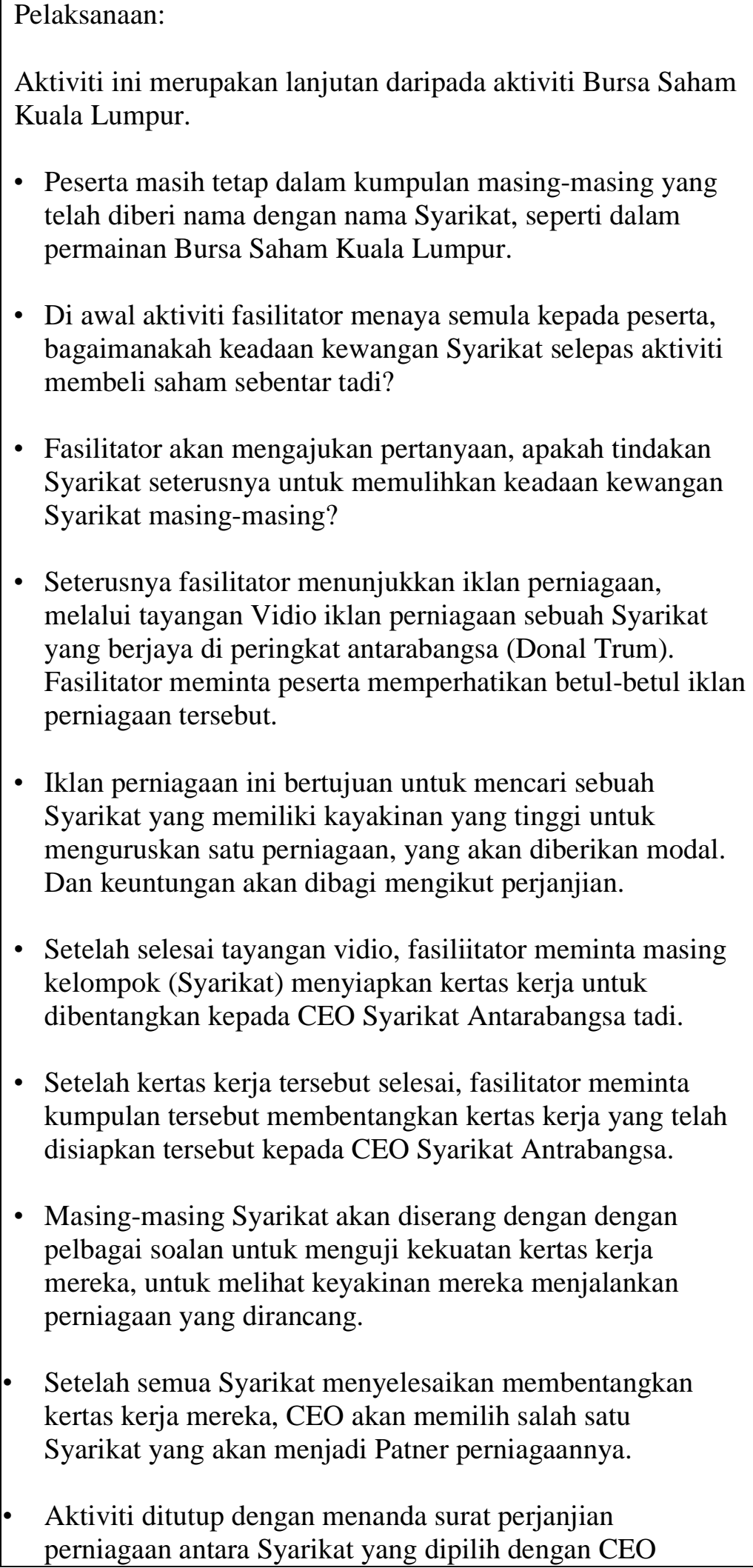 \\
\hline
\end{tabular}




\begin{tabular}{|l|l|}
\hline & Syarikat Atarabangsa. \\
Aktiviti Memproses: & $\begin{array}{l}\text { Trainer memudahkan cara perbincangan berdasarkan: } \\
\text { - Bagimana perasaan Tuan/puan melihat iklan perniagaan } \\
\text { yang ditanyangkan tadi? } \\
\text { - Adakah tuan/puan yakin bahawa kertas kerja tuan adalah } \\
\text { yang terbaik, yang akan dipilih oleh CEO Syarikat } \\
\text { antarabangsa? }\end{array}$ \\
$\begin{array}{l}\text { - Apa yang tuan/puan lakukan dalam kumpulan sehingga } \\
\text { tuan/puan yakin bahawa bahawa kertas kerja tuan/puan } \\
\text { adalah yang terbaik? } \\
\text { Bagaimana perasaan tuan/puan ketika orang lain } \\
\text { menyangsikan perniagaan yang tuan/puan rancang? } \\
\text { - Apakah yang tuan/puan rasakan ketika Syarikat tuan/puan } \\
\text { dipilih sebagai rakan perniagaan Syarikat antarabangsa? } \\
\text { - Apakah pembelajaran yang dapat tuan/puan ambil daripada } \\
\text { aktiviti yang kita lakukan? }\end{array}$ \\
\hline Falsafah & $\begin{array}{l}\text { Mertas Mahjung } \\
\text { - Pen Marker } \\
\text { Melalui aktiviti Think Tank Sdn. Bhd peserta dapat belajar } \\
\text { untuk pembinaan keyakinan diri }\end{array}$ \\
\hline
\end{tabular}

\section{(v) Niat \& Kebolehpercayaan}

- Niat merujuk kepada keupayaan individu untuk mengetahui dorongan dalaman (suara hati) dalam melakukan sesuatu.

- Keupayaan mengekalkan kejujuran dan jati diri yang tinggi. Sentiasa ikhlas dalam menjalin hubungan dengan orang lain dan juga dalam melaksanakan tugasan yang diamanahkan. Ini dapat dilihat daripada ketulusan mereka mengakui kesilapan sendiri dan keberanian mereka untuk menegur perbuatan orang lain yang kurang beretika. Mereka mempunyai pendirian yang tegas berasaskan prinsip yang dipegang walaupun tidak disukai oleh orang lain. 


\begin{tabular}{|c|c|}
\hline Aktiviti & Melakar Duniaku \\
\hline Masa & 90 Minit \\
\hline Objektif & $\begin{array}{l}\text { - Membimbing peserta supaya sentiasa dapat mengenal pasti } \\
\text { bisikan dalaman (suara hati) mereka dalam melakukan } \\
\text { sesuatu. } \\
\text { - Membimbing peserta supaya sentiasa menjadi individu yang } \\
\text { boleh dipercayai }\end{array}$ \\
\hline $\begin{array}{l}\text { Prosedur } \\
\text { Activiti: }\end{array}$ & $\begin{array}{l}\text { - Aktiviti ini biasanya dilaksanakan setelah makan tengah } \\
\text { hari. Pada masa rehat fasilitator telah menyiapkan Kertas } \\
\text { lukisan, beserta Pensil Warna pada kerusi masing-masing } \\
\text { peserta. } \\
\text { - Diringi dengan muzik lembut, fasilitator membawa peserta } \\
\text { latihan dalam suasana rileks melalui kaedah pernafasan } \\
\text { secara berulang-ulang. Dalam pernafasan peserta diminta } \\
\text { untuk mengosonkan minda mereka. } \\
\text { - Setelah Susana Nampak tenang, trainer memulakan aktiviti } \\
\text { dengan membawa peserta kepada zaman masa-masa lalu } \\
\text { mereka, untuk diimbas semula, dan diminta mereka } \\
\text { menghadirkan semua pengalaman tersebut. } \\
\text { - Trainer terus memancing supaya peserta dapat mengimbas } \\
\text { semula pengalaman-pengalaman mereka sehingga mereka } \\
\text { berada dalam ruang latihan. } \\
\text { - Setersunya peserta diminta untuk melakarkan perjalanan } \\
\text { pengalaman hidup mereka pada kertas lukisan yang } \\
\text { terdapat pada kerusi metreka masing-masing. } \\
\text { - Peserta diberikan kebebasan untuk membuat lakaran } \\
\text { mereka. } \\
\text { Trainer melakukan aktiviti memproses tentang aktiviti yang } \\
\text { dilakukan tadi. Trainer cuba mencungkil makna daripada } \\
\text { peserta latihan tentang aktiviti yang baru sahaja diselesaikan. } \\
\text { rakan sesame latihan tentang perjalanan pengalaman hidup } \\
\text { mereka tersebut. } \\
\text { Aktiviti Memproses: } \\
\text { a }\end{array}$ \\
\hline Bahan & $\begin{array}{l}\text { - Kertas Lukisan } \\
\text { - Pensil warna }\end{array}$ \\
\hline
\end{tabular}




\begin{tabular}{|l|l|}
\hline Falsafah & $\begin{array}{l}\text { Melalui aktiviti melakar duniaku, peserta dapat mempelajari } \\
\text { bisikan dalaman (suara hati) mereka sebelum memulakan } \\
\text { sesuatu tugasan. }\end{array}$ \\
\hline
\end{tabular}

\section{(vi) Dorongan Pencapaian}

Dorongan dalaman seseorang untuk mencapai suatu matlamat dan kecemerlangan. Individu ini, meletakkan sasaran yang mencabar dengan resiko tertentu. Menimba maklumat untuk mengurangkan ketidaktentuan dan mencari jalan untuk melakukan sesuatu dengan lebih baik. Mereka juga sentiasa belajar pelbagai cara untuk meningkatkan prestasi ke arah yang lebih baik.

\begin{tabular}{|l|l|}
\hline Aktiviti & Survey \\
\hline Masa & 90 Minit \\
\hline Objektif & $\begin{array}{l}\text { Peserta dapat mengenal pasti kepentingan memiliki dorongan } \\
\text { pencapaian di dalam kehidupan mereka }\end{array}$ \\
\hline Prosedur & $\begin{array}{l}\text { Fasilitator membahagikan borang survey yang telah } \\
\text { disiapkan dalam kepada seluruh pesta latihan }\end{array}$ \\
- $\begin{array}{l}\text { Fasilitator meminta semua peserta untuk menuliskan 5 } \\
\text { perkara yang menjadi pendorong mereka untuk melakukan } \\
\text { pekerjaan sehari-hari }\end{array}$ \\
$\begin{array}{l}\text { Peserta diminta menuliskan mengikut rengking, mulai dari } \\
\text { yang paling prioriti (1) sehingga yang kurang priority (5). } \\
\text { - } \begin{array}{l}\text { Fasilitator mengumpulkan semua kertas jawapanperserta } \\
\text { untuk dikira berama-sama }\end{array} \\
\text { - } \begin{array}{l}\text { Fasilitator akan mengira semua respons yang diberikan,dan } \\
\text { meminta salah seorang peserta untuk menjadi saksi bagi } \\
\text { mengesahkan jawapan peserta tersebut. }\end{array} \\
\text { - Fasilitator mengira semua jawapan peserta, jumlah paling } \\
\text { banyak dianggap menjadi pendorong utama mereka dalam } \\
\text { melaksanakan pekerjaan mereka. } \\
\text { tangani hasil survei tersebut. }\end{array}$ \\
\hline
\end{tabular}




\begin{tabular}{|l|l|}
\hline & $\begin{array}{l}\text { Aktiviti Memproses: } \\
\text { Trainer melakukan aktiviti memproses tentang aktiviti yang } \\
\text { dilakukan tadi. Trainer akan menjelaskan satu persatu perkara- } \\
\text { pekara yang menjadi pendorong peserta untuk melaksanakan } \\
\text { tugas harian mereka }\end{array}$ \\
$\begin{array}{l}\text { Trainer akan memproses satu persatu, apakah yang akan } \\
\text { berlaku sekiranya perkara tersebut sentiasa menjadi pendorong } \\
\text { mereka untuk bekerja. }\end{array}$ \\
$\begin{array}{l}\text { Trainer memberikan solusi tentang apakah sebaiknya dijadikan } \\
\text { sebagai pendorong untuk melaksanakan tugas sehari-hari. }\end{array}$ \\
\hline Bahan & $\begin{array}{l}\text { - Borang survey } \\
\text { - Pensil } \\
\text { Kertas mahjung/papan putih }\end{array}$ \\
\hline Falsafah & $\begin{array}{l}\text { Melalui aktiviti survey peserta dapat mempelajari pentingnya } \\
\text { dorongan pencapaian yang betul wujud di dalam diri } \\
\text { seseorang. }\end{array}$ \\
\hline
\end{tabular}

\section{(vii) Memahami Orang Lain}

Kebolehan seseorang untuk mengesan perasaan orang lain daipada perspektif mereka, dan menunjukkan minat yang mendalam ke atas kehendak dan masalah (concern) yang dihadapi oleh individu lain tersebut. Memberikan perhatian terhadap tingkah laku seseorang dan mahu mendengar secara aktif tentang apa sahaja yang dicurahkan oleh seseorang tersebut. Individu ini juga sedia membantu berdasarkan pemahaman tentang keperluan dan perasaan orang lain.

\begin{tabular}{|l|l|}
\hline Aktiviti & Kes Study \\
\hline Masa & 90 Minit \\
\hline Objektif & $\begin{array}{l}\text { Memberikan pemahaman kepada peserta tentang kepentingan } \\
\text { memahami orang lain. }\end{array}$ \\
\hline $\begin{array}{l}\text { Prosedur } \\
\text { Activiti: }\end{array}$ & $\begin{array}{l}\text { Aktiviti ini diawali dengan penayangan video yang dapat } \\
\text { menyentuh perasaan peserta,sehingga memancing mereka } \\
\text { untuk dapat memahami apa yang sedang dirasakan oleh } \\
\text { orang lain. }\end{array}$ \\
\hline
\end{tabular}




\begin{tabular}{|c|c|}
\hline & $\begin{array}{l}\text { - Setelah penayangan video, mereka dipecahkan kepada } \\
\text { beberapa kumpulan } \\
\text { - Fasilitator akan membacakan dan menunjukan beberapak } \\
\text { serius yang perlu mereka selesaikan, memandangkan tugas } \\
\text { kita sebagai makhluk sosial } \\
\text { - Masing-masing kumpulan diminta memilih satu kes, dan } \\
\text { menyelesaikan kes tersebut secara berkumpulan } \\
\text { Masing-masing kumpulan diminta untuk berbincang } \\
\text { terlebih dahulu dan cuba merasakan keadaan yang dialami } \\
\text { oleh individu yang terlibat di dalam kes tersebut sebelum } \\
\text { membantu menyelesaikanya. } \\
\text { - Apabila telah selesai berbincang dan mencarikan solusi, } \\
\text { masing-masing kumpulan diminta untuk membentangkan } \\
\text { cara-cara membantu yang mereka cadangkan. } \\
\text { Aktiviti Memproses: } \\
\text { Trainer melakukan aktiviti memproses tentang aktiviti yang } \\
\text { dilakukan. } \\
\text { Trainer cuba merasakan contoh-contoh situasi yang } \\
\text { ditunjukkan melalui video dan kes-kes yang ditunjukkan oleh } \\
\text { fasilitator sebelumnya. } \\
\text { mereka selalu sensitive dengan keadaan orang lain di dalam } \\
\text { kehidupan seharian mereka. } \\
\text { Diiringi dengan alunan muzik lembut, trainer terus berusaha } \\
\text { memancing perasaan peserta sehingga mereka dapat } \\
\text { merasakan situasi tersebut. } \\
\text { Takan mengeluarkan makna daripada aktiviti yang }\end{array}$ \\
\hline Bahan & $\begin{array}{l}\text { - Vidio } \\
\text { - Kes-kes sebenar yang berlaku di dalam kehidupan } \\
\text { - Kertas mahjung } \\
\text { - Pen marker }\end{array}$ \\
\hline Falsafah & $\begin{array}{l}\text { Melalui aktiviti kes study peserta dapat mempelajari tentang } \\
\text { kepentingan memahami orang lain di dalam kehidupan. }\end{array}$ \\
\hline
\end{tabular}




\section{(viii) Mengembangkan Potensi Orang Lain}

Individu ini dapat mengakui dan memberi ganjaran atas kekuatan dan pencapaian orang lain. sentiasa memberikan maklum balas yang berguna dan mengenal pasti keperluan orang lain untuk perkembangan diri mereka. Boleh menjadi pembimbing dan menawarkan tugasan yang mencabar yang dapat membentuk kemahiran individu lain.

\begin{tabular}{|c|c|}
\hline Aktiviti & Sibuta dan Sicelik \\
\hline Masa & 90 Minit \\
\hline Objektif & $\begin{array}{l}\text { Memberikan pemahaman kepada peserta tentang pentingya } \\
\text { mengembangkan potensi orang lain. }\end{array}$ \\
\hline $\begin{array}{l}\text { Prosedur } \\
\text { Activiti: }\end{array}$ & $\begin{array}{l}\text { Fasilitator membahagi peserta dalam beberapa kumpulan, } \\
\text { banyak kumulan bergantung kepada ramai peserta } \\
\text { - Masing-masing kumpulan akan menunjuk dua orang } \\
\text { peserta sebagai sicelik, ahli kumpulan yang lain akan jadi } \\
\text { sibuta } \\
\text { - Fasilitator mengarahkan peserta (sibuta dan sicelik) berdiri } \\
\text { pada garis yang telah ditetapkan. } \\
\text { - Sicelik akan memberikan arahan kepada sibuta daripada } \\
\text { garisan tersebut, tidak boleh berjalandan memegang badan } \\
\text { sibuta. Sicelik hanya memberikan arahan secara lisan. } \\
\text { - Di hadapan si buta dan sicelik, fasilitator meletakan benda- } \\
\text { benda pemainan (guli, mankok dan tali rapia yang telah } \\
\text { dibuatkan bulatan untuk meletakan mangok tersebut). } \\
\text { Bulatan tali tersebut diikat dengan } 3 \text { ikatan tali yang agak } \\
\text { panjang yang boleh dipegang oleh beberapa orang. } \\
\text { - Sekarang Guli dalam keadaan berselerak, mangkok dan tali } \\
\text { tersebut dilatakan secara tepisah-pisah di hadapan sibuta. } \\
\text { - Melalui arahan sicelik, sibuta diminta mengutip semua guli } \\
\text { dan dimasukan ke dalam mangkok. Guli mesti dimasukan } \\
\text { semuanya, tidak boleh ada yang tertinggal. } \\
\text { Setelah semua guli masuk ke dalam mangkok, sicelik } \\
\text { mengarahkan sibuta supaya mangkok tersebut diletakan di } \\
\text { atas butalan tali. }\end{array}$ \\
\hline
\end{tabular}




\begin{tabular}{|c|c|}
\hline & $\begin{array}{l}\text { - Setelah sibuta brjaya meletakan mangkok di atas bulatan } \\
\text { tali, sicelik terus mengarahkan sibuta untuk mengangkat } 3 \\
\text { ujung tali yang telah terletak diatasnya mangkok berisi } \\
\text { guli. } \\
\text { - Dengan mengangkat } 3 \text { ujung tali tersebu, sicelik } \\
\text { mengarahkan sibuta untuk meletakanya pada tempat yang } \\
\text { telah disediakan di hadapan mereka. } \\
\text { - Sibuta melalui arahan sicelik mesti meletakanmankok } \\
\text { tersebut betul-betul pada tempat yang telah disediakan. } \\
\text { - Sekranya mangkok jatuh, arahan yang sama diulang } \\
\text { semula, sehingga berjaya. } \\
\text { Masing-masing kumpulan melakukanya secar bergilir-gilir. } \\
\text { Aktiviti Memproses: } \\
\text { Trainer melakukan aktiviti memproses tentang aktiviti yang } \\
\text { dilakukan. } \\
\text { Mula-mula trainer akan menanya sibuta tentang arahan yang } \\
\text { diberikan oleh sicelik? } \\
\text { Kemudian trainer cuba menanya kepada sicelik, apa yang } \\
\text { mereka rasakan dalam meberikan arahan kepada sibuta? } \\
\text { metelah semua menyatakan pandangan mereka, trainer akan } \\
\text { potensi orang lain. } \\
\text { Diiringi dengan alunan muzik lembut, trainer terus } \\
\text { merangkan falsafah disebalik aktiviti yang baru sahaja } \\
\text { man. }\end{array}$ \\
\hline Bahan & $\begin{array}{l}\text { - Penututp mata } \\
\text { - Tali rafia } \\
\text { - Guli } \\
\text { - Tip Bainding }\end{array}$ \\
\hline Falsafah & $\begin{array}{l}\text { Melalui aktiviti sibuta dan sicelik peserta dapat mempelajai } \\
\text { bagaimana susahnya mengembangkan potensi orang lain. } \\
\text { Mereka perlu ada kemahiran yang mantap untuk membantu } \\
\text { orang lai. }\end{array}$ \\
\hline
\end{tabular}




\section{(ix) Mempengaruhi Orang Lain \& Pengurusan Konflik}

- Mempengaruhi orang lain merujuk kepada kemahiran individu dalam membujuk orang lain, iaitu seseorang yang berkemahiran dalam mempengaruhi orang lain dengan cara menyampaikan idea secara halus untuk menarik minat orang lain. Individu ini pandai menggunakan strategi yang pelbagai (seperti pengaruh tak langsung) untuk membina konsensus dan sokongan, serta mencetus suasana yang dramatik untuk menonjolkan idea secara efektif.

- Seseorang yang berkemahiran dalam pengurusan konflik boleh menangani individu yang sukar dihadapi serta boleh menenangkan keadaan yang tegang dengan bijaksana. Mereka juga boleh mengesan potensi konflik berlaku dalam sesuatu kedaan, menyelesaikan percanggahan pendapat secara terbuka dan membantu meredakannya, menggalakkan perbahasan dan perbincangan terbuka serta mampu merancang penyelesaian berbentuk tanpa merugikan salah satu pihak.

\begin{tabular}{|c|c|}
\hline Aktiviti & Tolong Selamatkan Masa Depan Saya \\
\hline Masa & 90 Minit \\
\hline Objektif & $\begin{array}{l}\text { Memberikan pemahaman kepada peserta tentang pentingya } \\
\text { keterampilan mempengaruhui orang lain dalam menyelesaikan } \\
\text { konflik. }\end{array}$ \\
\hline $\begin{array}{l}\text { Prosedur } \\
\text { Activiti: }\end{array}$ & $\begin{array}{l}\text { - Bentuk aktiviti adalah persidangan (mensyuarat) untuk } \\
\text { menjatuhkan hukuman buang sekolah kepada pelajar yang } \\
\text { mempunyai kes berat (kategori kesalahan yang sukar untuk } \\
\text { dimaafkan). } \\
\text { - Sekiranya kumpulan agak ramai buat dua kumpulan } \\
\text { (maksimum } 15 \text { orang setiap kumpulan). } \\
\text { - } \text { Fasilitator akan meberikan tugasan masing-masing kepada } \\
\text { semua peserta: } \\
\text { - } 2 \text { orang sebagai pelajar yang akan dibicarakan (akan } \\
\text { dibuang sekolah) } \\
\text { - } 1 \text { orang sebagai sebagai pengetua } \\
\text { - } 1 \text { orang guru kanan disiplin } \\
\text { - } 1 \text { orang sebagai penolong kanan kolej } \\
\text { - } 2 \text { orang sebagai guru kelas (guru kelas masing-masing }\end{array}$ \\
\hline
\end{tabular}




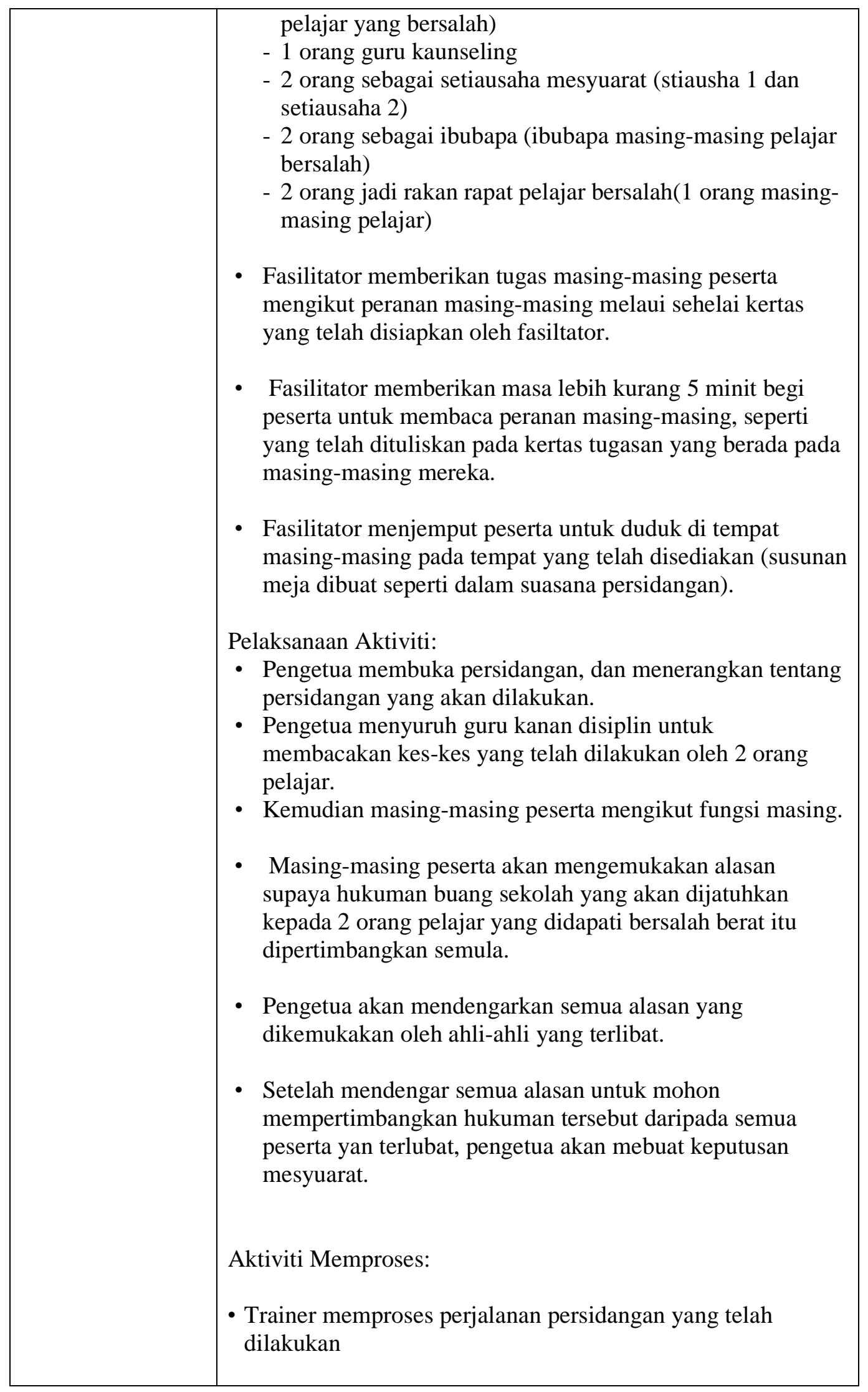




\begin{tabular}{|c|c|}
\hline & $\begin{array}{l}\text { - Trainer memandu peserta untuk menarik pembelajaran } \\
\text { daripada perjalanan persidangan, melalui diskusi-diskusi } \\
\text { selama persidangan dijalankan } \\
\text { - Trainer merumuskan hasil pembelajaran yang diperolehi oleh } \\
\text { masing-masing peserta }\end{array}$ \\
\hline Bahan & $\begin{array}{l}\text { - Kertas tugasan peserta yang telah disiapkan oleh fasilitator } \\
\text { - File simpanan kes pelajar } \\
\text { - File sesi kaunseling } \\
\text { - kertas } \\
\text { - Pen } \\
\text { - Tukul pengetuk meja }\end{array}$ \\
\hline Falsafah & $\begin{array}{l}\text { Peserta dapat mengambil pelajaran daridapa perjalanan } \\
\text { persidangan, khasnya dalam mempengaruhi orang lain dan } \\
\text { menyelesaikan konflik. }\end{array}$ \\
\hline
\end{tabular}

Note: Aktiviti-aktiviti dalam modul ini adalah sekedar untuk memandu peserta latihan untuk dapat menarik pempelajaran melalui pengalaman daripada aktifiti-aktifiti berkenaan. Yang paling penting adalah aktiviti memproses oleh juru latih terhadap setiap aktiviti yang dijalankan. Justru, juru latih perlu lebih kreatif untuk membantu mengukuhkan pembelajaran yang diperolehi oleh peserta melalui aktiviti-aktiviti yang dilakukan. 


\section{LAMPIRAN B}

\section{PROTOKOL TEMUBUAL PAKAR}

\section{Assalamualaikum Warahmatullahi Wabarakatuh}

Terima kasih atas kesediaan tuan/puan meluangkan masa untuk berbincang pada hari ini. Perbincangan kita ini berkisar tentang pengalaman-pengalaman yang tuan/puan alami sehingga tuan/puan berada pada tahap seperti sekarang ini. Sebelum kita mulakan perbincangan ini, mungkin tuan/puan boleh menceritakan sedikit latarbelakang Tuan/puan sehingga Tuan/puan berada tahap seperti sekarang ini.

Dari beberapa kajian yang dijalankan, kejayaan seseorang sangat berkait rapat dengan (i) kemampuan seseorang itu untuk menyedari atau mengenal pasti perasaan dirinya dan perasaan orang lain, (ii) mempunyai motivasi kendiri yang tinggi, (iii) boleh mengurus emosi sendiri serta (iv) mampu menjalin hubungan mesra dengan orang lain. Atau di dalam istilah psikologi dipanggil dengan istilah"Kecerdasan Emosi (EQ)". Agaknya, ada tak perkara-perkara tersebut membantu dalam kejayaan Tuan/puan?

Dari kajian yang dijalankan, paling tidak terdapat tujuh domain penting yang menunjukkan bahawa seseorang itu mempunyai EQ yang tinggi, domain-domain tersebut adalah (i) Kesedaran Kendiri (Self Awareness), (ii) Regulasi Kendiri (self regulation), (iii) Motivasi Kendiri (Self Motivation), (iv) Empati (Empathy), (v) Kemahiran Sosial (Social Skill), (vi) Kerohanian (Siprituality) dan (vii) Kematangan (Maturity). Mungkin tuan/puan boleh berkongsi pengalaman, ada tak perkara-perkara tersebut membantu dalam kejayaan tuan/puan?

Buat masa ini belum banyak lagi modul latihan yang boleh digunakan untuk meningkatkan EQ seseorang. Dari itu saya merasakan keperluan untuk membina modul latihan sedemikian. Bagaimanapun untuk pembinaan modul dimaksud saya memerlukan pandangan daripada tuan/puan yang dianggap sebagai individu yang boleh memberikan pandangan dan pengalaman untuk pembinaan modul tersebut.

\section{Soalan Pembuka}

Beberapa kajian yang dijalankan di luar negara mendapati bahawa EQ menyumbang lebih dari $80 \%$ berbanding dengan IQ yang hanya menyumbang 6\%-20\% dalam kejayaan seseorang. Saya merasakan bahawa tuan/puan adalah seorang yang mempunyai ciri-ciri EQ tersebut. 
1. Boleh tak tuan/puan terangkan tentang diri dan pengalaman tuan/puan sepanjang kerjaya tuan/puan, sehingga tuan/puan berada pada tahap sekarang ini?

\section{Soalan Pengenalan}

1. Pernahkah tuan/puan mengikuti sebarang kursus ataupun latihan tertentu yang dapat membantu tuan/puan menjalankan tugas dengan baik?

2. Boleh tak tuan/puan terangkan, apakah bentuk-bentuk latihan tersebut? Apakah pandangan tuan/puan tentang latihan itu?

3. Adakah latihan-latihan tersebut membantu tuan/puan dalam meningkat EQ?

\section{Soalan Transisi}

Tuan/puan adalah salah seorang individu yang telah berjaya dalam bidang yang diceburi. Saya percaya tuan/puan mempunyai ciri-ciri EQ yang membantu dalam prestasi kecmerlangan tuan/puan tersebut.

1. Apakah perkara-perkara yang telah tuan/puan lakukan untuk mewujudkan kejayaan tersebut?

2. Untuk sampai pada tahap ini, tentunya tuan/puan mempunyai rahasia ataupun kiatkiat tersendiri, apakah rahasia-rahasia yang membawa kepada kejayaan tuan/puan?

3. Apakah yang memandu tuan/puan sehingga boleh berjaya?

\section{Soalan Kunci}

Goleman (1999) mengaitkan EQ dengan dua jenis kompetensi iaitu; kompetensi peribadi dan kompetensi sosial. Kedua-dua kompetensi tersebut diwakili oleh lima domain seperti berikut: (i) kesedaran kendiri (self-awareness), (ii) regulasi kendiri (self-regulation), (iii) motivasi kendiri (self-motivation), (iv) empati (empathy), dan (v) kemahiran sosial (social skills). Bagaimanapun, kajian Noriah et al (2003) mendapati wujudnya penambahan domain baru yang memainkan peranan yang sangat penting dalam meningkatkan EQ seseorang. Dua domain tambahan tersebut adalah kerohanian (spirituality) dan kematangan (maturity).

Kompetensi peribadi merujuk kepada keupayaan seseorang untuk mengurus dan berinteraksi dengan diri sendiri. Kompetensi ini diwakili oleh tiga domain iaitu kesedaran kendiri, regulasi kendiri dan motivasi kendiri.

\section{a. Kesedaran Kendiri}

Seperti mana yang telah saya sebutkan tadi kesedaran kendiri adalah salah satu domain penting di dalam membangunkan EQ seseorang. Kesedaran kendiri ini adalah 
kemampuan individu untuk: (i) mengetahui perasaan sendiri, (ii) berkeupayaan menilai dengan tepat kekuatan dan kelemahan diri sendiri, (iii) mampu membina keyakinan diri dan (iv) sedar tentang niat dalam diri.

1. Berdasarkan pengalaman tuan/puan, adakah elemen-elemen tersebut berperanan dalam mencapai kejayaan tuan/puan sekarang ini? Kenapa tuan/puan mengatakan begitu? Bagaimana agaknya tuan/puan mengaitkanya dengan kejayaan yang telah tuan/puan perolehi sekarang?

2. Apakah yang tuan/puan lakukan untuk membina kesedaran tersebut, sehingga ianya sentiasa wujud di dalam diri tuan/puan?

3. Melalui pengalaman tuan/puan, apakah yang telah tuan/puan lakukan untuk mengetahui:

i. Perasaan sendiri

ii. Menilai dengan tepat kekuatan dan kelemahan diri

iii. Membina keyakinan diri

iv. Dan sentiasa sedar tentang niat di dlam diri?

\section{b. Regulasi Kendiri}

Ialah kemampuan seseorang untuk mengawal perasaan yang sedang bergejolak di dalam dirinya, sentiasa jujur dalam bertindak, bertanggung jawab dalam melakukan sesuatu, fleksibel dengan perubahan yang berlaku dan mahu menerima idea-idea baru dari sesiapa sahaja tanpa diiringi dengan perasaan negatif.

1. Berdasarkan pengalaman tuan/puan untuk mencapai kejayaan ini, adakah tuan/puan rasa perkara tersebut membantu tuan/puan untuk mewujudkan kejayaan yang tuan/puan dapatkan sekarang ini;

(i) Kemampuan mengawal perasaan?

(ii) Kejujuran dalam melakukan sesuatu?

(iii) Fleksibel dengan apa jua perubahan yang berlaku?

(iv) Dan terbuka dengan idea-idea baru? Kenapa tuan/puan mengatakan begitu?

2. Bagaimana tuan/puan mempergunakan elemen-elemen tersebut, sehingga ianya memberikan impak yang besar terhadap kejayaan yang tuan/puan dapatkan sekarang ini?

3. Melalui pengalaman yang telah dilalui selama ini, bagaimana tuan/puan memupuk elemen-elemen tersebut, sehingga ianya bersebati di dalam diri tuan/puan?

\section{c. Motivasi Kendiri}

Ialah kecenderungan emosi dalam membimbing seseorang untuk mencapai sesuatu matlamat. Sentiasa bersemangat untuk mencapai kecemerlangan, mempunyai komitmen yang tinggi untuk mencapai matlamat yang telah ditetapkan, mempunyai sikap proaktif dan sentiasa merebut peluang yang ada serta sentiasa istiqamah dalam mewujudkan matlamat, walaupun terdapat pelbagai rintangan dan halangan yang mencabar. 
1. Bagaimana agaknya tuan/puan memotivasikan diri sendiri untuk mewujudkan ruang bagi menempa kejayaan?

2. Pada pengalaman tuan/puan, bagaimana agaknya tuan/puan membina motivasi tersebut sehingga ianya sentiasa menjadi pendorong dalam mewujudkan kejayaan tuan/puan?

3. Apakah langkah-langkah yang tuan/puan lakukan untuk memotivasikan diri sehingga berjaya?

Kompetensi sosial pula merujuk kepada kemampuan seseorang dalam berinteraksi dengan orang lain, sama ada secara langsung mahupun sebaliknya. Kompetensi sosial diwakili oleh dua domain iaitu empati dan kemahiran sosial. Kompetensi sosial ini menentukan bagaimana seseorang itu menjalin hubungan mesra dengan individu lain.

\section{a. Empati}

Bermaksud menyedari perasaan, keperluan dan kehendak, masalah atau keperihatinan (concern) yang dirasakan oleh orang lain. Mampu mengesan perasaan orang lain daripada perspektif mereka, mengesan keperluan mengembangkan potensi orang lain, sentiasa berkeinginan untuk memenuhi keperluan orang lain, memupuk peluang melalui kepelbagaian manusia dan berupaya memahami perasaan kumpulan serta pemegang kekuasaan di sesebuah organisasi.

1. merujuk kepada definisi empati yang saya sebutkan tadi adakah tuan/puan mempergunakan elemen-elemen tersebut dalam membina hubungan dengan orang lain? Kenapa tuan/puan mengatakan begitu?

2. Mungkin tuan/puan boleh berkongsi pengalaman tentang bagaimana tuan/puan cuba:

(i) Memahami perasaan orang lain?

(ii) Memahami keperluan orang lain?

(iii) Memahami masalah orang lain?

(iv) Dan memahami keperihatinan yang dirasakan oleh orang lain?

3. Kalau Tuan/puan melihat ahli keluarga/kakitangan yang mempunyai potensi yang boleh dikembangkan, apakah yang Tuan/puan lakukan? Kenapa Tuan/puan mengatakan begitu?

4. Apakah yang Tuan/puan lakukan untuk membantu Tuan/puan boleh bekerja dengan individu dari pelbagai latarbelakang?

5. Untuk mewujudkan suasana kerja yang harmonis tentunya Tuan/puan memerlukan kakitangan yang boleh melihat kewujudan peluang yang ada di depan mata, apakah yang Tuan/puan lakukan untuk membantu kakitangan Tuan/puan supaya mereka dapat melihat peluang tersebut?

\section{Kemahiran sosial}

Ialah kemahiran mencetuskan respons yang dikehendaki daripada orang lain. Menggunakan cara yang efektif untuk memujuk orang lain, mampu menerima dan 
menyampaikan mesej dengan penuh keyakinan dan berkebolehan menyelesaikan konflik dengan baik.

1. Bagaimanakah tuan/puan membina hubungan dengan individu lain? Kenapa Tuan/puan mengatakan begitu?

2. Melalui pengalaman tuan/puan, bagaimakah tuan/puan mempengaruhi orang lain untuk mengikuti cadangan dan idea tuan/puan?

3. Bagaimanakah tuan/puan menyampaikan maklumat kepada orang lain, sehingga orang lain dapat menerima dengan baik?

4. Seperti sedia maklum di dalam sesebuah organisasi terkadang berlaku konflik luaran dan dalaman yang mungkin boleh membawa kepada kelemahan sistem sesebuah organisasi, jika tuan/puan berada di dalam situasi konflik sedemikian, apakah yang tuan/puan lakukan?

\section{Kerohanian}

Menggambarkan beberapa perkara seperti keredhaan, rasa tanggungjawab kepada pencipta serta kebolehan menghayati nilai-nilai agama. Keredhaan didefinisikan sebagai kebolehan seseorang untuk menerima dengan hati yang tulus peraturanperaturan tertentu yang digariskan oleh agama masing-masing. Peraturan-peraturan ini selalu dijadikan garis panduan dalam menjalani kehidupan seharian. Kesedaran tentang tanggungjawab terhadap penciptanya menjadikan seseorang itu sentiasa merasa bertanggung jawab serta tulus dan ikhlas dalam melaksanakan tugas seharian, kerana mereka memandang bahawa pekerjaan tersebut adalah sebagai satu ibadah di sisi Tuhannya.

1. Pada pengalaman tuan/puan selama ini, bagaimana tuan/puan mengaitkan kerjakerja harian tuan/puan dengan nilai-nilai kerohanian yang tuan/puan yakini?

2. Bagaimana cara tuan/puan menghayati nilai-nilai kerohanian tersebut, sehingga ianya boleh menjadi pendorong kepada kejayaan yang tuan/puan raih sekarang?

3. Bagaimanakah tuan/puan melaksanakan kerja-kerja harian tuan/puan sehingga ianya dipandang sebagai satu amanah yang mesti dekerjakan dengan penuh keikhlasan?

\section{Kematangan}

Kematangan menggambarkan aspek usia, pengalaman dan pengetahuan seseorang dan kesannya ke atas EQ seseorang tersebut. Dari segi usia, didapati seseorang biasanya menjadi lebih matang apabila usianya bertambah. Kematangan juga menggambarkan kebolehan seseorang untuk mengawal tingkah laku dalam melaksanakan sesuatu. Peningkatan usia terkadang boleh membantu seseorang untuk melakukan muhasabah diri untuk mengenal kelemahan dan kekuatan diri.

Dari aspek pengalaman pula, didapati ianya mempunyai perkaitan yang rapat dengan EQ. Seseorang yang mempunyai pengalaman positif tentang dunia kerjaya dan 
kehidupanya, biasanya dapat mengontrol emosi dengan baik dan menggunakan pengalaman tersebut sebagai bahan rujukan untuk meneruskan kehidupan.

1. Apakah persamaan dan perbezaan yang tuan/puan rasakan ketika mula-mula menceburkan diri di dalam kerjaya, dimana tuan/puan telah lama berada di dalam kerjaya tersebut?

2. Apakah faktor-faktor yang membawa kepada kejayaan di dalam diri tuan/puan?

3. Untuk sampai pada peringkat sekarang ini, tentunya tuan/puan mempunyai pelbagai pengalaman, bagaimana agaknya tuan/puan mempergunakan pengalaman tersebut untuk memperbaiki keadaan yang tuan/puan hadapi sekarang?

4. Setelah melalui pelbagai rintangan dalam kerjaya, apakah yang tuan/puan rasakan pada saat ini?

\section{Soalan Penutup}

1. Kita telah berbincang agak lama, secara umumnya apakah pandangan tuan/puan tentang perkara-perkara yang telah kita bincang tadi?

2. Adakah perkara-perkara yang tertinggal atau yang ingin tuan/puan tambahkan dalam perbincangan kita tadi?

Baiklah tuan/puan, perbincangan ini kita cukupkan sampai di sini, saya yakin banyak input-input penting yang dapat digunakan dalam profesion kita. Sekali lagi saya mengucapkan terima kasih kepada tuan/puan kerana telah sudi meluangkan masa dalam perbincangan ini. Sekiranya ada persoalan-persoalan yang baru dan penting untuk menjayakan kajian ini, saya menjemput tuan/puan semula untuk berkongsi maklumat.

Sekian dan terima kasih.

Wabillahi taufiq wal hidaayah

Wassalamu'alaikum Wr. Wb. 


\section{LAMPIRAN C}

\section{EQ Index Interpretation oleh Noriah (2007)}

\begin{tabular}{|c|c|}
\hline SCORE & INTERPRETATION \\
\hline $81-100$ & $\begin{array}{l}\text { This Could be The Strength To Build And Capitalize On } \\
\text { This range of score is definitely above average, and it could be } \\
\text { considered as higher than average when the score is within the } \\
\text { range of } 90-100 \text {. You realize that you have the competency; } \\
\text { however, you are not able to demonstrate the competency in } \\
\text { certain situations. But once polished it become natural to you. } \\
\text { Fortunately, in certain situations the same competency becomes } \\
\text { your strength that comes naturally to you. It looks like you just } \\
\text { need to be more consistent in your behavior, and maintain the } \\
\text { competency in almost any situation. This will help you seize } \\
\text { opportunities that can alleviate your love for success, so work to } \\
\text { capitalize on it, and maximize your potential. }\end{array}$ \\
\hline $61-80$ & $\begin{array}{l}\text { This Could Be The Strength Your Are Looking For } \\
\text { You should not look far when trying to improve your emotional } \\
\text { intelligence. The competency that has score within this range is } \\
\text { actually among your best competency especially when the score is } \\
\text { on the upper range }(70-80) \text {. You are aware of the competency } \\
\text { and are actually doing OK in life. However, there are some other } \\
\text { competencies that are pulling you back, and make you stuck below } \\
\text { the ceiling. You can start with this competency, and slowly bring it } \\
\text { out to your attention. This will help you develop your full potential } \\
\text { and become a more rounded person. }\end{array}$ \\
\hline $41-60$ & $\begin{array}{l}\text { Something You Need to Work On } \\
\text { If your competency score is within this range, it suggests that: (a) } \\
\text { you sometimes show emotionally intelligence behaviors, (b) it is } \\
\text { not your natural behavior; (c) it is not your favorite competency } \\
\text { that you always use. Find the right intervention and you can } \\
\text { improve on the competency. Once improved, your performance } \\
\text { will rise significantly }\end{array}$ \\
\hline Less than 4 & $\begin{array}{l}\text { A Concern You Must Address Immediately } \\
\text { The competencies having scores less than } 40 \text { can be categorized as } \\
\text { (a) a problem area for you, (b) you do not value the competency, or } \\
\text { (c) you do not think that the competency is important for you. } \\
\text { Because of the lack of the competency, you are not able to function } \\
\text { effectively. It is time for you to look for effective intervention that } \\
\text { will help you increase the score for the said competency and } \\
\text { change your behavior. To improve yourself, there should be a } \\
\text { sense of urgency }\end{array}$ \\
\hline
\end{tabular}




\section{LAMPIRAN D}

\section{PERSETUJUAN COHEN KAPPA TEMU BUAL INDIVIDU DAN BERKUMPULAN UNTUK MENDAPATKAN KOMPONEN-KOMPONEN PENTING DALAM PEMBINAAN MODUL EQ}

\begin{tabular}{|c|c|c|c|c|c|c|}
\hline No & $\begin{array}{l}\text { Kompetensi } \\
\text { Asas EQ }\end{array}$ & Tema Utama & Definisi Tema & Transkripsi & Ya & Tidak \\
\hline \multirow[t]{3}{*}{1.} & \multirow[t]{3}{*}{$\begin{array}{l}\text { Kesedaran } \\
\text { Emosi }\end{array}$} & $\begin{array}{l}\text { (i) Perbaiki } \\
\text { Diri }\end{array}$ & $\begin{array}{l}\text { Sentiasa berusaha } \\
\text { untuk memperbaiki } \\
\text { diri, mahu kerja } \\
\text { keras \& proaktif }\end{array}$ & $\begin{array}{l}\text {...cara saya belajar, saya sentiasa ke } \\
\text { hadapan, saya tidak tunggu guru } \\
\text { mengajarkan dulu. Maksudnya saya } \\
\text { dah baca lima atau tiga bab lebih awal } \\
\text { daripada apa yang ingin diajarkan oleh } \\
\text { guru. Jadi bila diajar saya faham. Kalau } \\
\text { saya tak faham saya akan tanya kepada } \\
\text { guru yang mengajar itu. Macam itu } \\
\text { juga dengan tugasan-tugasan saya, } \\
\text { kadang-kadang bila terfikir satu topik } \\
\text { saya pergi jumpa pensayarah, saya kata } \\
\text { kalau saya nak buat macam ini } \\
\text { macamana? Walaupun tajuk tugasan } \\
\text { belum keluar, jadi maksudnya saya } \\
\text { sentiasa proaktiflah, dan saya suka buat } \\
\text { sesuatu kreati (TBI3). }\end{array}$ & & \\
\hline & & $\begin{array}{l}\text { (ii) Mereflek } \\
\text { Pengalaman } \\
\text { Lepas }\end{array}$ & $\begin{array}{l}\text { Menjadikan } \\
\text { pengalaman sebagai } \\
\text { panduan untuk } \\
\text { mereflefsi diri }\end{array}$ & $\begin{array}{l}\text {... Ialah kesedaran tu datang daripada, } \\
\text { saya nampak kesedaran itu datang } \\
\text { daripada kegagalanlah, itu yang senang. } \\
\text { Jadi kegagalan tu yang orang kata } \\
\text { pengajaran yang paling betul-beatul } \\
\text { bermakna (TBI 2). }\end{array}$ & & \\
\hline & & $\begin{array}{l}\text { (iii) Usaha } \\
\text { Berterusan }\end{array}$ & $\begin{array}{l}\text { Tidak mudah } \\
\text { mengalah, sentiasa } \\
\text { berusaha dan } \\
\text { konsisten }\end{array}$ & $\begin{array}{l}\text { Jadi saya ingat dalam apapun, dalam } \\
\text { pengurusan, dalam research, } \\
\text { pekerjaanpun, itu cara sayalah. Saya } \\
\text { tidak laju tapi saya consisten. Saya terus } \\
\text { jalan, kalau tak boleh itu saya cuba cari } \\
\text { jalan lain sampai boleh. Walaupun dah } \\
\text { tak tahan sangat tapi saya cuba terus, } \\
\text { berdo'a banyaklah. Akhirnya saya dapat } \\
\text { habis ... (TBI 4). }\end{array}$ & & \\
\hline & & $\begin{array}{l}\text { (iv) Berfikir } \\
\text { Sebelum } \\
\text { Bertindak }\end{array}$ & $\begin{array}{l}\text { Sentiasa berhati-hati, } \\
\text { bertindak wajar \& } \\
\text { Tanya hati nurani }\end{array}$ & $\begin{array}{l}\text { O.... itu kena pikir sekejaplah, dan } \\
\text { kadang-kadang bercakap pada diri } \\
\text { sendiri. Kalau itu merupakan satu } \\
\text { keluhan, bercakap mengadu kepada } \\
\text { Allah S.W.T. Saya suka berfikir } \\
\text { sebelum melakukan sesuatu (TBI 1) }\end{array}$ & & \\
\hline & & $\begin{array}{l}\text { (v) Akidah atau } \\
\text { Keyakinan }\end{array}$ & $\begin{array}{l}\text { Timbul Kesedaran } \\
\text { kerana yakin dengan } \\
\text { keberadaan Tuhan }\end{array}$ & $\begin{array}{l}\text { Saya yang ketara sekali bila saya buat } \\
\text { PhD, bila kebetulan saya balik kali } \\
\text { kedua boleh dikatakan setiap malam } \\
\text { saya akan sembahyang tahajud, do'a, } \\
\text { sembahyang hajat. Maknanya benda tu } \\
\text { memang kita hendak sangat dan kita }\end{array}$ & & \\
\hline
\end{tabular}




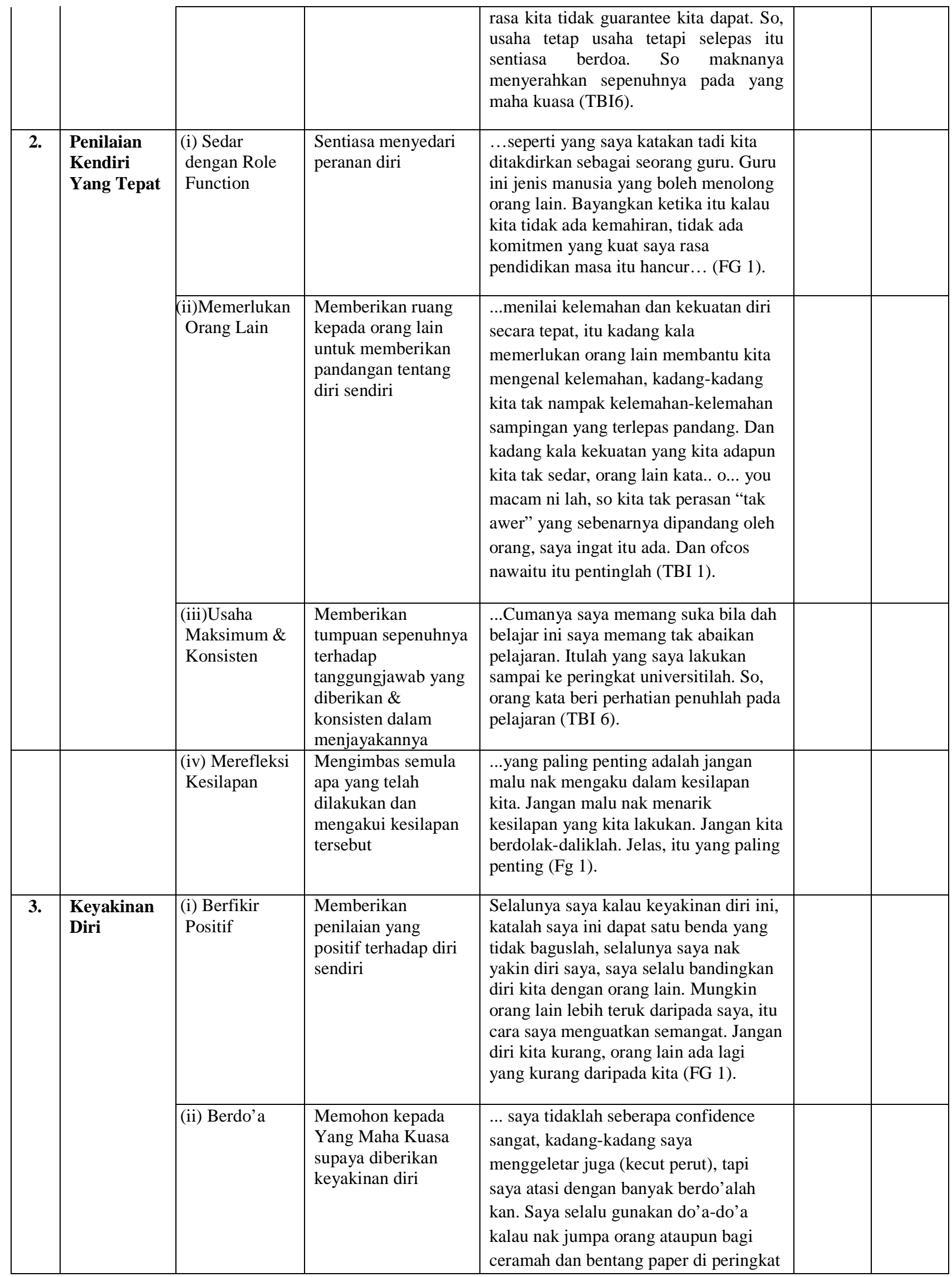




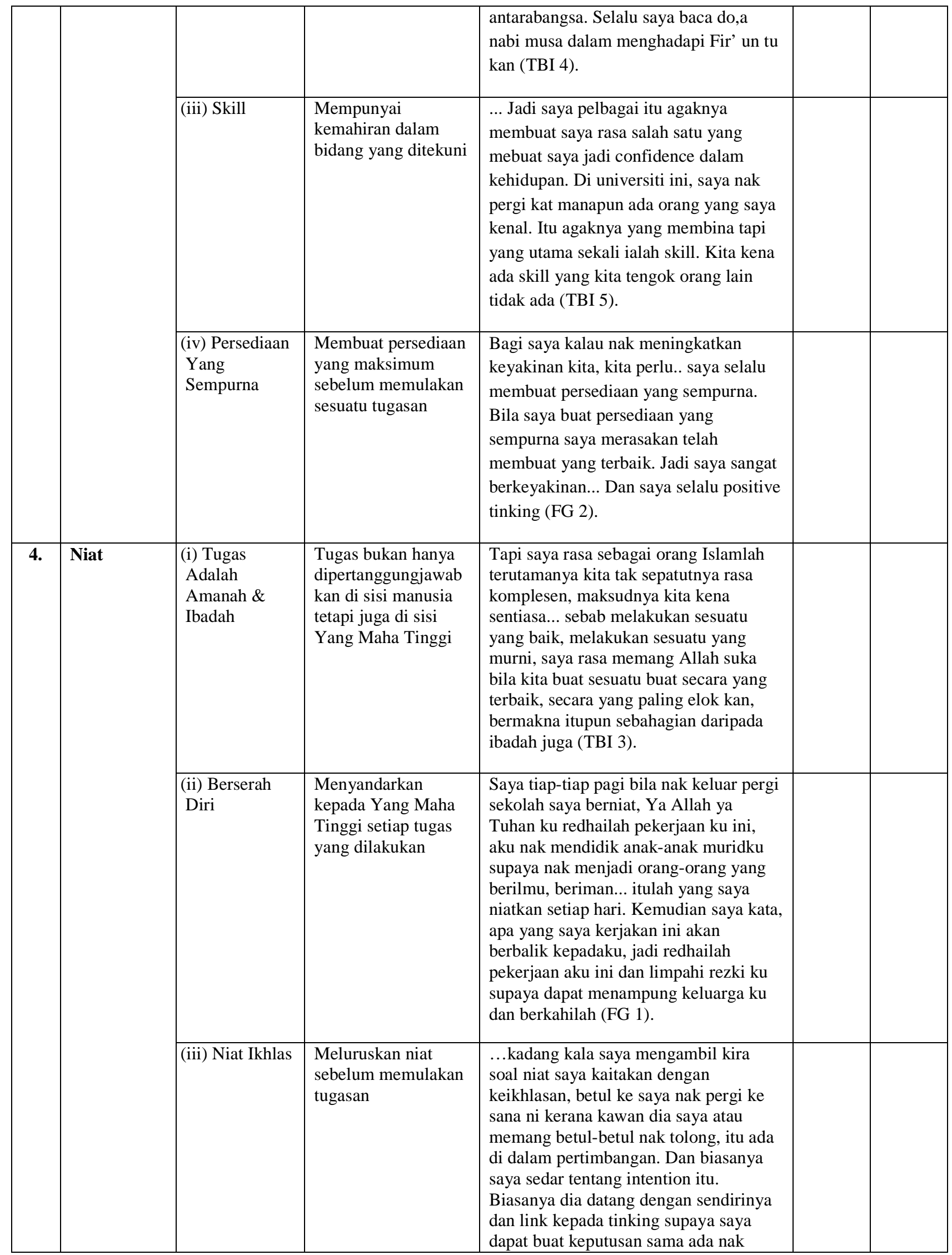




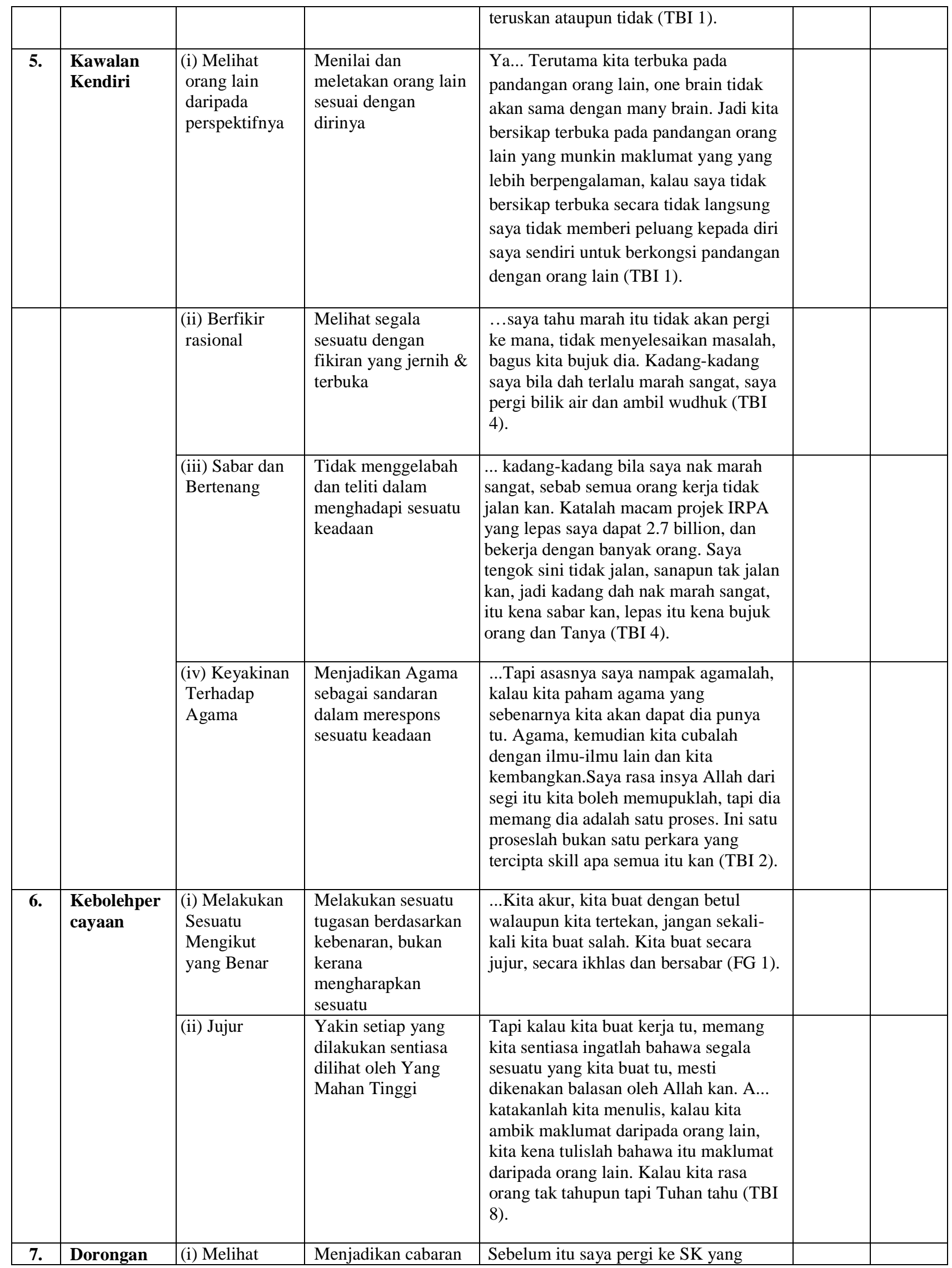




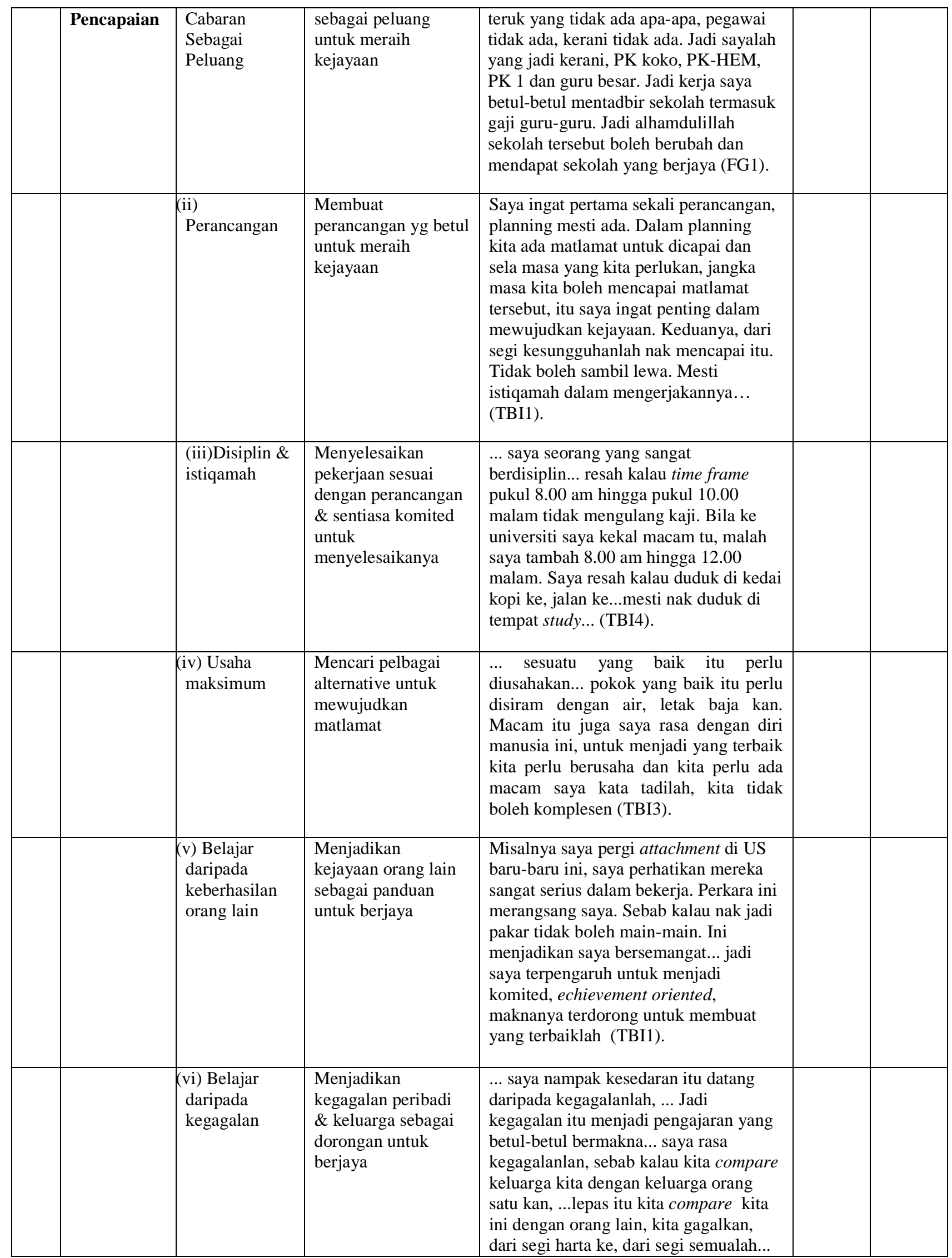




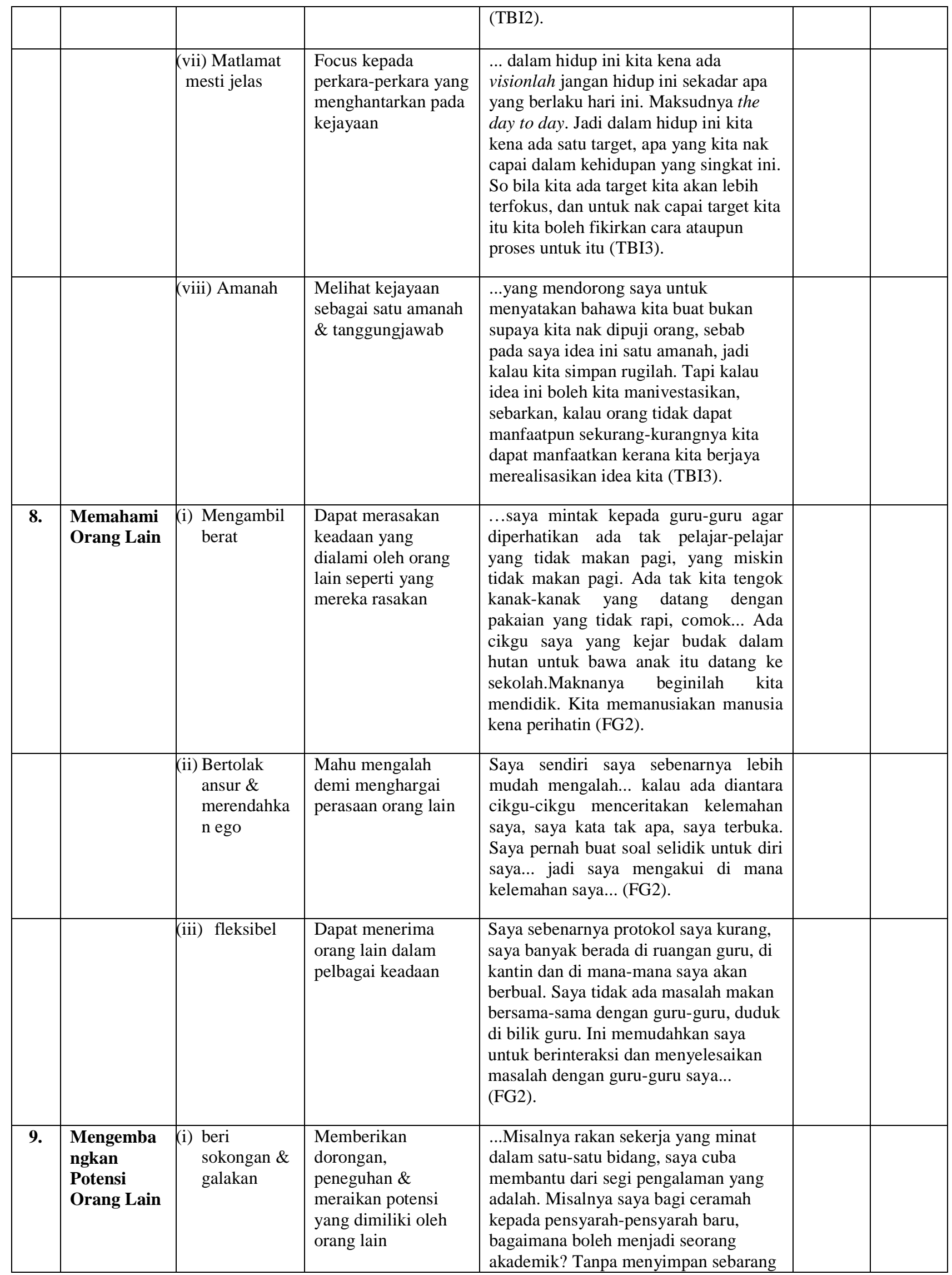




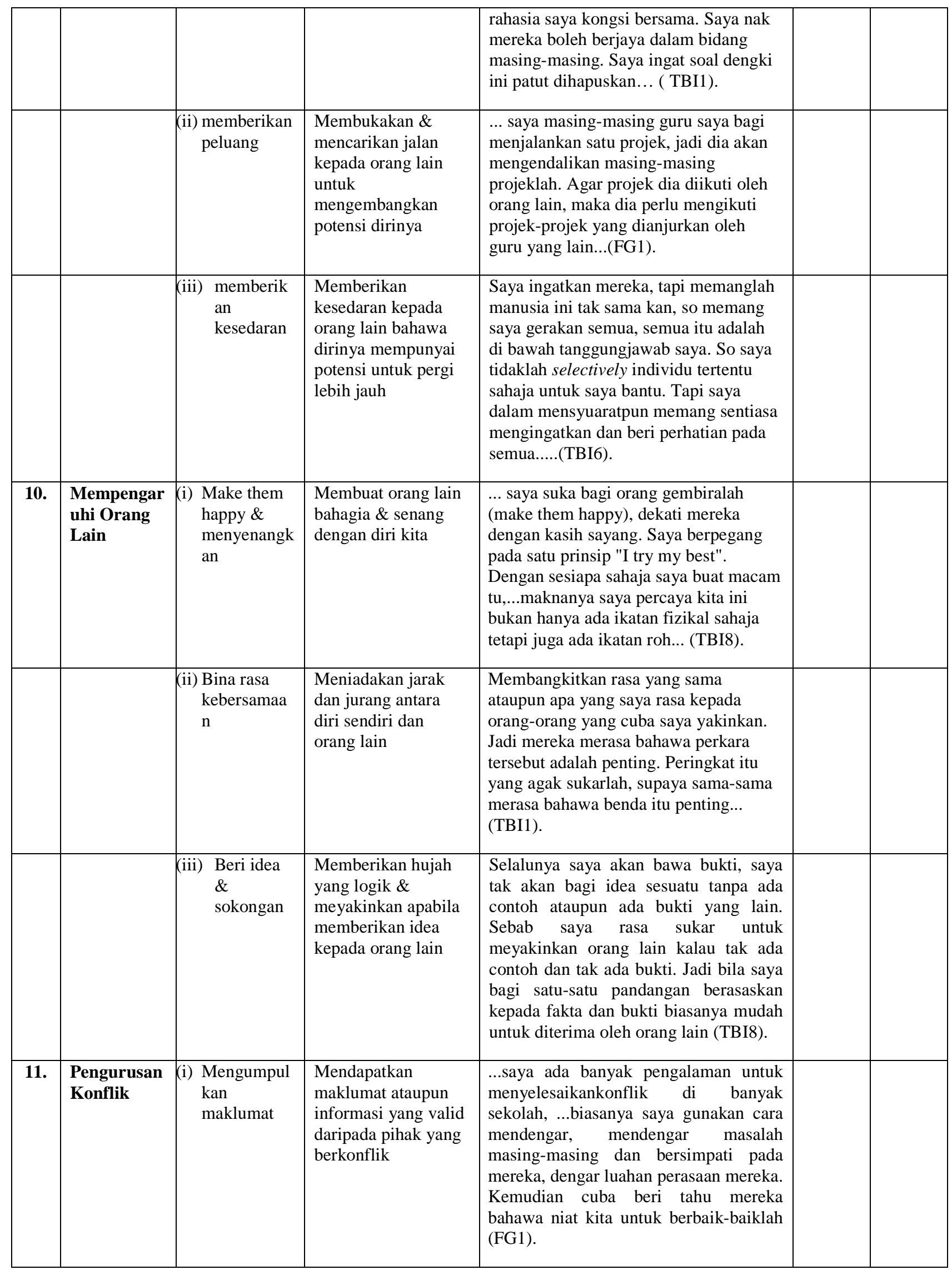




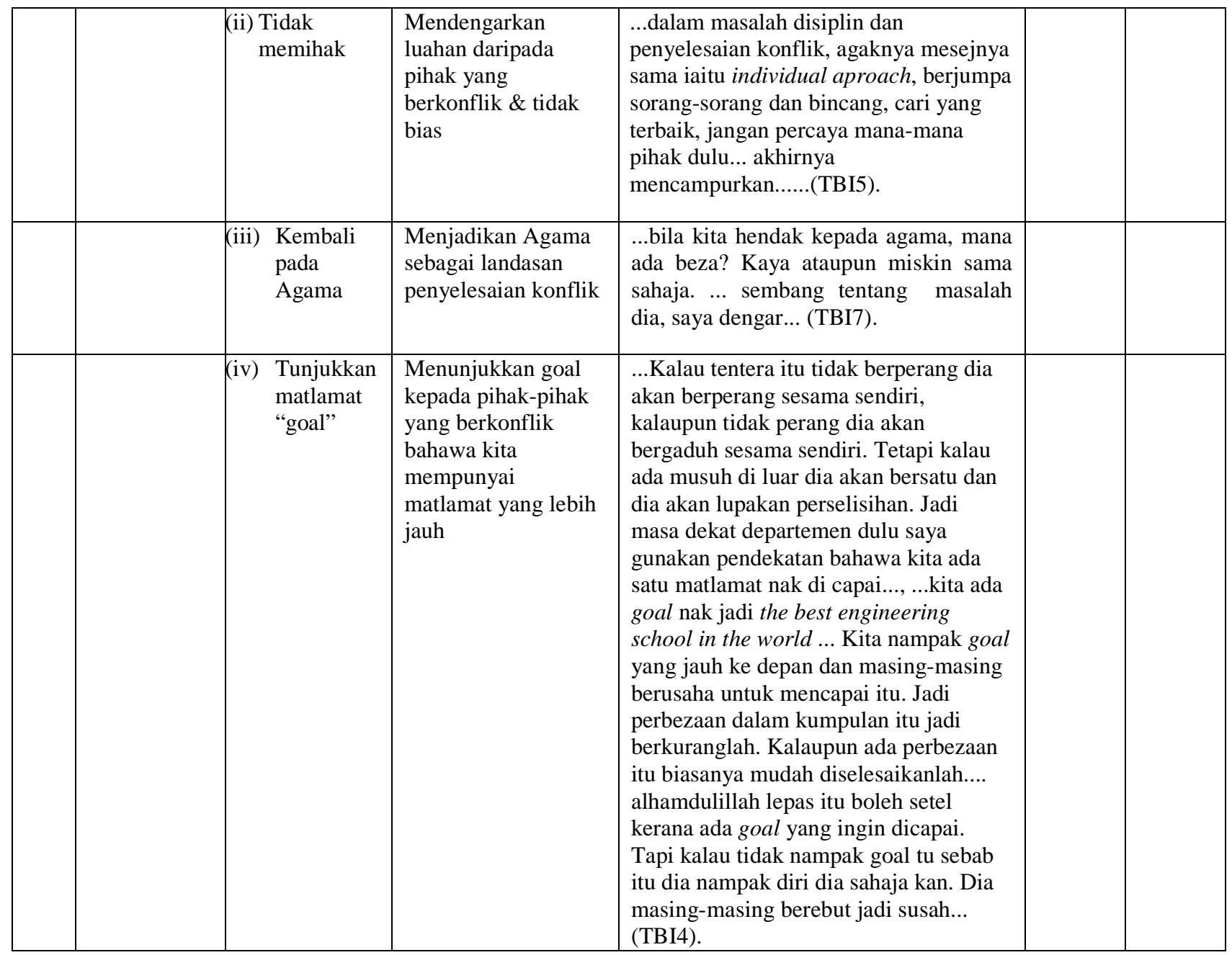

